

\section{Universidad Politécnica de Cartagena}

Tesis Doctoral

Evaluación de fitotecnologías para la extracción de metales pesados en el cauce del Río

Guadalentín, Lorca

Autor:

José Mora Navarro

Directores:

Dr. Ángel Faz Cano

Dra. Melisa Gómez Garrido

Dr. Fco. José Murcia Navarro

Cartagena, 2018 


\section{Universidad}

Politécnica

de Cartagena

DT-16

\section{CONFORMIDAD DE SOLICITUD DEAUTORIZACIÓN DE DEPÓSITO DE}

\section{TESIS DOCTORAL POR EL/LA DIRECTOR/A DE LA TESIS}

D. Ángel Faz Cano, Da. Melisa Gómez Garrido y D. Francisco José Murcia Navarro Directores de la Tesis doctoral Evaluación de fitotecnologías para la extracción de metales pesados en el cauce del Río Guadalentín, Lorca.

\section{INFORMAN:}

Que la referida Tesis Doctoral, ha sido realizada por D. José Mora Navarro, dentro del Programa de Doctorado de Tecnología y Modelización en Ingeniería Civil, Minería y Ambiental, dando mi conformidad para que sea presentada ante el Comité de Dirección de la Escuela Internacional de Doctorado para ser autorizado su depósito.

La rama de conocimiento en la que esta tesis ha sido desarrollada es:

¿ Ciencias

Ciencias Sociales y Jurídicas

$\square \quad$ Ingeniería y Arquitectura

$$
\text { En Cartagena, a } 16 \text { de Juhio de } 2018
$$

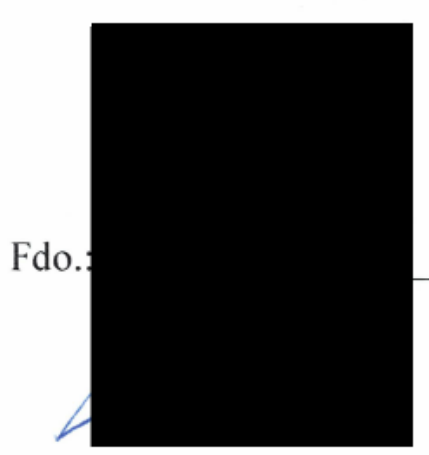

EL/LA DIRECTOR/A DE LA TESIS

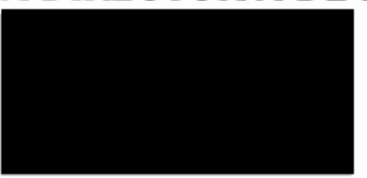

Fdo.: Melisa Gover
Fdo.: ERANCISLO J. TWRAA. 


\section{Universidad \\ Politécnica \\ de Cartagena}

DT-17

\section{CONFORMIDAD DE DEPÓSITO DE TESIS DOCTORAL POR LA COMISIÓN ACADÉMICA DEL PROGRAMA}

D. Ángel Faz Cano, Presidente/a de la Comisión Académica del Programa Tecnología y Modelización en Ingeniería Civil, Minería y Ambiental.

\section{INFORMA:}

Que la Tesis Doctoral titulada, "Evaluación de fitotecnologías para la extracción de metales pesados en el cauce del Río Guadalentín, Lorca", ha sido realizada, dentro del mencionado Programa de Doctorado, por D. José Mora Navarro, bajo la dirección y supervisión del Dr. Ángel Faz Cano, Dra. Melisa Gómez Garrido y Dr. Fco José Murcia Navarro.

En reunión de la Comisión Académica, visto que en la misma se acreditan los indicios de calidad correspondientes y la autorización del Director/a de la misma, se acordó dar la conformidad, con la finalidad de que sea autorizado su depósito por el Comité de Dirección de la Escuela Internacional de Doctorado.

La Rama de conocimiento por la que esta tesis ha sido desarrollada es:

$\mathrm{X}$ Ciencias

Ciencias Sociales y Jurídicas

Ingeniería y Arquitectura

En Cartagena, a 16 de Julio de 2018

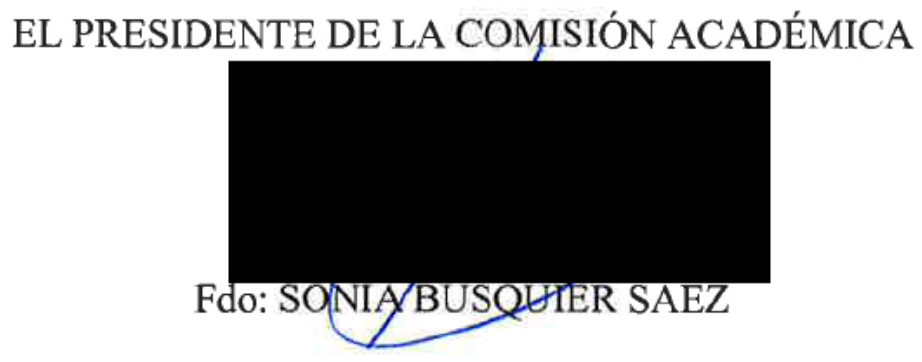

COMITÉ DE DIRECCIÓN ESCUELA INTERNACIONAL DE DOCTORADO 
A Valeria y José

"Si lo puedes soñar, lo puedes lograr" Walt Disney 
A todos los compañeros que han trabajado en el proyecto LIFE11 ENV/ES/000506 "REHABILITATION OF A HEAVY METAL CONTAMINATED RIVERBED BY PHYTOEXTRACTION TECHNIQUE”, en especial, por orden alfabético, Ana Agustí, Cándido Gabarrón, Melisa Gómez, Adelaida Jordán, Kiko Murcia y Ana Romero, por su implicación, entrega y paciencia para solventar los continuos imprevistos y dificultades que han ocurrido a lo largo del desarrollo del mismo.

A mis directores de tesis Dr. Ángel Faz por su confianza en mí para elaborar esta tesis bajo su dirección y por supuesto por sus orientaciones precisas en los momentos fundamentales de decisión para llegar a buen puerto, Dra. Melisa Gómez por la metodología, rigurosidad y disciplina que ha intentado transmitirme, sin su ayuda no hubiese llegado hasta aquí, Dr. Francisco José Murcia por hacer que se re-despertará en mí el interés por iniciar esta tesis, por sus consejos en los momentos en los que creo que todo doctorando se pregunta, ¿seguir o abandonar?

A la Dirección General de Medio Ambiente y Mar Menor de la Consejería de Empleo, Universidades, Empresa y Medio Ambiente de la Comunidad Autónoma de la Región de Murcia como socio coordinador del proyecto LIFE 11ENV/ES/000506, y al resto de organismos beneficiarios Confederación Hidrográfica del Segura, Ayuntamiento de Lorca y Universidad Politécnica de Cartagena.

A mis padres Antonio y Pepita que sin que se les notase inculcaron en mí el interés por el aprendizaje y la continua formación.

A ella, a Toñi, mi compañera de viaje durante ya más de 25 años, acompañándome y apoyándome incondicionalmente en todas las etapas y experiencias que he emprendido, no pudiendo ser menos en este proyecto. $\mathrm{Y}$ por supuesto a ellos, a Valeria y José que lo son todo "para ellos y por ellos", por sus continúas preguntas, que han sido estímulo para mí “¿papá esta noche vas a hacer doctorado?, así les ayudaba a calmar sus miedos porque sabían que habría alguien despierto en la casa hasta la madrugada. 


\section{PRODUCCIÓN CIENTÍFICA: PUBLICACIONES EN REVISTAS CIENTÍFICAS}

Publicaciones científicas generadas por la presente tesis doctoral:

The chelating effect of citric acid, oxalic acid, amino acids and Pseudomonas fluorescens bacteria on phytoremediation of $\mathrm{Cu}, \mathrm{Zn}$, and $\mathrm{Cr}$ from soil using Suaeda vera. Melisa Gómez-Garrido, José Mora Navarro, Francisco J. Murcia Navarro, and Angel Faz Cano. International Journal of Phytoremediation. DOI: 10.1080/15226514.2018.1452189)

$\mathrm{Cu}-\mathrm{Zn}-\mathrm{Cr}$ phytoextraction capacity of plants growing on tannery effluent and farm dumping sites under semiarid conditions. Melisa Gómez-Garrido, José Mora Navarro, Francisco J. Murcia Navarro, Ángel Faz Cano. Bioremediation Journal (en revisión).

\section{PRODUCCIÓN CIENTÍFICA: PUBLICACIONES EN CONGRESOS}

Autores: Zornoza, Raúl; Acosta, José A.; Faz Cano, Ángel; Martínez-Martínez, Silvia; Rosales, Rosa M.; Gómez, Melisa; González-Páez, Verónica; Murcia, Francisco José; Mora, José.

Título: Interrelationships between chromium and soil properties to evaluate the phytoextracion potential in a dry riverbed from Southeast Spain.

Tipo de participación: póster.

Congreso: $3^{\text {a }}$ Conferencia Científica International de la UNCCD.

Lugar de celebración: Cancún (Méjico).

Fecha: 9-12 marzo 2015.

Autores: Juan Carlos Beltrá Castillo, Fuensanta García Orenes, José Mora Navarro, Francisco José Murcia Navarro, Raúl Zornoza, Ángel Faz, and Melisa Gómez-Garrido Título: Rehabilitation of river sediments contaminated by heavy metals from tanning industries using the phytoextraction technique.

Tipo de participación: poster.

Congreso: European Geosciences Union General Assembly 2017.

Lugar de celebración: Vienna (Austria).

Fecha: 23-28 abril 2017. 
Autores: Melisa Gómez-Garrido, Ángel Faz, José Martín Soriano-Disla, Francisco José Murcia, José Mora.

Título: Biogeochemical distribution of $\mathrm{Cr}, \mathrm{Cu}$ and $\mathrm{Zn}$ in a riverbed contaminated by tannery effluents and pig farms.

Tipo de participación: poster.

Congreso: Society of Environmental Toxicology and Chemistry (SETAC).

Lugar de celebración: Bruselas (Bélgica).

Fecha: 7-11 mayo 2017.

Autores: Gómez Garrido,Melisa, Ángel Faz Cano, José Mora Navarro, Francisco José Murcia Navarro, Cándido Gabarrón Llamas, Ana Romero Barahona, Ana Agustí Peris, Adelaida Jordán Marín.

Título: PROJECT LIFE11 ENV/ES/000506 Riverphy "Rehabilitation of a heavy metal contaminated riverbed by phytoextraction technique".

Tipo de participación: poster.

Congreso: EU Platform Metering. Life Water Platform. One River Many Interests.

Lugar de celebración: Koblenz (Alemania).

Fecha: 27-28 junio 2017.

Autores: Melisa Gómez Garrido, Ángel Faz Cano, José Mora Navarro, Francisco José Murcia Navarro, Cándido Gabarrón Llamas, Ana Romero Barahona, Ana Agustí Peris, Adelaida Jordán Marín.

Título: Rehabilitation of a heavy metal contaminated riverbed by phytoextraction technique.

Tipo de participación: oral.

Congreso: REMTECH EXPO Remediation of contaminated sites, Land Management and Reclamation.

Lugar de celebración: Ferrara (Italia).

Fecha: 20-22 septiembre 2017.

Autores: Gómez-Garrido, Melisa, Faz Cano, Ángel, Murcia Navarro, Francisco, Gabarrón Llamas, Cándido, Mora Navarro, José.

Título: The use of chelating agents and microorganisms at enhancing the phytoextraction of metals from a multi-metal contaminated soil in SE Spain.

Tipo de participación: oral. 
Congreso: $2^{\text {nd }}$ International Caparica Conference on Pollutant Toxic Ions and Molecules.

Lugar de celebración: Costa da Caparica (Portugal).

Fecha: 6-9 noviembre 2017.

Autores: Gómez-Garrido Melisa, Beltrá Castillo Juan Carlos, Mora Navarro José, Zornoza Raúl, Murcia Navarro Francisco José, Faz Ángel.

Título: Rehabilitación de sedimentos fluviales contaminados por metales pesados de industrias curtidoras y actividades ganaderas mediante la técnica de fitoextracción (Proyecto Life+ Riverphy).

Tipo de participación: poster.

Congreso: VIII Congreso Ibérico de las Ciencias del Suelo.

Lugar de celebración: Donostia-San Sebastián (España).

Fecha: 20-22 junio 2018. 
El elevado coste de las tecnologías existentes para la limpieza de suelos ha conllevado a la búsqueda de nuevas estrategias que tengan el potencial de ser de bajo coste, bajo impacto y que sean visualmente benignas y ecológicas. La fitorremediación es una nueva estrategia de limpieza que implica el uso de plantas para limpiar o estabilizar ambientes contaminados. El fitomanejo de áreas contaminadas con vegetación autóctona espontánea es una buena opción para mejorar los indicadores ecológicos y evitar el transporte de contaminantes a las áreas cercanas. Sólo cuando los metales están presentes en formas biodisponibles y en niveles excesivos; tienen el potencial de volverse tóxicos para las plantas. En el pasado, como resultado de una mayor concienciación y protección de la salud ambiental, se han promulgado estrictas reglamentaciones ambientales para evitar la eliminación indiscriminada de los residuos de curtidos y de los residuos de ganadería en el suelo y en las masas de agua. Sin embargo, antes de que se promulgaran estas regulaciones, muchas industrias habían arrojado sus residuos sólidos y líquidos que contenían $\mathrm{Cu}, \mathrm{Zn}$ y $\mathrm{Cr}$ a los suelos y a los cuerpos de agua vecinos. Es por ello que el objetivo principal de la presente tesis doctoral como parte del proyecto LIFE11 ENV/ES/000506 "Rehabilitación de un cauce fluvial contaminado por metales mediante la técnica de fitoextracción" fue evaluar, demostrar y difundir una alternativa sostenible para la recuperación ambiental de un tramo contaminado de 1500 m del Río Guadalentín tras su paso por el núcleo urbano Lorca (Región de Murcia), concretamente entre los años 2013 y 2017. Este cauce seco está contaminado por metales pesados debido a antiguos vertidos directos por parte de industrias curtidoras (provocando contaminación por $\mathrm{Cr}$ ) y de granjas (provocando contaminación por $\mathrm{Cu}$ y $\mathrm{Zn}$ por vertido de purines porcinos y fertilizantes). También resultó interesante evaluar la eficiencia de fitoextracción de $\mathrm{Cu}, \mathrm{Cr}$ y Zn mediante el uso de agentes quelantes naturales y microorganismos y la caracterización físico-química y biológica de las propiedades del sistema suelo. Los resultados concluyeron que el grado de eliminación de metales $\mathrm{Cu}$, Zn y Cr total en suelo entre los años 2013 y 2017 es favorable y evidente para Zn y Cr total y menos evidente para $\mathrm{Cu}$ total. La vegetación fitoextractora implantada llega a estar muy influenciada por los periodos de escasez hídrica y por las condiciones meteorológicas, ambos hechos podrían haber condicionado la fitoextracción de metales por parte de la vegetación presente en el cauce y las concentraciones de metales totales registradas en las muestras de los sedimentos del suelo rizosférico $(0-20 \mathrm{~cm}$ y $20-50 \mathrm{~cm})$. Sobre el estudio de los sedimentos de suelo afectados por $\mathrm{Cu}, \mathrm{Zn}$ y $\mathrm{Cr}$ en parcelas tratadas con 5 tratamientos (control, ácido oxálico, ácido cítrico, aminoácidos y bacterias 
Pseudomonas fluorescens) con muestreos anuales y muestreos quincenales entre junio 2016 y septiembre 2017 se deduce que en condiciones de clima mediterráneo semiárido el riesgo de lixiviación (hasta $100 \mathrm{~cm}$ de profundidad) de metales solubles y metales biodisponibles es bajo. A largo plazo, el tratamiento más notable para aumentar la solubilidad y biodisponibilidad de metales en suelo es el tratamiento con ácido cítrico, siendo conveniente y recomendable realizar un seguimiento quincenal del suelo rizosférico $(0-20 \mathrm{~cm})$ y un seguimiento anual del suelo rizosférico y del suelo no rizosférico $(0-100 \mathrm{~cm})$. La aplicación de la técnica de fitoextracción en condiciones de clima mediterráneo semiárido tras el periodo de fitoextracción 2013-2017 es favorable pero teniendo en cuenta algunas recomendaciones como la realización de riegos de emergencia, la selección de la vegetación autóctona mejor adaptada y la realización de prácticas agronómicas que mejoren el desarrollo de la vegetación implantada como la aplicación aportes nutricionales que favorezcan el desarrollo de la vegetación así como una siega anual de la biomasa aérea.

José Mora Navarro, 2018 
The high cost of the existing cleanup technologies has led to the search for new strategies that have the potential to be of low cost, low-impact, visually benign and environmentally friendly. Phytoremediation is a new cleanup strategy that involves the use of plants to clean or stabilize contaminated environments and harvesting the plant shoots can help to permanently remove these contaminants from the soil. The phytomanagement of these polluted areas employing the spontaneous vegetation is a good option to improve the ecological indicators and to prevent the transport of pollutants to nearby areas. Metals have the potential to become toxic to plants when they are present in bioavailable forms and at excessive levels. In the past, as a result of an increased awareness and protection of environmental health, strict environmental regulations were enacted to prevent indiscriminate disposal of wastes into soil and water bodies in the world. However, before these regulations were enacted, many industries had dumped their solid and liquid waste containing $\mathrm{Cu}, \mathrm{Zn}$ and $\mathrm{Cr}$ into neighboring soils and water bodies. Therefore, the main objective of this thesis as part of the project LIFE11 ENV/ES/000506 "Rehabilitation of a heavy metal contaminated riverbed by phytoextraction technique" was to evaluate, demonstrate and disseminate a sustainable alternative for the environmental recovery of a contaminated stretch of $1500 \mathrm{~m}$ of the Guadalentín River after its flow through the town of Lorca (Murcia Region), specifically between 2013 and 2017. The dry riverbed is contaminated by heavy metals due to old direct spills by tanning industries (causing $\mathrm{Cr}$ contamination) and farms (causing $\mathrm{Cu}$ and $\mathrm{Zn}$ contamination with pig slurries and fertilizers). It was also interesting to evaluate the phytoextraction efficiency of $\mathrm{Cu}, \mathrm{Cr}$ and $\mathrm{Zn}$ through the use of natural chelating agents and microorganisms by the physical-chemical and biological characterization of the properties of the soil system. The results concluded that the elimination degree of $\mathrm{Cu}, \mathrm{Zn}$ and $\mathrm{Cr}$ total metals in soil between the years 2013 and 2017 is favorable and evident for total $\mathrm{Zn}$ and total $\mathrm{Cr}$ total and less evident for total $\mathrm{Cu}$. The phytoextracting vegetation implanted is very influenced by the periods of water scarcity and the weather conditions, both facts could have conditioned the phytoextraction of metals by the vegetation from the riverbed and also the concentrations of total metals recorded in the samples of rhizospheric soil sediments (0-20 cm and $20-50 \mathrm{~cm}$ ). On the study of the soil sediments affected by $\mathrm{Cu}, \mathrm{Zn}$ and $\mathrm{Cr}$ in plots treated with 5 treatments (control, oxalic acid, citric acid, amino acids and Pseudomonas fluorescens bacteria) with annual samplings and biweekly samplings between June 2016 and September 2017, it can be deduced that in semiarid Mediterranean climate conditions the risk of leaching (up to $100 \mathrm{~cm}$ deep) of soluble 
metals and bioavailable metals is low. In a long period of time, the most notable treatment to increase the solubility and the bioavailability of metals in soil is the treatment with citric acid, although it is advisable and it is recommended to perform a bi-weekly monitoring of the rhizospheric soil sediments $(0-20 \mathrm{~cm})$ and an annual sampling of the rhizospheric soil and the non-rhizospheric soil $(0-100 \mathrm{~cm})$. The application of the phytoextraction technique in semiarid Mediterranean conditions after the phytoextraction period $2013-2017$ is favorable but taking into account some recommendations such as the realization of emergency irrigations, the selection of best adapted native vegetation and the realization of agronomic practices to improve the development of the implanted vegetation through the application of nutritional contributions that favor the development of the vegetation as well as an annual harvest of the aerial biomass. 


\section{ÍNDICE GENERAL}

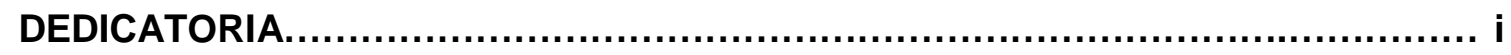

AGRADECIMIENTOS........................................................................ iii

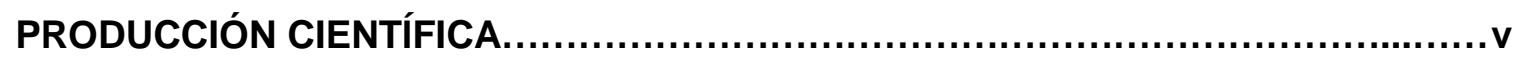

RESUMEN................................................................................ ix

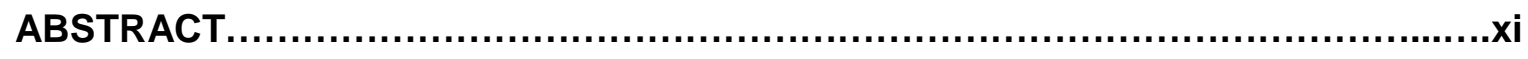

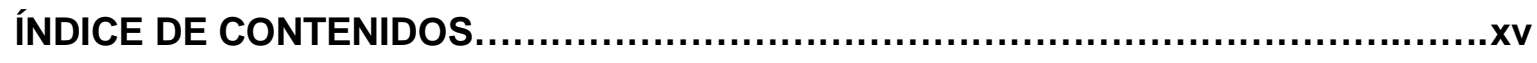

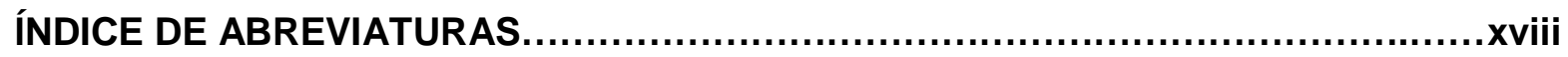




\section{ÍNDICE DE CONTENIDOS}

\section{Capítulo 1. PLANTEAMIENTO Y OBJETIVOS}

1.1 ORIGEN DE LA TEMÁTICA DESARROLLADA EN LA TESIS

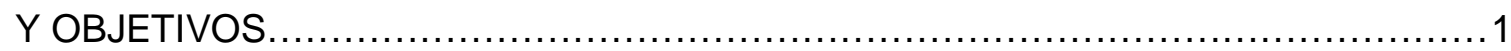

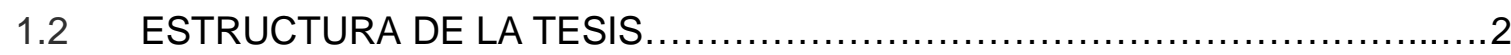

Capítulo 2. EFECTOS AMBIENTALES DE LOS RESIDUOS PROCEDENTES DE LA INDUSTRIA CURTIDORA Y DE LA GANADERÍA PORCINA INTENSIVA

2.1 INTRODUCCIÓN Y LOS PROCESOS DE CURTICIÓN......................... 4

2.1.1 ETAPAS DE UN PROCESO CONVENCIONAL DE CURTICIÓN................. 6

2.1.2 PROCESOS DE CURTICIÓN MÁS USUALES.............................. 20

2.1.3 EMISIONES Y CONSUMO DE ENERGÍA Y MATERIAS PRIMAS

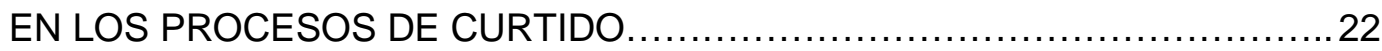

2.1.4 PROBLEMÁTICA AMBIENTAL DE LAS INDUSTRIAS DEL CURTIDO........ 33

2.1.5 GESTIÓN DE RESIDUOS Y TRATAMIENTOS DE AGUAS RESIDUALES

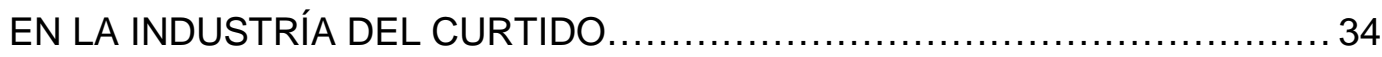

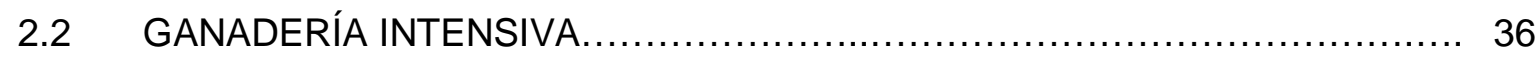

2.2.1 CONTAMINACIÓN DE AGUAS SUBTERRÁNEAS............................. 38

2.2.2 CONTAMINACIÓN DE AGUAS SUPERFICIALES .......................... 39

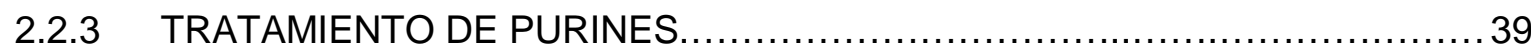

2.3 EFECTOS DE LA INDUSTRIA DEL CURTIDO Y LA ACTIVIDAD GANADERA EN EL CAUCE DEL RÍO GUADALENTÍN A SU PASO POR LORCA............41

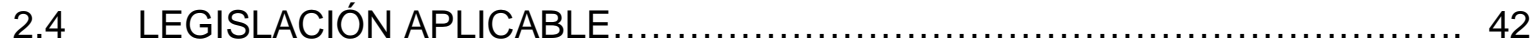

Capítulo 3. BIORREMEDIACIÓN: FITOTECNOLOGÍAS Y USO DE LA BIOMASA CONTAMINADA

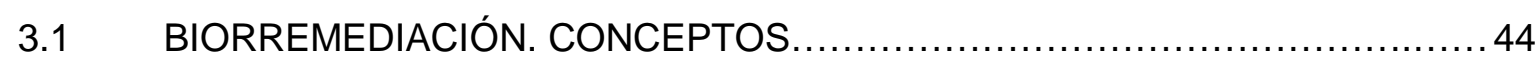

3.2 LA FITORREMEDIACIÓN COMO TÉCNICA DE RECUPERACIÓN

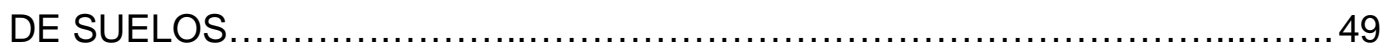

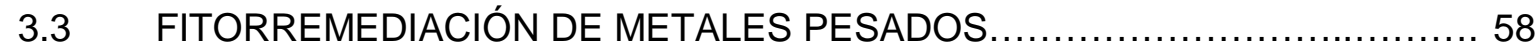

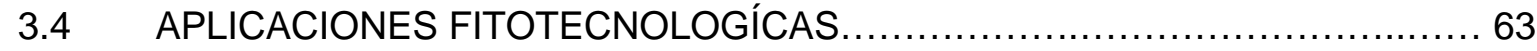

3.5 USOS DE LA BIOMASA. VALORIZACIÓN DE RESIDUOS $\ldots \ldots \ldots \ldots \ldots \ldots \ldots \ldots \ldots \ldots \ldots \ldots \ldots$

3.5.1 VIABILIDAD DE USO EN LA INDUSTRIA DE LA CONSTRUCCIÓN

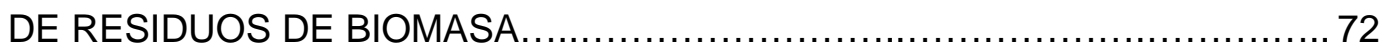


3.5.2 VENTAJAS DE LA VALORIZACIÓN DE RESIDUOS DE BIOMASA

EN LA INDUSTRIA DE LA CONSTRUCCIÓN.

\section{Capítulo 4. CARACTERÍSTICAS GENERALES DE LA ZONA DE ESTUDIO}

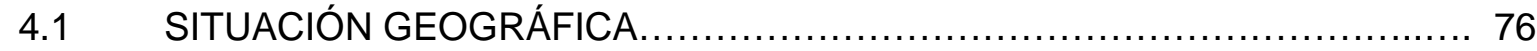

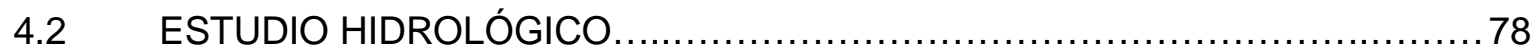

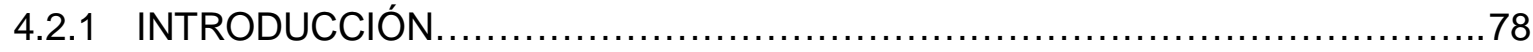

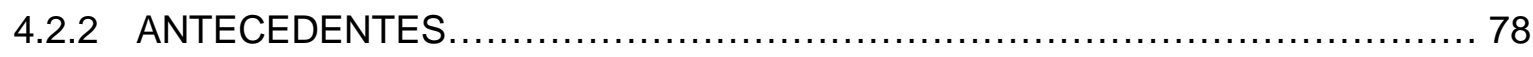

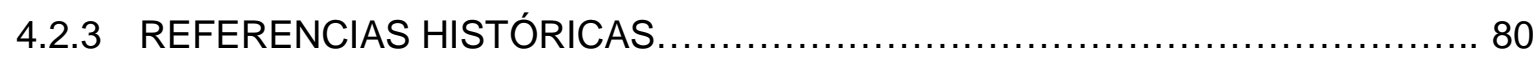

4.2.4 LOCALIZACIÓN DEL RÍO GUADALENTÍN Y DEL PROYECTO

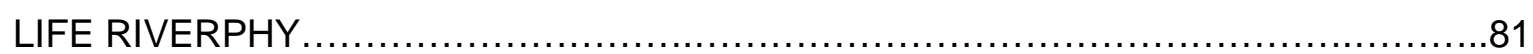

4.2.5 MORFOLOGÍA GENERAL DEL RÍO GUADALENTÍN .......................... 83

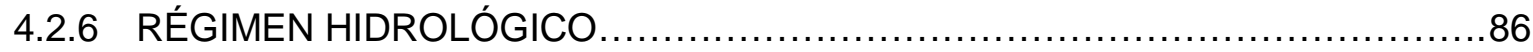

4.2.7 MODELIZACIÓN HIDRÁULICA DEL RÍO GUADALENTÍN $\ldots \ldots \ldots \ldots \ldots \ldots \ldots \ldots . \ldots$

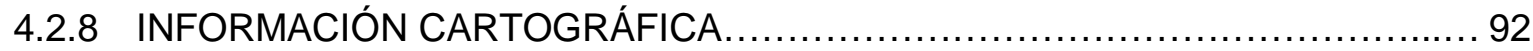

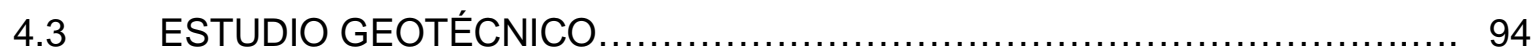

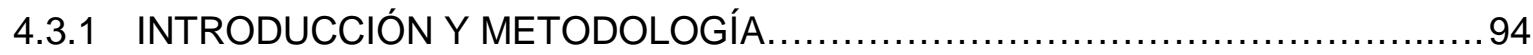

4.3.2 RESULTADOS DE LOS ANÁLISIS DE METALES EN LOS SEDIMENTOS....... 96

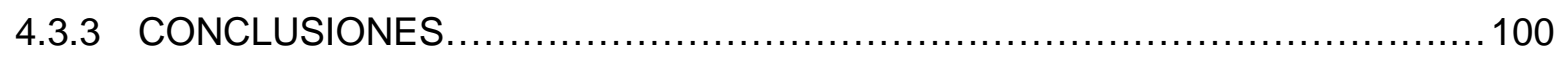

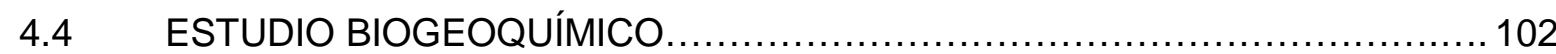

4.4.1 CARACTERIZACIÓN INICIAL DE LA ZONA DE ESTUDIO (LECHO

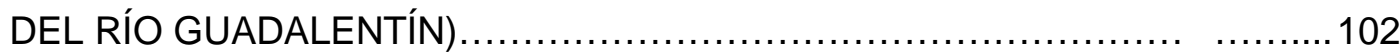

4.4.2 CONCLUSIÓN DE LA CARACTERIZACIÓN INICIAL $\ldots \ldots \ldots \ldots \ldots \ldots \ldots \ldots \ldots \ldots \ldots \ldots \ldots \ldots \ldots$

4.4.3 DELIMITACIÓN DE LA SUPERFICIE CONTAMINADA A REHABILITAR..........113

Capítulo 5. ESTUDIO DE FITOEXTRACCIÓN DE Cu, Zn Y Cr CON VEGETACIÓN AUTÓCTONA EN EL CAUCE DEL RÍO GUADALENTÍN

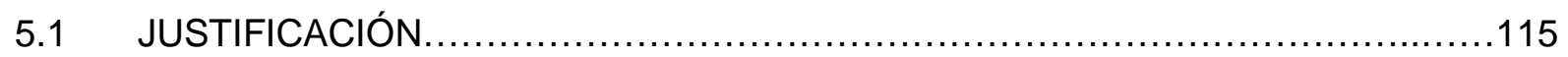

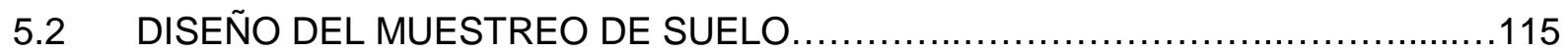

5.3 PARÁMETROS ANALIZADOS Y ANÁLISIS ESTADÍSTICO ......................117

5.4 EVOLUCIÓN 2013-2017 DE LOS RESULTADOS DE METALES PESADOS

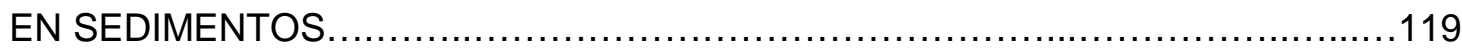

5.5 EVOLUCIÓN 2013-2017 DE LOS RESULTADOS FÍSICO-QUÍMICOS

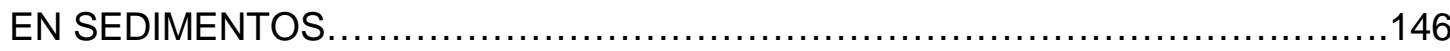

5.6 EVOLUCIÓN 2013-2017 DE LOS RESULTADOS BIOQUÍMICOS 


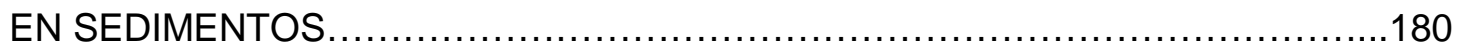

5.7 EFICIENCIA DE ELIMINACIÓN DE METALES EN SUELO ........................193

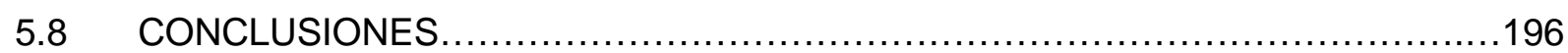

Capítulo 6. MONITORIZACIÓN AMBIENTAL DE LAS PROPIEDADES FÍSICO-QUÍMICAS Y BIOQUÍMICAS DE LOS SEDIMENTOS DEL SUELO EN PARCELAS EXPERIMENTALES TRATADAS CON AGENTES QUELANTES NATURALES $Y$ MICROORGANISMOS

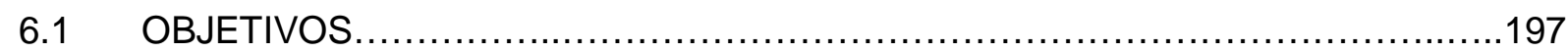

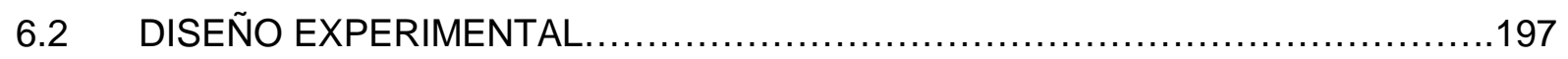

6.3 MUESTREOS, DETERMINACIONES ANALÍTICAS Y ANÁLISIS ESTADÍSTICO...200

6.4 EVOLUCIÓN ANUAL DE LAS CONCENTRACIONES DE METALES Y PROPIEDADES FÍSICO-QUÍMICAS Y BIOQUÍMICAS ............................202

6.5 EVOLUCIÓN QUINCENAL DE LAS CONCENTRACIONES DE METALES Y

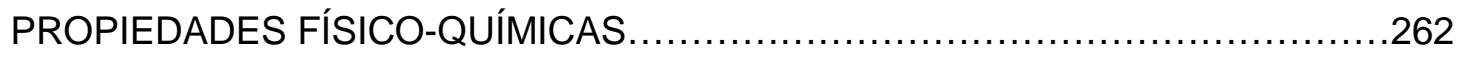

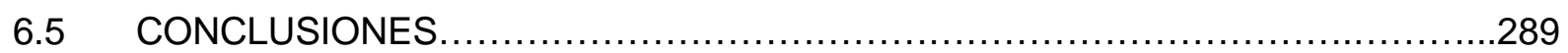

\section{Capítulo 7. REFERENCIAS}

ANEXOS (información en soporte digital):

Anexo 1. Planos 5.1-5.4. Planos de calados.

Anexo 2. Plano 4. Plano de zonas inundables.

Anexo 3. Planos 6.1-6.4. Plano de velocidades.

Anexo 4. Plano 1. Plano de situación y emplazamiento.

Anexo 5. Plano 2. Plano de estimación del DPH y zonas de servidumbre y policía.

Anexo 6. Plano 3. Plano de zona de flujo preferente.

Anexo 7. Plano 7. Plano cauce histórico 1928.

Anexo 8. Plano 8. Plano de perfiles transversales.

Anexo 9. Material geológico sondeos. 


\title{
ÍNDICE DE ABREVIATURAS
}

\author{
AA: aminoácidos \\ AC: ácido cítrico \\ AO: ácido oxálico \\ AOX: haluros orgánicos adsorbibles \\ BPF: bacterias Pseudomonas fluorescens \\ COV's: compuestos orgánicos volátiles \\ CT: control \\ DPH: dominio Público Hidráulico \\ DQO: demanda química de oxígeno \\ LIDAR: light Detection and Ranging ó Laser Imaging Detection and Ranking \\ MTD: mejor técnicas disponibles \\ NF: Niveles de Fondo \\ NGR: Niveles Genéricos de Referencia \\ p: peso \\ SNCZI: sistema Nacional de Cartografía de Zonas Inundables \\ SS: sólidos en suspensión \\ TKN: nitrógeno total Kjeldahl \\ UE: Unión Europea \\ v: volumen
}


Capítulo 1

\section{PLANTEAMIENTO Y OBJETIVOS}





\subsection{ORIGEN DE LA TEMÁTICA DESARROLLADA EN LA TESIS Y OBJETIVOS}

La ribera del Rio Guadalentín a su paso por el municipio de Lorca (Región de Murcia) se encuentra contaminada por metales pesados, principalmente por cromo procedente de los vertidos durante muchos años de las industrias del curtido de piel, así como por cobre y zinc de las granjas porcinas y de la agricultura como consecuencia de la fertilización excesiva con purines de cerdos, así como por vertidos directos al cauce. En la actualidad no existe ninguna legislación en la Región de Murcia que estipule unos valores límites legales de niveles genéricos para metales, pero la Subdirección General de Medio Ambiente sí cuenta con unos niveles genéricos de referencia de metales pesados para su uso en la Región de Murcia. La iniciativa de fitorremediación del cauce del Río Guadalentín forma parte del proyecto europeo LIFE 11 ENV/ES/000506 RIVERPHY "Rehabilitation of a heavy metal contaminated riverbed by phytoextraction technique" (2012-2018) y en el que participan la Subdirección General de Medio Ambiente de la Región de Murcia (Consejería de Empleo, Universidades, Empresa y Medio Ambiente), la Universidad Politécnica de Cartagena (Grupo de Investigación Gestión, Aprovechamiento y Recuperación de Suelos y Aguas), el Ayuntamiento de Lorca y la Confederación Hidrográfica del Segura.

El objetivo general de la presente tesis es evaluar, demostrar y difundir una alternativa sostenible para la recuperación ambiental de un tramo contaminado de $1500 \mathrm{~m}$ del Río Guadalentín tras su paso por el núcleo urbano de la ciudad de Lorca (Murcia). Este cauce está contaminado por metales pesados debido a antiguos vertidos directos por parte de industrias curtidoras (provocando contaminación por cromo) y granjas (provocando contaminación por cobre y zinc por vertido de purines porcinos y fertilizantes).

El objetivo del primer experimento en tramos en el cauce del Río Guadalentín (1500 m) fue:

- Evaluación del grado de contaminación por $\mathrm{Cu}, \mathrm{Cr}$ y Zn, su movilidad y su interacción con las propiedades físico-químicas y biológicas del suelo para definir una estrategia de fitoextracción.

Los objetivos del segundo experimento en parcelas experimentales en el cauce del Río Guadalentín fueron: 
- Estudio de la eficiencia de fitoextracción de $\mathrm{Cu}, \mathrm{Cr}$ y $\mathrm{Zn}$ mediante el uso de agentes quelantes naturales y microorganismos y la caracterización físicoquímica y biológica de las propiedades del sistema suelo-planta.

- Monitorización de la salinidad y biodisponibilidad de metales en suelo mediante la aplicación de agentes quelantes naturales y microorganismos.

\subsection{ESTRUCTURA DE LA TESIS}

La presente tesis doctoral está estructurada en 8 capítulos. A continuación, se presenta la organización detallada junto con un breve resumen de cada capítulo.

\section{Capítulo 1. Planteamiento y objetivos}

En el primer capítulo se ha realizado una breve introducción sobre la necesidad de esta investigación y cómo surgió la temática de esta tesis doctoral. Además se mencionan los objetivos de esta investigación.

Capítulo 2. Efectos ambientales de los residuos procedentes de la industria curtidora y de la ganadería porcina intensiva

El segundo capítulo trata sobre los aspectos generales y ambientales de la industria curtidora y de la ganadería porcina intensiva.

\section{Capítulo 3. Biorremediación: fitotecnologías y uso de la biomasa contaminada}

Este capítulo presenta las principales características de las técnicas de fitorremediación y de la biomasa contaminada.

\section{Capítulo 4. Características generales de la zona de estudio}

El capítulo cuarto expone la situación geográfica del cauce de estudio. Además presenta los resultados más sobresalientes de los estudios de hidrología, geofísica, geotecnia y biogeoquímica del cauce de estudio.

\section{Capítulo 5. Estudio de fitoextracción de $\mathrm{Cu}, \mathrm{Zn}$ y $\mathrm{Cr}$ con vegetación autóctona en el cauce del Río Guadalentín}

En el capítulo quinto se muestra la evolución de los resultados físico-químicos y bioquímicos de las muestras de los sedimentos del suelo muestreados en los años 2013 y 2017. 
Capítulo 6. Monitorización ambiental de las propiedades físico-químicas y bioquímicas de los sedimentos del suelo en parcelas experimentales tratadas con agentes quelantes naturales y microorganismos

Este capítulo muestra la evolución de los resultados de muestras de suelo en parcelas experimentales establecidas en el lecho del Guadalentín (tramos 1, 2 y 3) en 2015. Concretamente se muestran los resultados de la evolución anual 2015-2016-2017 y los resultados de la evolución quincenal 2016-2017.

\section{Capítulo 7. Conclusiones}

El séptimo capítulo presenta las conclusiones derivadas de los capítulos quinto y sexto sobre los experimentos realizados en campo.

\section{Capítulo 8. Referencias}

En el octavo y último capítulo aparecen recopiladas todas las referencias citadas en la presente tesis doctoral. 
Capítulo 2

EFECTOS AMBIENTALES DE LOS RESIDUOS PROCEDENTES DE LA INDUSTRIA CURTIDORA Y DE LA GANADERÍA PORCINA INTENSIVA 



\section{$2.1 \quad$ INTRODUCCIÓN Y LOS PROCESOS DE CURTICIÓN}

El curtido es un sector industrial de gran tradición en España, que desde unos inicios totalmente artesanales ha evolucionado progresivamente hasta alcanzar en el presente un alto grado de tecnificación. El sector está constituido por 99 empresas y da ocupación a unos 2219 trabajadores. La distribución geográfica de las empresas presenta una fuerte concentración en las Comunidades Autónomas de Cataluña, Comunidad Valenciana, Murcia. La producción del sector, en base a datos del año 2015, alcanza los 696 millones de euros. El curtido bovino supone alrededor del $66 \%$ del total de la producción del sector, seguido del ovino con y sin lana, que representa el $17 \%$, y el $14 \%$, que corresponde al resto de la curtición de piel caprina, porcina, conejo y reptil. El comercio exterior de curtido acabado en 2015 presenta un saldo negativo, con unas exportaciones de 364 millones de euros, (alrededor del 52\% de la producción), y unas importaciones de 494 millones de euros. Las cifras de exportación e importación incluyen los intercambios intracomunitarios.

La UE en su conjunto es el principal destino de las exportaciones de curtido acabado español, absorbiendo en el año 2015 el 67\% de las mismas. Los principales países de destino del curtido acabado son Italia, Portugal, Francia, Marruecos, China, Hong-Kong, Vietnam, Corea del Sur, Alemania, Rumanía, India y Reino Unido lo que certifica el prestigio y reconocimiento del curtido español, consecuencia de su alto contenido de diseño y moda, del know how y de la calidad de sus pieles.

Tabla 2.1.1. Clasificación de la industria del curtido según el tamaño de la empresa.

\begin{tabular}{|c|c|}
\hline $\mathbf{N}^{\circ}$ de trabajadores & $\mathbf{N}^{\mathbf{0}}$ de Empresas \\
\hline $1-10$ & 42 \\
\hline $11-20$ & 21 \\
\hline $21-50$ & 18 \\
\hline $51-100$ & 12 \\
\hline$>100$ & 6 \\
\hline Total & 99 \\
\hline
\end{tabular}

Fuente: http://www.leather-spain.com. 
Tabla 2.2.2. Distribución de la industria del curtido por comunidad autónoma.

\begin{tabular}{|c|c|c|}
\hline & $\mathbf{N}^{\mathbf{0}}$ de empresas & $\mathbf{N}^{\mathbf{0}}$ de trabajadores \\
\hline Cataluña & 49 & 1020 \\
\hline Valencia & 27 & 522 \\
\hline Murcia & 10 & 239 \\
\hline Madrid & 6 & 217 \\
\hline Otras & 7 & 206 \\
\hline Total & 99 & 2204 \\
\hline
\end{tabular}

Fuente: http://www.leather-spain.com.

Tabla 2.2.3. Producción del curtido en valor. (Miles $€$ )

\begin{tabular}{|c|c|c|c|c|c|}
\hline & $\mathbf{2 0 1 1}$ & $\mathbf{2 0 1 2}$ & $\mathbf{2 0 1 3}$ & $\mathbf{2 0 1 4}$ & $\mathbf{2 0 1 5}$ \\
\hline Suela & 28.970 & 28.101 & 28.101 & 28.185 & 26.775 \\
\hline Vacuno & 459.736 & 460.656 & 460.656 & 481.846 & 457.754 \\
\hline Ovino sin lana & 69.166 & 729.000 & 78.000 & 67.860 & 63.789 \\
\hline Caprino & 36.000 & 37.800 & 34.020 & 27.896 & 32.000 \\
\hline Otros & 56.000 & 60.000 & 63.000 & 63.945 & 60.747 \\
\hline Double Face & 65.000 & 67.000 & 62.868 & 58.467 & 55.544 \\
\hline Total & 14.872 & 726.457 & 726.645 & 728.199 & 696.609 \\
\hline \multicolumn{7}{|c|}{ Fuente: http://www.leather-spain.com. }
\end{tabular}

Aunque a escala macroeconómica no es una actividad relevante, su concentración geográfica hace que tenga una importancia relativa en la economía local de Lorca (Región de Murcia). En la actualidad, componen el sector alrededor de una decena de industrias con unos 200 trabajadores, según datos de ACEXPIEL (Asociación Española del Curtido). Según datos del INE en el año 2015, habían 34 empresas regionales ejerciendo trabajos en este sector.

A pesar de la tendencia general a la deslocalización de la producción de materias primas e intermedias (en especial las vinculadas al sector primario), y a la reducción de la capacidad de producción hacia países en vías de desarrollo, el curtido lorquino ha mantenido su actividad e incluso ha incrementado su volumen de exportación en el periodo 2010-2015. Esta actividad sectorial concentrada geográficamente, ha propiciado la aparición y el desarrollo en la zona de industrias y servicios conexos y de apoyo, entre las que destacan una empresa de fabricación de maquinaria de notable prestigio, diversos suministradores químicos y una instalación colectiva avanzada e innovadora, de tratamiento de aguas residuales. La estructura empresarial del sector del curtido de Lorca se caracteriza por una relativa concentración y por un tamaño medio elevado en el contexto de las pymes regionales. Se trata de un tejido empresarial 
maduro y con una presencia notable de empresas familiares, característico de sectores tradicionales. La industria del curtido regional no ha desarrollado procesos de integración vertical, estando la gran mayoría de las empresas centradas en los procesos de curtición, acabado y tinte de pieles de vacuno, a partir de materia prima en bruto o semicurtida.

Las técnicas utilizadas para curtir varían en función del producto que se quiere obtener y de la piel o cuero del que se parte. El proceso se divide en una serie de etapas, durante las cuales las pieles se van sometiendo a diversos procesos y se tratan con diversos productos químicos. A continuación se explicarán las etapas de un proceso de curtidos convencional, diferenciándose entre las etapas de los procesos de curtición de pieles de vacuno y pieles de ovino. Posteriormente se detallarán las diferencias entre los procesos de curtición más usuales. En el apartado 2.1.1 de este capítulo se explican las etapas de un proceso de curtidos convencional, para posteriormente en el apartado 2.1.3, describir las diferencias entre los diferentes procesos más usuales. Cabe destacar que las etapas varían entre los procesos de curtición de pieles de vacuno y pieles de ovino; en la descripción de las etapas se explicarán dichas diferencias cuando existan.

\subsubsection{ETAPAS DE UN PROCESO CONVENCIONAL DE CURTICIÓN}

En este apartado se describen las 20 etapas de un proceso convencional de curtición de forma secuencial, tal y como se realizan en la industria. Las etapas son las siguientes:
1) Recorte
11) Rebajado
2) Conservación
12) Neutralizado
3) Remojo
13) Recurtición
4) Pelambre y calero
14) Tintura
5) Descarnado
15) Engrase
6) Dividido
16) Escurrir/repasar
7) Rendido
17) Secado
8) Piquelado
18) Operaciones mecánicas
9) Desengrase
19) Acabado
10) Curtición
20) Prensado

Hay que tener en cuenta que se trata de una descripción básica y, por lo tanto, algunos de los procesos industriales que se aplican actualmente pueden tener diferencias significativas 
respecto al proceso convencional que aquí se presenta. Para cada etapa se presenta en primer lugar un tabla donde se describe la función de dicha etapa, los productos químicos más importantes que se consumen (columna izquierda) y los efluentes más significativos de dicha etapa (columna derecha). A continuación se muestra la información referente a la primera etapa de un proceso convencional de curtición:

Tabla 2.1.1.1. Información etapa de recorte de un proceso convencional de curtición.

\begin{tabular}{ccc}
\hline ENTRADA & RECORTE & SALIDA \\
\hline Piel fresca o salada & $\begin{array}{c}\text { Recortar las partes no } \\
\text { deseadas de la piel }\end{array}$ & Recortes con ó sin sal
\end{tabular}

Fuente: Guía mejores técnicas disponibles en España del sector de curtidos. Ministerio Medio Ambiente, 2003.

Es muy importante realizar la etapa de recorte de trozos no deseados puesto que permite ahorrar productos químicos utilizados en la conservación y ribera (principalmente sal). Esta etapa puede realizarse también con posterioridad a la conservación con sal. En el caso del proceso de curtición de piel pequeña esta etapa se realiza prácticamente en todas las tenerías. El trabajo de ribera es el conjunto de operaciones mecánicas y procesos químicos para eliminar de la piel todo lo inadecuado para la obtención del cuero confeccionable, preparando la estructura fibrosa de la piel hasta llegar a la curtición propiamente dicha. Incluye las operaciones de remojo, pelambre y calero, descarnado, dividido, rendido y piquelado.

Tabla 2.1.1.2. Información etapa de conservación de un proceso convencional de curtición.

\begin{tabular}{ccc}
\hline ENTRADA & CONSERVACIÓN & SALIDA \\
\hline Sal & $\begin{array}{l}\text { Tratamiento con sal o } \\
\text { putrefacción de la piel }\end{array}$ & Sal sucia
\end{tabular}

Fuente: Guía mejores técnicas disponibles en España del sector de curtidos. Ministerio Medio Ambiente, 2003.

Cuando el material no puede procesarse inmediatamente debe conservarse para evitar la putrefacción y pérdida de calidad de la materia prima. El tiempo entre recogida y preparación debe ser lo más breve posible. El proceso de conservación se realiza en los centros de recolección, dentro o fuera de los mataderos. Se suele conservar la materia prima en los mataderos y algunas veces los recolectores/almacenistas vuelven a reconservar y almacenar la materia en zonas frías del almacén o empleando frigoríficos. Los grados de conservación de la piel varían, aunque hoy día todas las pieles están preparadas para poder ser almacenadas y 


\section{LA GANADERÍA PORCINA INTENSIVA}

transportadas a cualquier lugar del mundo. Las técnicas de conservación más usuales son el salado y el secado.

Tabla 2.1.1.3. Información etapa de remojo de un proceso convencional de curtición.

\begin{tabular}{ccc}
\hline ENTRADA & REMOJO & SALIDA \\
\hline Agua & Limpiar y restablecer el & \\
Tensoactivos & $\begin{array}{c}\text { nivel de hidratación de la } \\
\text { piel }\end{array}$ & $\begin{array}{c}\text { Agua residual sucia y } \\
\text { salada }\end{array}$ \\
Enzimas & sada
\end{tabular}

Fuente: Guía mejores técnicas disponibles en España del sector de curtidos. Ministerio Medio Ambiente, 2003.

El remojo es la primera etapa de la fabricación en sí. Su función es la de restablecer el nivel de hidratación de la piel y empezar su limpieza y preparación para el curtido. La etapa de remojo depende del estado de las pieles y del método de conservación empleado. En general esta etapa se realiza en dos fases: una primera fase de limpieza y otra segunda fase de humectación, realizándose diferentes cambios de baño, así como la adición de auxiliares como tensoactivos, biocidas, productos alcalinos, enzimas de remojo, etc.

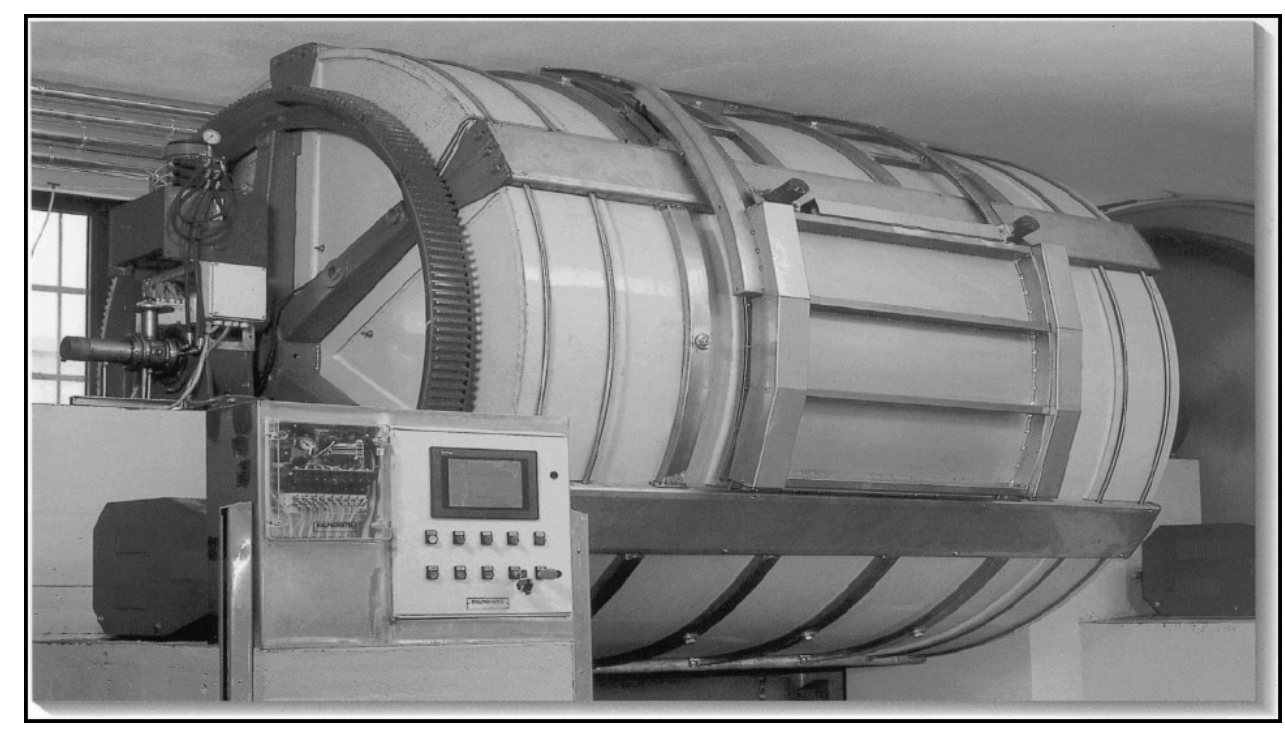

Figura 2.1.1.1. Bombo de remojo.

Fuente: Guía mejores técnicas disponibles en España del sector de curtidos. Ministerio Medio Ambiente, 2003.

La etapa puede realizarse en distintos tipos de recipientes: tinas, molinetas, bombos y mixers. La duración va desde horas hasta uno o dos días. En la anterior figura se muestra un ejemplo de bombo de remojo. 
Capítulo 2. EFECTOS AMBIENTALES DE LOS RESIDUOS PROCEDENTES DE LA INDUSTRIA CURTIDORA Y DE LA GANADERÍA PORCINA INTENSIVA

Tabla 2.1.1.4. Información etapa de pelambre y calero de un proceso convencional de curtición.

\begin{tabular}{ccc}
\hline ENTRADA & PELAMBRE Y CALERO & SALIDA \\
\hline $\begin{array}{c}\text { Agua } \\
\text { sulfuro o sulfhidrato } \\
\text { sódico }\end{array}$ & $\begin{array}{c}\text { Eliminar el pelo que está } \\
\text { fijado en la piel }\end{array}$ & $\begin{array}{c}\text { Agua residual alcalina y } \\
\text { sulfurada, con carga } \\
\text { orgánica elevada }\end{array}$ \\
Hidróxido cálcico & &
\end{tabular}

Fuente: Guía mejores técnicas disponibles en España del sector de curtidos. Ministerio Medio Ambiente, 2003.

La función de la etapa de pelambre es la de eliminar las raíces del pelo, la epidermis y el pelo, y dejar limpio el lado flor para las siguientes etapas y a la vez, producir una hidrólisis alcalina. Para la hidrólisis se utiliza sulfuro sódico ( $\mathrm{NaHS}, \mathrm{Na}_{2} \mathrm{~S}$ ) e hidróxido sódico y cálcico $(\mathrm{NaOH}$; $\left.\mathrm{Ca}(\mathrm{OH})_{2}\right)$. Por otro lado, en la etapa de calero, que consiste en homogeneizar el contacto de las sustancias alcalinas en la piel, provocando la una relajación de la estructura interfibrilar y de la epidermis, abriendo las fibras, y produciendo un hinchamiento de la piel, la cual se hidroliza y permite la penetración de los productos químicos en etapas posteriores. Como sustitutos parciales al sulfuro pueden usarse tioglicolatos, mercaptanos, aminas, enzimas. Hay procesos que evitan la hidrólisis del pelo y así reducen la carga contaminante en los efluentes. Al final de la etapa se efectúa un lavado exhaustivo para dejar la piel menos resbaladiza y en condiciones de ir a la etapa siguiente.

Tabla 2.1.1.5. Información etapa de descarnado de un proceso convencional de curtición.

\begin{tabular}{ccc}
\hline ENTRADA & DESCARNADO & SALIDA \\
\hline Agua & $\begin{array}{c}\text { Operación mecánica } \\
\text { donde eliminamos el tejido } \\
\text { adiposo de la piel } \\
\text { mediante cilindro de } \\
\text { cuchillas }\end{array}$ & Carnazas y agua alcalina \\
& &
\end{tabular}

Fuente: Guía mejores técnicas disponibles en España del sector de curtidos. Ministerio Medio Ambiente, 2003.

La etapa de pelambre y calero es la que se utiliza normalmente para piel vacuna. Para el caso de piel pequeña el proceso suele ser distinto, puesto que la etapa de dividido no se realiza, y se suele utilizar un deslanado-calero en lugar de pelambre-calero. En la tabla anterior se muestran los detalles sobre la séptima etapa de descarnado de un proceso convencional de curtición: 
El descarnado es una operación mecánica para limpiar la piel y eliminar el tejido adiposo adherido a la parte interna de la piel, y dejarla limpia, homogénea y preparada para ir recibiendo los productos siguientes. La máquina donde se realiza el descarnado es un cilindro con cuchillas helicoidales. Al aprisionar la piel entre unos cilindros y entrar en contacto con dichas cuchillas estas cortan y eliminan el material no deseado. Se puede realizar en distintos estados de la piel: cuando está fresca, después del remojo, después del calero o después del desencalado-rendido, que ha servido para la eliminación de la cal, unida químicamente, absorbida en los capilares, etc. Se llama descarnado en "verde" cuando se realiza antes del pelambre y calero, y descarnado en "tripa" cuando se realiza después del calero. Después del descarnado y una vez recortados los bordes desiguales, el cuero se pesa. Este peso se llama "peso tripa" y es el peso base para las operaciones siguientes. La Figura 2.1.1.2 muestra un esquema del proceso de funcionamiento de la máquina de descarnar.

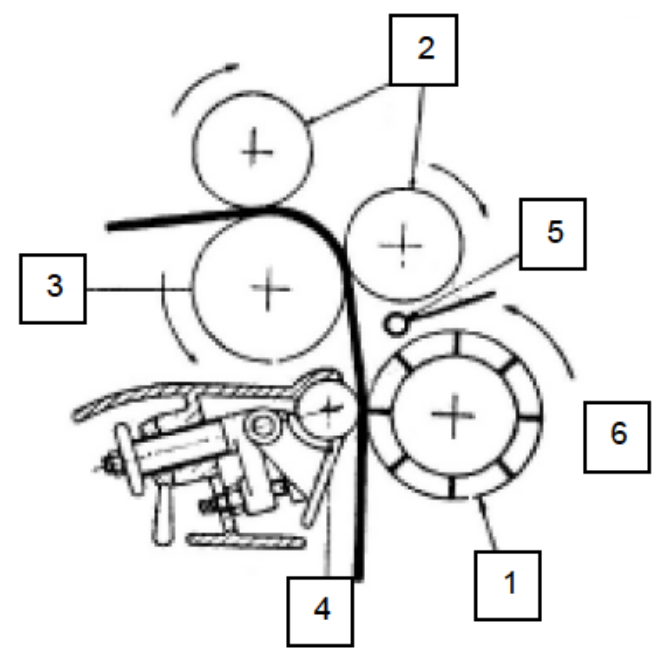
1. Cilindro de cuchillas
2. Cilindros de transporte
3. Cillindro de apoyo
4. Cilindro de presión
5. Conducción de agua
6. Afiladora

Figura 2.1.1.2. Esquema de la máquina de descarnar.

Fuente: Guía mejores técnicas disponibles en España del sector de curtidos. Ministerio Medio Ambiente, 2003.

A continuación se muestran los detalles sobre las etapas de dividido y rendido: 
Capítulo 2. EFECTOS AMBIENTALES DE LOS RESIDUOS PROCEDENTES DE LA INDUSTRIA CURTIDORA Y DE LA GANADERÍA PORCINA INTENSIVA

Tabla 2.1.1.6. Información etapa de dividido de un proceso convencional de curtición.

\begin{tabular}{ccc}
\hline ENTRADA & DIVIDIDO & SALIDA \\
\hline & Se regula el grosor de las \\
pieles mediante un corte \\
horizontal del material, \\
obteniendo diferentes \\
capas del cuero: flor y \\
singidir
\end{tabular}

Fuente: Guía mejores técnicas disponibles en España del sector de curtidos. Ministerio Medio Ambiente. 2003

Tabla 2.1.1.7. Información etapa de rendido de un proceso convencional de curtición.

\begin{tabular}{ccc}
\hline ENTRADA & RENDIDO & SALIDA \\
\hline Enzimas & $\begin{array}{c}\text { Acción enzimática para } \\
\text { degradar las fibras de la } \\
\text { dermis }\end{array}$ & $\begin{array}{c}\text { Agua residual ligeramente } \\
\text { básica/neutra }\end{array}$
\end{tabular}

Fuente: Guía mejores técnicas disponibles en España del sector de curtidos. Ministerio Medio Ambiente, 2003.

Se realiza a continuación de la etapa de desencalado en el mismo baño o en un baño aparte, y consiste en la adición de enzimas después de alcanzar el pH óptimo para las mismas. Su objetivo es la degradación parcial de las fibras cementantes de la dermis a fin de conseguir la relajación y la apertura fibrilar suficiente, para dar blandura a la piel por un lado, y elasticidad y finura a la flor por otro lado, así como una limpieza general de la piel. En ante lana (doble face), piel lanar curtida y acabada con afelpado por el lado carne, que lleva su lana corta original sobre el lado flor, si se realiza esta etapa es para obtener fundamentalmente blandura. En el caso contrario, se compensa reposando o engrasando en piquel. Al final de la etapa se realiza un buen lavado con agua fría para eliminar la suciedad, desactivar las enzimas y enfriar las pieles.

Tabla 2.1.1.8. Información etapa de piquelado de un proceso convencional de curtición.

\begin{tabular}{ccc}
\hline ENTRADA & PIQUELADO & SALIDA \\
\hline Agua & Ajuste de pH para & \\
Sal & $\begin{array}{c}\text { Agua residual ácida y } \\
\text { sroceder a las etapas de } \\
\text { curtición siguientes }\end{array}$ & $\begin{array}{c}\text { salina } \\
\text { Ácidos fuertes y/o débiles }\end{array}$
\end{tabular}

Fuente: Guía mejores técnicas disponibles en España del sector de curtidos. Ministerio Medio Ambiente, 2003.

El piquelado es una etapa en la que podemos obtener la piel ya limpia para su conservación, 
o bien ajustar el $\mathrm{pH}$, habitualmente en valores inferiores a 3,8, para poder proceder a las etapas de curtición siguientes. Se realiza usando soluciones salinas ( $\mathrm{NaCl}$ ) entre el 12-15\% de concentración, y el empleo de ácidos fuertes y/o débiles. Si el piquelado es para conservar las pieles también se emplean fungicidas. Este piquelado de conservación es útil en pieles lanares, ya que con el reposo en piquel se consigue preparar la piel para que la grasa pueda ser extraída con más facilidad. Los efluentes de salida llevan una elevada carga salina y ácida.

Tabla 2.1.1.9. Información etapa de desengrase de un proceso convencional de curtición.

\begin{tabular}{ccc}
\hline ENTRADA & DESENGRASE & SALIDA \\
\hline Tensioactivos & Erasa \\
Disolventes & $\begin{array}{c}\text { Eliminación del exceso de } \\
\text { grasa natural de la piel }\end{array}$ & Agua residual neutra \\
Sal & a
\end{tabular}

Fuente: Guía mejores técnicas disponibles en España del sector de curtidos. Ministerio Medio Ambiente, 2003.

La etapa de desengrase implica el uso de tensoactivos o bien el uso de tensoactivos y disolventes en medio acuoso. Se emplea agua a $35^{\circ} \mathrm{C}$, con sal o sin sal, según sea el método empleado con relación al pH de la piel. En esta etapa se elimina la materia orgánica (grasa) la cual es un foco de contaminación de los efluentes y por tanto requiere una elevada cantidad de productos químicos (solventes y/o tensoactivos), y por otro lado genera una gran cantidad de aguas residuales con una carga salina considerable. Ocasiona pues una elevada carga contaminante. El desengrase también puede realizarse en pieles ovinas en "crust", este tipo de desengrase implica el uso de disolventes orgánicos (percloroetileno) en máquinas de limpieza en seco, ss frecuente en artículos tipo ante. En pieles vacunas la etapa de desengrase puede realizarse después de la etapa de calero o bien tras del desencalado y rendido. A continuación se muestran los detalles sobre la etapa de curtición. 
Tabla 2.1.1.10. Información etapa de curtición de un proceso convencional de curtición.

\begin{tabular}{|c|c|c|}
\hline ENTRADA & CURTICIÓN & SALIDA \\
\hline $\begin{array}{l}\text { CURTICIÓN AL CROMO: } \\
\text { sal de cromo, formiato } \\
\text { sódico, sales orgánicas y } \\
\text { bicarbonato sódico. }\end{array}$ & & $\begin{array}{c}\text { CURTICIÓN AL CROMO: } \\
\text { Agua residual ácida con } \\
\text { Cr (III) }\end{array}$ \\
\hline $\begin{array}{l}\text { CURTICIÓN VEGETAL: } \\
\text { extractos vegetales y } \\
\text { taninos sintéticos }\end{array}$ & putrefacc & $\begin{array}{l}\text { CURTICIÓN VEGETAL: } \\
\text { agua residual con } \\
\text { extractos vegetales y } \\
\text { productos sintéticos }\end{array}$ \\
\hline
\end{tabular}

Fuente: Guía mejores técnicas disponibles en España del sector de curtidos. Ministerio Medio Ambiente, 2003.

En la etapa de curtición al cromo se utiliza agua salada con una concentración de unos $6^{\circ}$ Be, y sulfato básico de cromo (III). La equivalencia entre ${ }^{\circ}$ Be y densidad es la siguiente:

- Para líquidos más densos que el agua $\left(\rho>1 \mathrm{~g} / \mathrm{cm}^{3}\right)$ :

$$
{ }^{\circ} \mathrm{Be}=145-145 / \rho
$$

- Para líquidos menos densos que el agua $\left(\rho<1 \mathrm{~g} / \mathrm{cm}^{3}\right)$ :

$$
{ }^{\circ} \mathrm{Be}=140 / \rho-130
$$

Para optimizar el proceso se emplean además agentes complejantes orgánicos (ftalatos y similares), y para conseguir la fijación del cromo a la piel se emplean sustancias básicas como el carbonato y bicarbonato de sodio, el óxido de magnesio y similares. Además, se añaden además pequeñas cantidades de fungicidas con el fin de evitar la aparición de hongos durante un posible período de conservación de la piel con exceso de humedad (wet-blue), lo que es la piel después de la fase de piquelado sin eliminar el exceso de. Mediante este proceso se tiene la piel preparada para su conservación (wet-blue) o lista para proseguir el proceso y obtener el artículo deseado. La carga contaminante que se produce en esta etapa es importante debido a la cantidad de sal empleada, además de la presencia de sales de cromo (III), tanto en el baño residual de curtición como en los lavados posteriores.

En la etapa de curtición vegetal se utiliza agua sin sal o con poca sal y extractos vegetales. Para mejorar el resultado también se emplean sintanes como agente precurtiente precurtientes y dispersantes, así como algún ácido débil para fijar taninos. Los sintanes son taninos sintéticos 
que usados como agente precurtiente hace que los taninos vegetales penetren más rápidamente en la piel. Además, se añaden pequeñas cantidades de fungicidas a fin de evitar la aparición de hongos durante el corto reposo posterior de las pieles. Mediante este proceso se tiene la piel preparada para obtener el artículo deseado. Una parte importante del material empleado en los baños de curtición vegetal se reciclan.

A continuación tiene lugar la etapa de rebajado:

Tabla 2.1.1.11. Información etapa de rebajado de un proceso convencional de curtición.

\begin{tabular}{ccc}
\hline ENTRADA & REBAJADO & SALIDA \\
\hline Piel sin rebajar & $\begin{array}{c}\text { Ajusta e iguala el grosor } \\
\text { de la piel al valor deseado }\end{array}$ & Viruta de piel \\
\hline
\end{tabular}

Fuente: Guia mejores técnicas disponibles en España del sector de curtidos. Ministerio Medio Ambiente, 2003.

Antes de la etapa de rebajado se procede a un escurrido mecánico con el fin de reducir la humedad y estirar las pieles. Las pieles escurridas, abiertas y planas se pasan a la máquina de rebajar que, provista de un cilindro con cuchillas helicoidales cortantes y un cilindro de apoyo metálico, iguala sus grosores al valor deseado. El objetivo de esta etapa es proporcionar un grosor uniforme, se puede realizar en húmedo cuando las pieles (o cueros) están curtidas o recurtidas o en seco cuando las pieles están en crust, teñidas o acabadas. En la etapa de rebajado se generan virutas de piel al cromo o al vegetal (según el proceso de curtición). En la siguiente figura se muestra el esquema de funcionamiento de una máquina de rebajar.

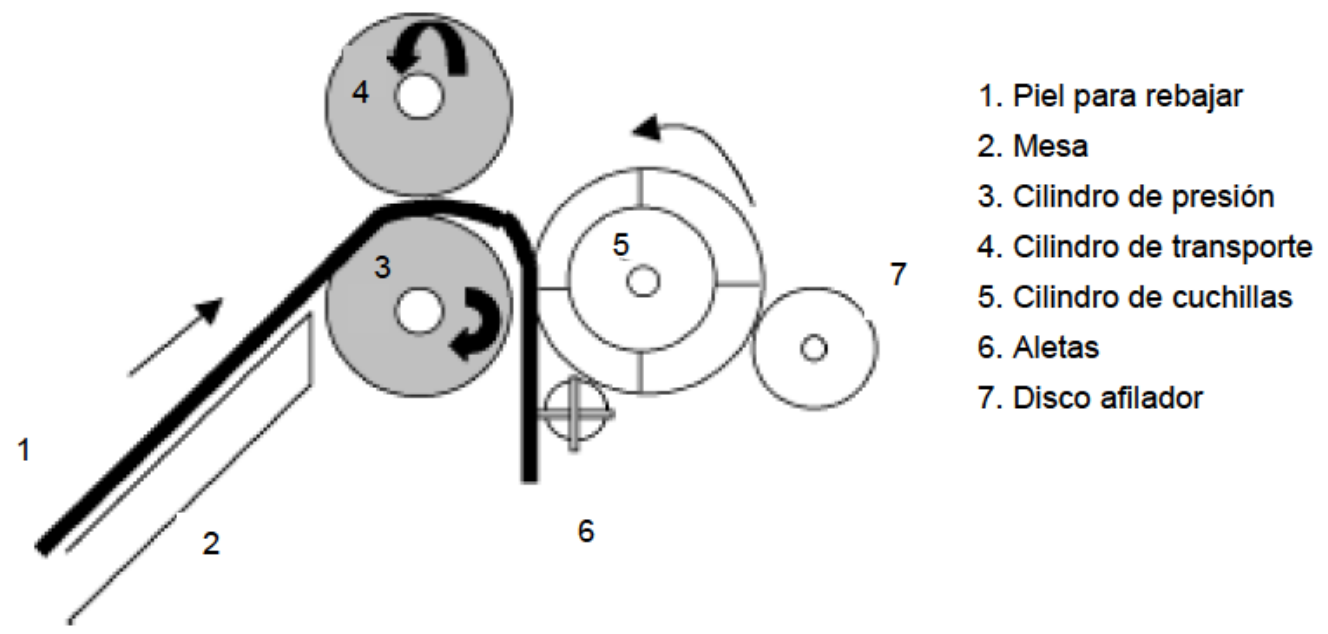

Figura 2.1.1.3. Esquema de la máquina de rebajar.

Fuente: Guía mejores técnicas disponibles en España del sector de curtidos. Ministerio Medio Ambiente, 2003. 
Capítulo 2. EFECTOS AMBIENTALES DE LOS RESIDUOS PROCEDENTES DE LA INDUSTRIA CURTIDORA Y DE LA GANADERÍA PORCINA INTENSIVA

Tabla 2.1.1.12. Información etapa de neutralizado de un proceso convencional de curtición.

\begin{tabular}{ccc}
\hline ENTRADA & NEUTRALIZADO & SALIDA \\
\hline Agua & $\begin{array}{c}\text { Adecuación del pH para } \\
\text { poder efectuar } \\
\text { correctamente la } \\
\text { recurtición, tintura y } \\
\text { engrase posteriores }\end{array}$ & Agua residual \\
& & \\
\hline
\end{tabular}

En la etapa de neutralizado de las pieles con curtición al cromo se reduce el pH del medio a valores menos ácidos ( $\mathrm{pH}=4,5-5,5$ según los casos) a fin de evitar los posibles efectos perniciosos del ácido sulfúrico residual que puede quedar procedente de la fase de piquelado y además se reduce el pH para poder efectuar correctamente la recurtición, tintura y engrase posteriores. Para ello se emplean productos de hidrólisis alcalina débil (formiatos, acetatos, bicarbonatos sódicos, etc.), en general son neutralizantes y complejantes de base sintética que ayudan a mejorar la calidad del artículo final. También se puede usar bicarbonato amónico. A continuación se pueden mecanizar y secar las pieles para obtener "crust", si han sido ya engrasadas durante la curtición al cromo. Se generan aguas con unas pocas sales y curtientes también en poca cantidad.

Tabla 2.1.1.13. Información etapa de recurtición de un proceso convencional de curtición.

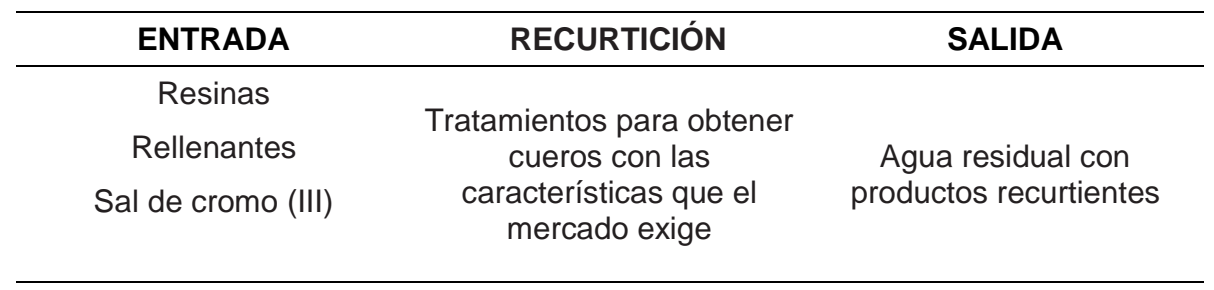

Debido a que la curtición al cromo no da a los cueros y pieles la plenitud ni todas las características que el mercado exige, los cueros y pieles curtidas al cromo en general se someten a otra etapa de recurtición. Esta recurtición se realiza empleando sintanes, extractos vegetales, resinas acrílicas, resinas mixtas, resinas a base de melamina, aldehídos, proteínas e hidratos de carbono como rellenantes. Con estos tratamientos se pretende obtener cueros con las características que el mercado exige para cada artículo concreto. Los cueros para empeine (fabricación de zapatos), tapicería, marroquinería (artículos como bolsos, estuches, etc) y similares, ya curtidos y neutralizados se someten a la recurtición en una etapa previa a las etapas de tintura y engrase, o conjuntamente con las etapas citadas 
empleando un proceso compacto. Las aguas residuales de la etapa de recurtición presentan un $\mathrm{pH}$ ligeramente ácido, contienen algunas sales y los restos de los productos recurtientes no fijados en la piel.

Tabla 2.1.1.14. Información etapa de tintura de un proceso convencional de curtición.

\begin{tabular}{|c|c|c|}
\hline ENTRADA & TINTURA & SALIDA \\
\hline $\begin{array}{c}\text { Colorante } \\
\text { Ácido fórmico } \\
\text { Productos auxiliares }\end{array}$ & $\begin{array}{l}\text { Da a las pieles el color y } \\
\text { las solideces deseadas } \\
\text { por el cliente }\end{array}$ & $\begin{array}{c}\text { Agua residual ácida y } \\
\text { coloreada }\end{array}$ \\
\hline
\end{tabular}

Las pieles neutralizadas, recurtidas o no, son sometidas a un tratamiento de tintura con colorantes, ácido fórmico y otros productos auxiliares con el fin de dar a la piel el color y las características deseadas. El ácido fórmico se usa para disminuir el pH del medio y mejorar la fijación del colorante a la piel, en ocasiones incluso se emplean productos catiónicos (resinas, tensoactivos y sales metálicas). Además de colorantes y ácido fórmico se usan productos auxiliares (tensoactivos, dispersantes, amoniaco, etc.) para mejorar la penetración y la igualación de la tintura en el cuero. El grado de contaminación de las aguas residuales es muy variable, dependiendo del grado de fijación del colorante al cuero, así como la carga de sales que llevan algunos productos, auxiliares y del ácido fórmico residual, por ejemplo en ante, ante lana (doble face) y en algunos otros casos como nobuck, las pieles proceden de estado crust esmerilado, es decir son pieles simplemente curtidas, secadas después de la neutralización y engrase, sin haber recibido tintura ni acabado.

Tabla 2.1.1.15. Información etapa de engrase de un proceso convencional de curtición.

\begin{tabular}{|c|c|c|}
\hline ENTRADA & ENGRASE & SALIDA \\
\hline Agua & & \\
\hline $\begin{array}{c}\text { Aceite emulsionado } \\
\text { Ácido fórmico y } \\
\text { Eventualemente sales de } \\
\text { Cromo (III) }\end{array}$ & $\begin{array}{l}\text { Da a las pieles el tacto, } \\
\text { suavidad e hidrofugación } \\
\text { deseadas por el cliente }\end{array}$ & $\begin{array}{c}\text { Agua residual con restos } \\
\text { de emulsionante }(y \\
\text { ventualmente sales de } \\
\text { Cromo (III) }\end{array}$ \\
\hline
\end{tabular}

Las pieles neutralizadas, recurtidas o no, en el mismo baño de tintura o en un baño aparte son tratadas con aceites emulsionables con el fin de lubricar las fibras y evitar que se unan unas pieles a otras durante la etapa de secado, obteniéndose así la flexibilidad y suavidad necesarias 
además de un cierto aumento de las resistencias físicas de las mismas. En algunas ocasiones (no frecuentemente) el engrase se realiza antes de la etapa de tintura.

Los productos empleados en la etapa de engrase son aceites vegetales, animales y minera- les, convertidos en emulsionables mediante operaciones de sulfonación, sulfitación, fosfatación, sulfocloración y/o mediante la adición de tensoactivos y algún alcohol miscible en el agua. Al final del proceso se puede realizar un enjuague antes de apilar las pieles. La fijación del engrase se consigue con un inicio de rotura de la emulsión, mediante una disminución de pH o sencillamente, con la reacción con las cargas catiónicas de la piel durante el tiempo de contacto. Si se pretende obtener hidrofugación, es decir obtener pieles repelentes y resistentes al agua, se escogen aceites especiales y la fijación se realiza adicionando sales de cromo, además de el ácido fórmico. Los baños resultantes de la etapa de engrase contienen restos de grasas no fijadas, tensoactivos y algún compuesto alcohólico, así como restos de ácido fórmico y de funguicidas si se han empleado.

Tabla 2.1.1.16. Información etapa de escurrir/repasar de un proceso convencional de curtición.

\begin{tabular}{ccc}
\hline ENTRADA & ESCURRIR/REPASAR & SALIDA \\
\hline Piel sin escurrir/repasar & $\begin{array}{c}\text { Eliminar el agua sobrante } \\
\text { y aumentar la superficie } \\
\text { de la piel. Permite reducir } \\
\text { el tiempo y la temperatura } \\
\text { en la fase del secado }\end{array}$ \\
& Agua con trazas de ácido \\
\hline
\end{tabular}

Las pieles teñidas o no teñidas, engrasadas y apiladas tras haber reposado un cierto tiempo se someten a las etapas de escurrido y estirado en húmedo con máquinas al efecto. Durante el proceso, en la etapa de escurrido se generan aguas residuales del mismo tipo que las que aguas que se generan en el baño final de de las etapas de tintura y engrase. En la siguiente figura se muestra el esquema del funcionamiento de la máquina de escurrir/repasar. 


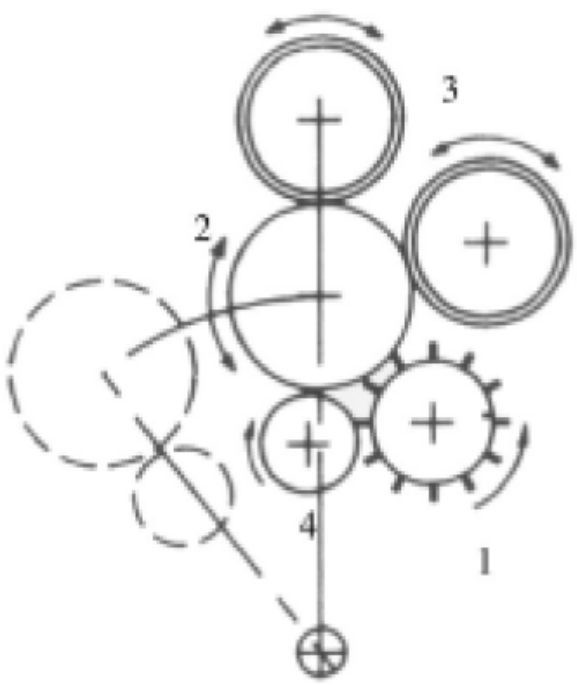

1. Cilindro de cuchillas

2. Cilindro de apoyo

3. Cilindro recubierto de fieltro

4. Cilindro de acercamiento o cachepi

Figura 2.1.1.4. Esquema de la máquina de escurrir/repasar.

Tabla 2.1.1.17. Información etapa de secado de un proceso convencional de curtición.

\begin{tabular}{ccc}
\hline ENTRADA & SECADO & SALIDA \\
\hline Aire caliente & $\begin{array}{c}\text { Permite obtener un cuero } \\
\text { con un contenido de } \\
\text { humedad bajo }(12 \%)\end{array}$ & Vapor de agua \\
Piel húmeda $(50-40 \%)$ & Vapor de ácido fórmico \\
\hline
\end{tabular}

En la décimo séptima etapa del proceso convencional de curtición se realiza la etapa de secado la cual permite obtener un cuero o piel con un contenido bajo en humedad (del orden del $12 \%$ ) que da la sensación de estar seco sin estar reseco. En esta etapa se consolidan algo más los enlaces de los productos introducidos y la piel, lográndose una cierta fijación de ellos con la dermis y ofreciendo las características deseadas, según el artículo. Los efluentes de salida que se generan son vapores de agua, vapores de ácido fórmico y en menor cantidad vapores de los productos volátiles empleados en las etapas de recurtición tintura y engrase. 
Capítulo 2. EFECTOS AMBIENTALES DE LOS RESIDUOS PROCEDENTES DE LA INDUSTRIA CURTIDORA Y DE LA GANADERÍA PORCINA INTENSIVA

Tabla 2.1.1.18. Información etapa de operaciones mecánicas de un proceso convencional de curtición.

\begin{tabular}{ccc}
\hline ENTRADA & $\begin{array}{c}\text { OPERACIONES } \\
\text { MECÁNICAS }\end{array}$ & SALIDA \\
\hline Piel seca (12\%) & $\begin{array}{c}\text { Acciones mecánicas } \\
\text { previas para realizar el } \\
\text { acabado de la piel }\end{array}$ & Polvo, trozo de piel \\
\hline
\end{tabular}

Una vez ya secas las pieles o cueros se someten a unas operaciones mecánicas previas a la etapa de acabado. Las operaciones mecánicas más comunes previas al acabado son las siguientes: acondicionado, ablandado, abatanado, esmerilado, eliminación del polvo, pinzado y recortado; y ya en la etapa de acabado o al final del mismo: pulido, abrillantado, prensado, grabado, satinado, planchado y rasado de la lana. En algunas ocasiones las operaciones mecánicas pueden realizarse durante la etapa de acabado o bien al final de la misma. Durante la etapa de operaciones mecánicas se generan polvos, recortes de piel teñida, lana muy corta, trozos de piel, etc.

Tabla 2.1.1.19. Información etapa de acabado de un proceso convencional de curtición.

\begin{tabular}{ccc}
\hline ENTRADA & ACABADO & SALIDA \\
\hline Agua & Agua residual \\
Resinas, lacas, ceras & $\begin{array}{c}\text { Aplicación de dispersiones } \\
\text { de productos al cuero } \\
\text { para recubrir su superficie }\end{array}$ & $\begin{array}{c}\text { Aire con trazas de } \\
\text { productos de acabado }\end{array}$ \\
\hline
\end{tabular}

La etapa de acabado consiste en la aplicación de dispersiones o soluciones de productos del acabado sobre la piel o el cuero y se lleva a cabo con máquinas. Finalmente se aplica un tratamiento sobre la superficie de la piel o el cuero para mejorar sus propiedades de uso. Las máquinas empleadas suelen ser bandas en continuo provistas de sistemas de aplicación de distintos tipos y también secadores de aire caliente para secar el film superficial aplicado. Los principales productos que se aplican entre los formadores de film son: resinas acrílicas de butadieno y similares, uretanos, caseínas, lacas acuosas o en solventes; y entre los no formadores de film son: pigmentos, colorantes de avivado, aceites, rellenantes, reticulantes, ceras y siliconas.

A continuación se muestran los detalles sobre la última y vigésima etapa de un proceso de convencional de curtición, la cual corresponde a la etapa de prensado: 
Capitulo 2. EFECTOS AMBIENTALES DE LOS RESIDUOS PROCEDENTES DE LA INDUSTRIA CURTIDORA Y DE LA GANADERIAA PORCINA INTENSIVA

Tabla 2.1.1.20. Información etapa de prensado de un proceso convencional de curtición.

\begin{tabular}{ccc}
\hline ENTRADA & PRENSADO & SALIDA \\
\hline $\begin{array}{c}\text { Temperatura } \\
\text { Presión }\end{array}$ & $\begin{array}{c}\text { Aportación de temperatura } \\
\text { y presión para favorecer la } \\
\text { formación de un film } \\
\text { homogéneo para } \\
\text { conseguir un tacto liso y } \\
\text { una flor fina y compacta }\end{array}$ & Calor \\
\hline
\end{tabular}

A continuación se muestra el esquema de una prensa:

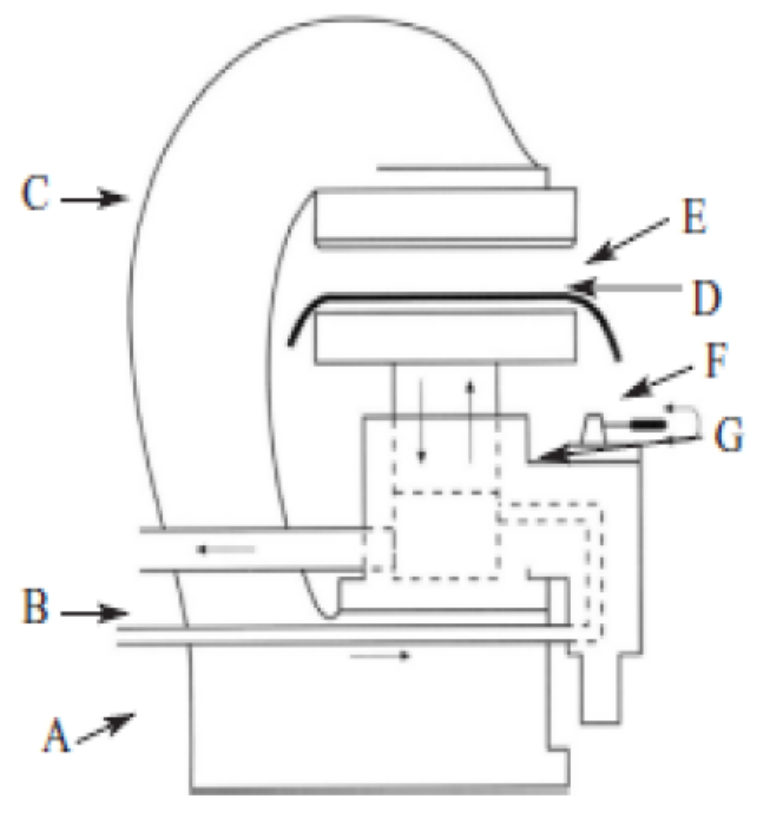
A. Presión de alimentación del aceite de la bomba
B. Tubo de retorno del aceite
C. Estructura rígida y pesante
D. Placa lisa o grabada
E. Placa caliente
F. Piel
G. Pistón

Figura 2.1.1.5. Esquema de una prensa.

Una vez realizadas todas las etapas de acabado y acondicionado de la piel, ya está preparada para su comercialización.

\subsubsection{PROCESOS DE CURTICIÓN MÁS USUALES}

A continuación se muestran los procesos de curtición más usuales en las industrias de curtidos:

- Piel vacuna curtida al cromo: se utiliza principalmente para empeine de zapatos y tapicería. 
- Piel vacuna curtida al vegetal: se utiliza para suela de zapatos y marroquinería.

- Piel pequeña (usualmente ovina) para napa y afelpado curtida al cromo: se utiliza para confección.

- Piel pequeña (usualmente ovina) para ante lana (doble face) curtida al cromo: se utiliza para confección (artículos con lana).

Las principales diferencias entre los procesos de curtición de pieles ovinas y de pieles vacunas son las siguientes:

- El consumo de agua por kilogramo de piel es mucho mayor para pieles ovinas (con respecto a las pieles vacunas) debido a que se trabaja con baños más largos, sobretodo en las etapas de ribera y curtición. Para una curtición de piel vacuna pueden gastarse de 20 a $40 \mathrm{~m}^{3}$ de agua por tonelada de piel, y para piel ovina pueden gastarse de 50 a 120 $\mathrm{m}^{3}$ de agua por tonelada de piel.

- Las pieles ovinas tienen un contenido de grasas mayor que las pieles vacunas y por este motivo el desengrase es más importante en las plantas de curtición de piel ovina.

- Los cueros de vacuno pueden curtirse de 2 maneras, con sales de cromo (para obtener pieles para empeine de zapato o tapicería) o con extractos vegetales de mimosa, quebracho o castaño (para suela de zapato o marroquinería). Las diferencias entre ambas son debidas a las características y aplicaciones del producto final deseado: empeine de zapatos o tapicería y suela de zapatos o marroquinería. La diferencia más importante es el agente curtiente utilizado en dicha etapa, el cual tiene implicaciones en la composición de los efluentes y residuos de eliminación generados.

- Las pieles ovinas (generalmente empleadas para confección) siempre se curten al cromo, puesto que así son más ligeras, excepto en algunos casos de pieles que se usan como forros y se curten con extractos vegetales. La diferencia entre la curtición de piel ovina para napa o para ante lana (doble face) se refiere a que en este último caso se conserva la lana $y$, por lo tanto, no son necesarias las etapas de pelambre y desencalado. Las implicaciones más importantes son que no se consumen sulfuro sódico $\left(\mathrm{Na}_{2} \mathrm{~S}\right)$ ni sulfato amónico $\left(\left(\mathrm{NH}_{4}\right)_{2} \mathrm{SO}_{4}\right)$, y que las aguas residuales no contienen sulfuros y menos concentración de sulfatos y nitrógeno. Sin embargo, se consume más agua para evitar enfieltramientos. 


\subsubsection{EMISIONES Y CONSUMO DE ENERGÍA Y MATERIAS PRIMAS EN LOS PROCESOS DE CURTIDO}

En este apartado se muestran los consumos de energía, materias primas, y emisiones típicas para los procesos de curtición más usuales. Debido a que hay una gran variedad de datos, los valores mostrados son el resultado de valores promedio. En función del proceso utilizado y del producto obtenido dichos valores deben tomarse como valores indicativos. En los casos en los que se ha podido disponer de información suficiente se ha distinguido entre los procesos de fabricación de pieles ovinas (tamaño pequeño) y pieles vacunas. En primer lugar se presenta un balance global entrada (materias primas)/salida (efluentes y residuos) para los procesos convencionales de fabricación de pieles ovinas y vacunas respectivamente.

Tabla 2.1.3.1. Entradas y salidas para un proceso convencional de una fábrica de curtidos de piel ovina sin lana.

\begin{tabular}{|c|c|c|c|c|c|}
\hline \multicolumn{2}{|c|}{ ENTRADAS } & \multicolumn{4}{|c|}{ SALIDAS } \\
\hline Piel salada & $1000 \mathrm{~kg}$ & Piel & $250 \mathrm{~kg}$ & & \\
\hline \multirow[t]{4}{*}{ Agua } & $50-120 \mathrm{~m}^{3}$ & & & DQO & $200-300 \mathrm{~kg}$ \\
\hline & & Agua & $50-120 \mathrm{~m}^{3}$ & SS & $100-180 \mathrm{~kg}$ \\
\hline & & & & Cromo (III) & $5-8 \mathrm{~kg}$ \\
\hline & & & & Recortes & $170 \mathrm{~kg}$ \\
\hline $\begin{array}{l}\text { Productos } \\
\text { químicos }\end{array}$ & $600-900 \mathrm{~kg}$ & $\begin{array}{l}\text { Residuos } \\
\text { sólidos }\end{array}$ & $770 \mathrm{~kg}$ & $\begin{array}{l}\text { Otros residuos } \\
\text { insolubles o } \\
\text { solubilizados }\end{array}$ & $400 \mathrm{~kg}$ \\
\hline & & & & Lana & $200 \mathrm{~kg}$ \\
\hline
\end{tabular}

Nota: se considera un peso aproximado de 2-2,5 kg por piel, por tanto entre 400 y 500 pieles por tonelada.

Fuente: Guía mejores técnicas disponibles en España del sector de curtidos. Ministerio Medio Ambiente, 2003. 
Tabla 2.1.3.2. Entradas y salidas para un proceso convencional de una fábrica de curtidos de piel vacuna.

\section{ENTRADAS}

Piel salada $\quad 1000 \mathrm{~kg}$

Agua $\quad 20-40 \mathrm{~m}^{3}$

\section{SALIDAS}

Cuero $250 \mathrm{~kg}$

\begin{tabular}{|c|c|c|c|}
\hline \multirow{5}{*}{ Agua } & \multirow{5}{*}{$20-40 \mathrm{~m}^{3}$} & DQO & $230-250 \mathrm{~kg}$ \\
\hline & & DBO & $\sim 100 \mathrm{~kg}$ \\
\hline & & SS & $\sim 150 \mathrm{~kg}$ \\
\hline & & Cromo (III) & $5-6 \mathrm{~kg}$ \\
\hline & & Sulfuros & $\sim 10 \mathrm{~kg}$ \\
\hline
\end{tabular}

\begin{tabular}{|c|c|c|c|}
\hline \multirow{6}{*}{$\begin{array}{l}\text { Residuos } \\
\text { sólidos }\end{array}$} & \multirow{6}{*}{$\sim 450-730 \mathrm{~kg}$} & Recortes no curtidos & $\sim 120 \mathrm{~kg}$ \\
\hline & & Carnazas no curtidas & $\sim 170-350 \mathrm{~kg}$ \\
\hline & & $\begin{array}{l}\text { Serrajes, rebajaduras } \\
\text { y recortes curtidos }\end{array}$ & $\sim 225 \mathrm{~kg}$ \\
\hline & & Polvos de acabados & $\sim 2 \mathrm{~kg}$ \\
\hline & & $\begin{array}{l}\text { Recortes de } \\
\text { acabados }\end{array}$ & $\sim 30 \mathrm{~kg}$ \\
\hline & & $\begin{array}{l}\text { Lodos de tratamiento } \\
(\sim 30 \% \text { materia seca })\end{array}$ & $\sim 500 \mathrm{~kg}$ \\
\hline
\end{tabular}

\begin{tabular}{|l|l|l|l}
\hline Aire $\quad \sim 0 \mathrm{~kg}$ & Disolventes orgánicos \\
\hline
\end{tabular}

Fuente: Guía mejores técnicas disponibles en España del sector de curtidos. Ministerio Medio Ambiente, 2003.

En la Tabla 2.1.3.2 se pueden observar las entradas y salidas para un proceso convencional de una fábrica de curtidos de piel vacuna. Hay que tener en cuenta que los valores de las Tablas 2.1.3.1 y 2.2.3.2 son para un caso general, y, por lo tanto, deben tomarse como valores indicativos. Las cantidades de materias primas utilizadas son muy variables según el proceso utilizado. La Tabla 2.1.3.3 muestra un promedio del consumo de los productos químicos en las diferentes etapas de un proceso de producción de pieles vacunas saladas y pieles ovinas; los valores se expresan en porcentaje con respecto al total de productos químicos utilizados. A continuación se detallan los balances 
Tabla 2.1.3.3. Consumo de productos químicos para dos procesos convencionales de curtición.

\begin{tabular}{lcc}
\hline Productos químicos utilizados & Piel vacuna & Piel ovina \\
\hline Productos inorgánicos (ácidos, bases, sulfuros, ...) & 36 & 47 \\
Productos de curtición (cromo, vegetales, aldehídos, ...) & 30 & 20 \\
Productos de acabado (pigmentos, ligantes, ...) & 3 & Dato no disponible \\
Agentes de engrase & 16 & 8 \\
Otros productos orgánicos (ácidos, bases, sales, ...) & 5 & 13 \\
Disolventes orgánicos & 2 & 8 \\
Colorantes y auxiliares & 6 & 4 \\
Otros (tensioactivos, enzimas, biocidas, ...) & 2 & Dato no disponible \\
\hline
\end{tabular}

Fuente: Guía mejores técnicas disponibles en España del sector de curtidos. Ministerio Medio Ambiente, 2003.

Respecto al agua, tal como se ve en las Tablas 2.1.3.1 y 2.1.3.2, su consumo es también muy variable (piel ovina sin lana: $50-120 \mathrm{~m}^{3}$ y piel vacuna: $20-40 \mathrm{~m}^{3}$ ). Una estimación estadística del consumo de agua en las distintas etapas se muestra para el caso de piel vacuna salada curtida al cromo, en la Tabla 2.1.3.4. .

Tabla 2.1.3.4. Consumo de agua para dos procesos convencionales de curtición.

\begin{tabular}{|c|c|c|}
\hline \multicolumn{3}{|c|}{ Consumo de agua por etapas (valores en porcentaje respecto al consumo total) } \\
\hline Etapas & & \\
\hline Remojo y lavados & $15-25$ & \\
\hline Calero y lavados & $23-27$ & \\
\hline \multirow[t]{2}{*}{ Desencalado, rendido y lavados } & $10-15$ & \\
\hline & & $50-65$ \\
\hline Piquel, curtición, neutralización y lavados & $10-20$ & \\
\hline Recurtición, tintura, engrase y lavados & $10-20$ & \\
\hline Total post-curtición & & $30-40$ \\
\hline Acabados & $5-10$ & 10 \\
\hline TOTAL & 100 & 100 \\
\hline
\end{tabular}

Fuente: Guía mejores técnicas disponibles en España del sector de curtidos. Ministerio Medio Ambiente, 2003.

Para profundizar un poco más en el consumo y generación de materias primas, efluentes, residuos y emisiones gaseosas es conveniente desglosar el proceso de curtición por etapas con el objetivo de especificar un poco más. Las materias primas que se utilizan en los procesos de 
curtición se muestran en la Tabla 2.1.3.5. Se distinguen los procesos de piel vacuna (curtida al cromo o al vegetal) y de piel ovina (con lana y sin lana), desglosándose en etapas para cada uno de los dos procesos.

Tabla 2.1.3.5. Materias primas utilizadas en los procesos de curtición de piel vacuna y pequeña (ovino).

\begin{tabular}{lll}
\hline \multicolumn{1}{c}{ Etapa } & \multicolumn{1}{c}{ Piel vacuna } & \multicolumn{1}{c}{ Piel pequeña (ovino) } \\
\multirow{2}{*}{ Remojo } & $\begin{array}{l}\text { Tensoactivos no iónicos (óxido de } \\
\text { etileno y ácidos grasos) } \\
\text { Bactericidas }\end{array}$ & $\begin{array}{l}\text { Tensoactivos no iónicos (óxido de } \\
\text { etileno y ácidos grasos) } \\
\end{array}$ \\
& Agentes humectantes & Bactericidas \\
& $\mathrm{Na}_{2} \mathrm{~S}$ & Agentes humectantes \\
\hline \multirow{4}{*}{ Pelambre y calero } & $\mathrm{NaHS}$ & $\mathrm{Na}_{2} \mathrm{~S}$ \\
& $\mathrm{Ca}(\mathrm{OH})_{2}$ & $\mathrm{NaHS}$ \\
& Aminas & $\mathrm{Ca}(\mathrm{OH})_{2}$ \\
& Tensioactivos & Aminas \\
& Enzimas & Tensioactivos \\
& & Enzimas \\
\hline
\end{tabular}

Fuente: Guía mejores técnicas disponibles en España del sector de curtidos. Ministerio Medio Ambiente, 2003. 
Tabla 2.1.3.5. Materias primas utilizadas en los procesos de curtición de piel vacuna y pequeña (continuación).

\begin{tabular}{|c|c|c|}
\hline Etapa & Piel vacuna & Piel pequeña (ovino) \\
\hline \multirow{4}{*}{ Desencalado } & $\begin{array}{l}\text { Ácidos orgánicos débiles (láctico, } \\
\text { cítrico, fórmico, etc.) }\end{array}$ & $\begin{array}{l}\text { Ácidos orgánicos débiles (láctico, } \\
\text { cítrico, fórmico, etc.) }\end{array}$ \\
\hline & $\mathrm{NH}_{4} \mathrm{Cl}$ & $\mathrm{NH}_{4} \mathrm{Cl}$ \\
\hline & $\left(\mathrm{NH}_{4}\right)_{2} \mathrm{SO}_{4}$ & $\left(\mathrm{NH}_{4}\right)_{2} \mathrm{SO}_{4}$ \\
\hline & $\mathrm{CO}_{2}$ & $\mathrm{CO}_{2}$ \\
\hline \multirow{3}{*}{ Rendido } & $\begin{array}{l}\text { Enzimas proteolíticas } \\
\text { pancreáticas (principalmente } \\
\text { tripsina y detergentes) }\end{array}$ & $\begin{array}{l}\text { Enzimas proteolíticos } \\
\text { pancreáticos (principalmente } \\
\text { tripsina) }\end{array}$ \\
\hline & & Serrín o caolín \\
\hline & $\begin{array}{l}\text { Sal amónica o } \mathrm{Na}_{2} \mathrm{SO}_{4} \text { o } \mathrm{NaCl} \\
\text { tensoactivo no iónico }\end{array}$ & Sal amónica o $\mathrm{Na}_{2} \mathrm{SO}_{4} \circ \mathrm{NaCl}$ \\
\hline \multirow{3}{*}{ Píquel } & Agua salada o $\mathrm{NaCl}$ sólido & Agua salada o NaCl sólido \\
\hline & $\mathrm{HCOOH}$ & $\mathrm{HCOOH}$ \\
\hline & $\mathrm{H}_{2} \mathrm{SO}_{4}$ & $\mathrm{H}_{2} \mathrm{SO}_{4}$ \\
\hline \multirow{5}{*}{ Desengrase } & & Agua salada, $\mathrm{NaHCO}_{3}$ \\
\hline & & Derivado de aldehido \\
\hline & & Isopropanol \\
\hline & & $\begin{array}{l}\text { Tensoactivo no iónico (alcoholes } \\
\text { o ácidos grasos oxietilenados) }\end{array}$ \\
\hline & & $\begin{array}{l}\text { Tensoactivo aniónico } \\
\text { (lauriletersulfato sódico) }\end{array}$ \\
\hline \multirow{3}{*}{ Curtición } & Sulfato básico de cromo(III) & Sulfato básico de cromo(III) \\
\hline & $\mathrm{NaHCO}_{3}, \mathrm{Na}_{2} \mathrm{CO}_{3}$ o $\mathrm{MgO}$ & $\mathrm{NaHCO}_{3}, \mathrm{Na}_{2} \mathrm{CO}_{3}$ o $\mathrm{MgO}$ \\
\hline & $\begin{array}{l}\text { Taninos vegetales: mimosa, } \\
\text { castaño y quebracho }\end{array}$ & \\
\hline \multirow{2}{*}{ Neutralizado } & $\mathrm{NaCOOH} \mathrm{o} \mathrm{NaHCO}_{3}$ & $\mathrm{NaCOOH}$ o $\mathrm{NaHCO}_{3}$ \\
\hline & $\mathrm{NH}_{4} \mathrm{HCO}_{3}$ & \\
\hline \multirow{4}{*}{ Recurtición } & $\begin{array}{l}\text { Resinas (acrílicas o de urea- } \\
\text { formol) }\end{array}$ & $\begin{array}{l}\text { Resinas (acrílicas o de urea- } \\
\text { formol) }\end{array}$ \\
\hline & Organocromo $\mathrm{MgSO}_{4}$ & Organocromo sal de cromo \\
\hline & Aceite sulfatado o sulfitado & \\
\hline & $\begin{array}{l}\text { Taninos vegetales (mimosa, } \\
\text { quebracho o castaño) o sintéticos } \\
\text { (base fenólica o naftalensulfónica) }\end{array}$ & \\
\hline
\end{tabular}


Tabla 2.1.3.5. Materias primas utilizadas en los procesos de curtición de piel vacuna y pequeña (continuación).

\begin{tabular}{|c|c|c|}
\hline Etapa & Piel vacuna & Piel pequeña (ovino) \\
\hline \multirow{4}{*}{ Engrase } & Tensoactivos & Tensoactivos \\
\hline & $\begin{array}{l}\text { Grasa sulfitada o sulfatada o } \\
\text { ésteres sintéticos }\end{array}$ & $\begin{array}{l}\text { Grasa sulfitada o sulfatada o } \\
\text { ésteres sintéticos }\end{array}$ \\
\hline & $\mathrm{HCOOH}$ & $\mathrm{HCOOH}$ \\
\hline & Aceites crudos & Aceites crudos \\
\hline Planchado & & Etanol y resinas \\
\hline Esmerilado & & Colas, silicatos y carborandum \\
\hline \multirow{3}{*}{ Tintura } & Colorantes aniónicos o catiónicos & Colorantes aniónicos o catiónicos \\
\hline & $\mathrm{HCOOH}$ & $\mathrm{HCOOH}$ \\
\hline & $\mathrm{NH}_{3}$ & $\mathrm{NH}_{4}$ \\
\hline \multirow{5}{*}{ Acabado } & Pigmentos y colorantes & Pigmentos y colorantes \\
\hline & Lacas, caseína, hidrofugantes & Lacas, caseína, hidrofugantes \\
\hline & Ceras naturales y sintéticas & Ceras naturales y sintéticas \\
\hline & Resinas acrílicas y uretanos & Resinas acrílicas y uretanos \\
\hline & $\begin{array}{l}\text { Disolventes como componentes } \\
\text { de productos comerciales: } \\
\text { isopropanol, butilglicol, acetato de } \\
\text { etilo, acetona, butilo }\end{array}$ & $\begin{array}{l}\text { Disolventes como componentes } \\
\text { de productos comerciales: } \\
\text { isopropanol, butilglicol, acetato de } \\
\text { etilo, acetona, butilo }\end{array}$ \\
\hline
\end{tabular}

Por lo que respecta a los elementos de salida (aguas residuales, residuos y emisiones a la atmósfera), la Tabla 2.1.3.6 muestra su composición para un proceso convencional de curtición, desglosándose por etapas.

Tabla 2.1.3.6. Aguas residuales, residuos y emisiones a la atmósfera en las diversas etapas del proceso de curtición.

\begin{tabular}{llll}
\hline \multicolumn{1}{c}{ Etapa } & \multicolumn{1}{c}{ Aguas residuales } & Residuos & Emisiones \\
\hline $\begin{array}{l}\text { Conservación y } \\
\text { almacenamiento }\end{array}$ & Sal & Olores \\
\hline & $\begin{array}{l}\text { DQO, SS, SD, restos de } \\
\text { suciedad, sal }\end{array}$ & \\
Remojo & Nitrógeno orgánico \\
& Biocidas, tierra, etc. \\
\hline
\end{tabular}

Fuente: Document on Best Available Techniques for the tanning of hides and skins. Marzo 2001. 
Tabla 2.1.3.6. Aguas residuales, residuos y emisiones a la atmósfera en las diversas etapas del proceso de curtición (continuación).

\begin{tabular}{|c|c|c|c|}
\hline Etapa & Aguas residuales & Residuos & Emisiones \\
\hline \multirow{4}{*}{$\begin{array}{l}\text { Pelambre, deslanado } \\
\text { y calero }\end{array}$} & Sulfuro, DQO, SS, SD, cal & \multirow{4}{*}{ Pelo, lana, lodos cálcicos } & $\mathrm{H}_{2} \mathrm{~S}$ (accidentalmente) \\
\hline & Nitrógeno & & Olores \\
\hline & Biocidas & & \\
\hline & pH básico & & \\
\hline Descarnado & pH básico & Carnazas & \\
\hline Dividido & & Recortes & \\
\hline \multirow{2}{*}{$\begin{array}{l}\text { Desencalado y } \\
\text { rendido }\end{array}$} & DQO, SS, SD, nitrógeno & & $\mathrm{NH}_{3}$, polvo \\
\hline & Sulfuro, sales cálcicas & & $\begin{array}{l}\mathrm{H}_{2} \mathrm{~S} \\
\text { (accidentalmente) }\end{array}$ \\
\hline \multirow[b]{2}{*}{ Píquel } & DQO, SD, sal, pH ácido & & Humos ácidos \\
\hline & Fungicidas & & $\begin{array}{l}\mathrm{H}_{2} \mathrm{~S} \\
\text { (accidentalmente) }\end{array}$ \\
\hline \multirow[b]{2}{*}{ Desengrase } & DQO, SD, tensoactivos & \multirow{2}{*}{$\begin{array}{l}\text { Residuos de destilación y de } \\
\text { tratamiento de aguas } \\
\text { residuales }\end{array}$} & \\
\hline & Disolventes orgánicos y grasas & & \\
\hline \multirow{4}{*}{ Curtición } & Cr(III), sal, SS, DQO, SD, & \multirow{4}{*}{$\begin{array}{l}\text { Desechos de pieles y lodos } \\
\text { de tratamiento de aguas } \\
\text { residuales }\end{array}$} & \\
\hline & Fungicidas, & & \\
\hline & Agentes complejantes & & \\
\hline & pH ácido & & \\
\hline \multirow[t]{2}{*}{ Dividido y rebajado } & & \multirow[t]{4}{*}{ Virutas de rebajado y dividido } & $\begin{array}{l}\text { Polvo (si se procesa } \\
\text { en seco) }\end{array}$ \\
\hline & DQO, SS, SD, curtientes & & \\
\hline \multirow[t]{2}{*}{ Neutralizado } & Curtientes no fijados & & $\mathrm{NH}_{3}, \mathrm{SO}_{2}$ \\
\hline & Tensoactivos & & \\
\hline \multirow{4}{*}{ Recurtición } & Cr(III), sal, SS, DQO, SD & \multirow{4}{*}{$\begin{array}{l}\text { Desechos de pieles y lodos } \\
\text { de tratamiento de aguas } \\
\text { residuales }\end{array}$} & \\
\hline & Fungicidas & & \\
\hline & Agentes complejantes & & \\
\hline & pH ácido & & \\
\hline Blanqueo & Carga orgánica & & $\mathrm{SO}_{2}$ \\
\hline \multirow{5}{*}{ Tintura } & Colorantes sintéticos & \multirow{5}{*}{$\begin{array}{l}\text { Restos de productos } \\
\text { químicos y colorantes }\end{array}$} & $\mathrm{NH}_{3}$, formaldehído \\
\hline & Agentes auxiliares & & Fenoles \\
\hline & Colorantes & & \\
\hline & AOX & & \\
\hline & Disolventes orgánicos & & \\
\hline \multirow{3}{*}{ Engrase } & $\begin{array}{l}\text { Compuestos orgánicos } \\
\text { halogenados (AOX) }\end{array}$ & & \\
\hline & Tensioactivos & & \\
\hline & $\begin{array}{l}\text { Restos de productos } \\
\text { engrasantes }\end{array}$ & & \\
\hline \multirow{2}{*}{ Secado } & & & Calor \\
\hline & & & Vapores ácidos \\
\hline
\end{tabular}

Fuente: Document on Best Available Techniques for the tanning of hides and skins. Marzo 2001. 
Tabla 2.1.3.6. Aguas residuales, residuos y emisiones a la atmósfera en las diversas etapas del proceso de curtición (continuación).

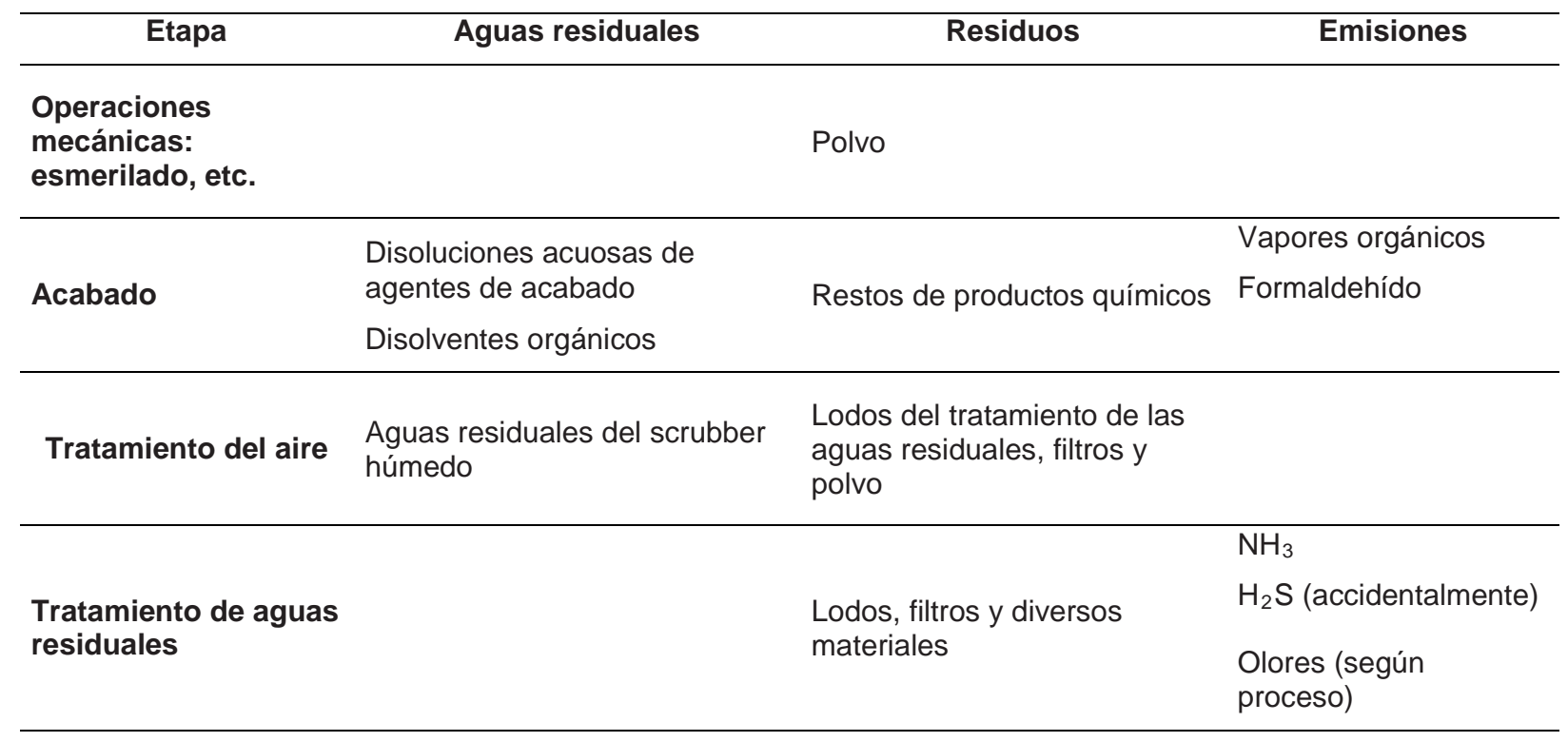

Fuente: Document on Best Available Techniques for the tanning of hides and skins. Marzo 2001.

La cuantificación del consumo de agua y productos químicos puede realizarse a partir de datos estadísticos. En las tablas siguientes se muestran los datos promedios obtenidos a partir de distintas fuentes. A continuación se muestran los valores para una curtición de cuero vacuno salado curtido al cromo.

Tabla 2.1.3.7. Valores de carga contaminante para un proceso convencional de cueros vacunos salados curtidos al cromo.

\begin{tabular}{|c|c|c|c|c|c|c|c|c|c|}
\hline \multicolumn{10}{|c|}{ Cueros vacunos curtidos al cromo } \\
\hline Etapas & $\begin{array}{l}\text { Agua } \\
\left(\mathrm{m}^{3} / \mathrm{t}\right)\end{array}$ & $\begin{array}{c}\text { SS } \\
(\mathrm{kg} / \mathrm{t})\end{array}$ & $\begin{array}{l}\text { DQO } \\
\text { (kg/t) }\end{array}$ & $\begin{array}{l}\text { DBO } \\
\text { (kg/t) }\end{array}$ & $\begin{array}{l}\text { TKN } \\
\text { (kg/t) }\end{array}$ & $\begin{array}{c}\mathrm{S}^{2-} \\
(\mathrm{kg} / \mathrm{t})\end{array}$ & $\begin{array}{c}\mathrm{Cr} \\
(\mathrm{kg} / \mathrm{t})\end{array}$ & $\begin{array}{c}\mathrm{Cl}^{-} \\
(\mathrm{kg} / \mathrm{t})\end{array}$ & $\begin{array}{l}\mathrm{SO}_{4}{ }^{2-} \\
(\mathrm{kg} / \mathrm{t})\end{array}$ \\
\hline Ribera $^{\dagger}$ & $7-25$ & $70-120$ & $120-160$ & $40-60$ & $9-14$ & $4-9$ & - & $120-150$ & $5-20$ \\
\hline Curtición & $1-3$ & $5-10$ & $10-20$ & $3-7$ & $0-1$ & - & $2-5$ & $20-60$ & $30-50$ \\
\hline Post-curtición & $4-8$ & $10-20$ & $15-40$ & $5-15$ & $1-2$ & - & $1-2$ & $5-10$ & $10-40$ \\
\hline Acabado & $0-1$ & $0-5$ & $0-10$ & $0-4$ & - & - & - & - & - \\
\hline Total & $12-37$ & $85-155$ & $145-230$ & $48-86$ & $10-17$ & $4-9$ & $3-7$ & $145-220$ & $45-110$ \\
\hline
\end{tabular}

${ }^{\dagger}$ Desde remojo hasta desencalado

Fuente: World Leather, noviembre 1996. http://www.leather-spain.com

La Tabla 2.1.3.8 muestra los valores para una curtición de piel ovina curtida al cromo según 
estudios realizados en varias empresas del sector.

Tabla 2.1.3.8. Valores de carga contaminante para un proceso convencional de cueros ovinos sin lana.

\begin{tabular}{|c|c|c|c|c|c|c|c|c|c|}
\hline \multicolumn{10}{|c|}{ Pieles de ovino sin lana cutidos al cromo } \\
\hline Etapas & $\begin{array}{c}\text { Agua } \\
\text { (L/piel) }\end{array}$ & $\begin{array}{c}\text { SS } \\
\text { (g/piel) }\end{array}$ & $\begin{array}{c}\text { DQO } \\
\text { (g/piel) }\end{array}$ & $\begin{array}{c}\text { DBO } \\
\text { (g/piel) }\end{array}$ & $\begin{array}{c}\text { TKN } \\
\text { (g/piel) }\end{array}$ & $\begin{array}{c}\mathrm{S}^{2-} \\
\text { (g/piel) }\end{array}$ & $\begin{array}{c}\mathrm{Cr} \\
\text { (g/piel) }\end{array}$ & $\begin{array}{c}\mathrm{Cl}^{-} \\
\text {(g/piel) }\end{array}$ & $\begin{array}{l}\mathrm{SO}_{4}{ }^{2-} \\
\text { (g/piel) }\end{array}$ \\
\hline Ribera $^{\dagger}$ & $65-90$ & $150-300$ & $250-600$ & $100-260$ & $15-30$ & $6-20$ & - & $150-400$ & $5-40$ \\
\hline $\begin{array}{l}\text { Desengrase- } \\
\text { curtición }\end{array}$ & $15-25$ & $15-30$ & $50-300$ & $20-100$ & $4-10$ & - & 8-12 & $40-200$ & $30-50$ \\
\hline Post-curtición & $30-50$ & $10-20$ & $30-100$ & $15-35$ & $2-4$ & - & $1-3$ & $20-40$ & $10-20$ \\
\hline Acabado & $0-7$ & $0-2$ & $0-5$ & $0-2$ & - & - & - & - & - \\
\hline TOTAL & $110-170$ & $175-352$ & 330-1005 & $135-397$ & $21-44$ & $6-20$ & $9-15$ & $210-640$ & $45-110$ \\
\hline
\end{tabular}

Fuente: Guía mejores técnicas disponibles en España del sector de curtidos. Ministerio Medio Ambiente, 2003.

Del análisis de las tablas anteriores 2.1.3.7 y 2.1.3.8 se observa que los procesos de curtición de pieles ovinas implican mayor consumo de agua, así como mayor carga contaminante expresado en DBO y DQO respecto a los procesos de curtido de pieles de vacuno.

En la siguiente tabla se pueden observar los valores de carga contaminante para una curtición de piel ovina con lana curtida al cromo. Se observa que para el caso de pieles de ovino con lana el consumo de agua es mayor que para pieles de ovino sin lana.

Tabla 2.1.3.9. Valores de carga contaminante para un proceso convencional de pieles de ovino con lana.

\begin{tabular}{|c|c|c|c|c|c|c|c|c|c|}
\hline \multicolumn{10}{|c|}{ Pieles de ovino con lana curtidas al cromo } \\
\hline Etapas & $\begin{array}{c}\text { Agua } \\
\text { (L/piel) }\end{array}$ & $\begin{array}{c}\text { SS } \\
\text { (g/piel) }\end{array}$ & $\begin{array}{c}\text { DQO } \\
\text { (g/piel) }\end{array}$ & $\begin{array}{c}\text { DBO } \\
\text { (g/piel) }\end{array}$ & $\begin{array}{c}\text { TKN } \\
\text { (g/piel) }\end{array}$ & $\begin{array}{c}\mathrm{S}^{2-} \\
\text { (g/piel) }\end{array}$ & $\begin{array}{c}\mathrm{Cr} \\
\text { (g/piel) }\end{array}$ & $\begin{array}{c}\mathrm{Cl}^{-} \\
\text {(g/piel) }\end{array}$ & $\begin{array}{l}\mathrm{SO}_{4}{ }^{2-} \\
\text { (g/piel) }\end{array}$ \\
\hline Ribera $^{\dagger}$ & $85-100$ & 100 & 550 & 150 & 16 & - & - & 400 & - \\
\hline Curtición & $70-80$ & 15 & 150 & 45 & 2 & - & 15 & 460 & - \\
\hline Tintura & $35-70$ & 80 & 80 & 25 & 3 & - & 5 & 50 & - \\
\hline TOTAL & $190-250$ & 195 & 780 & 220 & 21 & - & 20 & 910 & - \\
\hline
\end{tabular}

${ }^{\dagger}$ Desde remojo hasta desencalado

Fuente: Guía mejores técnicas disponibles en España del sector de curtidos. Ministerio Medio Ambiente, 2003. 
Por lo que se refiere a curtición vegetal, las Tablas 2.1.3.10 y 2.1.3.11 muestran los productos utilizados y los valores de consumos de agua y carga expresada como DQO para el caso de curtición vegetal para los dos casos más usuales en este tipo de curtición: marroquinería y suelas de zapato.

Tabla 2.1.3.10. Valores de consumo de agua, carga contaminante expresada como DQO, productos usados y composición de efluentes para el proceso de curtición vegetal para marroquinería.

\begin{tabular}{|c|c|c|c|}
\hline \multicolumn{4}{|c|}{ Cuero curtido al vegetal para marroquinería } \\
\hline Etapas & $\begin{array}{c}\text { Consumo } \\
\text { de agua } \\
\left(m^{3} / T n\right) \\
\end{array}$ & DQO (kg/Tn) & $\begin{array}{l}\text { Productos usados y } \\
\text { composición de efluentes }\end{array}$ \\
\hline \multirow{3}{*}{$\begin{array}{l}\text { Remojo } \\
\text { preliminar }\end{array}$} & \multirow{3}{*}{18} & & Tensoactivos \\
\hline & & & Biocidas/estiércol \\
\hline & & & Sangre, sal, AOX \\
\hline \multirow{4}{*}{$\begin{array}{l}\text { Remojo - } \\
\text { calero }\end{array}$} & & & Cal \\
\hline & & & Sulfuro sódico \\
\hline & & & $\begin{array}{l}\text { Proteína residual del pelo y } \\
\text { cuero }\end{array}$ \\
\hline & & & $\begin{array}{l}\text { Grasa y productos de } \\
\text { degradación }\end{array}$ \\
\hline \multirow{4}{*}{$\begin{array}{l}\text { Desencalado } \\
\text { - rendido y } \\
\text { lavado }\end{array}$} & & & Sulfato amónico, oxalatos \\
\hline & & & $\mathrm{CO}_{2}$, enzimas, epidermis \\
\hline & & & Pelo, restos de proteínas \\
\hline & & & Sales solubles \\
\hline \multirow{2}{*}{ Curtición } & \multirow{2}{*}{5} & & $\begin{array}{l}\text { Curtientes vegetales y } \\
\text { sintéticos }\end{array}$ \\
\hline & & & $\begin{array}{l}\text { Productos de degradación } \\
\text { orgánica }\end{array}$ \\
\hline Engrase & $1-2$ & & $\begin{array}{l}\text { Agentes de engrase, } \\
\text { emulsionantes y fibras de } \\
\text { cuero }\end{array}$ \\
\hline $\begin{array}{l}\text { Recurtición, } \\
\text { tintura, } \\
\text { engrase, } \\
\text { lavado }\end{array}$ & \multicolumn{2}{|l|}{5} & $\begin{array}{l}\text { Recurtientes sintéticos y } \\
\text { vegetales, colorantes, } \\
\text { grasas, emulsionantes }\end{array}$ \\
\hline TOTAL & $15-30$ & 150 & \\
\hline
\end{tabular}

Fuente: Guía mejores técnicas disponibles en España del sector de curtidos. Ministerio Medio Ambiente, 2003. 
Tabla 2.1.3.11. Valores de consumo de agua, carga contaminante expresada como DQO, productos usados y composición de efluentes para el proceso de curtición vegetal para cuero.

\begin{tabular}{|c|c|c|c|}
\hline \multicolumn{4}{|c|}{ Cuero curtido al vegetal para suela } \\
\hline Etapas & $\begin{array}{l}\text { Consumo } \\
\text { de agua } \\
\left(\mathrm{m}^{3} / \mathrm{Tn}\right)\end{array}$ & DQO (kg/Tn) & $\begin{array}{l}\text { Productos usados y } \\
\text { composición de efluentes }\end{array}$ \\
\hline \multirow{3}{*}{ Remojo } & \multirow{3}{*}{$16-18$} & \multirow{3}{*}{150} & Tensoactivos \\
\hline & & & Biocidas/estiércol \\
\hline & & & Sangre, sal, AOX \\
\hline \multirow{4}{*}{ Calero } & & & Cal \\
\hline & & & Sulfuro sódico \\
\hline & & & $\begin{array}{l}\text { Proteína residual del pelo y } \\
\text { cuero }\end{array}$ \\
\hline & & & $\begin{array}{l}\text { Grasa y productos de } \\
\text { degradación }\end{array}$ \\
\hline \multirow{4}{*}{$\begin{array}{l}\text { Desencalado } \\
\text { y rendido }\end{array}$} & & & Sulfato amónico, oxalatos \\
\hline & & & $\mathrm{CO}_{2}$, enzimas, epidermis \\
\hline & & & Pelo, restos de proteínas \\
\hline & & & Sales solubles \\
\hline \multirow[b]{2}{*}{ Curtición } & \multirow[b]{2}{*}{2} & \multirow[b]{2}{*}{50} & $\begin{array}{l}\text { Curtientes vegetales y } \\
\text { sintéticos }\end{array}$ \\
\hline & & & $\begin{array}{l}\text { Productos de degradación } \\
\text { orgánica }\end{array}$ \\
\hline TOTAL & 20 & 200 & \\
\hline
\end{tabular}

Fuente: Guía mejores técnicas disponibles en España del sector de curtidos. Ministerio Medio Ambiente, 2003.

Finalmente, para los residuos sólidos es posible cuantificar su porcentaje respecto a la cantidad de residuos total en el caso de cueros vacunos salados curtidos al cromo. Estos datos se muestran a continuación:

Tabla 2.1.3.12. Residuos.

\begin{tabular}{lc}
\hline \multicolumn{2}{c}{ Residuos (\%) } \\
\hline Recortes de piel en bruto & $2-5$ \\
Carnazas & $25-35$ \\
Serrajes & $10-20$ \\
Rebajaduras, recortes y serrajes cromados & $10-20$ \\
Polvo & $0,2-10$ \\
Pigmentos, lacas y otros productos & 0,5 \\
Lodos de planta de tratamiento de aguas residuales & $40-50$ \\
Embalajes & 1,5 \\
\hline
\end{tabular}

Fuente: Guía mejores técnicas disponibles en España del sector de curtidos. Ministerio Medio Ambiente, 2003. 


\subsubsection{PROBLEMÁTICA AMBIENTAL DE LAS INDUSTRIAS DEL CURTIDO}

Los dos problemas principales de las industrias de curtidos son los residuos sólidos y las aguas residuales.

Residuos sólidos:

La materia prima (piel fresca o salada) procedente de los mataderos va acompañada de una importante cantidad de grasa, proteínas, suciedad, etc., que deben retirarse de la piel en forma de residuos o subproductos (suponen el 75\%, aproximadamente).

Los residuos (sal, rebajaduras o virutas y recortes de piel curtida, fangos de depuradora, restos de envases de productos químicos, etc.), no revalorizables por causas técnicas o económicas, se eliminan en vertederos controlados. Aunque podrían tener algunas aplicaciones útiles como la fabricación de planchas de fibra de cuero, abonos agrícolas, etc.

Los residuos no curtidos -recortes de piel fresca, pelo o lana, sebos, carnazas, serraje, etc.tienen propiedades interesantes, como son el alto contenido en grasas, colágeno, proteínas, poder absorbente, poder calorífico en la combustión, resistencia mecánica, aislante térmico y acústico, etc, y por tanto muchas posibles aplicaciones industriales: fabricación de gelatinas, colas y extracción de colágeno. Sin embargo, aún en la mayoría de los casos no se llevan a cabo, principalmente, por el elevado coste del transporte de estos residuos hasta la planta de tratamiento, el reducido número de instalaciones de aprovechamiento, etc, por lo que en muchos casos su destino es depositarlos en vertedero controlado. Algunos de estos residuos, como las carnazas, serrajes y recortes de serraje deben acondicionarse antes de depositarlos, porque se pudren fácilmente, causando problemas por el ataque bacteriano, olores desagradables, atracción de moscas, etc.

Los residuos curtidos no plantean problemas de putrefacción en vertederos, ya que el curtido los ha estabilizado. Su contenido en cromo no debe determinar características de peligrosidad, debido a que se trata de cromo III y no cromo VI.

Aguas Residuales:

Las aguas residuales de las industrias de curtidos contienen una alta carga orgánica, debido a la materia prima que se trata y al proceso. Suponen un gran volumen $(25-50 \mathrm{~L} / \mathrm{Kg}$ piel bruta) porque una gran parte del proceso se realiza en medio acuoso. La depuración de estas aguas se realiza mediante tratamientos físico- químicos y, en algunos casos, también 
biológicos. Los principales parámetros que entrañan más dificultad en los procesos de depuración son la elevada salinidad (cloruros procedentes de la sal conservante de la piel bruta y la empleada en el piquelado) y la alta carga orgánica (proteínas solubilizadas y en suspensión procedentes de la materia prima).

\subsubsection{GESTIÓN DE RESIDUOS Y TRATAMIENTOS DE AGUAS RESIDUALES EN LA INDUSTRÍA DEL CURTIDO}

Es posible reducir el impacto ambiental de las operaciones de curtido empezando por llevar a cabo medidas tan sencillas y de tan bajo coste como las buenas prácticas de almacenamiento y manipulación de materiales, la prevención de fugas y accidentes, y la segregación de subproductos, ya que no hay que modificar tecnologías ni interferir en los procesos productivos y se consigue evitar la generación innecesaria de residuos y emisiones en las operaciones auxiliares como el almacenamiento y manipulación.

El primer paso hacia la reducción del impacto medioambiental del sector es la concienciación del empresario y la inclusión de los costes medioambientales (costes de gestión de residuos, consumo de materias, riesgos, seguros, cánones de vertido, etc.) en la cuenta de resultados de las empresas y así poder rentabilizar las acciones de reducción de residuos.

Por lo que se refiere al tratamiento de residuos se consideran Mejores Técnicas disponibles, por orden de prioridad:

- prevención

- reducción

- reutilización

- reciclaje / recuperación

- tratamientos térmicos

Durante el proceso de curtición se generan gran cantidad de residuos cuyas características pueden ser muy diferentes. Es de vital importancia la segregación de residuos para poder asegurar un tratamiento posterior adecuado. También hay que manipularlos de forma que no produzcan malos olores ni emisiones al aire. Siempre que sea posible hay que intentar la valorización o la comercialización de los residuos como subproductos.

En la tabla siguiente se muestran algunos de los residuos que se generan y su posible utilización posterior: 
Tabla 2.1.5.1 Residuos principales generados en industria del curtido

\begin{tabular}{|c|c|}
\hline Residuo & $\begin{array}{c}\text { Reutilización, reciclado, recuperación y } \\
\text { tratamientos MTD }\end{array}$ \\
\hline Sal & Materia auxiliar para industria de fundición de aluminio \\
\hline Serrajes & $\begin{array}{c}\text { Producción de cueros, producción de cuero } \\
\text { regenerado, marroquinería, piezas de piel pequeña, } \\
\text { proteínas hidrolizadas, gelatina y cola }\end{array}$ \\
\hline Serraje sin curtir & $\begin{array}{c}\text { Colágeno, proteína hidrolizada, cubiertas para } \\
\text { embutidos y tripa artificial }\end{array}$ \\
\hline Carnazas & Recuperación de grasa, cola y proteína hidrolizada \\
\hline Recortes de piel en bruto & Recuperación de grasa y cola \\
\hline Rebajaduras & $\begin{array}{l}\text { Producción d cuero regenerado, cola y proteína } \\
\text { hidrolizada }\end{array}$ \\
\hline Recortes curtidos & $\begin{array}{c}\text { Producción de cuero regenerado, piezas de piel } \\
\text { pequeñas y marroquinería }\end{array}$ \\
\hline Pelo y lana & $\begin{array}{l}\text { Proteína hidrolizada, material para relleno de tierras, } \\
\text { lana, compostaje y fertilizantes para agricultura }\end{array}$ \\
\hline Polvo esmerilado & Vertedero \\
\hline Grasas y aceites & Compostaje, tratamiento térmico \\
\hline Disolventes & Recuperación \\
\hline
\end{tabular}

Fuente: Guía mejores técnicas disponibles en España del sector de curtidos. Ministerio Medio Ambiente, 2003.

Respecto al tratamiento de las aguas residuales, se consideran Mejores Técnicas Disponibles:

- Segregar los efluentes que contienen sulfuros de otros efluentes, y a un pH alto hasta que se haya eliminado el sulfuro (normalmente mediante oxidación), con el objetivo de evitar las emisiones de sulfuro de hidrógeno a la atmósfera. Se pueden conseguir aguas residuales con contenidos en sulfuros de $2 \mathrm{mg} \mathrm{S^{2 }} / \mathrm{L}$. Después de la separación del sulfuro las aguas residuales pueden ser mezcladas.

- Recoger de forma separada las aguas residuales que contienen una concentración superior a $1 \mathrm{~g} \mathrm{Cr}$ total/L para recuperar el cromo. Esta operación puede no ser viable si no existe una planta especializada o si los licor es recuperados deben usarse para pieles de alta calidad Tratar los efluentes que contienen una concentración inferior a $1 \mathrm{~g} \mathrm{Cr}$ total/L conjuntamente con otros efluentes.

- Utilizar tratamiento mecánico, que es el primer tratamiento a que se someten las aguas residuales: filtrado para eliminar el material más grueso y eliminación de grasas y aceites mediante flotación. 
- Utilizar tratamientos biológicos directamente o después del tratamiento mecánico y físicoquímico. Las posibilidades son tratamiento aeróbico o anaeróbico, y las opciones de operación pueden ser filtros biológicos o lodos activados.

- Realizar un tratamiento correcto de los lodos: sedimentación para separar el lodo de la fase líquida, seguido de escurrido para reducir el contenido en agua y volumen de los lodos para su deposición. El uso de filtros prensa, centrífugas u otros sistemas permite obtener lodos con un contenido en sólidos del $25 \%$ al $35 \%$.

Cada situación específica requerirá de un tratamiento u otro (tratamiento mecánico, físicoquímico, biológico o manipulación de lodos) en función de la planta (aguas a tratar, cantidades, localización y otros factores), y de si el tratamiento va a ser individual o conjunto con otras plantas. Otros tratamientos específicos pueden ser necesarios en algunos casos.

\subsection{GANADERÍA INTENSIVA}

En la Región de Murcia, el sector ganadero tiene un peso importante ya que, en las últimas décadas, su contribución al valor de la producción de la rama agraria-ganadera ha ido ganando peso hasta el 35\%. En esta Región es el porcino la rama ganadera más importante, con el $71 \%$ del valor de la carne y el ganado, mientras que en España representa solo el 35\%. Es un sector que por su estado sanitario puntero en España ha favorecido notablemente la exportación.

En la Región de Murcia el sector ganadero ha tenido una profunda transformación en los últimos 30-40 años, pasando de ser un sector marginal a ser competitivo. Estos cambios están relacionados principalmente con la modernización de las explotaciones, su mayor intensividad, la creación de industrias derivadas, pero sobre todo con la erradicación de enfermedades que, en algunos casos, se podrían considerar como endémicas y que limitaban su comercialización.

En la Región de Murcia las cabezas de ganado, considerando promedio 2012-2014 son de 2,6 millones, de las que 1,8 millones millones pertenecen al porcino. La distribución por especies es: $69 \%$ porcino, $21 \%$ ovino, $7 \%$ caprino y $3 \%$ bovino.

El mayor número de cabezas de porcino se localizan en el municipio de Lorca, aproximadamente representa el 30\% y Fuente Álamo el 22\%. La Región de Murcia respecto al valor de la producción nacional representa rl 4,8\% de la producción ganadera, el 8,6\% de la producción de porcino.

Los principales efectos medioambientales ligados a las explotaciones ganaderas están relacionados con la producción de estiércoles y purines, debido a que, si bien son productos que inicialmente no contienen compuestos de alto riesgo ambiental, la producción y acumulación de los mismos en grandes volúmenes puede plantear problemas de gestión. 
Ahora bien, conviene precisar que el hecho de que el estiércol de algunas especies ganaderas, como el porcino intensivo y una elevada proporción del vacuno de leche, sean arrastrados de los establos mediante el uso de agua, no implica que cambien sus características agronómicas y ambientales intrínsecas, por lo que deberán catalogarse como cualquier otro tipo de compuesto orgánico.

Las características físicas-químicas de los estiércoles ganaderos presentan variaciones importantes asociadas principalmente a la especie de producción, tipo de explotación (estructura de la población de los animales, tipo de alojamiento o cama), tipo de alimentación y el grado de dilución de las deyecciones en agua. A efectos de sus consideraciones ambientales, los estiércoles ganaderos se caracterizan principalmente por los siguientes parámetros:

- Alto contenido en materia orgánica

- Alto contenido en macronutrientes (nitrógeno, fósforo y potasio) y otros micronutrientes (hierro, manganeso, etc.).

- Generación de compuestos volátiles (amoniaco, metano y óxido nitroso entre otros) y compuestos fácilmente volatilizables (amonio entre otros).

- Presencia de pesticidas y metales pesados (cobre, zinc, hierro, etc.)

Teniendo en cuenta lo anterior, los principales efectos ambientales que pueden originarse y deben tenerse en consideración en relación con la actividad ganadera intensiva son los siguientes:

- Contaminación difusa de aguas subterráneas por nitratos, ligada a prácticas de manejo de incorrectas.

- Eutrofización de aguas superficiales

- Acidificación producida por amoniaco

- Contribución al efecto invernadero producido por metano, óxido nitroso y en menor medida dióxido de carbono.

- Problemas locales por el olor, el ruido y el polvo

- Dispersión de metales pesados (cobre y zinc) y pesticidas

La calidad y composición del estiércol y del purín, así como la forma en que se almacenan y manejan, son los principales factores determinantes de los niveles de emisión de sustancias potencialmente contaminantes procedentes de la actividad ganadera intensiva (Guía MTD sector porcino, 2010). 


\subsubsection{CONTAMINACIÓN DE AGUAS SUBTERRÁNEAS}

El agua es un recurso de primera magnitud para el desarrollo presente y futuro de la población humana. Las aguas subterráneas, como recurso potencialmente destinado a satisfacer el consumo humano, deben protegerse en cuanto a su aptitud y salubridad. En este sentido, existe una gran preocupación por el incremento del contenido de nitratos en las aguas. El principal origen de la contaminación hídrica por nitratos son las fuentes agrarias, debido a prácticas inadecuadas de abonado nitrogenado. En este sentido, deben valorarse a los purines y a los estiércoles como un abono más y, por lo tanto, deben considerarse una fuente potencial de contaminación nitrogenada de las aguas. Cuando se aplica purín o estiércol al suelo con fines agrícolas, el amoniaco (principal componente nitrogenado del purín) sufre un proceso de oxidación (nitrificación) mediante el cual se transforma en nitrato. El nitrato es una forma muy soluble que se mueve fácilmente en el perfil de suelo, de tal manera que todo lo que no es absorbido por el cultivo es susceptible de lixiviación y, por lo tanto, fuente potencial de contaminación de las aguas subterráneas. Por esta razón, destaca la Directiva 91/676/CEE, que establece una serie de obligaciones que los Estados miembros deben cumplir en relación con la contaminación generada por nitratos procedentes de fuentes agrarias. Las disposiciones contenidas en su articulado están enfocadas por un lado, a conseguir una reducción progresiva de este tipo de contaminación y por otro, a actuar preventivamente frente a nuevos focos que puedan generarse en el futuro.

De acuerdo al Real Decreto 261/1996 es necesario controlar las cantidades de purín que se aplican al suelo, siendo, con carácter general, la cantidad específica por hectárea la cantidad de estiércol que contenga $170 \mathrm{Kg} / \mathrm{año}$ de nitrógeno. Debiendo considerarse además los factores que pueden acelerar este proceso, tales como la permeabilidad, la textura del suelo, las condiciones climáticas y, por supuesto, el tipo de cultivo y el momento de aplicación.

Por otro lado, el fósforo es otro de los componentes de los estiércoles que es solubilizado por la acción de microorganismos solubilizadores de fosfato. En los suelos agrícolas el fósforo es un elemento esencial, debiéndose aportar regularmente después de cada cultivo por la alta demanda de las plantas que lo absorben en forma de iones fosfato monobásico y dibásicos. Al contrario de lo que ocurre con el nitrógeno, el fósforo es uno de los nutrientes menos móviles en el perfil del suelo debido a que los fosfatos forman compuestos insolubles con los iones hierro y aluminio en suelos ácidos y con calcio en los suelos alcalinos, por lo que no se presenta riesgos de lixiviación ni de contaminación de las aguas subterráneas.

Cuando un subproducto como el purín, con alta carga de materia orgánica y de nutrientes, alcanza el curso de las aguas superficiales se pueden generar problemas de eutrofización, 
fenómeno muy bien conocido y que afecta a un número importante de lagos y embalses en el planeta y que está provocado por el exceso de nutrientes en el agua. Por esta razón, los vertidos directos al agua están completamente prohibidos e incluso los vertidos indirectos están penalizados por el Real Decreto Legislativo 1/2001, de 20 de julio, por el que se aprueba el texto refundido de la Ley de Aguas. Sólo las explotaciones que dispongan de sistemas de depuración podrán verter sus efluentes a los cauces, siempre y cuando cuenten y cumplan con la correspondiente autorización de vertido. Para evitar los posibles problemas de escorrentía que pudieran producirse tras la aplicación de los purines y estiércoles al terreno deberán respetarse los perímetros de protección establecidos en el Reglamento de Dominio Público Hidráulico, aprobado por el Real Decreto 849/1986, modificado parcialmente por el Real Decreto 606/2003, en el Real Decreto Legislativo 1/2001 por el que se aprueba el texto refundido de la Ley de Aguas y lo dispuesto en los diferentes planes hidrológicos de cuenca.

\subsubsection{CONTAMINACIÓN DE AGUAS SUPERFICIALES}

Por último, hay que tener en cuenta que también se aportan contaminantes a las aguas superficiales por vía aérea. Según la Guía MTD del sector porcino (2010), las condiciones meteorológicas y ambientales juegan un papel decisivo a la hora de valorar la dispersión de los contaminantes gaseosos desde las fuentes de emisión y su deposición en medios cercanos o lejanos, pudiendo convertirse en fuentes difusas de contaminación. En este sentido, deben considerarse las emisiones de amoniaco a la atmósfera como participantes en los problemas de acidificación en las aguas superficiales y como un aporte más de nitrógeno al medio, que contribuye a los procesos de eutrofización.

Otro riesgo potencial de contaminación de las aguas superficiales puede provenir de posibles incidencias en los sistemas de almacenamiento de purín (desbordamiento o fugas) o por fenómenos de lixiviación producidos desde sistemas de almacenamiento de estiércoles sólidos (Guía MTD sector porcino, 2010).

\subsubsection{TRATAMIENTO DE PURINES}

Ningún proceso de tratamiento es capaz de hacer desaparecer completamente los purines. Los únicos componentes que se pueden eliminar mediante su transformación en compuestos gaseosos son el agua (se transforma en vapor de agua), la materia orgánica (se transforma en dióxido de carbono) y el nitrógeno (se transforma en nitrógeno molecular). El resto de componentes únicamente se pueden separar o concentrar. La implantación de uno o varios procesos combinados dará lugar a estrategias de tratamiento. Sea cual sea la estrategia elegida, el propósito final debe ser aumentar la capacidad de gestión sobre las deyecciones. Algunos problemas particulares a abordar mediante un tratamiento podrían 
ser: reducir los costes asociados al trasporte, adecuar la capacidad de almacenamiento a las necesidades de los cultivos, valorizar el residuo energéticamente, eliminar o recuperar parte del nitrógeno producido, minimizar las emisiones de malos olores, etc.

Tabla 2.2.3.1. Procesos aplicables al tratamiento de purines.

\begin{tabular}{|l|l|}
\hline Objetivo principal & Proceso \\
\hline Procesos que actúan sobre las propiedades físicas y químicas & $\begin{array}{l}\text { Incorporación de aditivos } \\
\text { Separación sólido-Líquido }\end{array}$ \\
\hline Procesos para la estabilización de materia orgánica & $\begin{array}{l}\text { Compostaje } \\
\text { Digestión aerobia }\end{array}$ \\
\hline Procesos para la producción de energía & Digestión anaerobia \\
\hline Procesos que actúan sobre el contenido en nutrientes & $\begin{array}{l}\text { Stripping-Absorción } \\
\text { Precipitación de Stuvita } \\
\text { Nitrificación-Desnitrificación }\end{array}$ \\
\hline Procesos que actúan sobre el contenido en agua & $\begin{array}{l}\text { Evaporación y secado } \\
\text { Biosecado }\end{array}$ \\
\hline
\end{tabular}

Fuente: Albert Magri Aloy, tecnologías para el tratamiento de purines porcino (I).

\section{Separación sólido-líquido}

Proceso que permite separar los purines en dos fracciones distintas: una sólida de tipología similar al estiércol y otra líquida, solución acuosa que contiene elementos disueltos y en suspensión. Aunque la separación no supone una modificación en el contenido de componentes sí permite su redistribución, y por lo tanto, una mejora en las posibilidades de gestión. Con una separación sólido-líquido se propicia la aplicación de líneas de tratamiento, transporte y aplicación distintas para cada una de las fases obtenidas. Para aumentar la eficiencia en la separación es posible utilizar agentes químicos.

\section{Compostaje}

Proceso aplicable a materiales de tipología sólida (p. ej.: fracción sólida) que consiste en la estabilización de compuestos orgánicos en presencia de oxígeno. Deberán favorecerse condiciones que permitan el desarrollo de temperaturas entre $50-70^{\circ} \mathrm{C}$ como resultado de la generación de calor de origen biológico. Al final de este proceso se obtiene un producto estable, libre de patógenos y semillas (compost). El proceso de compostaje requiere de aire, que puede ser suministrado por volteo de las pilas o por sistemas mecánicos más complejos. Son también necesarias unas condiciones iniciales de humedad (entre el 4065\%), estructura y composición (relación carbono/nitrógeno entre 25-35) adecuadas. La preparación de mezclas con material vegetal permite regular estos tres parámetros clave. 


\section{Digestión anaerobia}

La descomposición microbiológica de la materia orgánica en ausencia total de oxígeno produce un gas combustible (biogás), y por tanto, permite valorizar energéticamente el residuo. Este gas contiene una elevada proporción de metano (concentraciones superiores al 60\%) y posee un poder calorífico inferior del orden de $5.500 \mathrm{kcal} / \mathrm{m} 3$. La digestión conjunta (codigestión) de dos o más sustratos distintos con características complementarias permite mejorar los rendimientos del proceso. En situaciones donde exista un excedente de nitrógeno, la digestión anaerobia debe combinarse con algún proceso que permita eliminar o recuperar el nitrógeno de la fase líquida. Serían de aplicación procesos no biológicos que permitan aprovechar como fuente de energía el biogás recuperado tales como strippingabsorción (arrastre del nitrógeno amoniacal mediante una corriente gaseosa y posterior fijación del nitrógeno en una medio líquido acidificado) o evaporación/secado (separación del agua de la matriz sólida). Es habitual que estos procesos se acompañen de sistemas de cogeneración con el propósito de producir energía térmica a bajo coste.

\section{Nitrificación-desnitrificación}

El principal objetivo de este tratamiento biológico radica en transformar el nitrógeno amoniacal en molecular, gas inocuo que será transferido a la atmósfera. Únicamente la fracción líquida de purines es susceptible de un tratamiento de este tipo, que debe plantearse para la eliminación de la parte sobrante del nitrógeno generado. Es difícil que el efluente de un tratamiento de nitrificación-desnitrificación cumpla con los límites legales para realizar un vertido a cauce público. Aunque esto es posible mediante un tratamiento terciario de afinado, su coste puede ser prohibitivo. Más interesante parece ser utilizar esta agua para el riego, previa valoración de su aptitud. Así pues, es conveniente buscar un compromiso entre la calidad del agua recuperada y el uso posterior que se haga de ella.

\subsection{EFECTOS DE LA INDUSTRIA DEL CURTIDO Y LA ACTIVIDAD GANADERA EN EL CAUCE DEL RÍO GUADALENTÍN A SU PASO POR LORCA}

La ribera del Río Guadalentín a su paso por el municipio de Lorca (Región de Murcia) presenta valores de contaminación de metales pesados, principalmente por cromo procedente de los vertidos durante muchos años de las industrias del curtido de piel, así como por cobre y zinc de las granjas porcinas y de la agricultura como consecuencia de la fertilización excesiva con purines de cerdos, así como por vertidos directos al cauce). Hasta el año 2003 la industria del curtido de pieles (mayoritariamente cuero) tuvo una gran actividad. Dicha actividad ha contribuido enormemente a la contaminación directa de las aguas del río y de sus sedimentos ya que esta industria es una gran consumidora de agua en todos sus procesos, las cuales vertían al río directamente, sin ningún tipo de tratamiento. 
Los vertidos de aguas residuales al río tuvieron picos máximos de hasta $10.000 \mathrm{~m}^{3} / \mathrm{d}$ con concentraciones totales de $\mathrm{Cr}$ superiores a $500 \mathrm{mg} / \mathrm{L}$. Por otro lado, los vertidos de purines de porcino pueden presentar concentraciones de $\mathrm{Cu}$ y $\mathrm{Zn}$ con valores en torno a $2 \mathrm{mg} / \mathrm{L}$ y 50 mg/L (Gómez-Garrido et al., 2014). Actualmente, el Río Guadalentín no presenta un caudal permanente, sólo tras episodios de lluvias intensas se puede observar un caudal en el rio, estas lluvias son típicas del clima Mediterráneo a finales de verano y otoño (Tapia et al., 2002). Un estudio biogeoquímico y geotécnico de los sedimentos de un tramo de 1,5 km del cauce del río reveló que en todo el tramo (hasta $100 \mathrm{~cm}$ de profundidad) se superan los niveles de referencia de contaminación por cromo. Los niveles de cromo en los sedimentos del cauce se situaron por encima del nivel genérico de referencia (66 mg/kg). Incluso, se alcanzaron concentraciones hasta diez veces más elevadas en algunos puntos, aunque el riesgo de transferencia y afección a zonas cercanas es reducido debido a que la mayor parte de cromo se encuentra inmovilizado en los sedimentos. En lo que respecta a cobre y zinc, los niveles no fueron especialmente altos y se localizaron en pequeñas áreas.

\subsection{LEGISLACIÓN APLICABLE}

- Decreto 16/1999, de 22 de abril, sobre Vertidos de Aguas Residuales Industriales al Alcantarillado.

- Ley 11/2014, de 3 de julio, por la que se modifica la ley 26/2007, de 23 de octubre, de Responsabilidad Medioambiental.

- Ley 21/2013, de 9 de diciembre, de evaluación ambiental.

- Ley 22/2011, de 28 de julio, de residuos y suelos contaminados.

- $\quad$ Ley $22 / 88$, de 28 de julio de costas.

- Ley 34/2007, de 15 de noviembre, de calidad del aire y protección de la atmósfera

- Ley 4/2009, de 14 de mayo, de protección ambiental integrada de la Región de Murcia.

- Real Decreto 100/2011, de 28 de enero, por el que se actualiza el catálogo de actividades potencialmente contaminadoras de la atmósfera y se establecen las disposiciones básicas para su aplicación.

- Real Decreto 102/2011, de 28 de enero, relativo a la mejora de la calidad del aire.

- Real Decreto 117/2003, de 31 de enero, sobre limitación de emisiones de compuestos orgánicos volátiles debidas al uso de disolventes en determinadas actividades.

- Real Decreto 508/2007, de 20 de abril, por el que se regula el suministro de información sobre emisiones del Reglamento E-PRTR y de las autorizaciones ambientales integradas. 
- Real Decreto 773/2017, de 28 de julio, por el que se modifican diversos reales decretos en materia de productos y emisiones industriales.

- Real Decreto 815/2013, de 18 de octubre, por el que se aprueba el Reglamento de emisiones industriales y de desarrollo de la Ley 16/2002, de 1 de julio, de prevención y control integrados de la contaminación.

- Real Decreto 817/2015, de 11 de septiembre, por el que se establecen los criterios de seguimiento y evaluación del estado de las aguas superficiales y las normas de calidad ambiental.

- Real Decreto 849/1986, de 11 de abril, por el que se aprueba el Reglamento del Dominio Público Hidráulico, que desarrolla los títulos preliminar I, IV, V, VI y VII de la Ley 29/1985, de 2 de agosto, de Aguas.

- Real Decreto 9/2005, de 14 de enero, por el que se establece la relación de actividades potencialmente contaminantes del suelo y los criterios y estándares para la declaración de suelos contaminados.

- Real Decreto Legislativo $1 / 2001$, de 20 de julio, por el que se aprueba el texto refundido de la Ley de Aguas.

- Real decreto legislativo 1/2016, por el que se aprueba el texto refundido de la ley de prevención y control integrado de la contaminación.

- Reglamento 166/2006, de 18 de enero, relativo al establecimiento de un registro europeo de emisiones y transferencias de contaminantes. 
Capítulo 3

\section{FITOTECNOLOGÍAS Y USO DE LA BIOMASA CONTAMINADA}





\subsection{BIORREMEDIACIÓN. CONCEPTOS}

El término biorremediación se utiliza para describir una variedad de sistemas que utilizan organismos vivos (plantas, hongos, bacterias, etc.) para degradar, transformar o remover compuestos tóxicos y transformarlos en productos metabólicos inocuos o menos tóxicos.

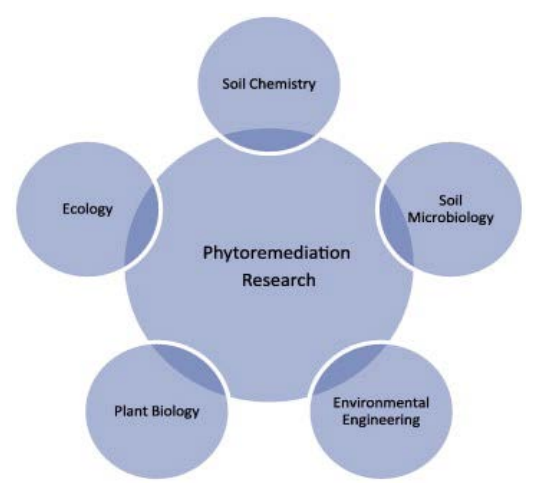

Figura 3.1.1. Discipinas englobadas por el término biorremediacion (Fuente: Ali et al., 2013).

Se entiende la biodegradación como el proceso natural por el cual los microorganismos degradan o alteran moléculas orgánicas transformándolas en moléculas más pequeñas y no tóxicas. Sin embargo, este proceso es muy lento y puede acelerarse introduciendo determinadas bacterias o plantas en los ambientes contaminados. Esta intervención se denomina "biorremediación" o "biocorrección" y se define como el empleo de organismos vivos para eliminar o neutralizar contaminantes del suelo o del agua. En los procesos de biorremediación generalmente se emplean mezclas de microorganismos, aunque algunos se basan en la introducción de definidas cepas de bacterias u hongos. Actualmente se están desarrollando microorganismos, algas (especialmente cianobacterias o algas azules) y plantas genéticamente modificadas para ser empleadas en biorremediación.

La biorremediación es el uso de seres vivos para restaurar ambientes contaminados. Es un concepto que no se debe de confundir con depuración. La depuración es la eliminación, ya sea por métodos físicos, químicos o biológicos de un contaminante antes de que éste alcance el medio ambiente. Cuando la contaminación ya se ha producido, se precisa restaurar el ecosistema contaminado, para lo que se pueden utilizar diversas estrategias, siendo la biorremediación una de ellas. Por otro lado, la biorremediación también se refiere a la transformación química de los contaminantes mediante el uso de microorganismos que satisfacen sus requerimientos nutricionales y energéticos contribuyendo a la desintoxicación del ambiente por mineralización o co-metabolismo (USEPA, 1996). 
La generación, la distribución y los derrames accidentales de diferentes moléculas orgánicas xenobióticas (herbicidas, insecticidas, acaricidas e hidrocarburos, entre otros) han ocasionado el deterioro del ambiente acumulándose directa o indirectamente en suelos, agua y aire. En términos generales, se puede decir que la velocidad de acumulación es mayor a la capacidad que tiene el planeta para remover estos compuestos orgánicos xenobióticos (Kvesitadze et al., 2001). De aquí surge el interés por colaborar con la naturaleza para revertir el efecto de los contaminantes en los ecosistemas (Sanderman, 1992). Uno de los conceptos que requiere atención especial es la biodegradación, que se refiere al proceso natural por el cual las bacterias $u$ otros organismos vivos alteran y convierten moléculas orgánicas en otras sustancias menos tóxicas como ácidos grasos y dióxido de carbono $\left(\mathrm{CO}_{2}\right)$.

La biorremediación es una tecnología que utiliza el potencial metabólico de los microorganismos (fundamentalmente bacterias, pero también hongos y levaduras) para transformar contaminantes orgánicos en compuestos más simples poco o nada contaminantes, y, por tanto, se puede utilizar para limpiar terrenos o aguas contaminadas (Glazer y Nikaido, 1995). Su ámbito de aplicabilidad es muy amplio, pudiendo considerarse como objeto de estudio cada uno de los estados de la materia (Atlas y Unterman, 1999):

- Sólido: con aplicaciones sobre medios contaminados como suelos o sedimentos, o bien directamente en lodos, residuos, etc.

- Líquido: aguas superficiales y subterráneas, aguas residuales, etc.

- Gases: emisiones industriales, así como productos derivados del tratamiento de aguas o suelos, etc.

También se puede realizar una clasificación de las técnicas o tratamientos de biorremediación en función de los contaminantes con los que se puede trabajar (Alexander, 1999; Eweis et al., 1999):

- Hidrocarburos de todo tipo (alifáticos, aromáticos, BTEX, PAH's,...).

- Hidrocarburos clorados (PCB's, TCE, PCE, pesticidas, herbicidas,...).

- Compuestos nitroaromáticos (TNT y otros).

- Metales pesados: estos no se metabolizan por los microorganismos de manera apreciable, pero pueden ser inmovilizados o precipitados.

- Otros contaminantes: compuestos organofosforados, cianuros, fenoles, etc.

Entre los microorganismos destacan especialmente las bacterias, los seres vivos con mayor capacidad metabólica del planeta. Las bacterias pueden degradar prácticamente cualquier sustancia orgánica. Si la sustancia se degrada completamente se habla de mineralización; este es el proceso ideal, pero no siempre ocurre. Algunas sustancias no son degradadas 
sino transformadas en otras (biotransformación). La biotransformación puede ser peligrosa, ya que la nueva sustancia formada puede ser tan nociva o más que la de partida. Finalmente hay sustancias que no son degradadas y se las denomina recalcitrantes. Éstas se acumulan durante mucho tiempo en el medio ambiente, especialmente si además son resistentes a procesos físicoquímicos como la radiación ultravioleta o la oxidación.

Las bacterias además pueden eliminar los contaminantes en ambientes donde hay oxígeno (ambientes aeróbicos), pero también en ambientes sin oxígeno (ambientes anaeróbicos), ya que pueden respirar otras sustancias diferentes al oxígeno (aceptores de electrones), como por ejemplo el nitrato, sulfato, hierro (III), manganeso, selenio, etc.

Todos aquellos contaminantes que puedan ser degradados o transformados por los seres vivos son susceptibles de ser eliminados mediante procesos de biorremediación. Los compuestos orgánicos suelen ser degradados total o parcialmente y eliminados por completo del ecosistema. Por ejemplo, compuestos contaminantes tales como el tolueno, el fenol o los polibifenilos clorados (PCB's) pueden ser utilizados como fuente de carbono por bacterias, tanto en condiciones aeróbicas como anaeróbicas. Bacterias de los géneros Pseudomonas, Ralstonia, Burkholderia o Mycobacterium pueden eliminar hidrocarburos aromáticos como el tolueno o el naftaleno, pesticidas como las triazinas, aditivos de la gasolina como el tricloruro de etilo o sustancias venenosas como el cianuro potásico, tanto de ambientes sólidos (suelos) como líquidos (ríos y mares).

Pero además, muchas bacterias son capaces de modificar sustancias químicas peligrosas, transformándolas en otras menos tóxicas. Así, algunas bacterias pueden reducir la biodisponibilidad (hacerlas menos accesible y por tanto menos tóxicas) de metales pesados tales como el mercurio, el arsénico, el cromo, el cadmio, el zinc o el cobre.

Básicamente, los procesos de biorremediación pueden ser de tres tipos: degradación enzimática, remediación microbiana y fitorremediación. Los explicamos brevemente a continuación:

- La degradación enzimática consiste en el empleo de enzimas en el sitio contaminado con el fin de degradar las sustancias nocivas. Dichas enzimas son previamente producidas en bacterias transformadas genéticamente. Esta aplicación de la biotecnología lleva décadas en el mercado y hoyen día las compañías biotecnológicas ofrecen las enzimas y los microorganismos genéticamente modificados para tal fin.

- La remediación microbiana se refiere al uso de microorganismos directamente en el foco de la contaminación. Estos microorganismos pueden ya existir en ese sitio o pueden provenir de otros ecosistemas, en cuyo caso deben ser inoculados en el sitio 
contaminado (proceso de inoculación). Cuando no es necesaria la inoculación de microorganismos, suelen administrarse más nutrientes, como fósforo y nitrógeno con el fin de acelerar el proceso.

Hay bacterias y hongos que pueden degradar con relativa facilidad petróleo y sus derivados, benceno, tolueno, acetona, pesticidas, herbicidas, éteres, alcoholes simples, entre otros. También pueden degradar, aunque parcialmente, otros compuestos químicos como el PCB, arsénico, selenio, cromo. Los metales pesados como uranio, cadmio y mercurio no son biodegradables, pero las bacterias pueden concentrarlos de tal manera de aislarlos para que sean eliminados más fácilmente.

Sin embargo, existen contaminantes difíciles de degradar y para los cuales no se han encontrado microorganismos capaces de transformarlos. La biotecnología moderna puede solucionar en parte este problema, generando organismos genéticamente modificados con nuevas capacidades para eliminar tales contaminantes. La base de esta estrategia se basa en la búsqueda de las enzimas adecuadas y la posterior transferencia de los genes correspondientes a los microorganismos que se inocularán en el lugar contaminado.

- La fitorremediación es el uso de plantas y los microorganismos asociados para remover contaminantes del ambiente o para dejar el ambiente limpio. Puede aplicarse a contaminantes orgánicos e inorgánicos, presentes en sustratos sólidos como el suelo o líquidos como el agua.

La biorremediación tiene también inconvenientes y limitaciones. Por ejemplo, la biodegradación incompleta puede generar intermediarios metabólicos inaceptables, con un poder contaminante similar o incluso superior al producto de partida. Por otra parte, algunos compuestos, como veremos, son resistentes o inhiben la biorremediación.

El tiempo requerido para que un tratamiento sea adecuado puede ser difícil de predecir y el seguimiento y control de la velocidad y/o extensión del proceso es laborioso. La aplicabilidad de esta técnica depende de varios factores:

- Propiedades del contaminante (biodegradabilidad). En general, los hidrocarburos alifáticos se degradan rápidamente. Las estructuras más ramificadas son más difíciles de degradar que las cadenas lineales, al producir impedimentos estéricos. Las cadenas ramificadas de sulfonatos de alquilo o arilo a menudo se degradan muy 
lentamente. Los dobles enlaces hacen la molécula más resistente, así como un incremento del número de anillos bencénicos. Las sustituciones químicas (ácidos dicarboxílicos, nitrilos, metilaciones, halogenaciones) también hacen la molécula más resistente. Por otra parte, la biodegradación de compuestos que contienen átomos de $\mathrm{N}$ ó S está ligada frecuentemente a su utilización como nutrientes.

- Presencia de comunidades microbianas adecuadas, con capacidad enzimática para metabolizar el compuesto(s). Los microorganismos pueden ser autóctonos (biorremediación intrínseca o atenuación) o añadidos al sistema para mejorar la degradación (bioaumentación).

- Disponibilidad del contaminante. Es un factor crítico, más importante que la propia presencia de comunidades microbianas. Para que la degradación de un contaminante pueda producirse, es necesario que interaccione con la célula en medio acuoso. Inicialmente lo hará con la parte exterior de su pared para posteriormente ser transportado al interior de la misma. La forma más común de transporte es la complejación con enzimas extracelulares producidos por los microorganismos. Muchos contaminantes orgánicos, como los derivados del petróleo, PCB's, hidrocarburos aromáticos policíclicos (naftaleno, pireno, fluoreno), solventes halogenados, etc., son hidrofóbicos y tienden a adsorberse en el suelo, concretamente a la fracción orgánica (ácidos húmicos, ácidos fúlvicos y humina). Esta es una de las causas, por ejemplo, de la persistencia de muchos pesticidas. La producción de surfactantes por los microorganismos es un factor determinante, como veremos, que atenúa este problema y facilita la degradación.

- Condiciones del medio contaminado: Propiedades que permiten o limitan el crecimiento microbiano y el metabolismo del compuesto. A veces es necesario modificar las condiciones, por ejemplo, añadiendo nutrientes 0 aireando (bioestimulación).

A modo de resumen, la biorremediación consiste en la adición de materiales exógenos a los ambientes contaminados para acelerar el proceso natural de biodegradación (Senan y Abraham, 2004). Estos conceptos necesariamente conducen a la noción de una nueva opción biológica viable para colaborar con la naturaleza, en donde es necesario tomar en cuenta otros elementos como el diagnóstico preciso del tipo de contaminante, la dimensión 
de la contaminación en suelo y aguas subterráneas, así como el futuro uso del lugar contaminado. Con estos elementos es posible evaluar las opciones técnicas de remediación considerando las ventajas y desventajas de las mismas (Harvey et al., 2002).

\subsection{LA FITORREMEDIACIÓN COMO TÉCNICA DE RECUPERACIÓN DE SUELOS}

La fitorremediación es la descontaminación de los suelos, la depuración de las aguas residuales o la limpieza del aire interior, usando material vegetal, también se incluyen a los hongos, y por extensión a los ecosistemas que contienen estas plantas. Entre las diferentes opciones técnicas de remediación, la fitorremediación ocupa un lugar importante porque es una tecnología emergente basada en la acción combinada de plantas (terrestres o acuáticas) con comunidades microbianas nativas (Wetzel et al., 1997). La fitorremediación no es un concepto nuevo, pues desde hace 3000 años los hombres han utilizado la capacidad natural de purificación de las plantas para el tratamiento del agua. Desde la década de 1970 esta práctica ha encontrado un renovado interés, en particular para el tratamiento de los plaguicidas y de los metales.

Aunque se encuentra en continuo desarrollo, la técnica de fitorremediación constituye una estrategia muy interesante, debido a la capacidad que tienen algunas especies vegetales de absorber, acumular y/o tolerar altas concentraciones de contaminantes como metales pesados, compuestos orgánicos y compuestos radioactivos, etc. Las ventajas que ofrece la fitorremediación frente a los procesos descritos anteriormente son el bajo costo y la rapidez con que pueden llevarse a cabo ciertos procesos degradativos. La fitorremediación se basa principalmente en las interacciones entre las plantas, el suelo y los microorganismos. El suelo es una compleja estructura que sirve de soporte para el desarrollo de las plantas y los microorganismos que se alimentan de los compuestos orgánicos o inorgánicos que lo componen. Cuando algunos de estos compuestos se encuentran en exceso con respecto al estado inicial del suelo, éste se describe como un suelo contaminado (esto también se aplica al agua y al aire, a diferencia del suelo son fluidos). Los compuestos en exceso pueden ser utilizados como fuente de energía por las plantas y microorganismos.

En el sistema planta-suelo-microorganismos, la biodegradación bacteriana es a menudo independiente de la absorción por medio de la raíz. Las plantas y los microorganismos han coevolucionado para adoptar una estrategia de aprovechamiento recíproca, para soportar la fitotoxicidad, de la que los microorganismos aprovechan los exudados de la raíces y también la planta se beneficia de la capacidad de degradación de los microorganismos rizosféricos para reducir el estrés debido a la fitotoxicidad. En última 
instancia, la planta es el agente esencial de la exportación de un contaminante fuera de su entorno.

La comunidad de la rizósfera está constituida por una microbiota (bacterias, hongos y algas) y por la micro y la mesofauna (protozoos, nematodos, insectos y ácaros). La micro y la mesofauna contribuyen significativamente en procesos de descomposición con el catabolismo de sustancias nocivas en la rizósfera. La rizósfera provee un microambiente complejo y dinámico, donde las bacterias y los hongos en asociación con las raíces, forman comunidades únicas que responden a exudados radiculares. Estas asociaciones pueden causar un beneficio o una enfermedad a la planta y tienen considerable potencial para la desintoxicación. Entre las interacciones benéficas destacan las que sostienen las plantas con bacterias que sintetizan factores de crecimiento útiles para la planta, como las hormonas, las simbiosis con fijadoras de $\mathrm{N}_{2}$ y las establecidas con hongos (Walton et al., 1994).

Un caso particular muy importante es el que se refiere a la micorriza, que es la interacción mutualista entre plantas y hongos. Esta interacción facilita la absorción de nutrientes en la raíz al aumentar el volumen de absorción de la planta. Las dimensiones físicas y la actividad microbiana en la rizósfera dependen de factores específicos del sitio y de la planta, como por ejemplo los referidos a las especies, edad, vigor de las plantas y el tipo de suelo.

Según la planta y el agente contaminante, la fitorremediación puede producirse por:

- acumulación del contaminante en las partes aéreas de la planta (por ejemplo metales pesados).

- absorción, precipitación y concentración del contaminante en raíces (por ejemplo metales pesados, isótopos radioactivos).

- reducción de la movilidad del contaminante para impedir la contaminación de aguas subterráneas o del aire (por ejemplo lagunas de deshecho de yacimientos mineros)

- desarrollo de bacterias y hongos que crecen en las raíces y degradan contaminantes (por ejemplo hidrocarburos del petróleo, benceno, etc.)

- captación y modificación del contaminante para luego liberarlo a la atmósfera con la transpiración (por ejemplo mercurio, selenio y metales clorados).

- captación y degradación del contaminante para originar compuestos menos tóxicos (por ejemplo pesticidas, herbicidas, TNT, etc.). 
Actualmente, gran parte de las investigaciones sobre fitorremediación están enfocadas en dilucidar los mecanismos del transporte de metales en las plantas y porqué algunas son capaces de absorber y tolerar altas cantidades de metales tóxicos, mientras que otras no. En este sentido, se está experimentando con la transformación de plantas, por ejemplo, con genes bacterianos de resistencia al mercurio.

La fitorremediación se realiza empleando al menos uno de los siguientes mecanismos: fitoextracción, rizofiltración, fitoestimulación, fitoestabilización, fitovolatilización y fitodegradación. Se explican a continuación:

La fitoextracción o fitoacumulación consiste en la absorción de contaminantes por las raíces; es la capacidad de algunas plantas para acumular contaminantes en sus raíces, tallos o follaje. Este mecanismo ha sido ampliamente estudiado en plantas que acumulan metales (Jian et al., 1997) y recientemente con materiales radioactivos (Dushenkov, 2003).

La rizofiltración se basa en la utilización de plantas que crecen en cultivos hidropónicos, se prefieren raíces de plantas terrestres con alta tasa de crecimiento y área superficial para absorber, concentrar y precipitar contaminantes.

En la fitoestimulación o rizodegradación las plantas generan los exudados radiculares que estimulan el crecimiento de los microorganismos nativos capaces de degradar compuestos orgánicos xenobióticos. Por ejemplo, Pivetz et al. (1997) ensayaron con éxito el crecimiento de diferentes especies de plantas en presencia de pentaclorofenol e hidrocarburos aromáticos policíclicos. Recientemente, Joner y Leyval (2003) probaron la fitoestimulación mediante la adición de un flavonoide hidroxilado y una flavona sintética no hidroxilada, ambos metabolitos secundarios de álamos; encontraron que concentraciones superiores a $10 \mu \mathrm{mol} / \mathrm{L}$ impedían la mineralización de benzo(a)pireno marcado en ensayos con lodos provenientes de las raíces. Finalmente, Siciliano et al., 2003 investigaron la capacidad de degradación y la composición de las comunidades microbianas durante la fitoestimulación en la raíz de Festuca arundinacea expuesta a hidrocarburos del petróleo. Encontraron que la máxima tasa de degradación fue de $38 \mathrm{mg}$ de hidrocarburos $/ \mathrm{kg}$ mes; este resultado es el doble de lo que se encontró en el testigo, también observó la alternancia en la composición de las comunidades microbianas.

La fitoestabilización es un mecanismo que utiliza a la planta para desarrollar un sistema denso de raíces que le permite reducir la biodisponibilidad y la movilidad de los contaminantes evitando el transporte a capas subterráneas o a la atmósfera. Dec y Bollang (1994) demostraron que Raphanus sp. desarrolla su sistema radicular en un año y que, 
durante el mismo tiempo, absorbe o remueve compuestos fenólicos hasta en un $90 \%$ de la concentración inicial.

La fitovolatilización se produce a medida que las plantas en crecimiento absorben agua junto con los contaminantes orgánicos solubles. Algunos de los contaminantes pueden llegar hasta las hojas y evaporarse o volatilizarse a la atmósfera. Los álamos, volatilizan el $90 \%$ del tricloroetileno que absorben (Núñez et al. 2004). Por ejemplo, las raíces de Populus deltoides fueron expuestas a una solución de tricloroetileno $(70 \mathrm{mg} / \mathrm{L})$ durante 26 días y el $90 \%$ del tricloroetileno fue volatilizado a través de las hojas (Orchard et al. 2000). Con la misma planta se ha demostrado que hay volatilización del éter metil terbutílico expuesto en las raíces y encontrado en las hojas (Aitchison et al. 2000, Hong et al. 2001, Kelley et al. 2001, Rubin y Ramaswami 2001).

La fitodegradación consiste en la transformación de los contaminantes orgánicos en moléculas más simples. En determinadas ocasiones, los productos de la degradación le sirven a la planta para acelerar su crecimiento, en otros casos los contaminantes son biotransformados. Por ejemplo, Marjories et al., (2001), Newman et al., (1999) y Kassel et al., (2002), encontraron que el álamo fitodegradó moléculas como el éter metil terbutílico y el tricloroetileno presente en acuíferos.

Según López-Martínez et al. (2005), una planta fitorremediadora realiza cualquiera de los mecanismos anteriores siguiendo tres fases: absorción, excreción y desintoxicación de contaminantes:

- La absorción de contaminantes se realiza a través de las raíces y las hojas mediante los estomas y la cutícula de la epidermis (Watt y Evans, 1999). Esta absorción ocurre en la rizodermis de las raíces jóvenes, que absorben los compuestos por ósmosis dependiendo de factores externos como la temperatura y el $\mathrm{pH}$ del suelo. Otros factores importantes que inciden en la penetración del contaminante son su peso molecular e hidrofobicidad, ambos factores determinan que estas moléculas atraviesen las membranas celulares de la planta. Después de cruzar la membrana, los contaminantes son distribuidos a través de toda la planta (Harvey et al., 2002).

- Los contaminantes que se absorben por las raíces, se excretan vía foliar (fitovolatilización). Cuando las concentraciones de los contaminantes son elevadas, sólo pequeñas fracciones (menos del $5 \%$ ) se excretan sin cambios en su estructura química.

- La desintoxicación de los compuestos orgánicos se lleva a cabo por la vía de la mineralización hasta dióxido de carbono. 
La elección de una estrategia de remediación dependerá de la naturaleza de los contaminantes. Los suelos contaminados con metales pesados son extremadamente difíciles de remediar y normalmente son excavados y sustituidos con suelo nuevo. Además, algunas zonas contaminadas con metales son tratadas con otras técnicas, como la lixiviación ácida, separación física del contaminante o procesos electroquímicos que tienen costes muy elevados (Cunningham et al, 1997). Por ello, se buscan utilizar técnicas de remediación biológicas menos invasivas y costosas. La fitorremediación es considerada a menudo como una alternativa para las tecnologías de remediación convencionales por ser una actividad económicamente sostenible, eficaz y respetuosa con el medio ambiente (Kumar et al, 1995).

Respecto a tecnologías de fitorremediación, las fitotecnologías se basan en los mecanismos fisiológicos básicos que tienen lugar en las plantas y en los microorganismos asociados a ellas, tales como: traspiración, fotosíntesis, metabolismo y nutrición. Según Thangavel y Subhuram (2004), dependiendo del tipo de contaminante, las condiciones del sitio y el nivel de limpieza requerido; las tecnologías de fitorremediación ((rizofiltración, fitoestabilización y fitoinmovilización) o eliminación (fitodegradación, fitoextracción y fitovolatilización)) se pueden utilizar como medio de contención.

La fitoestabilización es el uso de plantas para estabilizar los contaminantes en suelos contaminados (Singh, 2012). Esta técnica es utilizada para inmovilizar y reducir la biodisponibilidad de contaminantes en el suelo, previniendo su migración a aguas subterráneas o su entrada en la cadena trófica. Permite inmovilizar contaminantes en el suelo a través de su absorción y acumulación en las raíces o bien, por precipitación en la zona de la rizosfera. Este proceso reduce la movilidad de los contaminantes y evita su migración a las aguas subterráneas o al aire (Barton et al., 2005; Méndez y Maier, 2008). La fitoestabilización es efectiva en suelos de textura fina con alto contenido de materia orgánica (Padmavathiamma y Li, 2007). Se aplica principalmente en terrenos extensos en donde existe contaminación superficial. Esta tecnología tiene como ventajas, sobre otros métodos de remediación de suelos, que es de menor costo, fácil de aplicar y estéticamente agradable. Algunas plantas empleadas con fines de fitoestabilización son: Hyparrhenia hirta (Pb); Zygophyllum fabago (Zn); Lupinus albus (Cd, As); Anthyllis vulneraria ( $\mathrm{Zn}, \mathrm{Pb}$, $\mathrm{Cd})$; Deschampsia cespitosa (Pb, Cd, Zn); Cardaminopsis arenosa (Cd, Zn); Horedeum vulgare, Lupinus angustifolius y Sécale cereale (As); Lolium italicum y Festuca arundinaceae (Pb, Zn); y Brassica júncea (Cd, Zn, Cu, Mn, Fe, Pb) (Bolán et al., 2003; Clemente et al., 2003; Rizzi et al., 2004; Kucharski et al., 2005; Clemente et al., 2006; Frérot et al., 2006; Mains et al., 2006; Vázquez et al., 2006; Conesa et al., 2007). 
Esta técnica no es una solución permanente porque los metales pesados permanecen en el suelo, sólo se limita su movimiento, por ello actualmente es una estrategia utilizada para estabilizar o inactivar contaminantes potencialmente tóxicos (Hazrat Ali et al., 2013).

La rizofiltracion utiliza las plantas para eliminar del medio hídrico los contaminantes a través de la raíz (Dushenkov et al., 1995). En la rizofiltracion las plantas utilizadas se cultivan de manera hidropónica. Cuando el sistema radicular está bien desarrollado, las plantas se introducen en el agua contaminada con metales, en donde las raíces los absorben y acumulan. A medida que las raíces se van saturando, las plantas se cosechan y se disponen para su uso final (Nedelkoska y Doran, 2000; Eapen et al., 2003; Cherian y Oliveira, 2005).

Existe una gran cantidad de estudios relacionados con la capacidad de acumulación de contaminantes de diversas plantas acuáticas, algunos ejemplos de ellas son: Scirpus lacustris ( $\mathrm{Cd}, \mathrm{Cu}, \mathrm{Pb}, \mathrm{Mg}, \mathrm{Fe}$, Se, Cr), Lemna gibba (Pb, As, Cu, Cd, Ni, Cr, Al, Fe, Zn, $\mathrm{Mn}$ ), Azolla caroliniana ( $\mathrm{Hg}, \mathrm{Cr} \mathrm{Sr}, \mathrm{Cu}, \mathrm{Cd}, \mathrm{Zn}, \mathrm{Ni}, \mathrm{Pb}, \mathrm{Au}, \mathrm{Pt})$, Elatine Manda (As), Wolffia papulifera (Cd), Polygonum punctatum ( $\mathrm{Cu}, \mathrm{Cd}, \mathrm{Pb}, \mathrm{Se}, \mathrm{As}, \mathrm{Hg}, \mathrm{Cr}, \mathrm{Mn})$ y Myriophylhum aquaticum, Ludwigina palustris y Mentha aquatic (Cu, Zn, Mn, Fe, Ni) (Zhao y Duncan, 1998; Boniardi et al., 1999; Fogarty et al., 1999; Antones et al., 2001; Groudeva et al., 2001; Cohen-Shoel et al., 2002; Suseela et al., 2002; Quin y Terry, 2003; Zheng et al., 2003; Bennicelli et al., 2004; Chandra y Kulshreshtha, 2004; Kamal et al., 2004; Maleva et al., 2004; Weis y Weis, 2004; Mkandawire et al.,2005; Vardanyan y Ingole, 2006; Dilek, 2007; Li et al., 2007).

La fitoextracción o fitoacumulación consiste en la absorción de metales contaminantes mediante las raíces de las plantas y su acumulación en tallos y hojas. El primer paso para la aplicación de esta técnica es la selección de las especies de planta más adecuadas para los metales presentes y las características del emplazamiento. Una vez completado el desarrollo vegetativo de la planta el siguiente paso es cortarlas y proceder a su incineración y traslado de las cenizas a un vertedero de seguridad. La fitoacumulación se puede repetir ilimitadamente hasta que la concentración remanente de metales en el suelo esté dentro de los límites considerados como aceptables (Kumar et al., 1995). Algunas plantas empleadas para esta técnica fitocorrectiva son: Thlaspi caerulescens (Cd); Sedum alfredii, Viola baoshanensis y Vertiveria zizanioides ( $\mathrm{Zn}, \mathrm{Cd}, \mathrm{Pb})$; Alyssum múrale, Trifolium nigriscens, Psychotria douarrei, Geissois pruinosa, Homalium guillainii, Hybanthus floribundus, Sebertia acuminata, Stackhousia tryonii, Pimelea leptospermoides, Aeollanthus biformifolius y Haumaniastrum robertii (Ni); Brassica júncea, Helianthus annuus, Sesbania drummondii (Pb); Brassica napus (Cu, Pb, Zn); y Pistia stratiotes (Ag. Cd, Cr, Cu, Hg, Ni, Pb, Zn) (Begonia et al., 1998; Reeves, 2003; Schwartz et al., 2003; Wenzel et al., 2003; Odjegba 
y Fasidi, 2004; Sharma et al., 2004; Boonyapookana et al., 2005; Chandra et al., 2005; Zhuang et al., 2005; Bani et al., 2007; Wu et al., 2007; Zhuang et al., 2007).

La fitovolatilización se produce a medida que los árboles y otras plantas en crecimiento absorben agua junto con contaminantes orgánicos e inorgánicos. Algunos de estos pueden llegar hasta las hojas y evaporarse o volatilizarse en la atmósfera (Prasad y Freitas, 2003). Mediante este proceso se pueden eliminar contaminantes como: compuestos orgánicos volátiles (benceno, nitrobenceno, tolueno, etilbenceno y $\mathrm{m}$-xileno), As, Se y $\mathrm{Hg}$ (Burken y Ma, 2006; Padmavathiamma y Li, 2007). Las plantas Salicornia bigelovii, Brassica júncea, Astragalus bisulcatus y Chara canescens se han empleado para la remediación de sitios contaminados con Se (Lin et al, 2002; Shrestha et al, 2006) y la Arabidopsis thaliana para sitios contaminados con Hg (Olerían y Oliveira, 2005).

En la fitodegradación, las plantas y los microorganismos asociados a ellas degradan los contaminantes orgánicos en productos inofensivos, o bien los mineralizan hasta $\mathrm{CO}_{2} \mathrm{y}_{2} \mathrm{O}$, básicamente consiste en la degradación de contaminantes orgánicos por las plantas con la ayuda de enzimas como la deshalogenasa y la oxigenasa, no dependientes de los microorganismos de la rizosfera (Vishnoi and Srivastava, 2008). Las plantas pueden acumular compuestos xenobióticos orgánicos de suelos contaminados y detoxificarlos por sus actividades metabólicas. Esta estrategia está limitada sólo a contaminantes orgánicos, ya que los metales pesados no son biodegradables (Doty et al., 2007). La fitodegradación se ha empleado para la remoción de explosivos como el TNT, hidrocarburos halogenados, bisfenol A, PAH's y pesticidas organoclorados y organofosforados (Hannink et al., 2001; Chaudhry et al., 2002; Denys et al., 2006; Zhang et al., 2007).

La fitoinmovilización provoca la sujeción y reducción de la biodisponibilidad de los contaminantes mediante la producción de compuestos químicos en la interfaz suelo-raíz, los que inactivan las substancias tóxicas, ya sea por procesos de absorción, adsorción o precipitación (Carpena y Bernal, 2007).

Según los autores Brooks (1998) y Raskin y Ensley (2000) las principales ventajas de la fitorremediación son:

- Es una tecnología sostenible.

- Es eficiente para tratar diversos tipos de contaminantes in situ.

- Es aplicable a ambientes con concentraciones de contaminantes de bajas a moderadas.

- Es de bajo costo, no requiere personal especializado para su manejo ni consumo de energía.

- Es poco perjudicial para el ambiente. 
- No produce contaminantes secundarios y por lo mismo no hay necesidad de lugares para desecho.

- Tiene una alta probabilidad de ser aceptada por el público, ya que es estéticamente agradable.

- Evita la excavación y el tráfico pesado.

- Tiene una versatilidad potencial para tratar una gama diversa de materiales peligrosos.

- Se pueden reciclar recursos (agua, biomasa, metales).

Y las principales desventajas son:

- Es un proceso relativamente lento (cuando las especies son de vida larga, como árboles o arbustos).

- Es dependiente de las estaciones del año.

- El crecimiento de la vegetación puede estar limitado por los extremos de la toxicidad ambiental

- Los contaminantes acumulados en las hojas pueden ser liberados nuevamente al ambiente durante el otoño (especies perennes).

- Los contaminantes pueden acumularse en maderas para combustión.

- No todas las plantas son tolerantes o acumuladoras.

- La solubilidad de algunos contaminantes puede incrementarse, resultando en un mayor daño ambiental o migración de contaminantes

- Se requieren áreas relativamente grandes.

- Pudiera favorecer el desarrollo de mosquitos (en sistemas acuáticos).

No debemos olvidar que la fitorremediación se limita a la superficie y a la profundidad ocupada por las raíces, considerando que muchos contaminantes basados en los metales también se mantienen en la capa superior del suelo.

En general, lo más aconsejable es usar con plantas de crecimiento rápido que muestran una amplia gama de elección para la mayoría de los contaminantes de todo tipo. La fitoacumulación está relacionada con la fitotolerancia de la planta hacia los contaminantes. La toxicidad de algunos contaminantes puede reducirse mediante la reducción química de los elementos implicados, que se transforman así en sustancias menos contaminantes, y/o mediante la incorporación de componentes orgánicos (otra forma de biotransformación).

Las plantas seleccionadas en la fitoextracción son elegidos por su capacidad de extraer grandes cantidades de contaminantes, son plantas llamadas hiperacumuladoras. Las características comunes de las plantas hiperacumuladoras son: un rápido crecimiento, 
plantas resistentes y fáciles de arraigar, mantener una alta capacidad de evapotranspiración (evaporación del agua a través de hojas) y la capacidad de transformar los contaminantes en productos no tóxicos o menos tóxicos. Entre las plantas más utilizadas en fitoextracción están los Populus (álamos), que tienen un rápido crecimiento, adaptación climática grande y la capacidad de absorber grandes cantidades de agua (en relación con otras especies). Esta última cualidad les permite manejar grandes cantidades de contaminantes disueltos, así como limitar la cantidad de agua que escapa más allá de la zona contaminada - lo que limita también la dispersión de la contaminación.

Los autores Reeves et al. (1999) listaron 320 especies acumuladoras provenientes de 43 familias. Su número es mucho mayor: por ejemplo, hasta el año 2006 se conocen cerca de 300 plantas hiperacumuladoras de níquel. Los centros de biodiversidad están en Cuba (clima subtropical) y Nueva Caledonia (clima tropical). Muchas de las especies estudiadas por su acumulación de metales son de la familia Brassicaceae (clima templado y frío, hemisferio norte).

Cierta relevancia cabe mencionar que el equipo de investigación de Abdelhak El Amrani de la Universidad de Rennes (Francia) que ha trabajado con diversos contaminantes, especialmente en el herbicida atrazina. Estos investigadores han descubierto un mecanismo en algunas plantas que les permite prosperar incluso cuando la concentración del contaminante de los suelos en los que se hallan es normalmente letal para una planta no tratada. La presencia de algunos compuestos naturales biodegradables como las poliaminas exógenas, permite a las plantas tolerar concentraciones de contaminación 500 veces más alta en comparación con las plantas control. Este tratamiento da lugar a cambios en la expresión génica de las plantas, que afectan a genes conocidos en el proceso de resistencia al estrés ambiental. La técnica genética ha sido patentada por la Universidad de Rennes.

La eficiencia de remoción de contaminantes durante el proceso de fitorremediación depende principalmente de las especies de planta utilizadas, el estado de crecimiento de las plantas, su estacionalidad y el tipo de metal a remover. Por lo mismo, para lograr buenos resultados, las plantas a utilizar deben tener las siguientes características:

- Ser tolerantes a altas concentraciones de metales.

- Ser acumuladoras de metales.

- Tener una rápida tasa de crecimiento y alta productividad.

- Ser especies locales, representativas de la comunidad natural.

- Ser fácilmente cosechables.

- Deben tolerar y acumular altas concentraciones de metales en las partes cosechables. 
- Deben tener una alta tasa de crecimiento.

- Deben producir un gran volumen de biomasa.

- Capacidad de traslocación.

- Sistema radicular muy desarrollado.

- Tolerancia a patógenos y herbívoros.

- Síntesis de quelantes.

\subsection{FITORREMEDIACIÓN DE METALES PESADOS}

El término de "metal pesado" se refiere a aquellos metales de la tabla periódica cuyo peso específico es superior a $5 \mathrm{~g} / \mathrm{cm}^{3}$ o que tienen un número atómico por encima de 20 , excluyendo generalmente a los metales alcalinos y elementos alcalinotérreos (Breckle, 1991; Tiller, 1989). El término resulta algo impreciso si se tiene en cuenta las propiedades físicoquímicas de los elementos, especialmente las propiedades iónicas que definen la capacidad de complejación y las propiedades biológicas. Se han utilizado otros términos como "metal tóxico" o "elemento traza", sin que ninguno de ellos se refiera a los mismos elementos, resultando igualmente poco satisfactorios.

En cualquier caso, de acuerdo con Tiller (1989), el término "metal pesado" puede ser utilizado de una forma globalizadora para referirse a aquellos metales clasificados como contaminantes ambientales. Los metaloides, por su parte, poseen características intermedias entre los metales y los no metales de acuerdo con sus propiedades de enlace e ionización. Metaloides como el As, Se o Sb también pueden constituir importantes contaminantes ambientales. Pueden dañar a los organismos vivos a bajas concentraciones y tienden a acumularse en la cadena alimentaria

Los metales han cumplido un papel importante en el curso de la evolución por sus propiedades químicas:

- Esenciales: metales necesarios para los organismos vivos en cantidades mínimas para cumplir funciones fisiológicas y bioquímicas vitales (redox, complejos de coordinación, sitio activo de enzimas). Ejemplos: $\mathrm{Fe}, \mathrm{Mn}, \mathrm{Co}, \mathrm{Cu}, \mathrm{Zn}$ y $\mathrm{Ni}$.

- No esenciales: metales que no son necesarios para los organismos vivos para ninguna función y son tóxicos en mínimas concentraciones. Ejemplos: $\mathrm{Cd}, \mathrm{Pb}, \mathrm{As}$, $\mathrm{Se}, \mathrm{Hg}$ y $\mathrm{Cr}$.

Los metales pesados constituyen uno de los grupos de contaminantes ambientales sujetos a una mayor investigación y preocupación, fundamentalmente debido a su persistencia y a las bajas concentraciones a las que pueden manifestar sus efectos tóxicos (Salazar y Pignata, 
2014). Su perpetuación, acumulación progresiva y/o su transferencia a otros medios naturales, como las aguas subterráneas, entrada en la cadena trófica, etc., supone una amenaza para la salud humana y la salud de los ecosistemas (Becerril Soto et al., 2007). En particular, los metales pesados forman radicales libres que causan estrés oxidativo en los seres vivos (Mudipalli, 2008). El estrés oxidativo se refiere a una mayor generación de especies reactivas de oxígeno (ROS), que pueden disminuir las defensas antioxidantes intrínsecas de las células, conduciendo a daño o muerte celular (Das et al., 2008, Krystofova et al., 2009 y Sánchez-Chardi et al., 2009). Además, pueden sustituir a los metales esenciales en pigmentos o enzimas interrumpiendo algunas de sus funciones (Malayeri et al., 2008).

En cuanto a sus efectos tóxicos, los metales pesados más problemáticos son $\mathrm{Hg}, \mathrm{Cd}, \mathrm{Pb}$, As, $\mathrm{Cu}, \mathrm{Zn}, \mathrm{Sn}$ y $\mathrm{Cr}$. De estos, $\mathrm{Hg}, \mathrm{Cd}, \mathrm{Pb}$ y As son metales pesados no esenciales, mientras que $\mathrm{Cu}$ y $\mathrm{Zn}$ son metales pesados esenciales (oligoelementos). Los problemas de salud causados dependen del metal pesado que se trate, su estado de concentración, su estado de oxidación, etc.

Dentro del amplio abanico de tecnologías existentes para la restauración de los suelos contaminados por metales pesados, la fitorremediación, que implica la utilización de plantas, se presenta como una técnica emergente que supone generalmente unos menores costes y una menor destrucción y alteración del medio. Sin embargo, todavía es una técnica en fase experimental y presenta grandes limitaciones que la convierten en un proceso lento y difícil de llevar a la práctica dada la competencia con otras técnicas usualmente empleadas (Salazar y Pignata, 2014).

Las plantas presentan diferente capacidad para hacer frente al exceso de metales o a la presencia de metales no esenciales. Se pueden clasificar en 3 grupos:

- Hipotolerantes (reseñadas también como hipersensible o sensible) a los metales y plantas genéticamente modificadas que son más sensibles a uno o varios metales que las plantas silvestres.

- Tolerantes basales (descriptas también como constitutivamente tolerantes, normales o no resistentes) son las especies vegetales o ecotipos que pueden regular la distribución del metal a nivel de la célula y de la planta entera de manera que pueda sobrevivir y reproducirse sobre suelos no enriquecidos en el metal. La cantidad de metal que no daña el cumplimiento del ciclo de vida es específica para dicho metal y para la especie vegetal o su ecotipo.

- Hipertolerantes (también nombradas metal tolerante, metal resistente o adaptada a metales) son una especie o ecotipo que puede sobrevivir y reproducirse en suelos 
enriquecidos en ciertos metales. Las plantas serán hipertolerantes a esos metales que se encuentran en niveles altos en su ambiente natural, pero tienen tolerancia basal al resto de los metales en el ambiente.

Algunas especies vegetales denominadas hiperacumuladoras son capaces de concentrar metales de manera activa en sus tejidos, sobre las cuales cabría mencionar lo siguiente:

- se sugiere que la planta es capaz de hiperacumular un metal cuando contiene una concentración igual o superior al $0,1 \%$ de su peso seco para elementos como $\mathrm{Ni}$, Co $\mathrm{o} \mathrm{Pb}$, de forma independiente de la concentración encontrada en el suelo, sin presentar efectos tóxicos.

- para el Zn el límite es mayor del $1 \%$.

- para algunos metales como el Cd una concentración menor $(0,01 \%)$ la clasifica a la planta como hiperacumuladoras.

El mayor número de especies hiperacumuladoras concentran $\mathrm{Ni}$, aunque se han descripto también para $\mathrm{Zn}, \mathrm{Cd}, \mathrm{As}, \mathrm{Mn}, \mathrm{Pb}$ y $\mathrm{Cu}$. Las especies hiperacumuladoras se encuentran descriptas especialmente en la familia Brassicaceae.

La fitoextracción es la técnica de fitorremediación más útil para eliminar los metales pesados de los suelos contaminados (Hazrat Ali et al., 2013). Sin embargo, la eficiencia de esta técnica depende de las formas químicas en las que se encuentran los metales en el suelo, cuya movilidad y biodisponibilidad viene determinada, en gran medida, por el conjunto de los diferentes componentes del suelo, así como por los factores químicos, físicos y biológicos que influyen en la reactividad de los componentes.

Los procesos que gobiernan la compartimentalización de metales en los suelos se traducen en reacciones de adsorción-desorción y en reacciones de precipitación-disolución, que afectan directamente al reparto de metales entre la fase sólida y la acuosa, así como las reacciones de complejación y oxidación-reducción que afectan a la reactividad del propio metal (solubilidad y biodisponibilidad). Como se dijo anteriormente, estas reacciones están controladas por factores ambientales como el $\mathrm{pH}$, la capacidad de intercambio de cationes, el contenido de humedad de los suelos, el potencial redox y el propio tipo y especiación química de los elementos (Díez, 2008).

La biodisponibilidad de un elemento se refiere a las formas biológicamente disponibles que pueden llegar a ser absorbidas por un organismo e integrarse en su metabolismo y va a depender fundamentalmente de las formas o especiación en las que se encuentren los metales en el suelo y de la capacidad de absorción del propio organismo. A causa de esto, las plantas han desarrollado ciertos mecanismos de "solubilización" de metales pesados en el suelo: 
- Las raíces pueden secretar a la rizosfera sustancias capaces de movilizar metales, denominadas fitosideróforos (Lone et al., 2008).

- $\quad$ También se pueden excretar protones, que acidifican la rizosfera e incrementan la disolución de metales ya que pueden desplazar los cationes de metales pesados adsorbidos en partículas del suelo (Alford et al., 2010). Los exudados radiculares pueden disminuir el $\mathrm{pH}$ de la rizosfera en una o dos unidades, esto hace que aumente la concentración de metales pesados en disolución promoviendo su desorción (Thangavel y Subbhuraam, 2004).

- $\quad$ Además de lo anterior, los microorganismos rizosféricos (mayoritariamente bacterias y hongos micorriza) pueden aumentar considerablemente la biodisponibilidad de metales pesados en el suelo, ya que las interacciones de sideróforos microbianos pueden aumentar la labilidad de los metales y aumentar la absorción radicular (Mench et al., 2009).

La absorción de metales pesados por las plantas es generalmente el primer paso para su entrada en la cadena alimentaria. La absorción y posterior acumulación dependen, en primera instancia, de la movilidad de los metales desde la solución en el suelo a la raíz de la planta. Algunos contaminantes son más susceptibles a ser más fitodisponibles que otros. Estos contaminantes pueden alcanzar niveles que provocan efectos negativos en las propiedades físicas, químicas y biológicas como: reducción del contenido de materia orgánica, disminución de nutrientes, variación del pH generando suelos ácidos, amplias fluctuaciones en la temperatura, efectos adversos en el número, diversidad y actividad en los microorganismos de la rizósfera, dificultad en el crecimiento de una cubierta vegetal protectora favoreciendo la aridez, la erosión del suelo y la dispersión de los contaminantes hacia zonas y acuíferos adyacentes y, como consecuencia, aumenta la vulnerabilidad de la planta al ataque por insectos, plagas y enfermedades (Zang et al., 2006).

La movilidad relativa de los elementos traza en los suelos es de suma importancia en cuanto a su disponibilidad y su potencial para lixiviarse de los perfiles del suelo hacia las aguas subterráneas y difiere de si su origen es natural o antrópico y del tipo de fuente antrópica. Los factores que influyen en la movilización de metales pesados en el suelo son factores característicos del suelo: $\mathrm{pH}$, potencial redox, composición iónica de la solución del suelo, capacidad de intercambio (catiónico y/o aniónico), presencia de carbonatos, materia orgánica, textura, entre otras. La naturaleza de la contaminación y el origen de los metales y formas de deposición y condiciones medio ambientales producen acidificación, cambios en las condiciones redox, variación de temperatura y humedad en los suelos. (Sauquillo et al., 2003) 
En general, los metales pesados incorporados al suelo pueden seguir cuatro mecanismos diferentes: quedan retenidos en el suelo, ya sea disueltos en la fase acuosa del suelo, ocupando sitios de intercambio o específicamente adsorbidos sobre constituyentes inorgánicos del suelo, asociados con la materia orgánica del suelo y/o precipitados como sólidos puros o mixtos; pueden ser absorbidos por las plantas y así incorporarse a las cadenas tróficas; pasan a la atmósfera por volatilización y se movilizan a las aguas superficiales o subterráneas. (Mc Graths et al., 2001). Una vez en el interior de la planta, los metales pesados son transportados en forma de iones. Estos atraviesan una serie de transportadores especializados o acoplados a proteínas portadoras de protones en la membrana plasmática de la raíz (Greipsson, 2011). Posteriormente, los iones podrán ser almacenados en las raíces o translocados a los tejidos a través de los vasos del xilema (Prasad, 2004) donde serán depositados en vacuolas, eliminando así el exceso de iones metálicos del citosol y así reducir las interacciones con los procesos metabólicos celulares.

La compartimentalización de complejos metálicos en vacuolas es parte de los mecanismos de tolerancia en hiperacumuladoras, que se basan en la unión de la pared celular, activar el transporte 19 de iones a la vacuola y la quelación a través de la formación de complejos metálicos (Sheoran et al., 2011). El viaje de los metales pesados desde el suelo hasta las vacuolas está controlado y regulado por gran variedad de moléculas especializadas en distintas funciones de transporte, complejación y secuestro. Las moléculas más importantes en los procesos de acumulación y tolerancia de metales son las fitoquelatinas y las metalotioninas. Estas moléculas son ricas en grupos cisteinsulfidrilo que unen y secuestran iones de metales pesados formando complejos muy estables. Las plantas las expresan de manera natural para facilitar la traslocación a través del xilema. Las fitoquelatinas son péptidos sintetizados por la enzima fitoquelatina sintetasa, que se unen a los metales y son parte del sistema de detoxificación vegetal (Ali et al., 2013). Se expresan mayormente en las raíces y en menor medida en las hojas (Gomez et al., 2009). Por otro lado, las metalotioninas son un grupo de genes modificados, de bajo peso molecular, que unen proteínas a metales y cuya función es la de proteger las plantas de los efectos tóxicos de los iones metálicos (Sheoran et al., 2011).

Schat et al. (2000) clasificaron a la tolerancia en dos tipos de acuerdo con el conjunto de mecanismos moleculares o bioquímicos que la conforman:

(1) co-tolerancia, la cual puede ser el resultado de un mecanismo específico que confiere una tolerancia a diversos metales.

(2) tolerancia múltiple, en la que la tolerancia es generada por una serie de mecanismos independientes para cada metal o metales que interactúan de manera conjunta para evitar el 
daño a la planta. De estas dos ideas, las evidencias sugieren que la tolerancia múltiple es el tipo que se presenta en la mayoría de las plantas (Macnair et al., 2000).

\subsection{APLICACIONES FITOTECNOLOGÍAS}

Las principales aplicaciones de las fitotecnologías son:

\section{En suelos y residuos sólidos}

- Residuos militares (TNT, metales, orgánicos).

- Campos agrícolas (herbicidas, pesticidas, metales).

- Suelos industriales (orgánicos, metales).

- Minas (metales).

- Zonas de tratamiento de maderas (hidrocarburos aromáticos policíclicos, PAH's)

\section{En efluentes líquidos}

- Aguas residuales (nutrientes, metales).

- Drenajes de agricultura (nutrientes, fertilizantes, metales, pesticidas orgánicos y herbicidas).

- Efluentes industriales (metales).

- Efluentes de minería (metales).

- Plumas subterráneas (metales, compuestos orgánicos).

\section{En corrientes gaseosas}

- Aire libre e interior (óxidos de nitrógeno, $\mathrm{SO}_{2}$, ozono, $\mathrm{CO}_{2}$, gases neurotóxicos, partículas de hollín, e hidrocarburos halogenados volátiles).

La eficiencia de una fitotecnología está influenciada por factores como:

- Tipo de contaminación

- Tipo de suelo

- Tipo de vegetación

- Condiciones climatológicas 
Es por ello que la realización de estudios previos a pequeña escala (laboratorio y parcelas experimentales) antes de la aplicación a gran escala es crucial para lograr las metas ambientales propuestas. En la Figura 3.4.1 se representa un esquema de las pautas para la selección de la fitotecnología a aplicar. Así mismo, en la Tabla 3.4.1 se representan los diferentes mecanismos de extracción utilizados por las plantas y el resultado alcanzado sobre los contaminantes.

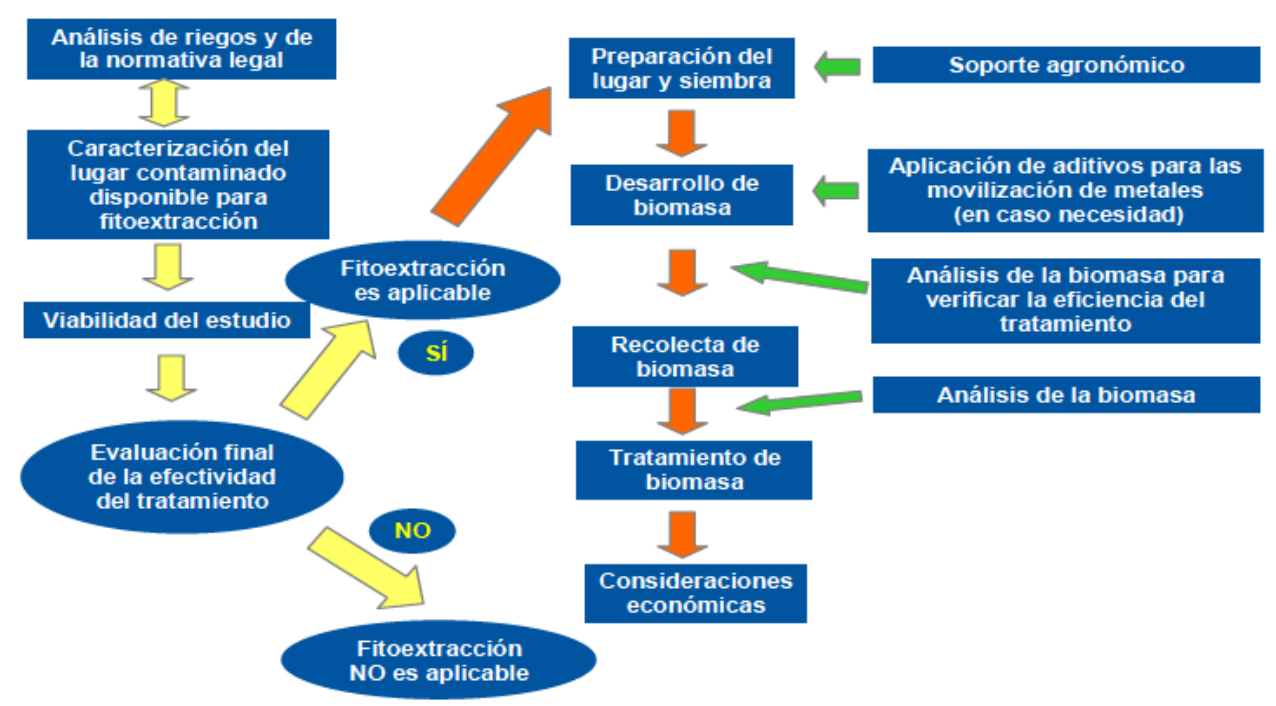

Figura 3.4.1. Pautas para la selección de una fitotecnología.

Tabla 3.4.1. Mecanismos de fitoextracción y resultado sobre los contaminantes

\begin{tabular}{|l|c|c|}
\hline \multicolumn{1}{|c|}{ Mecanismo } & Descripción & Meta de limpieza \\
\hline Fitodegradación & $\begin{array}{c}\text { Capacidad de las plantas para absorber y descomponer } \\
\text { los contaminantes en sus tejidos vegetales a través de la } \\
\text { actividad enzimática interna }\end{array}$ & Remediación por destrucción \\
\hline Fitoextracción & $\begin{array}{c}\text { Capacidad de las plantas para absorber y secuestrar los } \\
\text { contaminantes dentro del tejido vegetal }\end{array}$ & $\begin{array}{c}\text { Remediación por eliminación } \\
\text { de las plantas que contienen el } \\
\text { contaminante }\end{array}$ \\
\hline Fitosecuestración & $\begin{array}{c}\text { Capacidad de las plantas para secuestrar determinados } \\
\text { contaminantes en la rizosfera mediante la liberación de } \\
\text { compuestos fitoquímicos, y secuestrar los contaminantes } \\
\text { en/sobre las raíces y tallos a través del transporte de } \\
\text { proteínas y procesos celulares }\end{array}$ & Contención \\
\hline Fitovolatilización & $\begin{array}{c}\text { Capacidad de las plantas para asimilar, traslocar, y } \\
\text { posteriormente volatilizar los contaminantes en la corriente } \\
\text { de transpiración }\end{array}$ & $\begin{array}{c}\text { Remediación por eliminación a } \\
\text { través de plantas }\end{array}$ \\
\hline Rizodegradación & $\begin{array}{c}\text { Capacidad de liberación de compuestos fitoquímicos para } \\
\text { mejorar la biodegradación microbiana de contaminantes } \\
\text { en la rizosfera }\end{array}$ & \begin{tabular}{c} 
Remediación por destrucción \\
\hline
\end{tabular} \\
\hline
\end{tabular}


Las fitotecnologías pueden ser aplicadas a una gran variedad de metales, se discuten a continuación:

\section{Arsénico}

La fitoextracción es aplicable a pequeña y a gran escala. Mediante la fitoextracción se han remediado exitosamente suelos y aguas subterráneas contaminados con arsénico, cuando la contaminación es muy profunda se recomienda el reciclado (con fluidos) o eliminación en vertederos. El reciclado permite recuperar hasta el $70 \%$ del metal que puede volverse a utilizar en aplicaciones industriales.

Helechos hiperacumuladores, como Pteris vittata (Figura 3.4.2) y Pityrogramma calomelanos (Figura 3.4.3) son capaces de acumular hasta el $2 \%$ de arsénico en su biomasa (Gonzalez et al., 2006), los compuestos acumulados son muy tóxicos y hay que manipular estas plantas con precaución.

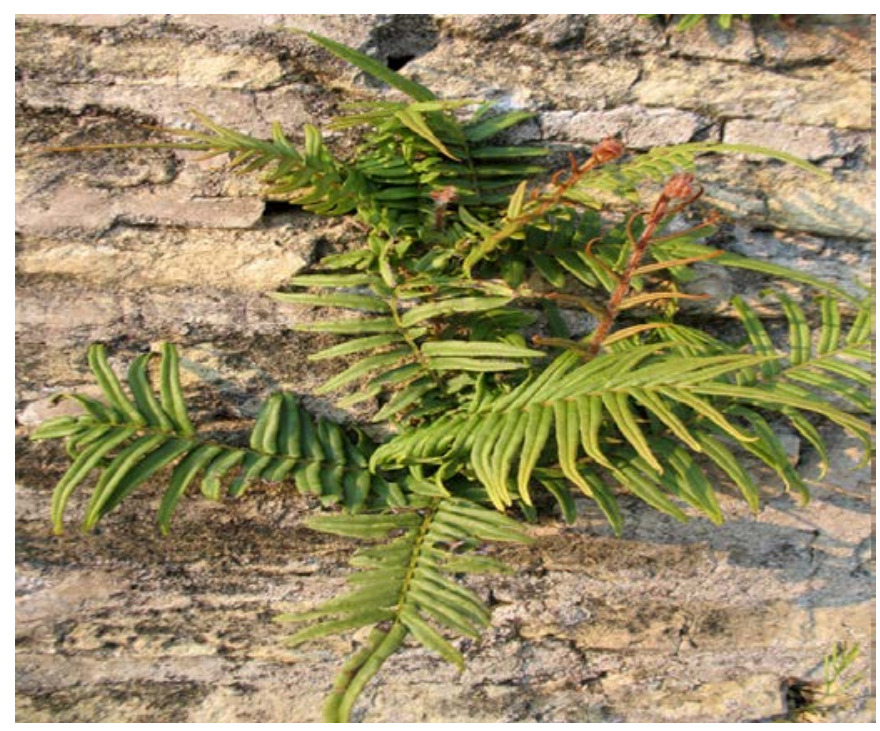

Figura 3.4.2. Pteris vittata. 


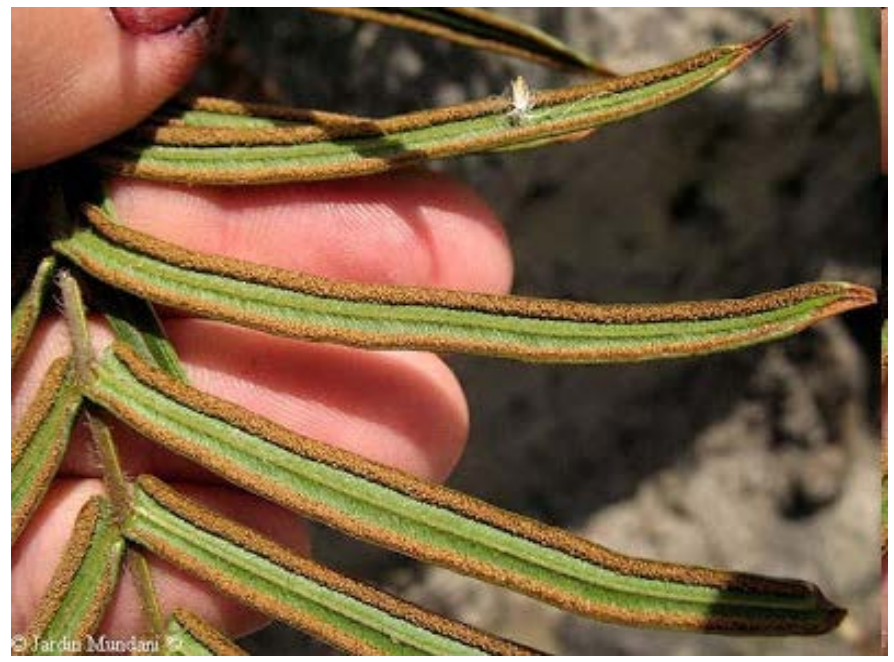

Figura 3.4.3. Pityrogramma calomelanos.

\section{$\underline{\text { Cadmio }}$}

La fitoextracción de suelos contaminados por cadmio es muy lenta debido a la baja formación de biomasa de las plantas hiperacumuladoras de cadmio específicas. Destaca la hiperacumuladora Rorippa globosa. La técnica puede ser mejorada mediante dos fases de siembra, es decir, las plantas se trasplantan dos veces un año mediante la recolección de las plantas cuando están en flor.

\section{$\underline{\text { Cromo }}$}

En relación al cromo no se ha identificado ninguna especie hiperacumuladora específica. Ciertas especies de plantas pueden acumular cromo del suelo y de aguas mediante fitoextracción y fitoestabilización. El cromo permanece principalmente dentro de las raíces (Pulford et al., 2006). Ejemplos de estas especies son árboles de sauce (Salix spp.) y el abedul (Betula spp.). Las especies Salsola oppositifolia (Figura 3.4.4) acumula cromo en sus raíces y la especie Salsola kali (Figura 3.4.5) acumula específicamente Cromo (VI); esto puede indicar que esta planta podría ser considerada un buen fitoextractor de este metal en el suelo. 


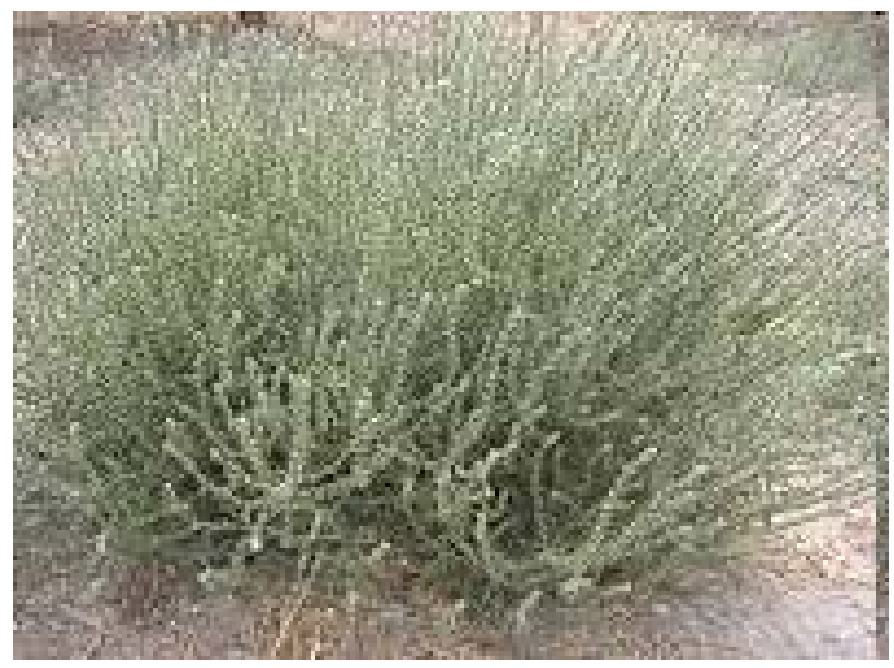

Figura 3.4.4. Salsola oppositifolia.

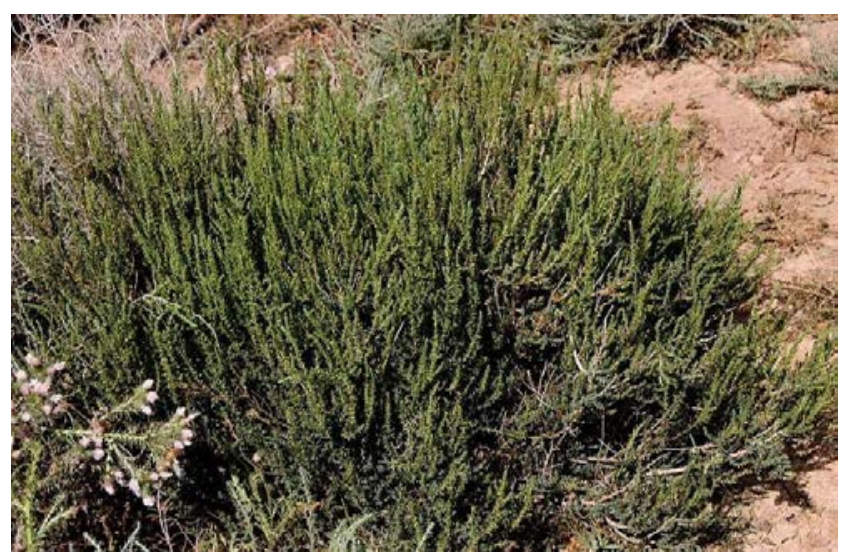

Figura 3.4.5. Salsola kali.

\section{$\underline{\text { Cobre }}$}

No se conoce ninguna especie hiperacumuladora específica de cobre para extraerlo por fitoextracción. Estudios en invernadero con sistema hidropónico han demostrado que el sauce negro (Salix nigra, Figura 3.4.6) acumula más cobre que otras especies de sauce, aunque serían necesarios estudios de campo para determinar la viabilidad de esta especie para fitoextraer cobre (Kuzovkina et al., 2004). En estudios usando la mostaza India (Brassica juncea, Figura 3.4.7) se ha aumentado la captación de cobre usando enmiendas ricas en fosfatos (Wu et al., 2004). 


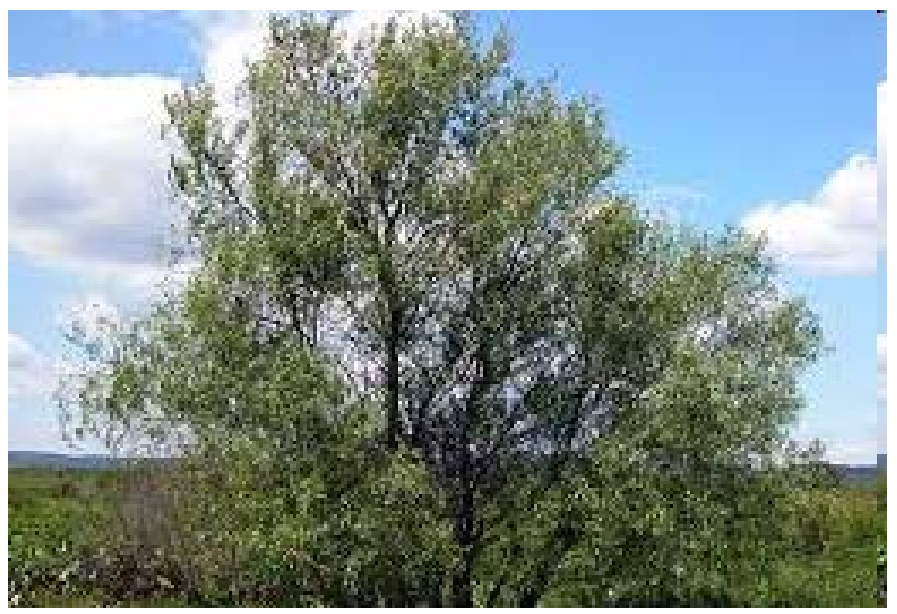

Figura 3.4.6. Salix Nigra.

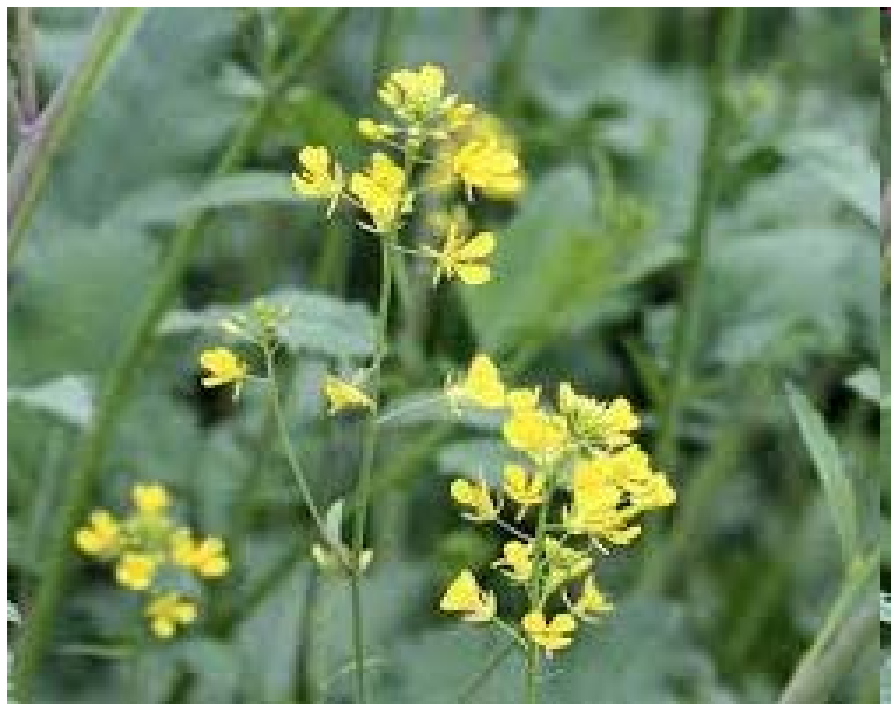

Figura 3.4.7. Brassica juncea.

\section{$\underline{\text { Plomo }}$}

Debido a que el plomo está escasamente biodisponible en el suelo la fitoextracción es poco eficaz. La biodisponibilidad de plomo mejora bastante mediante el uso de enmiendas y agentes quelantes en suelo. La aplicación de agentes quelantes en suelo mejora bastante la biodisponibilidad de plomo aunque la absorción del mismo por la planta siga siendo lenta. En estos casos hay que llevar un control especial de la movilidad y lixiviación del plomo quelatado (Chaney et al., 2005). 


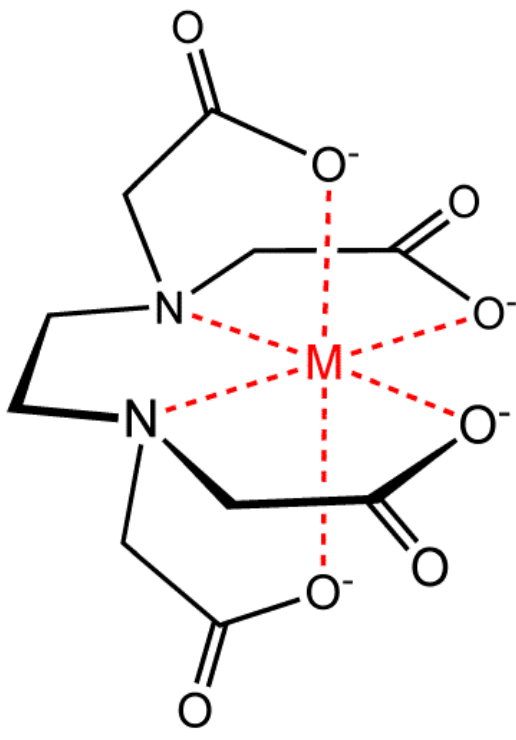<smiles>O=C(O)CN(CCN(CC(=O)O)CC(=O)O)CC(=O)O</smiles>

Figura3.4.8. Agente quelatante

\section{$\underline{\text { Níquel }}$}

Ejemplos de especies hiperacumuladoras de níquel son Alyssum sp (Figura 3.4.9). Se han desarrollado híbridos Alyssum para permitir fitominería, es decir, la extracción de níquel a partir de las plantas mediante su secado y combustión. La fitoextracción de níquel en minas es ampliamente utilizada (Chaney et al., 2005).

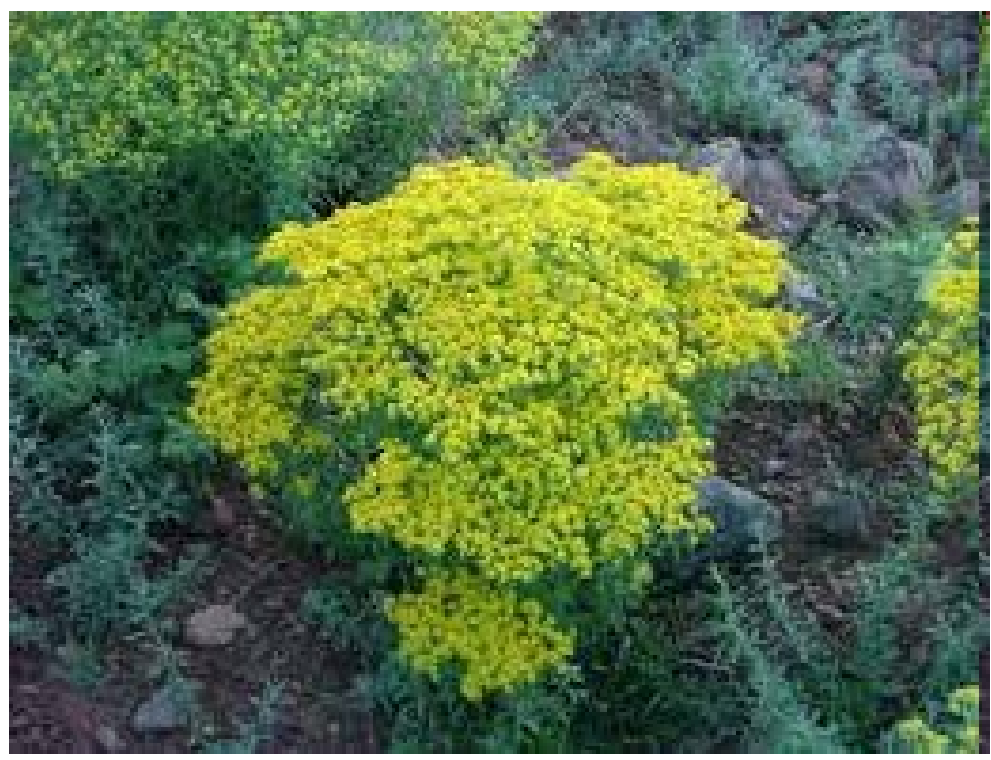

Figura 3.4.9. Alyssum sp 


\section{$\underline{\text { Selenio }}$}

Existen experiencias exitosas de descontaminación de selenio en suelos y aguas mediante fitoextracción, fitosecuestración y fitovolatilización. La lenteja de agua (Lemnaoideae, Figura 3.4.10) y el jacinto de agua (Eichhornia spp Figura 3.4.11.) se usan para la remediación de selenio en aguas contaminadas mediante el uso de humedales artificiales (EPA, 2001).

La fitovolatilización de selenio se ha logrado con especies como la mostaza india (Brassica juncea, Figura 3.4.7) y colza (Brassica napus, Figura 3.4.12); el selenato $\left(\mathrm{SeO}_{4}{ }^{2-}\right.$ ) se convierte en dimetilo selenito que es un compuesto gaseoso (se libera a la atmósfera) y es menos tóxico (EPA, 2000).

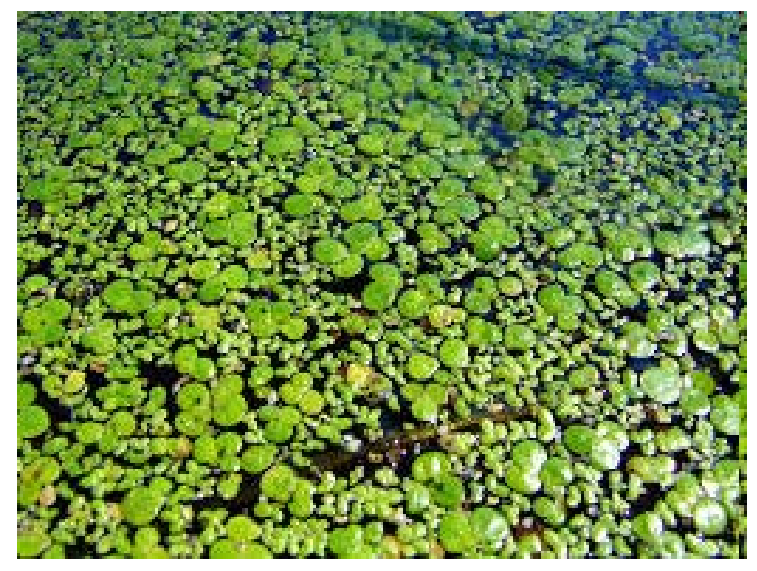

Figura 3.4.10. Lemmanoideae.

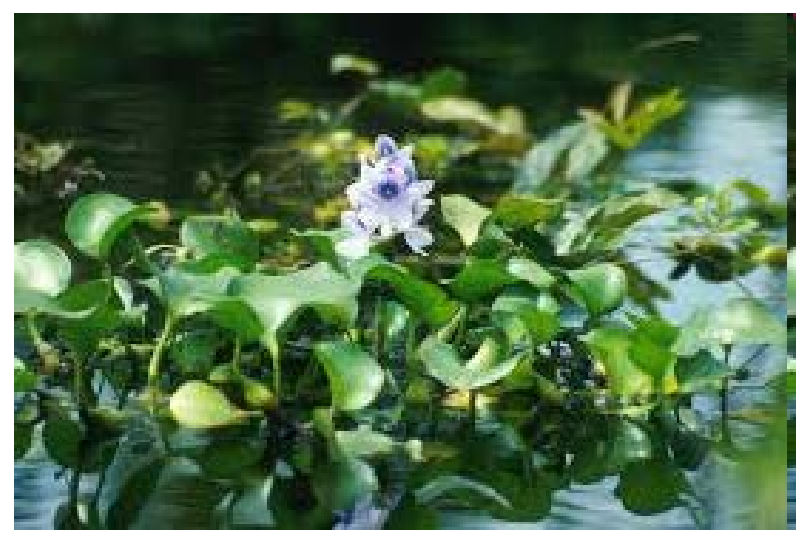

Figura 3.4.11.Echhornnia spp. 


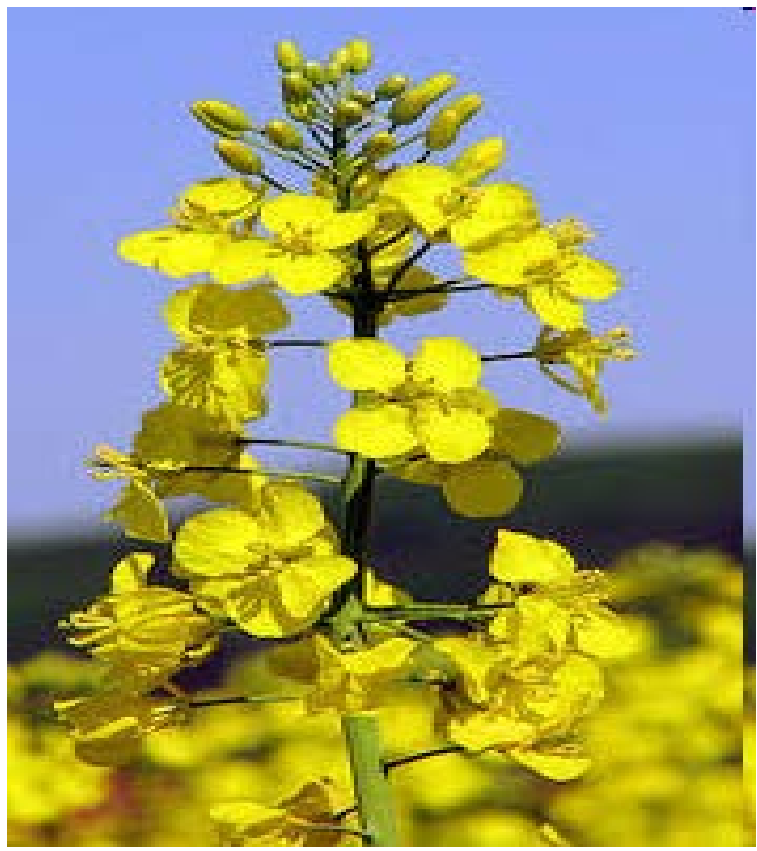

Figura 3.4.12. Brassica napus.

\section{Zinc}

La fitoextracción de zinc no es muy eficaz. Las plantas que eliminan zinc exitosamente presentan un crecimiento lento o no tienen mucha biomasa, la presencia de otros contaminantes que se encuentran comúnmente con el zinc tal como el cobre, pueden limitar el crecimiento de estos plantas y la absorción de zinc (Lombi et al., 2001). Plantas acumuladoras de zinc: Thlaspi caerulenscens (Figura 3.4.13).

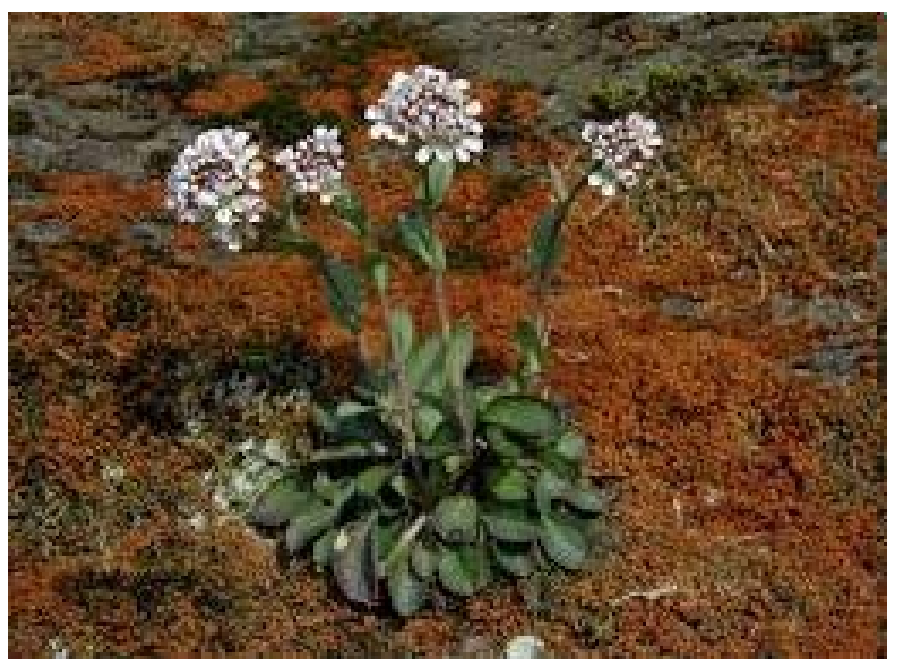

Figura 3.4.13. Thlaspi caerulenscens. 


\subsection{USOS DE LA BIOMASA. VALORIZACIÓN DE RESIDUOS}

La directiva 2008/98/CE del Parlamento Europeo y del Consejo establece un marco jurídico para el tratamiento de los residuos en la Unión Europea. Su objetivo es proteger el medio ambiente y la salud humana mediante la prevención de los efectos nocivos que suponen la producción y la gestión de residuos. Según esta directiva, con el fin de proteger mejor el medio ambiente, los estados miembros deberán adoptar medidas para tratar los residuos de conformidad con la siguiente jerarquía de residuos:

- Prevención

- Preparación para la reutilización

- Reciclado

- Otro tipo de valorización, por ejemplo, la valorización energética

- Eliminación

Se define la valorización como cualquier operación cuyo resultado principal sea que el residuo sirva a una finalidad útil. La valorización incluye todos aquellos circuitos que permiten el aprovechamiento de los recursos contenidos en los residuos y puede ser material o energética.

\subsubsection{VIABILIDAD DE USO EN LA INDUSTRIA DE LA CONSTRUCCIÓN DE RESIDUOS DE BIOMASA}

Podemos considerar varios tipos de biomasa. La biomasa natural, sería la que se produce en la naturaleza sin intervención humana en bosques, matorrales, etc.

Otro tipo de biomasa es la residual, o la que se produce en cualquier actividad humana, destacando los subproductos de las industrias forestales, agrícolas, ganaderas, etc. Este tipo de biomasa debe aprovecharse, bien con fines energéticos, bien con otros fines de valorización (reutilización y/o aprovechamiento másico).

La industria de la construcción puede adsorber una gran cantidad de residuos. Los residuos pueden entrar como materias primas (hablamos entonces de valorización material) o como combustibles alternativos (lo que se denomina valorización energética). La valorización material y especialmente la energética suponen dos alternativas prioritarias en la gestión de residuos. En este sentido, el sector de la construcción aporta un gran potencial en la colaboración con la gestión global de los residuos, ya que es capaz de incorporar ciertos residuos o subproductos de otros sectores. 


\section{Valorización material. Residuos como materias primas}

Las cementeras pueden aprovechar los residuos generados por otras industrias, en el proceso de producción del cemento y en la fabricación de morteros y hormigones. En la valorización material tenemos varias posibilidades:

- Residuos que se emplean como materias primas de sustitución

- Algunos residuos minerales tienen una composición similar a la de las materias primas con las que se fabrica el cemento y pueden sustituir a las materias primas naturales que son extraídas de las canteras: arcillas, calizas y esquistos, entre otras, disminuyendo de esta forma la explotación de recursos naturales. Estos residuos minerales se añaden al resto de materias primas antes de entrar en el horno de cemento, en la parte del proceso que se denomina preparación del «crudo», y aportan calcio, hierro, silicio o aluminio, minerales necesarios para fabricar el clínker (producto intermedio que sale del horno y que al molerse da lugar al cemento). Sustituyendo la piedra caliza necesaria para la fabricación del cemento se evita el $\mathrm{CO}_{2}$ que se produce en el proceso de descarbonatación de la caliza.

Entre los residuos que pueden utilizarse como materias primas alternativas están las cenizas de fondo y cenizas volantes producidas en la combustión de biomasa. Las cenizas de fondo, concretamente, son ricas en minerales y podrían sustituir a alguna de las materias primas para la fabricación de cemento.

\section{Residuos que se usan como adiciones al cemento}

Determinados residuos industriales se pueden añadir como adiciones en el proceso de molienda del clínker para dar lugar al cemento. Así, dependiendo del tipo de cemento que se desee producir, parte del clínker se puede sustituir por componentes alternativos, reduciéndose de esta forma el volumen de las materias primas extraídas de las canteras.

Por otra parte, esta sustitución, técnicamente viable y regulada por la normativa europea, permite fabricar cemento con menos proporción de clínker sin disminuir la calidad ni las prestaciones del producto final.

Los dos principales ejemplos de residuos que se utilizan tradicionalmente como adiciones son las escorias de alto horno, un subproducto del proceso de fabricación del hierro, y las cenizas volantes, uno de los residuos generados por la combustión del carbón en las centrales térmicas. El uso de residuos industriales con propiedades hidráulicas o puzolánicas humo de sílice, cenizas volantes, escorias de altos hornos- como componente en materiales con base cemento está enfocado a disminuir los costes de producción, 
mejorar las propiedades micro-estructurales del producto final y también los aspectos medioambientales al transformar materiales residuales en componentes con valor añadido. Los dos tipos de residuos producidos en la combustión de biomasa; cenizas de fondo (CF) formadas por el material total o parcialmente quemado y cenizas volantes (CV), partículas arrastradas por la corriente de gases al exterior de la cámara de combustión también podrían ser utilizados para sustituir Parcialmente al cemento, en los casos que presenten actividad hidraúlica.

\section{Residuos que se utilizan como material de relleno en morteros y hormigones}

Otra posibilidad es la utilización de adiciones minerales tal como la cascarilla de arroz, la cual es un buen sustituto de la grava como agregado, y contribuye a mejorar las características del hormigón, disminuyendo la permeabilidad del mismo e incrementando sus propiedades mecánicas. Además, el uso de la cascarilla de arroz como material de relleno de morteros y hormigones, contribuye a la capacidad de aislamiento térmico de dichos materiales.

En cuanto al medio ambiente, si se fomenta el uso de mezclas con desechos o subproductos agrícolas, estaremos contribuyendo a su preservación a través del reciclaje de este tipo de materiales.

\section{Valorización energética. Combustibles alternativos}

La biomasa (residuos de aprovechamientos forestales y cultivos agrícolas, residuos de podas de jardines, lodos de depuradora, harinas cárnicas, etc.), una vez preparada puede abastecer instalaciones de generación de energía, tanto térmica como eléctrica, en aplicaciones que varían desde calefacciones domésticas hasta instalaciones industriales, como es el caso de las fábricas de cemento.

La utilización de combustibles con biomasa se considera neutra en cuando a sus emisiones de CO2. Por tanto, la utilización de estos residuos como Combustible en las cementeras, permite ahorrarse las emisiones de gases que se producirían si estos residuos se quemasen en una incineradora.

Entre los principales beneficios de la valorización energética de residuos de biomasa en la fabricación de cemento se encuentran:

- La contribución a la sostenibilidad de la cadena agroindustrial.

- La mitigación de emisiones de $\mathrm{CO}_{2}$ gracias a la sustitución de combustibles fósiles (no renovables) por combustibles renovables como la biomasa.

- Conservación de combustibles no renovables como el carbón. 
- Reducción de las emisiones de otros gases de efecto invernadero como $\mathrm{NO}_{x}$ y $\mathrm{SO}_{x}$.

\subsubsection{VENTAJAS DE LA VALORIZACIÓN DE RESIDUOS DE BIOMASA EN LA INDUSTRIA DE LA CONSTRUCCIÓN}

En general podemos concluir resaltando algunas de las ventajas sociales, económicas y medioambientales, como consecuencia del empleo de residuos de biomasa en el proceso de fabricación de cemento, morteros y hormigones:

- Se utilizan residuos destinados a eliminación.

- Se facilita a la sociedad una herramienta complementaria para la gestión global de sus residuos, y reducir las inversiones necesarias al aprovechar instalaciones ya existentes, como son las fábricas de cemento. Por tanto, se produce un ahorro en instalaciones de tratamiento de residuos.

- Disminuir el uso de materias primas en la fabricación de cemento, sustituyendo parte de las mismas por residuos que tienen características similares en su composición. De este modo se produce un ahorro de recursos naturales.

- Se mitigan las emisiones de $\mathrm{CO} 2$ y se reducen las emisiones de otros gases de efecto invernadero.

- Disminución del consumo de combustibles fósiles aprovechando el poder calorífico de los residuos, dejando así de utilizar otros combustibles fósiles y finitos.

- La sustitución de combustibles fósiles por biomasa produce una reducción de costes.

- Supone una garantía de tratamiento ambiental adecuado porque la combustión se realiza en condiciones de muy alta temperatura, lo que garantiza la destrucción de los compuestos orgánicos existentes en el residuo.

- No se genera ningún residuo al final del proceso de valorización. La valorización genera cenizas de fondo y cenizas volátiles, pero éstas se pueden incorporar al clínker (material intermedio necesario para la fabricación del cemento) de forma permanente e irreversible, manteniendo garantías ambientales.

- Generación de fuentes de empleo directo e indirecto por el manejo y transporte de residuos de biomasa, que antes no existían. 
Capítulo 4

CARACTERÍSTICAS GENERALES DE LA ZONA DE ESTUDIO 



\subsection{SITUACIÓN GEOGRÁFICA}

Las actuaciones previstas se localizan en el término municipal de Lorca, dentro de la comarca centro-oeste de la Región de Murcia. La zona de actuación se encuentra en la hoja 953-3 del mapa topográfico nacional a escala 1:25.000, denominada Lorca.

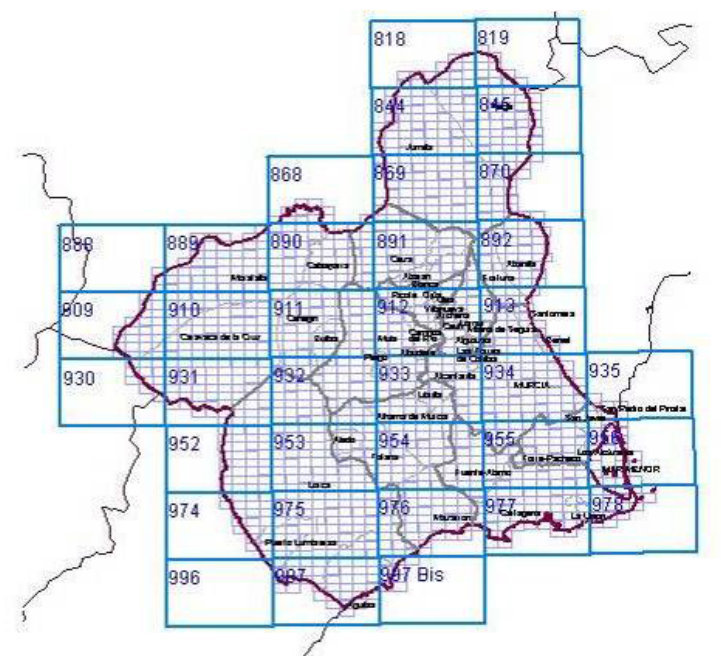

Figura 4.1.1. Ubicación geográfica de las actuaciones.

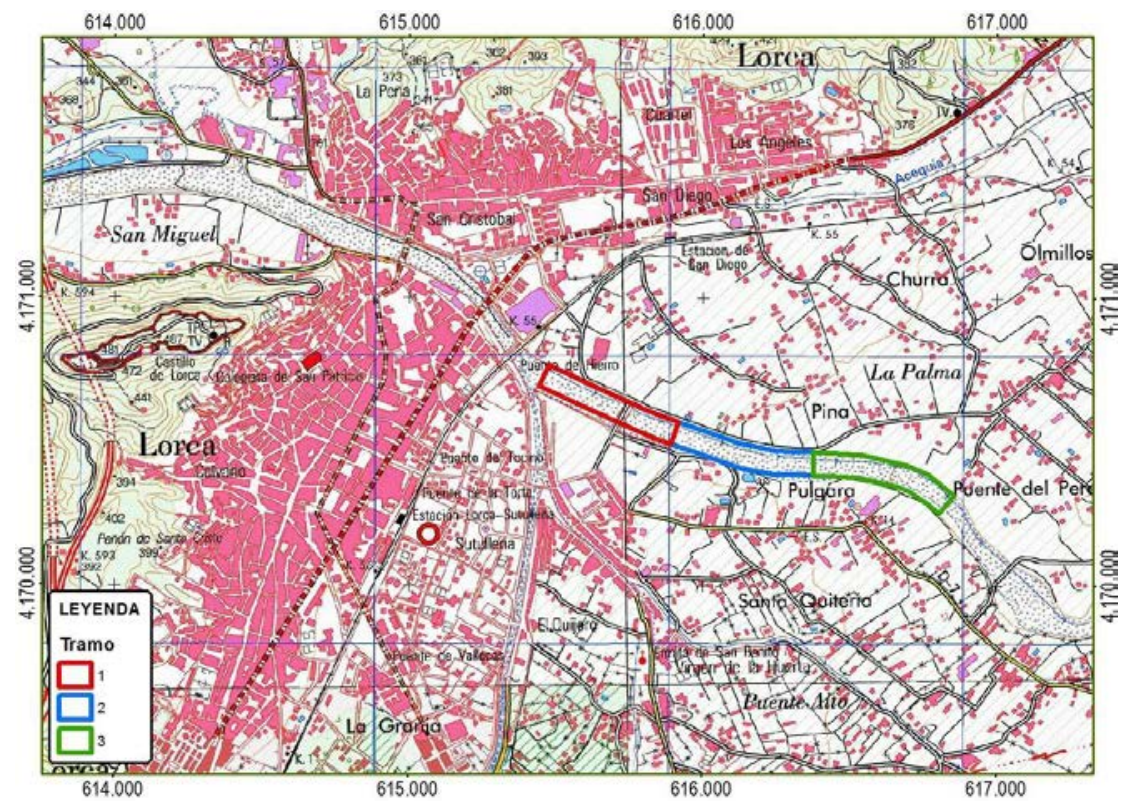

Figura 4.1.2. Zona de actuación de 1500 m (tramos 1, 2 y 3). 
En las figuras puede observarse que la localización de la zona de actuación está en el cauce del Río Guadalentín, próximo al núcleo urbano de la ciudad de Lorca. Mantiene una altitud media de $360 \mathrm{~m}$ sobre el nivel del mar y presenta una suave pendiente hacia el noreste. Esta zona es el área de huerta fértil de la vega del eje Guadalentín-Biznaga La depresión prelitoral por la cual discurre el río hasta su desembocadura en el Río Segura es la del Valle del Guadalentín.

Lorca es un municipio de amplio territorio y que ocupa toda el área suroccidental de la Comunidad Autónoma de la Región de Murcia. El término municipal de Lorca, geográficamente y territorialmente expresado, se puede dividir en tres grandes áreas. Estas tres áreas son:

- $\quad$ Tierras altas del norte

- Depresión prelitoral

- $\quad$ Llanuras costeras.

Las tierras altas del norte, también conocidas comúnmente como las Pedanías Altas ocupan los sectores norte y noroeste del territorio municipal y mantienen una altitud media por encima de los $500 \mathrm{~m}$. Todas forman un conjunto de terrenos en el que hay que distinguir dos importantes alineaciones montañosas. La más septentrional, en el ángulo noreste de la comarca, está formada por las sierras del Cambrón, Pedro Ponce y Madroño. Al noroeste, el área queda delimitada por otra unidad de montañas, de características similares. Se trata del Macizo de la Culebrina, cuyo eslabón septentrional es la Sierra del Almirez (1126 m), que continúa al noreste, por los cabezos del Sordo, Mingrano y a través del Cabezo Redondo enlaza con la alineación montañosa de las sierras del Madroño y Pedro Ponce. En la parte sureste de estas tierras encontramos un territorio relativamente llano que nos conduce hacia la cabecera municipal. Las alineaciones montañosas anteriormente citadas enmarcan una amplia cuenca hidrográfica por la que discurre el Río Guadalentín, que actúa como arteria principal.

Esta alta cuenca está enmarcada por el sur por una serie de elevaciones que forman el reborde de la depresión prelitoral. Estas elevaciones desaparecen poco antes de alcanzar la ciudad de Lorca y este hundimiento es aprovechado por el Río Guadalentín para llegar hasta la depresión prelitoral. 


\subsection{ESTUDIO HIDROLÓGICO}

\subsubsection{INTRODUCCIÓN}

El estudio del régimen hidrológico del cauce del Río Guadalentín nos proporciona información sobre la velocidad de drenaje, la capacidad de infiltración del agua, la magnitud y la frecuencia de las avenidas. El mejor parámetro que define el régimen hidrológico es la pendiente longitudinal de cada parte del área de rehabilitación. Esto se puede clasificar en 3 tipos: rápido, torrencial y torrente. El objetivo del estudio hidrológico es establecer las características hidrológicas de los regímenes de máxima inundación y varios factores hidráulicos a fin de conocer la estimación real del comportamiento hidráulico del río, lo que puede llevarnos a determinar la densidad de las plantas nativas que se utilizarán para restaurar la vegetación nativa del lecho y las márgenes para evitar riesgos de inundación. Además, desempeña un papel importante para definir los requisitos mínimos de caminos, áreas recreativas o estructuras similares en el diseño del paisaje.

\subsubsection{ANTECEDENTES}

En fechas recientes la Confederación Hidrográfica del Segura ha concluido los mapas de peligrosidad de diversos cauces situados en su ámbito geográfico, en el marco de elaboración del Sistema Nacional de Cartografía de Zonas Inundables (SNCZI), entre los que se encuentra el Río Guadalentín, desde aguas arriba de Lorca hasta su confluencia en el Río Segura. Este trabajo se ha desarrollado en el marco de aplicación de la Directiva 2007/60/CE relativa a la evaluación y gestión de los riesgos de inundación y transpuesta a la legislación española mediante el RD 903/2010. La misión principal de SNCZI ha consistido en la implementación de un sistema de información cartográfica donde se integran todos los estudios de inundabilidad elaborados ex profeso así como los existentes con anterioridad.

En base a lo anterior, el estudio hidrológico se desarrolló con el objetivo de definir las zonas inundables de los cauces de la Confederación Hidrográfica del Segura para los que se identificó la existencia de peligrosidad por inundación o avenida de acuerdo a los criterios establecidos en la Ley de Aguas y en el Reglamento del Dominio Público Hidráulico (DPH). Se definieron cartográficamente los siguientes elementos: dominio público hidráulico, zonas de servidumbre y policía, zonificación de las áreas inundables, zonas de flujo preferente y caracterización del flujo (mapas de calados y velocidades). Siguiendo las indicaciones del Reglamento del Dominio Público Hidráulico, la cartografía de peligrosidad se determinó mediante los estudios geomorfológico e hidráulico. Ambos se apoyan en la recopilación de referencias históricas, la 
realización de encuestas y trabajos de campo. La figura siguiente obtenida de "Método para el análisis de la peligrosidad por inundaciones" (modificado de Marquínez et al., 2006) muestra esquemáticamente una síntesis de la metodología seguida en dichos trabajos:

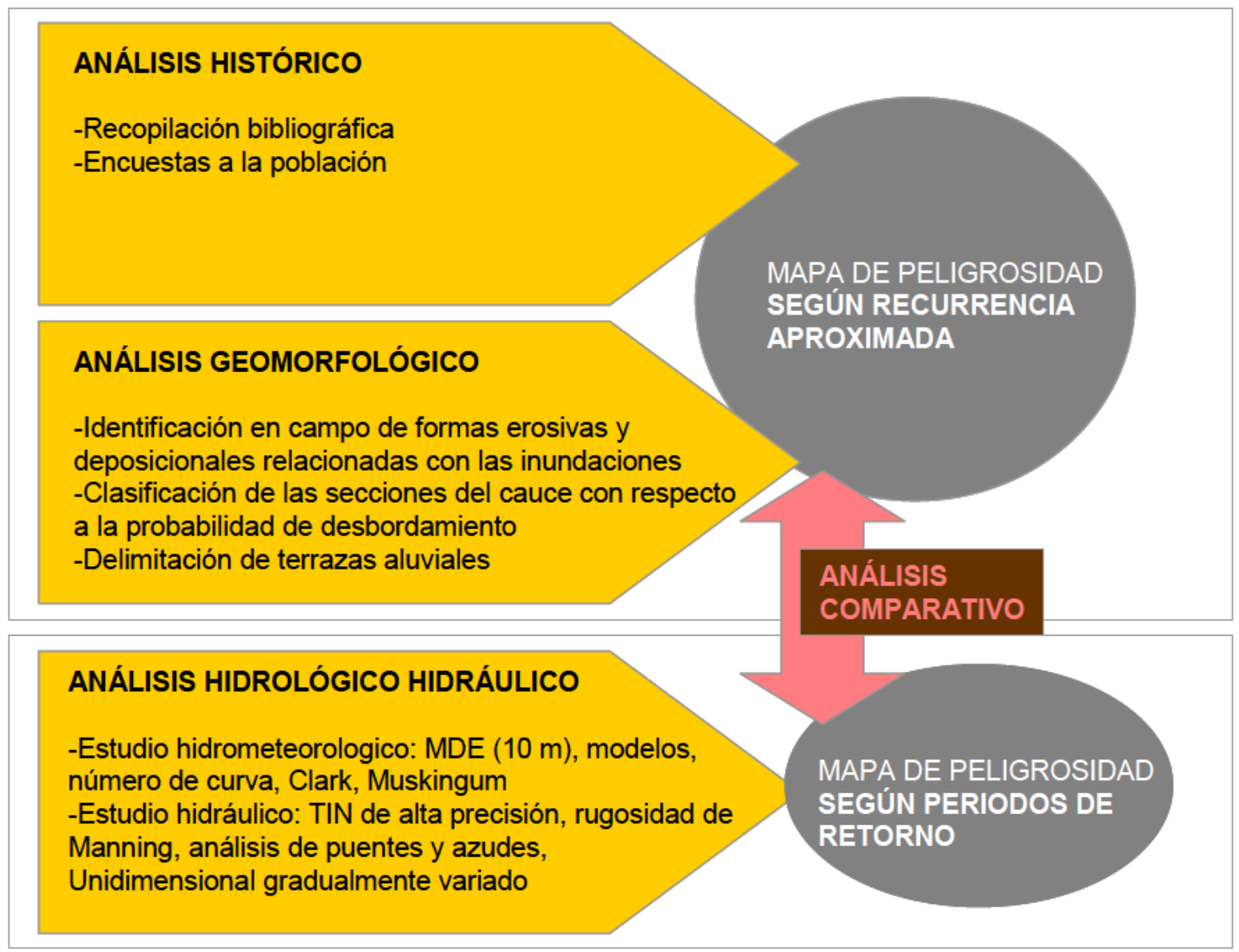

Figura 4.2.2.1. Método para el análisis de la peligrosidad por inundaciones" (modificado de Marquínez et al., 2006)

A continuación se relacionan las distintas fases en las que se desarrollaron los trabajos:

- Realización de cartografía LIDAR, ortofotografía y caracterización de infraestructuras

- Realización y adaptación de estudios hidrológicos

- Estudios de antecedentes de inundaciones y recopilación de información histórica

- Estudio geomorfológico

- Estudio hidráulico

- Determinación del DPH, zonas inundables y zonas de flujo preferente

- Generación de cartografía 
Por tanto, los análisis y resultados que contiene este estudio son un traslado de la información que figura sobre el tramo objeto de estudio en el Sistema Nacional de Cartografía de Zonas Inundables.

\subsubsection{REFERENCIAS HISTÓRICAS}

El caudal del Río Guadalentín es de lo más variable, siendo capaz de pasar de una sequedad extrema a la mayor de las crecidas en apenas cuestión de horas. Sin afluentes de importancia, puede clasificarse como un río rambla de la zona árida del sureste peninsular. Su reducido régimen permanente es retenido en los pantanos lorquinos de Puentes y Valdeinfierno, donde las aguas embalsadas se aprovechan para el regadío. Como consecuencia de lluvias torrenciales, el Río Guadalentín alcanza periódicamente caudales espectaculares que causan grandes daños en su valle. Algunas de las riadas más destacadas en este río son:

- El 15 de octubre de 1879, cuando se produjo la riada de Santa Teresa, en la cabecera del Guadalentín se estima que cayeron $600 \mathrm{~mm}$ en una hora. Tuvo a su paso por Lorca una punta de $1.510 \mathrm{~m}^{3} / \mathrm{s}$ y ocasionó 13 muertos.

- El mes de septiembre de 1891, la conocida como riada de San Jacinto fue superior a la riada anterior, pero gracias a la presa de Puentes, Lorca y la comarca se salvaron de una nueva catástrofe.

- El mes de junio de 1900 se produce la riada de San Aniceto, siendo superior a la de Santa Teresa y que inundó el barrio de San Cristóbal de Lorca.

- El mes de octubre de 1948, el caudal estimado en el puente de la carretera de Murcia a Granada fue superior a los $800 \mathrm{~m}^{3} / \mathrm{s}$.

- El 19 de octubre de 1973 se produjo la peor crecida del siglo tras unas precipitaciones de más de $300 \mathrm{~mm}$ en el norte de Almería. El río alcanzó un caudal de $2.500 \mathrm{~m} 3 / \mathrm{s}$ en Lorca y su afluente, la rambla de Nogalte, $1.974 \mathrm{~m}^{3} / \mathrm{s}$ a su paso por Puerto Lumbreras, donde se registraron muchas víctimas.

- El 28 de septiembre de 2012, la gota fría descargó gran cantidad de agua en toda la cuenca, provocando innumerables daños materiales en los términos de Lorca y Puerto Lumbreras, con pérdida incluso de vidas humanas. En el Pantano de Puentes se llegó a registrar un caudal de entrada de $1.870 \mathrm{~m}^{3} / \mathrm{s}$, aumentando el agua embalsada de $5,125 \mathrm{hm}^{3}$ a $13,318 \mathrm{hm}^{3}$ en apenas unas horas. El Río Guadalentín a su paso por la ciudad de Lorca llegó a los 616 m³/s y 2,26 m, que es el límite del caudal que puede acoger en este tramo urbano. Aguas abajo llegó en el Paretón de Totana a 1.082 m³/s y 6,27 m, y en Murcia, en el punto de aforo de Salabosque, la punta de la crecida se vio reducida a $58 \mathrm{~m}^{3} / \mathrm{s}$ y $3,48 \mathrm{~m}$ ya que $924 \mathrm{~m}^{3} / \mathrm{s}$ habían sido desviados 
al mar por la Rambla de las Moreras y el embalse de José Bautista había retenido el caudal circulante hasta Librilla.

\subsubsection{LOCALIZACIÓN DEL RÍO GUADALENTÍN Y DEL PROYECTO LIFE RIVERPHY}

El Río Guadalentín, en árabe Oued al Iznain, «segundo río», o Oued al Lentin, «río de fango», también conocido como Sangonera es un río del sureste de España que pasa por las provincias de Almería y Murcia atravesando el valle del mismo nombre que se encuentra entre las sierras de Espuña y Carrascoy. Es el afluente más grande por la derecha del Río Segura. Nace en la Sierra de María, al norte de la provincia de Almería, y recibe a la rambla de Chirivel en el Pantano de Puentes, ya en la Región de Murcia. En el mismo pantano desembocan los Ríos Luchena y Turrilla, y desde allí se dirige al sureste pasando por Lorca, donde entra en el amplio Valle del Guadalentín originado por una fosa tectónica, cambiando el rumbo hacia el noreste. Recibe a la rambla Nogalte, que pasa por Puerto Lumbreras, para discurrir después por los términos de Totana, Alhama de Murcia y Librilla, recibiendo tan sólo la aportación de diversas ramblas. En la pedanía del Paretón de Totana comienza un cauce alternativo que desvía sus aguas, en caso de crecidas, hacia la rambla de las Moreras, de Mazarrón, de modo que se reduzca el caudal en su curso bajo y el aporte al Segura minimizando el peligro de inundaciones. Se une al Río Segura en la Huerta de Murcia, dentro del término municipal de Murcia, en la localidad de Beniaján y aguas abajo de la capital. Lo hace por medio de un canal artificial Ilamado canal del Reguerón, singular obra de ingeniería proyectada en el siglo XVIII por Sebastián Feringán, ingeniero militar director de las obras del Arsenal de Cartagena, con el fin de prevenir las avenidas ya que la confluencia original estaba aguas arriba de la ciudad de Murcia. Existe un canal alternativo denominado Reguerón Viejo, el cuál desvía las aguas del Guadalentín en época de crecida hasta un punto más bajo, ya en la provincia de Alicante, evitando así las inundaciones en su afluencia con el Segura, lo que afecta directamente a las poblaciones de Beniel y Orihuela.

El tramo objeto de actuación en la presente tesis es de 1500 metros de longitud, se ubica aguas abajo de la ciudad de Lorca, según se puede observar en la Figura 4.2.4.2. Exactamente se ubica inmediatamente aguas abajo de la denominada históricamente como "rambla de Tiata", que pasó de ser un cauce afluente del Río Guadalentín a un canal de alivio del mismo, por la alteración de su pendiente efectuada por los regantes de la zona con objeto de convertirla en una boquera de riego, una obra muy utilizada en la zona para facilitar la captación de aguas. De hecho, en la actualidad en la margen derecha del río por donde tiene su origen esta infraestructura se ubican dos compuertas de regulación. 


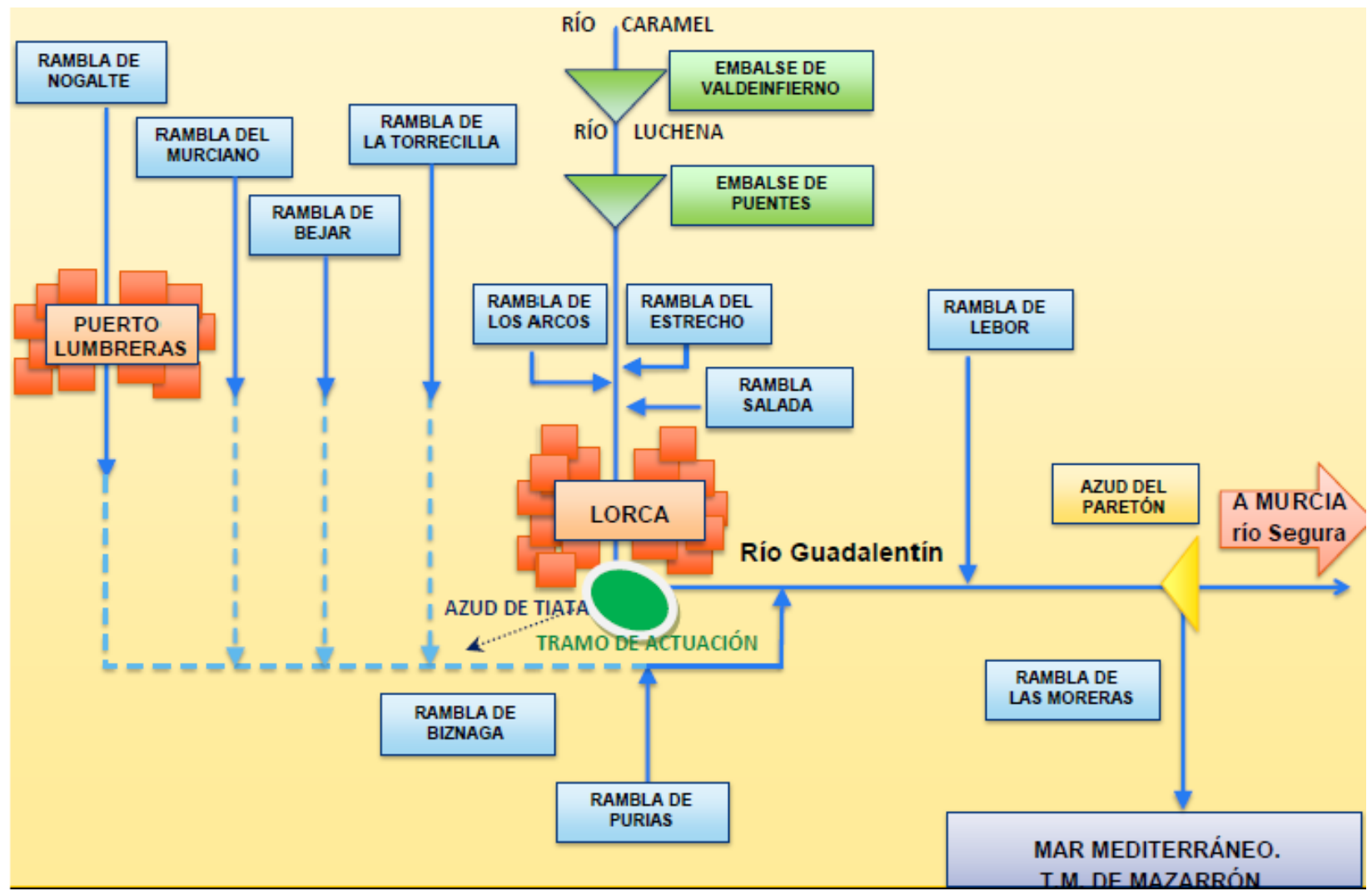

Figura 4.2.4.1. Esquema de drenaje de la cuenca del Alto Guadalentín.

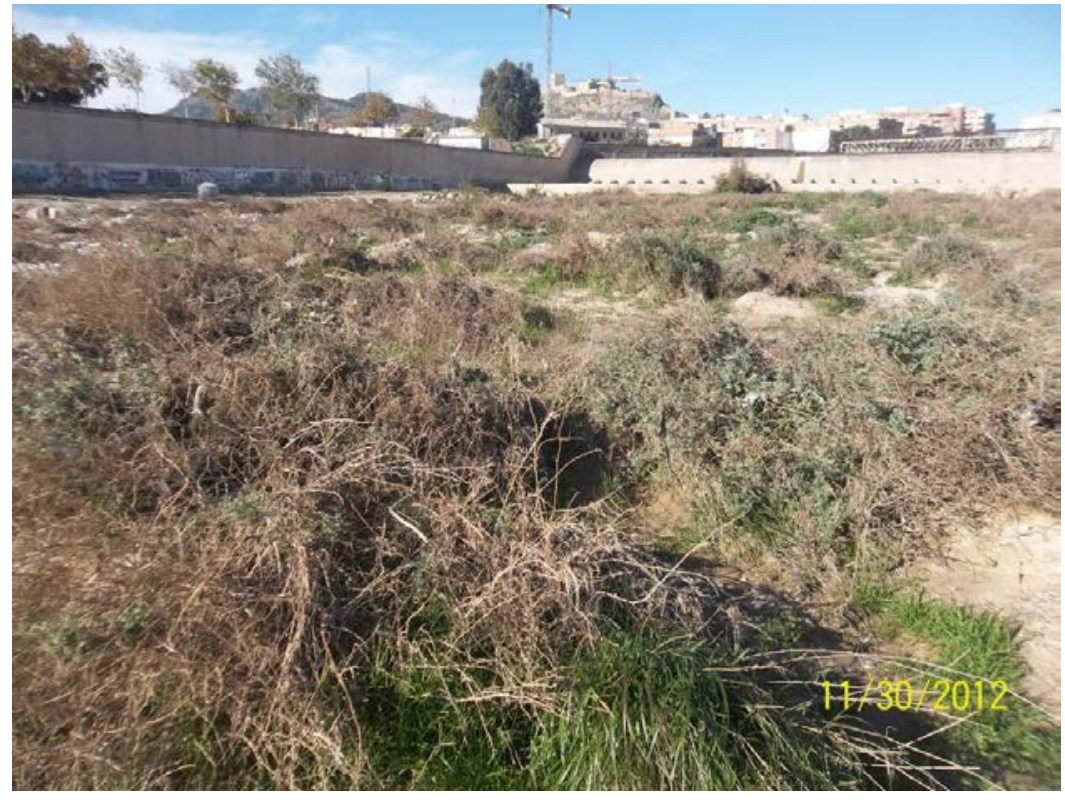

Figura 4.2.4.2. Vista del lecho del cauce. 


\subsubsection{MORFOLOGÍA GENERAL DEL RÍO GUADALENTÍN}

El desarrollo del sistema fluvial Guadalentín-Sangonera ha estado muy condicionado por la dinámica de la Falla Lorca-Alhama, en concreto a la actividad tectónica asociada a los frentes montañosos que se generan a lo largo de su trazado (Silva et al., 1996). Inicialmente, el paleoGuadalentín se dirigía hacia el Mediterráneo desembocando en un antiguo Mar Menor. Posteriormente, durante el Pleistoceno, hubo una reestructuración tectónica de los márgenes de la Depresión, convirtiéndose en una cuenca endorreica dominada por sistemas de abanicos aluviales y playa-lake (Figura 4.2.5.1A). Durante el Holoceno, la cuenca se abrió de nuevo al Mediterráneo dando origen al Río Sangonera mediante procesos de erosión remontante (Figura 4.2.5.2B). Al mismo tiempo, el Río Guadalentín vertía al Mediterráneo a través de la captura que se hizo de un canal distributario del Guadalentín paralelo al Canal de Derivación del Paretón, para posteriormente continuar por la actual rambla de las Moreras desembocando en el actual Puerto de Mazarrón. La morfología de este distributario apenas puede percibirse en la actualidad como un pequeño valle relicto de fondo plano, inconexo a los sistemas de drenaje existentes de ahora (Silva et al., 1996). Posteriormente el Río Sangonera se desconectó de nuevo del Río Segura por la aportación de material de las avenidas torrenciales del propio río convirtiéndose de nuevo en una cuenca endorreica. Finalmente, durante el periodo 1689-1768 se realizó la unión del Río Guadalentín y Sangonera por medio del Canal de Alcanara (Figura 4.2.5.1C). Esta canalización se hizo a lo largo de unos $5 \mathrm{~km}$ y morfológicamente se detecta por ser un tramo anómalamente estrecho, de geometría rectilínea, con márgenes muy escarpados y sin ningún tributario por ambas márgenes (Silva et al., 1996). A partir de entonces un único cauce recorre la Depresión, conociéndose en la actualidad todo él como Río Guadalentín. Toda esta evolución se traduce en la actualidad en un predominio de procesos de agradación y encharcamiento, ya que en algunos puntos todavía se trata de una Depresión semiendorreica (IGME, 2010). Asimismo, las márgenes de la rambla son bastante inestables, facilitando la erosión lateral del cauce.

Respecto a los afluentes vertientes al Río Guadalentín, lo más resaltable es el carácter torrencial de la mayor parte de ellos lo que ha dado lugar a amplios sistemas de abanicos aluviales. Estos procesos se hayan activos siendo un factor determinante los desniveles formados por la actividad tectónica en los frentes montañosos de falla. Esta actividad conlleva a que muchas de las ramblas laterales del Río Guadalentín estén desconectadas de él o con una conexión incipiente con su nivel de base (IGME, 2010). 


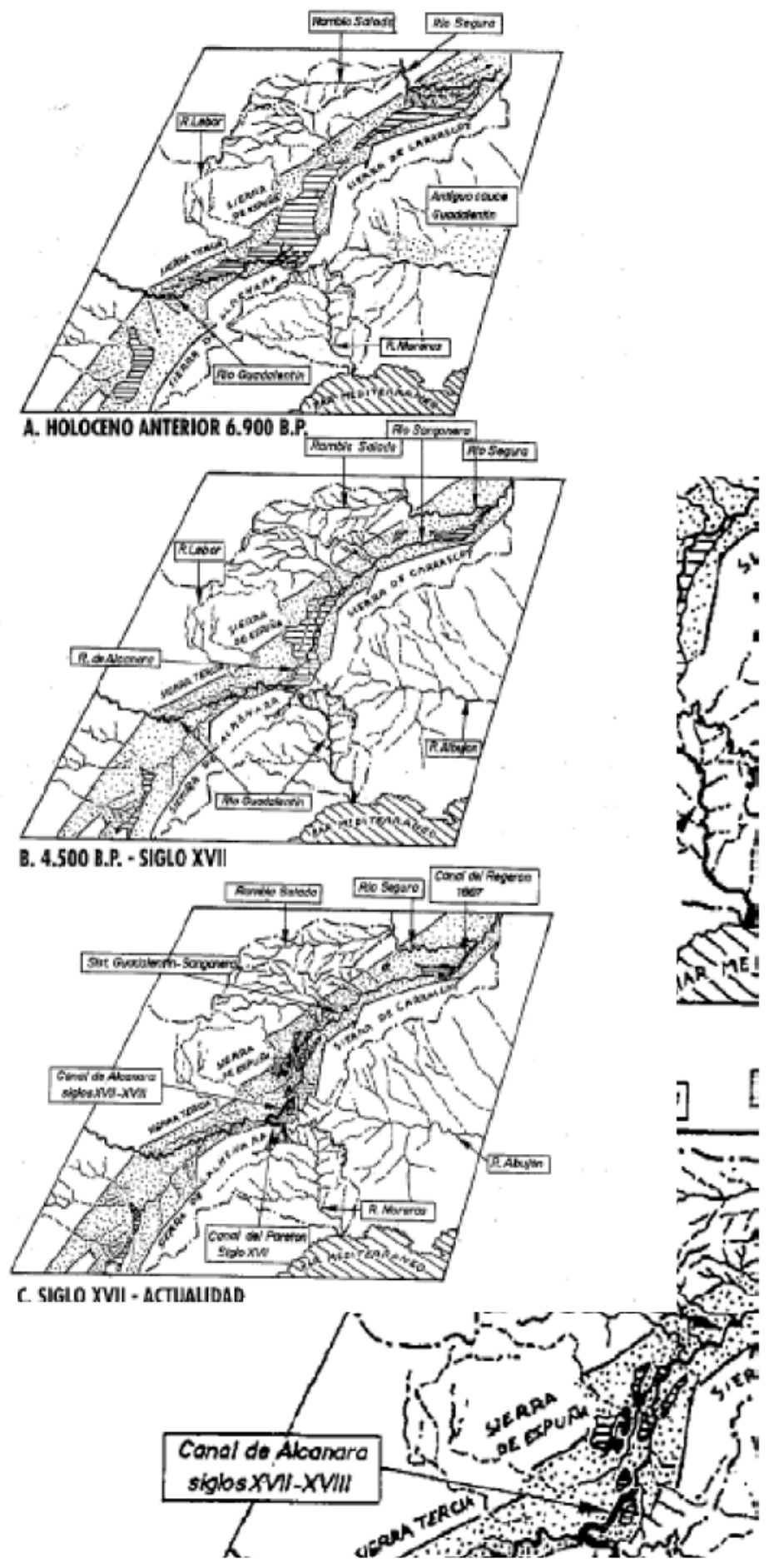

Figura 4.2.5.1. Principales estados evolutivos del drenaje de la Depresión del Guadalentín desde el Holoceno (Silva et al., 1996). 
El tramo superior del Río Guadalentín, el cual es objeto de esta tesis se caracteriza por la alta torrencialidad de sus avenidas, con un importante aporte de material sedimentario no sólo por el propio Río Guadalentín, sino también por los abanicos aluviales situados en ambas márgenes. Debido al comportamiento endorreico de la zona a lo largo de etapas de su evolución geológica, existen numerosas zonas con elevadas posibilidades de encharcamiento por falta de capacidad de drenaje de sus materiales. En toda la zona la llanura de inundación es estrecha, estando controlada en la actualidad por los aportes de los abanicos aluviales altamente activos. También es de destacar los elevados procesos erosivos que se producen dando lugar a cárcavas a lo largo de todo el sistema fluvial. El cauce en 1956 presentaba un gran número de meandros en su tramo alto, con pocas variaciones respecto al actual respecto al trazado. Es una zona de alta actividad ya que aunque no existen amplias llanuras de inundación o terrazas bajas, sí que se observan en la fotografía de 1956 (Figura 4.2.5.2) bastantes zonas de cárcavas. La amplitud del cauce es muy similar a la de 1956, aunque sí que se observa algún punto más estrecho. Estas variaciones se produjeron con las obras de encauzamiento del río en las que las curvas de algunos meandros se suavizaron. Muchas zonas de cárcavas coinciden con las existentes en la fotografía de 1956. A parte del cauce actual, otras evidencias topográficas prácticamente no se han observado. Las zonas inundables más bajas aparecen de forma interrumpida a lo largo de todo el tramo analizado del Guadalentín. Son unidades muy estrechas, mientras que las zonas inundables más elevadas abarcan una gran extensión apareciendo también en ambas márgenes.

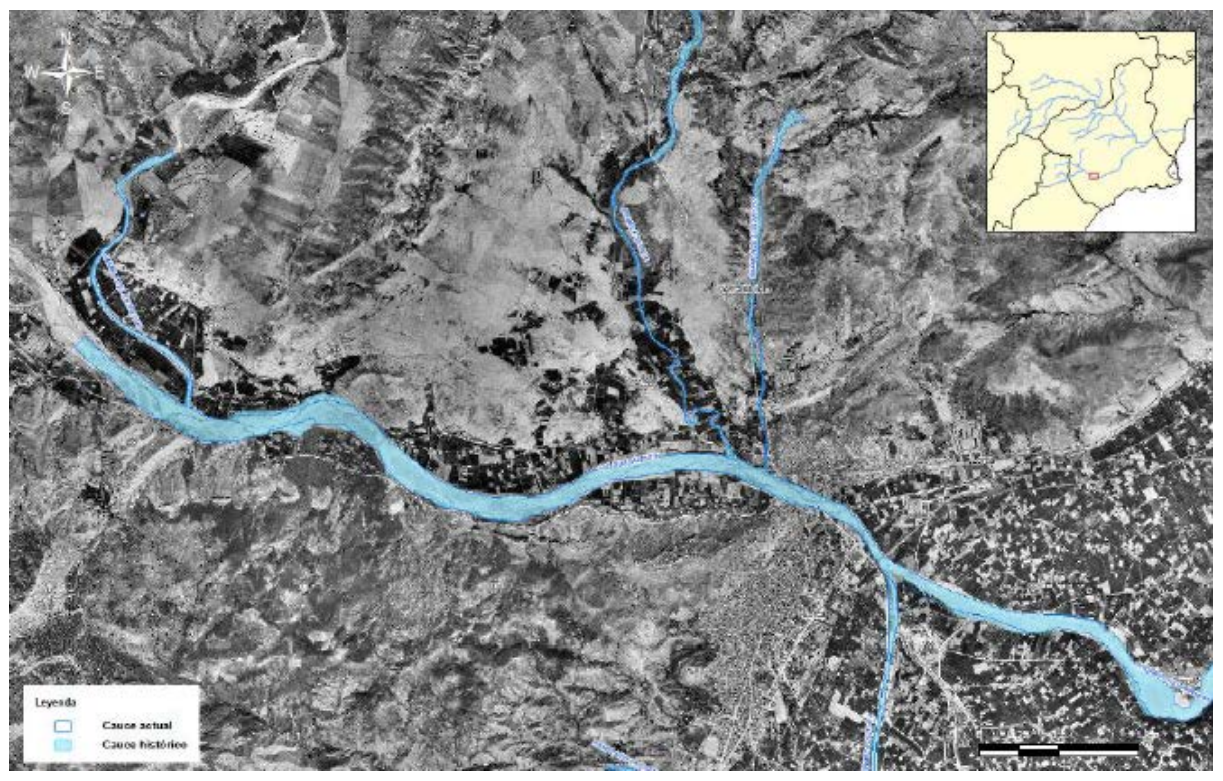

Figura 4.2.5.2. Cauce histórico sobre ortofoto del año 1956. 
La zona de flujo preferente potencial en la actualidad no ha variado prácticamente nada respecto a la natural. Las zonas inundables de mayor extensión presentan una inundabilidad media-baja, siendo las de menor extensión de una inundabilidad alta. La torrencialidad directa por la dinámica del Río Guadalentín sólo se ha descrito en el tramo superior (primeros $500 \mathrm{~m}$ del área de estudio), coincidiendo con la apertura del valle, aunque la descripción de avenidas históricas muestra que es un cauce de elevada torrencialidad.

\subsubsection{RÉGIMEN HIDROLÓGICO}

En el desarrollo del SNCZI, la determinación de los caudales máximos y los hidrogramas por medio del método hidrométrico se llevó a cabo mediante la aplicación del modelo de simulación del proceso de conversión precipitación en escorrentía HEC-HMS, versión 3.4. desarrollado por el Hydrologic Engineering Center del U.S. Army Corps of Engineers. El programa permite simular la respuesta de una cuenca frente a una precipitación dada, determinando dicha respuesta a través de una combinación de mecanismos hidráulicos e hidrológicos interconectados. Cada uno de estos mecanismos constituye uno de los componentes del programa y se refiere a un aspecto del proceso precipitación-escorrentía. Cada componente requiere la definición de un conjunto de parámetros que especifiquen las características particulares, así como las relaciones matemáticas que describen los procesos físicos que tienen lugar. El resultado final consiste en el hidrograma correspondiente a los puntos deseados. El ámbito de aplicación de dicho modelo se restringió a la cuenca del Río Segura y sus afluentes, lo que representa el $80 \%$ de la superficie perteneciente a la Confederación Hidrográfica del Segura. La cuenca total se simuló a través de un conjunto de subcuencas interconectadas, de tal forma que cada una puede representarse a través de parámetros que reflejan las condiciones medias, tanto espaciales como temporales. Los procesos que tiene en cuenta el programa se refieren fundamentalmente a:

- Generación de la escorrentía: es necesario definir el hidrograma patrón de la tormenta de cálculo para cada subcuenca (pudiendo ser el mismo o diferente). Este es el dato de entrada para la determinación de la escorrentía en la subcuenca parcial. La escorrentía superficial se obtiene substrayendo del volumen total precipitado - en cada intervalo de tiempo - los volúmenes derivados por efecto de infiltración, retención e intercepción (paso de la lluvia bruta a la lluvia neta). Esta escorrentía unitaria se convierte en el hidrograma generado por cada subcuenca a partir de la aplicación de las técnicas correspondientes al hidrograma unitario. No se tienen en cuenta en la obtención del hidrograma los caudales provenientes de infiltración devuelta al cauce, ni las pérdidas por evapotranspiración. Según la guía metodológica para el 
desarrollo del SNCZI estos procesos tienen una importancia secundaria y en la práctica pueden ignorarse.

- Propagación de hidrogramas generados a través de los cauces para la obtención del hidrograma de la crecida en el punto de desagüe. Los hidrogramas parciales de las diferentes subcuencas pueden sumarse, para simular las confluencias, o modificarse, para tener en cuenta los efectos de la propagación a lo largo de los cauces, para lo que pueden utilizarse diferentes técnicas, tales como el método de Muskingum, el de la onda cinemática, etc.

- Operaciones especiales: además de los procesos normales de generación de la escorrentía y propagación de ésta a lo largo de los cauces, el programa HEC-HMS puede simular el funcionamiento de la infraestructura, incluyendo embalses de laminación, canales de derivación y trasvase...

El modelo se planteó a través de la consideración de los hidrogramas de cada una de las subcuencas que componen el Río Segura y sus afluentes, quedando fuera del modelo aquellas cuencas endorreicas así como las ramblas costeras. En la simulación del Guadalentín se tuvo en cuenta los siguientes aspectos:

- Sólo contribuyen efectivamente a la formación del hidrograma en el Guadalentín las "zonas de drenaje instantáneo". En la cuenca del Guadalentín, según dichos estudios, la superficie de drenaje instantáneo supone un 72\% de la cuenca vertiente total. La consideración de la zona de drenaje instantáneo supuso una reducción en la superficie vertiente a la presa de El Romeral de $3125 \mathrm{~km}^{2}$ a $2332 \mathrm{~km}^{2}$.

- En esta simulación el nivel de los embalses se situó al 40\% de su capacidad excepto en el caso del embalse de Puentes IV en el que se empleó como cota inicial, el máximo nivel mensual alcanzado en el periodo 2002-2012.

- Para los periodos de retorno de 5, 10, 50 y 100 años, el caudal de avenida en el Guadalentín, se produce como consecuencia de la lluvia caída en la parte baja de su cuenca, desde El Paretón hasta su desembocadura, ya que hasta el periodo de retorno de 100 años, dicha infraestructura es capaz de desviar la práctica totalidad del caudal entrante.

- Únicamente para la avenida de 500 años, el caudal punta que se observa en la desembocadura del Guadalentín viene originado por los caudales procedentes de la parte alta de la cuenca, (el Paretón deriva sólo parte de los caudales entrantes) que son superiores a los que se generan en su parte baja. 


\subsubsection{MODELIZACIÓN HIDRÁULICA DEL RÍO GUADALENTÍN}

Respecto al origen de los caudales simulados en el SNCZI, a partir de los hidrogramas procedentes del modelo HEC-HMS e introducidos en cabecera, se modelizaron con el programa Guad-2D el Río Guadalentín desde la confluencia con la rambla del Estrecho hasta Murcia, mediante 7 submodelos cuya distribución se refleja en el esquema adjunto. El modelo Guad-2D es un modelo bidimensional de simulación hidráulica diseñado para el análisis de ondas de avenida provocadas por la lluvia o por la destrucción gradual o espontánea de presas y muros de contención de grandes depósitos de agua. En el modelo matemático el movimiento del fluido se supone gobernado por los principios fundamentales de conservación de la masa y segunda ley de Newton en dos direcciones horizontales. Los hidrogramas correspondientes a las aportaciones laterales también proceden del modelo hidrológico HEC-HMS. En el caso que nos ocupa, se tuvieron en cuenta los hidrogramas del Río Guadalentín y de su afluente por margen izquierda, la rambla del Estrecho. Aunque no es objeto del tramo en estudio, es importante destacar que si bien hasta el Paretón la hidrología y la hidráulica van parejas, es a partir de este punto cuando existe una divergencia importante entre los datos arrojados por el modelo HECHMS y los obtenidos del modelo hidráulico bidimensional. Esto se debe a que en el modelo hidrológico no es posible introducir correctamente la geometría de la obra de derivación con lo que, en cualquier caso, los resultados correctos serían los del Guad-2D. En la tabla y figura siguientes se muestran todas las entradas de caudal del río. 
Tabla 4.2.7.1. Esquema de caudales del Río Guadalentín.

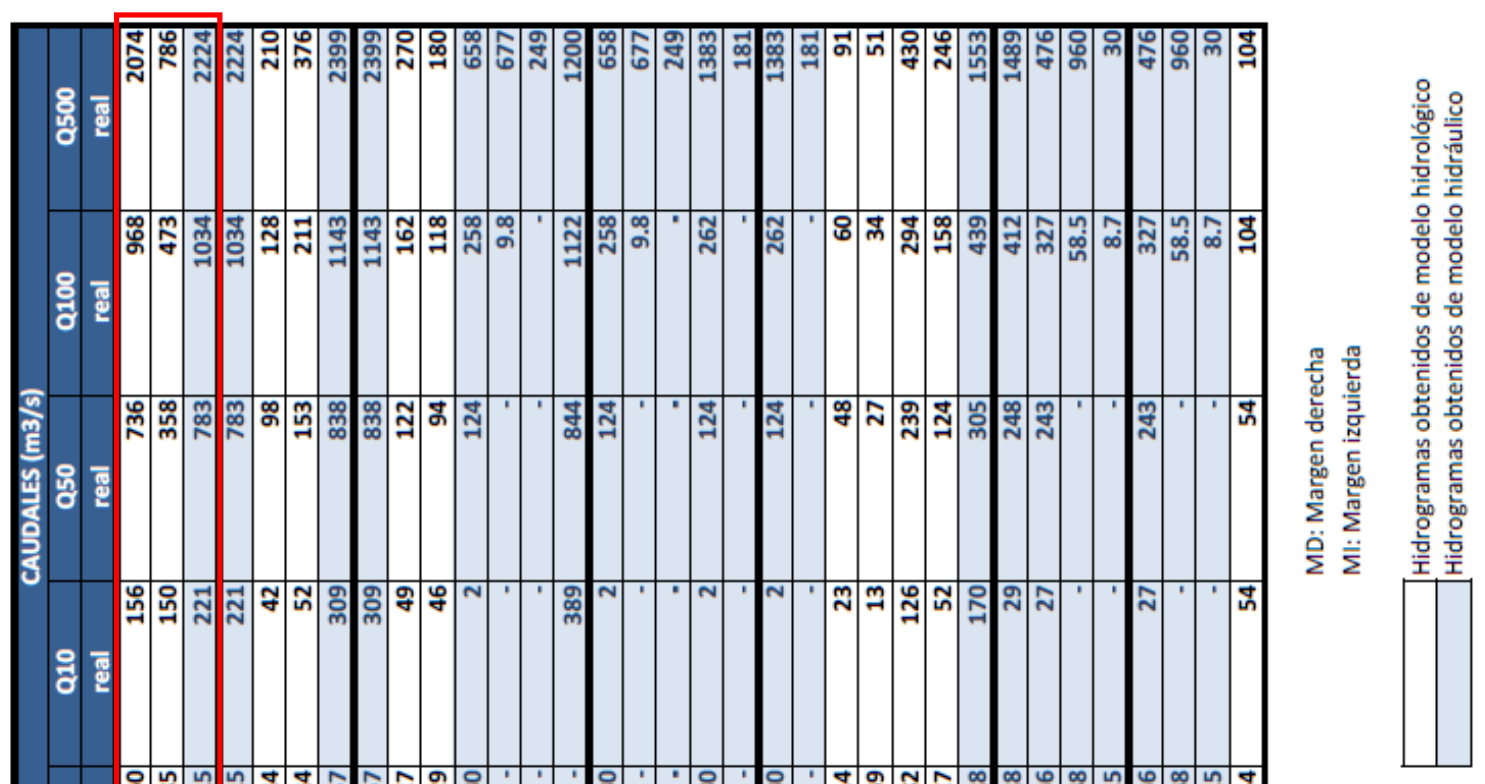

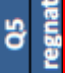

$\stackrel{\dddot{s}}{\bar{s}}$

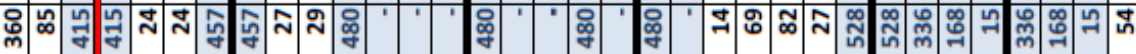

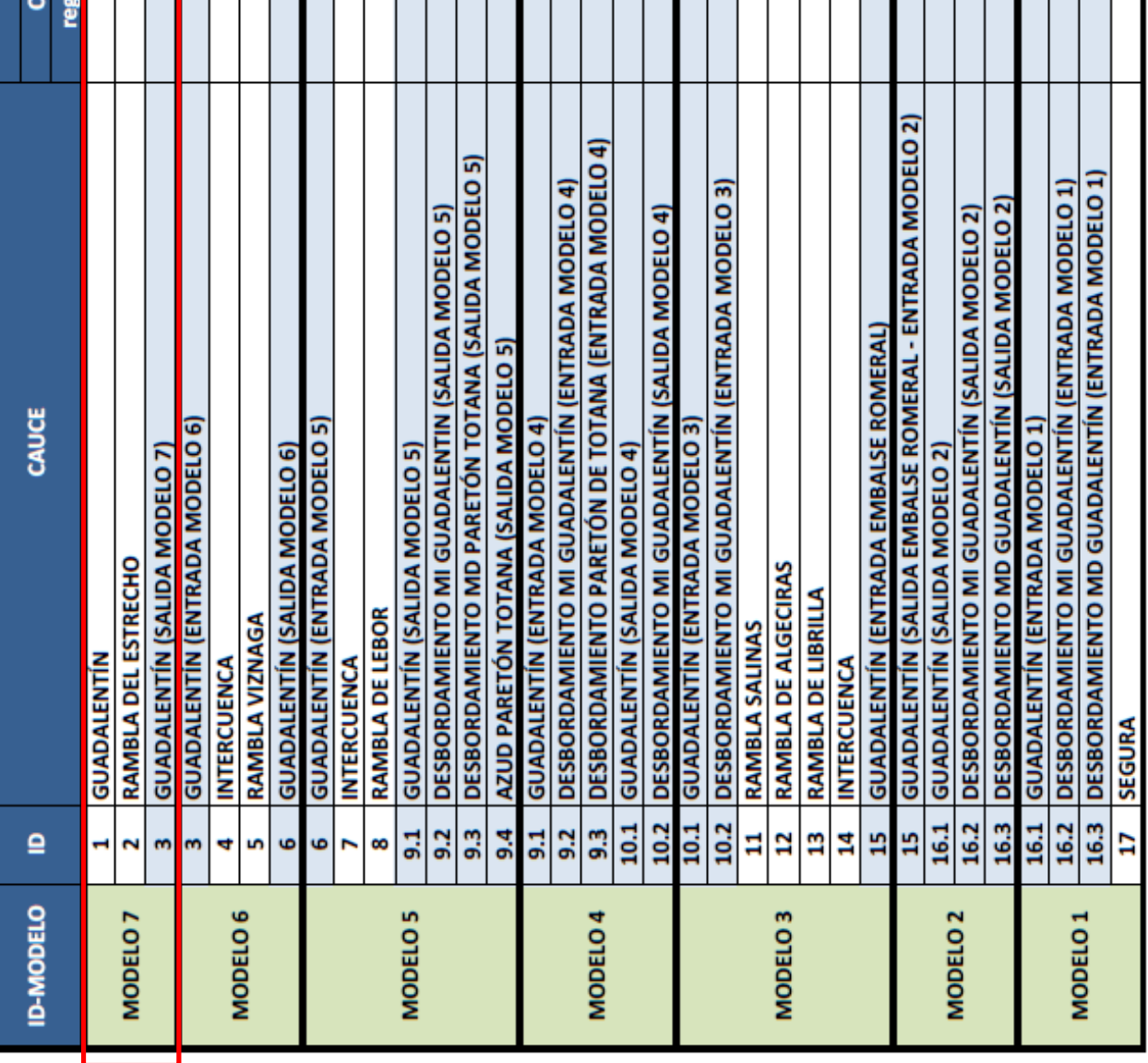

응 


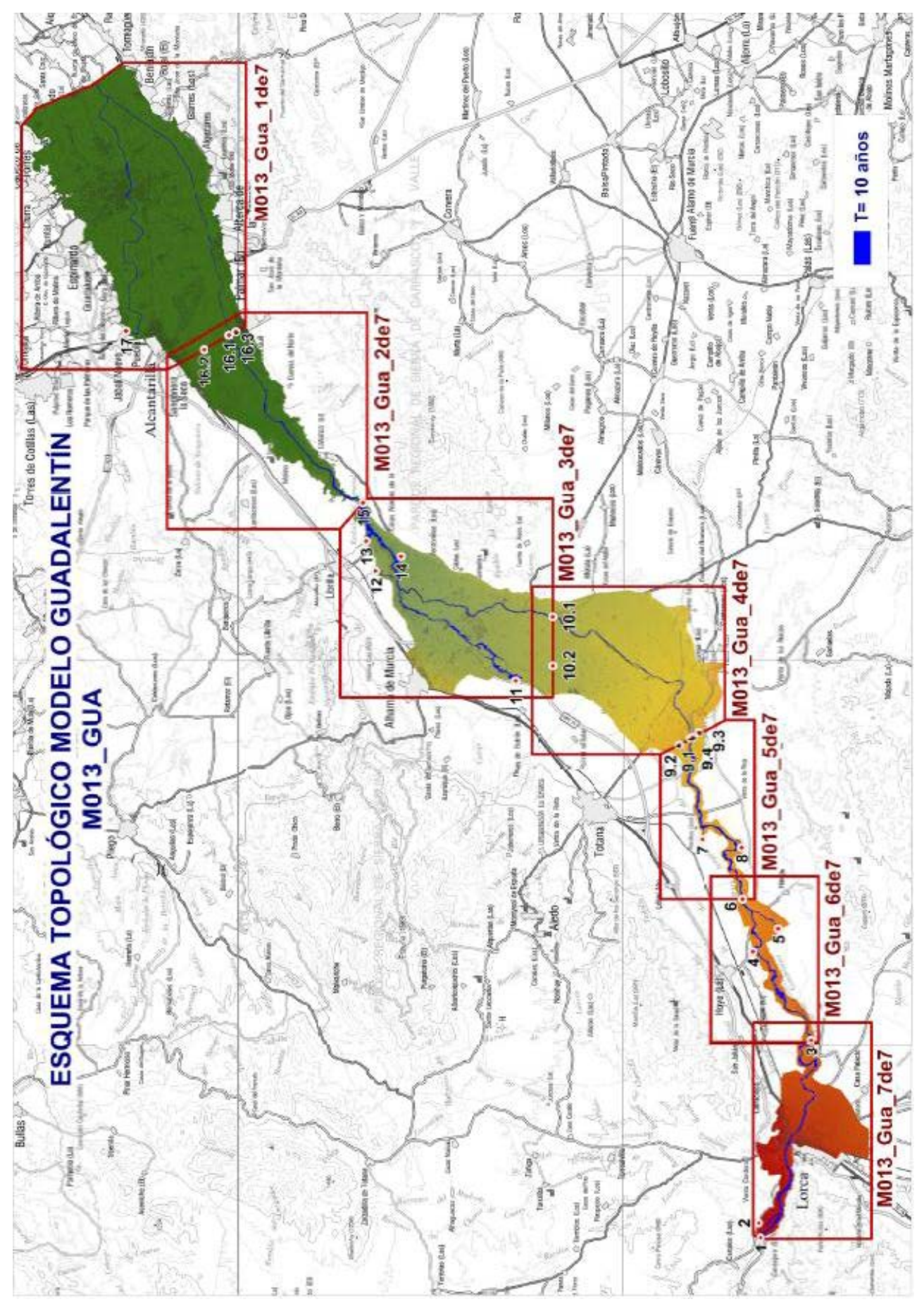

Figura 4.2.7.1. Entradas de caudal en el Río Guadalentín. 


\section{DESCRIPCIÓN DEL MODELO HIDRÁULICO BIDIMENSIONAL}

El modelo bidimensional seleccionado fue el Guad-2D, modelo que realiza modelizaciones hidráulicas bidimensionales con obras de drenaje transversales (obras de paso y accidentes significativos) y tramos cubiertos. Este modelo incorpora:

- La modelización numérica de flujo variable en dos dimensiones horizontales en la hipótesis de flujo verticalmente homogéneo.

- Adaptabilidad de la malla a la morfología de la zona a modelizar.

- Posibilidades de modelizar procesos de secado e inundación en zonas de la malla no predefinidas.

- Cálculo por volúmenes finitos.

Los datos necesarios para completar el modelo son los siguientes:

- Terreno: Ráster del Modelo Digital de Terreno (con edificaciones y sin puentes).

- Ráster de rugosidades, empleando el parámetro de Manning.

- Establecimiento de las condiciones de contorno: externas (condiciones de entrada como hidrogramas con los caudales de cálculo, y condiciones de salida como curva de desagüe, calado crítico, etc.), o internas (puentes y tramos cubiertos).

- Definición de las condiciones iniciales de simulación.

- Establecimiento de los parámetros de cálculo (tiempo de modelización, grabación de resultados).

\section{ANÁLISIS DE RESULTADOS}

Los calados máximos que el modelo arrojó en el área de estudio fueron de 3,13 (T10 (m)) 5,06 (T50 (m) 5,76 (T100 (m)) y 7,43 (T500 (m). Los calados máximos en el cauce oscilan entre 3,13 m para la avenida de 10 años y 7,43 m para la avenida de 500 años (obsérvense planos 5.1 a 5.4, anexo 1). Por otro lado, las velocidades máximas en el cauce son las que siguen: $5,82(\mathrm{~T} 10(\mathrm{~m} / \mathrm{s}))$ 9,48 (T50 (m/s)) 10,44 (T100 (m/s)) y 7,42 (T500 (m/s)). La velocidad máxima para 10 años se encuentra en $5,82 \mathrm{~m} / \mathrm{s}$. La velocidad máxima de todos los escenarios se da para la avenida de 100 años de periodo de retorno $(10,44 \mathrm{~m} / \mathrm{s})$, ya que para la avenida de 500 años se producen desbordamientos laterales del cauce (como se puede observar en el plano $\mathrm{n}^{\circ}$ 4, anexo 2), y la velocidad-límite en el mismo decrece $(7,42 \mathrm{~m} / \mathrm{s})$. Los mapas de velocidad aparecen en los planos 6.1 a 6.4 (anexo 3). Se ha prescindido en este apartado de las características correspondientes a periodo de retorno de 5 años, puesto que esos datos de caudal sólo se tuvieron en cuenta para determinar los límites del dominio público hidráulico, 
considerando un régimen natural, es decir no teniendo en cuenta la influencia de las presas que regulan los volúmenes del cauce (presas de Valdeinfierno y de Puentes IV).

\subsubsection{INFORMACIÓN CARTOGRÁFICA}

Los planos contenidos en este estudio reflejarán la siguiente información para el tramo en estudio:

- Situación y emplazamiento del proyecto (plano $n^{\circ} 1$, anexo 4).

- Delimitación del dominio público hidráulico, y zonas de servidumbre y policía (plano $n^{\circ} 2$, anexo 5). Para la estimación del dominio público hidráulico se consideró el alcance de la avenida correspondiente a 5 años de periodo de retorno en régimen natural (sin considerar la presencia de las presas situadas agua arriba de Lorca), y la configuración geomorfológica del cauce (incorporando aquellos terrenos del cauce histórico que habían sufrido alteraciones y/o ocupaciones con respecto del año 1956), cumpliendo así con lo establecido en el Reglamento del Dominio Público Hidráulico. Asimismo se determinaron las zonas asociadas al cauce: de policía (franja lateral de cien metros de anchura a cada lado, contados a partir de la línea que delimita el cauce, en las que se condiciona el uso del suelo y las actividades que en él se desarrollen), y de servidumbre (franja situada lindante con el cauce, dentro de la zona de policía, con ancho de cinco metros, que se reserva para usos de vigilancia, pesca y salvamento).

- Zona de flujo preferente (plano $n^{\circ} 3$, anexo 6). Es aquella constituida por la unión de la zona donde se concentra preferentemente el flujo durante las avenidas, o vía de intenso desagüe, y de la zona donde, para la avenida de 100 años de periodo de retorno, se pueden producir graves daños sobre las personas y los bienes, quedando delimitado su límite exterior mediante la envolvente de ambas. Se entiende por vía de intenso desagüe la zona por la que pasaría la avenida de 100 años de periodo de retorno sin producir una sobre elevación mayor que 0,3 m, respecto a la cota de la lámina de agua que se produciría con esa misma avenida considerando toda la llanura de inundación existente. La sobre elevación anterior puede, a criterio del organismo de cuenca, reducirse hasta 0,1 m cuando el incremento de la inundación pueda producir graves perjuicios o aumentarse hasta 0,5 m en zonas rurales o cuando el incremento de la inundación produzca daños reducidos. Se considera que pueden producirse graves daños sobre las personas y los bienes cuando las condiciones hidráulicas durante la avenida satisfagan uno o más de los siguientes criterios:

a) Que el calado sea superior a $1 \mathrm{~m}$.

b) Que la velocidad sea superior a $1 \mathrm{~m} / \mathrm{s}$. 
c) Que el producto de ambas variables sea superior a $0,5 \mathrm{~m}^{2} / \mathrm{s}$.

Siguiendo lo establecido en el Real Decreto 9/2008, para la determinación de la zona de flujo preferente, además de los criterios hidrológico-hidráulico se han considerado los geomorfológicos, contemplándose así los terrenos aluviales donde se reconocen formas erosivas y sedimentarias. Es decir la zona de flujo preferente es resultado de la fusión de la zona de flujo preferente hidráulica y la zona de flujo preferente potencial geomorfológica.

- Alcance de las zonas inundables para distintos periodos de retorno (plano $\mathrm{n}^{\circ} 4$, anexo 2 ).

Abarcan las zonas inundables para 10, 50, 100 y 500 años de periodo de retorno.

- Mapas de calados para los distintos escenarios (planos $n^{0} 5$, anexo 1 ).

- Mapas de velocidades para los distintos escenarios (planos $n^{\circ} 6$, anexo 3).

- Cauce histórico sobre ortofoto del año 1.928 (plano $n^{\circ} 7$, anexo 7).

- Perfiles transversales (plano $n^{\circ} 8$, anexo 8). En este plano se incluyen una serie de perfiles transversales-tipo del tramo en estudio. 


\subsection{ESTUDIO GEOTÉCNICO}

\subsubsection{INTRODUCCIÓN Y METODOLOGÍA}

Durante los días 3 y 4 de diciembre de 2013 se llevaron a cabo tres sondeos mecánicos a lo largo de los $1500 \mathrm{~m}$ de tramo de río a rehabilitar con el proyecto LIFE+ Riverphy. Concretamente, se realizó un sondeo en cada uno de los tres tramos de $500 \mathrm{~m}$ de longitud en los que se ha dividido el cauce para la implementación del proyecto, sondeo 1 en el tramo 1 (0$500 \mathrm{~m}$ ), sondeo 2 en el tramo 2 (500-1000 m) y sondeo 3 en el tramo 3 (1000-1500 m). En la Figura 4.3.1.1 se muestra la localización de cada sondeo mecánico con puntos azules. Para caracterizar completamente el sedimento en profundidad también se hizo un estudio geofísico complementario mediante la aplicación de tomografía eléctrica realizando tres perfiles coincidiendo con la localización de cada sondeo, aunque los resultados de dicho estudio no se muestran en la presente tesis. Las coordenadas en las que se llevaron a cabo los sondeos fueron:

Sondeo 1: $37^{\circ} 40^{\prime} 31^{\prime \prime} \mathrm{N}, 1^{\circ} 41^{\prime} 14^{\prime \prime} \mathrm{O}$

Sondeo 2: $37^{\circ} 40^{\prime} 26^{\prime \prime} \mathrm{N}, 1^{\circ} 40^{\prime} 50^{\prime \prime} \mathrm{O}$

Sondeo 3: $37^{\circ} 40^{\prime} 23^{\prime \prime} \mathrm{N}, 1^{\circ} 40^{\prime} 35^{\prime \prime} \mathrm{O}$

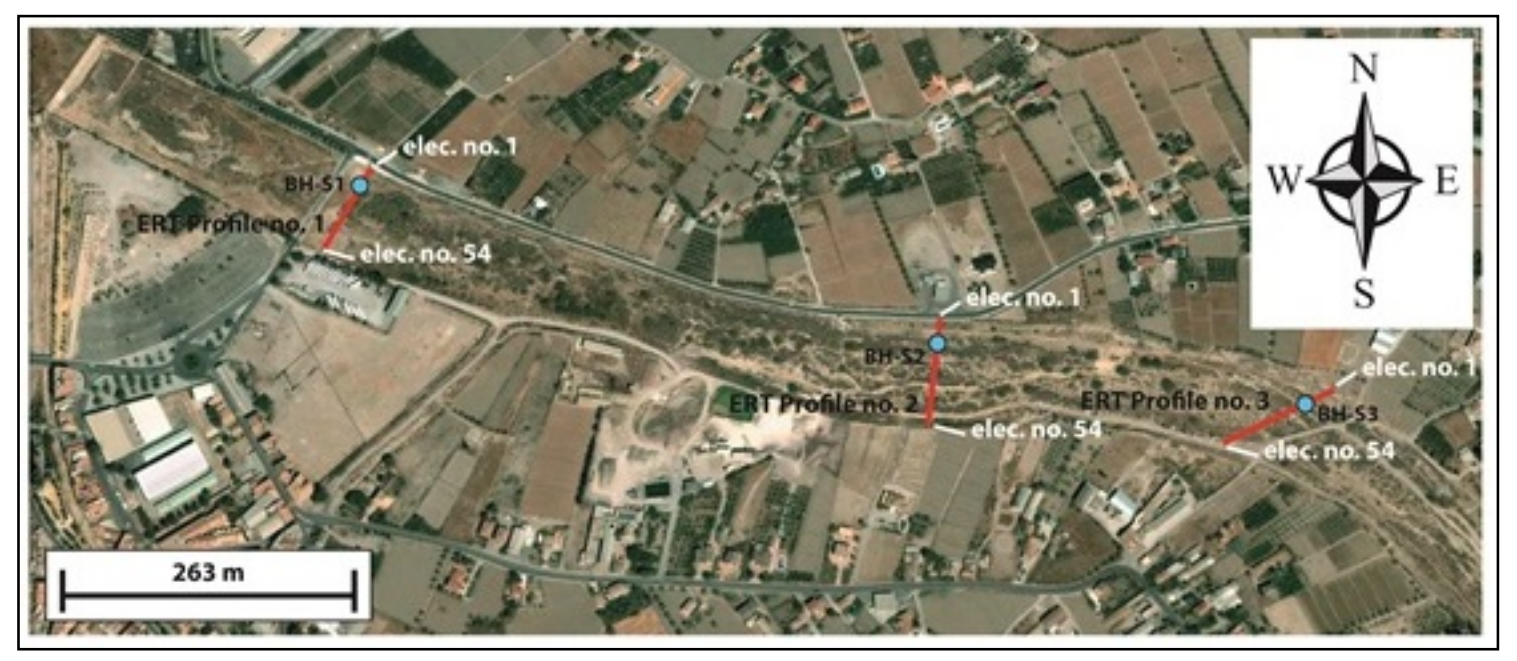

Figura 4.3.1.1. Localización de los sondeos mecánicos realizados en cada tramo del cauce del Río Guadalentín. Los sondeos están mostrados con puntos azules (S1-S3).

Los sondeos se realizaron hasta una profundad de 9-10 m, para determinar la naturaleza de los materiales sedimentados y el grado de contaminación por $\mathrm{Cu}, \mathrm{Zn}$ y $\mathrm{Cr}$ en profundidad. La 
Figura 4.3.1.2 muestra fotografías del momento de la realización de los sondeos. La anchura de cada sondeo fue de $101 \mathrm{~mm}$ hasta los primeros $3 \mathrm{~m}$ de profundidad y de $86 \mathrm{~mm}$ a partir de esta profundidad. Se extrajo la columna litológica con testigo continuo para caracterizar el material geológico y determinar la concentración de metales pesados. En base a los diferentes materiales identificados en la columna litológica de cada sondeo (anexo 9), se tomaron muestras a diferentes profundidades para su análisis en el laboratorio.

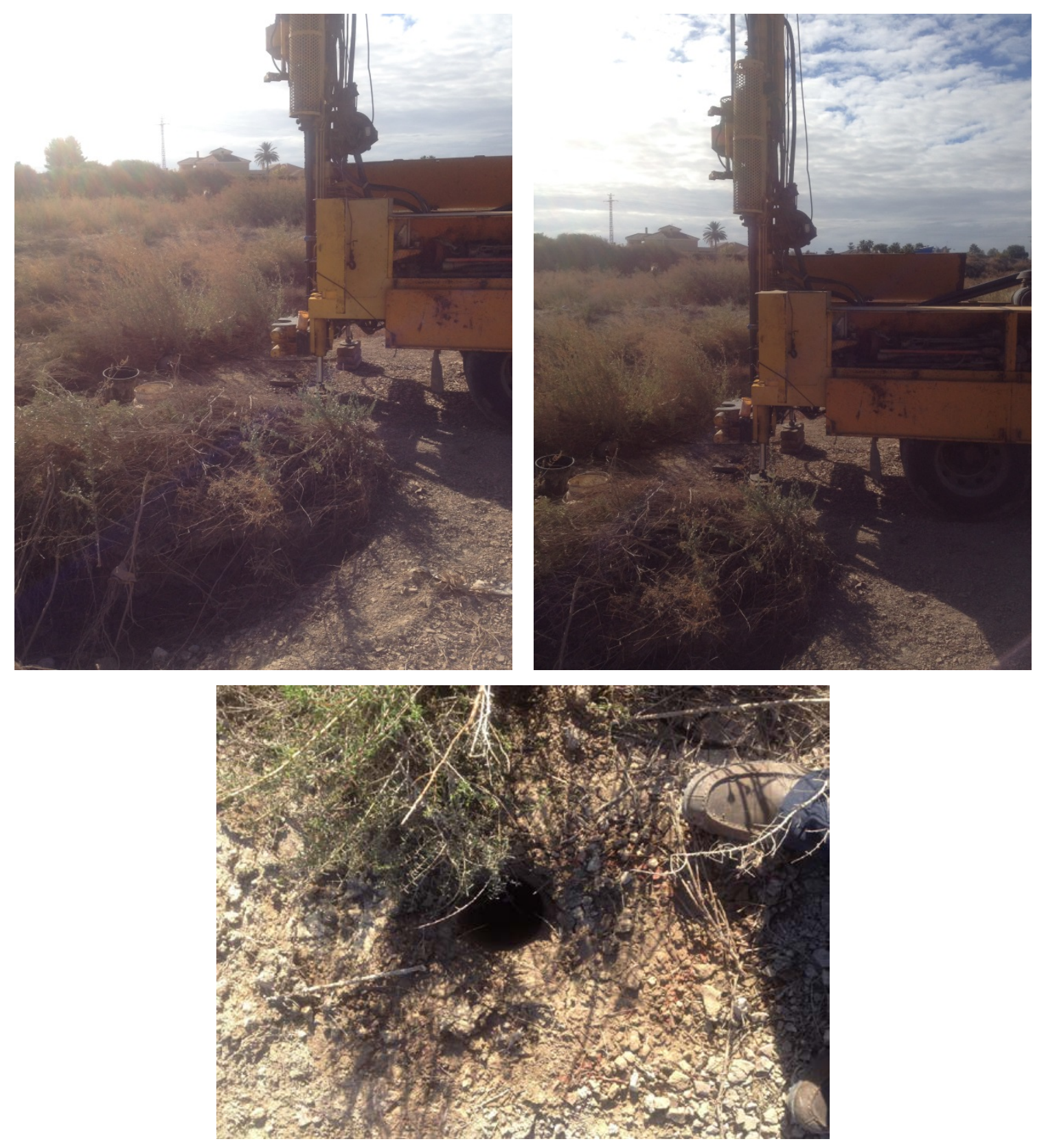

Figura 4.3.1.2. Fotografías de los sondeos realizados en el lecho del río. 
Las diferentes muestras tomadas en la columna estratigráfica de cada sondeo se secaron al aire durante una semana y se tamizaron a una malla inferior a $2 \mathrm{~mm}$ para eliminar las fracciones gruesas. En estas muestras se determinó el contenido total de los metales pesados ( $\mathrm{Cu}, \mathrm{Zn}$ y Cr) mediante una digestión con $\mathrm{HNO}_{3} / \mathrm{HClO}_{4}$ a $210^{\circ} \mathrm{C}$ durante $1,5 \mathrm{~h}$ (Risser y Baker, 1990). La fracción soluble de los metales pesados se extrajo con agua desionizada (relación 1:5 p/v) (Buurman et al., 1996). La concentración de los metales pesados se midió por espectroscopía de absorción atómica (AAnalyst 800, Perkin Elmer), siendo los límites de detección de 0,05 $\mathrm{mg} / \mathrm{L}$ para $\mathrm{Cu}, 0,05 \mathrm{mg} / \mathrm{L}$ para Zn y 0,50 mg/L para Cr. La metodología para la concentración total de metales se referenció usando el material certificado de referencia BAM-U110 (Federal Institute for Materials Research and Testing, Alemania). Para determinar el grado de contaminación del material del lecho del cauce se han utilizado los niveles de fondo (NF) y niveles genéricos de referencia (NGR) propuestos para la Región de Murcia (Martínez y Pérez, 2007). Estos niveles están recogidos en la siguiente tabla:

Tabla 4.3.1.1. Niveles de fondo y niveles genéricos de referencia para el cromo, cobre y zinc en la Región de Murcia (Martínez y Pérez, 2007).

\begin{tabular}{lccc}
\hline & Cu (mg/kg) & Zn (mg/kg) & Cr (mg/kg) \\
\hline Niveles de fondo & 18,7 & 55,2 & 44,6 \\
Niveles genéricos de referencia & 32,0 & 105,0 & 66,0 \\
\hline
\end{tabular}

\subsubsection{RESULTADOS DE LOS ANÁLISIS DE METALES EN LOS SEDIMENTOS SONDEO 1}

Los resultados correspondientes a las concentraciones de metales totales y metales solubles del sondeo 1 realizado en el tramo $1(0-500 \mathrm{~m})$ del lecho fluvial más próximo al núcleo urbano de Lorca se muestran en la Figura 4.3.2.1. En dicha figura aparecen los niveles totales de los metales $\mathrm{Cu}$, Zn y Cr y su fracción soluble, es decir, la que se puede solubilizar con el agua de lluvia y ser transportada en disolución por ella. La concentración total de Cu presenta valores por encima de $32 \mathrm{mg} / \mathrm{kg}$ (NGR) en el primer metro de profundidad del lecho, descendiendo a niveles por debajo del NGR a partir de esta profundidad. El Zn presenta una concentración total en toda la profundidad del sondeo dentro de los NF para la Región de Murcia, con algunos incrementos, pero siempre por debajo del NGR propuesto. La concentración total de Cr es superior a $200 \mathrm{mg} / \mathrm{kg}$ en el primer metro de profundidad, superando los NGR propuestos para la Región de Murcia. Por debajo del metro de profundidad los niveles de Cr se encuentran dentro del rango de los NF de la Región de Murcia. 

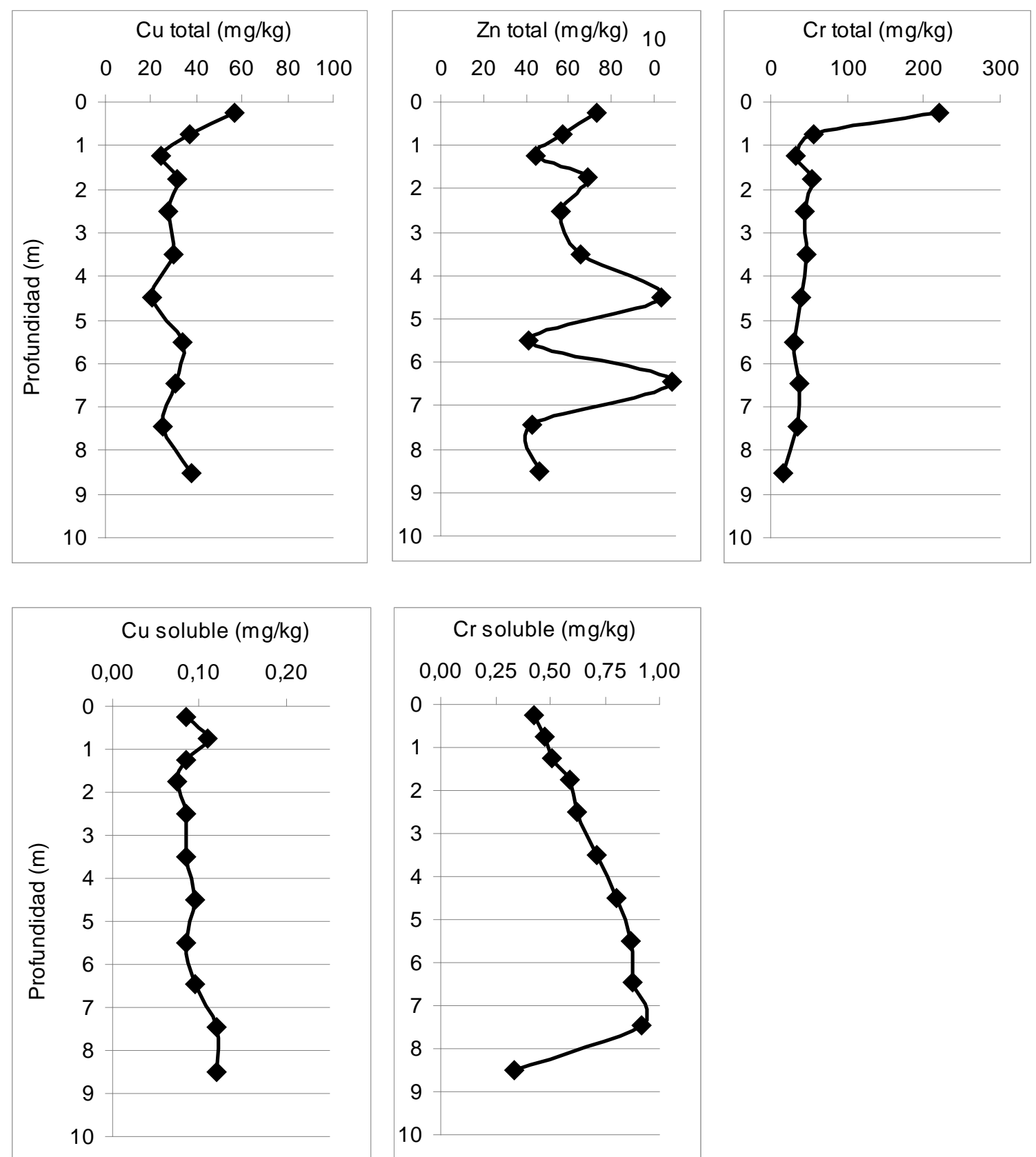

Figura 4.3.2.1. Concentraciones total y soluble de cobre (Cu), zinc ( $\mathrm{Zn})$ y cromo (Cr) en el sondeo 1 ubicado en el primer tramo de 500 m del lecho fluvial del Guadalentín tras su paso por el núcleo urbano de Lorca. Zinc soluble por debajo del nivel de detección del equipamiento $(0,05 \mathrm{mg} / \mathrm{mL})$.

La solubilidad de los tres metales estudiados es muy baja, indicando que la mayor parte de su contenido total se encuentra precipitada, favorecida posiblemente por las altas concentraciones de carbonato cálcico y un alto pH. De hecho la fracción soluble del Zn se encuentra por debajo 
del nivel de detección del equipo $(0,05 \mathrm{mg} / \mathrm{mL})$. Como consecuencia, el riesgo de transferencia de estos metales por lixiviación tras episodios de lluvia y avenida es bajo.

\section{SONDEO 2}
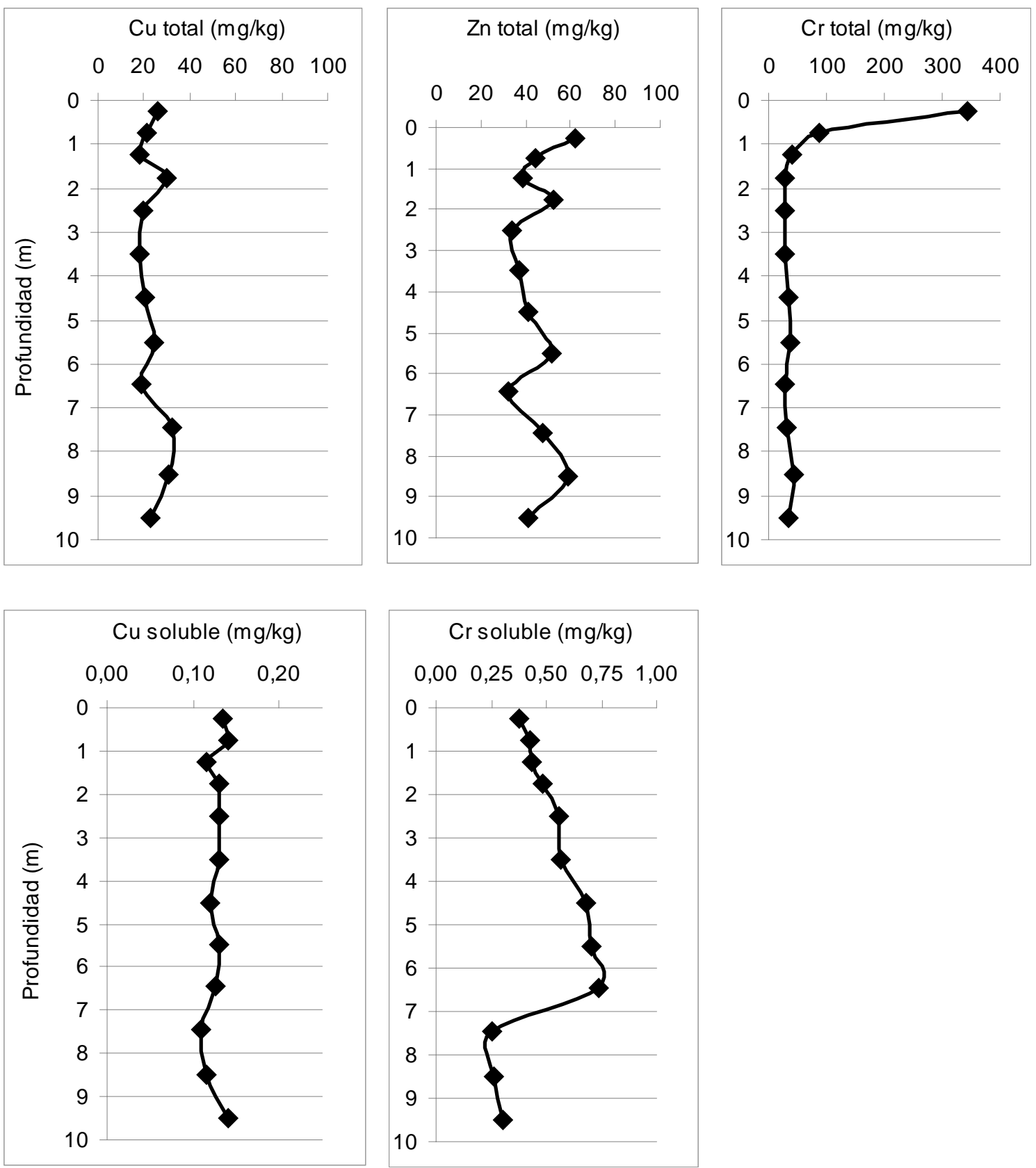

Figura 4.3.2.2. Contenidos total y soluble de cobre (Cu), zinc $(\mathrm{Zn})$ y cromo $(\mathrm{Cr})$ en el sondeo 2 ubicado en el segundo tramo de $500 \mathrm{~m}$ del lecho fluvial del Guadalentín tras su paso por el núcleo urbano de Lorca. Zinc soluble por debajo del nivel de detección del equipamiento (0,05 $\mathrm{mg} / \mathrm{mL})$. 
Los niveles totales de los metales $\mathrm{Cu}, \mathrm{Zn}$ y $\mathrm{Cr}$ y su fracción soluble, es decir, la que se puede solubilizar con el agua de lluvia y ser transportada en disolución por ella aparecen en la Figura 4.3.2. El Cu y el Zn presentan una concentración total en toda la profundidad del sondeo dentro de los NF para la Región de Murcia, con algunos incrementos, pero siempre por debajo de los NGR propuestos. La concentración total de Cr es superior a $300 \mathrm{mg} / \mathrm{kg}$ en el primer metro de profundidad, superando los NGR propuestos para la Región de Murcia. Por debajo del metro de profundidad los niveles de $\mathrm{Cr}$ se encuentran dentro del rango de los niveles de fondo de la Región. La solubilidad de los tres metales estudiados es muy baja, indicando que la mayor parte de su contenido total se encuentra precipitada, favorecida posiblemente por las altas concentraciones de carbonato cálcico y alto $\mathrm{pH}$. De hecho la fracción soluble del $\mathrm{Zn}$ se encuentra por debajo del nivel de detección del equipo. Como consecuencia, el riesgo de transferencia de estos metales por lixiviación tras episodios de lluvia y avenida es bajo.

\section{SONDEO 3}

Los niveles totales de los metales $\mathrm{Cu}, \mathrm{Zn}$ y $\mathrm{Cr}$ y su fracción soluble, es decir, la que se puede solubilizar con el agua de lluvia y ser transportada en disolución por ella aparecen en la Figura 4.3.2.3. El $\mathrm{Cu}$ y el Zn presentan una concentración total en toda la profundidad del sondeo dentro de los NF para la Región de Murcia, con algunos incrementos, pero siempre por debajo de los NGR propuestos. La concentración total de Cr se encuentra en torno a $200 \mathrm{mg} / \mathrm{kg}$ en el primer metro de profundidad, superando los NGR propuestos para la Región de Murcia. Por debajo del metro de profundidad los niveles de $\mathrm{Cr}$ se encuentran dentro del rango de los niveles de fondo de la Región.

La solubilidad de los tres metales estudiados es muy baja, indicando que la mayor parte de su contenido total se encuentra precipitada, favorecida por las altas concentraciones de carbonato cálcico y alto $\mathrm{pH}$. De hecho la fracción soluble del $\mathrm{Zn}$ se encuentra por debajo del nivel de detección del equipo. Como consecuencia, el riesgo de transferencia de estos metales por lixiviación tras episodios de lluvia y avenida es bajo. 

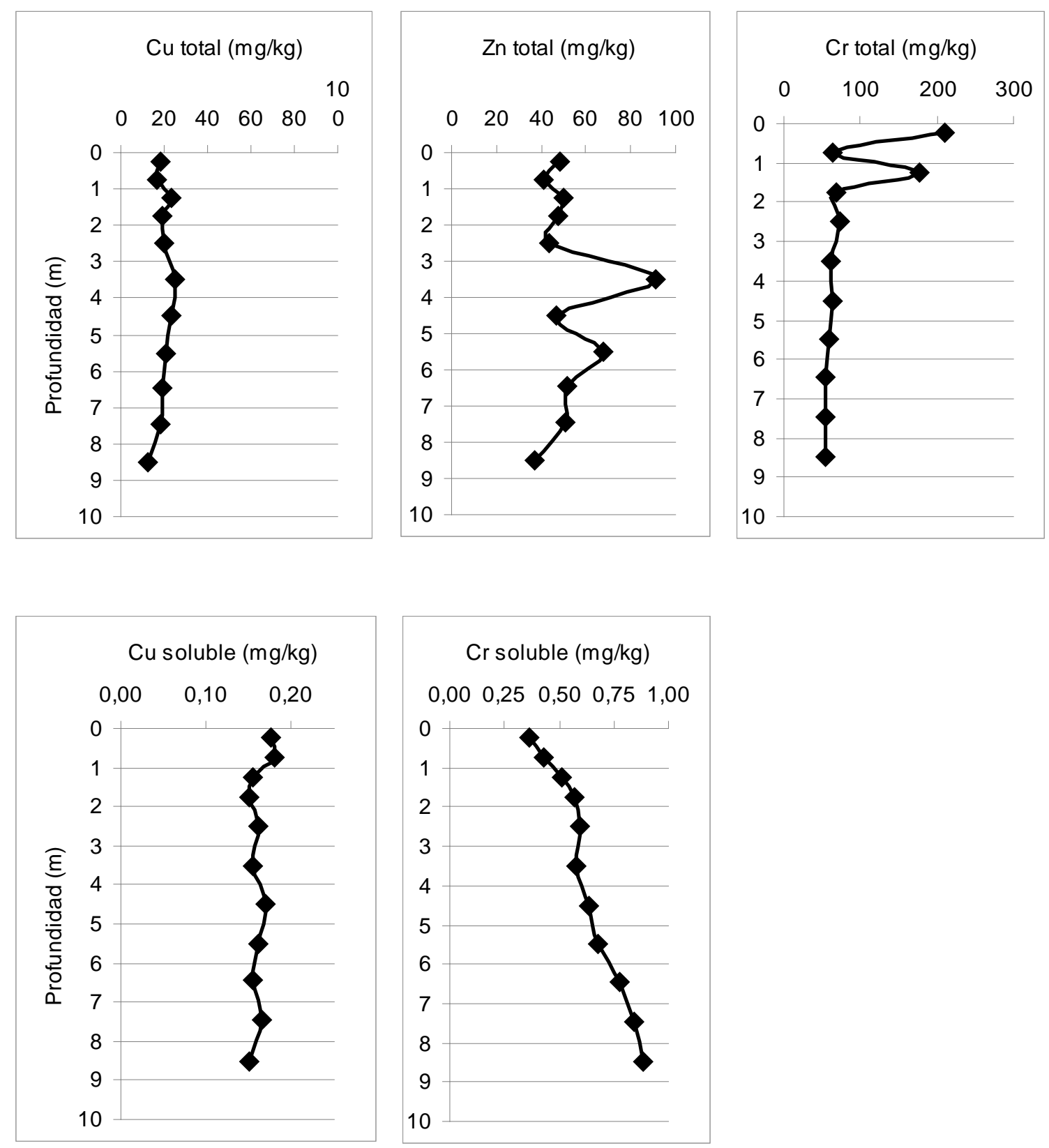

Figura 4.3.2.3. Contenidos total y soluble cobre (Cu), zinc $(\mathrm{Zn})$ y cromo $(\mathrm{Cr})$ en el sondeo 3 ubicado en el tercer tramo de $500 \mathrm{~m}$ del lecho fluvial del Guadalentín tras su paso por el núcleo urbano de Lorca. Zn soluble por debajo del nivel de detección del equipamiento $(0,05 \mathrm{mg} / \mathrm{mL})$.

\subsubsection{CONCLUSIONES}

Tras el análisis de los tres sondeos realizados se concluye que existe una contaminación por $\mathrm{Cr}$ en el primer metro de profundidad del lecho del río. Por debajo de estos valores los niveles de Cr se encuentran dentro de los NF observados en la Región de Murcia. Por tanto, el vertido directo de lodos y aguas procedentes de la industria de curtidos ha provocado la contaminación 
del cauce con una afección hasta un metro de profundidad. No existen efectos de contaminación por $\mathrm{Cu}$ y $\mathrm{Zn}$ en profundidad, con niveles altos de $\mathrm{Cu}$ observados solamente en el primer tramo a nivel superficial. La solubilidad de estos metales es muy baja, por lo que el riesgo de lixiviación de los metales no es muy alto. 


\subsection{ESTUDIO BIOGEOQUÍMICO}

\subsubsection{CARACTERIZACIÓN INICIAL DE LA ZONA DE ESTUDIO (LECHO DEL RÍO GUADALENTÍN)}

Se ha definido un muestreo de los sedimentos del tramo de $1500 \mathrm{~m}$ del lecho del Río Guadalentín a recuperar, ubicado inmediatamente aguas abajo del núcleo urbano de Lorca, para determinar la concentración de metales pesados en el para analizar los riesgos ambientales. Un muestreo detallado para realizar una caracterización biogeoquímica del sedimento es crucial para identificar diferentes parches o áreas en el lecho con diferente grado de contaminación, de modo que se adopten diferentes estrategias de rehabilitación ajustadas al riesgo ambiental real y las condiciones edáficas del lecho. Esta caracterización servirá además de línea base para evaluar los cambios una vez se inicie la estrategia de fitoextracción. Además, es necesario hacer un estudio de la vegetación que crece actualmente en el cauce, para conocer el grado de acumulación de metales pesados y su potencialidad para ser utilizadas para la extracción de los metales tóxicos del sedimento. En base a estos resultados de caracterización inicial, se decidirán las especies a utilizar para la fitoextracción del sedimento, la localización exacta de dónde se plantarán o sembrarán, y el marco de plantación.

\section{MUESTREO INICIAL Y MÉTODOS ANALÍTICOS}

Se ha definido una malla de muestreo regular de $2000 \mathrm{~m}^{2}$, con 60 puntos de muestreo distados $45 \mathrm{~m}$ unos de otros. Esta malla se ha diseñado para que el muestreo de la superficie total del tramo del río a recuperar sea representativo, usando para ello una fotografía aérea (Figura 4.4.1.1). En cada punto de muestreo se tomaron muestreas de sedimento a tres profundidades: 0-20 cm, 20-50 cm y 50-100 cm, para evaluar el nivel de contaminación en función de la profundidad hasta $100 \mathrm{~cm}$. El muestreo tuvo lugar el 11 de febrero de 2013. Las muestras de sedimento se llevaron al laboratorio, donde fueron secadas al aire durante siete días y tamizadas con una malla de tamiz de $2 \mathrm{~mm}$. La concentración de los metales pesados se ha utilizado como datos de entrada para crear mapas de distribución. El programa utilizado ha sido Arcview 3.1. Para la interpolación de los datos se ha utilizado el método de distancia inversa ponderada (Burrough y McDonnell, 1998).

Durante el muestreo de sedimentp se hizo un inventario de la vegetación presente en el lecho del río. En base a este inventario, se seleccionaron las cuatro de las especies más abundantes: Atriplex halimus (A. halimus), Salsola oppositifolia (S. oppositifolia), Suaeda vera (S. vera) y Tamarix africana ( $T$. africana). Se tomaron muestras de raíz, tallo y hoja de un mínimo de 3 
ejemplares de cada una de estas especies a lo largo de los tramos del río a recuperar, para determinar el grado de acumulación de metales pesados en sus tejidos.

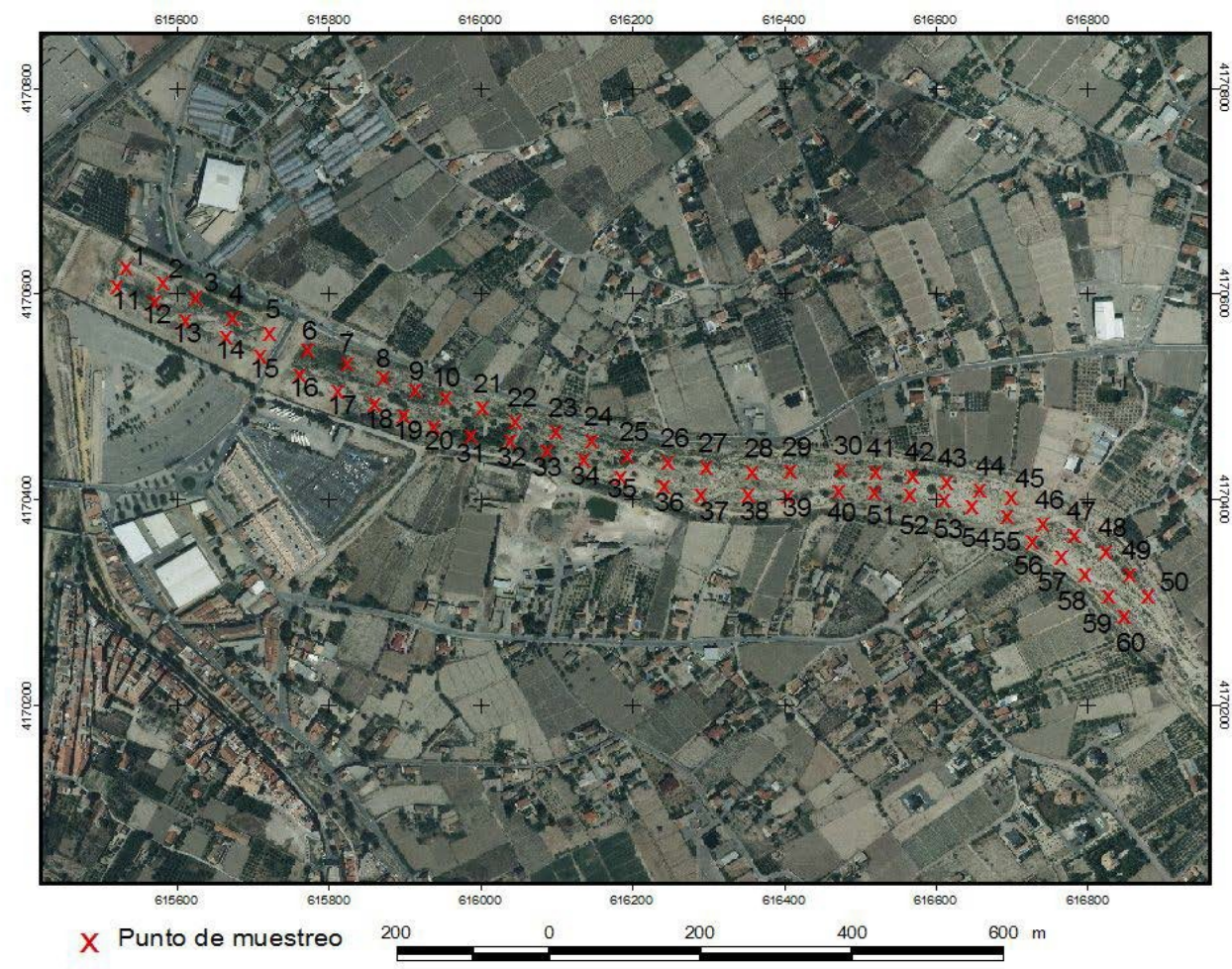

Figura 4.4.1.1. Localización de los 60 puntos de muestreo en el tramo del Río Guadalentín a recuperar donde se ha tomado sedimento a tres profundidades diferentes.

Para la dellimitación de la superficie contaminada a rehabilitar mediante la técnica de fitoextracción se han usado los resultados del análisis de los metales totales. El contenido total de $\mathrm{Cu}, \mathrm{Zn}$ y $\mathrm{Cr}$ se determinó mediante digestión a $210^{\circ} \mathrm{C}$ durante 1,5 h (Risser y Baker, 1990), y se midió mediante espectroscopía de absorción atómica (AAnalyst 800, Perkin Elmer). Con respecto a las muestras de planta (raíz, tallo y hoja), éstas se lavaron con agua desionizada y se secaron a $55^{\circ} \mathrm{C}$ durante $72 \mathrm{~h}$. La materia seca se molió y se incineró a $480^{\circ} \mathrm{C}$ durante $12 \mathrm{~h}$. Las cenizas resultantes se disolvieron en $\mathrm{HNO}_{3} 0,6 \mathrm{~N}$ y se filtraron para la medición de la concentración de Cr, Cu y Zn mediante espectroscopía de absorción atómica (AAnalyst 800, Perkin Elmer).

Igualmente, para determinar el grado de contaminación del material del lecho del cauce se han utilizado los NF y NGR propuestos para la Región de Murcia (Martínez y Pérez, 2007). Estos 
niveles están recogidos a continuación:

Tabla 4.4.1.1. Niveles de fondo y niveles genéricos de referencia para el $\mathrm{Cu}, \mathrm{Zn}$ y $\mathrm{Cr}$ en la Región de Murcia (Martínez y Pérez, 2007).

\begin{tabular}{lccc}
\hline & Cu (mg/kg) & Zn (mg/kg) & Cr (mg/kg) \\
\hline Niveles de fondo & 18,7 & 55,2 & 44,6 \\
Niveles genéricos de referencia & 32,0 & 105,0 & 66,0 \\
\hline
\end{tabular}

\section{RESULTADOS DE LA CARACTERIZACIÓN INICIAL}

A continuación se muestran los mapas de distribución de las concentraciones de metales totales ( $\mathrm{Cu}, \mathrm{Zn}$ y $\mathrm{Cr})$ de los sedimentos del cauce muestreados a 3 profundidades $(0-20 \mathrm{~cm}, 20-50 \mathrm{~cm}$ y 50-100 cm), usados para identificar geográficamente las zonas contaminadas y evaluar la futura implantación de la vegetación para la fitoextracción.

En la distribución de la concentración total de los metales pesados se ha utilizado el color amarillo y sus tonalidades para indicar las zonas donde la concentración de cada metal se encuentra dentro de los NF de la Región de Murcia (amarillo claro) o por debajo de los NGR (amarillo oscuro). Los colores rojos indican concentraciones por encima de los NGR propuestos para la Región de Murcia, indicando las tonalidades del metal pesado.

La concentración total de Cu se muestra en las Figuras 4.4.1.2-4. La distribución del Cu es bastante similar y homogénea en toda la superficie del tramo a rehabilitar. Su concentración total se encuentran en el rango de los NF de la Región de Murcia excepto en dos áreas donde esta concentración excede los NGR, indicando contaminación del sedimento hasta 1 $\mathrm{m}$ de profundidad. Estas dos áreas se encuentran a $100 \mathrm{~m}$ del margen occidental del tramo fluvial a rehabilitar (el más cercano al núcleo urbano de Lorca) y a 500 m del mismo margen. 
Capítulo 4. CARACTERÍSTICAS GENERALES DE LA ZONA DE ESTUDIO

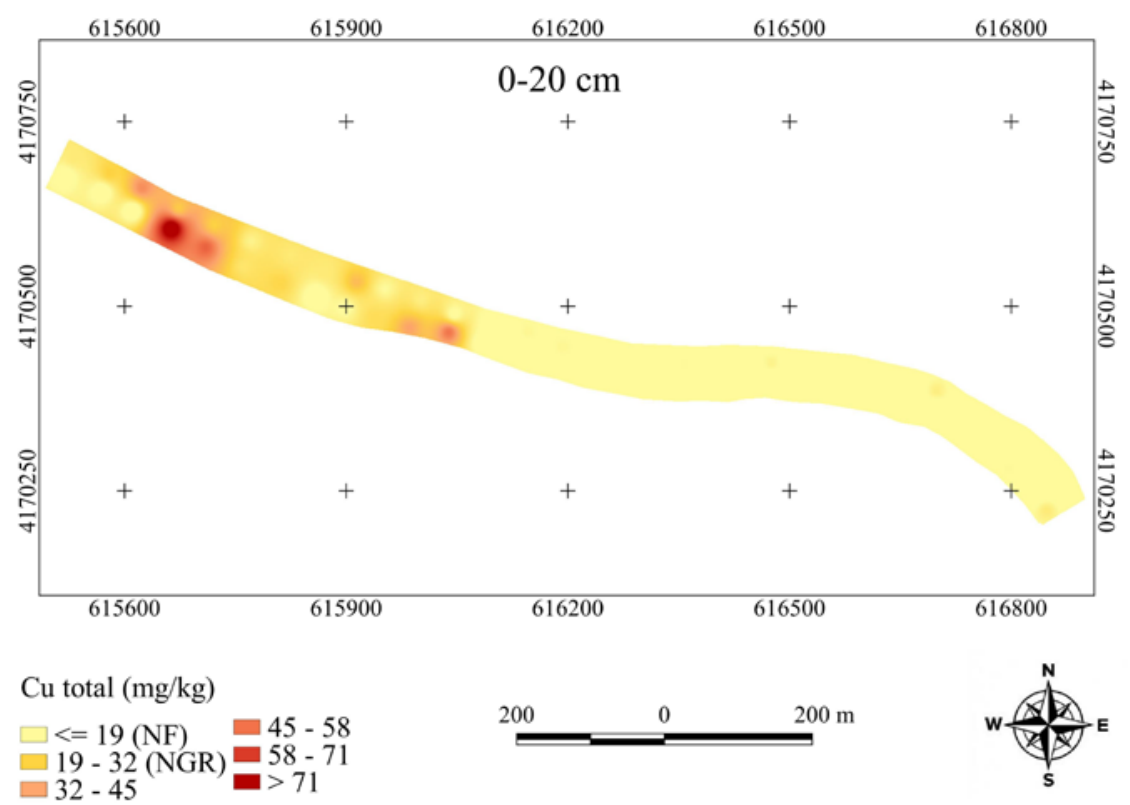

Figura 4.4.1.2. Distribución espacial de la concentración total de Cu en el tramo del río a rehabilitar a 0-20 $\mathrm{cm}$ de profundidad.

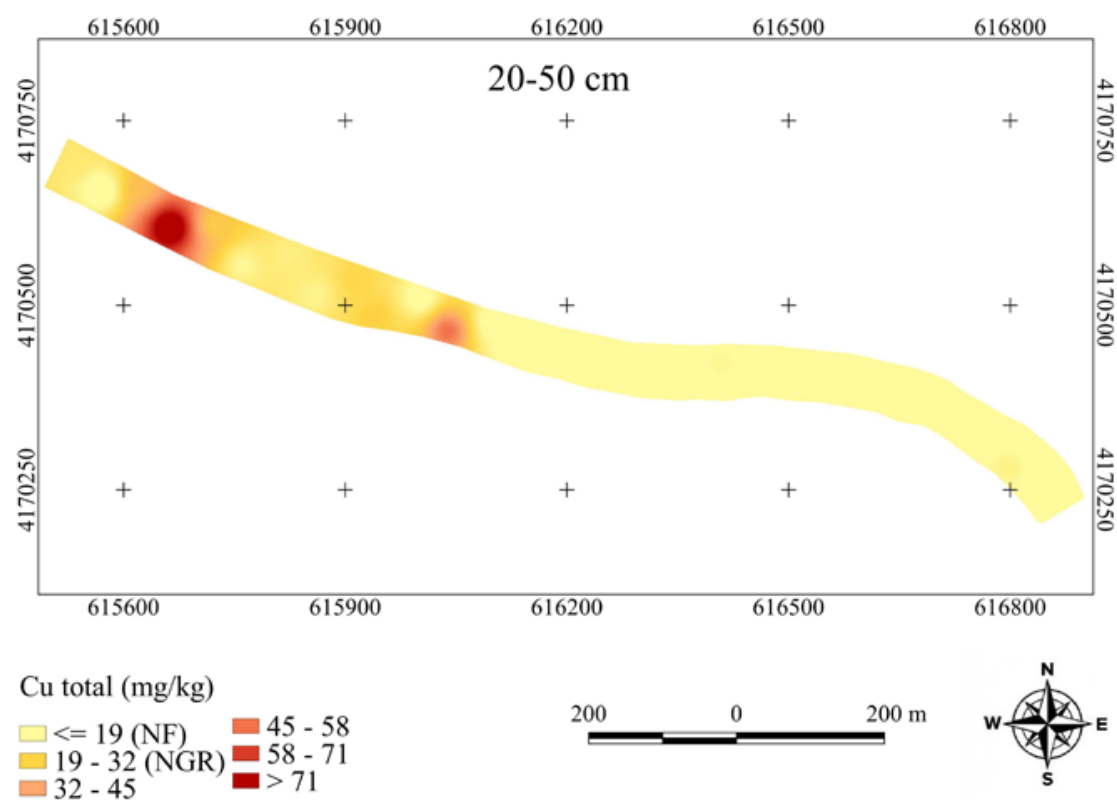

Figura 4.4.1.3. Distribución espacial de la concentración total de Cu en el tramo del río a rehabilitar a 20-50 cm de profundidad. 
Capítulo 4. CARACTERÍSTICAS GENERALES DE LA ZONA DE ESTUDIO

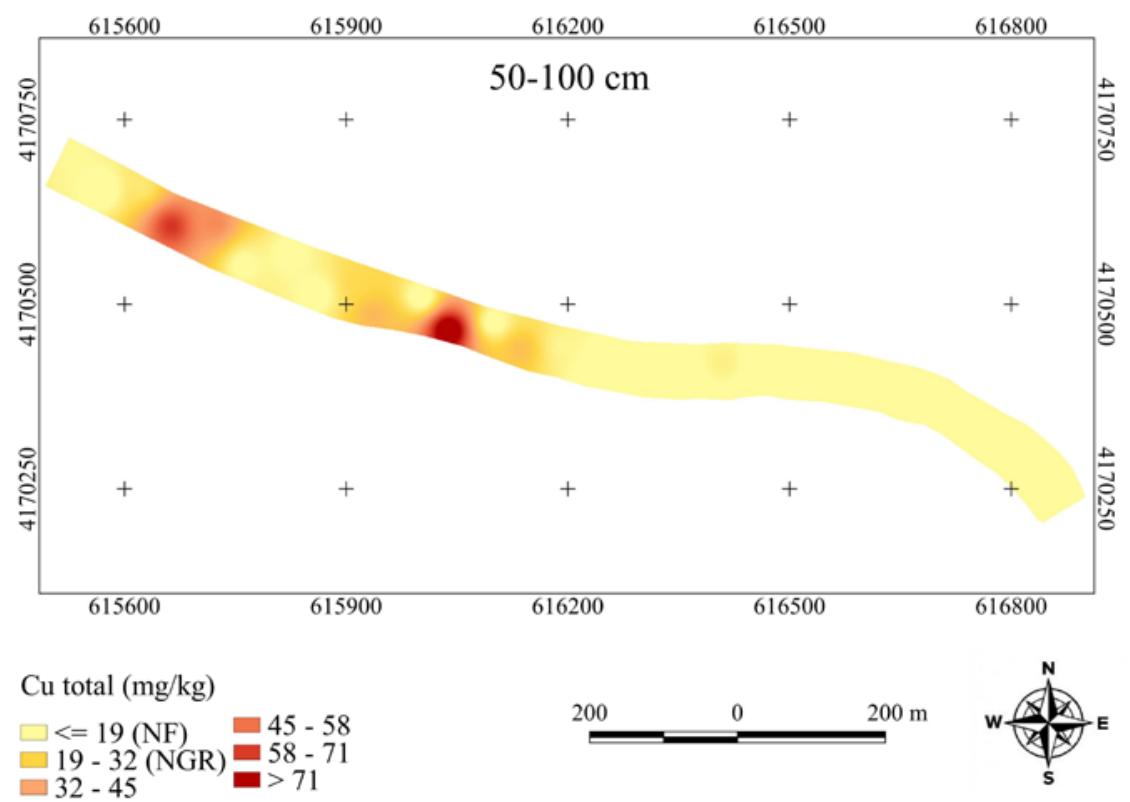

Figura 4.4.1.4. Distribución espacial de la concentración total de Cu en el tramo del río a rehabilitar a 50-100 $\mathrm{cm}$ de profundidad.

La concentración total de Zn se muestra en las Figuras 4.4.1.5-7. La mayor parte del tramo del cauce fluvial no está contaminado, con contenidos totales por debajo de los NGR.

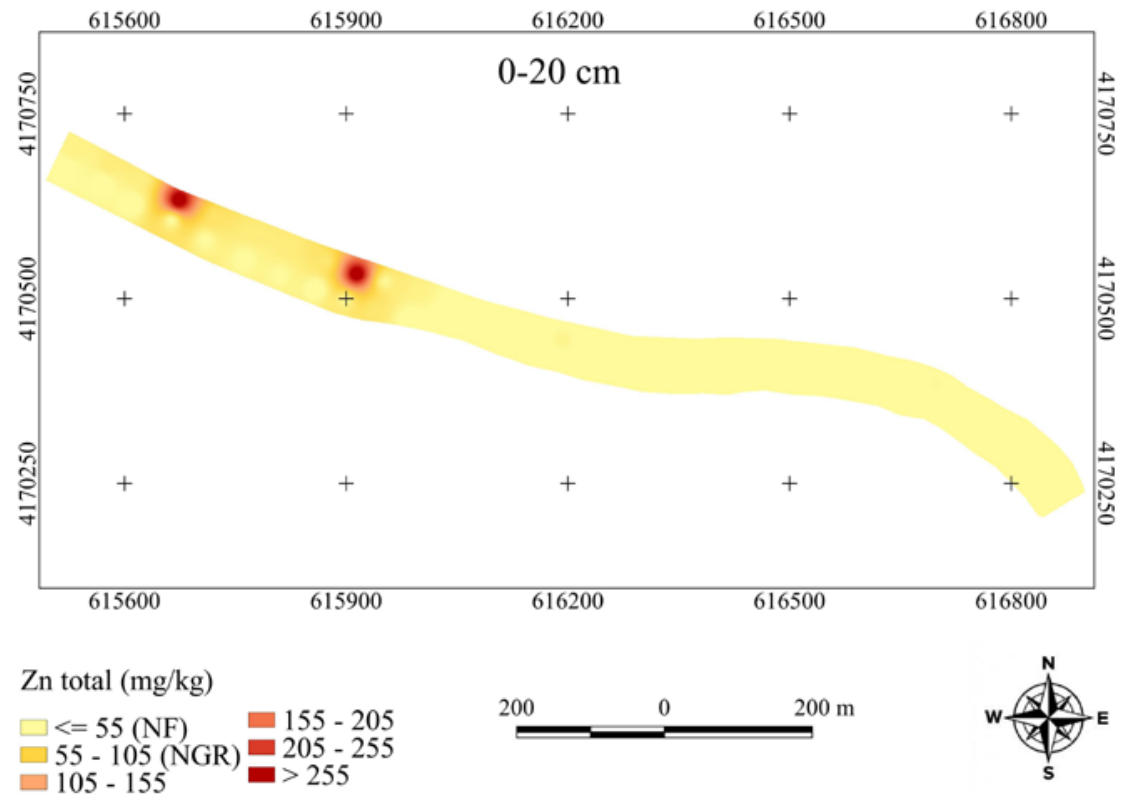

Figura 4.4.1.5. Distribución espacial de la concentración total de Zn en el tramo del río a rehabilitar a 0-20 $\mathrm{cm}$ de profundidad. 
Capítulo 4. CARACTERÍSTICAS GENERALES DE LA ZONA DE ESTUDIO

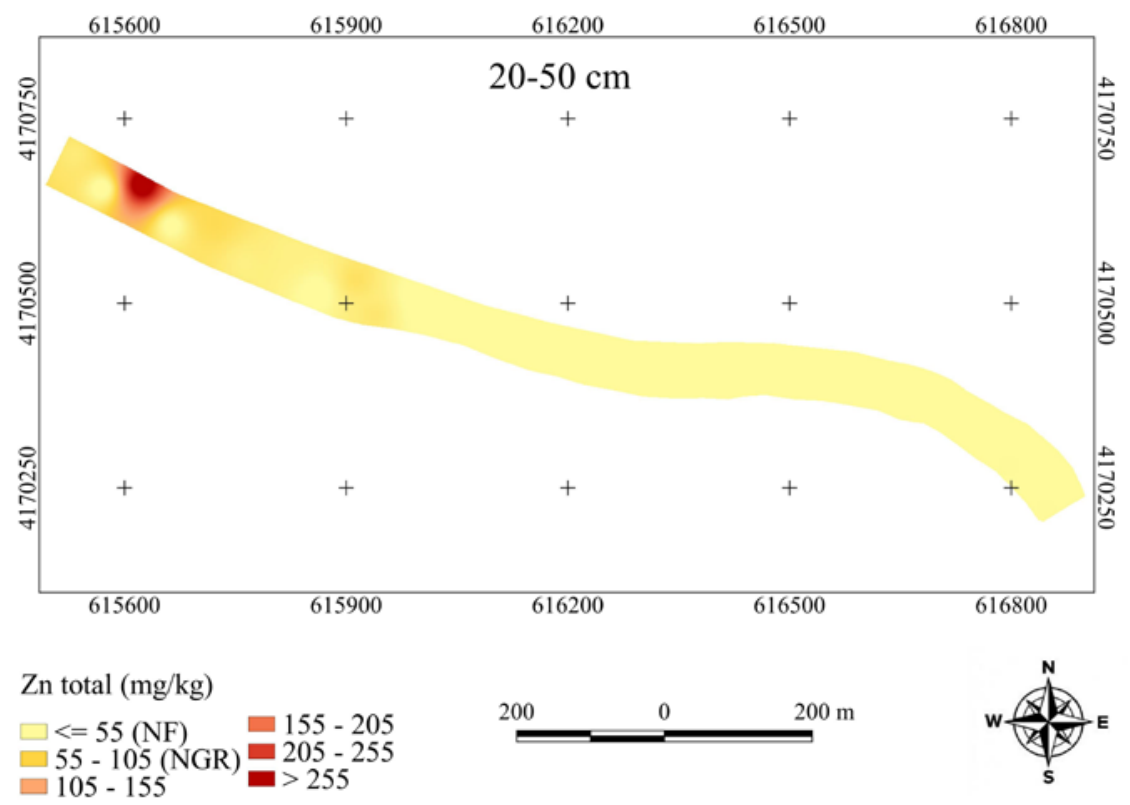

Figura 4.4.1.6. Distribución espacial de la concentración total de Zn en el tramo del río a rehabilitar a $20-50 \mathrm{~cm}$ de profundidad.

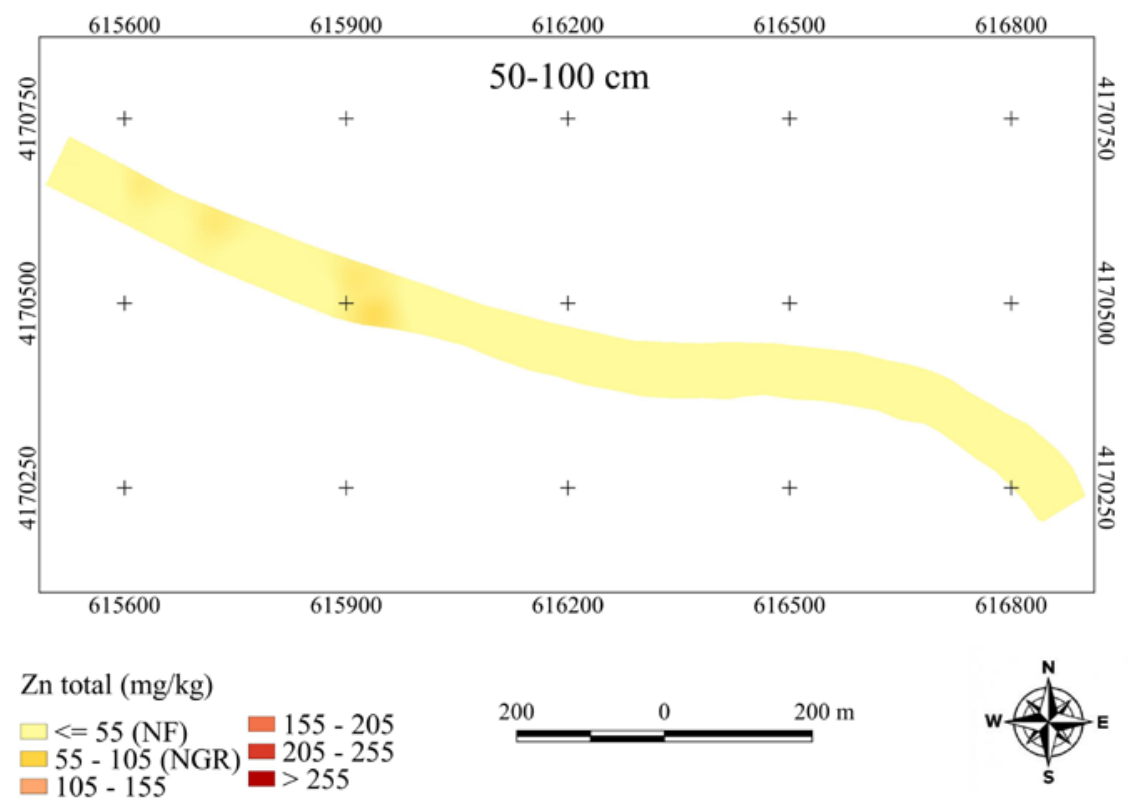

Figura 4.4.1.7. Distribución espacial de la concentración total de Zn en el tramo del río a rehabilitar a 50-100 $\mathrm{cm}$ de profundidad. 
Sólo existe contaminación por Zn en dos pequeñas áreas en el margen septentrional a lo largo de los primeros $500 \mathrm{~m}$ desde el límite occidental del tramo a rehabilitar a la profundidad de $0-20 \mathrm{~cm}$, y en una pequeña área a los $100 \mathrm{~m}$ del inicio de este mismo límite a $20-50 \mathrm{~cm}$ de profundidad. No hay contaminación por Zn a profundidades superiores a $50 \mathrm{~cm}$.

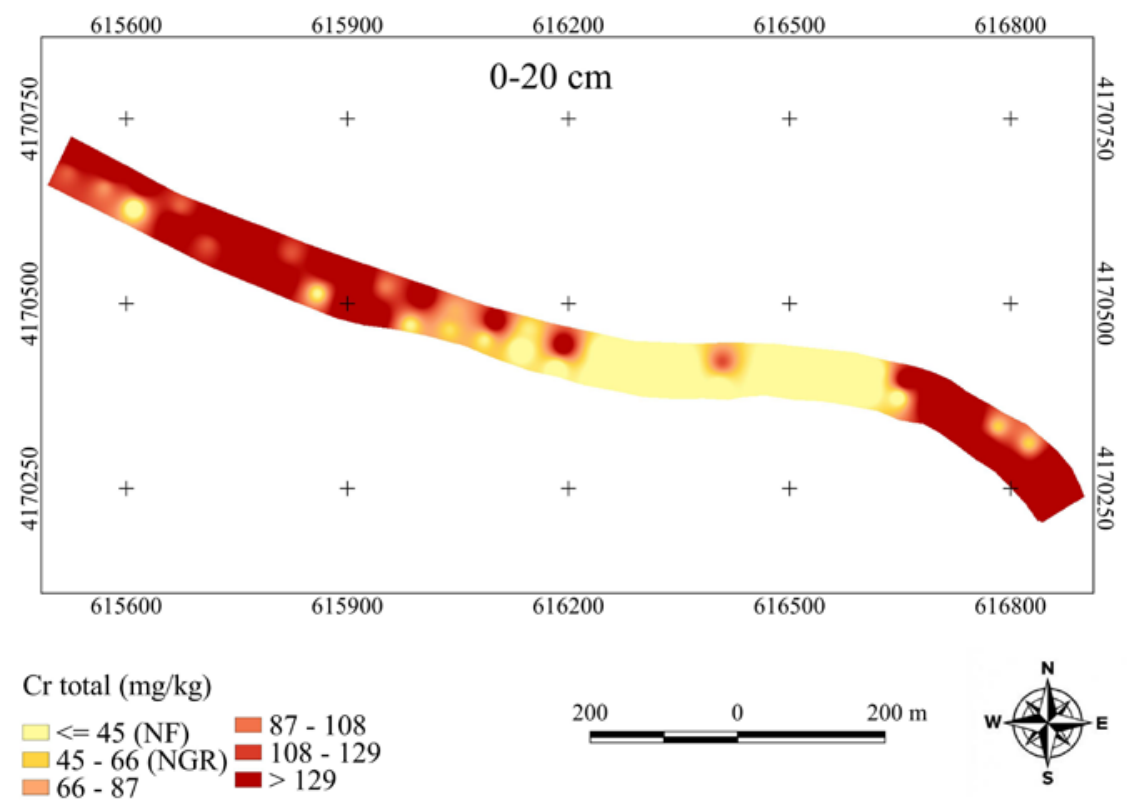

Figura 4.4.1.8. Distribución espacial de la concentración total de $\mathrm{Cr}$ en el tramo del río a rehabilitar a 0-20 $\mathrm{cm}$ de profundidad. 


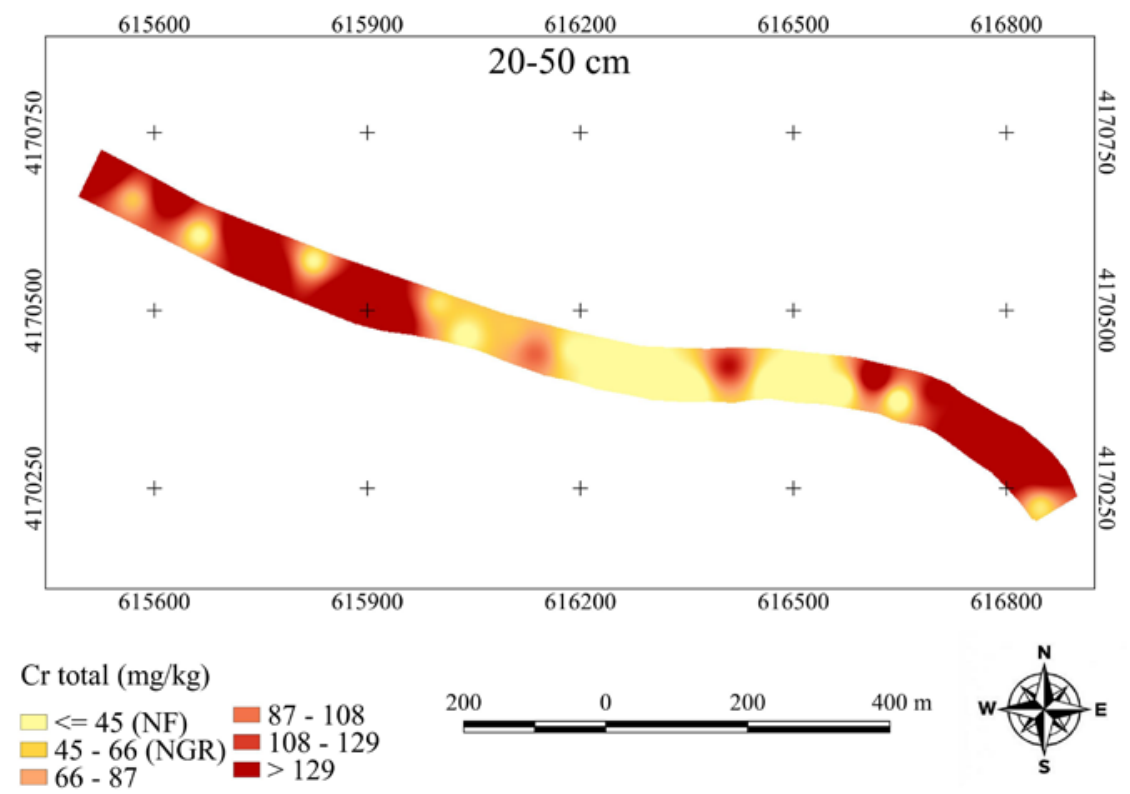

Figura 4.4.1.9. Distribución espacial de la concentración total de Cr en el tramo del río a rehabilitar a $20-50 \mathrm{~cm}$ de profundidad.

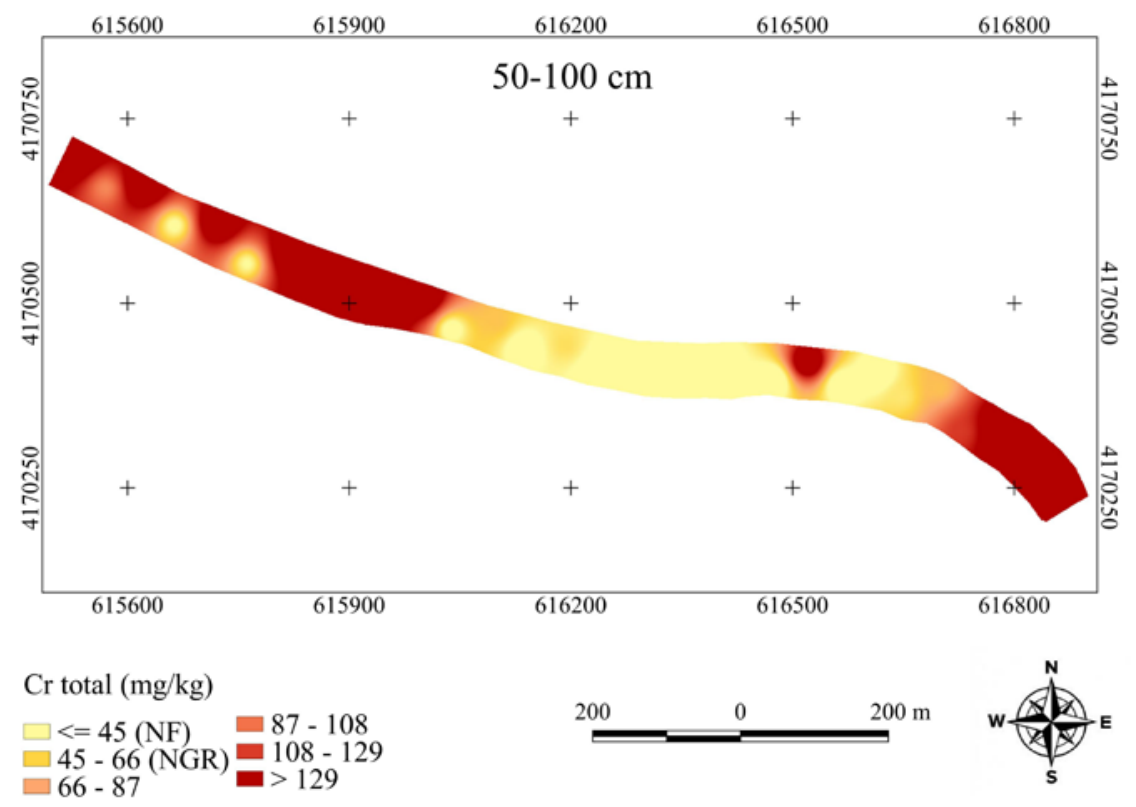

Figura 4.4.1.10. Distribución espacial de la concentración total de Cr en el tramo del río a rehabilitar a 50-100 cm de profundidad.

Como se observa en las Figuras 4.4.1.8-10, la concentración total de Cr supera los NGR en gran parte del tramo del cauce del río en las tres profundidades muestreadas, indicando 
contaminación del sedimento hasta $1 \mathrm{~m}$ de profundidad. El mayor grado de contaminación se encuentra en los primeros $600 \mathrm{~m}$ desde el núcleo urbano de Lorca (localizado inmediatamente al este del tramo del río), y en los últimos $300 \mathrm{~m}$. Los mayores niveles de este metal se encuentran entre 50-100 m de profundidad.

\section{PLANTA}

A continuación se muestra el inventario de especies identificadas en el área de estudio del Río Guadalentín a restaurar:

\section{Especies autóctonas:}

- Piptatherum miliaceum (L.) Coss.

- Brachypodium retusum (Pers.) Beauv.

- Malva parviflora L.

- Atriplex halimus L.

- Tamarix africana Poiret

- Diplotaxis erucoides (L.) DC.

- Diplotaxis ilorcitana (Sennen) Aedo Mart. Laborde \& Muñoz Garm.

- Moricandia arvensis L. DC.

- Euphorbia lagascae Spreng.

- Silybum marianum (L.) Gaertn.

- Pallenis spinosa (L.) Cass.

- Carthamus lanatus L.

- Salsola oppositifolia Desf.

- Suaeda vera Forsskal ex J.F. Gmelin

- Andryala ragusina L.

- Polygonum sp. pl.

-Cynodon dactylon (L.) Pers.

- Marrubium alysson L.

- Foeniculum vulgare Mill. subsp. piperitum

- Calendula sp.

- Lygeum spartum (L.) Kunth.

- Sonchus asper (L). Hill 
- Cichorium intybus L.

- Asteriscus aquaticus (L.) Less.

- Vicia sp.

- Scandix pecten-veneris $\mathrm{L}$.

\section{Especies invasivas:}

- Arundo donax L. $\left(^{*}\right)$

- Aster squamatus (Spreng.) Hieron

- Conyza sp. pl.

- Opuntia maxima Miller(*)

- Opuntia subulata (Mühlenpfordt) Engelm. (*)

- Oxalis pes-caprae L. $\left(^{*}\right)$

- Parkinsonia aculeata L.

- Zygophyllum fabago L.

(*) Especies incluidas en el Real Decreto 630/2013, de 2 de agosto, por el que se regula el Catálogo español de especies exóticas invasoras

La cobertura vegetal fue entre el 30-40\%, con menor cobertura los primeros $200 \mathrm{~m}$ del tramo del río de $1500 \mathrm{~m}$ a rehabilitar, y en los últimos $400 \mathrm{~m}$.

En la Figura 4.4.1.11 se muestra la concentración de metales pesados en los tejidos (raíz, tallo y hoja) de las cuatro especies muestreadas en el lecho del río ( $A$. halimus, $S$. oppositifolia, S. vera y T. africana). Como se puede observar, los metales se acumulan en las plantas con el siguiente orden decreciente: $\mathrm{Zn}>\mathrm{Cu}>\mathrm{Cr}$. La especie que más $\mathrm{Zn}$ acumula es $A$. halimus, fundamentalmente en sus hojas, seguida de $S$. vera, $T$. africana y $S$. oppositifolia, sin grandes diferencias entre estas tres últimas. No hay grandes diferencias entre las especies con respecto a la acumulación de $\mathrm{Cu}$, aunque $A$. halimus y $\mathrm{S}$. oppositifolia acumulan las mayores cantidades. Con respecto al $\mathrm{Cr}$, las especies muestreadas no acumulan grandes cantidades, siendo $S$. vera y $A$. halimus las especies que más Cr acumulan en la raíz. 
Capítulo 4. CARACTERÍSTICAS GENERALES DE LA ZONA DE ESTUDIO

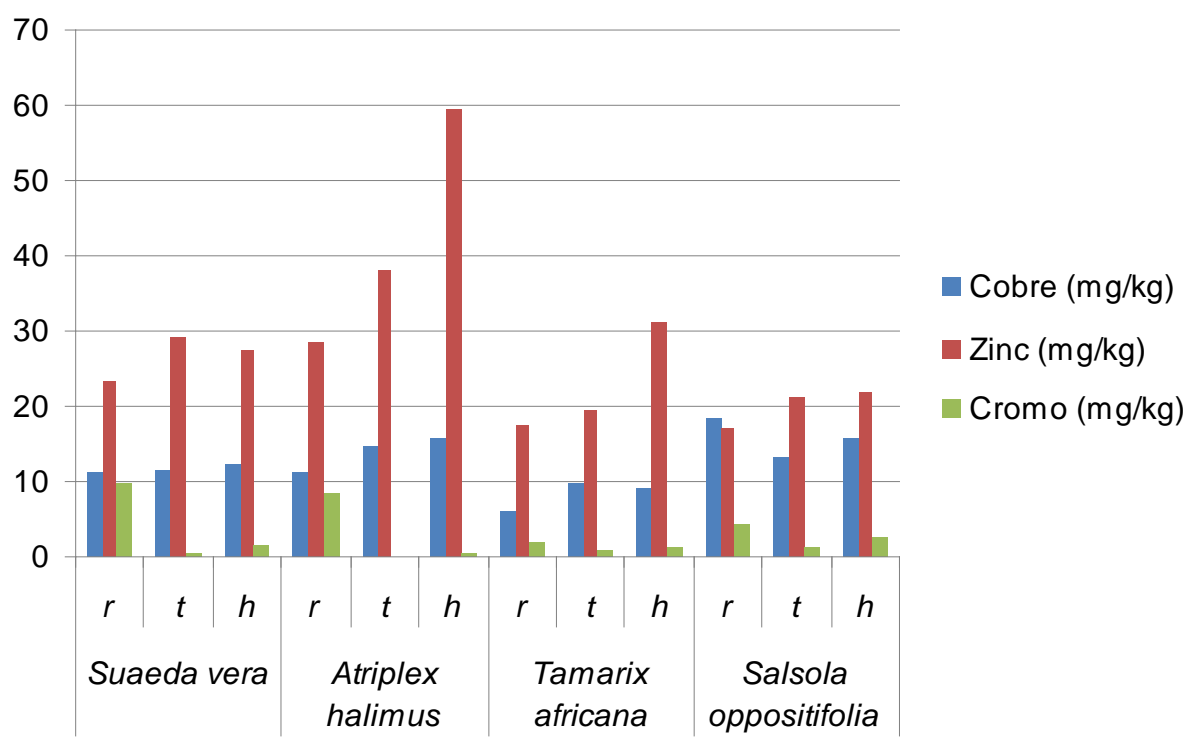

Figura 4.4.1.11. Concentración de cobre $(\mathrm{Cu})$, zinc $(\mathrm{Zn})$ y cromo $(\mathrm{Cr})$ en los tejidos de las cuatro especies vegetales muestreadas a lo largo del tramo del lecho del Río Guadalentín a restaurar (r: raíz; t: tallo; h: hoja).

\subsubsection{CONCLUSIÓN DE LA CARACTERIZACIÓN INICIAL}

La concentración total de Cu no es muy elevada en general en el lecho del río, con solo dos áreas contaminadas hasta un metro de profundidad a $100 \mathrm{~m}$ del margen occidental del tramo fluvial estudiado (el más cercano al núcleo urbano de Lorca) y a $500 \mathrm{~m}$ del mismo margen. La concentración total de Zn se encuentra por debajo de los NGR de la Región de Murcia en prácticamente todo el tramo estudiado, excepto en dos pequeñas áreas a lo largo de los primeros $500 \mathrm{~m}$ desde el margen occidental del tramo a rehabilitar a la profundidad de 0-20 cm, y en una pequeña área a los $100 \mathrm{~m}$ del inicio de este mismo margen a 20-50 cm de profundidad. No hay contaminación por Zn a profundidades superiores a $50 \mathrm{~cm}$. La concentración total de Cr supera los NGR de la Región de Murcia en gran parte del tramo del cauce del río en las tres profundidades muestreadas, indicando contaminación del sedimento hasta un metro de profundidad. El mayor grado de contaminación se encuentra en los primeros $600 \mathrm{~m}$ desde el núcleo urbano de Lorca, y en los últimos $300 \mathrm{~m}$. Por tanto, el vertido directo de lodos y aguas procedentes de la industria de curtidos ha provocado la contaminación del cauce con una afección hasta $1 \mathrm{~m}$ de profundidad.

Con respecto a la vegetación, se han identificado 34 especies vegetales diferentes en el 
tramo a restaurar, siendo 8 de las cuales especies invasivas (Arundo donax, Opuntia subulata, Opuntia máxima, Parkinsonia aculeata, Oxalis pes-caprae, Conyza sp. pl., Aster squamatus y Zygophyllum fabago). La cobertura vegetal se encuentra entre el 30-40\%, con menor cobertura los primeros $200 \mathrm{~m}$ del tramo del río de $1500 \mathrm{~m}$ a rehabilitar, y en los últimos $400 \mathrm{~m}$. De las especies muestreadas para evaluar la acumulación de metales pesados, se concluye que los metales se acumulan en las plantas con el siguiente orden decreciente: $\mathrm{Zn}>\mathrm{Cu}>\mathrm{Cr}$. La especie que más $\mathrm{Zn}$ acumula es $A$. halimus, fundamentalmente en sus hojas, seguida de S. vera, T. africana y S. oppositifolia, sin grandes diferencias entre estas tres últimas. No hay grandes diferencias entre las especies con respecto a la acumulación de $\mathrm{Cu}$. Con respecto al $\mathrm{Cr}$, las especies muestreadas no acumulan grandes cantidades, siendo $S$. vera y $A$. halimus las especies que más $\mathrm{Cr}$ acumulan en la raíz.

\subsubsection{DELIMITACIÓN DE LA SUPERFICIE CONTAMINADA A REHABILITAR}

En la siguiente figura se muestra el área a rehabilitar mediante la técnica de fitoextracción.

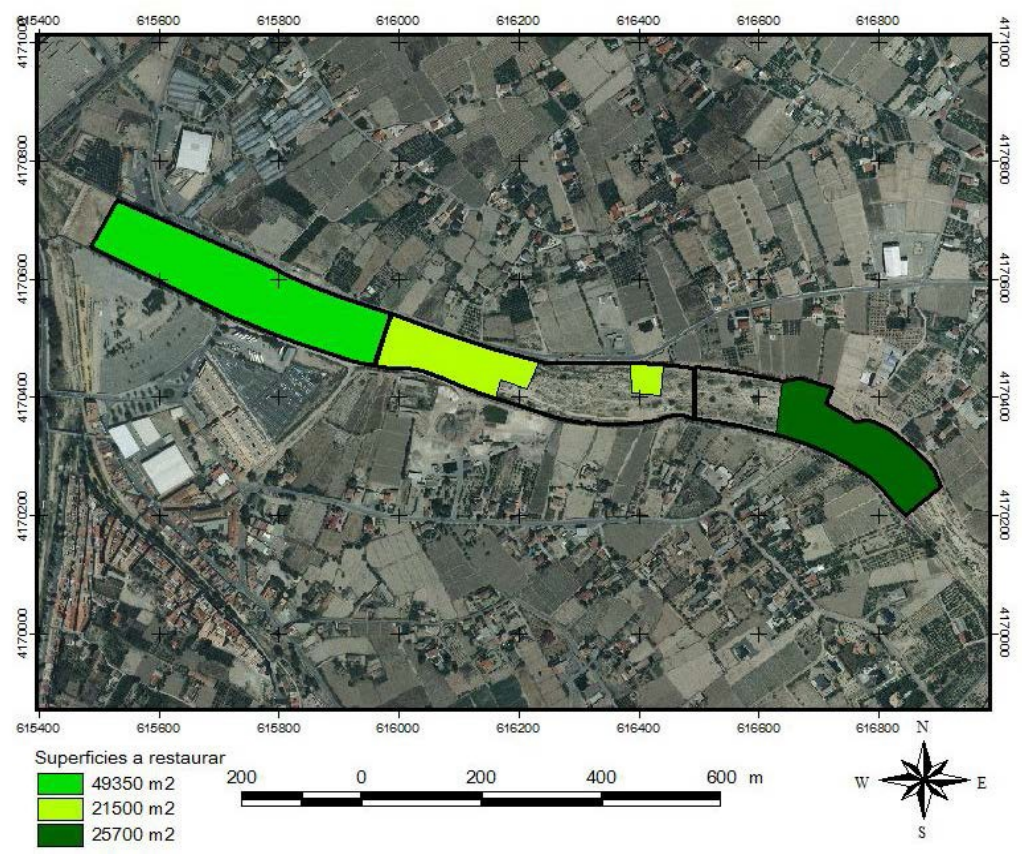

Figura 4.4.3.1. Delimitación de la superficie contaminada por metales pesados (Cu, Zn y Cr) en el tramo de estudio del Río Guadalentín.

De los tres tramos de $500 \mathrm{~m}$ en los que se ha dividido el área de estudio, solo el tramo 1 (0-500 m), localizado en el margen occidental, presenta contaminación en toda su superficie (49 350 $\mathrm{m}^{2}$ ). El tramo central (tramo 2, 500-1000 m) presenta contaminación en $21500 \mathrm{~m}^{2}$ de su 
superficie total, mientras que el tramo oriental (tramo 3, 1000-1500 m) presenta contaminación en $25700 \mathrm{~m}^{2}$ de su superficie total. La superficie total a recuperar mediante la técnica de fitoextracción asciende por tanto a $96550 \mathrm{~m}^{2}$. 
Capítulo 5

ESTUDIO DE FITOEXTRACCIÓN DE Cu, Zn Y Cr CON VEGETACIÓN AUTÓCTONA EN EL CAUCE DEL RÍO GUADALENTÍN 



\subsection{JUSTIFICACIÓN}

Para evaluar el grado de eliminación de los metales pesados $\mathrm{Cu}, \mathrm{Zn}$ y $\mathrm{Cr}$ en el cauce del Río Guadalentín mediante la técnica de fitoextracción se han llevado a cabo 3 muestreos de los sedimentos del mismo. El primer muestreo se realizó en 2013 (tramos 1, 2 y 3, caracterización inicial), el segundo muestreo en 2016 (tramo 1, seguimiento plantación en tramo 1) y el tercer muestreo en 2017 (tramos 1, 2 y 3, caracterización final). Una caracterización biogeoquímica completa del sedimento es crucial para identificar y estudiar la evolución de los diferentes parches o áreas en el lecho con diferente grado de contaminación, de modo que se adopten diferentes estrategias de rehabilitación ajustadas al riesgo ambiental real y las condiciones edáficas del lecho. Los muestreos de caracterización de sedimentos sirven además como línea base para evaluar los cambios una vez se inicie la estrategia de fitoextracción. Junto con un muestreo de sedimento, además, es necesario hacer un estudio y muestreo de la vegetación que crece actualmente en el cauce, para conocer el grado de acumulación de metales pesados y su potencialidad para ser utilizadas para la extracción de los metales tóxicos del sedimento. En el presente proyecto los muestreos de vegetación se realizaron en otoño de 2016 y otoño de 2017. En este capítulo se muestran los resultados de la caracterización inicial y final de los sedimentos del suelo.

\subsection{DISEÑO DEL MUESTREO DE SUELO}

Los muestreos de sedimento programados en el proyecto Life Riverphy correspondieron a primavera 2013 (tramos 1, 2 y 3), otoño de 2016 (tramo 1) y otoño de 2017 (tramos 1, 2 y 3). Debido a que en otoño de 2015 solamente se plantaron especies fitoextractoras en el tramo 1 (primeros $500 \mathrm{~m}$ de la zona de estudio), en otoño de 2016 solamente se muestreó dicho tramo para evaluar el grado de eliminación metales totales en los sedimentos entre los años 2013 y 2016. También se han evaluado diferentes propiedades físicas, químicas y biológicas en sedimento necesarias para analizar los riesgos ambientales, las posibilidades de restauración y la estabilización ecológica.

Los muestreos de sedimento se realizaron antes de las fases de siega, recogida y almacenamiento de biomasa contaminada y nos han aportado información sobre el grado de eliminación de metales en los sedimentos del cauce. Concretamente, el muestreo final de sedimentos de los tramos 1, 2 y 3 fue realizado en el mes de octubre de 2017 (caracterización final), concretamente los días 23 y 26 y se recogieron un total de 120 muestras de sedimento. 
Para el muestreo de sedimentos de los tramos 1, 2 y $3(1500$ m) se usó la misma malla de muestreo regular de $2000 \mathrm{~m}^{2}$ que se usó en el muestreo de sedimento del año 2013 (caracterización inicial). Esta malla se diseñó para que el muestreo sea representativo de la superficie total del tramo del río a recuperar, usando para ello la fotografía aérea (Figura 5.2.1). En cada punto de muestreo se tomaron muestreas de sedimento a tres profundidades: $0-20 \mathrm{~cm}, 20-50 \mathrm{~cm}$ y $50-100 \mathrm{~cm}$, para evaluar el nivel de contaminación en función de la profundidad hasta $100 \mathrm{~cm}$. Se recogieron un total de 120 muestras de sedimento (40 muestras por tramo).

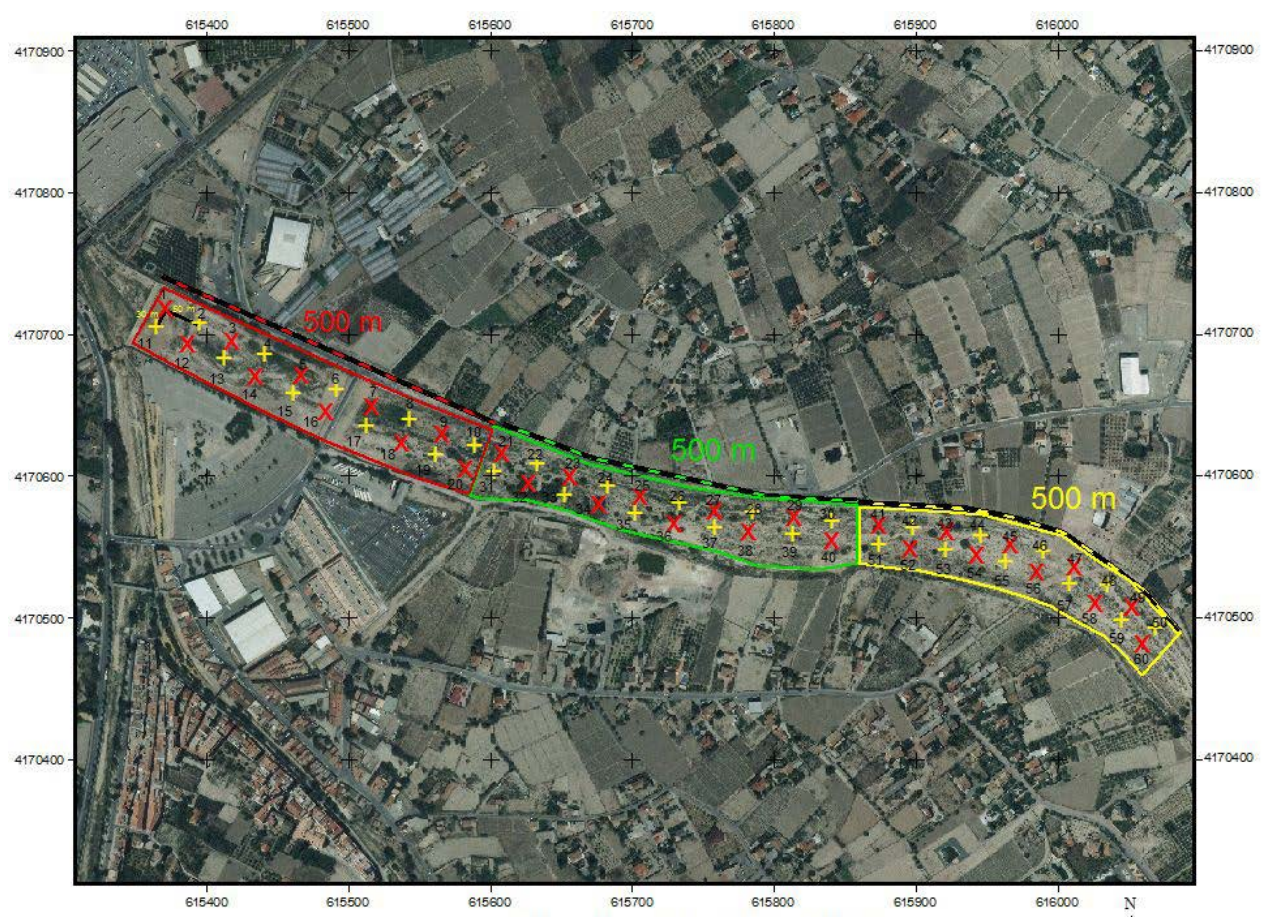

Figura 5.2.1. Localización de la zona general de muestreo de sedimentos (tramos 1, 2 y $3)$. 
Las muestras de sedimento se llevaron al laboratorio del grupo de investigación Gestión, Aprovechamiento y Recuperación de Suelos y Aguas (GARSA) de la Universidad Politécnica de Cartagena, donde fueron secadas al aire durante siete días y tamizadas con una malla de tamiz de $2 \mathrm{~mm}$. Una fracción de cada muestra fue además molida para la determinación de algunas propiedades edáficas. La concentración de los metales pesados y de las propiedades físicas, químicas y biológicas del sedimento se ha utilizado como datos de entrada para crear mapas de distribución. El programa utilizado ha sido Quantum GIS. Para la interpolación de los datos se ha utilizado el método de distancia inversa ponderada (Burrough y McDonnell, 1998).

\subsection{PARÁMETROS ANALIZADOS Y ANÁLISIS ESTADÍSTICO}

En las muestras de los sedimentos del suelo se han analizado las siguientes propiedades edáficas:

- Contenido total de cobre $(\mathrm{Cu})$, zinc $(\mathrm{Zn})$ y cromo $(\mathrm{Cr})$, determinado mediante digestión a $210^{\circ} \mathrm{C}$ durante $1,5 \mathrm{~h}$ (Risser y Baker, 1990), y medido mediante espectroscopía de absorción atómica (AAnalyst 800, Perkin Elmer).

- Contenido total de cromo hexavalente, determinado usando el método de la difenilcarbazida (US EPA 3060A (1996), Romero et al. 2006; Severiche y Gonzalez, 2013).

- Fracción extraíble de $\mathrm{Cu}, \mathrm{Zn}$ y $\mathrm{Cr}$ utilizando ácido dietilentriaminopentaacético (DTPA) (relación 1:2 p/v) (Linday y Norvell, 1978) y medida mediante espectroscopía de absorción atómica (AAnalyst 800, Perkin Elmer). Representa la fracción potencialmente biodisponible del metal pesado.

- Fracción intercambiable de $\mathrm{Cu}, \mathrm{Zn}$ y $\mathrm{Cr}$ extraída con $\mathrm{CaCl}_{2}$ 0,01 M (relación 1:10 p/v) (Pueyo et al., 2004) y medida en espectroscopía de masas ICP-MS (Agilent 7500 CE). Representa la fracción actualmente biodisponible del metal pesado.

- Fracción soluble de $\mathrm{Cu}, \mathrm{Zn}$ y $\mathrm{Cr}$ utilizando agua desionizada como extractante en la relación 1:5 p/v (Ernst, 1996) y medida mediante espectroscopía de absorción atómica (AAnalyst 800, Perkin Elmer).Representa la fracción que puede solubilizarse con el agua de lluvia o de escorrentía.

- pH y conductividad eléctrica (CE) medidos en agua desionizada (relación 1:2,5 y 1:5 p/v, respectivamente).

- Textura (contenido de arena, limo y arcilla), usando el método del densímetro de Bouyoucos.

- Carbono orgánico total (COT) y nitrógeno total (NT) medidos con un analizador elemental CNHS-O (EA-1108, Carlo Elba).

- Carbonato cálcico determinado con el método del calcímetro de Bernard. 
- Carbono soluble $\left(\mathrm{C}_{\text {sol }}\right.$ ) extraído con $\mathrm{K}_{2} \mathrm{SO}_{4}$ 0,5 M (relación 1:5 p/v) y medido por colorimetría tras oxidación con $\mathrm{K}_{2} \mathrm{Cr}_{2} \mathrm{O}_{7}$.

- Capacidad de intercambio catiónico (CIC), determinada con el método de Roig et al. (1980) que utiliza $\mathrm{BaCl}_{2}$ para saturar el complejo de cambio.

- Cationes de cambio calcio $(\mathrm{Ca})$, magnesio $(\mathrm{Mg})$, potasio $(\mathrm{K})$ y sodio $(\mathrm{Na})$ medidos en el extracto de $\mathrm{BaCl}_{2}$ de la determinación de la CIC mediante espectroscopía de absorción atómica (AAnalyst 800, Perkin Elmer).

- Fósforo (P) biodisponible determinado mediante el método Burriel-Hernando (Díez, 1982).

- Hierro (Fe) y manganeso (Mn) biodisponibles utilizando como extractante DTPA (relación 1:2 p/v) (Linday y Norvell, 1978) y medidos por espectroscopía de absorción atómica (AAnalyst 800, Perkin Elmer).

- Aniones nitrato, cloruro y sulfato extraídos con agua desionizada en la relación 1:5 p/v y medidos por cromatografía iónica (Metrohm 861 Advanced Compact IC).

- Carbono de la biomasa microbiana (CBM) analizado mediante el método de fumigaciónextracción (Vance et al., 1987). Representa la biomasa total de microorganismos.

- Respiración edáfica basal, como indicador de la actividad metabólica microbiana, mediante el método de Anderson (1982).

- Actividad enzimática $\beta$-glucosidasa, ligada al ciclo biogeoquímico del carbono, determinada según el método propuesto por Tabatabai (1982).

- Actividad enzimática ureasa, ligada al ciclo biogeoquímico del nitrógeno, determinada según el método propuesto por Nannipieri et al. (1980).

- Actividad enzimática fosfatasa, ligada al ciclo biogeoquímico del fósforo, determinada según el método propuesto por Tabatabai y Bremner (1969).

- Actividad enzimática arilsulfatasa, ligada al ciclo biogeoquímico del azufre, determinada según el método propuesto por Tabatabai y Bremner (1970).

El contenido total de cromo (III) se determinó por sustracción del cromo (VI) al cromo total.

Todos los resultados fueron sometidos a un tratamiento estadístico. Para ello se usaron los programas estadísticos SPSS versión 24 y Statistix 9. Mediante la prueba de KolmogorovSmirnov se comprobó si la distribución de datos era normal. En función de que la distribución de los datos fuese o no normal se seleccionaron los test paramétricos y no paramétricos para detectar si existen o no diferencias significativas entre muestras y los test para estudiar las correlaciones entre parámetros y demás. Con respecto a las correlaciones, sólo se han mostrado las más relevantes cuyos valores del coeficiente de regresión es próximo o superior a 0,5. 
Para determinar el grado de contaminación del material del lecho del cauce se han utilizado los Niveles de Fondo (NF) y los Niveles Genéricos de Referencia (NGR) propuestos para la Región de Murcia (Martínez y Pérez, 2007). Estos niveles están recogidos en la siguiente tabla.

Tabla 5.3.1. Niveles de Fondo y Niveles Genéricos de Referencia para el cromo, cobre y zinc en la Región de Murcia (Martínez y Pérez, 2007).

\begin{tabular}{cccc}
\hline & $\mathrm{Cr}(\mathrm{mg} / \mathrm{kg})$ & $\mathrm{Cu}(\mathrm{mg} / \mathrm{kg})$ & $\mathrm{Zn}(\mathrm{mg} / \mathrm{kg})$ \\
\hline Niveles de fondo (NF) & 44,6 & 18,7 & 55,2 \\
\hline Niveles genéricos de referencia (NGR) & 66 & 32 & 105 \\
\hline
\end{tabular}

\subsection{EVOLUCIÓN 2013-2017 DE LOS RESULTADOS DE METALES PESADOS EN SEDIMENTOS}

A continuación se muestran diferentes mapas de distribución de los resultados de las concentraciones de metales $\mathrm{Cu}, \mathrm{Zn}$ y $\mathrm{Cr}$ totales (incluidos $\mathrm{Cr}$ (III) total y $\mathrm{Cr}$ (VI) total), intercambiables y solubles y las concentraciones de metales hierro y manganeso biodisponibles, medidos a las tres profundidades muestreadas $(0-20 \mathrm{~cm}, 20-50 \mathrm{~cm}$ y $50-100$ $\mathrm{cm}$ ) para estudiar la evolución biogeoquímica de las zonas contaminadas entre los años 2013 y 2017.

En los mapas de distribución se han usado 2 tonalidades de colores, amarillo y rojo, tonalidades amarillas, rojas claras y rojas oscuras indican que los valores son bajos, intermedios y elevados respectivamente. Las tonalidades se adaptan a cada conjunto de valores de cada parámetro y no coinciden entre los diferentes parámetros ni elementos.

Con respecto a la distribución de la concentración de los metales totales se ha utilizado el tono de color amarillo para indicar las zonas donde la concentración de cada metal se encuentra dentro de los NF de la Región de Murcia (amarillo claro) o por debajo de los NGR (amarillo oscuro). Los colores rojos indican concentraciones por encima de los NGR propuestos para la Región de Murcia, indicando las tonalidades más oscuras mayor concentración, y por tanto, mayor nivel de contaminación. Por tanto, los colores rojos indican zonas con sedimento contaminado por el metal pesado. En las fracciones intercambiable, 
Capítulo 5. ESTUDIO DE FITOEXTRACCIÓN DE Cu, Zn Y Cr CON VEGETACIÓN AUTÓCTONA EN EL CAUCE DEL RÍO GUADALENTÍN

soluble y biodisponible se ha utilizado solo el color rojo y amarillo, aunque para estas fracciones no existen NGR, solo para la concentración de metales totales.

A continuación se muestra la evolución temporal de las concentraciones de metales entre los años 2013 y 2017 de la Figura 5.4.1 a la Figura 5.4.13. 
Capítulo 5. ESTUDIO DE FITOEXTRACCIÓN DE Cu, Zn Y Cr CON VEGETACIÓN AUTÓCTONA EN EL CAUCE DEL RÍO GUADALENTÍN

2013
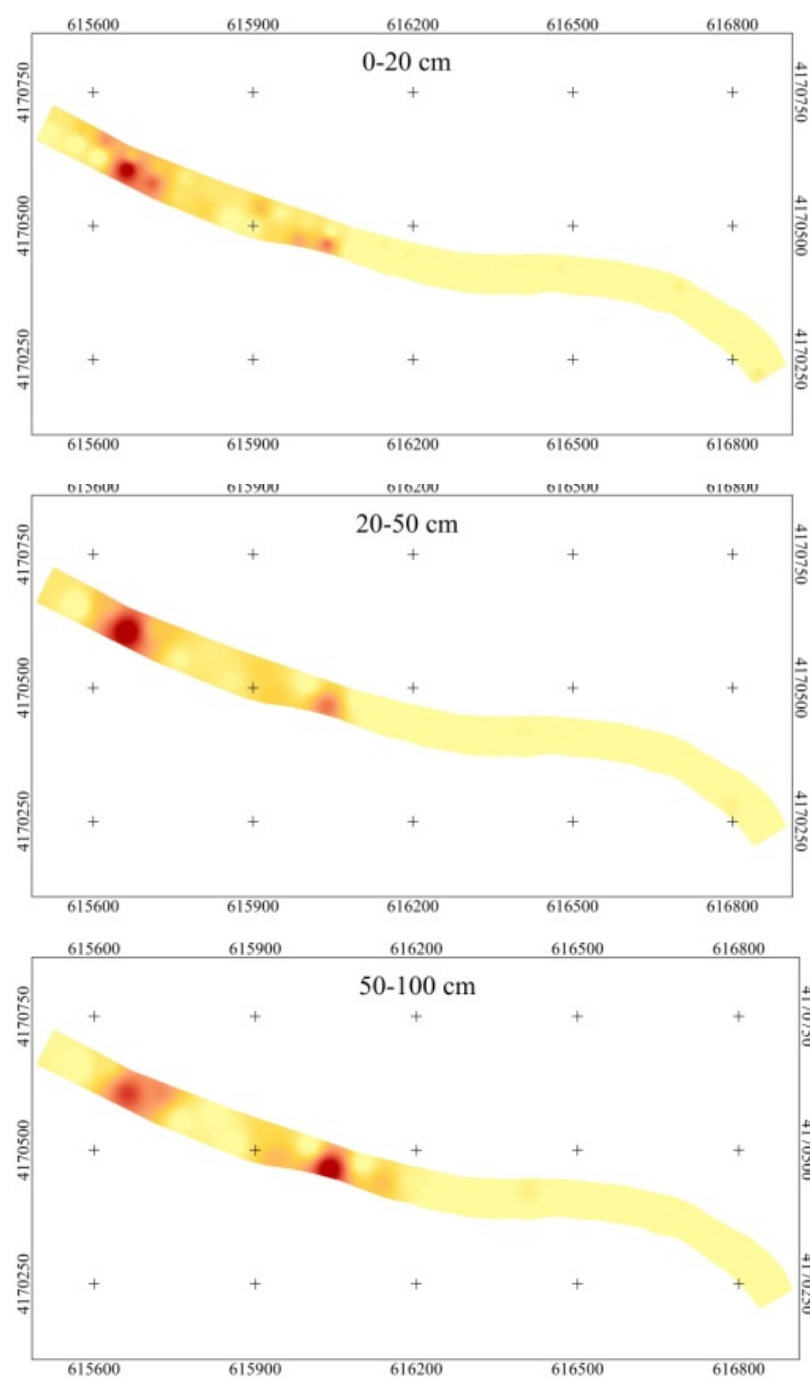

$\mathrm{Cu}$ total $(\mathrm{mg} / \mathrm{kg})$

$\square=19(\mathrm{NF})=45-58$
$19-32$ (NGR) $=58-71$
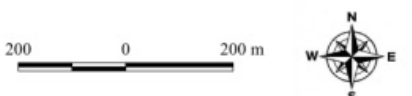

Cu Total $(\mathrm{mg} / \mathrm{kg})$

$\square=19(\mathrm{NF})=45-58$
$19-32(\mathrm{NGR})=58-71$

2017
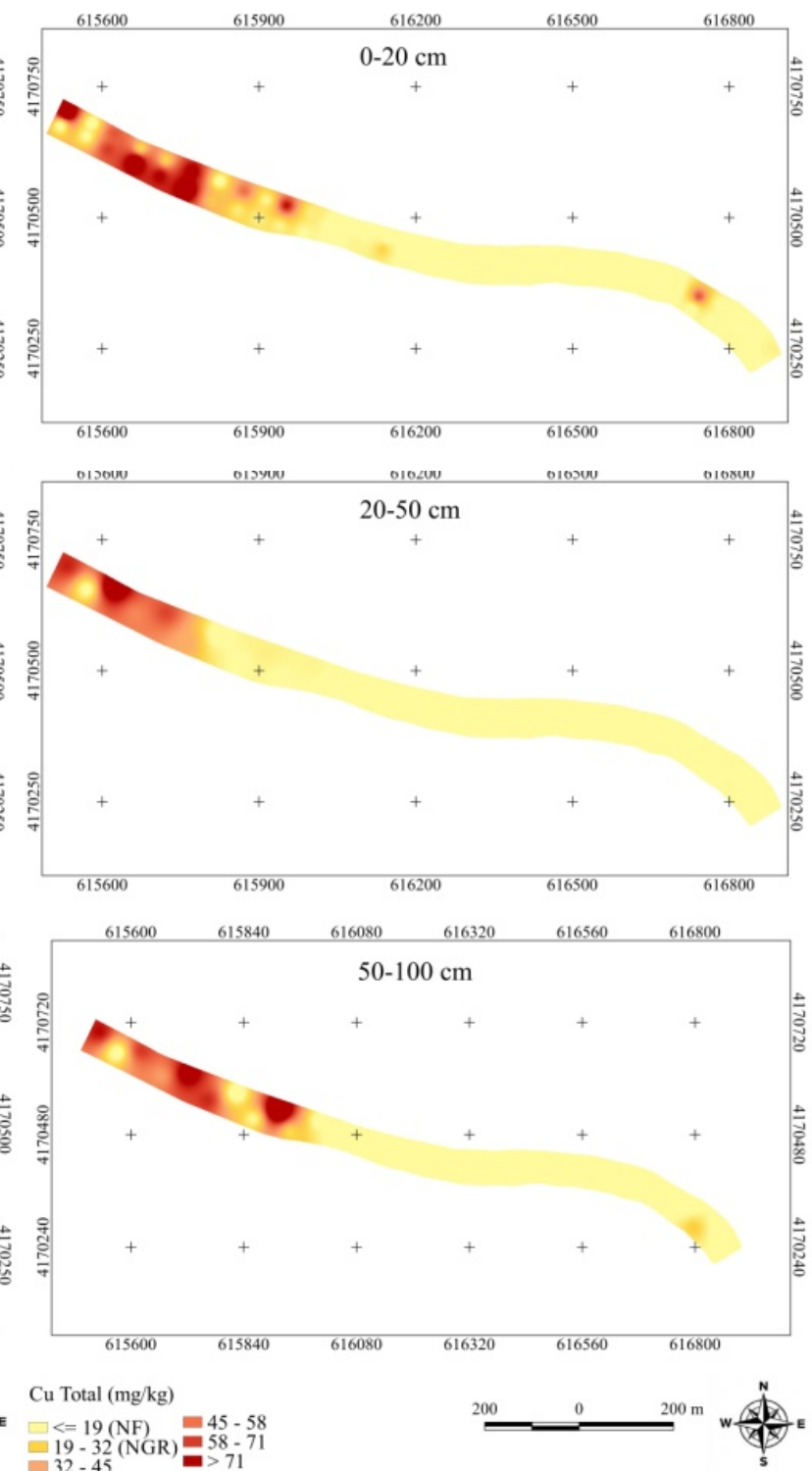

Figura 5.4.1. Evolución de la distribución espacial de la concentración de cobre total en los tramos 1, 2 y 3 (1500 m) entre los años 2013 y 2017. 


\section{Concentración de cobre total:}

En el año 2013 se registraron concentraciones promedio de 21,28 mg/kg (comprendidas entre $9,02-97,81 \mathrm{mg} / \mathrm{kg}), 23,38 \mathrm{mg} / \mathrm{kg}(11,32-129,93 \mathrm{mg} / \mathrm{kg})$ y $23,32 \mathrm{mg} / \mathrm{kg}(10,64-103,90$ $\mathrm{mg} / \mathrm{kg}$ ) en los horizontes de 0-20 cm, 20-50 cm y 50-100 cm respectivamente. La distribución de cobre total es bastante similar y homogénea en toda la superficie del tramo a rehabilitar. Su concentración total se encuentra en el rango de los NF de la Región de Murcia excepto en dos áreas donde esta concentración excede los NGR (32 mg/kg), indicando contaminación del sedimento hasta $1 \mathrm{~m}$ de profundidad. Estas dos áreas se encuentran a $100 \mathrm{~m}$ del margen occidental del tramo fluvial a rehabilitar (el más cercano al núcleo urbano de Lorca) y a $400 \mathrm{~m}$ del mismo margen.

En el año 2017 se han registrado concentraciones promedio de $28,57 \mathrm{mg} / \mathrm{kg}$ (comprendidas entre 10,86-125,67 mg/kg), 24,16 mg/kg (10,03-113,77 mg/kg), 29,53 mg/kg (8,65-138,98 $\mathrm{mg} / \mathrm{kg}$ ) en los horizontes de 0-20 cm, 20-50 cm y 50-100 cm respectivamente. La distribución espacial de cobre total muestra una mayor superficie en el año 2017 con respecto al año 2013 con concentraciones que rebasan los NGR (32 mg/kg), especialmente en el horizonte de 0-20 cm (superficial) y el horizonte de 50-100 cm de la sección occidental del tramo 1. En el horizonte de $20-50 \mathrm{~cm}$ la superficie de la sección oriental que rebasa los NGR también es superior con respecto al año 2013. El incremento del año 2013 al año 2017 no es estadísticamente significativo para todos los horizontes estudiados $(0-20 \mathrm{~cm}$, 20-50 cm y 50-100 cm). El Cu es fuertemente dependiente del pH, su movilidad aumenta al disminuir el pH (Kabata-Pendias., 2000). El incremento de cobre total puede ser debido a un aumento de la disponibilidad de las distintas fracciones de cobre, fenómenos de evotranspiración que afectan al contenido de sales, otros factores. Por otro lado se ha registrado una correlación positiva entre el cobre total con el zinc total $\left(r=+0,73^{\star}\right)$, zinc biodisponible $\left(r=+0,68^{\star *}\right)$ y cromo total $\left(r=+0,52^{\star *}\right)$. $Y$ una correlación negativa entre la concentración de cobre total con y los carbonatos $\left(r=-0,65^{\star \star}\right)$. 
Capítulo 5. ESTUDIO DE FITOEXTRACCIÓN DE Cu, Zn Y Cr CON VEGETACIÓN AUTÓCTONA EN EL CAUCE DEL RÍO GUADALENTÍN

2013
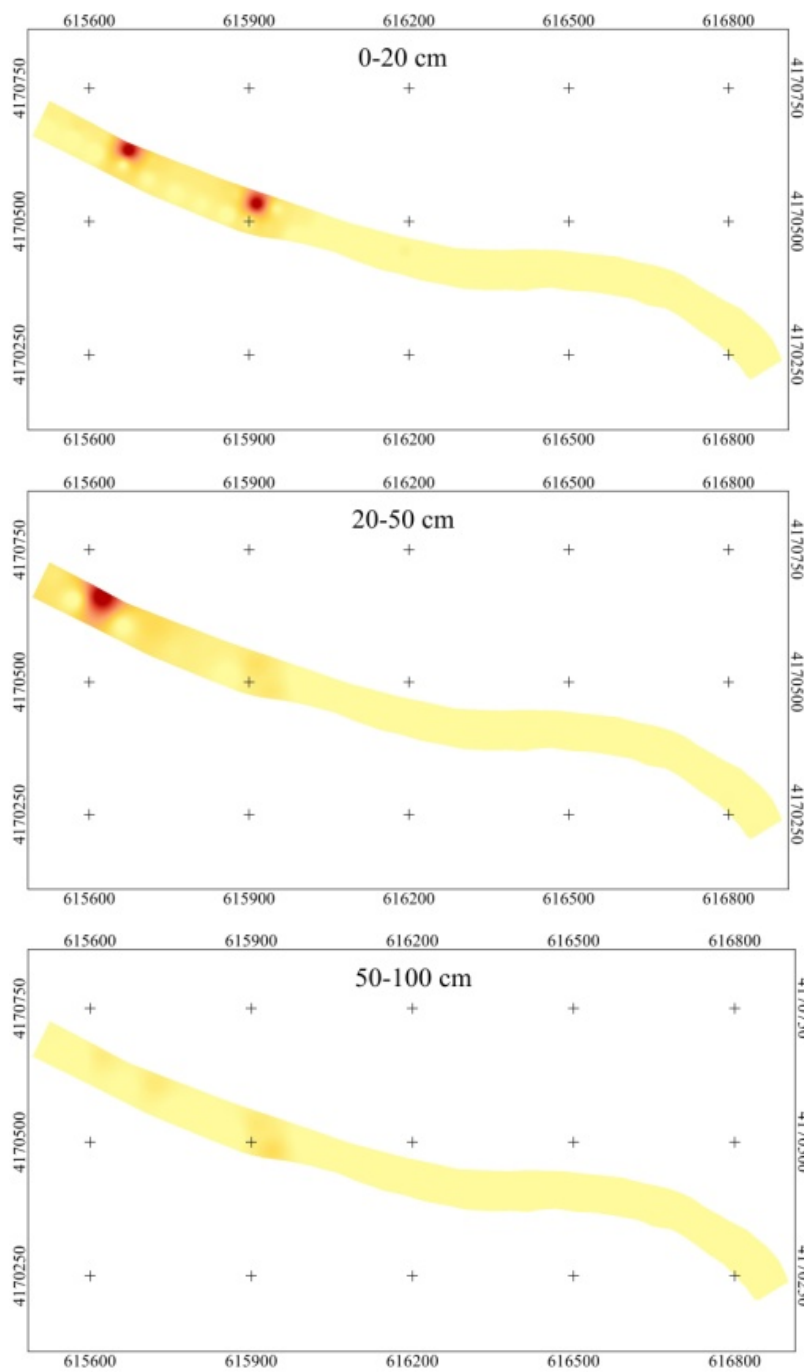

$\mathrm{Zn}$ total $(\mathrm{mg} / \mathrm{kg})$

$\square=55$ (NF) $=155-205$
$55-105$ (NGR) $205-255$

$55-105$ (NGR) $=205-25$
$105-155$
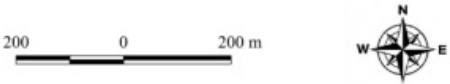

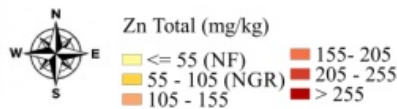
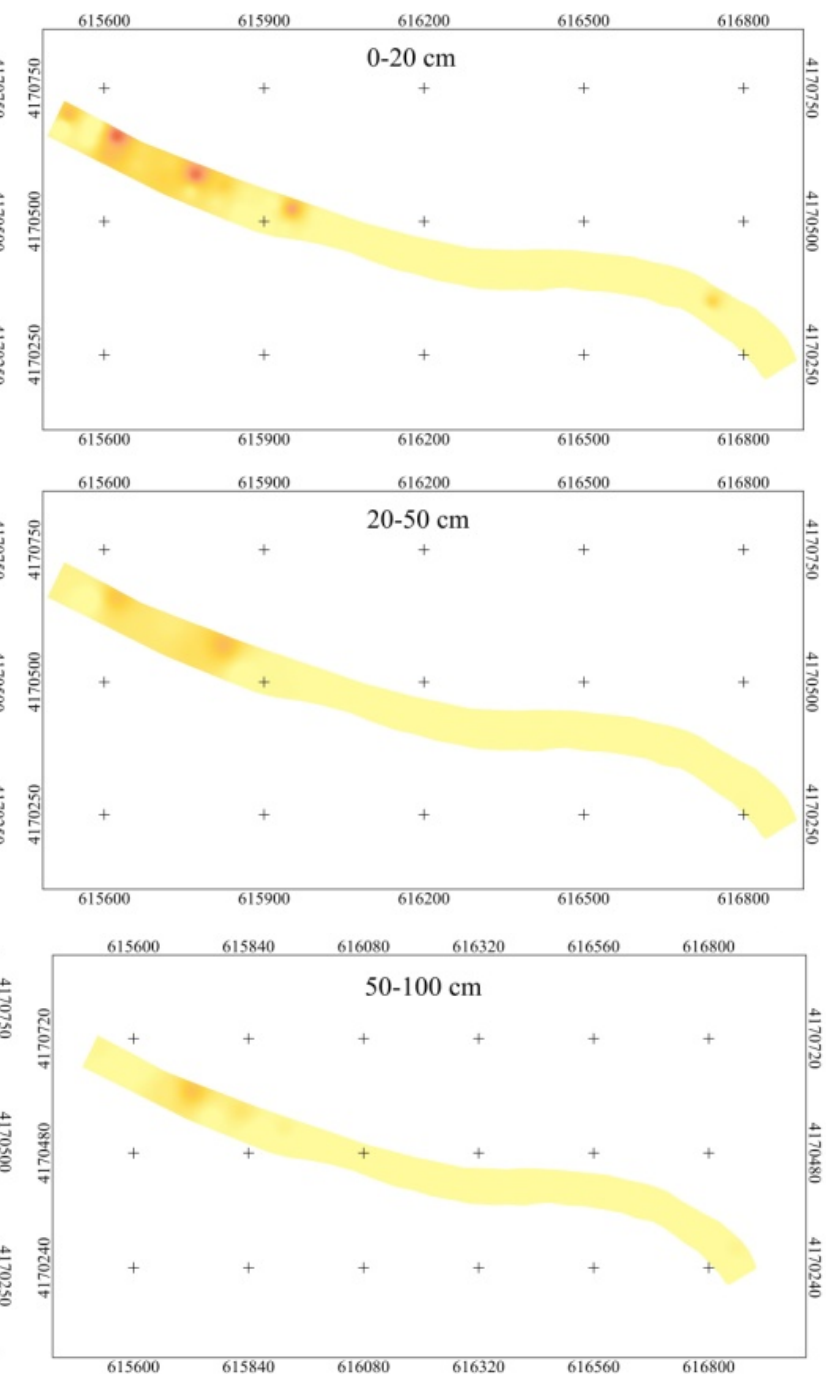

Figura 5.4.2. Evolución de la distribución espacial de la concentración de zinc total en los tramos 1, 2 y 3 (1500 m) entre los años 2013 y 2017. 


\section{Concentración de zinc total:}

En el año 2013 se registraron concentraciones promedio de 84,23 mg/kg (comprendidas entre $26,02-1242,38 \mathrm{mg} / \mathrm{kg}), 78,46 \mathrm{mg} / \mathrm{kg}(30,99-914,74 \mathrm{mg} / \mathrm{kg})$ y $47,12 \mathrm{mg} / \mathrm{kg}(29,71-92,60$ $\mathrm{mg} / \mathrm{kg}$ ) en los horizontes de $0-20 \mathrm{~cm}, 20-50 \mathrm{~cm}$ y $50-100 \mathrm{~cm}$ respectivamente. La mayor parte del tramo 1 del cauce fluvial está contaminado con contenidos totales por encima de los NGR (105 mg/kg) en dos áreas en el margen septentrional a lo largo de los primeros $500 \mathrm{~m}$ desde el límite oriental del tramo a rehabilitar a la profundidad de 0-20 cm, y en 250 $\mathrm{m}$ del horizonte de $20-50 \mathrm{~cm}$ en $250 \mathrm{~m}$ desde el inicio por la sección occidental. No hay contaminación por Zn a profundidades superiores a $50 \mathrm{~cm}$.

En el año 2017 se han registrado concentraciones promedio de 56,68 mg/kg (comprendidas entre 25,77-210,44 mg/kg), 50,94 mg/kg (27,66-129,59 mg/kg), 47,92 mg/kg (23,38-121,39 $\mathrm{mg} / \mathrm{kg}$ ) en los horizontes de $0-20 \mathrm{~cm}, 20-50 \mathrm{~cm}$ y $50-100 \mathrm{~cm}$ respectivamente. Solamente queda contaminación por zinc en 2 pequeñas áreas en el margen septentrional del tramo 1. La superficie contaminada por zinc total es menor en el año 2017 con respecto al año 2013 como consecuencia de la vegetación fitoextractora implantada en el año 2015. Las variaciones observadas no son estadísticamente significativas en ninguno de los horizontes muestreados. Se registra una disminución en los horizontes de 0-20 cm y de $20-50 \mathrm{~cm}$ y un aumento en el horizonte de 50-100 cm, aunque ninguna variación es significativa. Con respecto las asociaciones entre el zinc total y el resto de parámetros, se han registrado las siguientes correlaciones entre el zinc total y los siguientes parámetros: carbonatos ( $r=-$ $\left.0,74^{\star \star}\right)$ y el cromo total $\left(r=+0,67^{\star \star}\right)$. Conforme disminuye la concentración de zinc total aumenta el contenido de carbonatos, posiblemente debido a que el zinc adherido a los carbonatos es absorbido por la vegetación y los carbonatos quedan libres en la matriz del suelo. El trabajo de McBride y Blasiak (1979) mostró una mayor retención de Zn con el aumento del $\mathrm{pH}$, como es habitual para los cationes metálicos. Sin embargo, cuando el pH aumentó por encima de 7,5 se incrementó la concentración de Zn en solución. Este fenómeno se ha observado en otros estudios cuando los suelos ácidos se ajustaron a $\mathrm{pH}>7$ (Kuo y Baker, 1980) y se ha atribuido a la solubilización de ligandos complejantes orgánicos que compiten efectivamente con las superficies del suelo para el catión metálico. La mayoría de los grupos funcionales de ligandos complejantes son ácidos débiles, por lo que la estabilidad del complejo metálico es dependiente del pH, con poca asociación en medios ácidos. El grado de asociación aumenta con el pH. Esto junto con que las especies vegetales actúan mejor sobre este metal que sobre los demás explicarían la disminución que se aprecia en los mapas de distribución. 
Capítulo 5. ESTUDIO DE FITOEXTRACCIÓN DE Cu, Zn Y Cr CON VEGETACIÓN AUTÓCTONA EN EL CAUCE DEL RIOO GUADALENTÍN

2013

2017
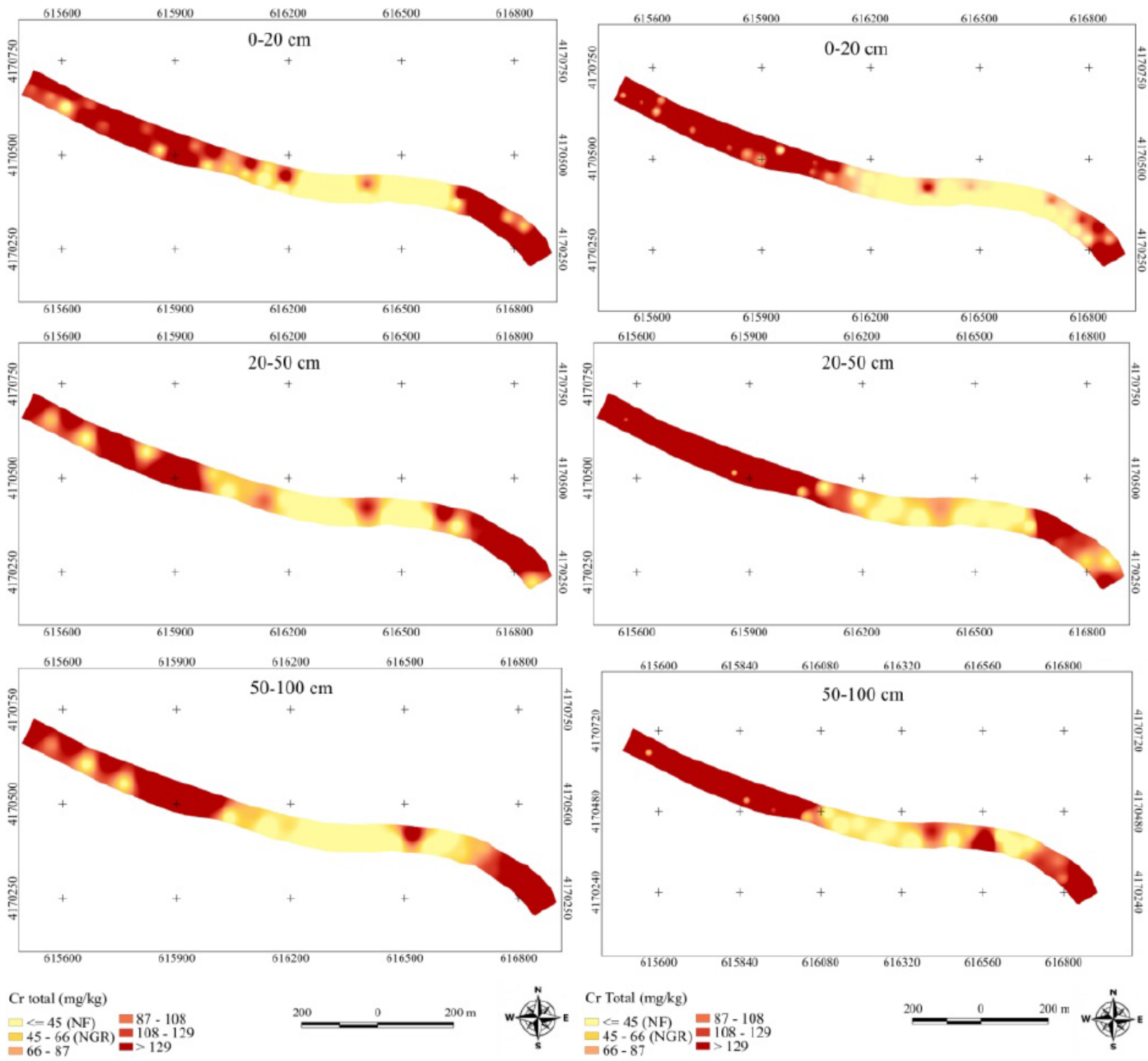

$50.100 \mathrm{~cm}$

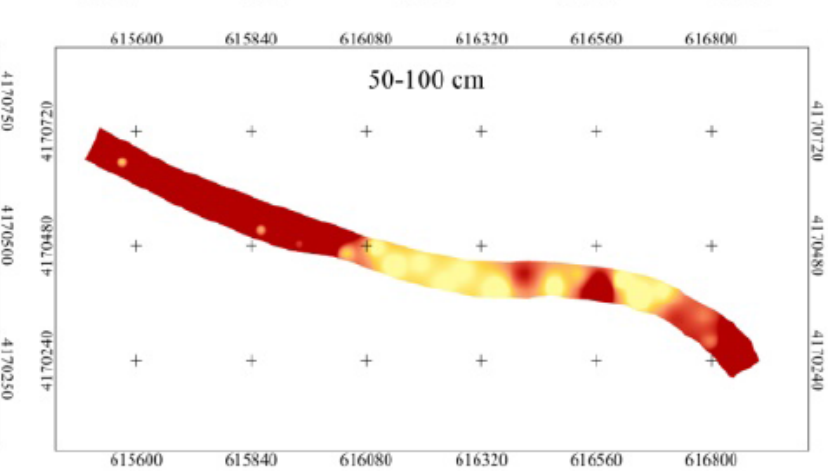

Cr total (mg/kg)
$\begin{aligned} \square=45 \text { (NF) } & =87-108 \\ 45-66 \text { (NGR) } & =108-129 \\ & 66-87\end{aligned}=129$

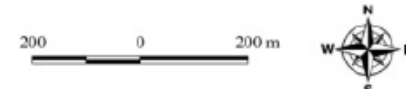

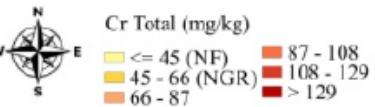

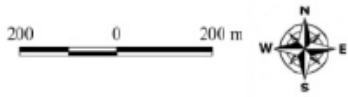

Figura 5.4.3. Evolución de la distribución espacial de la concentración de cromo total en los tramos 1,2 y $3(1500$ m) entre los años 2013 y 2017. 


\section{Concentración de cromo total:}

La concentración total de cromo en el año 2013 registró concentraciones promedio de $501,60 \mathrm{mg} / \mathrm{kg}$ (comprendidas entre 12,16-7685,52 mg/kg), 1169,78 mg/kg (13,08-11098,93 $\mathrm{mg} / \mathrm{kg}$ ) y $701,39 \mathrm{mg} / \mathrm{kg}(11,72-10274,32 \mathrm{mg} / \mathrm{kg})$ en los horizontes de 0-20 cm, 20-50 cm y 50-100 cm respectivamente. Los valores registrados superaron los NGR en gran parte del cauce del río en las tres profundidades muestreadas, indicando contaminación del sedimento hasta $1 \mathrm{~m}$ de profundidad. El mayor grado de contaminación se encuentra en los primeros $600 \mathrm{~m}$ del cauce de estudio (tramos 1 y 2) desde el núcleo urbano de Lorca (localizado inmediatamente al este del tramo del río), y en los últimos $300 \mathrm{~m}$ (tramo 3). Los mayores niveles de este metal se encuentran entre 20-100 m de profundidad.

En el año 2017 se han registrado concentraciones promedio de $152,51 \mathrm{mg} / \mathrm{kg}$ (comprendidas entre 7,22-1095,35 mg/kg), 402,09 mg/kg (9,55-3661,12 mg/kg), 313,30 $\mathrm{mg} / \mathrm{kg}(3,56-2307,71 \mathrm{mg} / \mathrm{kg})$ en los horizontes de 0-20 cm, 20-50 cm y 50-100 cm respectivamente. Las concentraciones de cromo total apenas han sufrido variaciones del año 2013 al año 2017. Se registra una disminución en las concentraciones de cromo total entre los años 2013 y 2017 en todos los horizontes, aunque ninguna variación es estadísticamente significativa. Las variaciones registradas pueden ser debidas a procesos de movilidad, un aumento de la disponibilidad de las diferentes fracciones u otros factores. Con respecto las asociaciones entre parámetros, se han registrado las siguientes correlaciones con el cromo total: carbonatos $\left(r=-0,63^{\star \star}\right)$ y hierro biodisponible $\left(r=+0,60^{\star \star}\right)$. Al igual que con el zinc total, conforme disminuye la concentración de cromo total aumenta el contenido de carbonatos, posiblemente debido a que el cromo adherido a los carbonatos es absorbido por la vegetación y los carbonatos quedan libres en la matriz del suelo. Las concentraciones observadas por el momento nos indican que el grado de eliminación de cromo total en suelo por la vegetación fitoextractora implantada es entre bajo y medio. Destacan especialmente la disminución de los valores máximos de la concentración de cromo total. Por otro lado, la vegetación fitoextractora ha podido verse influenciada por las condiciones de sequía y el estrés hídrico que ha tenido que soportar desde el año 2015, viéndose afectado su desarrollo vegetativo. Para el aumento de la capacidad extractora de estas plantas se pueden realizar la adición de enmiendas orgánicas o plantar junto con las especies fitoextractoras otras especies fijadoras de $\mathrm{N}$ como las leguminosas (aumento de $\mathrm{N}$ y aumento de la biodisponibilidad del $\mathrm{Cr}$ ), varios trabajos apoyan estas prácticas para la mejora de resultados en el campo de la fitorremediación (Shakoor et al., 2014; Guo y Cutright, 2015). 
Capítulo 5. ESTUDIO DE FITOEXTRACCIÓN DE Cu, Zn Y Cr CON VEGETACIÓN AUTÓCTONA EN EL CAUCE DEL RÍO GUADALENTÍN

2013
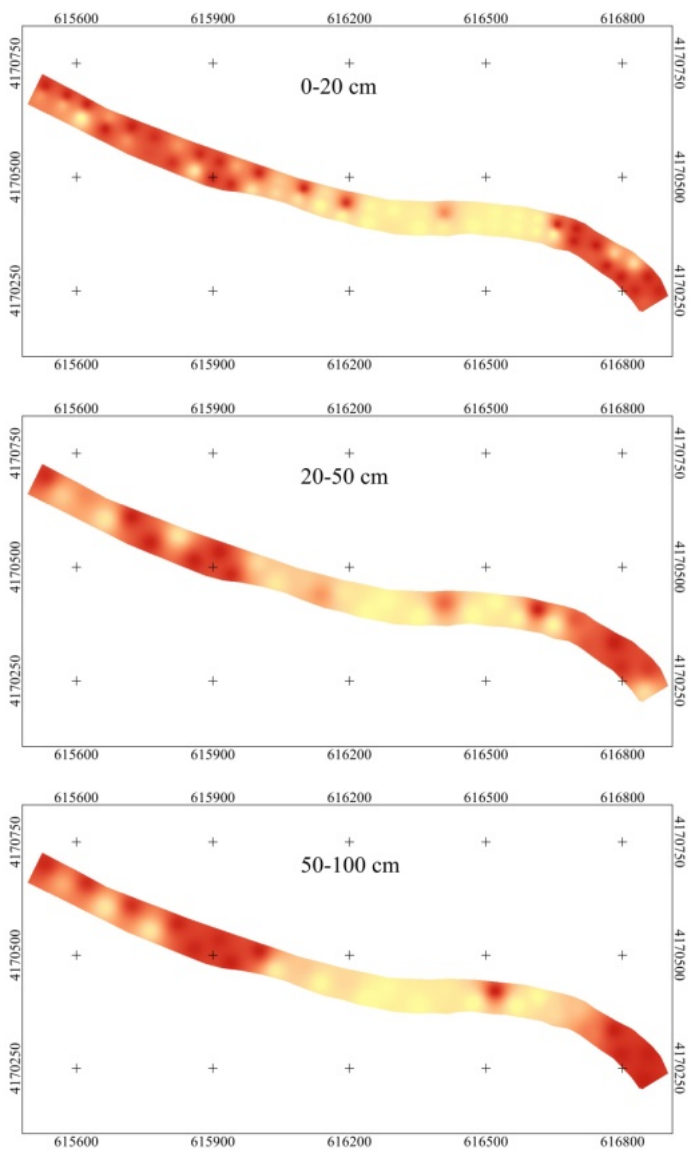

$\mathrm{Cr}(\mathrm{III})(\mathrm{mg} / \mathrm{kg})$ $\begin{array}{rl}\square<=20 & =100-140 \\ 20-60 & 110-1 \\ 60-100 & >180 \\ 60 & >180\end{array}$

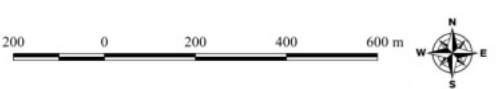

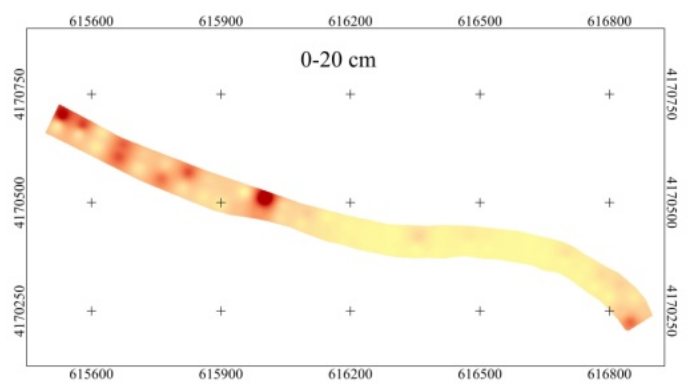
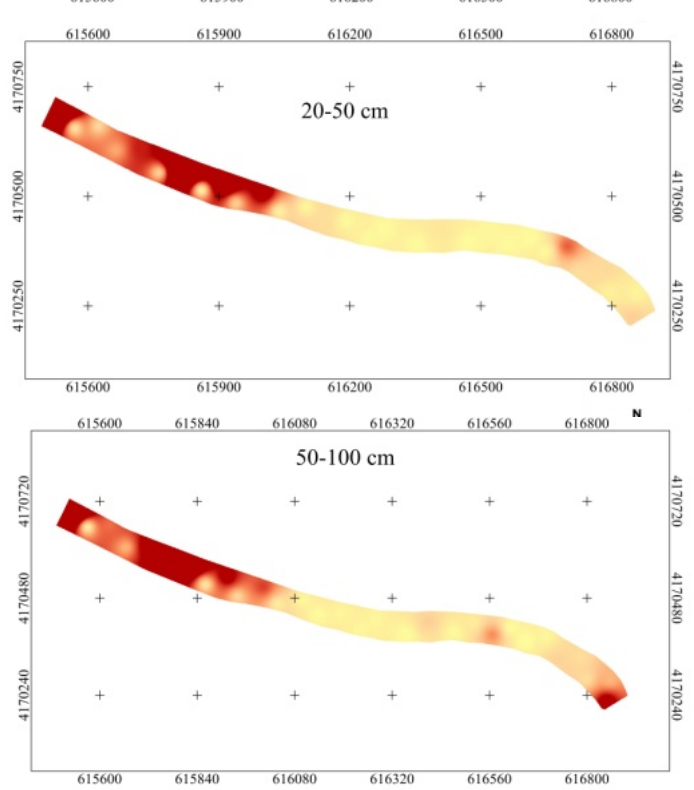

Cr (III) (mg/kg)

$\square=25=245-355$
$25-135=355-465$
$-135-245=465$

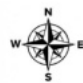

Figura 5.4.4. Evolución de la distribución espacial de la concentración de cromo (III) total en los tramos 1, 2 y 3 (1500 m) entre los años 2013 y 2017. 


\section{Concentración de cromo (III) total:}

En el año 2013 se registraron concentraciones promedio de 497,61 mg/kg (comprendidas entre $9,58-7676,91 \mathrm{mg} / \mathrm{kg}), 1163,79 \mathrm{mg} / \mathrm{kg}(12,93-11020,01 \mathrm{mg} / \mathrm{kg})$ y $697,88 \mathrm{mg} / \mathrm{kg}(10,95-$ $10271,47 \mathrm{mg} / \mathrm{kg}$ ) en los horizontes de $0-20 \mathrm{~cm}, 20-50 \mathrm{~cm}$ y $50-100 \mathrm{~cm}$ respectivamente. Los mapas de distribución de la concentración de cromo (III) total muestran pequeñas áreas de la sección central de los horizontes de 0-20 cm, 20-50 cm y de 50-100 cm donde se registran las menores concentraciones de cromo (III). Aproximadamente el $90 \%$ del cromo total está en forma de cromo (III) y el resto en cromo (VI).

En el año 2017 se han registrado concentraciones promedio de 151,97 mg/kg (comprendidas entre 7,20-1095,34 mg/kg), 401,99 mg/kg $(9,54-3661,11 \mathrm{mg} / \mathrm{kg}$ ) у 313,08 $\mathrm{mg} / \mathrm{kg}(3,41-2307,37 \mathrm{mg} / \mathrm{kg})$ en los horizontes de $0-20 \mathrm{~cm}, 20-50 \mathrm{~cm} \mathrm{y} 50-100 \mathrm{~cm}$ respectivamente. En el horizonte de $0-20 \mathrm{~cm}$ se registra una disminución no significativa de las concentraciones de cromo (III) del año 2013 al 2017, al igual que en cromo total (siendo significativa). Sin embargo, para la sección oriental del horizonte de $20-50 \mathrm{~cm}$ la concentración de cromo (III) es menor y en las secciones centrales y orientales del horizonte de $50-100 \mathrm{~cm}$ las concentraciones son mayores y menores respectivamente, aunque ninguna de estas variaciones es estadísticamente significativa. Con respecto las asociaciones entre parámetros, se han registrado las siguientes correlaciones con el cromo (III) total: carbonatos $\left(r=-0,63^{\star \star}\right)$, hierro biodisponible $\left(r=+0,60^{\star *}\right)$, cromo total $\left(r=+0,99^{\star \star}\right)$, zinc biodisponible $\left(r=+0,73^{\star \star}\right)$ y cobre biodisponible $\left(r=+0,66^{\star \star}\right)$. La fracción de cromo (III) representa el $99 \%$ del cromo total presente en los sedimentos del suelo y por tanto exhibe las mismas correlaciones que el cromo total. El cromo (III) se correlaciona directamente con la fracción biodisponible de hierro, zinc y cobre, sin embargo, los resultados observados manifiestan entre los años 2013 y 2017 una disminución no significativa de la concentración de cromo (III), un aumento (no significativo en 20-100 cm) para hierro, un aumento no significativo $(0-20 \mathrm{~cm})$ y una disminución no significativa $(20-100 \mathrm{~cm})$ para zinc y un aumento no significativo para cobre. 
Capítulo 5. ESTUDIO DE FITOEXTRACCIÓN DE Cu, Zn Y Cr CON VEGETACIÓN AUTÓCTONA EN EL CAUCE DEL RÍO GUADALENTÍN

2013
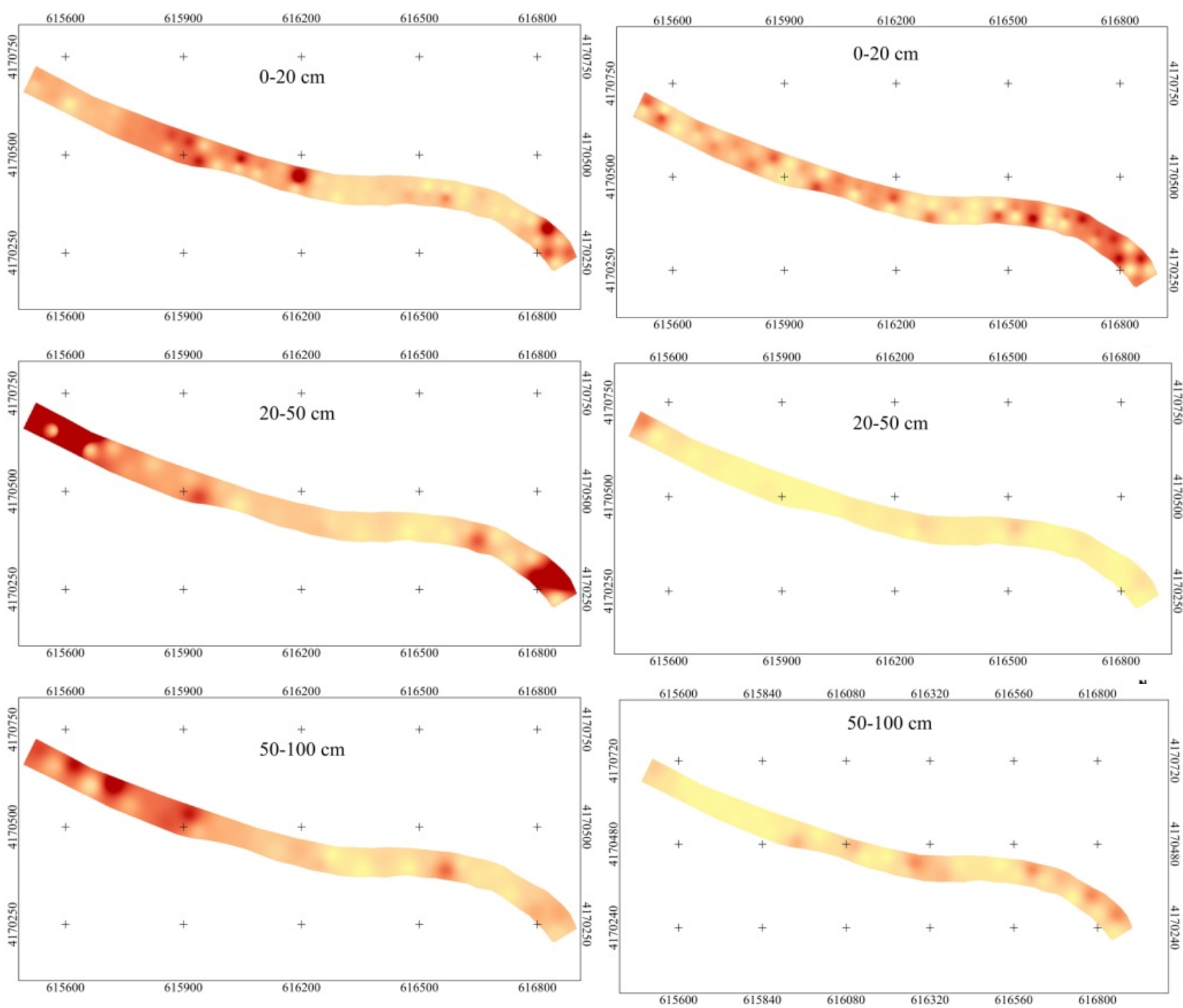

$\mathrm{Cr}(\mathrm{VI})(\mathrm{mg} / \mathrm{kg})$
$\square<=0=4-6$
$0-2=6-8$
$2-4=>8$

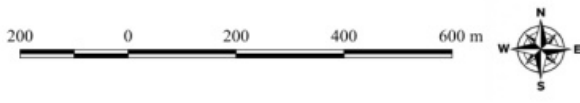

$\mathrm{Cr}(\mathrm{VI})(\mathrm{mg} / \mathrm{kg})$
$-<=0 \quad=0,6-0,9$
$0-0,3 \quad \mathbf{E}=0,9-1,2$
$0,3-0,6=1,2$
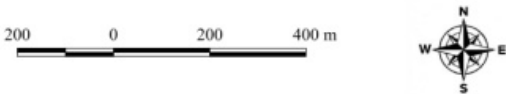

Figura 5.4.5. Evolución de la distribución espacial de la concentración cromo (VI) total en los tramos 1, 2 y 3 (1500 m) entre los años 2013 y 2017. 


\section{Concentración de cromo (VI) total:}

En el año 2013 se registraron concentraciones promedio de 3,45 mg/kg (comprendidas entre $0,01-14,83 \mathrm{mg} / \mathrm{kg}), 6,00 \mathrm{mg} / \mathrm{kg}(0,15-78,92 \mathrm{mg} / \mathrm{kg})$ y $3,51 \mathrm{mg} / \mathrm{kg}(0,01-12,57 \mathrm{mg} / \mathrm{kg})$ en los horizontes de $0-20 \mathrm{~cm}, 20-50 \mathrm{~cm}$ y $50-100 \mathrm{~cm}$ respectivamente. La distribución espacial de las concentraciones de cromo (VI) total muestra un patrón de distribución heterogéneo. Las mayores concentraciones de cromo (VI) (>7 mg/kg) se registran para el horizonte de 0-20 cm en la sección oriental, para el horizonte de $20-50 \mathrm{~cm}$ en la sección occidental y para el horizonte de 50-100 cm en la sección septentrional.

En el año 2017 se han registrado concentraciones promedio de 0,54 mg/kg (comprendidas entre $0,01-1,62 \mathrm{mg} / \mathrm{kg}), 0,10 \mathrm{mg} / \mathrm{kg}(0,01-0,79 \mathrm{mg} / \mathrm{kg})$ y $0,22 \mathrm{mg} / \mathrm{kg}(0,01-0,76 \mathrm{mg} / \mathrm{kg})$ en los horizontes de 0-20 cm, $20-50 \mathrm{~cm}$ y $50-100 \mathrm{~cm}$ respectivamente. Tras el periodo de fitoextracción 2013-2017 los mapas de distribución muestran una disminución estadísticamente significativa en las concentraciones de cromo (VI) total en los horizontes muestreados. Sin embargo, en los mapas de distribución de las concentraciones de cromo (VI) total se puede apreciar una disminución en la sección oriental de los horizontes de 20$50 \mathrm{~cm}$ y de 50-100 cm y un aumento apreciable en la sección occidental del horizonte de 0$20 \mathrm{~cm}$. Con respecto las asociaciones entre parámetros, se han registrado las siguientes correlaciones con el cromo ( $\mathrm{VI})$ total: fósforo biodisponible $\left(r=-0,51^{\star \star}\right)$, zinc intercambiable $\left(r=-0,55^{\star \star}\right)$, ureasa $\left(r=-0,58^{\star \star}\right)$, carbono orgánico $\left(r=+0,67^{\star \star}\right)$ y zinc soluble $\left.r=+0,65^{\star \star}\right)$. Conforme disminuye la concentración de cromo (VI) aumenta la concentración de fósforo disponible, zinc biodisponible (apreciable en el horizonte 0-20 cm) y ureasa en los sedimentos del suelo. El aumento de la actividad enzimática ureasa podría deberse a que al disminuir la concentración de cromo (VI) que es considerado como tóxico, pues aumenta o se favorece la actividad de los microorganismos en los sedimentos del suelo del cauce. Del mismo modo podría justificarse la disminución en parámetros como carbono orgánico y zinc soluble conforme disminuye la concentración de cromo (VI), favoreciéndose su acumulación por las plantas y por los microorganismos presentes en los sedimentos del suelo, aunque no se ha registrado una correlación directa con el carbono de la biomasa microbianda. 
Capítulo 5. ESTUDIO DE FITOEXTRACCIÓN DE Cu, Zn Y Cr CON VEGETACIÓN AUTÓCTONA EN EL CAUCE DEL RÍO GUADALENTÍN

2013
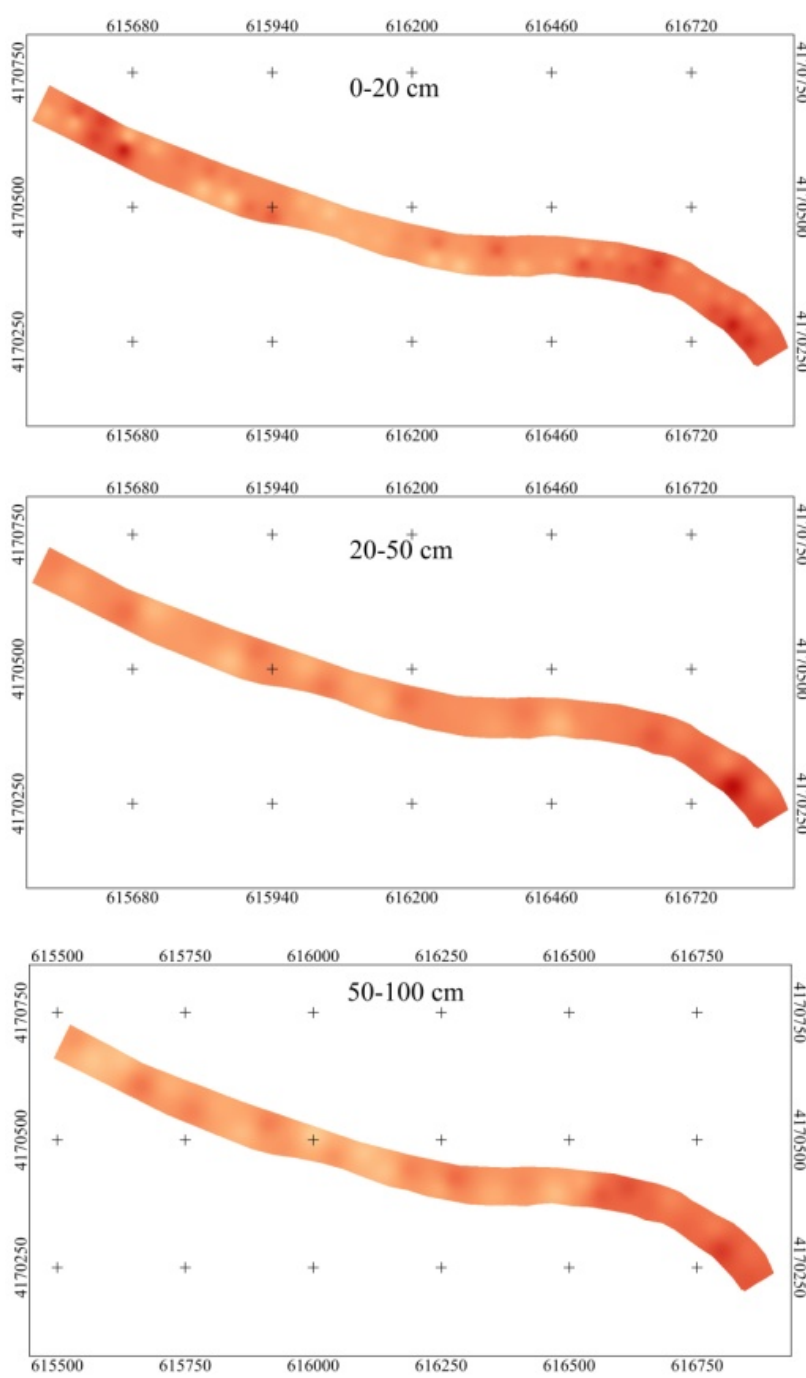

Cu Intercambiable $(\mathrm{mg} / \mathrm{kg})$

Cu Intercambiable (mg kg) $\square<\begin{aligned} & \square=0, \\ & 0-0,1 \quad 0,2-0,3 \\ & 0,3-0,4 \\ & 0,1-0,2=0,4\end{aligned}$

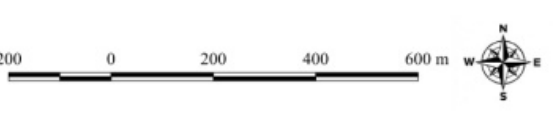

2017
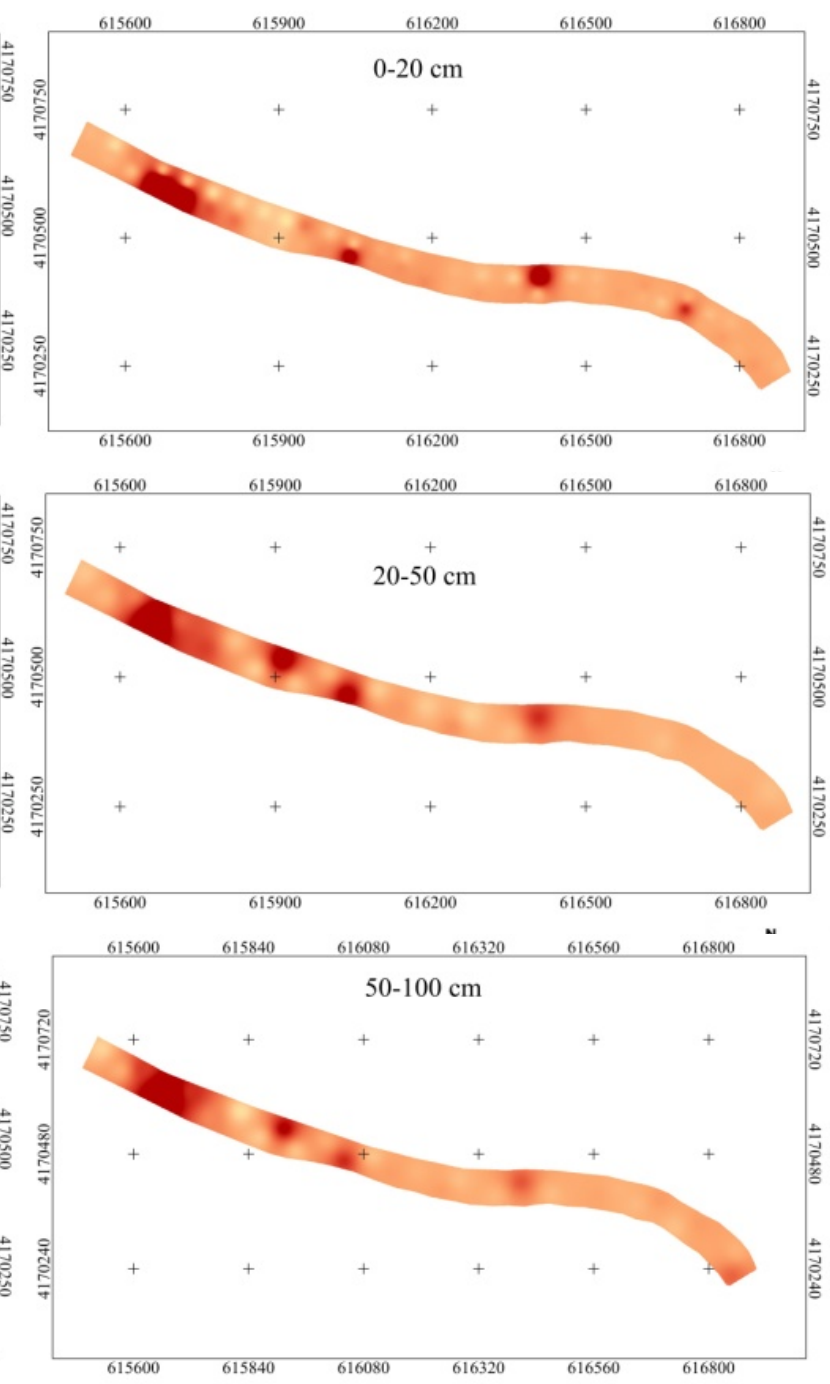

Cu Intercambiable $(\mathrm{mg} / \mathrm{kg})$

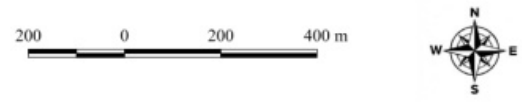

Figura 5.4.6. Evolución de la distribución espacial de la concentración de cobre intercambiable en los tramos 1, 2 y 3 (1500 m) entre los años 2013 y 2017. 


\section{Concentración de cobre intercambiable:}

En el año 2013 se registraron concentraciones promedio de 0,27 mg/kg (comprendidas entre $0,13-0,45 \mathrm{mg} / \mathrm{kg}), 0,26 \mathrm{mg} / \mathrm{kg}(0,15-0,48 \mathrm{mg} / \mathrm{kg})$ y $0,24 \mathrm{mg} / \mathrm{kg}(0,11-0,40 \mathrm{mg} / \mathrm{kg})$ en los horizontes de 0-20 cm, 20-50 cm y 50-100 cm respectivamente. La fracción de cobre intercambiable es entre aproximadamente 10 veces más baja que la fracción total, indicando que la disponibilidad temporal es mayor, y por tanto el cobre puede estar más disponible que el cromo a medio-largo plazo. La mayor concentración de cobre intercambiable se encuentra en el horizonte de 0-20 cm, especialmente en la sección oriental y parte de la sección occidental.

En el año 2017 se han registrado concentraciones promedio de 0,23 mg/kg (comprendidas entre $0,05-1,17 \mathrm{mg} / \mathrm{kg}), 0,24 \mathrm{mg} / \mathrm{kg}(0,11-0,90 \mathrm{mg} / \mathrm{kg})$ y $0,25 \mathrm{mg} / \mathrm{kg}(0,07-0,96 \mathrm{mg} / \mathrm{kg})$ en los horizontes de $0-20 \mathrm{~cm}, 20-50 \mathrm{~cm}$ y $50-100 \mathrm{~cm}$ respectivamente. Tras el periodo de fitoextracción 2013-2017 los mapas de distribución muestran un aumento de las concentraciones de cobre intercambiable en los horizontes de 0-20 cm y de 50-100 cm, siendo significativo sólo para el horizonte más superficial $(0-20 \mathrm{~cm})$; y una disminución significativa en el horizonte de $20-50 \mathrm{~cm}$. Con respecto las asociaciones entre parámetros, no se han registrado correlaciones destacables $(r \geq 0,50)$ con el cobre intercambiable. La correlación más notable se ha observado entre el cobre intercambiable y el zinc soluble $\left(r=+0.34^{\star *}\right)$. 
Capítulo 5. ESTUDIO DE FITOEXTRACCIÓN DE Cu, Zn Y Cr CON VEGETACIÓN AUTÓCTONA EN EL CAUCE DEL RÍO GUADALENTÍN

2013
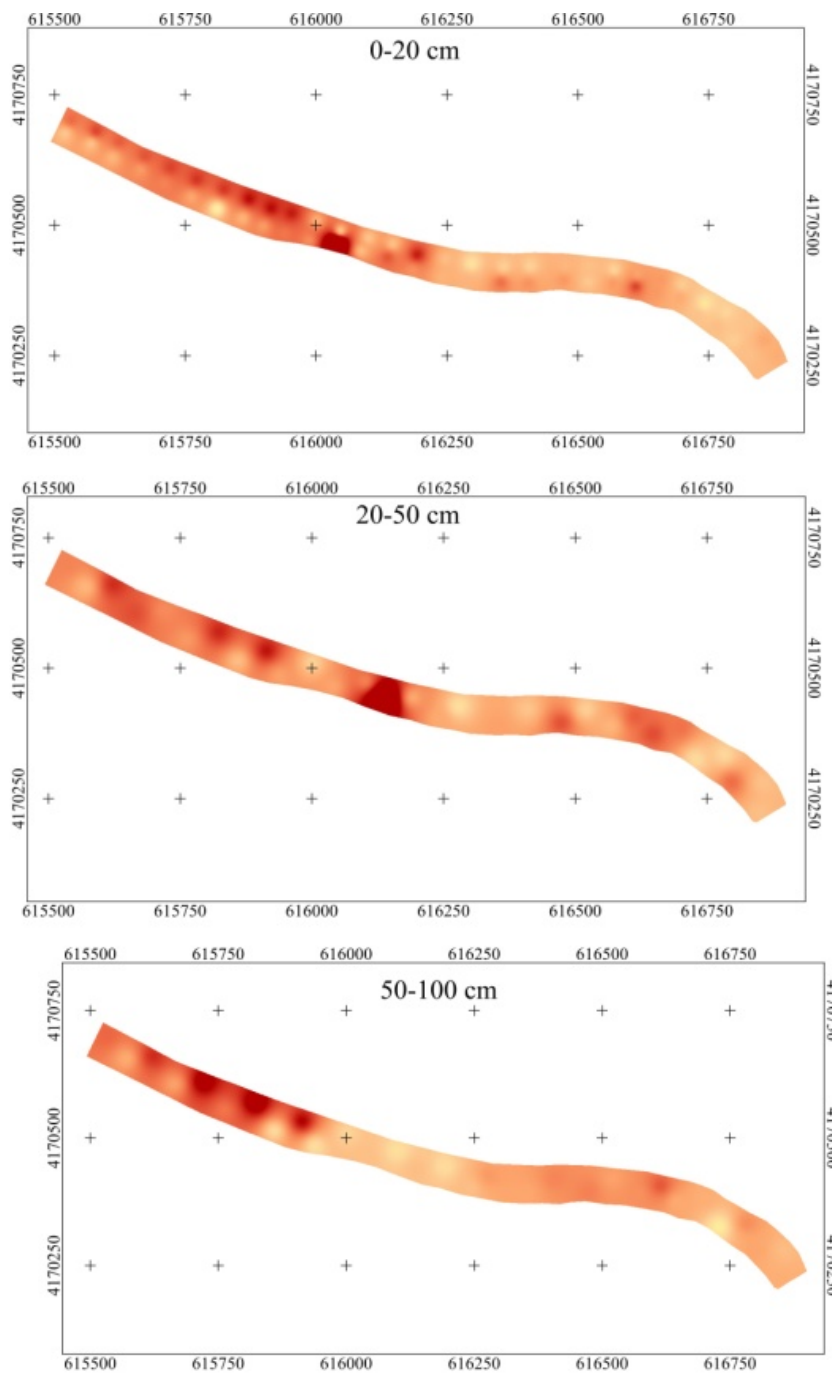

$\mathrm{Zn}$ Intercambiable $(\mathrm{mg} / \mathrm{kg})$

$\square<0$
$0-0,08 \quad=0,16-0,2420$
$0,24-0,32$ $0-0,08$
$0,08-0,16$
2017
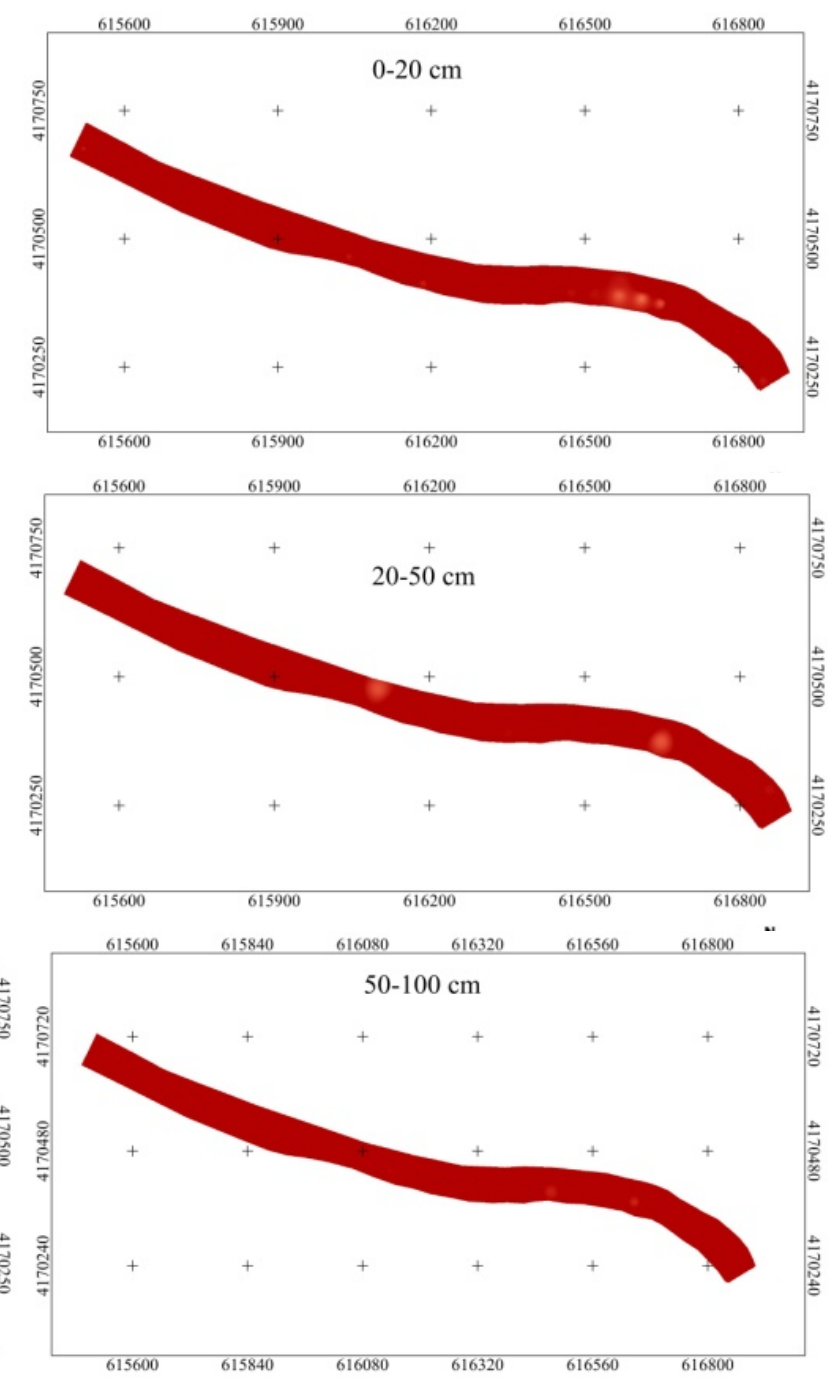

$\mathrm{Zn}$ Intercambiable $(\mathrm{mg} / \mathrm{kg})$ $\square=0$
$\square=0,08 \quad$$\quad \begin{aligned} & 0,16-0,24 \\ & 0,24-0,32\end{aligned}$
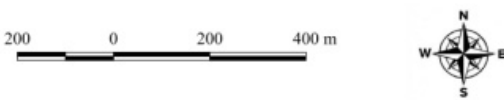

Figura 5.4.7. Evolución de la distribución espacial de la concentración de zinc intercambiable en los tramos 1,2 y 3 (1500 m) entre los años 2013 y 2017. 


\section{Concentración de zinc intercambiable:}

En el año 2013 se registran concentraciones promedio de 0,19 mg/kg (comprendidas entre $0,02-1,02 \mathrm{mg} / \mathrm{kg}), 0,21 \mathrm{mg} / \mathrm{kg}(0,06-0,85 \mathrm{mg} / \mathrm{kg})$ y $0,18 \mathrm{mg} / \mathrm{kg}(0,03-0,48 \mathrm{mg} / \mathrm{kg})$ en $\mathrm{los}$ horizontes de 0-20 cm, 20-50 cm y 50-100 cm respectivamente. La fracción de zinc intercambiable es bastante baja, indicando que la biodisponibilidad potencial de este metal es mayor que la real, y por tanto el zinc es más disponible que el cromo y el cobre a mediolargo plazo. Es importante remarcar, que aunque la concentración de la fracción extraíble de los tres metales es diferente, con una concentración creciente según $\mathrm{Cr}<\mathrm{Cu}<\mathrm{Zn}$, la fracción intercambiable es muy similar en los tres metales, indicando una disponibilidad real similar, y bastante baja.

En el año 2017 se han registrado concentraciones promedio de 0,57 mg/kg (comprendidas entre $0,25-1,22 \mathrm{mg} / \mathrm{kg}), 0,53 \mathrm{mg} / \mathrm{kg}(0,28-1,00 \mathrm{mg} / \mathrm{kg})$ y $0,56 \mathrm{mg} / \mathrm{kg}(0,35-1,10 \mathrm{mg} / \mathrm{kg})$ en los horizontes de $0-20 \mathrm{~cm}, 20-50 \mathrm{~cm}$ y $50-100 \mathrm{~cm}$ respectivamente. Tras el periodo de fitoextracción 2013-2017 los mapas de distribución muestran un aumento significativo de las concentraciones de zinc intercambiable en todos los horizontes muestreados. Con respecto las asociaciones entre parámetros, se han registrado las siguientes correlaciones con el zinc intercambiable: carbono orgánico $\left(r=-0,64^{\star *}\right), \mathrm{pH}\left(\mathrm{r}=-0,56^{\star \star}\right)$ y fosforo asimilable $\left(r=+0,65^{\star \star}\right)$. Conforme aumenta la concentración de zinc intercambiable, disminuyen los valores de carbono orgánico y de $\mathrm{pH}$, estas variaciones pueden estar influenciadas por los cambios de $\mathrm{pH}$ registrados en los sedimentos del suelo como consecuencia del periodo de sequía y de la vegetación presente, tanto la implantada como la existente segada que ha rebrotado. 
Capítulo 5. ESTUDIO DE FITOEXTRACCIÓN DE Cu, Zn Y Cr CON VEGETACIÓN AUTÓCTONA EN EL CAUCE DEL RÍO GUADALENTÍN

2013
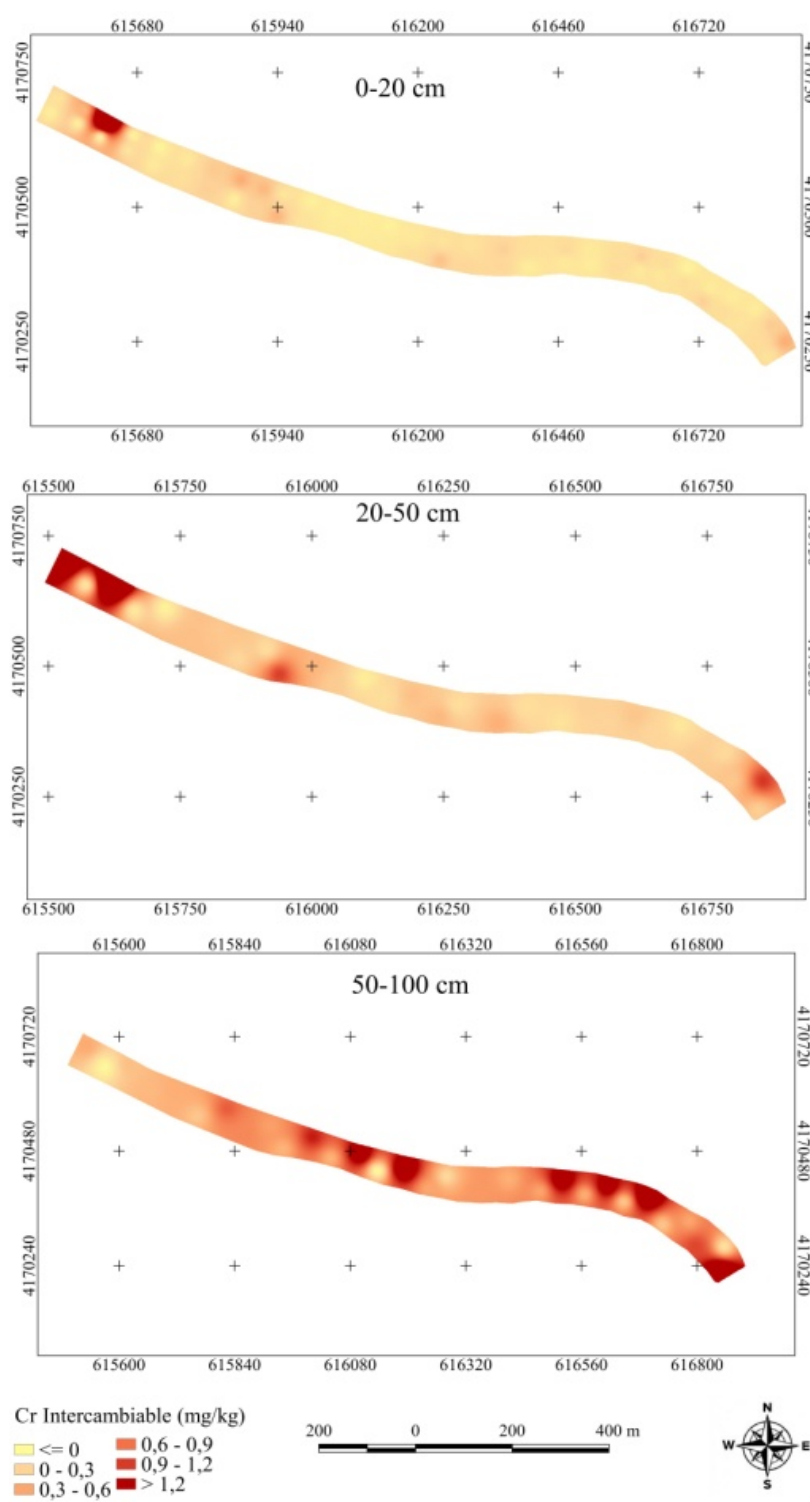

2017
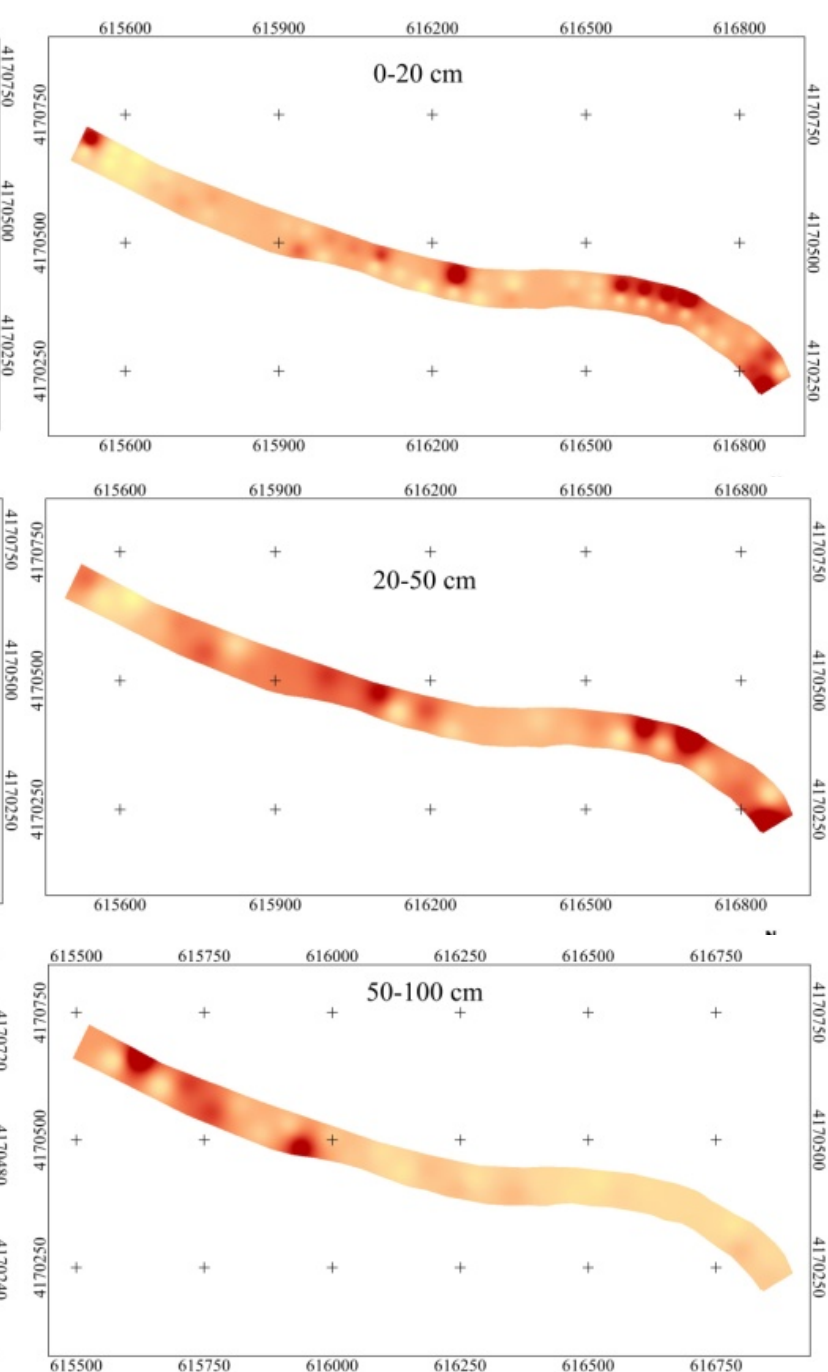

Cr Intercambiable $(\mathrm{mg} / \mathrm{kg})$ $\square=0$
$0-0,3 \quad 0,6-0,9$
$0,3-0,6=1,2=1,2$

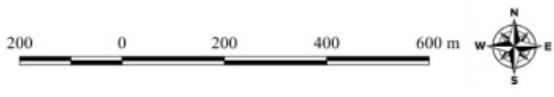

Figura 5.4.8. Evolución de la distribución espacial de la concentración de cromo intercambiable en los tramos 1, 2 y 3 (1500 m) entre los años 2013 y 2017. 


\section{Concentración de cromo intercambiable:}

En el año 2013 se registraron concentraciones promedio de 0,37 $\mathrm{mg} / \mathrm{kg}$ (comprendidas entre 0,06-6,05 mg/kg), 0,53 mg/kg (0,06-3,64 mg/kg) y 0,47 mg/kg (0,15-2,17 mg/kg) en los horizontes de $0-20 \mathrm{~cm}, 20-50 \mathrm{~cm}$ y $50-100 \mathrm{~cm}$ respectivamente. La fracción intercambiable de cromo es bastante baja y muestra una distribución totalmente homogénea con concentraciones $\leq 20 \mathrm{mg} / \mathrm{kg}$.

En el año 2017 se han registrado concentraciones promedio de 0,62 mg/kg (comprendidas entre $0-2,33 \mathrm{mg} / \mathrm{kg}), 0,77 \mathrm{mg} / \mathrm{kg}(0-2,38 \mathrm{mg} / \mathrm{kg})$ y $0,88 \mathrm{mg} / \mathrm{kg}(0-2,72 \mathrm{mg} / \mathrm{kg})$ en los horizontes de $0-20 \mathrm{~cm}, 20-50 \mathrm{~cm}$ y $50-100 \mathrm{~cm}$ respectivamente. Tras el periodo de fitoextracción 2013-2017 los mapas de distribución muestran un aumento significativo de las concentraciones de cromo intercambiable en todos los horizontes muestreados $(0-20 \mathrm{~cm}$, 20-50 cm y 50-100 cm). Con respecto las asociaciones entre parámetros, no se han registrado correlaciones destacables entre el cromo intercambiable y el resto de parámetros, siendo la más notable con el cromo biodisponible $\left(r=+0.42^{\star \star}\right)$. Las variaciones observadas podrían deberse a la vegetación presente en el cauce y a sus exudados radiculares que favorecen la solubilización de las diferentes fracciones de los metales presentes en los sedimentos del suelo. También podrían verse influenciadas por el periodo de sequía y de escasez hídrica. 
Capítulo 5. ESTUDIO DE FITOEXTRACCIÓN DE Cu, Zn Y Cr CON VEGETACIÓN AUTÓCTONA EN EL CAUCE DEL RÍO GUADALENTÍN

2013
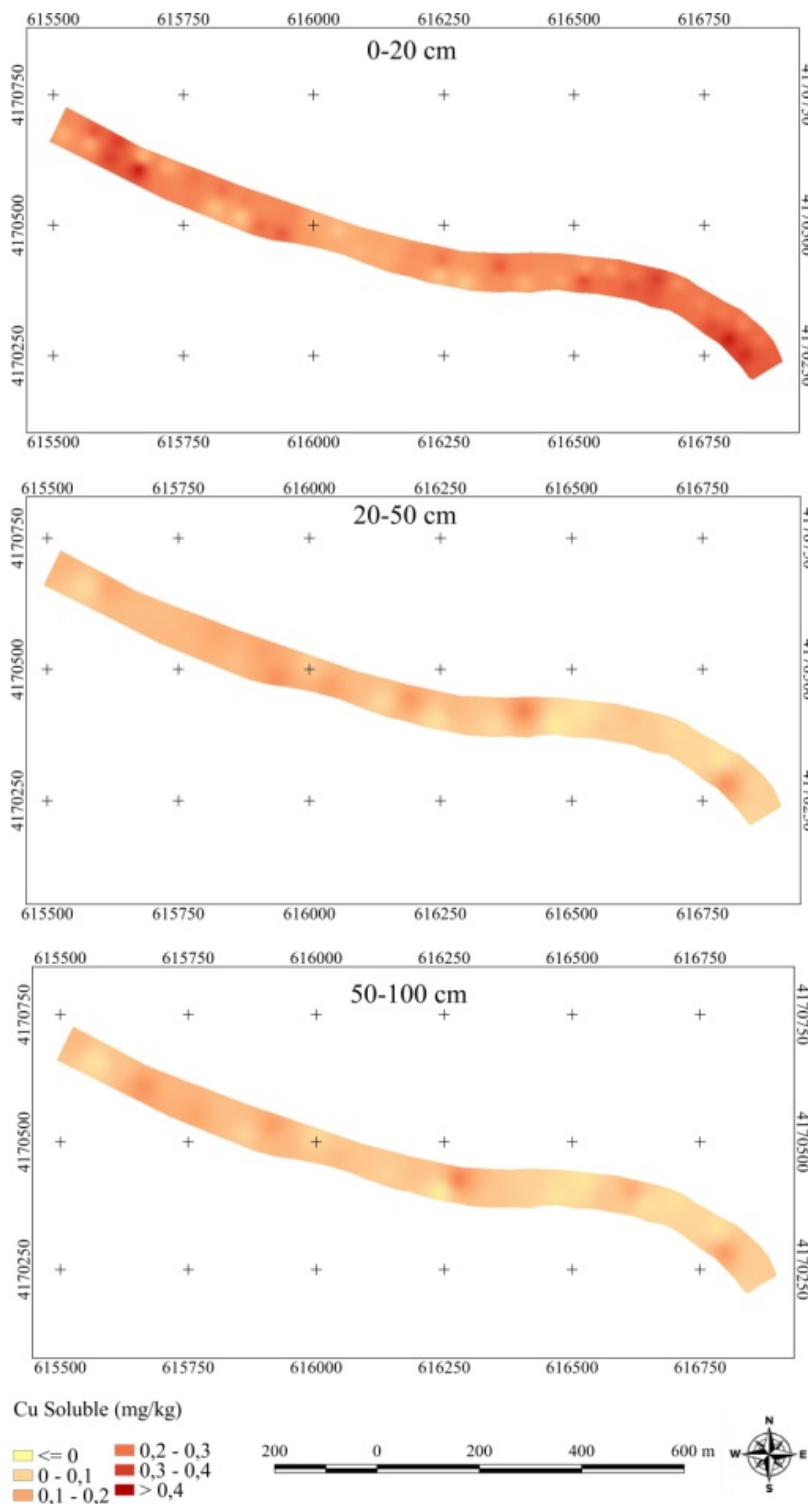

2017
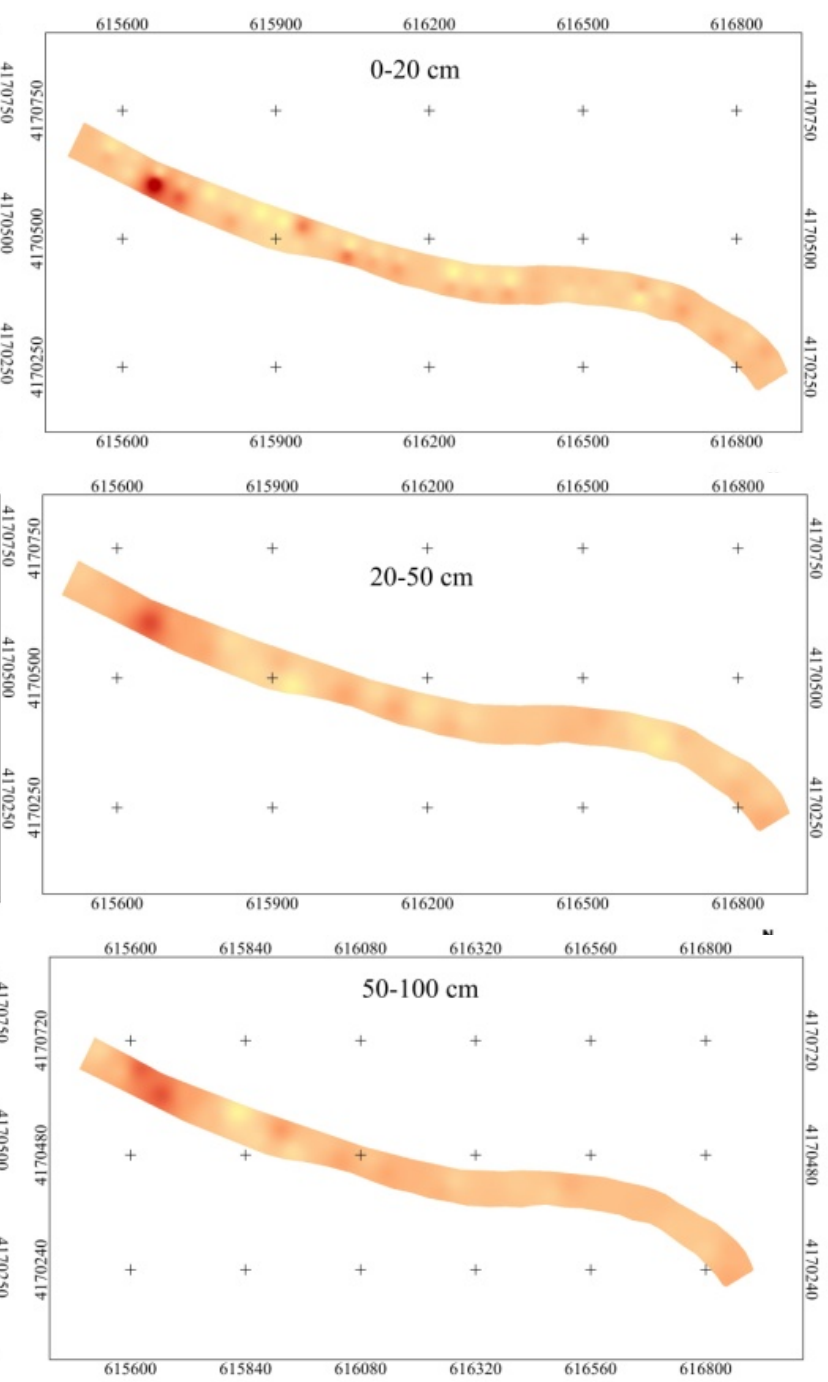

Cu soluble $(\mathrm{mg} / \mathrm{kg})$ $\square<=0$
$\square-0,1 \quad=0,2-0,3$
$0,1-0,2=0,3-0,4$
0,4

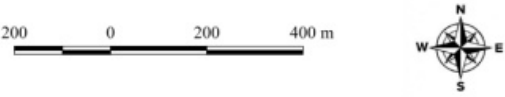

Figura 5.4.9. Evolución de la distribución espacial de la concentración de cobre soluble en los tramos 1,2 y 3 (1500 m) entre los años 2013 y 2017. 


\section{Concentración de cobre soluble:}

En el año 2013 se registraron concentraciones promedio de 0,14 mg/kg (comprendidas entre $0,02-0,29 \mathrm{mg} / \mathrm{kg}), 0,14 \mathrm{mg} / \mathrm{kg}(0,04-0,26 \mathrm{mg} / \mathrm{kg})$ y $0,13 \mathrm{mg} / \mathrm{kg}(0,04-0,26 \mathrm{mg} / \mathrm{kg})$ en los horizontes de $0-20 \mathrm{~cm}, 20-50 \mathrm{~cm}$ y $50-100 \mathrm{~cm}$ respectivamente. La fracción de cobre soluble es la mitad de la fracción de cobre intercambiable, lo que indica que gran parte de la fracción disponible que puede ser actualmente absorbida por la vegetación es también soluble y puede lavarse tras eventos de precipitación. No obstante, esta fracción es muy baja, por debajo de $0,40 \mathrm{mg} / \mathrm{kg}$.

Para el año 2017 se han registrado concentraciones promedio de 0,13 mg/kg (comprendidas entre $0-0,61 \mathrm{mg} / \mathrm{kg}), 0,13 \mathrm{mg} / \mathrm{kg}(0,02-0,37 \mathrm{mg} / \mathrm{kg})$ y $0,15 \mathrm{mg} / \mathrm{kg}(0,01-0,35 \mathrm{mg} / \mathrm{kg})$ en los horizontes de $0-20 \mathrm{~cm}, 20-50 \mathrm{~cm}$ y $50-100 \mathrm{~cm}$ respectivamente. Tras el periodo de fitoextracción 2013-2017 los mapas de distribución muestran una disminución no significativa de las concentraciones de cobre soluble en los horizontes de 0-20 cm y de 20$50 \mathrm{~cm}$ y un aumento no significativo en el horizonte de 50-100 cm. Con respecto las asociaciones entre parámetros, se ha registrado una correlación entre el cobre soluble y el cobre intercambiable $\left(r=+0,48^{\star \star}\right)$. La correlación observada no es muy elevada dadas las concentraciones de cobre soluble tan bajas registradas tanto en el muestreo de 2013 como en el muestreo de 2017. 
Capítulo 5. ESTUDIO DE FITOEXTRACCIÓN DE Cu, Zn Y Cr CON VEGETACIÓN AUTÓCTONA EN EL CAUCE DEL RÍO GUADALENTÍN

2013
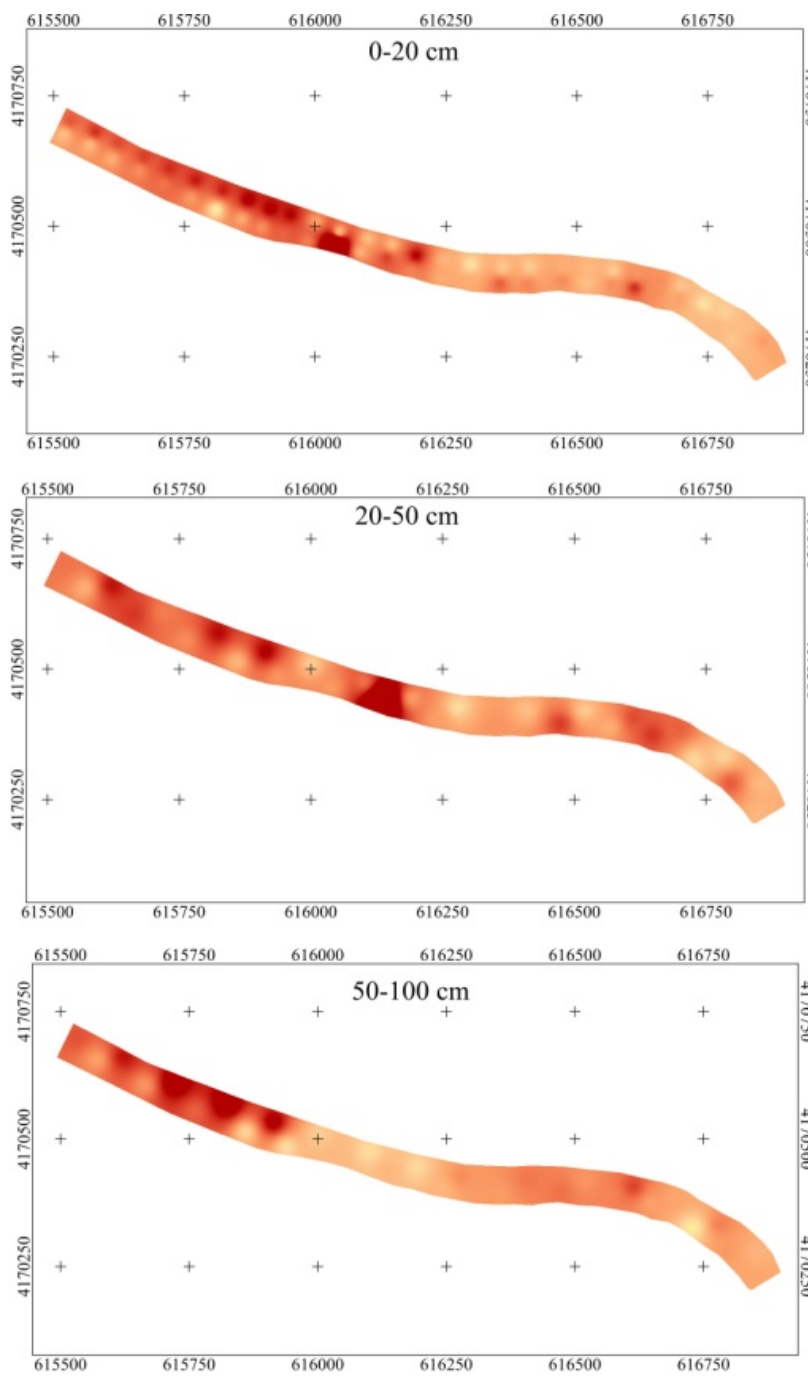

Zn Soluble $(\mathrm{mg} / \mathrm{kg})$

$\square<=0 \quad=0,12-0,1820$ $<=0$
$0-0,06=0,12-0,18$
$0,06-0,12=0,24$

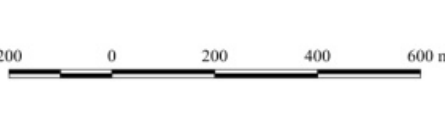

2017
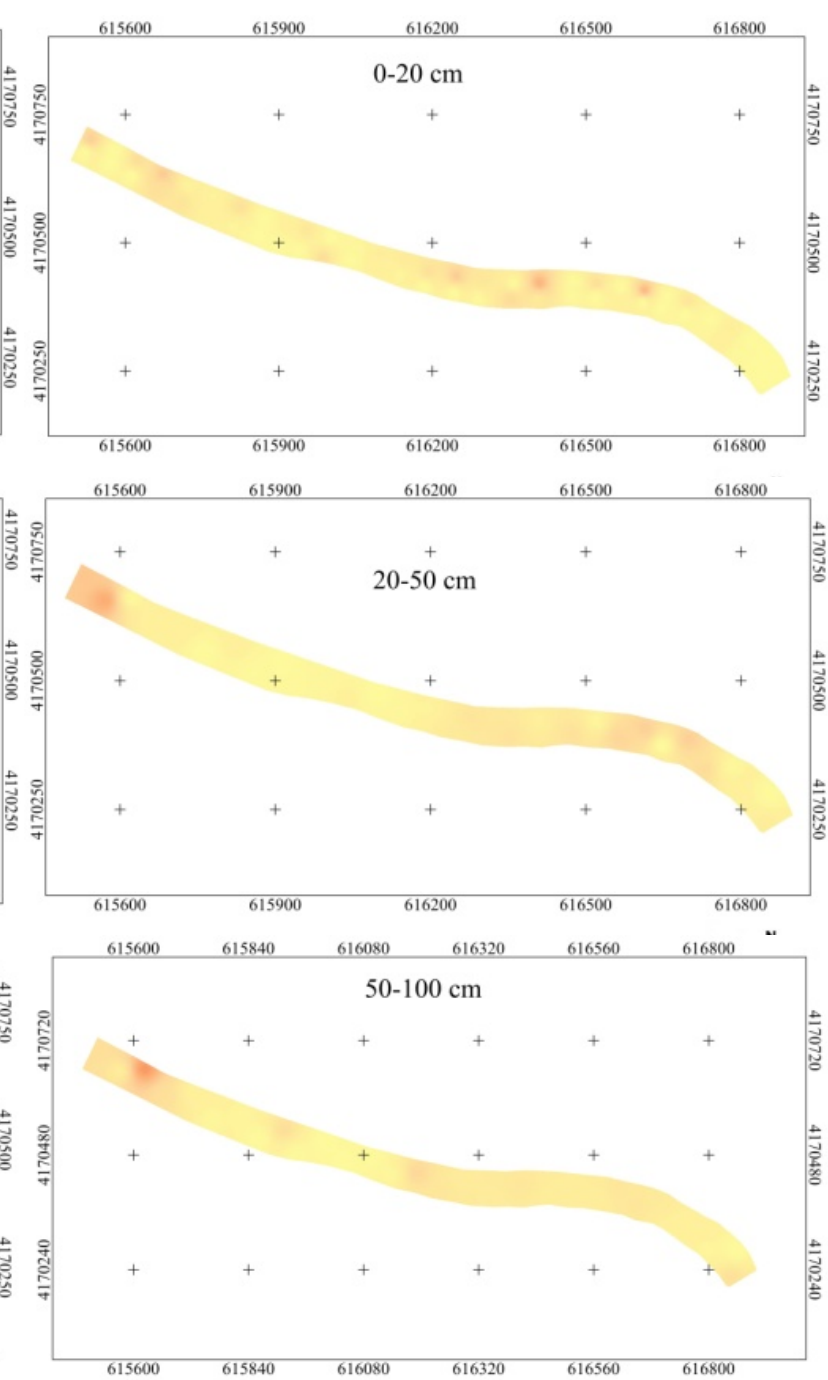

Zn Soluble (mg/kg)

$\square=0$
$0-0,06 \quad=0,12-0,18$
$0,18-0,24$ $0-0,06$
$0,06-0,12=0,18-0$,
$>0,24$
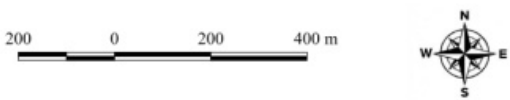

Figura 5.4.10. Evolución de la distribución espacial de la concentración de zinc soluble en los tramos 1, 2 y 3 (1500 m) entre los años 2013 y 2017. 


\section{Concentración de zinc soluble:}

Para el año 2013 se registraron concentraciones promedio de 0,16 mg/kg (comprendidas entre $0,01-0,85 \mathrm{mg} / \mathrm{kg}), 0,17 \mathrm{mg} / \mathrm{kg}(0,05-0,75 \mathrm{mg} / \mathrm{kg})$ y $0,15 \mathrm{mg} / \mathrm{kg}(0,02-0,40 \mathrm{mg} / \mathrm{kg})$ en los horizontes de 0-20 cm, 20-50 cm y 50-100 cm respectivamente. La distribución de la fracción soluble de zinc es ligeramente inferior a la fracción intercambiable, lo que indica que la mayor parte de la fracción disponible y por tanto que puede ser actualmente absorbida por la vegetación es también soluble y puede lavarse tras eventos de precipitación. No obstante, esta fracción es muy baja, por debajo de 1,00 mg/kg. El hecho de que el Zn soluble pueda ser absorbido por la vegetación se vería favorecido si se realiza un siega anual de la vegetación presente en el cauce. Aunque la vegetación sea autóctona también podría ayudar a mejorar la eficiencia de fitoextracción la realización de riegos de emergencia y aplicación de prácticas agrícolas.

Para el año 2017 se han registrado concentraciones promedio de 0,02 $\mathrm{mg} / \mathrm{kg}$ (comprendidas entre 0-0,10 mg/kg), 0,02 mg/kg (0-0,11 mg/kg) y 0,02 mg/kg (0-0,13 mg/kg) en los horizontes de $0-20 \mathrm{~cm}, 20-50 \mathrm{~cm}$ y $50-100 \mathrm{~cm}$ respectivamente. Tras el periodo de fitoextracción 2013-2017 los mapas de distribución muestran una disminución significativa de las concentraciones de zinc soluble (al igual que para cobre soluble, excepto el horizonte más profundo) en todos los horizontes muestreados. Con respecto las asociaciones entre parámetros, se han registrado las siguientes correlaciones entre el zinc soluble y los siguientes parámetros: fósforo biodisponible $\left(r=-0,61^{* *}\right)$, carbono orgánico $\left(r=+0,69^{\star *}\right)$ y $\mathrm{pH}$ $\left(r=+0,62^{\star \star}\right)$. Conforme disminuye la concentración de zinc soluble en los sedimentos del cauce aumenta el fósforo biodisponible y disminuyen el carbono orgánico y el $\mathrm{pH}$, estas variaciones podrían deberse a las variaciones registradas de $\mathrm{pH}$, siendo un factor muy influyente en las propiedades edáficas. 
Capítulo 5. ESTUDIO DE FITOEXTRACCIÓN DE Cu, Zn Y Cr CON VEGETACIÓN AUTÓCTONA EN EL CAUCE DEL RÍO GUADALENTÍN

2013

2017
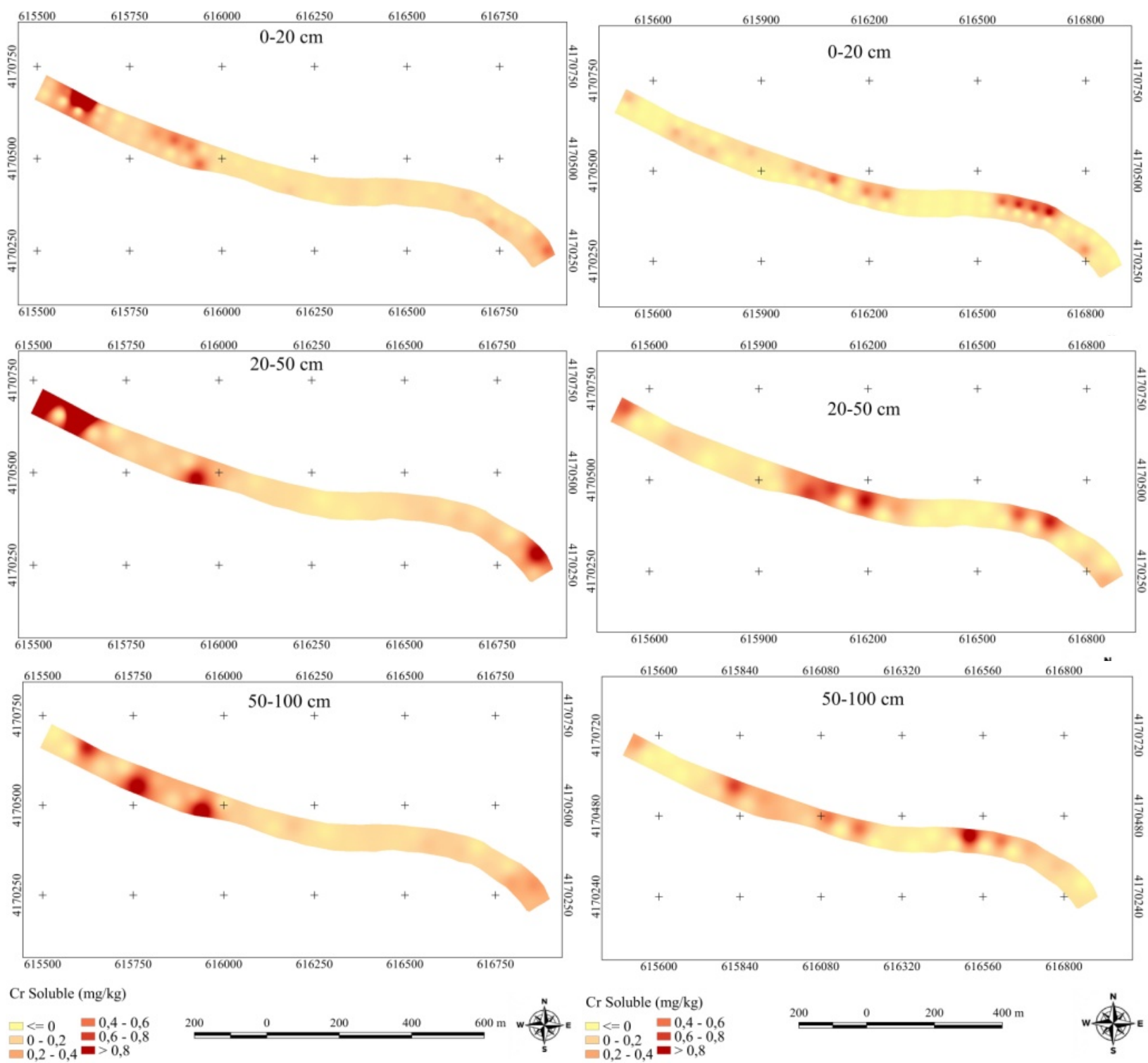

Figura 5.4.11. Evolución de la distribución espacial de la concentración de cromo soluble en los tramos 1,2 y 3 (1500 m) entre los años 2013 y 2017. 


\section{Concentración de cromo soluble:}

En el año 2013 se registran concentraciones promedio de $0,27 \mathrm{mg} / \mathrm{kg}$ (comprendidas entre $0,01-5,25 \mathrm{mg} / \mathrm{kg}), 0,13 \mathrm{mg} / \mathrm{kg}(0,02-3,52 \mathrm{mg} / \mathrm{kg})$ y $0,28 \mathrm{mg} / \mathrm{kg}(0,02-1,34 \mathrm{mg} / \mathrm{kg})$ en los horizontes de 0-20 cm, 20-50 cm y 50-100 cm respectivamente. La fracción soluble de cromo es como promedio la mitad de la fracción intercambiable. Por tanto, estos datos evidencian la baja disponibilidad y movilidad del cromo en el sedimento del rio, con valores solubles muy cercanos a los disponibles en el complejo de cambio.

En el año 2017 se han registrado concentraciones promedio de 0,27 mg/kg (comprendidas entre $0,01-5,25 \mathrm{mg} / \mathrm{kg}), 0,13 \mathrm{mg} / \mathrm{kg}(0,02-3,52 \mathrm{mg} / \mathrm{kg})$ y $0,28 \mathrm{mg} / \mathrm{kg}(0,02-1,34 \mathrm{mg} / \mathrm{kg})$ en los horizontes de $0-20 \mathrm{~cm}, 20-50 \mathrm{~cm}$ y $50-100 \mathrm{~cm}$ respectivamente. Tras el periodo de fitoextracción 2013-2017 los mapas de distribución muestran una disminución de las concentraciones de cromo soluble en los horizontes de $0-20 \mathrm{~cm}$, de $20-50 \mathrm{~cm}$ y de $50-100$ cm (siendo significativa para $0-20 \mathrm{~cm}$ y $20-50 \mathrm{~cm}$ ), al igual que lo registrado para cobre y zinc soluble. Con respecto las asociaciones entre parámetros, no se han registrado correlaciones destacables entre el cromo soluble y el resto de parámetros, siendo la correlación más notable con el cromo intercambiable $\left(r=+0,51^{* *}\right)$. Las variaciones observadas podrían deberse a la vegetación presente en el cauce y a sus exudados radiculares que favorecen la solubilización de las diferentes fracciones de los metales presentes en los sedimentos del suelo. También podrían verse influenciadas por el periodo de sequía y de escasez hídrica. 
Capítulo 5. ESTUDIO DE FITOEXTRACCIÓN DE Cu, Zn Y Cr CON VEGETACIÓN AUTÓCTONA EN EL CAUCE DEL RÍO GUADALENTÍN

2013

2017
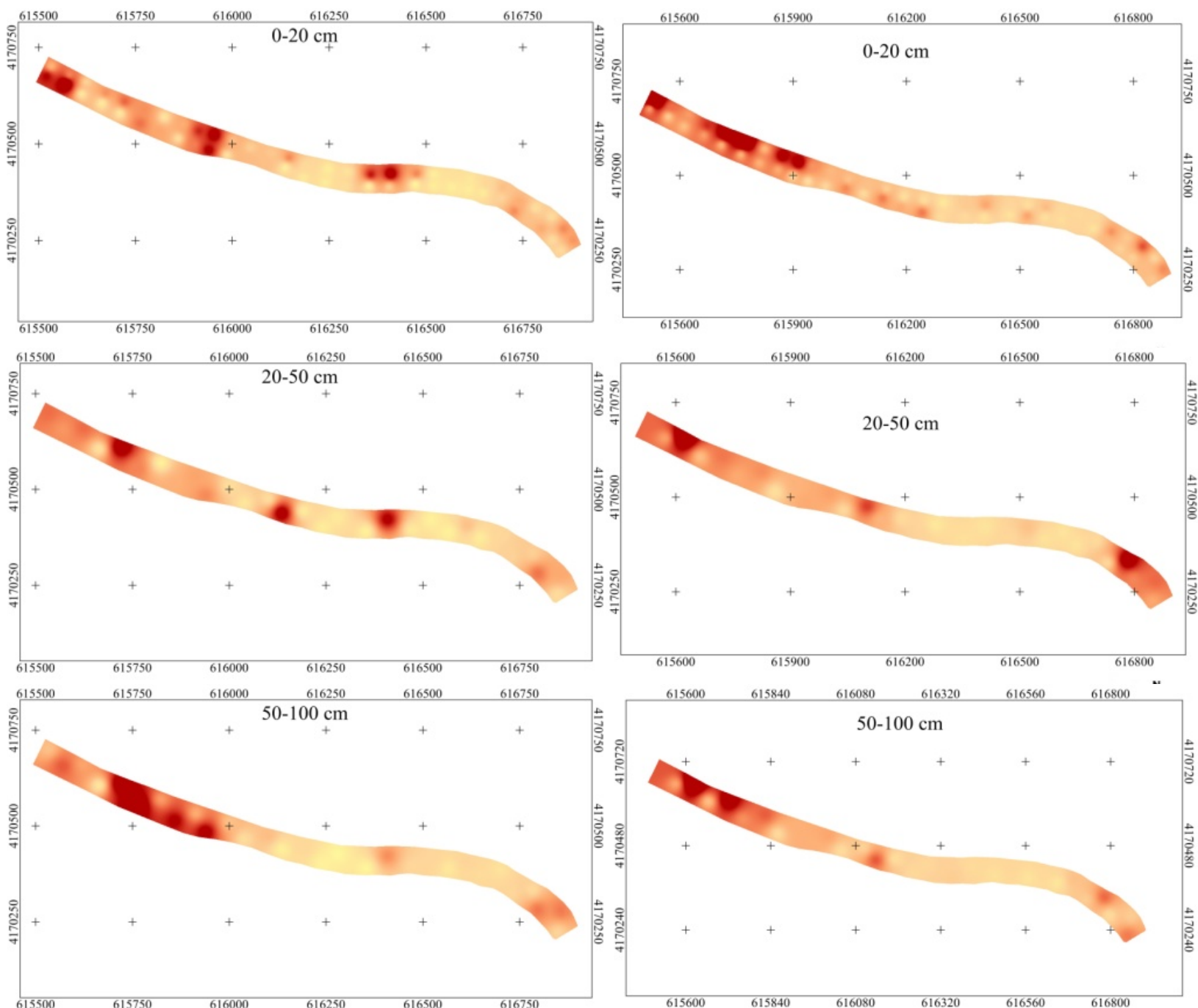

Fe Biodisponible ( $\mathrm{mg} / \mathrm{kg}$ )

$\begin{aligned} \square<0 & =10-15 \\ 0-5 & =15-20 \\ 5-10 & =20\end{aligned}$

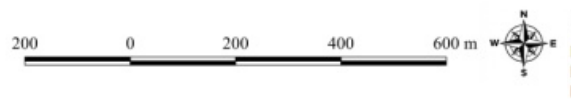

Fe Biodisponible ( $\mathrm{mg} / \mathrm{kg}$ )

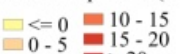
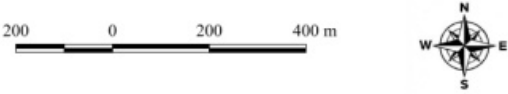

Figura 5.4.12. Evolución de la distribución espacial de la concentración de hierro biodisponible en los tramos 1, 2 y 3 (1500 m) entre los años 2013 y 2017. 


\section{Concentración de hierro biodisponible:}

En el año 2013 se registraron concentraciones promedio de 6,98 mg/kg (comprendidas entre $0,65-31,46 \mathrm{mg} / \mathrm{kg}), 8,43 \mathrm{mg} / \mathrm{kg}(1,07-32,52 \mathrm{mg} / \mathrm{kg})$ y $9,48 \mathrm{mg} / \mathrm{kg}(0,40-37,76 \mathrm{mg} / \mathrm{kg})$ en los horizontes de 0-20 cm, 20-50 cm y 50-100 cm respectivamente. La distribución del contenido de hierro biodisponible presenta valores adecuados desde el punto de vista de fertilidad edáfica en todo el cauce en las tres profundidades muestreadas.

Para el año 2017 se han registrado concentraciones promedio de 10,66 mg/kg (comprendidas entre 2,27-63,57 mg/kg), 9,88 mg/kg (2,34-43,88 mg/kg) y 9,76 mg/kg $(2,67-$ $45,99 \mathrm{mg} / \mathrm{kg}$ ) en los horizontes de $0-20 \mathrm{~cm}, 20-50 \mathrm{~cm}$ y $50-100 \mathrm{~cm}$ respectivamente. Tras el periodo de fitoextracción 2013-2017 los mapas de distribución muestran un aumento en las concentraciones de hierro biodisponible en todos los horizontes muestreados, siendo el aumento significativo sólo en el horizonte superficial $(0-20 \mathrm{~cm})$. Con respecto las asociaciones entre parámetros, se ha registrado la siguiente correlación entre el hierro biodisponible y los siguiente parámetro: carbonatos $\left(r=-0,53^{\star *}\right)$. Conforme aumenta la concentración de hierro biodisponible aumenta el porcentaje de carbonatos. Dicha variación, especialmente el aumento del porcentaje de carbonatos, podría ser debida a la disminución de los valores del pH de los sedimentos del suelo del cauce. 
Capitulo 5. ESTUDIO DE FITOEXTRACCIÓN DE Cu, Zn Y Cr CON VEGETACIÓN AUTÓCTONA EN EL CAUCE DEL RIOO GUADALENTÍN

2013
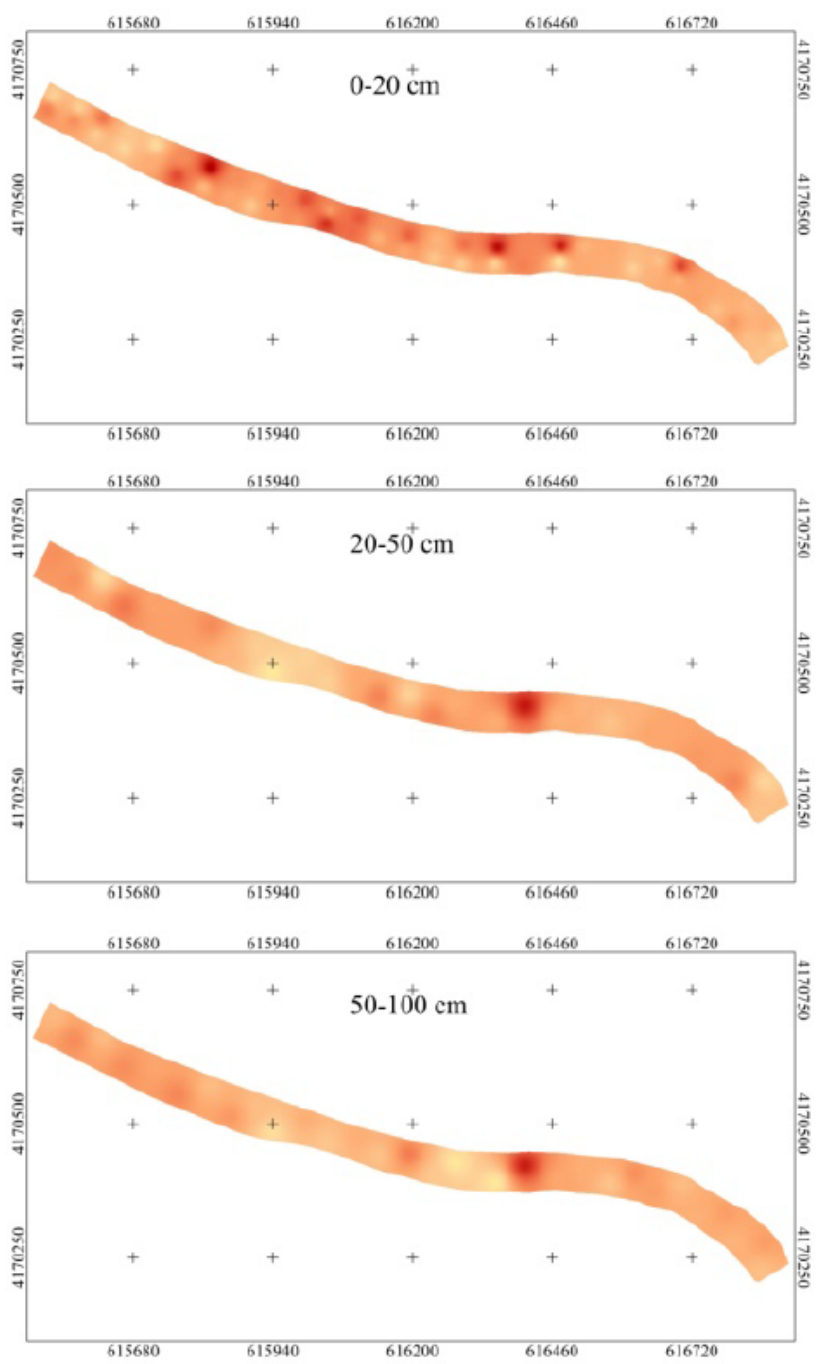

Mn Biodisponible $(\mathrm{mg} / \mathrm{kg})$

$\square=0=4-6$
$0-2=6.8$

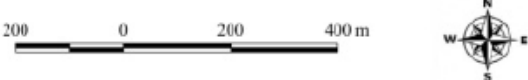

2017
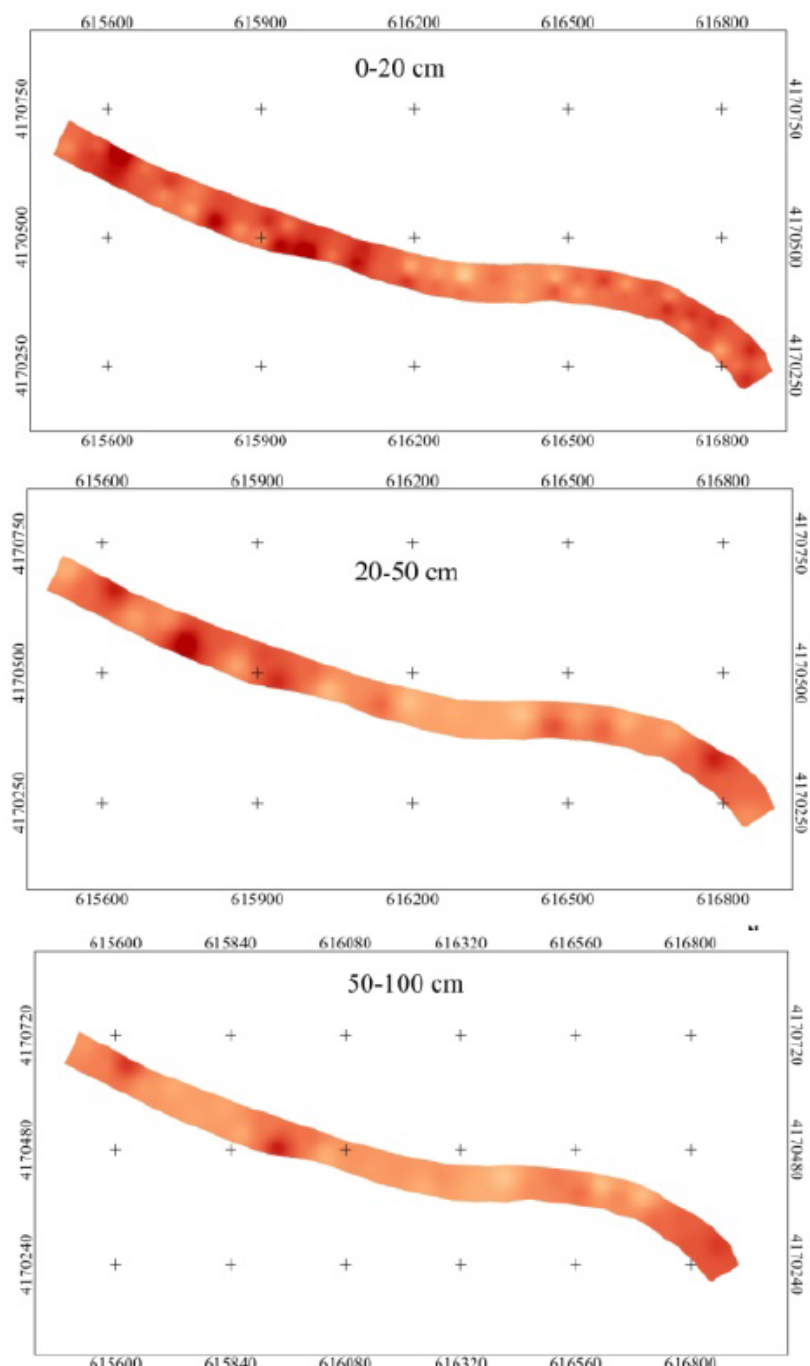

Mn Biodisponible (mg $/ \mathrm{kg})$ $\square=0=4-6$
$0-2=6-8$
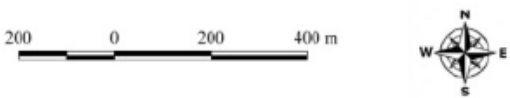

Figura 5.4.13. Evolución de la distribución espacial de la concentración de manganeso biodisponible en los tramos 1, 2 y 3 (1500 m) entre los años 2013 y 2017. 


\section{Concentración de manganeso biodisponible:}

En el año 2013 se registraron concentraciones promedio de 4,28 mg/kg (comprendidas entre $1,08-10,35 \mathrm{mg} / \mathrm{kg}), 3,78 \mathrm{mg} / \mathrm{kg}(0,88-9,27 \mathrm{mg} / \mathrm{kg})$ y $3,63 \mathrm{mg} / \mathrm{kg}(0,95-9,01 \mathrm{mg} / \mathrm{kg})$ en los horizontes de 0-20 cm, 20-50 cm y 50-100 cm respectivamente. La distribución del contenido de manganeso biodisponible presenta valores adecuados desde el punto de vista de fertilidad edáfica en todo el cauce en las tres profundidades muestreadas.

En el año 2017 se han registrado concentraciones promedio de 6,71 mg/kg (comprendidas entre $2,17-12,98 \mathrm{mg} / \mathrm{kg}), 5,60 \mathrm{mg} / \mathrm{kg}(2,88-11,07 \mathrm{mg} / \mathrm{kg})$ y $5,14 \mathrm{mg} / \mathrm{kg}(2,59-9,05 \mathrm{mg} / \mathrm{kg})$ en los horizontes de $0-20 \mathrm{~cm}, 20-50 \mathrm{~cm}$ y $50-100 \mathrm{~cm}$ respectivamente. Tras el periodo de fitoextracción 2013-2017 los mapas de distribución muestran un aumento significativo de las concentraciones de manganeso biodisponible en los horizontes de $0-20 \mathrm{~cm}$, de $20-50 \mathrm{~cm}$ y de $50-100 \mathrm{~cm}$. Con respecto las asociaciones entre parámetros, se han registrado las siguientes correlaciones con el manganeso biodisponible: $\mathrm{pH} \quad\left(r=-0,52^{\star \star}\right)$ y fósforo biodisponible $\left(r=+0,49^{* *}\right)$. Conforme aumenta la concentración de manganeso biodisponible aumenta la concentración de fósforo biodisponible y los valores de $\mathrm{pH}$ se mantienen estables desde 2013, lo cual puede observarse en los resultados registrados de los parámetros mencionados. Dichas variaciones pueden deberse a las variaciones registradas en el $\mathrm{pH}$, siendo un factor muy influyente en la biodisponibilidad de metales.

\subsection{EVOLUCIÓN 2013-2017 DE LOS RESULTADOS FÍSICO-QUímicos EN SEDIMENTOS}

A continuación se muestra la evolución temporal 2013-2017 de los resultados físicoquímicos de $\mathrm{pH}$, conductividad eléctrica, textura (arena, limo y arcilla), nitrógeno total, carbonatos, carbono orgánico, carbono soluble, capacidad de intercambio catiónico, cationes intercambiables (calcio, magnesio, potasio sodio), fósforo biodisponible y aniones (nitratos, cloruros y sulfatos). 
Capítulo 5. ESTUDIO DE FITOEXTRACCIÓN DE Cu, Zn Y Cr CON VEGETACIÓN AUTÓCTONA EN EL CAUCE DEL RÍO GUADALENTÍN

2013
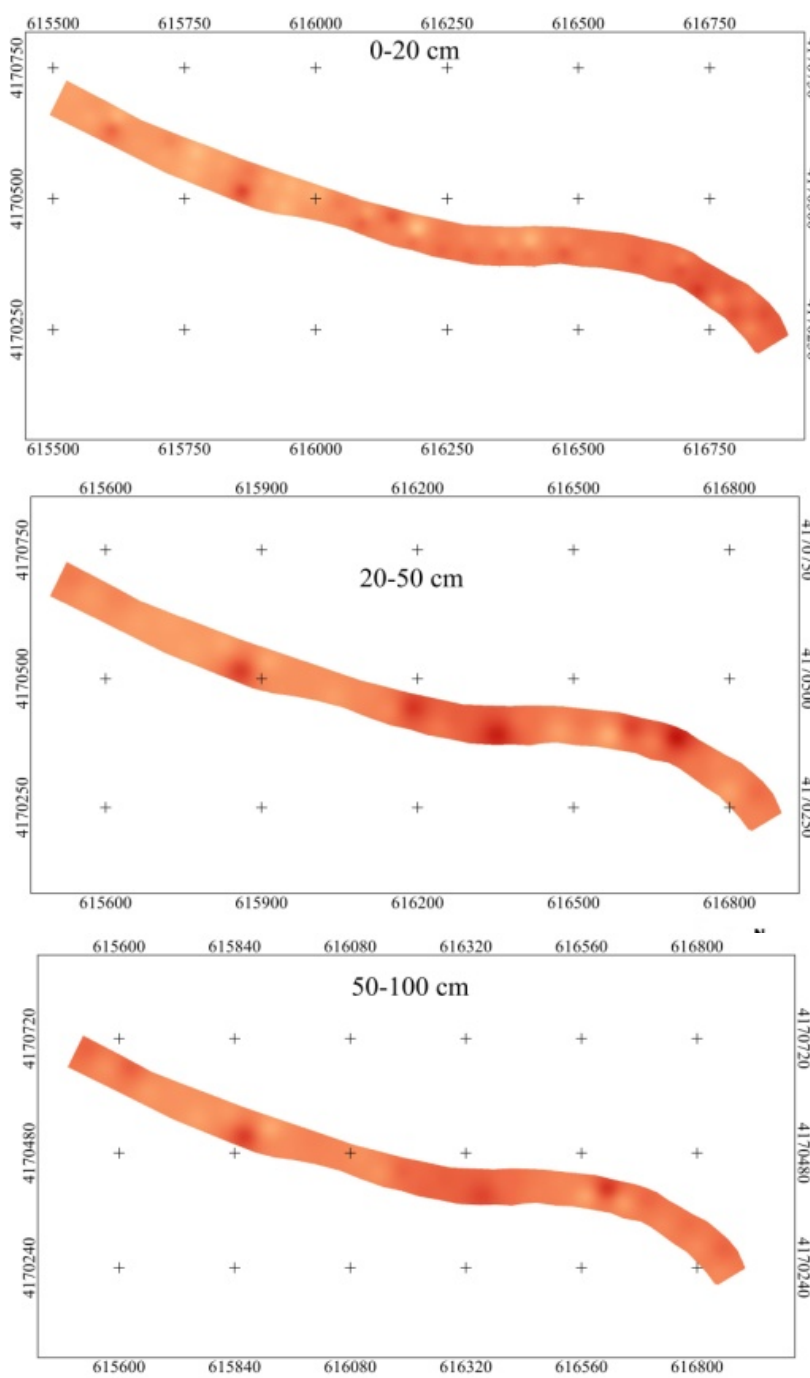

$\mathrm{pH}$
$<=7 \quad=7,8-8,2$
$7-7,4=8,2-8,6$
$7,4-7,8=8,6$

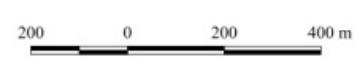

2 $400 \mathrm{~m}$

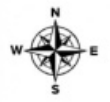

2017
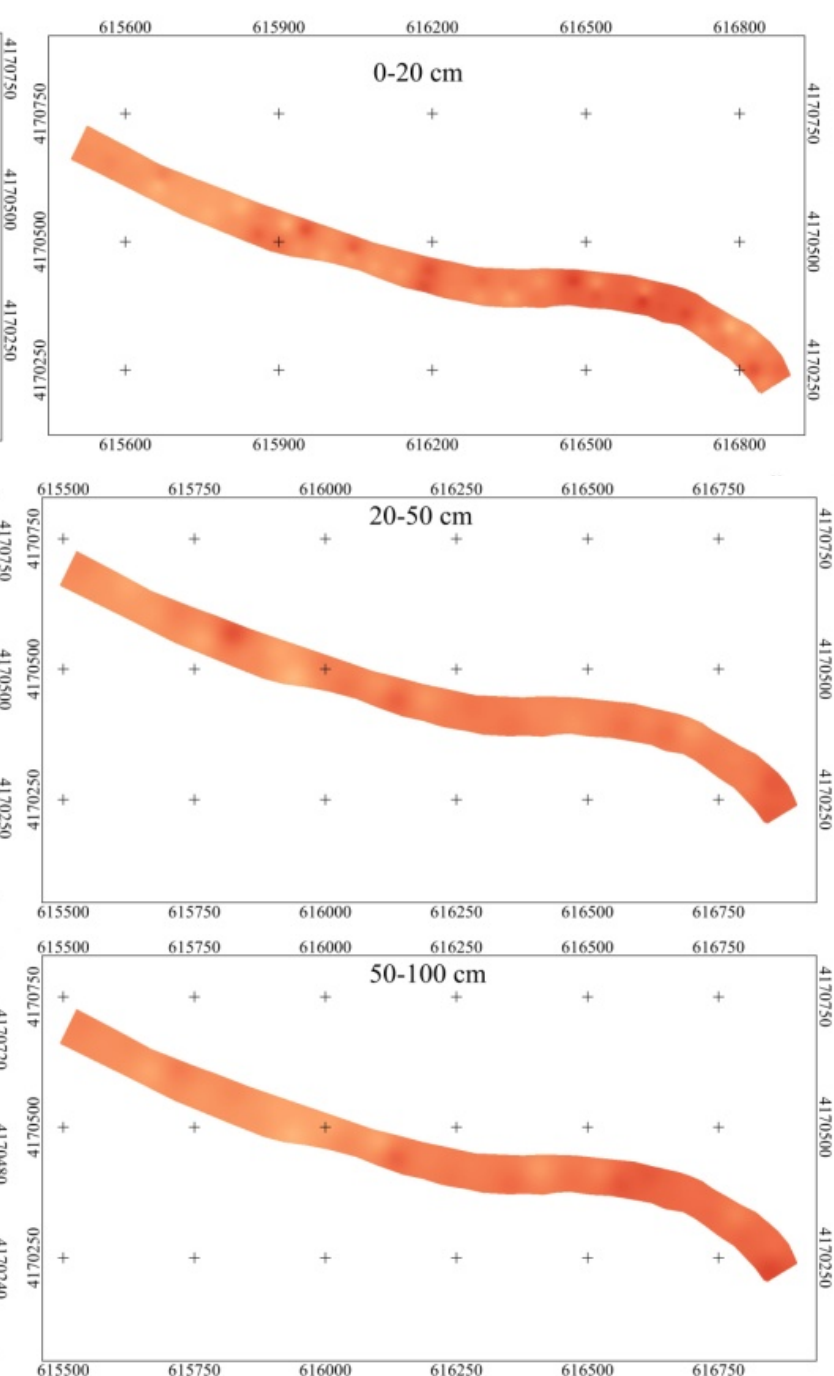

$\mathrm{pH}$

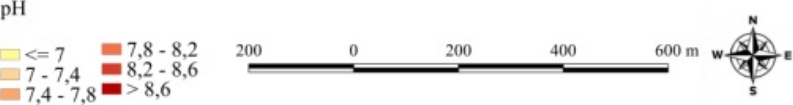

Figura 5.5.1. Evolución de la distribución espacial del pH en los tramos 1, 2 y 3 (1500 m) entre los años 2013 y 2017. 
$\underline{p H:}$

La movilidad de los iones metálicos en el suelo depende principalmente del pH del suelo, a $\mathrm{pH}$ ácidos los metales se vuelven más solubles y por lo tanto más biodisponibles para su extracción por las plantas mientras que a pH básico el metal se queda retenido en el suelo (Rieuwerts et al., 1998). En el año 2013 se registraron valores promedio de $\mathrm{pH}$ de 8,07 (comprendidos entre $7,58-8,61)$, 8,06 $(7,65-8,42)$ y $8,09(7,68-8,51)$ en los horizontes de 0 $20 \mathrm{~cm}, 20-50 \mathrm{~cm}$ y $50-100 \mathrm{~cm}$ respectivamente.

Para el año 2017 se han registrado valores promedio de $\mathrm{pH}$ de 8,08 (comprendidos entre $7,70-8,59), 8,11(7,75-8,85)$ y $8,12(7,79-8,64)$ en los horizontes de $0-20 \mathrm{~cm}, 20-50 \mathrm{~cm}$ y $50-$ $100 \mathrm{~cm}$ respectivamente. Tras el periodo de fitoextracción 2013-2017 los mapas de distribución no muestran variaciones significativas de los valores de $\mathrm{pH}$ en los horizontes muestreados. Con respecto las asociaciones entre parámetros, para el pH se han registrado correlaciones con los siguientes parámetros: fosforo biodisponible $(r=-0,56)$, manganeso biodisponible $(r=-0,52)$, zinc intercambiable $(r=-0,56)$, ureasa $(r=-0,34)$ y zinc soluble $(r=+0,62)$. Los sedimentos del cauce fluvial son básicos en todos los casos, con valores entre 7,50 y 9,00. Estos niveles altos de $\mathrm{pH}$ son los que condicionan la baja movilidad y disponibilidad del cobre y el zinc, ya que favorecen su precipitación. El cromo no muestra una dependencia tan directa con el $\mathrm{pH}$, siendo también móvil con valores de $\mathrm{pH}>8$. Lo que condiciona con mayor intensidad la movilidad del cromo es su estado de oxidación, siendo el cromo (VI) altamente móvil y tóxico, pero el cromo (III) presenta muy baja movilidad y disponibilidad al ser fuertemente retenido por las partículas del suelo. La mayor proporción del cromo en los suelos se encuentra en forma reducida (cromo (III)), con muy baja biodisponibilidad, como se pone de manifiesto en este estudio sobre los sedimentos del Río Guadalentín. No obstante, en medios alcalinos y en condiciones aerobias como las que se dan en el lecho del Guadalentín, puede ocurrir la oxidación del cromo (III) a cromo (VI). Esta oxidación es más intensa a temperaturas altas. Se ha observado además en diferentes trabajos consultados que la oxidación de cromo (III) a cromo (VI) suele ser frecuente en suelos alcalinos, pobres en materia orgánica, con alto contenido en humedad y en presencia de óxidos de manganeso. Los sedimentos del cauce fluvial estudiado presentan $\mathrm{pH}$ alcalino y bajo contenido en materia orgánica, por lo que en épocas de lluvia y altas temperaturas se puede producir la oxidación del cromo (III) mayoritario a cromo (VI), favoreciendo su movilidad y por tanto su lavado con las aguas de escorrentía y lixiviación. 
Capítulo 5. ESTUDIO DE FITOEXTRACCIÓN DE Cu, Zn Y Cr CON VEGETACIÓN AUTÓCTONA EN EL CAUCE DEL RÍO GUADALENTÍN

2013
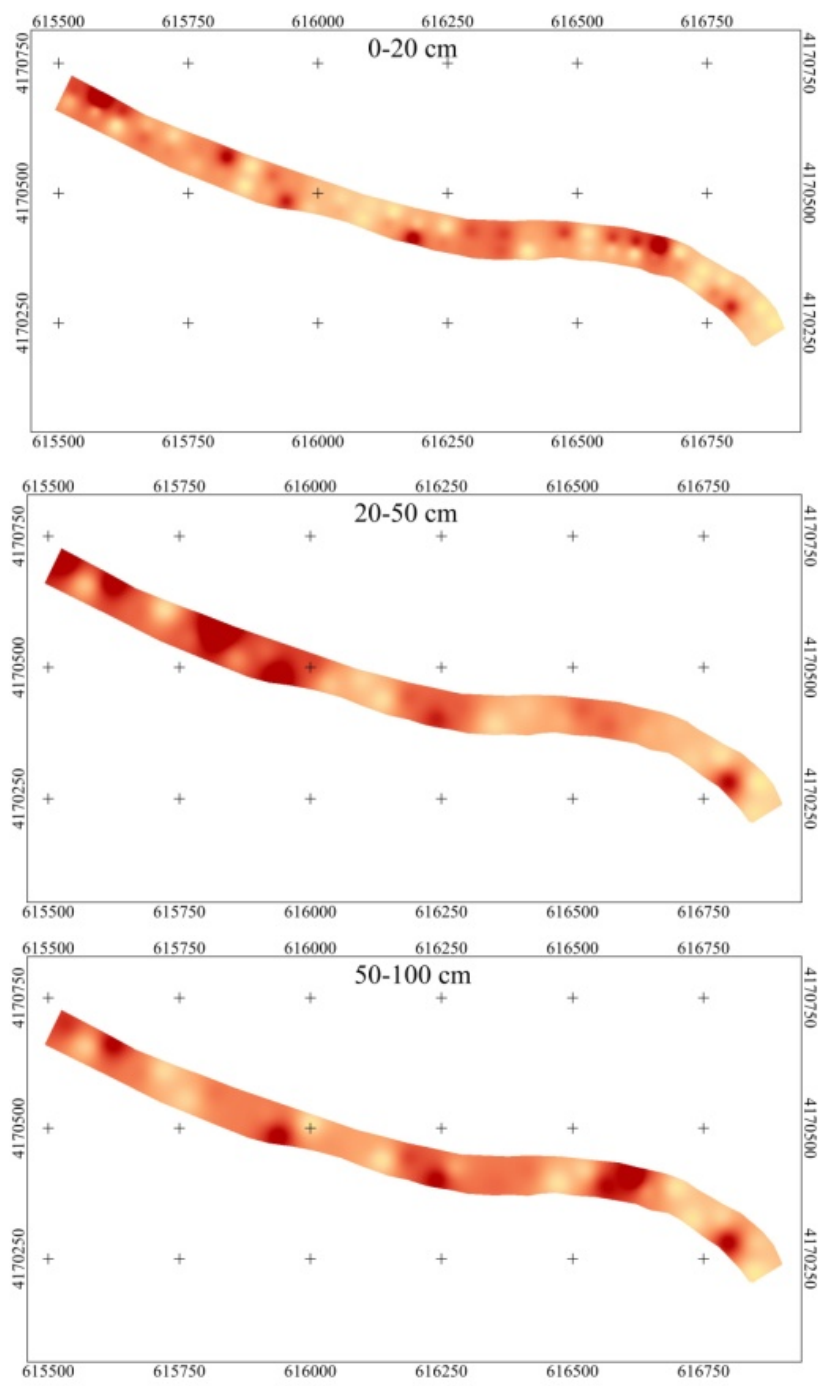

$\mathrm{CE}(\mathrm{mS} / \mathrm{cm})$

$\square=0 \quad=1,6-2,4$
$0-0,8=2,4-3,2$
$0,8-1,6=3,2$
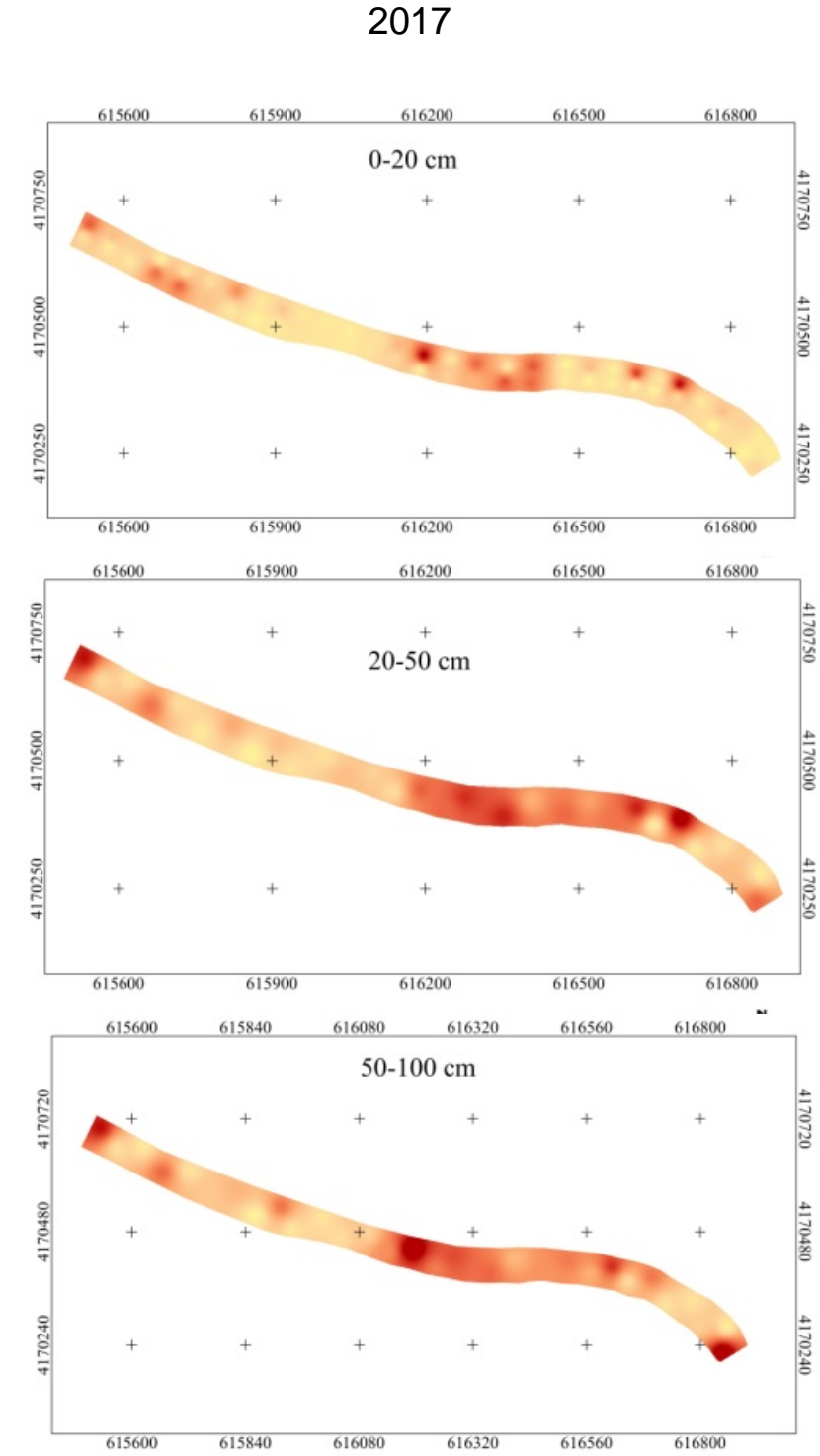

$\mathrm{CE}(\mathrm{mS} / \mathrm{cm})$ $\square=0$
$\square=0,8=1,6-2,4$
$0,0=2,4-3,2$
$0,8-1,6=3,2$
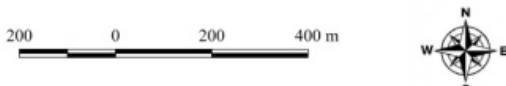

Figura 5.5.2. Evolución de la distribución espacial de la conductividad eléctrica en los tramos 1,2 y 3 (1500 m) entre los años 2013 y 2017. 


\section{Conductividad eléctrica (CE):}

Las sales, y por ello la conductividad eléctrica influye en la movilidad de los iones metálicos en el suelo (Rieuwerts et al., 1998). La CE representa el nivel de salinidad del medio. En el año 2013 se registraron valores promedio de 1,84 mS/cm (comprendidos entre 0,23-7,11 $\mathrm{mS} / \mathrm{cm}), 2,26 \mathrm{mS} / \mathrm{cm}(0,28-7,20 \mathrm{mS} / \mathrm{cm})$ y $2,36 \mathrm{mS} / \mathrm{cm}(0,35-9,75 \mathrm{mS} / \mathrm{cm})$ en los horizontes de $0-20 \mathrm{~cm}, 20-50 \mathrm{~cm}$ y $50-100 \mathrm{~cm}$ respectivamente. Un suelo se considera salino por encima de $2 \mathrm{mS} / \mathrm{cm}$, por lo que el sedimento del lecho para el año 2013 puede considerarse salino en su mayor parte, sobre todo a profundidades entre 20-100 cm. Por tanto, las plantas a introducir en el lecho deberán de adaptarse a la salinidad.

En el año 2017 se han registrado valores promedio de 0,55 mS/cm (comprendidos entre 0,14-1,94 mS/cm), 0,75 mS/cm (0,13-1,66 mS/cm) y 0,81 mS/cm $(0,15-1,91 \mathrm{mS} / \mathrm{cm})$ en los horizontes de $0-20 \mathrm{~cm}, 20-50 \mathrm{~cm}$ y $50-100 \mathrm{~cm}$ respectivamente. Tras el periodo de fitoextracción 2013-2017 los mapas de distribución muestran una disminución significativa de la CE en todos los horizontes muestreados entre los años 2013 y 2017. Con respecto las asociaciones entre parámetros se ha registrado una correlación destacable entre la CE y el $\mathrm{pH}\left(r=-0,50^{\star \star}\right)$. Conforme disminuyen los valores de $\mathrm{pH}$ aumentan los valores de la $\mathrm{CE}$, sin embargo, según los resultados registrados, esto solamente se cumple en el horizonte de 20-50 cm (en el resto de horizontes los valores de la CE disminuyen al igual que el pH). 
Capítulo 5. ESTUDIO DE FITOEXTRACCIÓN DE Cu, Zn Y Cr CON VEGETACIÓN AUTÓCTONA EN EL CAUCE DEL RÍO GUADALENTÍN

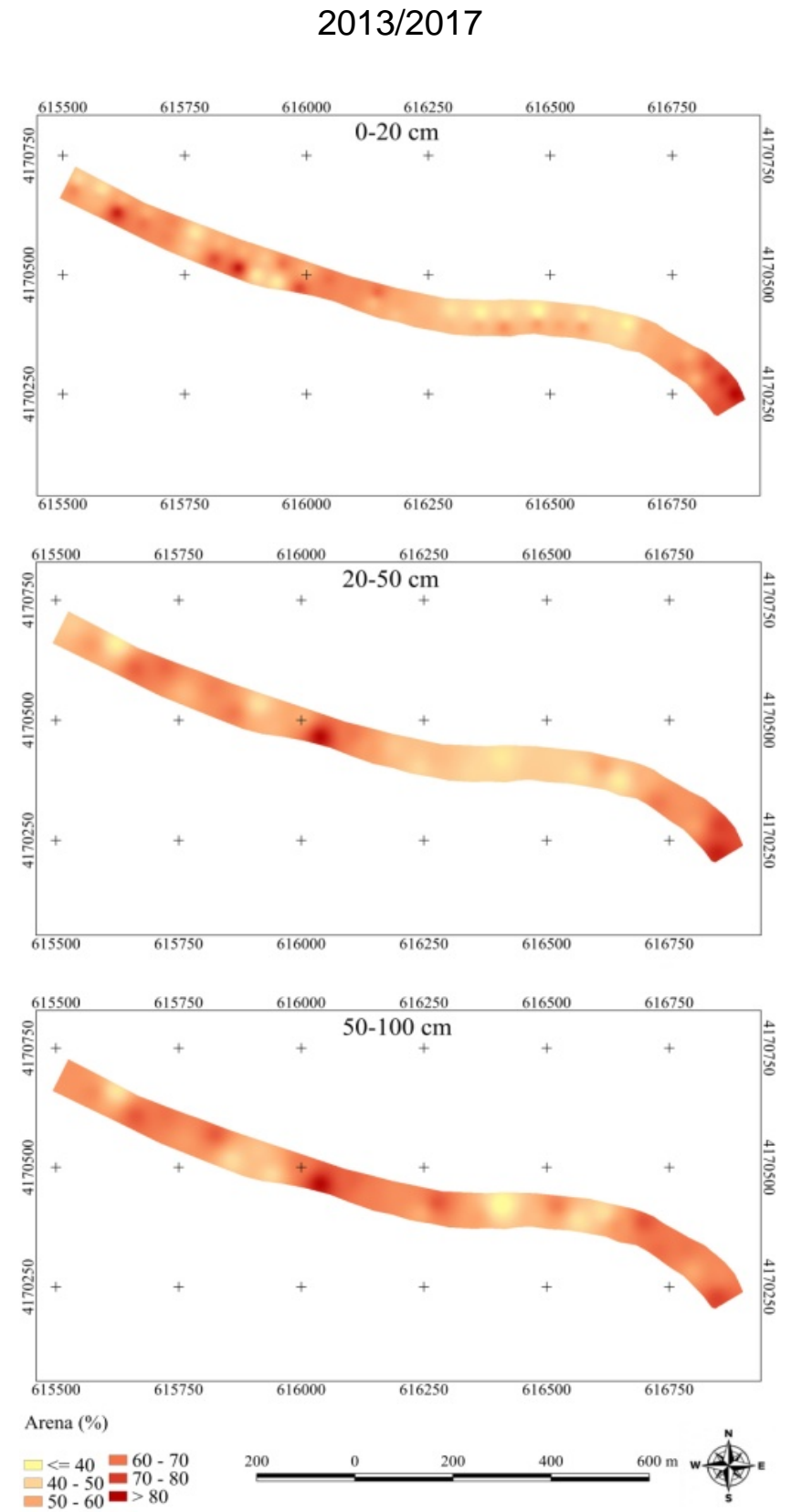

Figura 5.5.3. Evolución de la distribución espacial del porcentaje de arena en los tramos 1, 2 y $3(1500$ m) entre los años 2013 y 2017. 
Capítulo 5. ESTUDIO DE FITOEXTRACCIÓN DE Cu, Zn Y Cr CON VEGETACIÓN AUTÓCTONA EN EL CAUCE DEL RÍO GUADALENTÍN

$2013 / 2017$
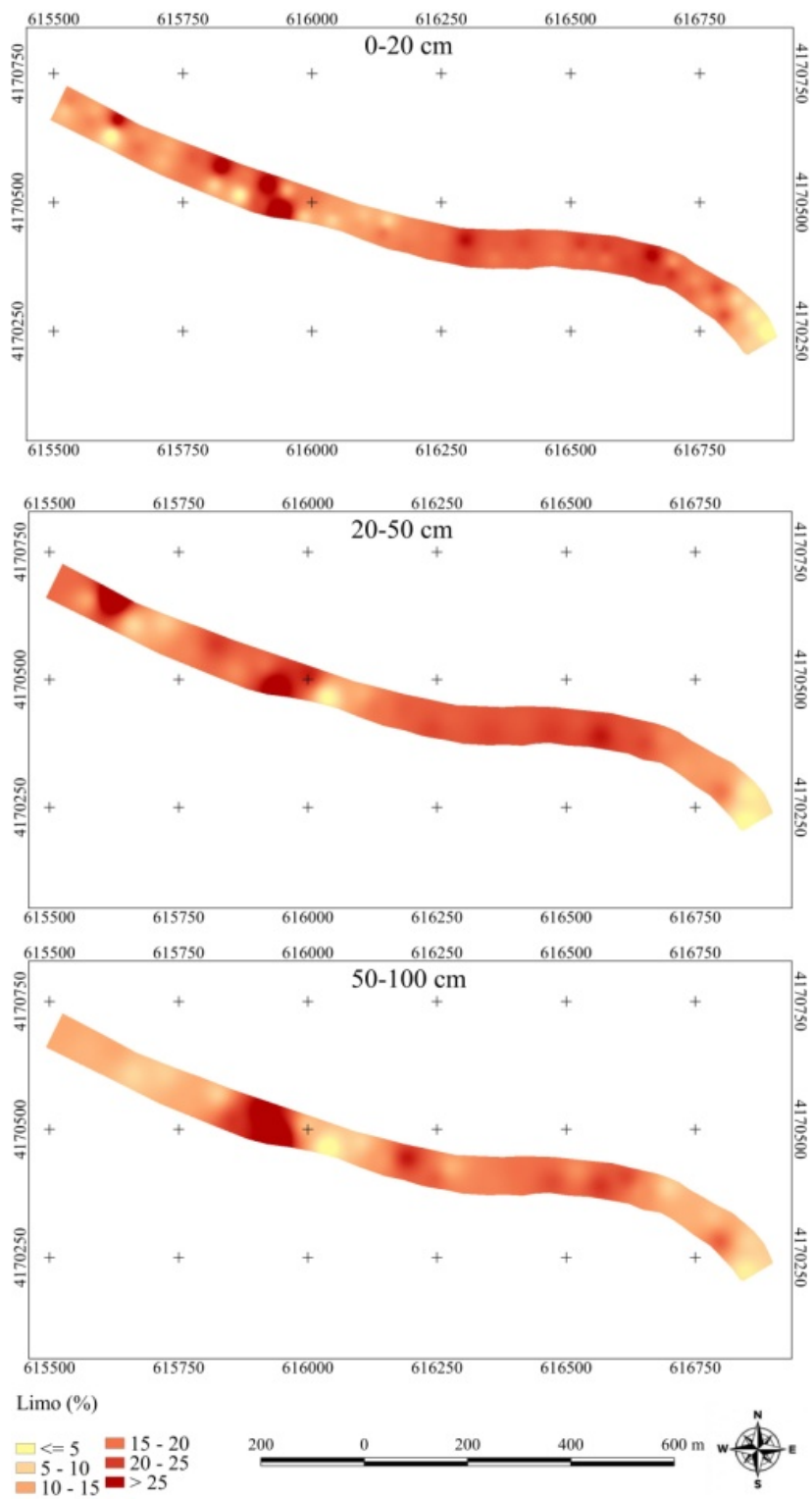

Figura 5.5.4. Evolución de la distribución espacial de porcentaje de limo en los tramos 1, 2 y 3 (1500 m) entre los años 2013 y 2017. 
Capítulo 5. ESTUDIO DE FITOEXTRACCIÓN DE Cu, Zn Y Cr CON VEGETACIÓN AUTÓCTONA EN EL CAUCE DEL RÍO GUADALENTÍN

$2013 / 2017$
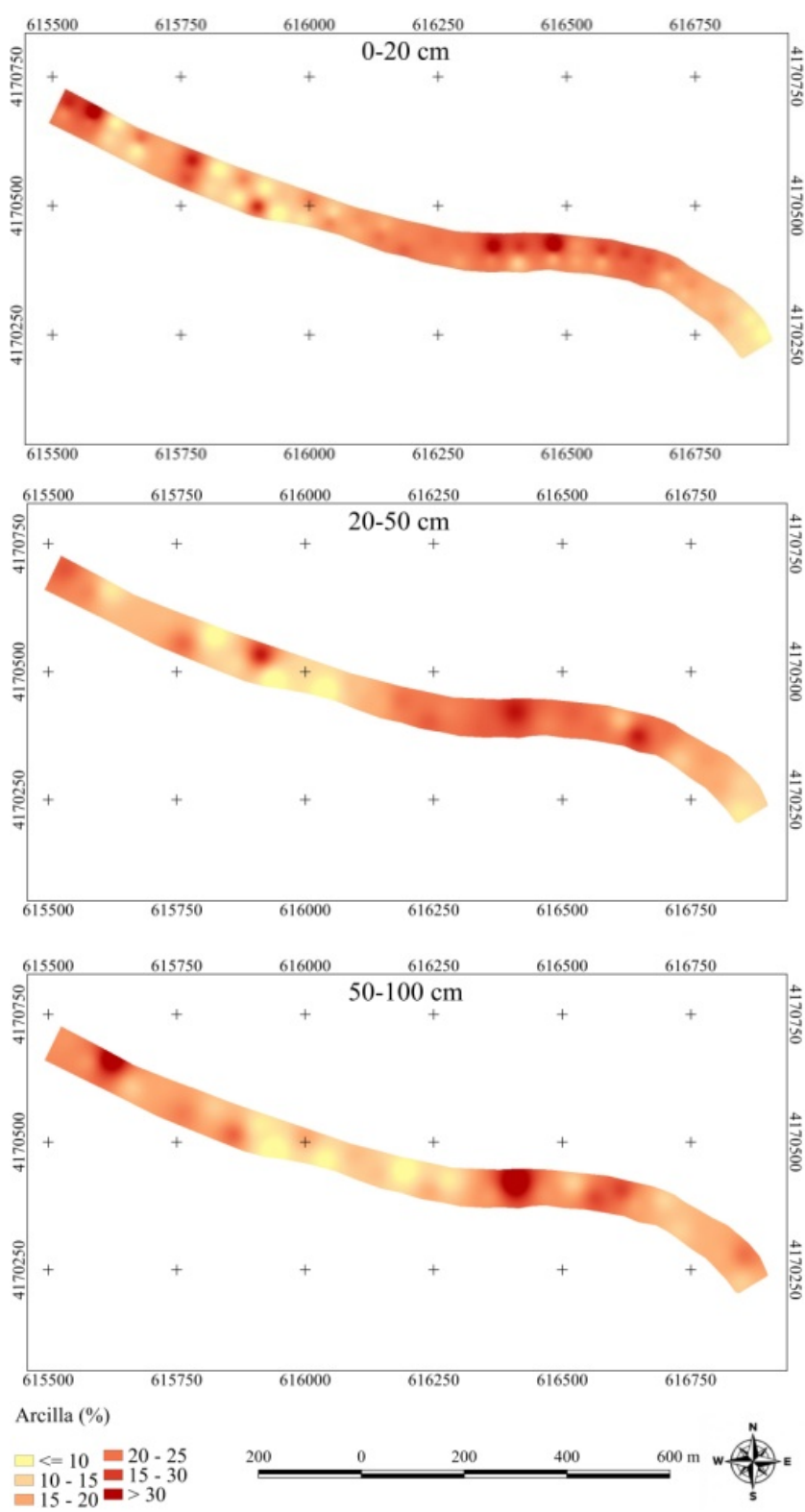

Figura 5.5.5. Evolución de la distribución espacial del porcentaje de arcilla en los tramos 1, 2 y 3 (1500 m) entre los años 2013 y 2017. 


\section{Porcentajes de arena, limo y arcilla:}

La textura del sedimento, es decir, su contenido de arena, limo y arcilla es importante para seleccionar las especies a introducir, así como para evaluar la capacidad del medio para retener nutrientes y metales pesados, ya que los suelos con mayores contenidos de arcilla tienen mayor capacidad de adsorber cationes, pero si su contenido es muy alto puede dificultar el desarrollo de la vegetación. Por otro lado, la textura es una propiedad física que apenas sufre variaciones con el paso de tiempo, siendo considerado un parámetro físico bastante estable. Para la caracterización de las muestras de sedimento del año 2017 y la realización de las pruebas estadísticas se han usado los datos de las clases texturales obtenidos el año 2013.

Con respecto a las correlaciones registradas se han encontrado correlaciones negativas entre el porcentaje de arena y los siguientes parámetros: arcilla $\left(r=-0,59^{\star *}\right)$, limo $\left(r=-0,81^{\star *}\right)$ y magnesio intercambiable $\left(r=-0,50^{\star \star}\right)$. No se han encontrado relaciones fuertes y directas entre los porcentajes de arena, limo y arcilla y las concentraciones de metales totales. 
Capítulo 5. ESTUDIO DE FITOEXTRACCIÓN DE Cu, Zn Y Cr CON VEGETACIÓN AUTÓCTONA EN EL CAUCE DEL RÍO GUADALENTÍN

2013
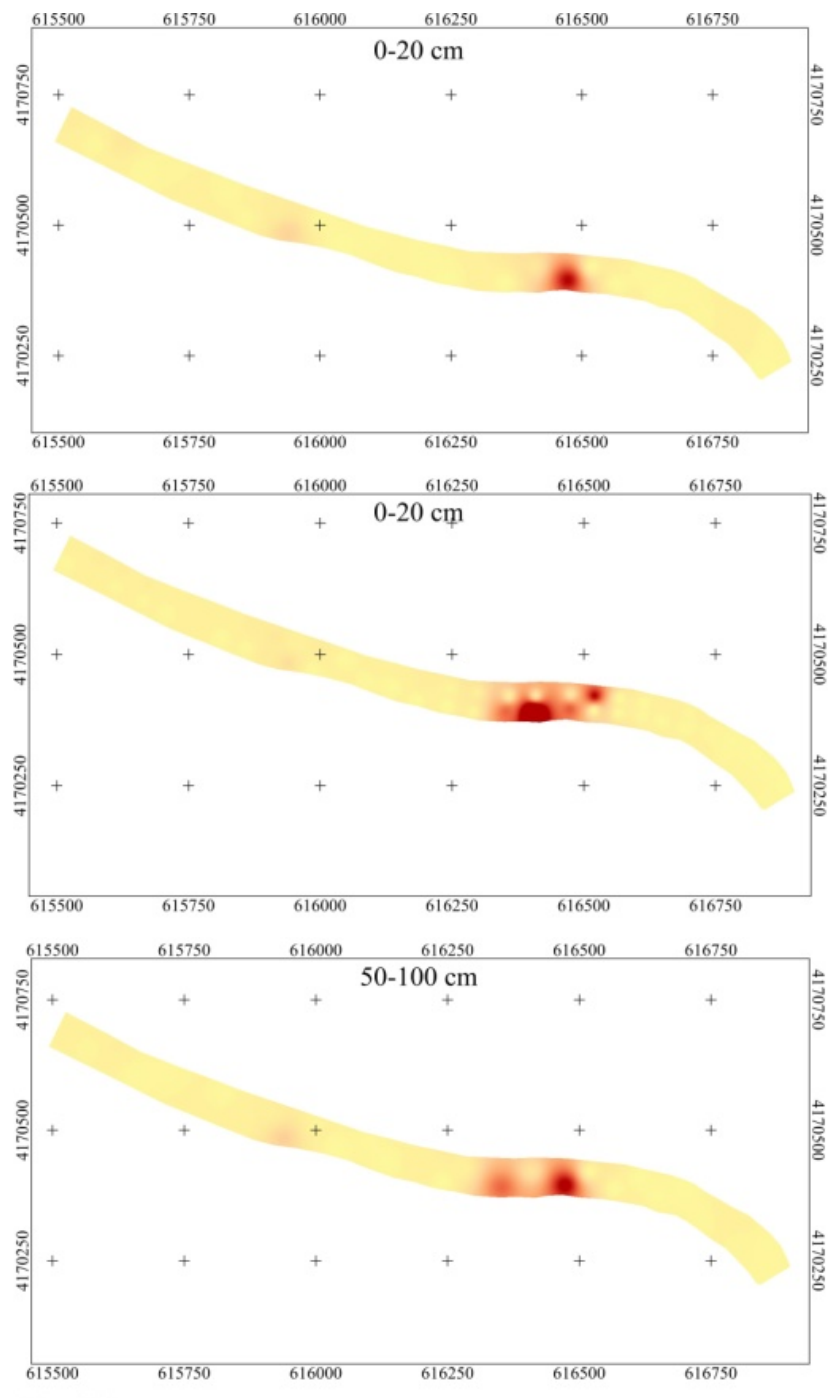

N Total (\%)

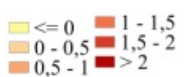

2017
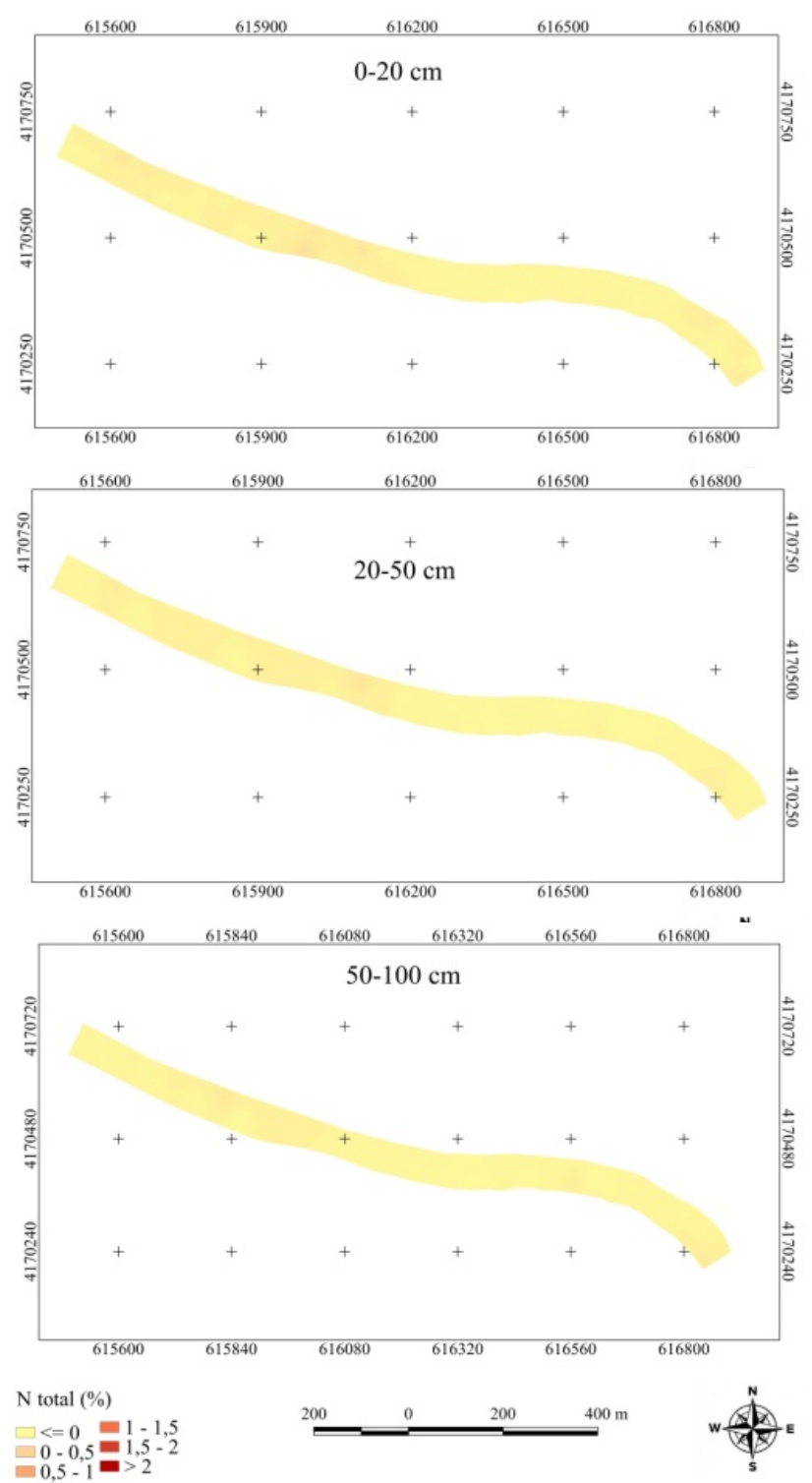

Figura 5.5.7. Evolución de la distribución espacial del porcentaje de nitrógeno total en los tramos 1, 2 y 3 (1500 m) entre los años 2013 y 2017. 


\section{Porcentaje de nitrógeno total:}

En el año 2013 se registraron valores promedio de 0,29\% (comprendidos entre 0,02-6,50\%), $0,17 \%(0,02-2,50 \%)$ y $0,23 \%(0,02-2,70 \%)$ en los horizontes de $0-20 \mathrm{~cm}, 20-50 \mathrm{~cm}$ y $50-100$ $\mathrm{cm}$ respectivamente. Los valores registrados de nitrógeno total son bastante bajos en todo el cauce, con un promedio de $0,20 \%$. Sorprende el alto contenido de nitrógeno total en el subtramo del cauce de los últimos $200 \mathrm{~m}$ de longitud en las tres profundidades, con valores superiores a 0,30\%. Estos mayores valores podrían deberse a lixiviaciones por parte de campo agrícolas adyacentes abonados. Este tramo coincide además con las concentraciones más bajas de metales pesados en su contenido total y en todas sus fracciones, aunque no existe relación directa entre el contenido de nitrógeno total y el contenido de metales pesados en ninguna de sus fracciones. Los valores de nitrógeno total podrían mejorarse mediante la aplicación de prácticas agrícolas para mejorar la eficiencia de fitoextracción y junto con la realización de riegos de emergencia se podría aumentar el volumen de biomasa vegetal fitoextractora.

En el año 2017 se han registrado valores promedio de 0,10\% (comprendidos entre 0,030,35\%), 0,08\% (0,02-0,25\%) y 0,08\% (0,02-0,21\%) en los horizontes de 0-20 cm, $20-50 \mathrm{~cm}$ y 50-100 cm respectivamente. Tras el periodo de fitoextracción 2013-2017 los mapas de distribución muestran una disminución del porcentaje de nitrógeno total en los horizontes muestreados, aunque no es significativa. El nitrógeno es un macronutriente fundamental para las plantas, con lo que una buena cantidad de este favorecerá el desarrollo de las especies y su posibilidad de fitoextracción de los metales contaminantes como son el $\mathrm{Cu}$, Zn y Cr. Se observa una disminución, la que estadísticamente no le podemos atribuir la baja extracción de los metales, sin embargo esto junto con otros factores si puede formar parte de la causa. Con respecto a las asociaciones entre parámetros no se han registrado correlaciones destacables entre el nitrógeno total y el resto de parámetros analizados. 
Capítulo 5. ESTUDIO DE FITOEXTRACCIÓN DE Cu, Zn Y Cr CON VEGETACIÓN AUTÓCTONA EN EL CAUCE DEL RÍO GUADALENTÍN

2013
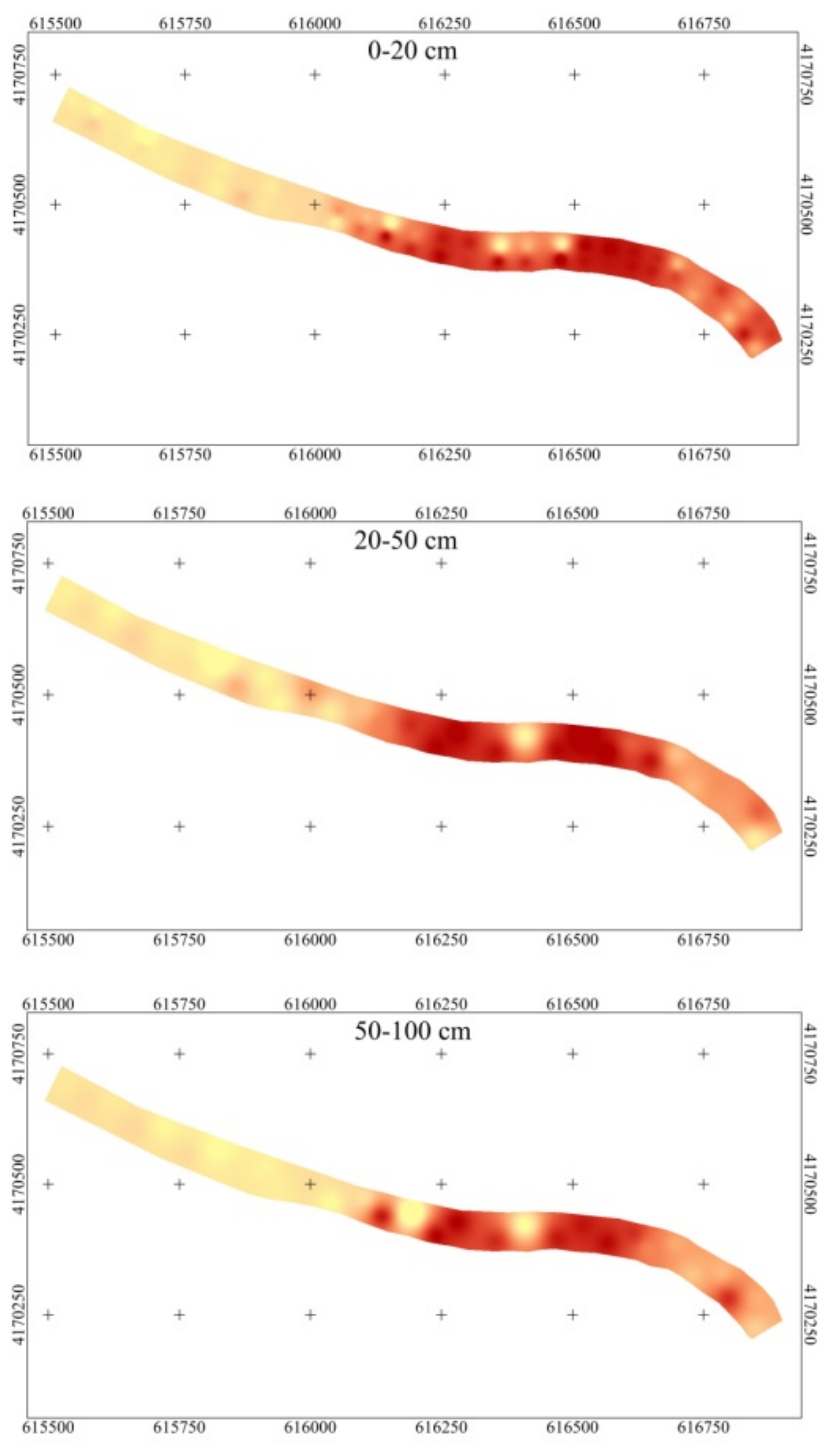

Carbonatos (\%)

$\square<=35=45-50$

$35-40=50-55$

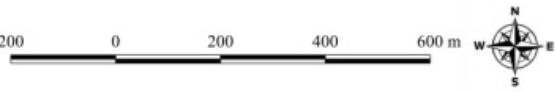

Figura 5.5.8. Evolución de la distribución espacial del porcentaje de carbonatos en los tramos 1, 2 y 3 (1500 m) entre los años 2013 y 2017.
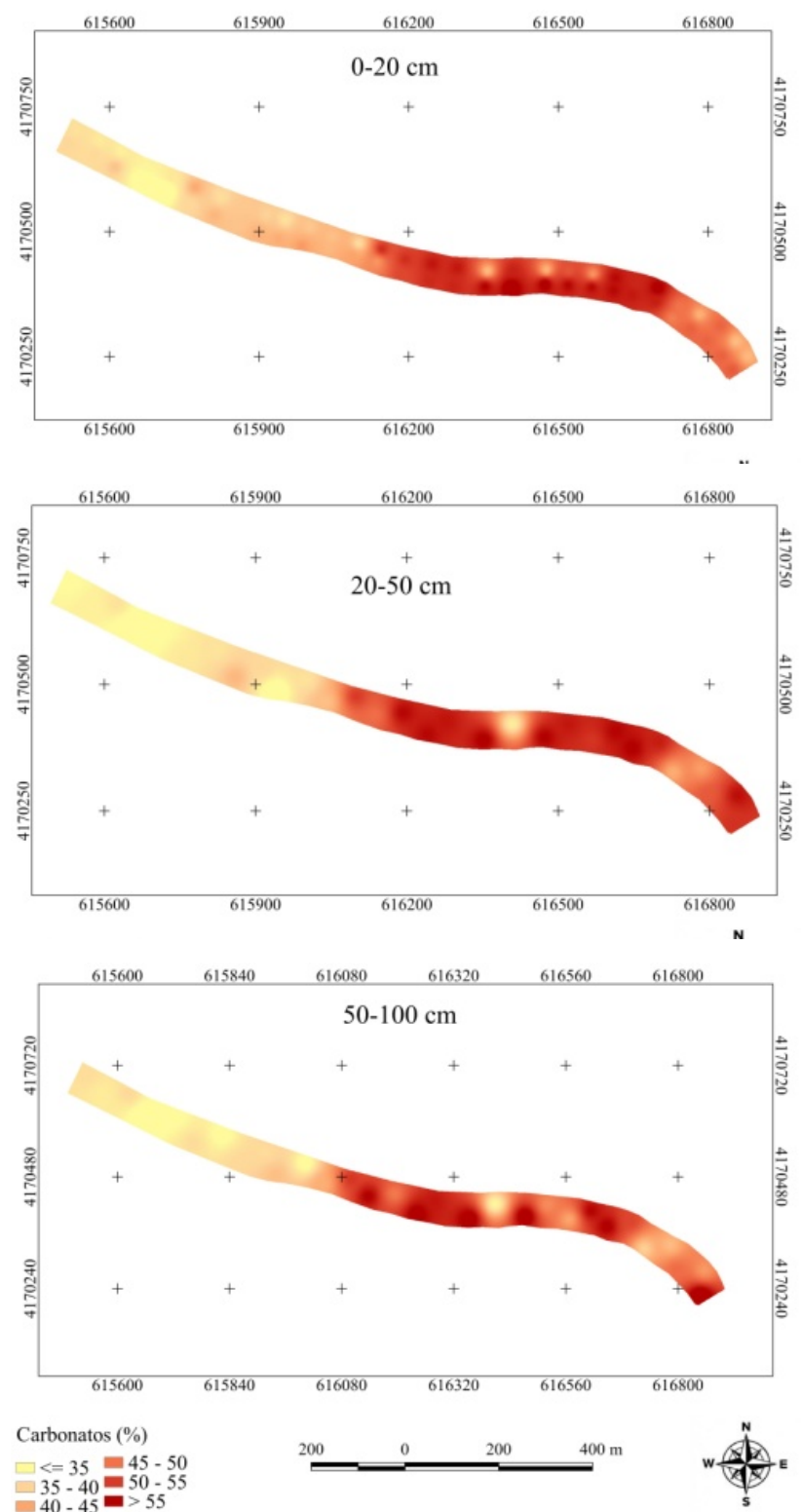

2017

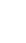




\section{Porcentaje de carbonatos:}

En el año 2013 se registraron valores promedio de 46,54\% (comprendidos entre 31,67$62,33 \%), 45,76 \%(29,25-63,96 \%)$ y $44,18 \%(25,84-60,36 \%)$ en los horizontes de $0-20 \mathrm{~cm}$, 20-50 cm y 50-100 cm respectivamente. El contenido de carbonato cálcico es elevado, encontrándose por encima del $35 \%$ en casi todo el cauce en las tres profundidades estudiadas.

Para el año 2017 se han registrado valores promedio de 47,71\% (comprendidos entre $28,08-63,81 \%), 47,55 \%(27,75-60,65 \%)$ y $46,81 \%(29,99-64,34 \%)$ en los horizontes de $0-20$ cm, 20-50 cm y 50-100 cm respectivamente. Tras el periodo de fitoextracción 2013-2017 los mapas de distribución muestran un aumento no significativo del porcentaje de carbonatos en todos los horizontes muestreados. Con respecto las asociaciones entre parámetros, no se ha registrado ninguna correlación destacable $(r \geq 0,50)$ entre los parámetros estudiados. 
Capítulo 5. ESTUDIO DE FITOEXTRACCIÓN DE Cu, Zn Y Cr CON VEGETACIÓN AUTÓCTONA EN EL CAUCE DEL RÍO GUADALENTÍN

2013
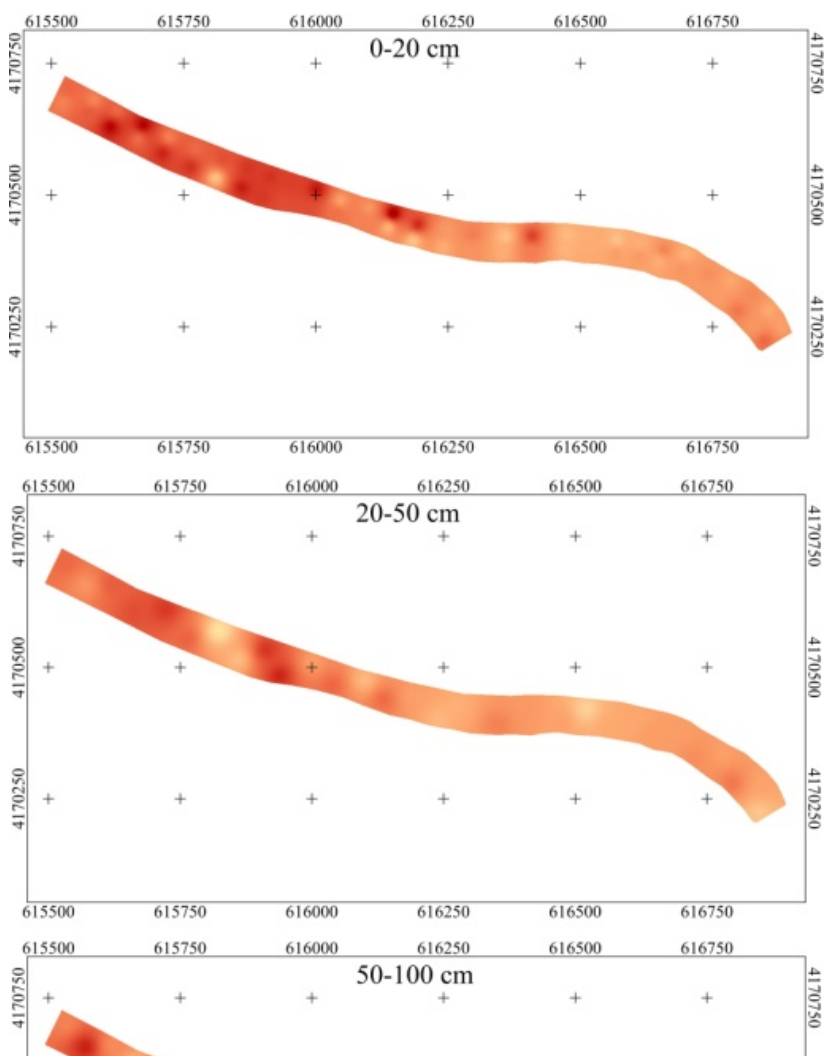

\&

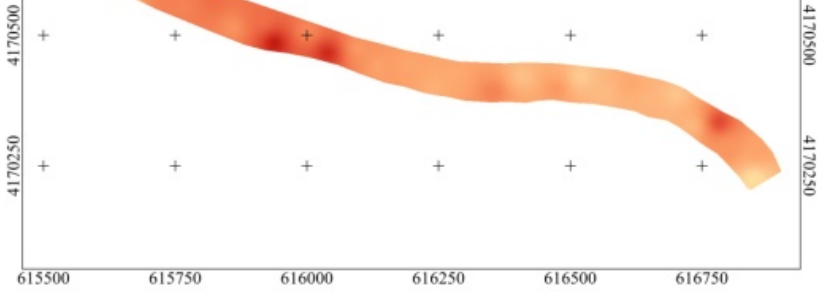

$\mathrm{CO}(\%)$

$\square=0$
$0-0,5$
$0,5-1,1,5$
0,5
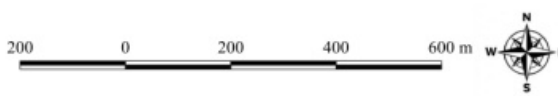

2017
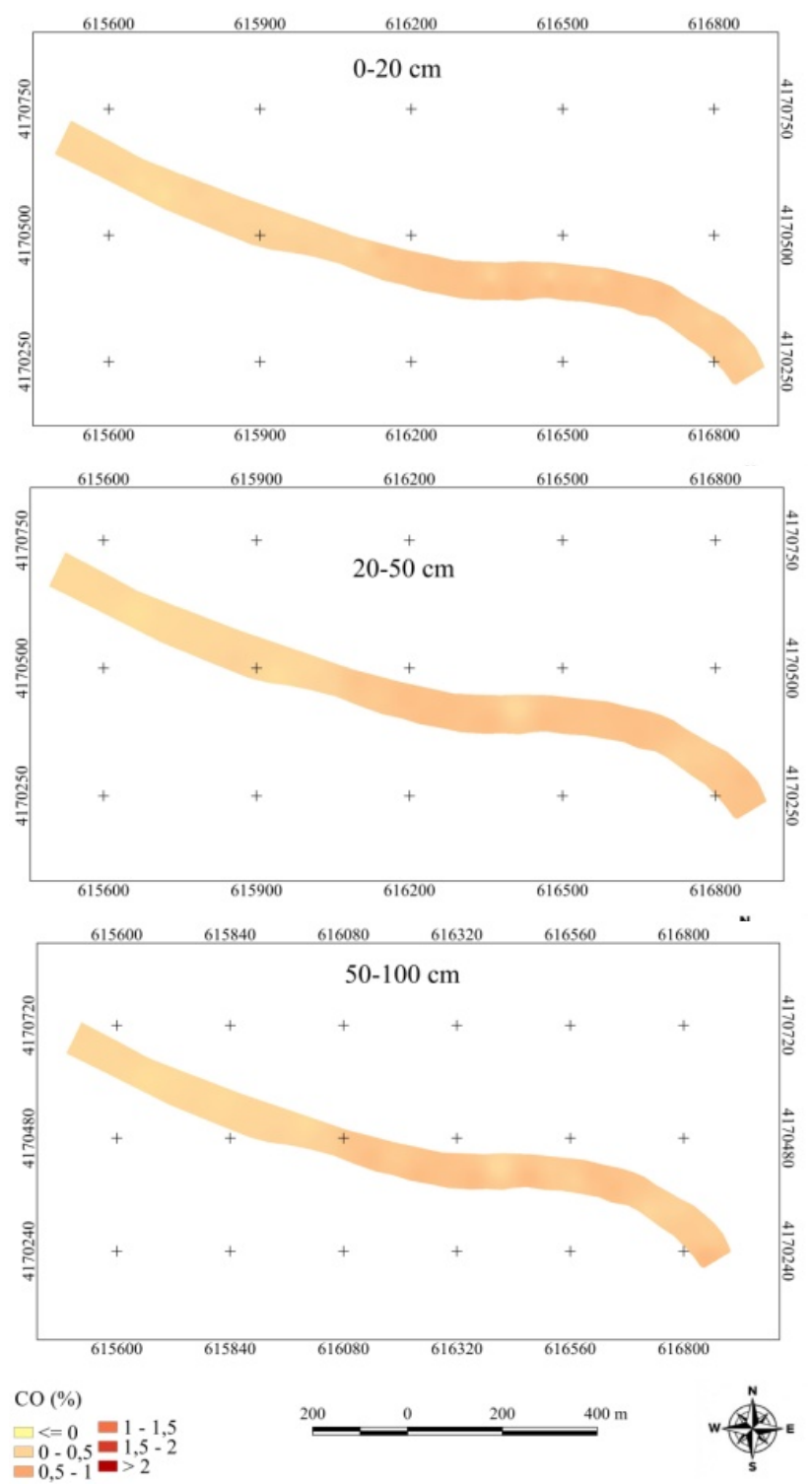

Figura 5.5.11. Evolución de la distribución espacial del porcentaje de carbono orgánico en los tramos 1, 2 y 3 (1500 m) entre los años 2013 y 2017. 


\section{Porcentaje de carbono orgánico:}

En el año 2013 se registraron valores promedio de 1,40\% (comprendidos entre 0,64-2,68\%), $1,21 \%(0,29-2,18 \%)$ y $1,17 \%(0,35-2,27 \%)$ en los horizontes de $0-20 \mathrm{~cm}, 20-50 \mathrm{~cm}$ y $50-100$ $\mathrm{cm}$ respectivamente. El contenido en carbono orgánico es bajo en la mayor parte del cauce, con valores entre $0.30-3,00 \%$ en casi toda su superficie. Dicho contenido está directamente relacionado con el contenido de materia orgánica del suelo (\% materia orgánica = \% carbono orgánico $\times 1,724$ ), el contenido de materia orgánica influirán en la tendencia del metal a existir en forma iónica y disponible en la planta, con el aumento del carbono orgánico obtenemos un mayor índice de fitorremediación, debido a un desarrollo de la vegetación más pronunciada y un aumento de la disponibilidad de los metales para estas.

En el año 2017 se han registrado valores promedio de 0,57\% (comprendidos entre 0,34$0,77 \%), 0,57 \%(0,33-0,73 \%)$ y $0,56 \%(0,36-0,77 \%)$ en los horizontes de $0-20 \mathrm{~cm}, 20-50 \mathrm{~cm}$ y 50-100 cm respectivamente. Tras el periodo de fitoextracción 2013-2017 los mapas de distribución muestran una disminución significativa del porcentaje de carbono orgánico en todos los horizontes muestreados $(0-20 \mathrm{~cm}, 20-50 \mathrm{~cm}$ y $50-100 \mathrm{~cm})$. Con respecto a las asociaciones entre parámetros, no se han registrado correlaciones destacables con el porcentaje de carbono orgánico y el resto de parámetros analizados. 
Capítulo 5. ESTUDIO DE FITOEXTRACCIÓN DE Cu, Zn Y Cr CON VEGETACIÓN AUTÓCTONA EN EL CAUCE DEL RIOO GUADALENTÍN

2013

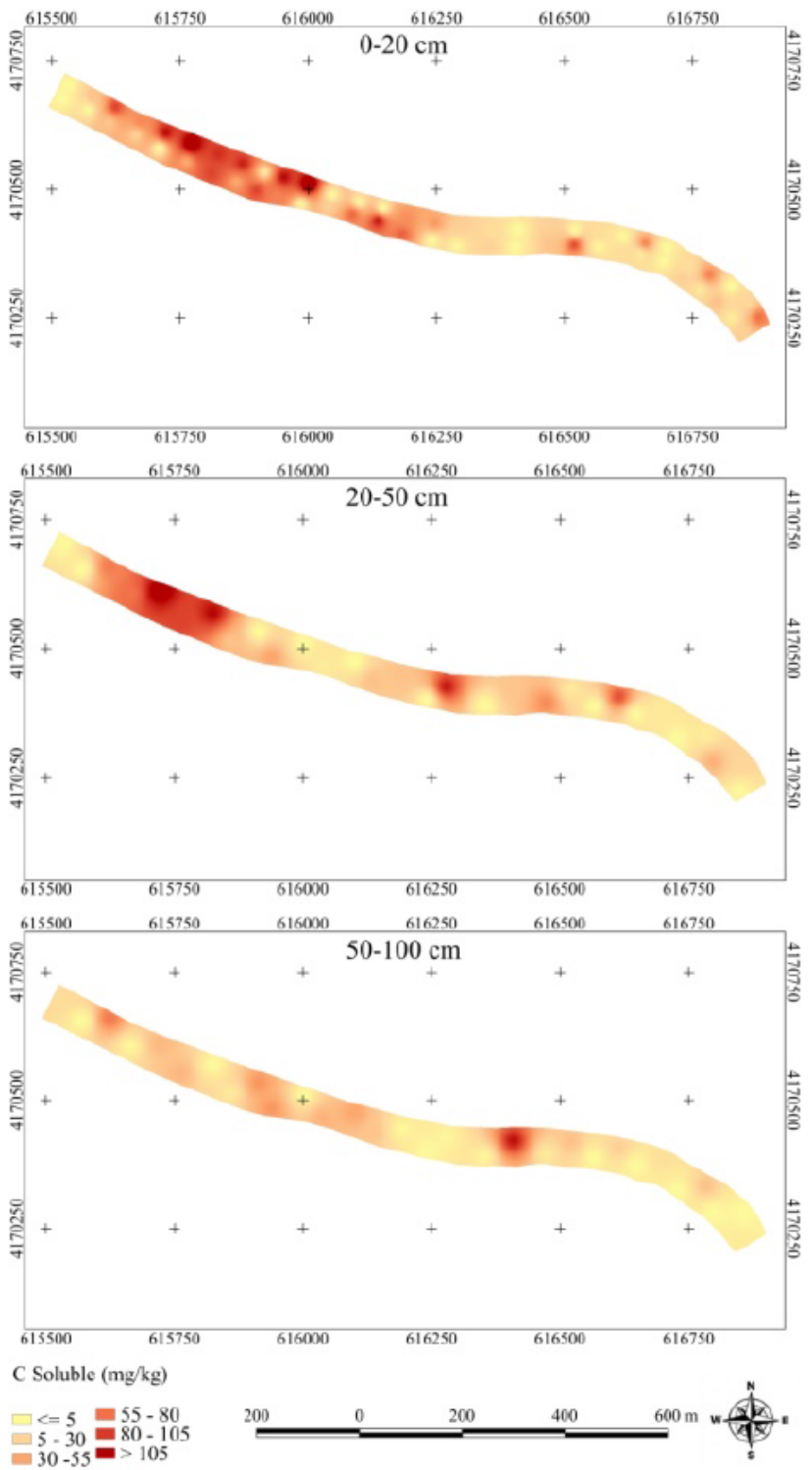

2017

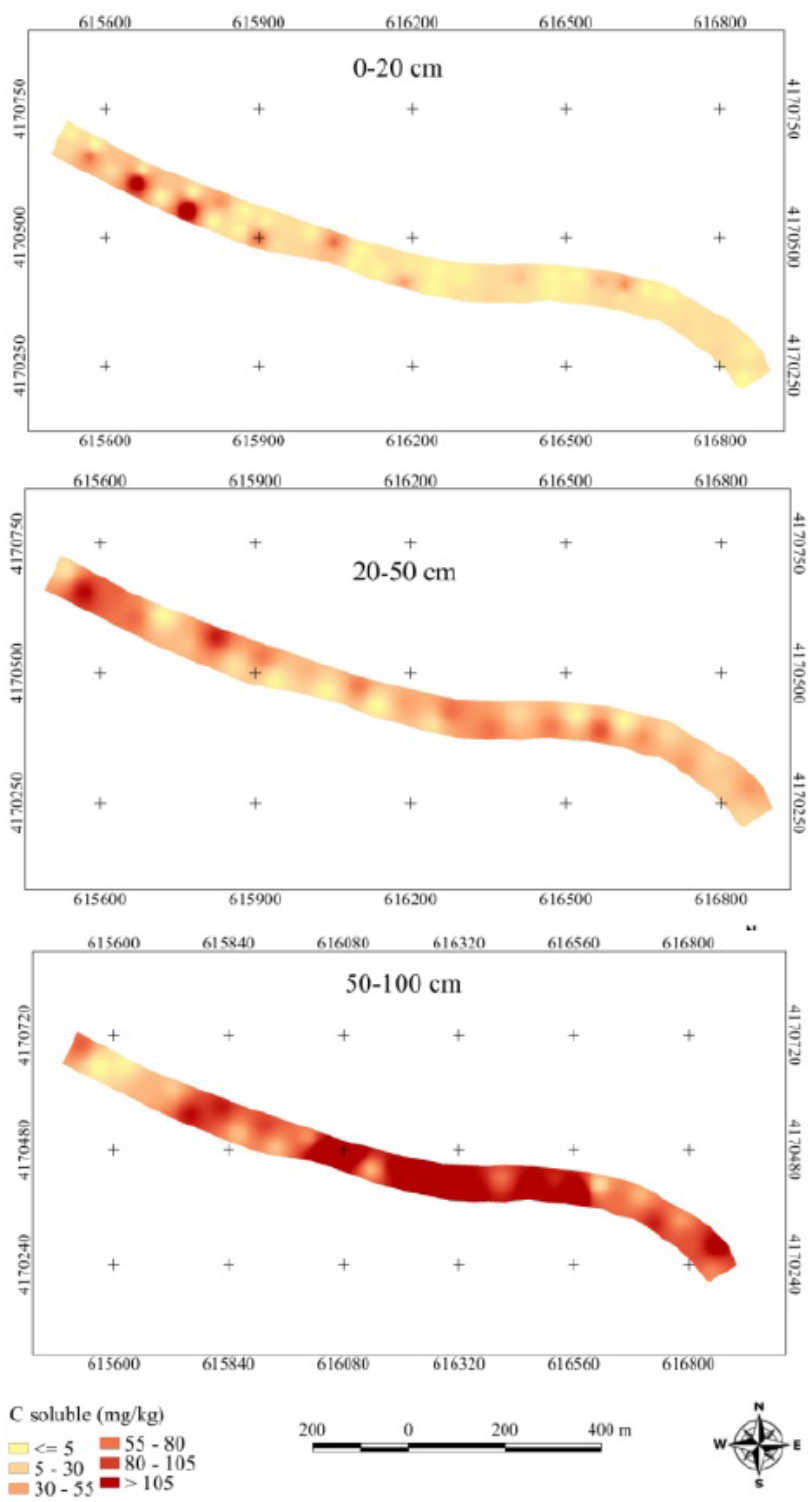

Figura 5.5.12. Evolución de la distribución espacial de la concentración de carbono soluble en los tramos 1, 2 y 3 (1500 m) entre los años 2013 y 2017. 


\section{Concentración de carbono soluble:}

En el año 2013 se registraron concentraciones promedio de 45,95 mg/kg (comprendidas entre $5,00-170,76 \mathrm{mg} / \mathrm{kg}), 40,57 \mathrm{mg} / \mathrm{kg}(5,00-148,55 \mathrm{mg} / \mathrm{kg})$ y $27,80 \mathrm{mg} / \mathrm{kg}(5,00-122,71$ $\mathrm{mg} / \mathrm{kg}$ ) en los horizontes de $0-20 \mathrm{~cm}, 20-50 \mathrm{~cm}$ y $50-100 \mathrm{~cm}$ respectivamente. El contenido en carbono soluble en los sedimentos fue muy bajo, sobre todo en profundidades de 20 a $100 \mathrm{~cm}$, como consecuencia del también bajo contenido en carbono orgánico total, aunque no existe relación directa entre ambos parámetros, indicando que la labilidad del carbono no está controlada en este ambiente por su contenido total.

En el año 2017 se han registrado concentraciones promedio de 27,51 mg/kg (comprendidas entre $2,76-191,42 \mathrm{mg} / \mathrm{kg}), 48,55 \mathrm{mg} / \mathrm{kg}(2,92-129,15 \mathrm{mg} / \mathrm{kg})$ y $97,82 \mathrm{mg} / \mathrm{kg}(2,57-218,05$ $\mathrm{mg} / \mathrm{kg}$ ) en los horizontes de 0-20 cm, $20-50 \mathrm{~cm}$ y $50-100 \mathrm{~cm}$ respectivamente. Tras el periodo de fitoextracción 2013-2017 los mapas de distribución muestran variaciones significativas de las concentraciones de carbono soluble en el horizonte de $0-20 \mathrm{~cm}$ (disminuyen) y en el horizonte de $20-50 \mathrm{~cm}$ y de 50-100 cm muestran un aumento no significativo. Con respecto las asociaciones entre parámetros, no se han registrado correlaciones destacables entre el carbono soluble y el resto de parámetros analizados. 
Capítulo 5. ESTUDIO DE FITOEXTRACCIÓN DE Cu, Zn Y Cr CON VEGETACIÓN AUTÓCTONA EN EL CAUCE DEL RIOO GUADALENTÍN

2013

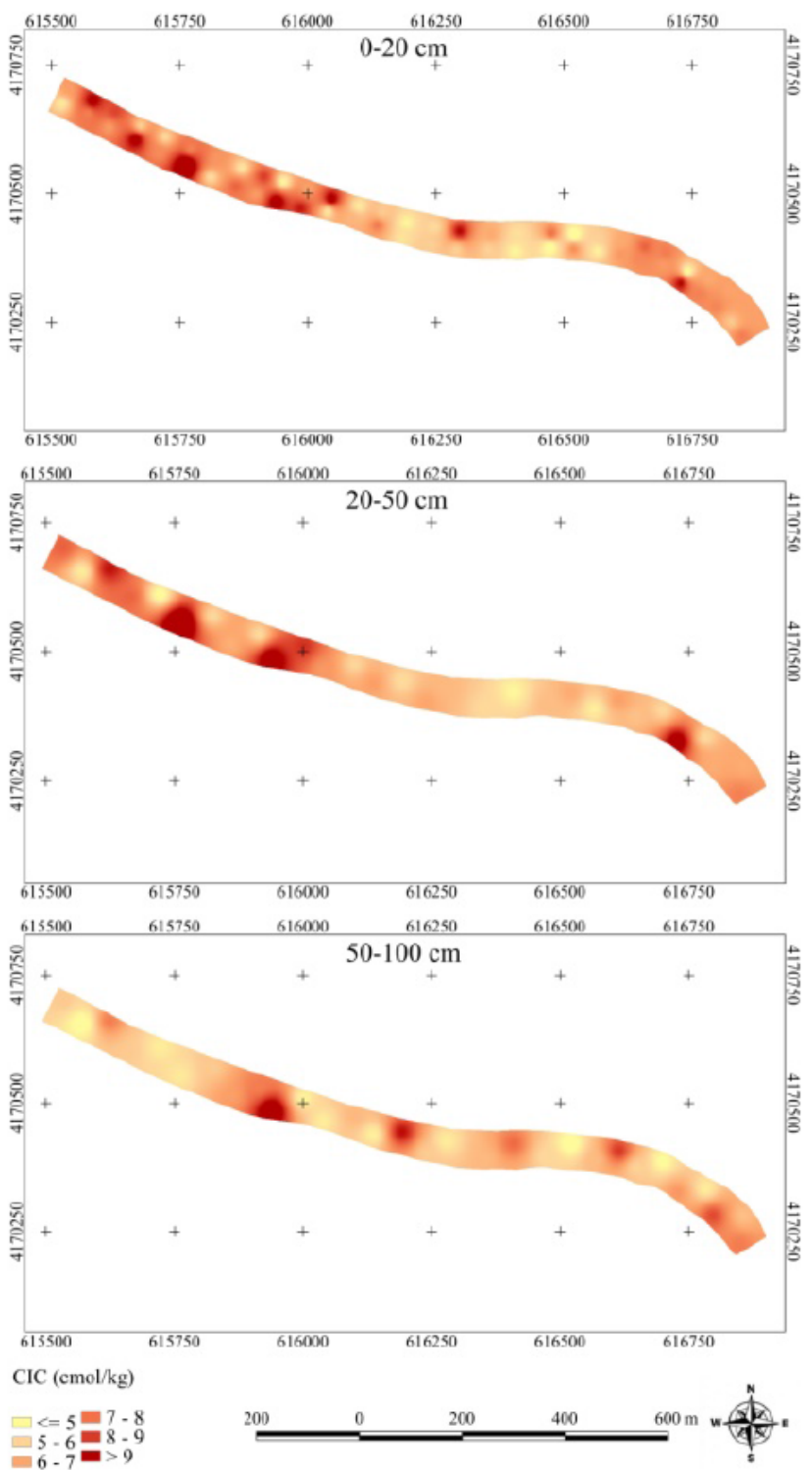

2017
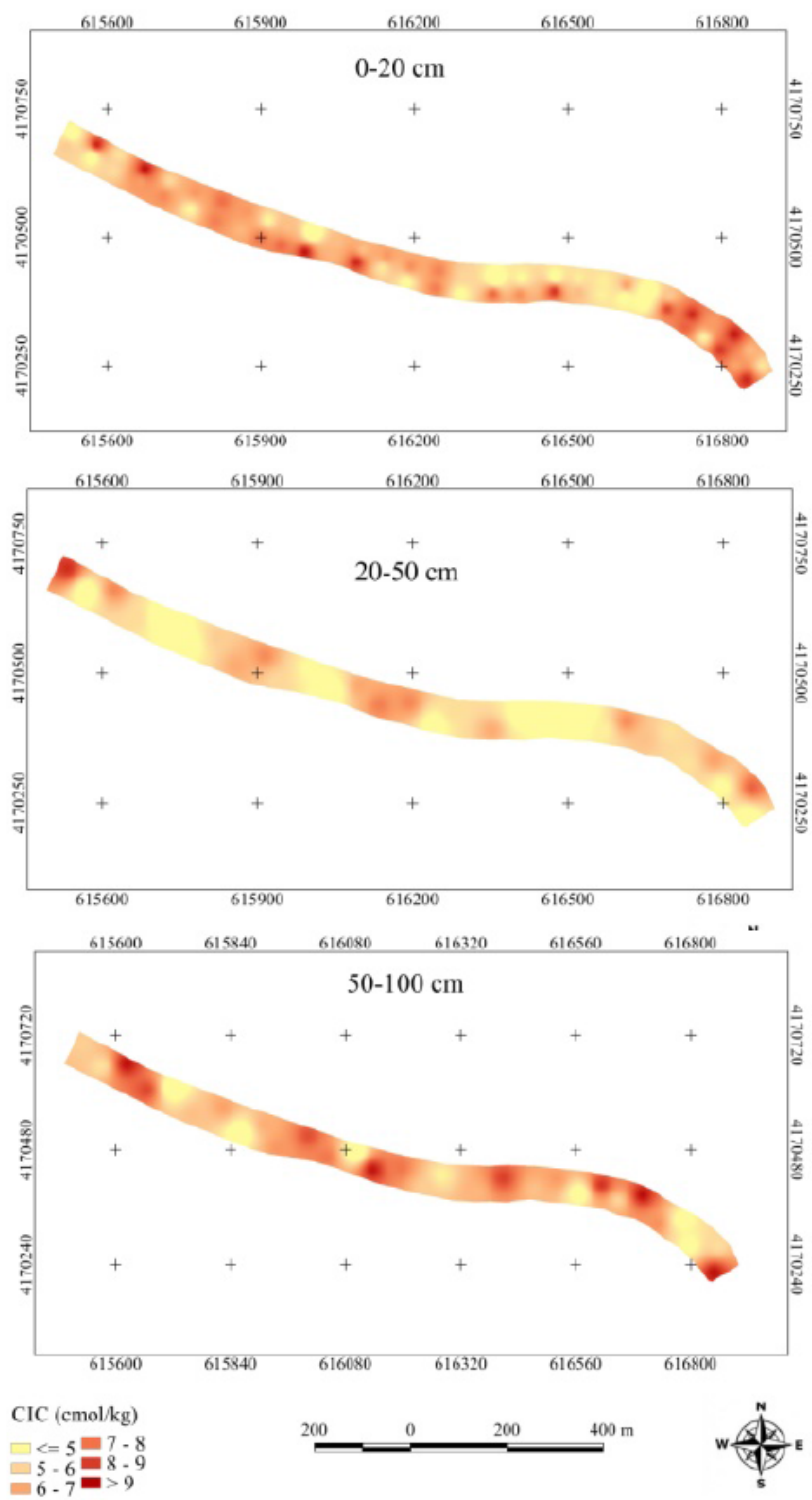

Figura 5.5.13. Evolución de la distribución espacial de la capacidad de intercambio catiónico en los tramos 1, 2 y 3 (1500 m) entre los años 2013 y 2017. 


\section{Capacidad de intercambio catiónico:}

En el año 2013 se registraron valores promedio de $7,19 \mathrm{cmol}_{+} / \mathrm{kg}$ (comprendidos entre 4,51$\left.13,39 \mathrm{cmol}_{+} / \mathrm{kg}\right), 7,18 \mathrm{cmol}_{+} / \mathrm{kg}\left(4,80-13,15 \mathrm{cmol}_{+} / \mathrm{kg}\right)$ y $6,64 \mathrm{cmol}_{+} / \mathrm{kg}\left(4,57-11,94 \mathrm{cmol}_{+} / \mathrm{kg}\right)$ en los horizontes de $0-20 \mathrm{~cm}, 20-50 \mathrm{~cm}$ y $50-100 \mathrm{~cm}$ respectivamente. La capacidad de intercambio catiónico de los sedimentos es baja, con valores promedio inferiores a 10 $\mathrm{cmol}_{+} / \mathrm{kg}$ en casi todo el cauce de estudio. Este parámetro representa la capacidad del sedimento para retener nutrientes adsorbidos a los coloides (arcilla y materia orgánica principalmente). Por tanto, el sedimento presenta limitada capacidad para retener los nutrientes y evitar que sean lavados, así como para retener metales pesados en su fracción biodisponible. El bajo contenido en carbono orgánico explica los bajos valores de este parámetro.

En el año 2017 se han registrado valores promedio de 6,65 $\mathrm{cmol}_{+} / \mathrm{kg}$ (comprendidos entre $\left.2,94-9,71 \mathrm{cmol}_{+} / \mathrm{kg}\right), \quad 5,86 \mathrm{cmol}_{+} / \mathrm{kg}\left(3,42-9,23 \mathrm{cmol}_{+} / \mathrm{kg}\right)$ y $6,78 \mathrm{cmol}_{+} / \mathrm{kg} \quad(3,47-9,76$ $\mathrm{cmol}_{+} / \mathrm{kg}$ ) en los horizontes de $0-20 \mathrm{~cm}, 20-50 \mathrm{~cm}$ y $50-100 \mathrm{~cm}$ respectivamente. Tras el periodo de fitoextracción 2013-2017 los mapas de distribución muestran una disminución en los valores de la capacidad de intercambio catiónico en los horizontes de 0-20 cm y de 20$50 \mathrm{~cm}$, siendo dicha disminución significativa en el horizonte de $20-50 \mathrm{~cm}$. En el horizonte de 50-100 cm se registra un aumento de los valores aunque no es significativo. Con respecto las asociaciones entre parámetros, no se han registrado correlaciones destacables entre la capacidad de intercambio catiónico y el resto de parámetros analizados. 
Capítulo 5. ESTUDIO DE FITOEXTRACCIÓN DE Cu, Zn Y Cr CON VEGETACIÓN AUTÓCTONA EN EL CAUCE DEL RÍO GUADALENTÍN

2013
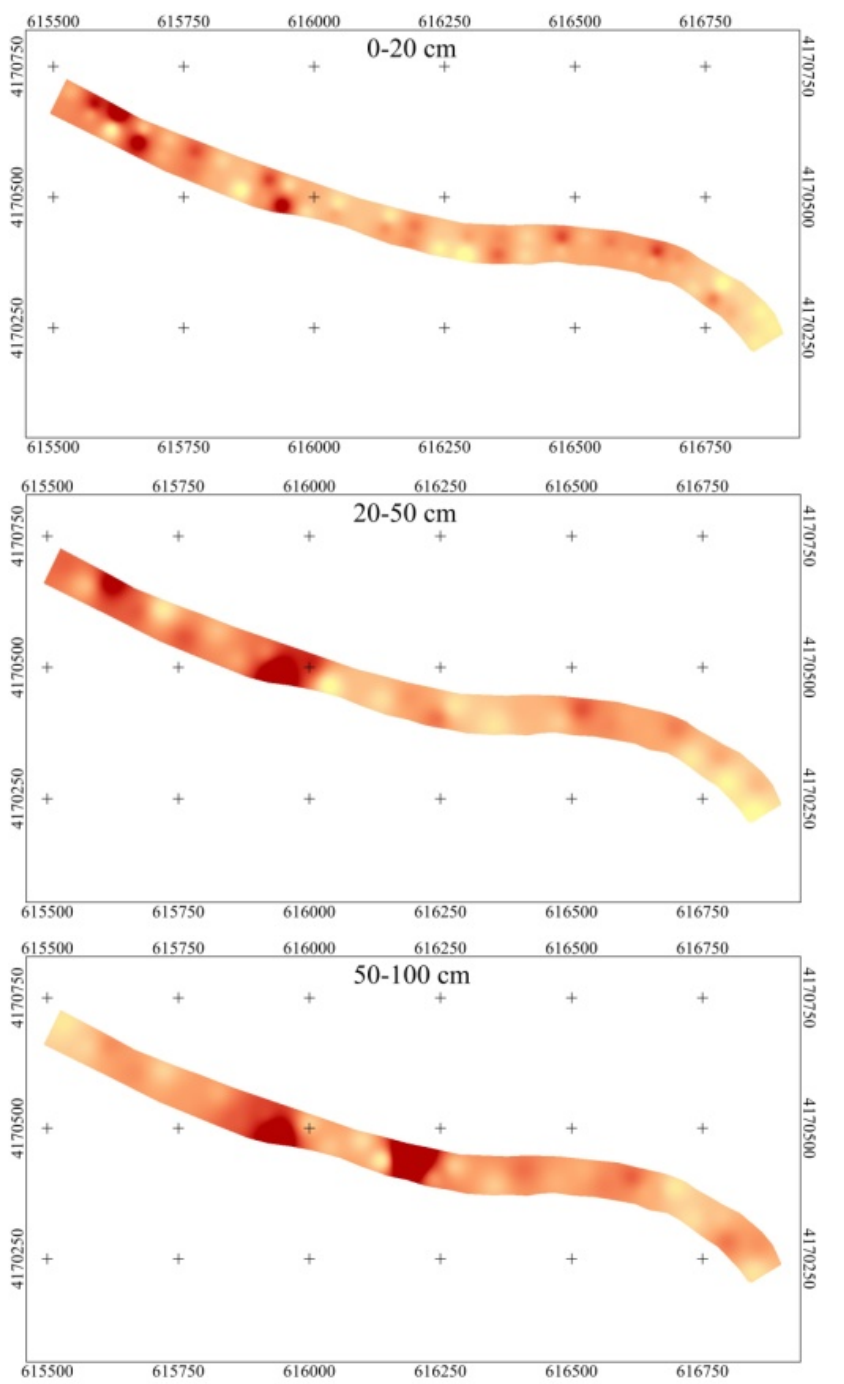

Ca Intercambiable $(\mathrm{mg} / \mathrm{kg})$

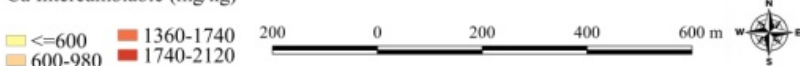
$600-980$
$980-1360$
2017
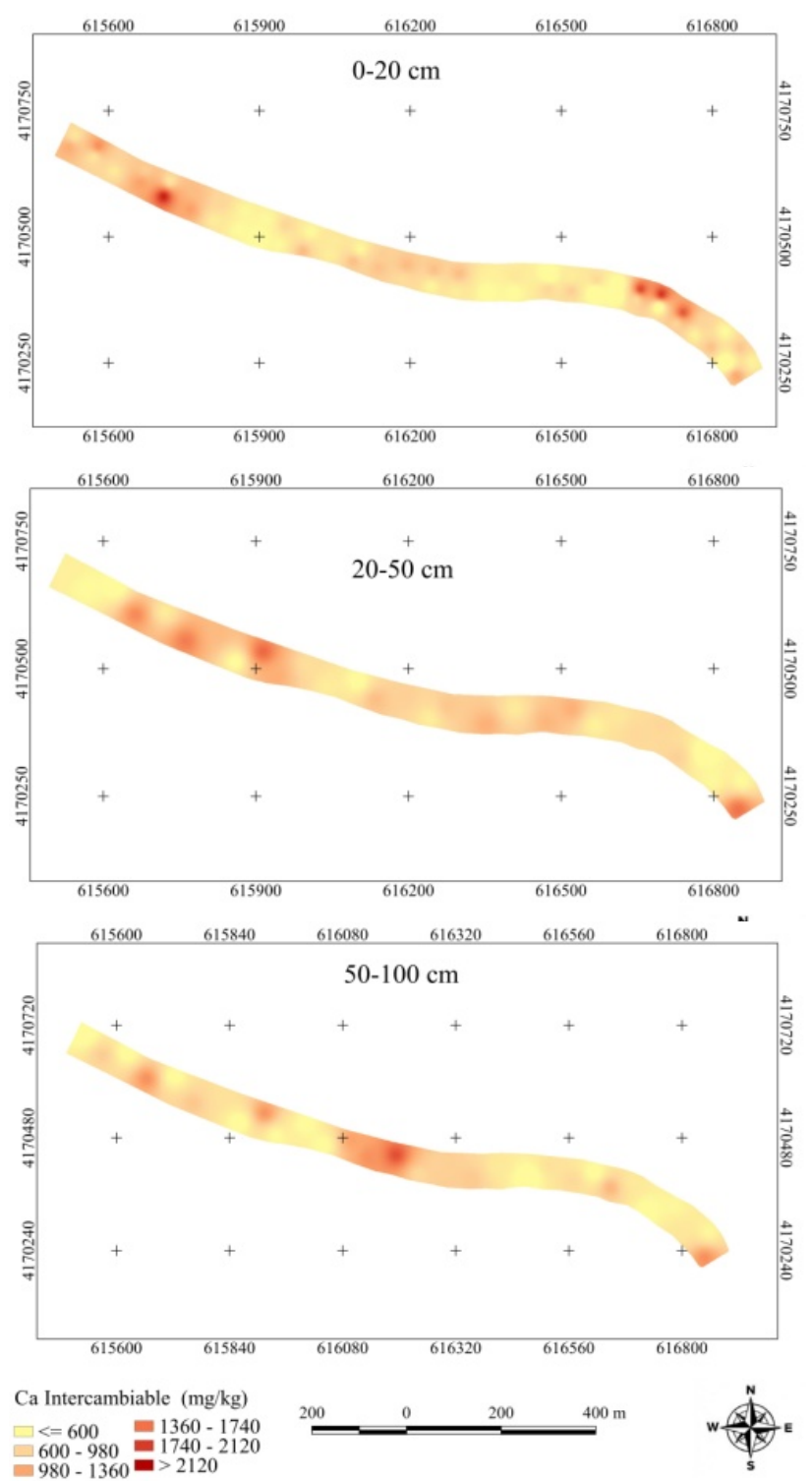

Figura 5.5.14. Evolución de la distribución espacial de la concentración de calcio intercambiable en los tramos 1, 2 y 3 (1500 m) entre los años 2013 y 2017. 


\section{Concentración de calcio intercambiable:}

En el año 2013 se registraron concentraciones promedio de 1326,05 mg/kg (comprendidas entre $341,54-3503,85 \mathrm{mg} / \mathrm{kg}), 1434,50 \mathrm{mg} / \mathrm{kg}(496,15-4253,50 \mathrm{mg} / \mathrm{kg})$ y $1554,54 \mathrm{mg} / \mathrm{kg}$ $(686,50-6892,86 \mathrm{mg} / \mathrm{kg})$ en los horizontes de 0-20 cm, 20-50 cm y 50-100 cm respectivamente. La distribución del contenido de calcio de cambio o intercambiable presenta valores relativamente bajos para sedimentos carbonatados. El calcio está muy relacionado con la $\mathrm{CE}$, sugiriendo que contribuye al incremento de la salinidad en el sedimento.

En año 2017 se han registrado concentraciones promedio de 911,45 mg/kg (comprendidas entre 268,68-2292,40 mg/kg), 958,70 mg/kg (410,11-1803,66 mg/kg) y 896,44 mg/kg (394,26-1979,09 mg/kg) en los horizontes de 0-20 cm, 20-50 cm y 50-100 cm respectivamente. Tras el periodo de fitoextracción 2013-2017 los mapas de distribución muestran una disminución significativa de las concentraciones de calcio intercambiable en todos los horizontes muestreados. Con respecto las asociaciones entre parámetros se han registrado las siguientes correlaciones entre el calcio intercambiable y los siguientes parámetros: potasio intercambiable $\left(r=+0,52^{\star *}\right)$ y magnesio intercambiable $\left(r=+0,57^{\star \star}\right)$. Conforme disminuye la concentración de calcio intercambiable disminuyen también las concentraciones de potasio y magnesio intercambiable. Dicha disminución podría ser debida principalmente a la absorción de los cationes por parte de la vegetación existente. 
Capitulo 5. ESTUDIO DE FITOEXTRACCIÓN DE Cu, Zn Y Cr CON VEGETACIÓN AUTÓCTONA EN EL CAUCE DEL RIOO GUADALENTÍN

2013
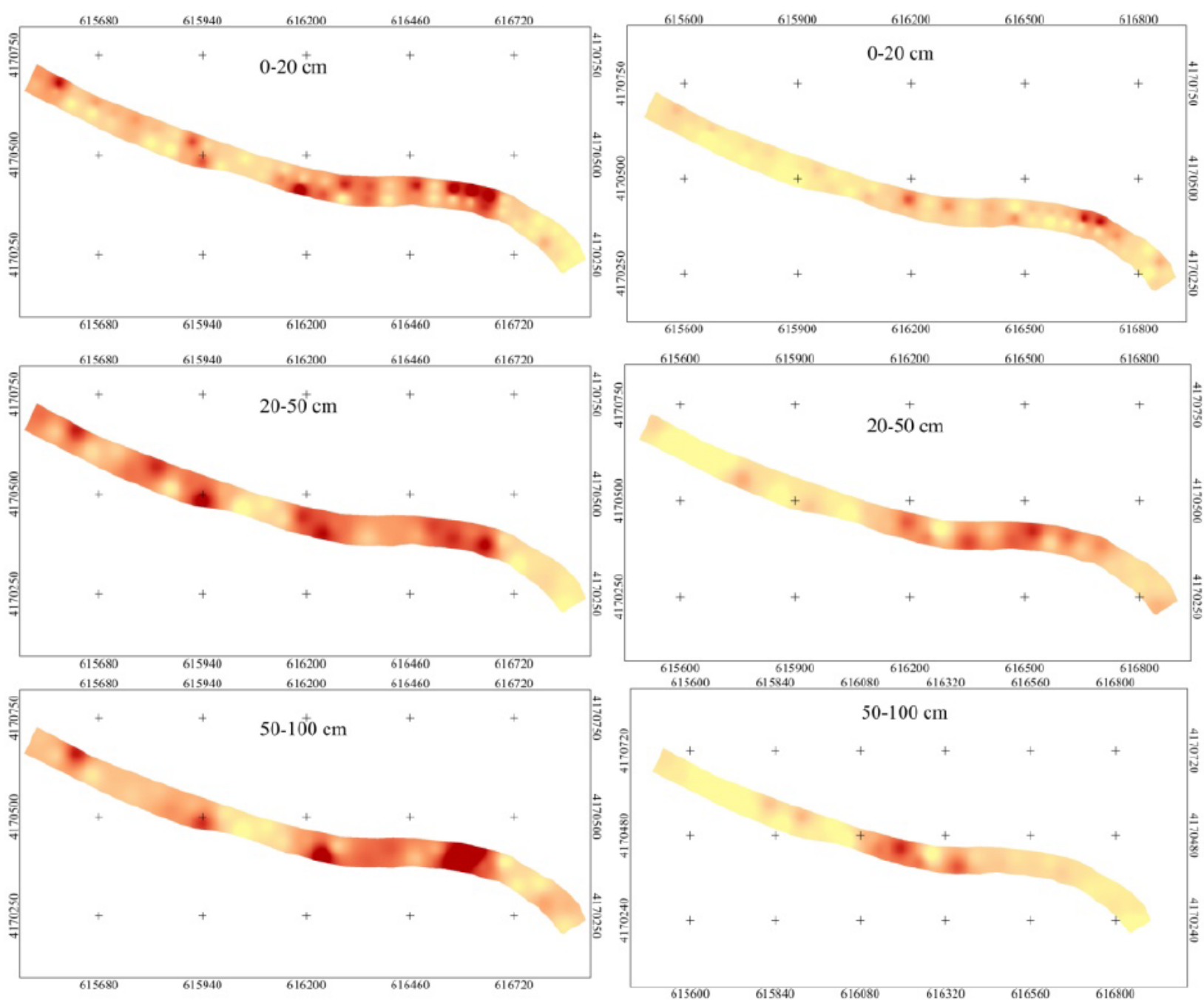

$\mathrm{Mg}$ Intercambiable (mg/kg)

$\square=120=340-450$
$120-230=450-560$
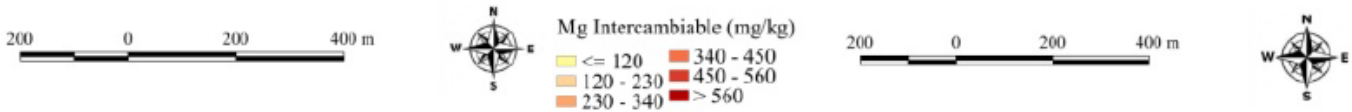

Figura 5.5.15. Evolución de la distribución espacial de la concentración de magnesio intercambiable en los tramos 1, 2 y $3(1500$ m) entre los años 2013 y 2017. 


\section{Concentración de magnesio intercambiable:}

En el año 2013 se registraron concentraciones promedio de 307,03 mg/kg (comprendidas entre $79,57-862,25 \mathrm{mg} / \mathrm{kg}), 356,20 \mathrm{mg} / \mathrm{kg}(60,87-738,50 \mathrm{mg} / \mathrm{kg})$ y $350,72 \mathrm{mg} / \mathrm{kg}(75,67-$ $1106,86 \mathrm{mg} / \mathrm{kg}$ ) en los horizontes de $0-20 \mathrm{~cm}, 20-50 \mathrm{~cm}$ y $50-100 \mathrm{~cm}$ respectivamente. La distribución del contenido de magnesio de cambio o intercambiable presenta valores bastante bajos en prácticamente todo el lecho. La concentración del magnesio en los sedimentos está directamente relacionada con la concentración de calcio, por lo que en las zonas con mayor contenido de calcio también suele haber mayor contenido de magnesio.

En el año 2017 se han registrado concentraciones promedio de 212,55 mg/kg (comprendidas entre 19,64-679,82 mg/kg), 252,50 mg/kg $(51,08-606,06 \mathrm{mg} / \mathrm{kg}$ ) у 202,45 $\mathrm{mg} / \mathrm{kg}(37,05-609,47 \mathrm{mg} / \mathrm{kg})$ en los horizontes de 0-20 cm, 20-50 cm y 50-100 cm respectivamente. Tras el periodo de fitoextracción 2013-2017 los mapas de distribución muestran una disminución de las concentraciones de magnesio intercambiable en todos los horizontes muestreados, siendo significativa en los horizontes de 0-20 cm y 50-100 cm. Con respecto las asociaciones entre parámetros, se han registrado las siguientes correlaciones entre el magnesio intercambiable y los siguientes parámetros: arena $\left(r=-0,50^{* *}\right)$ y sodio intercambiable $\left(r=+0,74^{\star \star}\right)$. Conforme disminuye la concentración de magnesio intercambiable disminuye la concentración de sodio intercambiable, posiblemente debido al desarrollo de la vegetación existente en el cauce. 
Capítulo 5. ESTUDIO DE FITOEXTRACCIÓN DE Cu, Zn Y Cr CON VEGETACIÓN AUTÓCTONA EN EL CAUCE DEL RÍO GUADALENTÍN

2013

2017
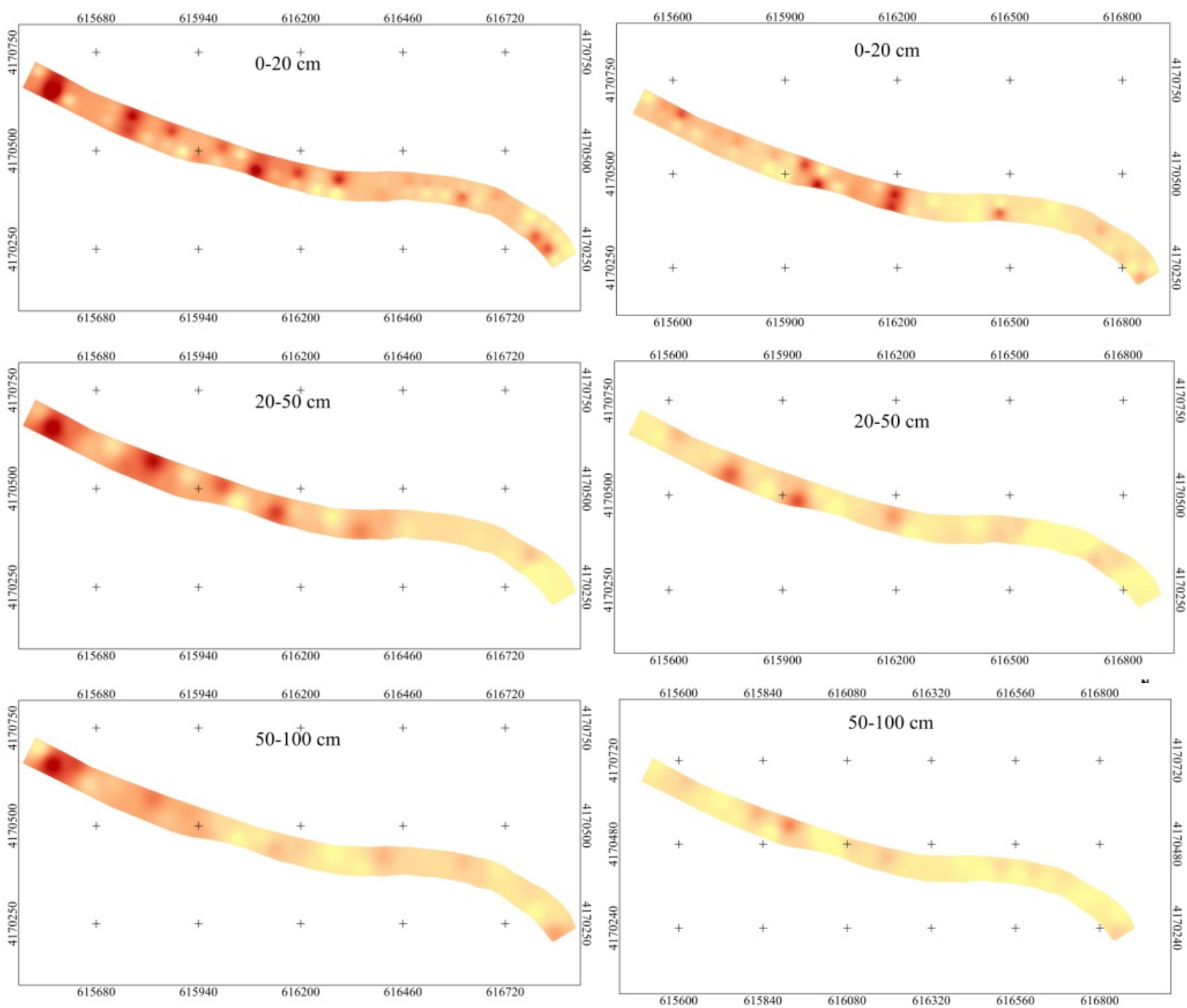

K Intercambiable $(\mathrm{mg} / \mathrm{kg})$ $\square=50 \quad=150-200$
$50-100 \quad \mathbf{E} 200-250$
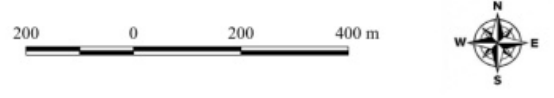

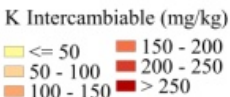
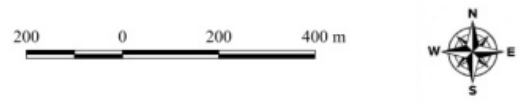

Figura 5.5.16. Evolución de la distribución espacial de la concentración de potasio intercambiable en los tramos 1, 2 y 3 (1500 m) entre los años 2013 y 2017. 


\section{Concentración de potasio intercambiable:}

En el año 2013 se registraron concentraciones promedio de 141,55 mg/kg (comprendidas entre $23,13-434,02 \mathrm{mg} / \mathrm{kg}), 125,74 \mathrm{mg} / \mathrm{kg}(15,44-323,00 \mathrm{mg} / \mathrm{kg})$ y $108,56 \mathrm{mg} / \mathrm{kg}(37,50-$ $315,10 \mathrm{mg} / \mathrm{kg}$ ) en los horizontes de $0-20 \mathrm{~cm}, 20-50 \mathrm{~cm}$ y $50-100 \mathrm{~cm}$ respectivamente. La distribución del contenido de potasio de cambio o intercambiable presenta valores bajos en la mayor parte del cauce.

En el año 2017 se han registrado concentraciones promedio de $104,79 \mathrm{mg} / \mathrm{kg}$ (comprendidas entre 30,37-289,68 mg/kg), 80,24 mg/kg $(19,22-230,65 \mathrm{mg} / \mathrm{kg}$ ) y 71,45 $\mathrm{mg} / \mathrm{kg}(26,90-180,10 \mathrm{mg} / \mathrm{kg})$ en los horizontes de 0-20 cm, 20-50 cm y 50-100 cm respectivamente. Tras el periodo de fitoextracción 2013-2017 los mapas de distribución muestran una disminución significativa de las concentraciones de potasio intercambiable en todos los horizontes muestreados. Con respecto las asociaciones entre parámetros, no se han registrado correlaciones destacables entre el potasio intercambiable y el resto de parámetros analizados en suelo. 
Capítulo 5. ESTUDIO DE FITOEXTRACCIÓN DE Cu, Zn Y Cr CON VEGETACIÓN AUTÓCTONA EN EL CAUCE DEL RÍO GUADALENTÍN

2013
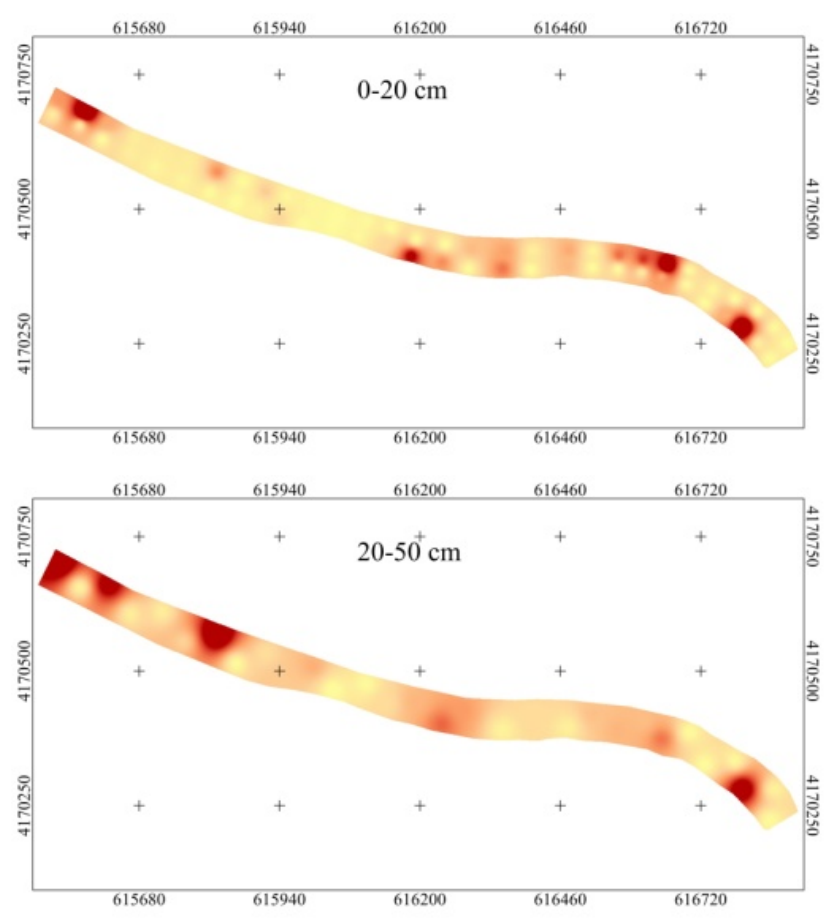

$\begin{array}{lrrrr}615680 & 615940 & 616200 & 616460 & 616720\end{array}$

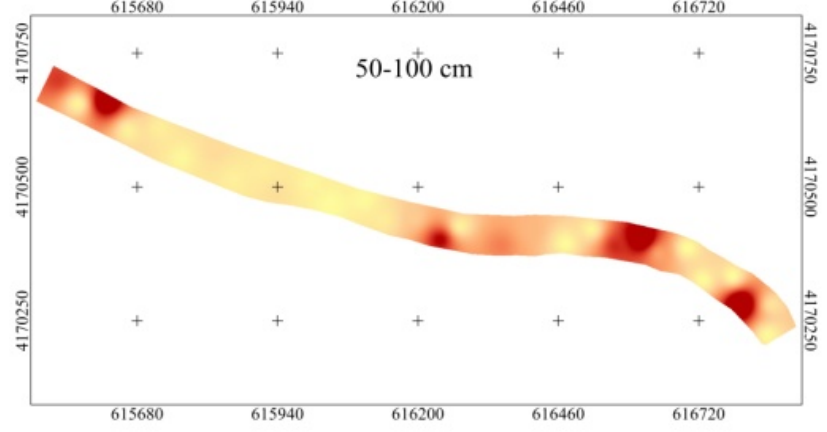

$\mathrm{Na}$ Intercambiable $(\mathrm{mg} / \mathrm{kg})$ $\square=100$
$\square=00-600=1100-1600$
$1000-2100$ $600-1100=2100$
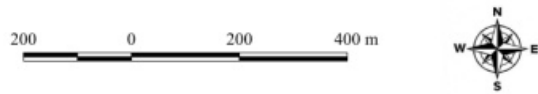

2017
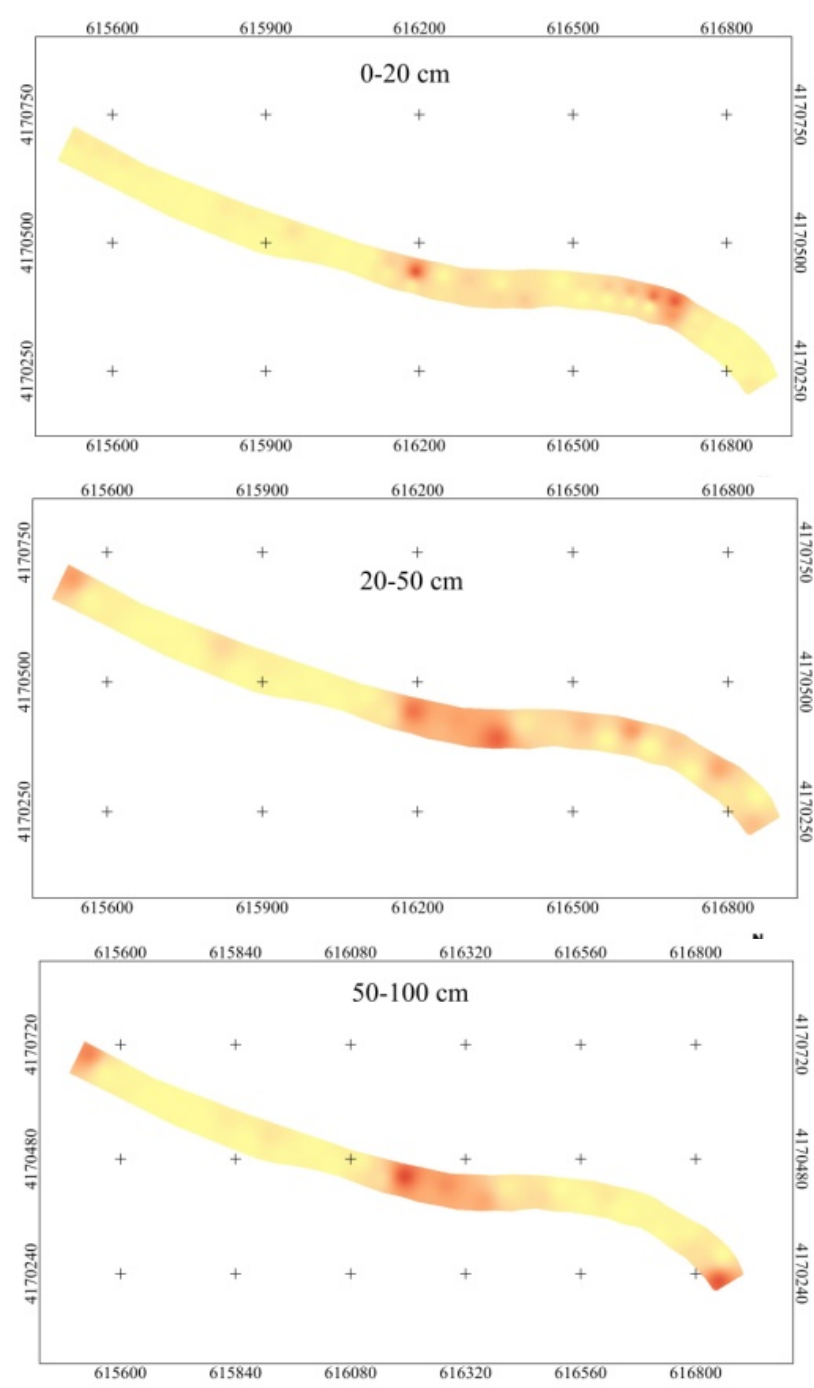

$\mathrm{Na}$ Intercambiable $(\mathrm{mg} / \mathrm{kg})$ $\square<100=1100-1600$
$\square=00-600=1600-2100$ $100-600=1600-2100$
$600-1100=2100$

Figura 5.5.17. Evolución de la distribución espacial de la concentración de sodio intercambiable en los tramos 1, 2 y 3 (1500 m) entre los años 2013 y 2017. 


\section{Concentración de sodio intercambiable:}

En el año 2013 se registraron concentraciones promedio de 686,70 mg/kg (comprendidas entre $34,60-5250,00 \mathrm{mg} / \mathrm{kg}), 939,86 \mathrm{mg} / \mathrm{kg}(43,65-4308,00 \mathrm{mg} / \mathrm{kg})$ y $910,79 \mathrm{mg} / \mathrm{kg}(51,35-$ $4325,49 \mathrm{mg} / \mathrm{kg}$ ) en los horizontes de $0-20 \mathrm{~cm}, 20-50 \mathrm{~cm}$ y $50-100 \mathrm{~cm}$ respectivamente. La distribución del contenido de sodio de cambio o intercambiable presenta valores muy heterogéneos a lo largo del cauce en las tres profundidades muestreadas, con valores desde 34 hasta $5250 \mathrm{mg} / \mathrm{kg}$. En general, los niveles de sodio son altos en todo el lecho, con determinadas áreas concretas donde son muy altos, indicando altos niveles de salinidad.

En el año 2017 se han registrado concentraciones promedio de 306,48 $\mathrm{mg} / \mathrm{kg}$ (comprendidas entre 7,25-1826,14 mg/kg), 481,16 mg/kg (16,25-1720,15 mg/kg) y 415,85 $\mathrm{mg} / \mathrm{kg}$ (0-1938,45 mg/kg) en los horizontes de 0-20 cm, 20-50 cm y 50-100 cm respectivamente. Tras el periodo de fitoextracción 2013-2017 los mapas de distribución muestran una disminución de las concentraciones de sodio intercambiable en todos los horizontes muestreados, siendo significativa en el horizonte de $50-100 \mathrm{~cm}$. Con respecto las asociaciones entre parámetros no se han registrado correlaciones destacables entre el sodio intercambiable y el resto de parámetros analizados en suelo. 


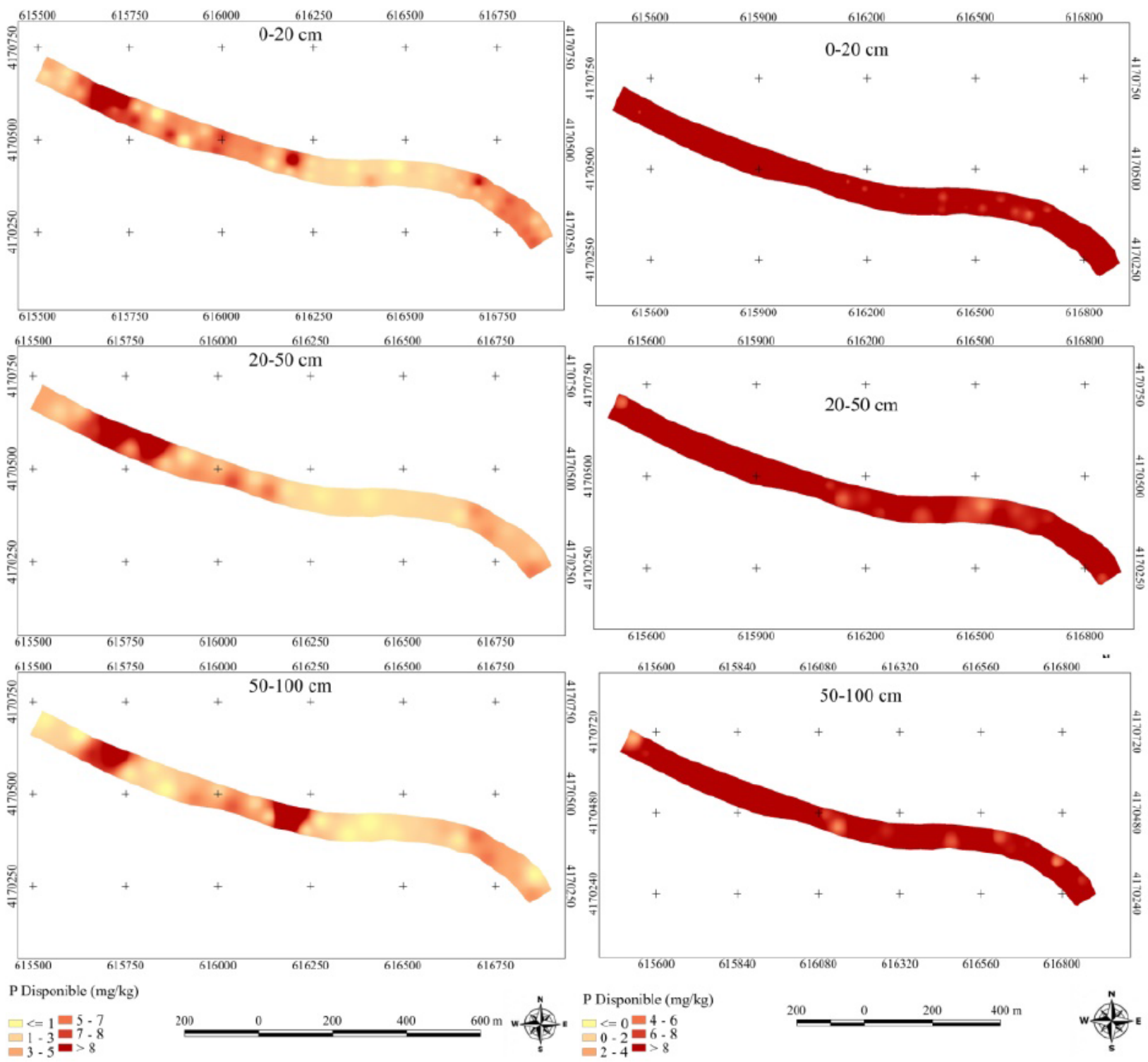

Figura 5.5.18. Evolución de la distribución espacial de la concentración de fósforo biodisponible en los tramos 1, 2 y 3 (1500 m) entre los años 2013 y 2017. 


\section{Concentración de fósforo biodisponible:}

En el año 2013 se registraron concentraciones promedio de 5,34 mg/kg (comprendidas entre $0-20,68 \mathrm{mg} / \mathrm{kg}), 5,16 \mathrm{mg} / \mathrm{kg}(1,46-22,44 \mathrm{mg} / \mathrm{kg})$ y $5,10 \mathrm{mg} / \mathrm{kg}(0,36-39,91 \mathrm{mg} / \mathrm{kg})$ en los horizontes de 0-20 cm, 20-50 cm y 50-100 cm respectivamente. La distribución del contenido de fósforo biodisponible presenta valores bajos en todo el cauce en las tres profundidades muestreadas.

En el año 2017 se han registrado concentraciones promedio de 20,34 mg/kg (comprendidas entre $6,27-65,69 \mathrm{mg} / \mathrm{kg}), 18,82 \mathrm{mg} / \mathrm{kg}(4,89-65,78 \mathrm{mg} / \mathrm{kg})$ y $16,28 \mathrm{mg} / \mathrm{kg}(3,37-68,25 \mathrm{mg} / \mathrm{kg})$ en los horizontes de 0-20 cm, $20-50 \mathrm{~cm}$ y $50-100 \mathrm{~cm}$ respectivamente. Tras el periodo de fitoextracción 2013-2017 los mapas de distribución muestran un aumento significativo de las concentraciones de fósforo biodisponible en todos los horizontes muestreados. Con respecto las asociaciones entre parámetros se han registrado correlaciones entre el fósforo biodisponible y los siguientes parámetros: carbono orgánico $\left(r=-0,62^{\star \star}\right)$ y $\mathrm{pH}\left(r=-0,56^{\star \star}\right)$. Conforme disminuye el pH aumenta la concentración de fósforo biodisponible. Dicha variación podría deberse a la presencia de la vegetación fitoextractora y a la escasez hídrica registrada desde 2015. 
Capítulo 5. ESTUDIO DE FITOEXTRACCIÓN DE Cu, Zn Y Cr CON VEGETACIÓN AUTÓCTONA EN EL CAUCE DEL RÍO GUADALENTÍN
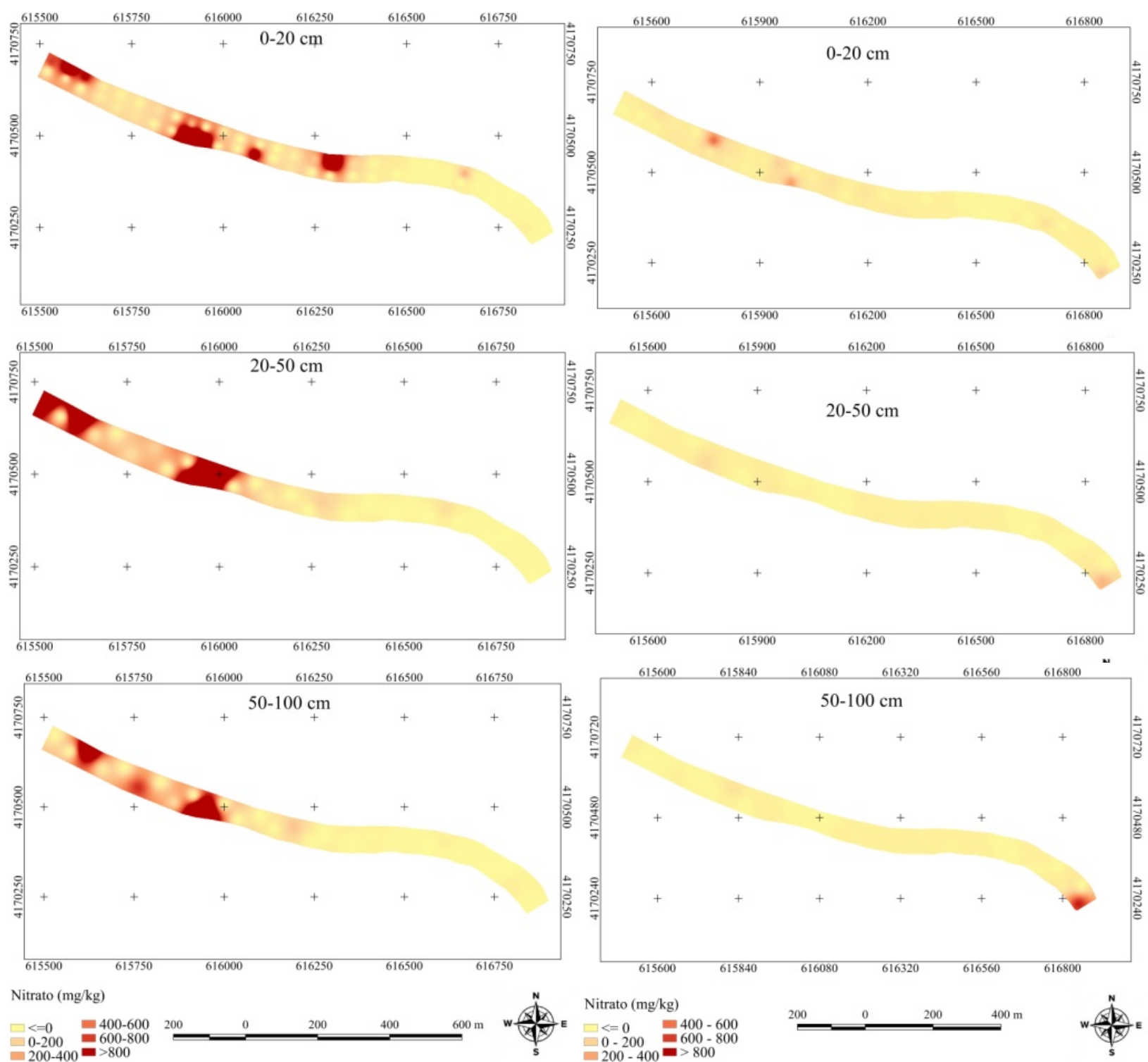

Nitrato $(\mathrm{mg} / \mathrm{kg})$ $\square<=0$
$\square=200 \quad=600-800$
$0-200$ $0-200$
$200-400$

Figura 5.5.19. Evolución de la distribución espacial de la concentración de nitratos en los tramos 1, 2 y 3 (1500 m) entre los años 2013 y 2017. 


\section{Concentración de nitratos:}

En el año 2013 se registraron concentraciones promedio de 322,29 mg/kg (comprendidas entre $0-4290,80 \mathrm{mg} / \mathrm{kg}), 434,12 \mathrm{mg} / \mathrm{kg}(0-4339,13 \mathrm{mg} / \mathrm{kg})$ y $273,91 \mathrm{mg} / \mathrm{kg}(0-4377,95$ $\mathrm{mg} / \mathrm{kg}$ ) en los horizontes de 0-20 cm, 20-50 cm y 50-100 cm respectivamente. La concentración de nitratos en el sedimento se encuentra dentro de niveles normales para un suelo agrícola (<500 mg/kg) excepto en varias zonas puntuales localizadas fundamentalmente en el margen central del tramo a rehabilitar, y a $500 \mathrm{~m}$ de este mismo margen aguas abajo del cauce donde se alcanzan niveles excesivos de nitrato con valores superando los $3000 \mathrm{mg} / \mathrm{kg}$. Estas zonas también presentaban mayor contenido en nitrógeno total (Figura 5.5.7).

En el año 2017 se han registrado concentraciones promedio de 72,89 mg/kg (comprendidas entre $6,71-612,49 \mathrm{mg} / \mathrm{kg}), 53,02 \mathrm{mg} / \mathrm{kg}(5,50-319,97 \mathrm{mg} / \mathrm{kg})$ y $64,88 \mathrm{mg} / \mathrm{kg}(5,62-899,71$ $\mathrm{mg} / \mathrm{kg}$ ) en los horizontes de 0-20 cm, $20-50 \mathrm{~cm}$ y $50-100 \mathrm{~cm}$ respectivamente. Tras el periodo de fitoextracción 2013-2017 los mapas de distribución muestran una disminución de las concentraciones de nitratos en todos los horizontes muestreados, siendo significativa sólo en el horizonte más superficial $(0-20 \mathrm{~cm})$. Con respecto a las asociaciones entre parámetros se ha registrado una correlación positiva entre los nitratos y los cloruros $\left(r=+0,53^{\star \star}\right)$. Conforme disminuye el contenido en nitrato disminuye el contenido en cloruros y a la inversa, lo cual podría ser debido a su naturaleza aniónica influyente en el contenido salino de los sedimentos del suelo del cauce. 
Capítulo 5. ESTUDIO DE FITOEXTRACCIÓN DE Cu, Zn Y Cr CON VEGETACIÓN AUTÓCTONA EN EL CAUCE DEL RÍO GUADALENTÍN

2013
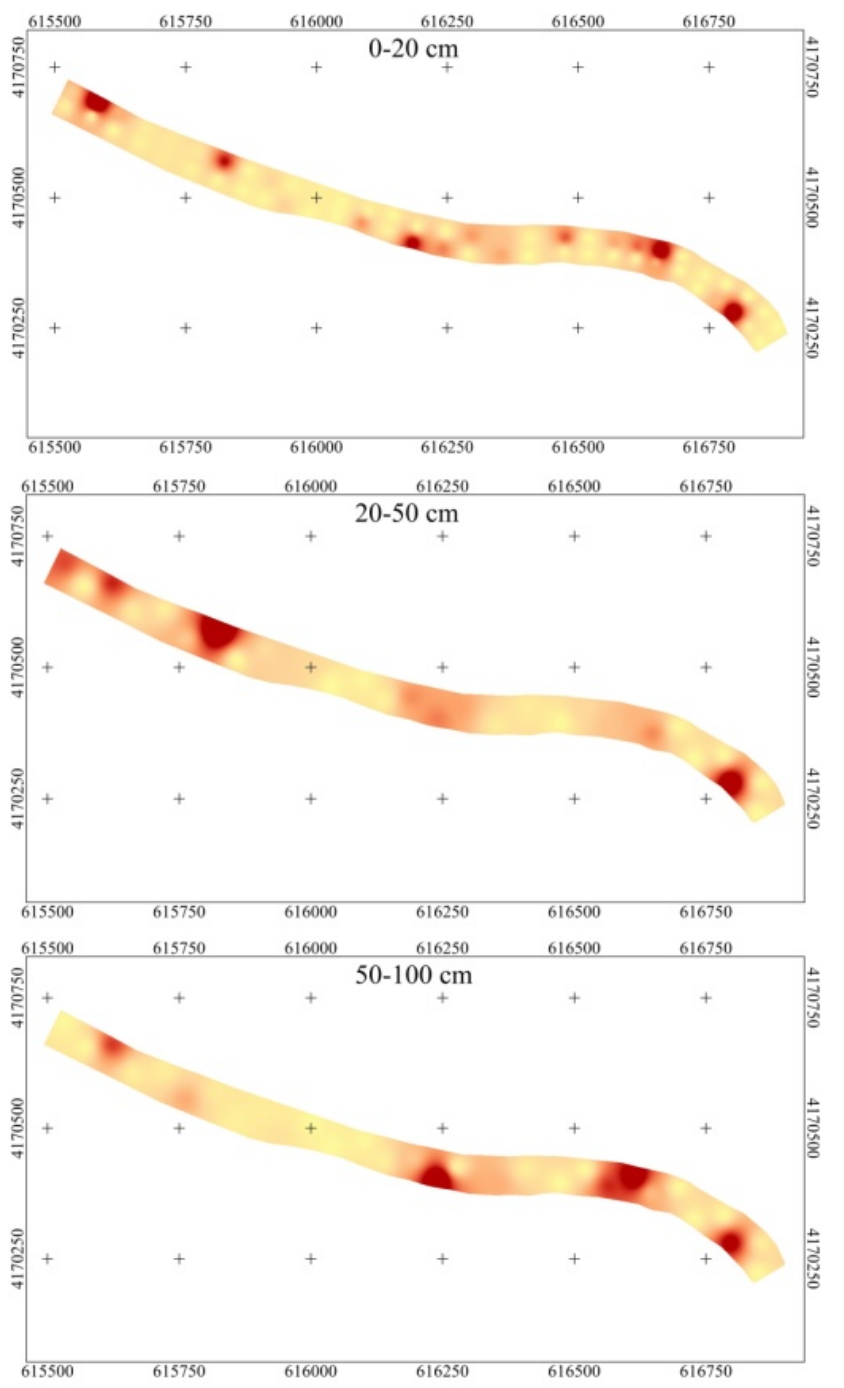

Cloruro $(\mathrm{mg} / \mathrm{kg}$ )

$\square<=0 \quad=800-12000^{200}$ $0-400 \quad=1200-1600$
$400-800=$
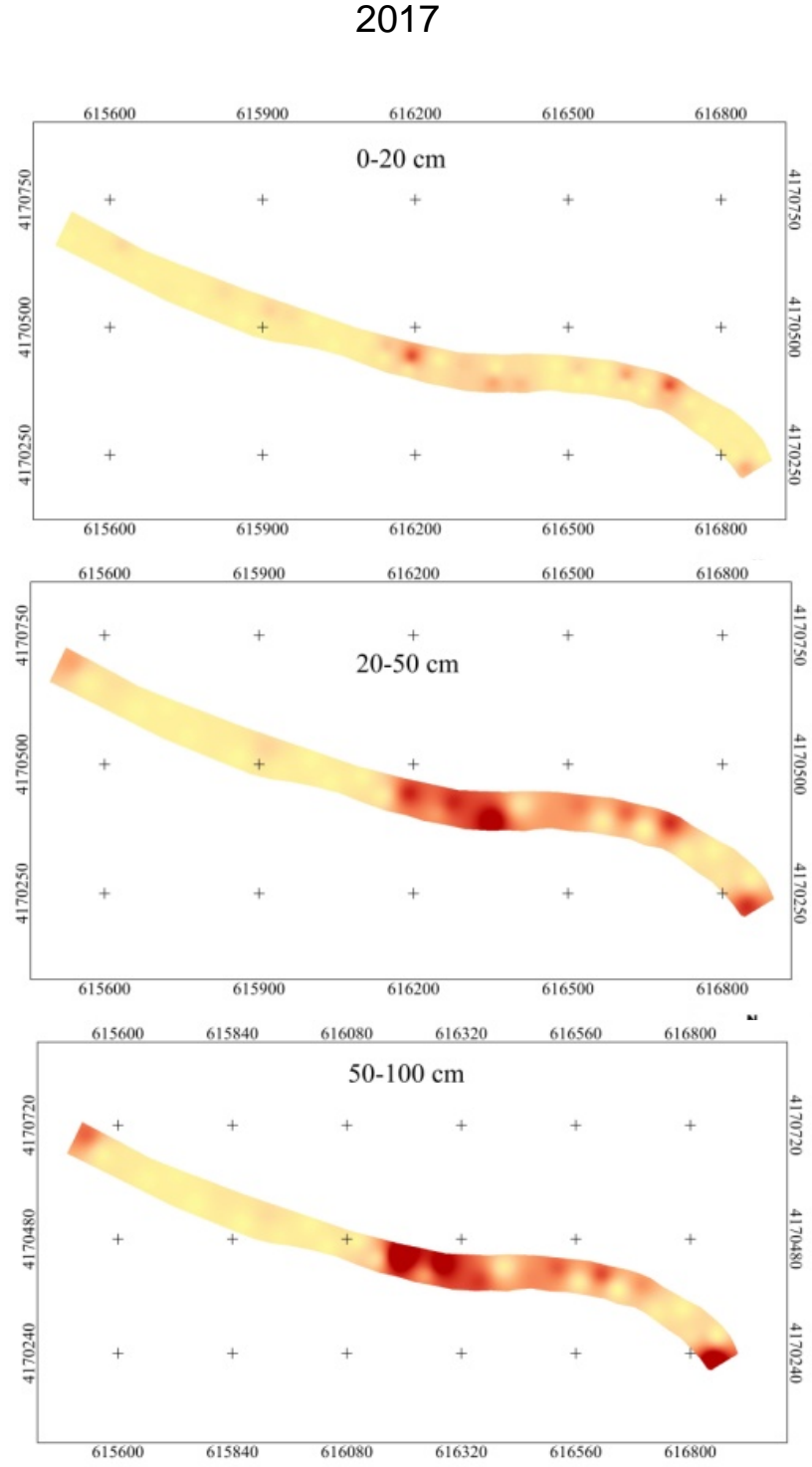

Cloruro $(\mathrm{mg} / \mathrm{kg})$ $\square<=0$
$\square=-400 \quad 800-1200$
$0-1200-1600$
$=1600$
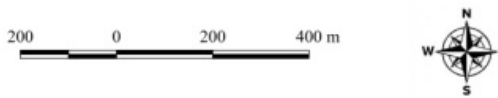

Figura 5.5.20. Evolución de la distribución espacial de la concentración de cloruros en los tramos 1, 2 y 3 (1500 m) entre los años 2013 y 2017. 


\section{Concentración de cloruros:}

En el año 2013 se registraron concentraciones promedio de 476,58 mg/kg (comprendidas entre $5,36-4234,89 \mathrm{mg} / \mathrm{kg}), 603,60 \mathrm{mg} / \mathrm{kg}(4,67-3922,31 \mathrm{mg} / \mathrm{kg})$ y $539,72 \mathrm{mg} / \mathrm{kg}(10,74-$ $3374,35 \mathrm{mg} / \mathrm{kg}$ ) en los horizontes de $0-20 \mathrm{~cm}, 20-50 \mathrm{~cm}$ y $50-100 \mathrm{~cm}$ respectivamente. La distribución del contenido de cloruro presenta valores muy heterogéneos a lo largo del cauce en las tres profundidades muestreadas, con valores desde 4 hasta $4200 \mathrm{mg} / \mathrm{kg}$. Aunque en la mayor parte del cauce los niveles de cloruro se encuentran por debajo de 500 $\mathrm{mg} / \mathrm{kg}$, hay áreas específicas con valores muy altos que contribuyen a incrementos en la salinidad de los sedimentos.

En el año 2017 se han registrado concentraciones promedio de 230,62 mg/kg (comprendidas entre 16,29-1466,62 mg/kg), 549,53 mg/kg $(20,20-2410,21 \mathrm{mg} / \mathrm{kg}$ ) y 646,02 $\mathrm{mg} / \mathrm{kg}(15,78-3353,59 \mathrm{mg} / \mathrm{kg})$ en los horizontes de 0-20 cm, 20-50 cm y 50-100 cm respectivamente. Tras el periodo de fitoextracción 2013-2017 los mapas de distribución muestran una disminución de las concentraciones de cloruros en los horizontes de $0-20 \mathrm{~cm}$ y 20-50 cm y un aumento en el horizonte de 50-100 cm, aunque ninguna de las variaciones observadas es significativa. Con respecto las asociaciones entre parámetros, se han registrado correlaciones positivas entre los cloruros y los siguientes parámetros: nitratos $\left(r=+0,53^{\star \star}\right)$, sodio intercambiable $\left(r=+0,83^{\star \star}\right)$ y magnesio intercambiable $\left(r=+0,62^{\star \star}\right)$. Conforme disminuye la concentración de cloruro disminuyen los nitratos, sodio intercambiable y magnesio intercambiable. Cuantitativamente la correlación de cloruros con los cationes sodio intercambiable es superior, lo cual podría ser debido a que ambos iones se encuentran presentes como sal iónica en los sedimentos del cauce. 
Capítulo 5. ESTUDIO DE FITOEXTRACCIÓN DE Cu, Zn Y Cr CON VEGETACIÓN AUTÓCTONA EN EL CAUCE DEL RIOO GUADALENTÍN

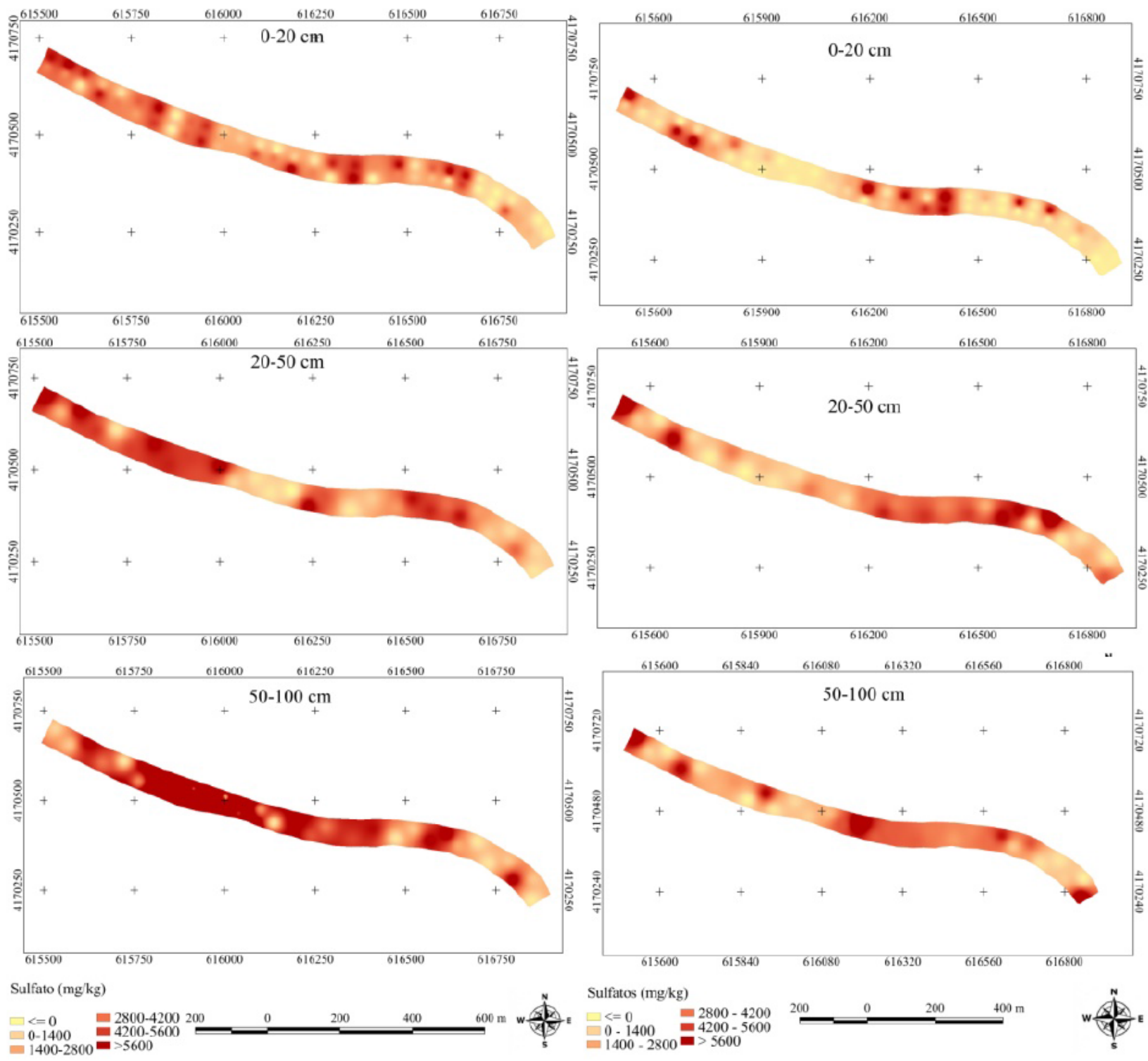

Figura 5.5.21. Evolución de la distribución espacial de la concentración de sulfatos en los tramos 1,2 y $3(1500$ m) entre los años 2013 y 2017. 


\section{Concentración de sulfatos:}

En el año 2013 se registraron concentraciones promedio de 3319,38 mg/kg (comprendidas entre $90,03-8082,29 \mathrm{mg} / \mathrm{kg}), 3991,81 \mathrm{mg} / \mathrm{kg}(0-7899,73 \mathrm{mg} / \mathrm{kg})$ у $13292,94 \mathrm{mg} / \mathrm{kg}(564,42-$ $285330,00 \mathrm{mg} / \mathrm{kg}$ ) en los horizontes de $0-20 \mathrm{~cm}, 20-50 \mathrm{~cm}$ y $50-100 \mathrm{~cm}$ respectivamente. Existe alta heterogeneidad en los niveles de sulfato en los sedimentos con valores en general por encima de $2500 \mathrm{mg} / \mathrm{kg}$ (830 mg/kg de azufre), que indican niveles bastante elevados, sobre todo en profundidad.

En el año 2017 se han registrado concentraciones promedio de 2088,49 $\mathrm{mg} / \mathrm{kg}$ (comprendidas entre 80,67-9615,79 mg/kg), 3502,65 mg/kg (133,66-10749,30 mg/kg) y $3605,07 \mathrm{mg} / \mathrm{kg}(163,88-10412,45 \mathrm{mg} / \mathrm{kg})$ en los horizontes de 0-20 cm, 20-50 cm y 50-100 cm respectivamente. Tras el periodo de fitoextracción 2013-2017 los mapas de distribución muestran una disminución de las concentraciones de sulfatos en los horizontes muestreados, siendo significativa únicamente en el horizonte más superficial (0-20 cm). Con respecto las asociaciones entre parámetros, se han registrado correlaciones positivas entre los sulfatos y los siguientes parámetros: sodio intercambiable $\left(r=+0,60^{\star \star}\right)$, calcio intercambiable $\left(r=+0,50^{\star \star}\right)$ y cloruros $\left(r=+0,61^{\star \star}\right)$.

\subsection{EVOLUCIÓN 2013-2017 DE LOS RESULTADOS BIOQUÍMICOS EN SEDIMENTOS}

A continuación se muestra la evolución temporal 2013-2017 de los resultados bioquímicos de carbono de la biomasa microbiana, respiración edáfica basal y actividades enzimáticas $\beta$ glucosidasa, ureasa, fosfatasa alcalina y arilsulfatasa. 
Capítulo 5. ESTUDIO DE FITOEXTRACCIÓN DE Cu, Zn Y Cr CON VEGETACIÓN AUTÓCTONA EN EL CAUCE DEL RIOO GUADALENTÍN

2013
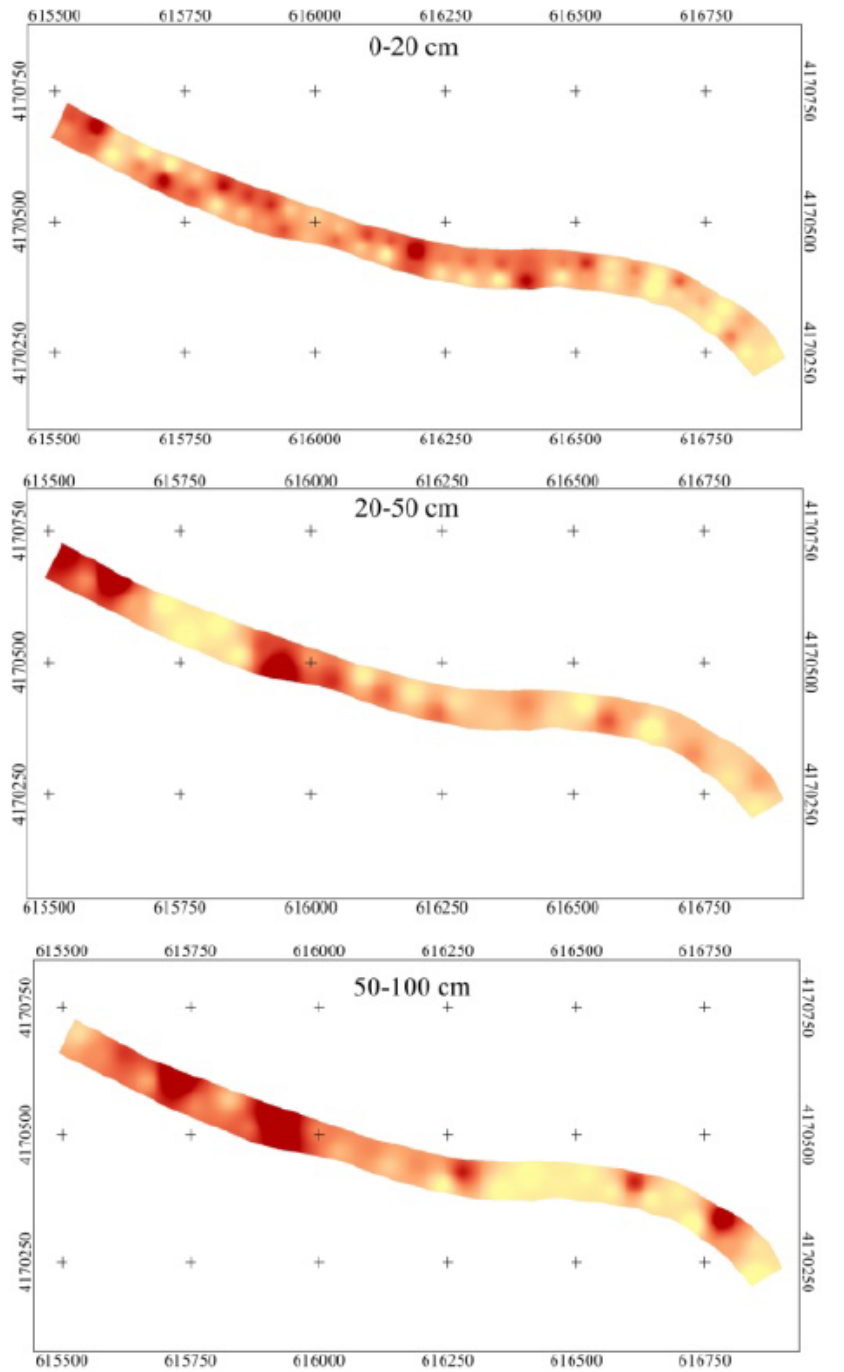

$\mathrm{CBM}(\mathrm{mg} / \mathrm{kg})$

$\square<=150=350-450 \quad 2$

$150-250$
$250-350=$
2550
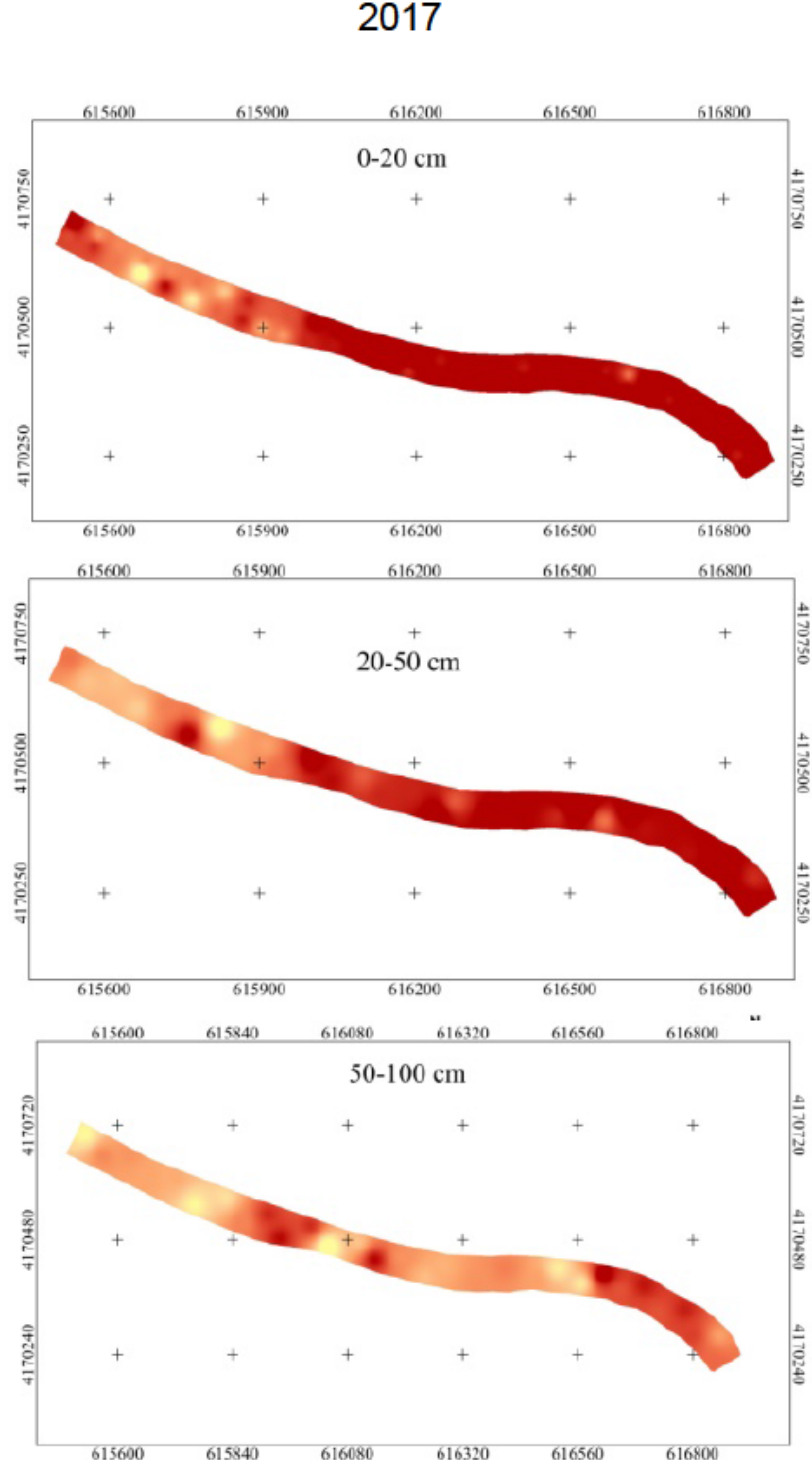

CBM (mg $/ \mathrm{kg}$ )

$\square=150=350-450$
$\square=250=450-550$ $150-250=$
$250-350=550-550$

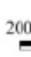

200
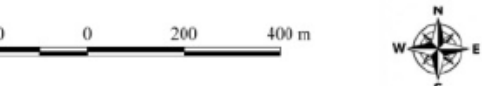

Figura 5.6.1. Evolución de la distribución espacial de la concentración de carbono de la biomasa microbiana en los tramos 1, 2 y 3 (1500 m) entre los años 2013 y 2017. 


\section{Concentración de carbono de la biomasa microbiana (CBM):}

En el año 2013 se registraron concentraciones promedio de 349,26 mg/kg (comprendidas entre $57,78-772,01 \mathrm{mg} / \mathrm{kg}), 348,30 \mathrm{mg} / \mathrm{kg}(91,34-998,35 \mathrm{mg} / \mathrm{kg})$ y $376,08 \mathrm{mg} / \mathrm{kg}(80,36-$ $1124,23 \mathrm{mg} / \mathrm{kg}$ ) en los horizontes de 0-20 cm, 20-50 cm y 50-100 cm respectivamente. El CBM representa la población total de microorganismos que habitan el sedimento, sin distinción entre diferentes grupos. Por tanto, a mayor nivel de CBM mayor cantidad de microorganismos en el sedimento. En general los sedimentos del cauce presentan valores similares a los encontrados en suelos agrícolas de la zona, con un promedio de $350 \mathrm{mg} / \mathrm{kg}$, lo que indica que los sedimentos mantienen una importante biomasa microbiana a pesar del bajo contenido en materia orgánica. En general se observa una relación directa entre el contenido de CBM y el carbono orgánico, indicando que en aquellas zonas con mayor cantidad de materia orgánica se incrementan las poblaciones de microorganismos.

En el año 2017 se han registrado concentraciones promedio de 606,13 mg/kg (comprendidas entre $31,91-875,31 \mathrm{mg} / \mathrm{kg}), 553,15 \mathrm{mg} / \mathrm{kg}(92,74-886,99 \mathrm{mg} / \mathrm{kg}$ ) у 401,92 $\mathrm{mg} / \mathrm{kg}(60,23-732,70 \mathrm{mg} / \mathrm{kg})$ en los horizontes de 0-20 cm, 20-50 cm y 50-100 cm respectivamente. Tras el periodo de fitoextracción 2013-2017 los mapas de distribución muestran una disminución significativa de los valores del CBM en el horizonte de 0-20 cm y un aumento en el resto de horizontes, siendo estadísticamente significativo en el horizonte de $20-50 \mathrm{~cm}$. Con respecto las asociaciones entre parámetros no se han registrado correlaciones destacables entre el CBM y el resto de parámetros. Tampoco se ha observado ninguna relación entre la biomasa microbiana y el contenido de $\mathrm{Cr}$ en ninguna de sus fracciones, lo que en principio sugiere que no existe un efecto tóxico directo significativo del $\mathrm{Cr}$ en las poblaciones de microorganismos. Esto puede ser debido a su baja movilidad. 
Capítulo 5. ESTUDIO DE FITOEXTRACCIÓN DE Cu, Zn Y Cr CON VEGETACIÓN AUTÓCTONA EN EL CAUCE DEL RIOO GUADALENTÍN

2013
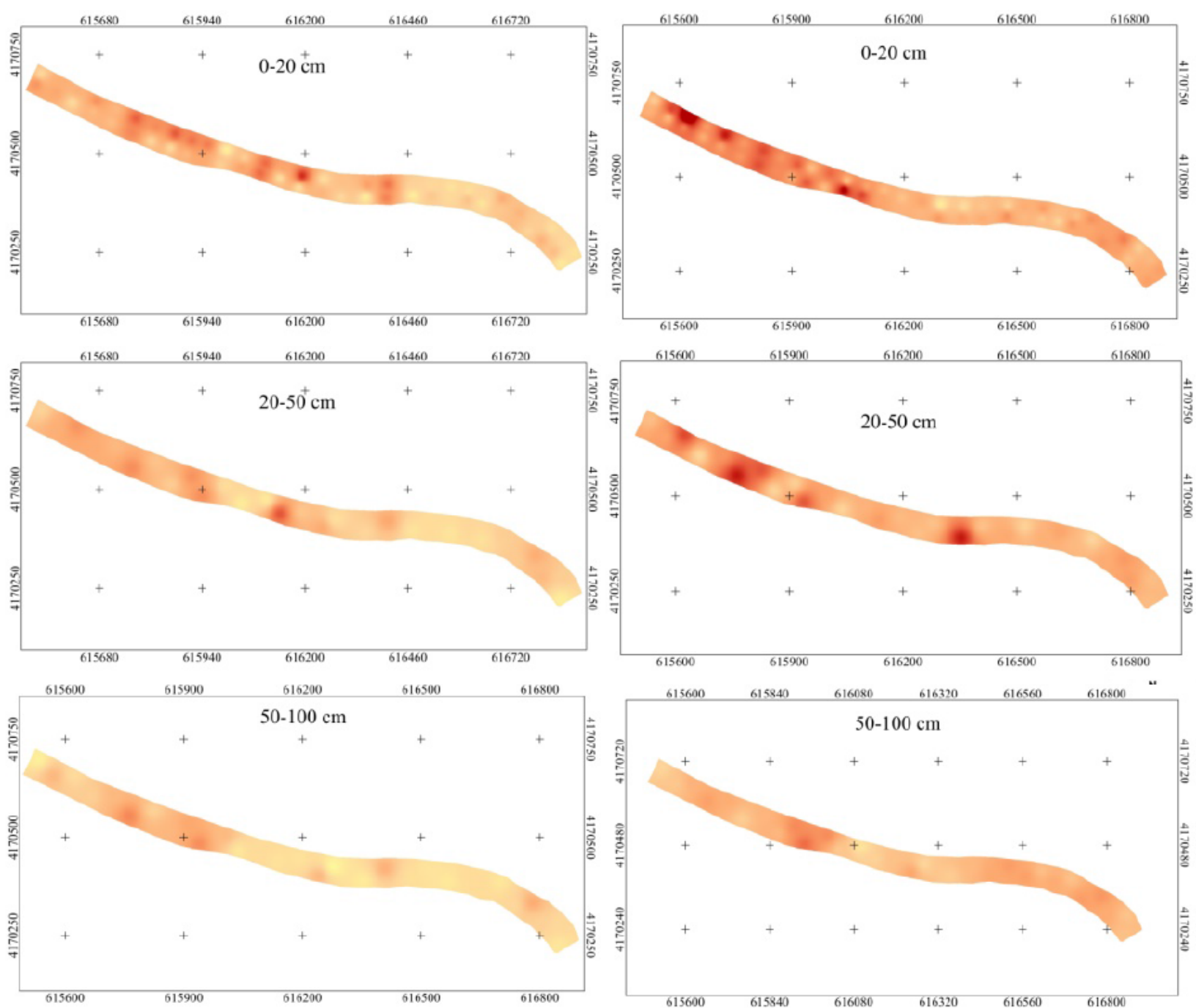

Respiración (mg C-CO2/kg suelo/h)

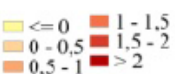

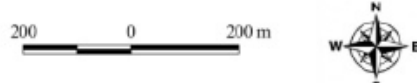

Respiración (mg C-CO2/kg suelo/h)

$\square<=0=1-1,5$

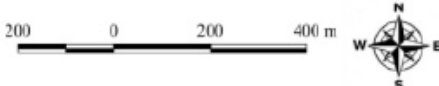

Figura 5.6.2. Evolución de la distribución espacial de la respiración edáfica basal en los tramos 1,2 y $3(1500 \mathrm{~m})$ entre los años 2013 y 2017. 


\section{Respiración edáfica basal (REB):}

En el año 2013 se registraron concentraciones promedio de 0,78 mg/kg (comprendidas entre $0,15-2,14 \mathrm{mg} / \mathrm{kg}), 0,67 \mathrm{mg} / \mathrm{kg}(0,16-1,73 \mathrm{mg} / \mathrm{kg})$ y $0,53 \mathrm{mg} / \mathrm{kg}(0,04-1,28 \mathrm{mg} / \mathrm{kg})$ en los horizontes de 0-20 cm, 20-50 cm y 50-100 cm respectivamente. La REB representa la emisión de $\mathrm{CO}_{2}$ a la atmósfera a través de la mineralización de la materia orgánica del suelo por acción de los microorganismos. Por tanto, es un parámetro que representa la actividad metabólica de los microorganismos. En general los sedimentos del cauce presentan valores de respiración similares a los encontrados en suelos agrícolas de la zona, con un promedio de $0,80 \mathrm{mg} \mathrm{C}-\mathrm{CO}_{2} / \mathrm{kg} / \mathrm{h}$. La actividad microbiana, como era de esperar, desciende en profundidad como consecuencia de descensos en los contenidos de materia orgánica.

En el año 2017 se han registrado concentraciones promedio de 1,11 mg/kg (comprendidas entre $0,17-4,33 \mathrm{mg} / \mathrm{kg}), 0,99 \mathrm{mg} / \mathrm{kg}(0,47-2,31 \mathrm{mg} / \mathrm{kg})$ y $0,83 \mathrm{mg} / \mathrm{kg}(0,28-1,55 \mathrm{mg} / \mathrm{kg})$ en los horizontes de 0-20 cm, $20-50 \mathrm{~cm}$ y $50-100 \mathrm{~cm}$ respectivamente. Tras el periodo de fitoextracción 2013-2017 los mapas de distribución muestran un aumento significativo de los valores de la REB en todos los horizontes muestreados. Con respecto las asociaciones entre parámetros, se ha registrado una correlación positiva entre la REB y el manganeso biodisponible $\left(r=+0,58^{\star \star}\right)$, lo cual indica que que la presencia de este nutriente estimula la actividad microbiana. No se ha observado ninguna relación entre la respiración edáfica basal y el contenido de $\mathrm{Cr}$ en ninguna de sus fracciones, lo que en principio sugiere que no existe un efecto tóxico directo significativo del $\mathrm{Cr}$ en la actividad de las poblaciones de microorganismos. Esto puede ser debido a su baja disponibilidad y movilidad. 
Capítulo 5. ESTUDIO DE FITOEXTRACCIÓN DE Cu, Zn Y Cr CON VEGETACIÓN AUTÓCTONA EN EL CAUCE DEL RÍO GUADALENTÍN

2013
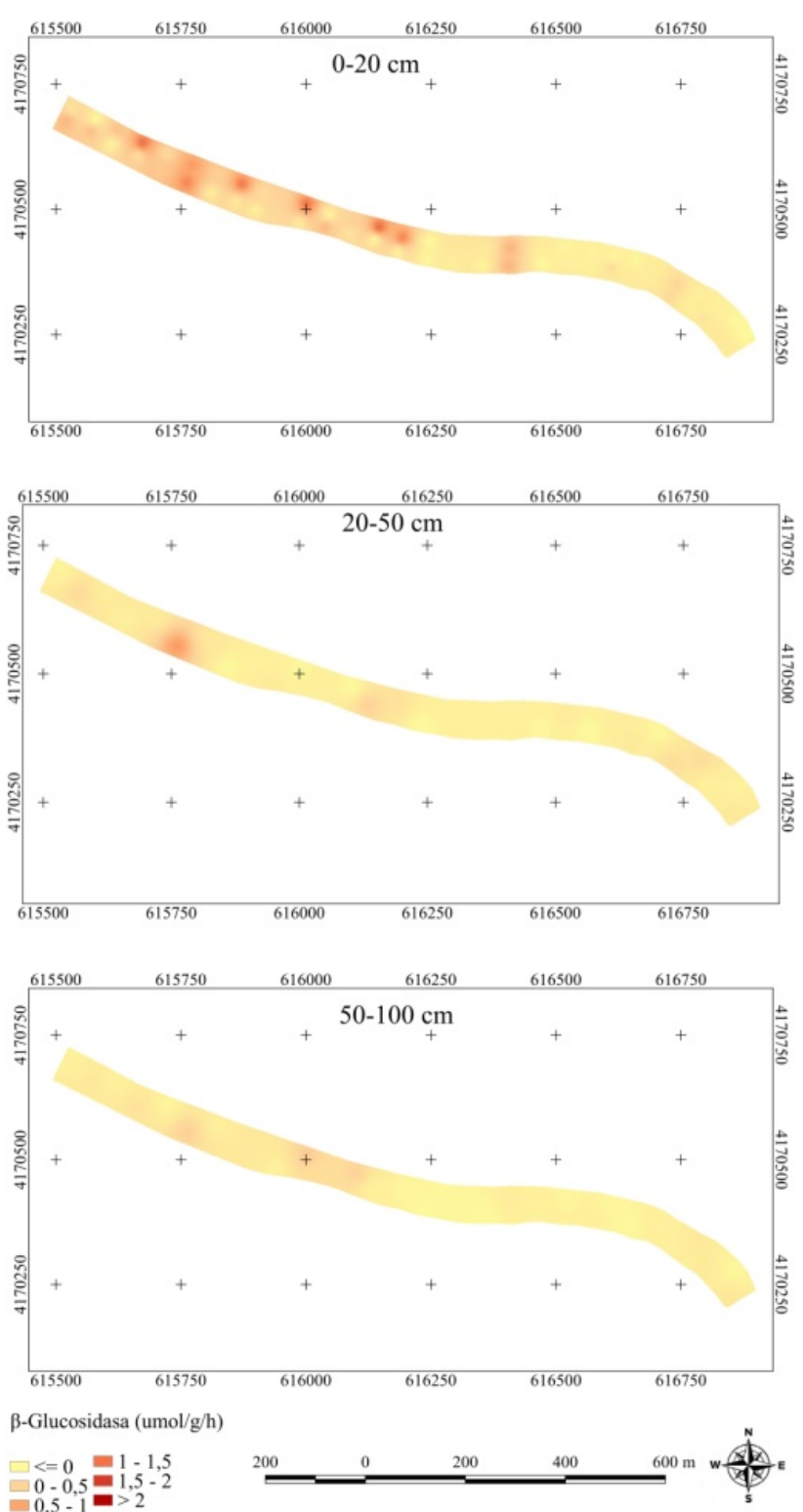

2017
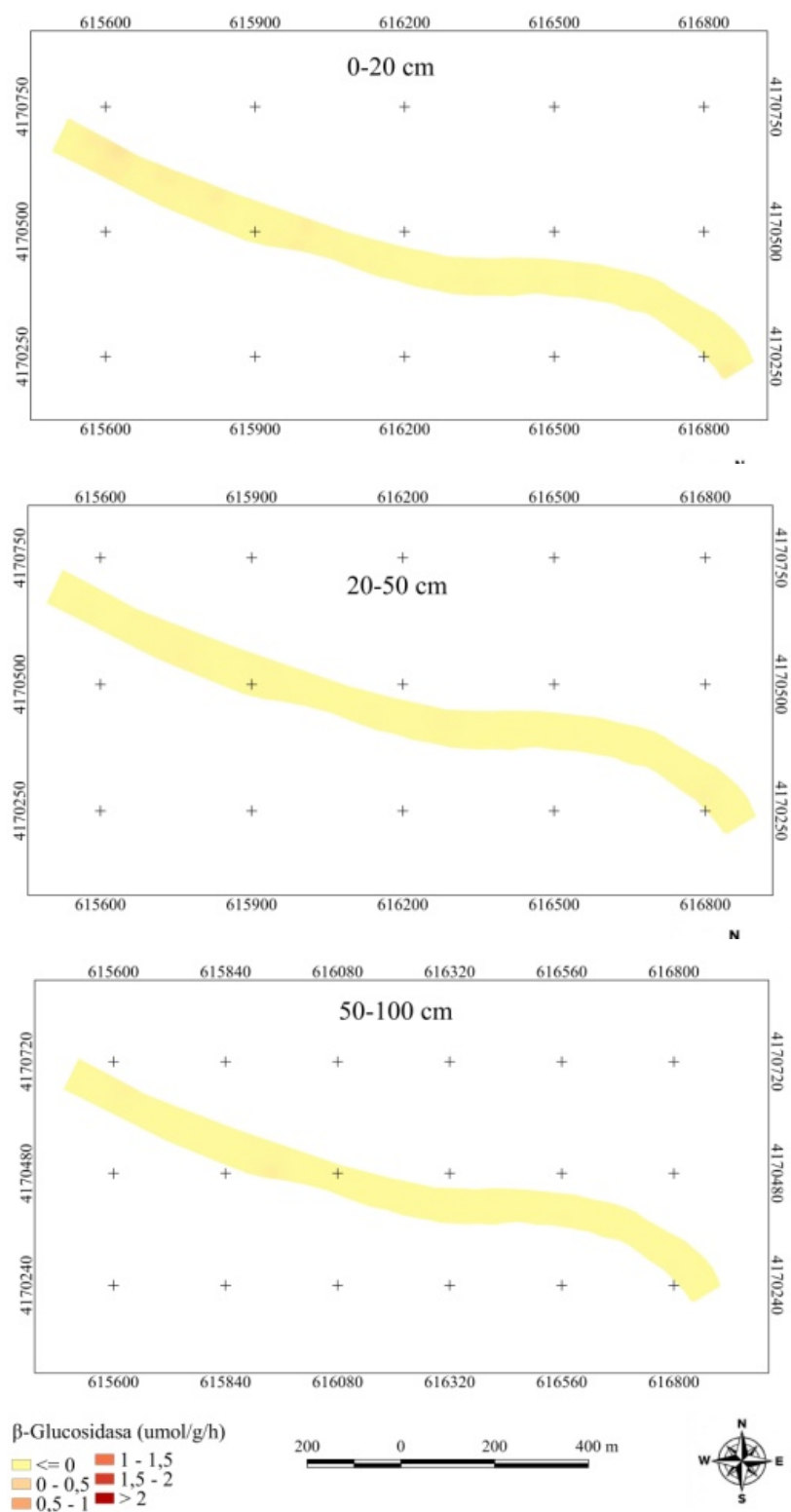

Figura 5.6.3. Evolución de la distribución espacial de la actividad enzimática $\beta$-glucosidasa en los tramos 1, 2 y 3 (1500 m) entre los años 2013 y 2017. 


\section{Actividad enzimática $\beta$-glucosidasa:}

En el año 2013 se registraron concentraciones promedio de 0,40 $\mathrm{mg} / \mathrm{kg}$ (comprendidas entre $0-1,52 \mathrm{mg} / \mathrm{kg}), 0,19 \mathrm{mg} / \mathrm{kg}(0,01-1,08 \mathrm{mg} / \mathrm{kg})$ y $0,17 \mathrm{mg} / \mathrm{kg}(0,01-0,58 \mathrm{mg} / \mathrm{kg})$ en los horizontes de $0-20 \mathrm{~cm}, 20-50 \mathrm{~cm}$ y $50-100 \mathrm{~cm}$ respectivamente. La actividad enzimática $\beta$ glucosidasa representa la capacidad del sedimento para degradar bioquímicamente compuestos orgánicos lábiles del carbono. En general los sedimentos del cauce presentan valores de actividad $\beta$-glucosidasa similares a los encontrados en suelos agrícolas de la zona a nivel superficial, con un promedio de $0,50 \mu \mathrm{mol} p$-nitrofenol/g/h. Esta actividad enzimática, como era de esperar, desciende en profundidad como consecuencia de descensos en los contenidos de materia orgánica.

En el año 2017 se han registrado concentraciones promedio de 0,21 mg/kg (comprendidas entre $0-1,21 \mathrm{mg} / \mathrm{kg}), 0,12 \mathrm{mg} / \mathrm{kg}(0-0,56 \mathrm{mg} / \mathrm{kg})$ y $0,13 \mathrm{mg} / \mathrm{kg}(0-0,63 \mathrm{mg} / \mathrm{kg})$ en $\mathrm{los}$ horizontes de 0-20 cm, $20-50 \mathrm{~cm}$ y $50-100 \mathrm{~cm}$ respectivamente. Tras el periodo de fitoextracción 2013-2017 los mapas de distribución muestran una disminución de los valores de la actividad enzimática $\beta$-glucosidasa en todos los horizontes muestreados, siendo significativa en los horizontes de 0-20 cm y 50-100 cm. Con respecto las asociaciones entre parámetros, la actividad enzimática $\beta$-glucosidasa no ha mostrado ninguna correlación destacable con el resto de parámetros analizados en suelo. No se ha observado ninguna relación entre esta actividad enzimática y el contenido de metales pesados en ninguna de sus fracciones, lo que en principio sugiere que no existe un efecto tóxico directo significativo de los metales pesados en la actividad $\beta$-glucosidasa. Esto puede ser debido a su baja disponibilidad y movilidad. 
Capítulo 5. ESTUDIO DE FITOEXTRACCIÓN DE Cu, Zn Y Cr CON VEGETACIÓN AUTÓCTONA EN EL CAUCE DEL RÍO GUADALENTÍN

2013
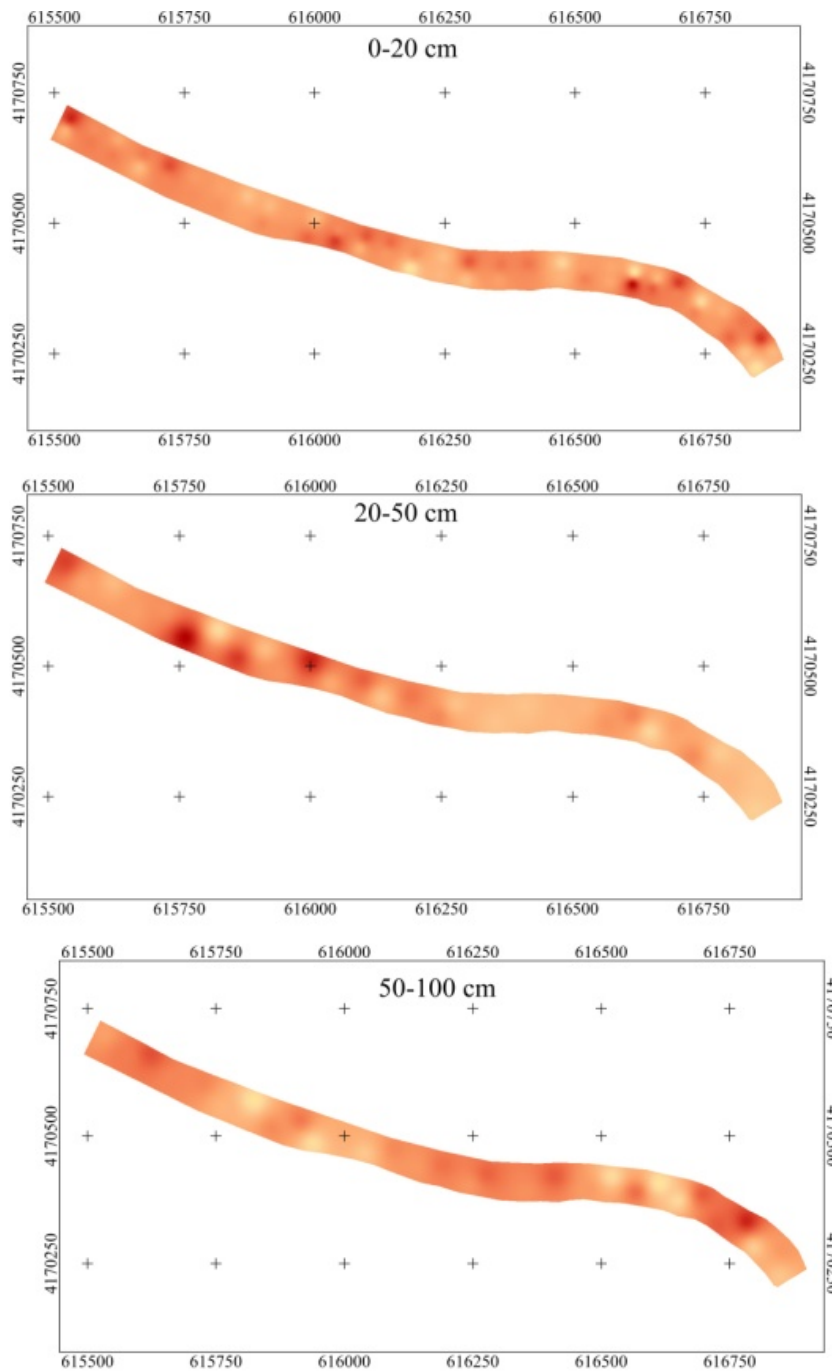

Ureasa $(\mathrm{umol} / \mathrm{g} / \mathrm{h})$

$\square<=0 \quad=0,4-0,6$
$0-0,2 \quad \begin{aligned} & 0,6-0,8 \\ & 0,2-0,4\end{aligned}=0,8$

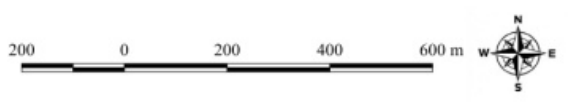

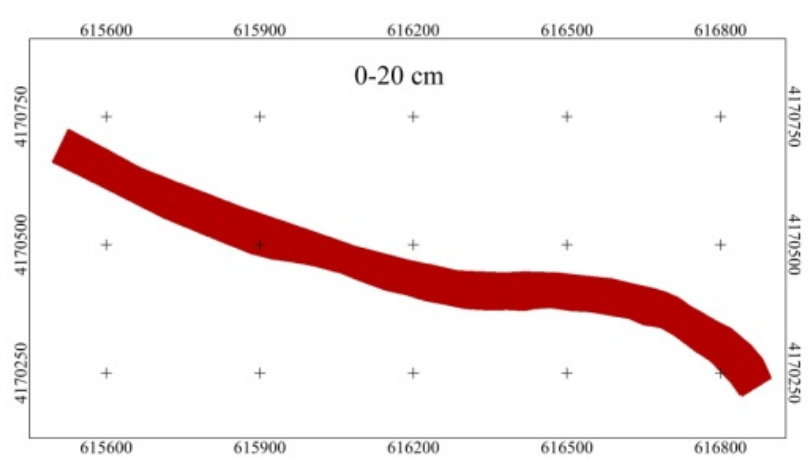
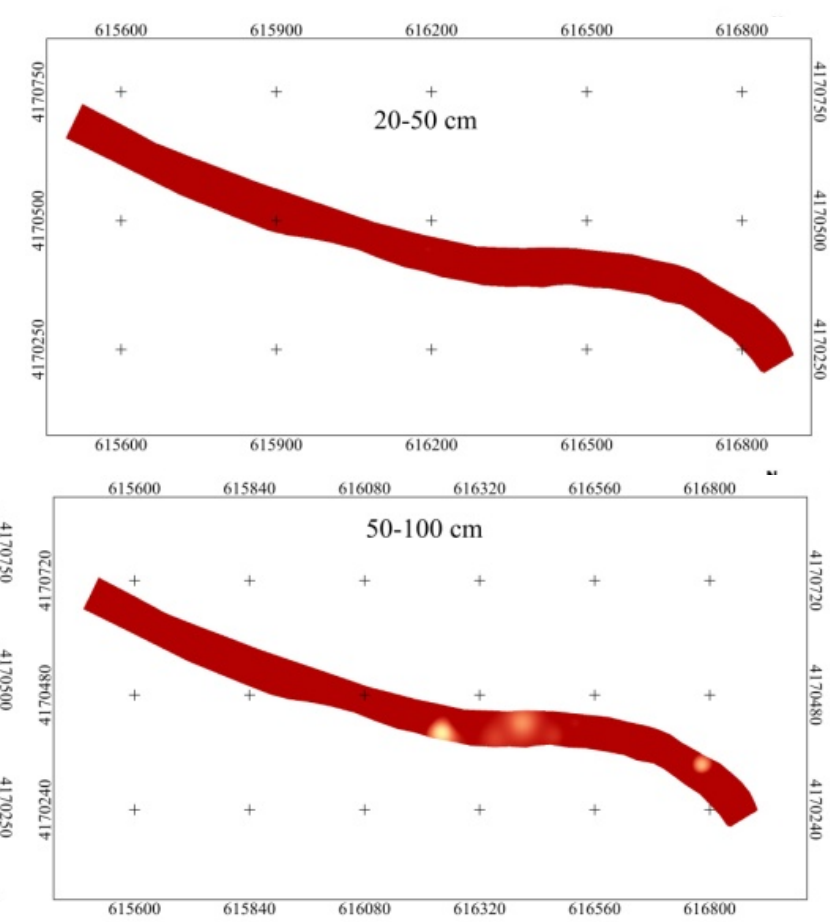

Ureasa (umol/g/h) $\square=0$
$\square=0,2 \quad=0,4-0,6$
$0,6-0,8$ $0,2-0,4$
$0,0,0$
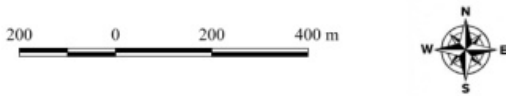

Figura 5.6.4. Evolución de la distribución espacial de la actividad enzimática ureasa en los tramos 1, 2 y 3 (1500 m) entre los años 2013 y 2017. 


\section{$\underline{\text { Actividad enzimática ureasa: }}$}

En el año 2013 se registraron concentraciones promedio de 0,47 mg/kg (comprendidas entre $0,11-0,98 \mathrm{mg} / \mathrm{kg}), 0,44 \mathrm{mg} / \mathrm{kg}(0,17-1,00 \mathrm{mg} / \mathrm{kg})$ y $0,45 \mathrm{mg} / \mathrm{kg}(0,11-0,88 \mathrm{mg} / \mathrm{kg})$ en los horizontes de $0-20 \mathrm{~cm}, 20-50 \mathrm{~cm}$ y $50-100 \mathrm{~cm}$ respectivamente. La actividad enzimática ureasa representa la capacidad del sedimento para degradar bioquímicamente compuestos orgánicos lábiles del nitrógeno. En general los sedimentos del cauce presentan valores de actividad ureasa similares a los encontrados en suelos agrícolas de la zona, sin diferencias

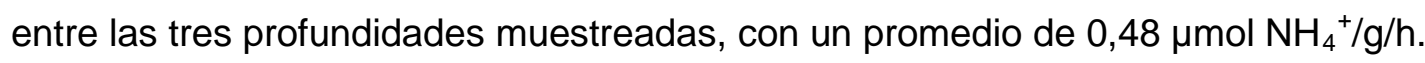

En el año 2017 se han registrado concentraciones promedio de 3,28 mg/kg (comprendidas entre $1,08-13,22 \mathrm{mg} / \mathrm{kg}), 2,99 \mathrm{mg} / \mathrm{kg}(0,95-8,78 \mathrm{mg} / \mathrm{kg})$ y $2,29 \mathrm{mg} / \mathrm{kg}(0,01-9,82 \mathrm{mg} / \mathrm{kg})$ en los horizontes de $0-20 \mathrm{~cm}, 20-50 \mathrm{~cm}$ y $50-100 \mathrm{~cm}$ respectivamente. Tras el periodo de fitoextracción 2013-2017 los mapas de distribución muestran un aumento significativo de los valores de la actividad enzimática ureasa en todos los horizontes muestreados. Con respecto las asociaciones entre parámetros se han registrado correlaciones destacables entre la actividad enzimática ureasa y las siguientes propiedades edáficas: carbono orgánico $\left(r=-0,69^{\star \star}\right), \mathrm{pH}\left(r=-0,64^{\star \star}\right)$, zinc soluble $\left(r=-0,72^{\star \star}\right)$, fósforo disponible $\left(r=+0,71^{\star}\right)$, manganeso biodisponible $\left(r=+0,54^{\star \star}\right)$ y zinc intercambiable $\left(r=+0,71^{\star \star}\right)$. Conforme aumenta la ureasa disminuye el contenido de carbono orgánico, posiblemente debido a la acción de los microorganismos los cuales que lo toman como nutriente. El hecho de que la ureasa y el fósforo biodisponible se correlacionen directamente podría ser en parte ser debido al amonio liberado por las enzimas que provoca una precipitación y aumento de biodisponibilidad del fósforo presente en el suelo, e igualmente podría ocurrir con el manganeso biodisponible y el zinc intercambiable, cuya biodisponibilidad también puede estar influenciada por los valores de $\mathrm{pH}$. No se ha observado ninguna relación entre esta actividad enzimática y el contenido de cromo en ninguna de sus fracciones, lo que en principio sugiere que no existe un efecto tóxico directo significativo del cromo en la actividad ureasa. Esto puede ser debido a su baja disponibilidad y movilidad. Tampoco está relacionada con la biomasa microbiana o la respiración edáfica, indicando que esta actividad no está directamente controlada por los microorganismos en los sedimentos del río. 
Capítulo 5. ESTUDIO DE FITOEXTRACCIÓN DE Cu, Zn Y Cr CON VEGETACIÓN AUTÓCTONA EN EL CAUCE DEL RÍO GUADALENTÍN

2013
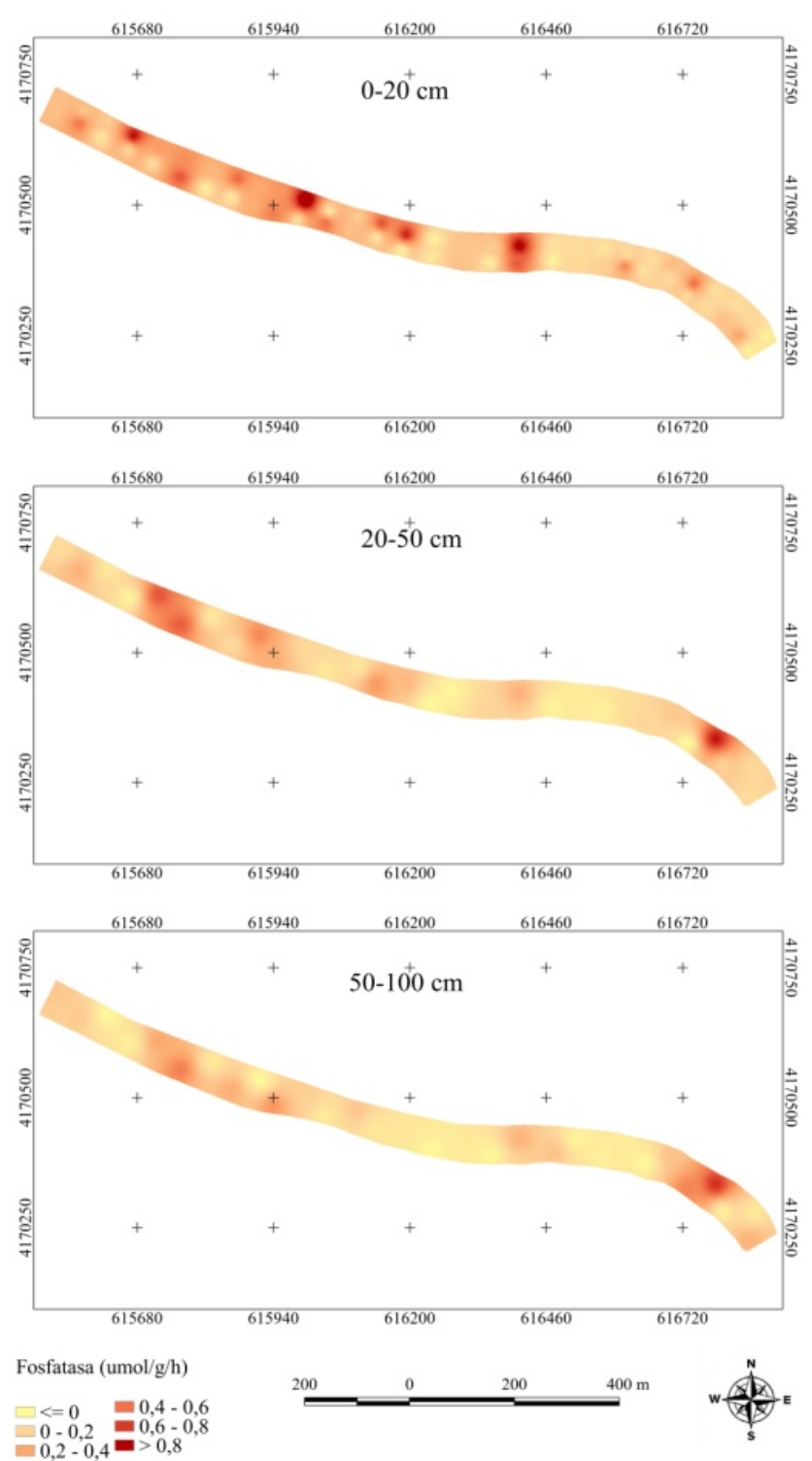

2017
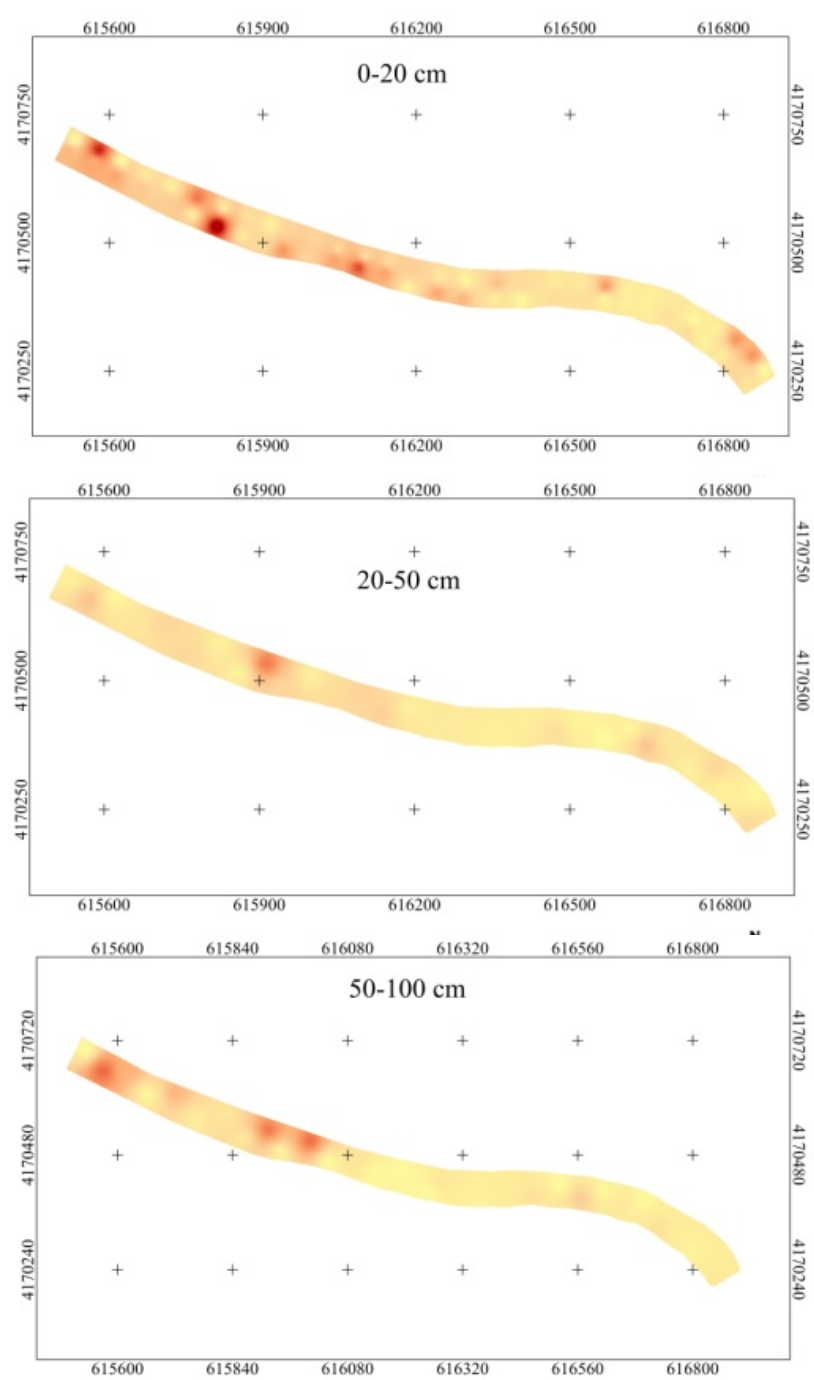

Fosfatasa (umol/g/h) $\square=0$
$\square=0,2=0,4-0,6$
$0,0-0,6$
$0,2-0,4=0,8$

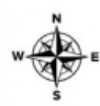

Figura 5.6.5. Evolución de la distribución espacial de la actividad enzimática fosfatasa ácida en los tramos 1, 2 y 3 (1500 m) entre los años 2013 y 2017. 


\section{Actividad enzimática fosfatasa ácida:}

En el año 2013 se registraron concentraciones promedio de 0,32 mg/kg (comprendidas entre $0,03-1,31 \mathrm{mg} / \mathrm{kg}), 0,23 \mathrm{mg} / \mathrm{kg}(0,01-0,93 \mathrm{mg} / \mathrm{kg})$ y $0,20 \mathrm{mg} / \mathrm{kg}(0-0,85 \mathrm{mg} / \mathrm{kg})$ en los horizontes de 0-20 cm, $20-50 \mathrm{~cm}$ y $50-100 \mathrm{~cm}$ respectivamente. La actividad enzimática fosfatasa representa la capacidad del sedimento para degradar bioquímicamente compuestos orgánicos lábiles de fósforo. En general los sedimentos del cauce presentan valores de actividad fosfatasa ligeramente inferiores a los encontrados en suelos agrícolas de la zona a nivel superficial, con un promedio de 0,50 $\mu \mathrm{mol} \mathrm{p}$-nitrofenol/g/h. Esta actividad enzimática, como era de esperar, desciende en profundidad como consecuencia de descensos en los contenidos de materia orgánica.

En el Año 2017 se han registrado concentraciones promedio de 0,12 mg/kg (comprendidas entre $0-0,70 \mathrm{mg} / \mathrm{kg}), 0,09 \mathrm{mg} / \mathrm{kg}(0-0,43 \mathrm{mg} / \mathrm{kg})$ y $0,06 \mathrm{mg} / \mathrm{kg}(0-0,19 \mathrm{mg} / \mathrm{kg})$ en $\mathrm{los}$ horizontes de $0-20 \mathrm{~cm}, 20-50 \mathrm{~cm}$ y $50-100 \mathrm{~cm}$ respectivamente. Tras el periodo de fitoextracción 2013-2017 los mapas de distribución muestran una disminución significativa de los valores de la actividad enzimática fosfatasa en los horizontes muestreados. Con respecto las asociaciones entre parámetros, la actividad enzimática fosfatasa no se ha correlacionado de manera destacable $(r \geq 0,50)$ con ningún parámetro edáfico. No se ha observado ninguna relación entre esta actividad enzimática y el contenido de metales pesados en ninguna de sus fracciones, lo que en principio sugiere que no existe un efecto tóxico directo significativo de los metales pesados en la actividad fosfatasa. Esto puede ser debido a su baja disponibilidad y movilidad. Aunque la actividad enzimática fosfatasa no está relacionada directamente con el carbono de la biomasa microbiana, indicando que no abunda más donde hay más microorganismos, sí que muestra una pequeña relación positiva $\left(r=+0,28^{\star \star}\right)$ con la respiración edáfica basal, lo que sugiere que en las zonas con mayor actividad metabólica se libera más esta enzima. También presenta una relación estrecha positiva con la actividad $\beta$-glucosidasa $\left(r=+0,46^{\star \star}\right)$ y con el contenido de carbono orgánico $\left(r=+0,40^{\star \star}\right)$, lo que confirma que en las zonas donde hay más materia orgánica se libera más cantidad de esta enzima para degradar los compuestos. 
Capítulo 5. ESTUDIO DE FITOEXTRACCIÓN DE Cu, Zn Y Cr CON VEGETACIÓN AUTÓCTONA EN EL CAUCE DEL RIOO GUADALENTÍN

2013
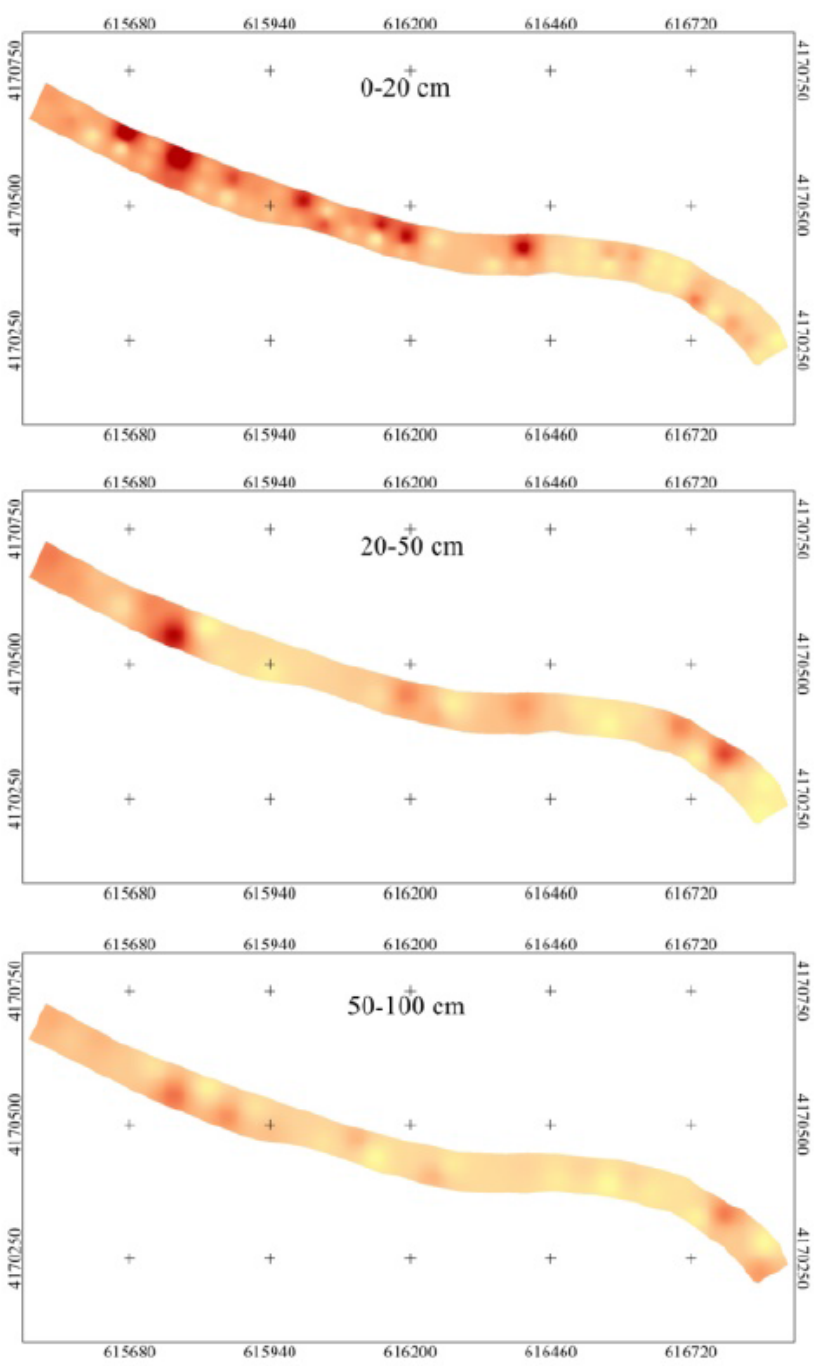

Arilsulfatasa (umol/g/h) $\square=0$
$\square=0,05$
$0.0,0.1-0.15$
$0,05-0,1=0,2$

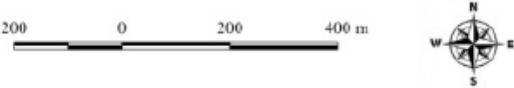

".
2017
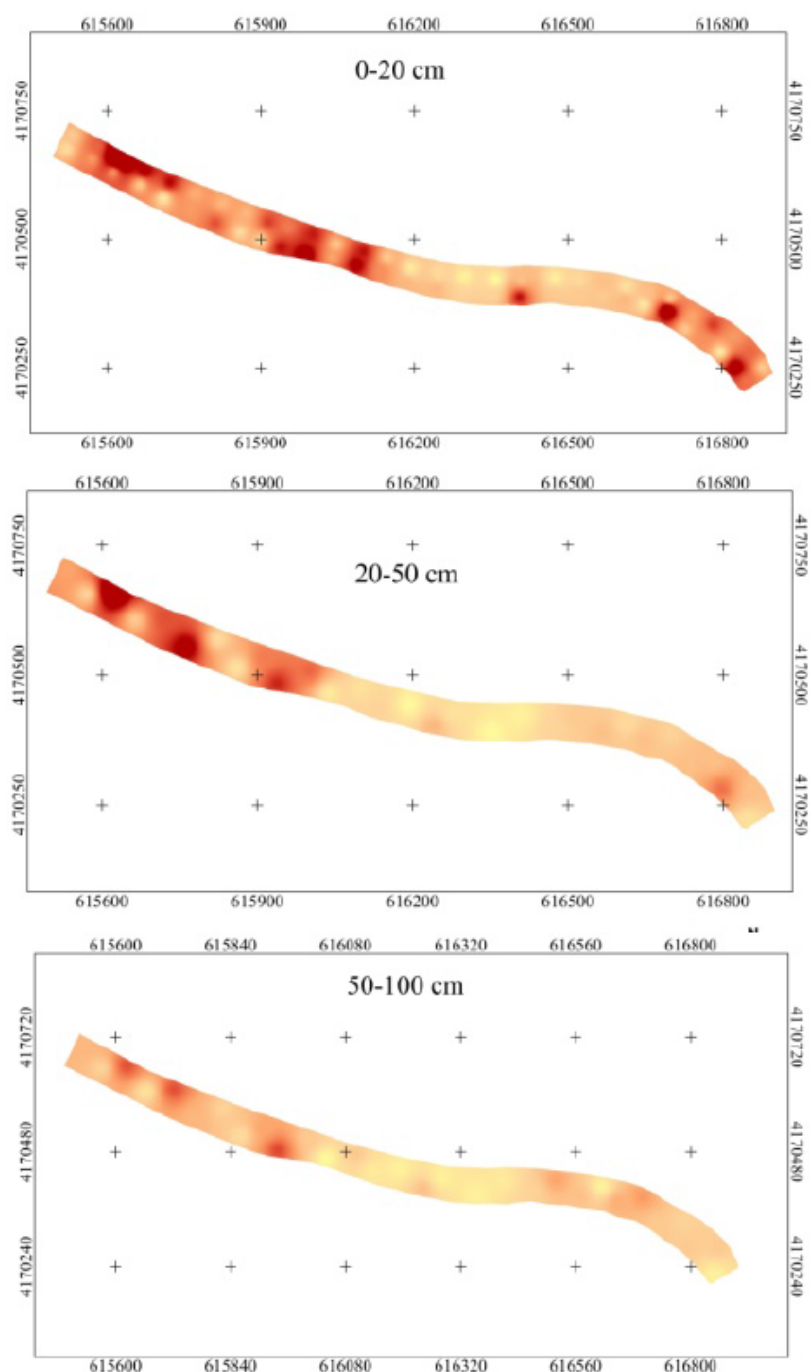

Arilsulfatasa (umol/g/h)

\[ =0 \quad=0,1-0,15 \]
$\square-0,05 \quad=0,15-0,2$
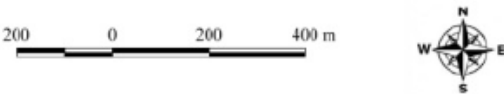

Figura 5.6.6. Evolución de la distribución espacial de la actividad enzimática arilsulfatasa en los tramos 1, 2 y 3 (1500 m) entre los años 2013 y 2017. 


\section{Actividad enzimática arilsulfatasa:}

En el año 2013 se registraron valores promedio de 0,09 mg/kg (comprendidos entre 0-0,39 $\mathrm{mg} / \mathrm{kg}), 0,06 \mathrm{mg} / \mathrm{kg}(0-0,25 \mathrm{mg} / \mathrm{kg})$ y $0,05 \mathrm{mg} / \mathrm{kg}(0-0,15 \mathrm{mg} / \mathrm{kg})$ en los horizontes de $0-20$ cm, 20-50 cm y 50-100 cm respectivamente. La actividad enzimática arilsulfatasa representa la capacidad del sedimento para degradar bioquímicamente compuestos orgánicos lábiles del azufre. En general los sedimentos del cauce presentan valores de actividad arilsulfatasa ligeramente inferiores a los encontrados en suelos agrícolas de la zona a nivel superficial, con un promedio de 0,10 $\mu \mathrm{mol} \mathrm{p}$-nitrofenol/g/h, debido seguramente a la alta concentración de sulfato, producto de la enzima. Esta actividad enzimática, como era de esperar, desciende en profundidad como consecuencia de descensos en los contenidos de materia orgánica.

En el año 2017 se han registrado concentraciones promedio de 0,05 mg/kg (comprendidas entre $0-0,28 \mathrm{mg} / \mathrm{kg}), 0,02 \mathrm{mg} / \mathrm{kg}(0-0,08 \mathrm{mg} / \mathrm{kg})$ y $0,01 \mathrm{mg} / \mathrm{kg}(0-0,11 \mathrm{mg} / \mathrm{kg})$ en los horizontes de $0-20 \mathrm{~cm}, 20-50 \mathrm{~cm}$ y $50-100 \mathrm{~cm}$ respectivamente. Tras el periodo de fitoextracción 2013-2017 los mapas de distribución muestran una disminución significativa de los valores de la actividad enzimática arilsulfatasa en todos los horizontes muestreados. Con respecto a las correlaciones entre parámetros, se han registrado las siguientes correlaciones con la actividad enzimática arilsulfatasa: potasio intercambiable $(r=+0,49 * \star)$ y fosfatasa $\left(r=+0,59^{\star *}\right)$. La enzima arilsulfatasa ( $y$ también la fosfatasa) se correlacionan directamente con el potasio intercambiable, por lo que ambas enzimas degradan este macronutriente en las zonas donde más abunda. No se ha observado ninguna relación entre esta actividad enzimática y el contenido de metales pesados en ninguna de sus fracciones, lo que en principio sugiere que no existe un efecto tóxico directo significativo de los metales pesados en la actividad arilsulfatasa. Esto puede ser debido a su baja disponibilidad y movilidad. 


\subsection{EFICIENCIA DE ELIMINACIÓN DE METALES EN SUELO}

Este apartado resume los principales resultados alcanzados sobre el grado de eliminación de metales $\mathrm{Cu}, \mathrm{Zn}$ y $\mathrm{Cr}$ a partir de los resultados obtenidos en las muestras de los sedimentos del suelo de los tramos 1, 2 y 3 de los años 2013 (120 muestras) y 2017 (120 muestras).

Tabla 5.7.1. Variación (A: aumento; D: disminución) de propiedades físico-químicas y bioquímicas del suelo de los tramos 1, 2 y 3 antes y después del periodo de fitoextracción ( $n=120$ muestras).

\begin{tabular}{|c|c|c|c|c|c|c|}
\hline \multirow{3}{*}{$\begin{array}{l}\text { (a) Parámetro } \\
\text { Cu total }\end{array}$} & \multicolumn{6}{|c|}{ (b) Profundidad } \\
\hline & \multicolumn{2}{|c|}{$0-20 \mathrm{~cm}$} & \multicolumn{2}{|c|}{$20-50 \mathrm{~cm}$} & \multicolumn{2}{|c|}{$50-100 \mathrm{~cm}$} \\
\hline & A & ns & A & ns & A & ns \\
\hline Zn total & $\mathrm{D}$ & ns & $\mathrm{D}$ & ns & A & ns \\
\hline Cr total & $\mathrm{D}$ & ns & $\mathrm{D}$ & ns & $\mathrm{D}$ & ns \\
\hline Cr (III) total & $\mathrm{D}$ & ns & $\mathrm{D}$ & ns & $\mathrm{D}$ & ns \\
\hline $\mathrm{Cr}(\mathrm{VI})$ total & $\mathrm{D}$ & 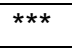 & $\mathrm{D}$ & $\star \star \star$ & $\mathrm{D}$ & $\star \star \star$ \\
\hline Cu intercambiable & $A$ & 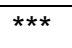 & $\mathrm{D}$ & ** & $A$ & ns \\
\hline Zn intercambiable & $A$ & 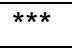 & $\mathrm{A}$ & $\star \star \star *$ & $A$ & $\star \star \star$ \\
\hline Cr intercambiable & $A$ & 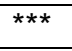 & $\mathrm{A}$ & * & A & $\star \star \star$ \\
\hline Cu soluble & $\mathrm{D}$ & ns & $\mathrm{D}$ & ns & $A$ & ns \\
\hline Zn soluble & $\mathrm{D}$ & 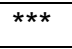 & $\mathrm{D}$ & $\star \star \star *$ & $\mathrm{D}$ & $\star \star \star$ \\
\hline Cr soluble & $\mathrm{D}$ & 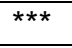 & $\mathrm{D}$ & * & $\mathrm{D}$ & ns \\
\hline Fe biodisponible & A & $\star \star$ & A & ns & A & ns \\
\hline Mn biodisponible & A & $\star \star \star *$ & $\mathrm{~A}$ & $\star \star \star *$ & A & $\star \star \star$ \\
\hline pH & - & ns & - & ns & - & ns \\
\hline CE & $\mathrm{D}$ & 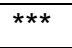 & $\mathrm{D}$ & $\star \star \star$ & $\mathrm{D}$ & $\star \star \star$ \\
\hline Total N total & $\mathrm{D}$ & ns & $\mathrm{D}$ & ns & $\mathrm{D}$ & ns \\
\hline Carbonatos & $A$ & ns & $A$ & ns & $A$ & ns \\
\hline C orgánico & $\mathrm{D}$ & 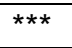 & $\mathrm{D}$ & $\star \star \star$ & $\mathrm{D}$ & $\star \star \star$ \\
\hline C soluble & $\mathrm{D}$ & $\star \star$ & $A$ & ns & A & $\star \star \star$ \\
\hline $\mathbf{C I C}$ & $\mathrm{D}$ & ns & $\mathrm{D}$ & * & A & ns \\
\hline Ca intercambiable & $\mathrm{D}$ & $\star \star \star$ & $\mathrm{D}$ & $\star \star$ & $\mathrm{D}$ & $\star \star \star$ \\
\hline Mg intercambiable & $\mathrm{D}$ & * & $\mathrm{D}$ & ns & $\mathrm{D}$ & 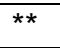 \\
\hline Na intercambiable & $\mathrm{D}$ & ns & $\mathrm{D}$ & ns & $\mathrm{D}$ & * \\
\hline K intercambiable & $\mathrm{D}$ & $\star \star$ & D & $\star \star$ & $\mathrm{D}$ & $\star \star$ \\
\hline P disponible & $A$ & 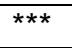 & $A$ & $\star \star \star$ & $A$ & $\star \star \star$ \\
\hline Nitratos & $\mathrm{D}$ & $\star \star$ & $\mathrm{D}$ & ns & $\mathrm{D}$ & ns \\
\hline Cloruros & $\mathrm{D}$ & ns & $\mathrm{D}$ & ns & $A$ & ns \\
\hline Sulfatos & $\mathrm{D}$ & $\star \star$ & $\mathrm{D}$ & ns & $\mathrm{D}$ & ns \\
\hline CBM & $\mathrm{D}$ & $\star \star \star *$ & A & 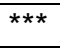 & A & ns \\
\hline Respiración & 1 & 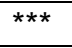 & $\mathrm{A}$ & ** & A & $\star \star \star$ \\
\hline$\beta$-Glucosidasa & $\mathrm{D}$ & $\star \star$ & D & ns & $\mathrm{D}$ & * \\
\hline Ureasa & A & $\star \star \star *$ & $\mathrm{~A}$ & 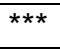 & A & $\star \star \star$ \\
\hline Fosfatasa & $\mathrm{D}$ & 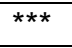 & $\mathrm{D}$ & $\star \star$ & $\mathrm{D}$ & $\star \star$ \\
\hline Arilsulfatasa & $\mathrm{D}$ & $\star \star \star$ & D & $\star \star$ & D & $\star \star \star$ \\
\hline
\end{tabular}

(a) CE: conductividad eléctrica, CIC: capacidad de intercambio catiónico; CBM: carbono de la biomasa microbiana.

(b) $\quad *{ }^{* *}, y^{* * *}$ indicant diferencias significativas a $P<0,05, P<0,01, y P<0,001$, respectivamente. 
En la Tabla 5.7.1 podemos observar un resumen estadístico de los principales resultados asociados a las propiedades físico-químicas y bioquímicas que han presentado las muestras de los sedimentos del suelo.

Entre los años 2013 y 2017 puede observarse lo siguiente:

- Las concentraciones de Cu total aumentan en todos los horizontes muestreados (0$20 \mathrm{~cm}, 20-50 \mathrm{~cm}$ y $50-100 \mathrm{~cm}$ ) aunque el aumento no es estadísticamente significativo.

- Las concentraciones de Zn total disminuyen en los horizontes más superficiales (0$20 \mathrm{~cm}$ y $20-50 \mathrm{~cm}$ ) y aumentan en el horizonte más profundo $(50-100 \mathrm{~cm})$, aunque ninguna de las variaciones registradas es estadísticamente significativa.

- Las concentraciones de $\mathrm{Cr}$ total, $\mathrm{Cr}$ (III) total y $\mathrm{Cr}(\mathrm{VI})$ total disminuyen en todos los horizontes muestreados. La disminución es significativa para $\mathrm{Cr}(\mathrm{VI})$ en todos los horizontes (0-20 cm, 20-50 cm 50-100 cm).

- Las concentraciones de $\mathrm{Cu}, \mathrm{Zn}$ y $\mathrm{Cr}$ intercambiable aumentan en todos los horizontes muestreados, excepto el $\mathrm{Cu}$ intercambiable (horizonte $20-50 \mathrm{~cm}$ ). Las variaciones registradas son significativas en la mayoría de casos (excepto en el horizonte $50-100 \mathrm{~cm}$ para $\mathrm{Cu}$ intercambiable).

- Las concentraciones de $\mathrm{Cu}, \mathrm{Zn}$ y $\mathrm{Cr}$ soluble disminuyen en todos los horizontes muestreados, excepto el $\mathrm{Cu}$ soluble (horizonte $50-100 \mathrm{~cm}$ ). Las variaciones registradas no son significativas para $\mathrm{Cu}$ soluble $(0-100 \mathrm{~cm})$ y para $\mathrm{Cr}$ soluble (50$100 \mathrm{~cm})$.

- Las concentraciones de Fe y Mn biodisponible aumentan en todos los horizontes muestreados, siendo significativas en todos los casos excepto para Fe biodisponible (horizontes $20-50 \mathrm{~cm}$ y $50-100 \mathrm{~cm}$ ).

- Los valores de pH se mantienen estables en todos los horizontes muestreados (0-20 $\mathrm{cm}, 20-0 \mathrm{~cm}$ y de $50-100 \mathrm{~cm}$ ). No muestran variaciones significativas.

- Los valores de CE disminuyen significativamente en todos los horizontes.

- Los valores de nitrógeno total disminuyen en todos los horizontes muestreados, siendo las variaciones no significativas.

- Los valores de carbonatos aumentan en todos horizontes, siendo las variaciones no significativas.

- Los valores de carbono orgánico disminuyen significativamente en todos los horizontes muestreados. 
- Las concentraciones de C soluble disminuyen significativamente en el horizonte superficial $(0-20 \mathrm{~cm})$ y aumentan en el resto de horizontes (siendo significativas en el horizonte de $50-100 \mathrm{~cm})$.

- Los valores de la CEC disminuyen en los horizontes de 0-20 cm y de 20-50 cm y aumentan en el horizonte más profundo. Las variaciones registradas son significativas sólo en el horizonte de $20-50 \mathrm{~cm}$. Con respecto a las concentraciones de cationes intercambiables ( $\mathrm{Ca}, \mathrm{Mg}, \mathrm{Na}$ y $\mathrm{K}$ ), se observa que todas las concentraciones disminuyen, siendo la disminución significativa en todos los casos, excepto para $\mathrm{Mg}$ intercambiable $(20-50 \mathrm{~cm})$ y para $\mathrm{Na}$ intercambiable $(0-20 \mathrm{~cm}$ y $20-$ $50 \mathrm{~cm})$.

- Las concentraciones de P biodisponible aumentan significativamente en todos los horizontes muestreados.

- Las concentraciones de aniones solubles (nitratos, cloruros y sulfatos) disminuyen en todos los horizontes muestreados, excepto para los cloruros (horizonte $50-100 \mathrm{~cm}$ ) que aumentan. Las variaciones registradas solamente son significativas en el horizonte más superficial $(0-20 \mathrm{~cm})$ para nitratos y sulfatos.

- Las concentraciones del CBM disminuyen significativamente en el horizonte más superficial $(0-20 \mathrm{~cm})$ y aumentan en el resto de horizontes $(20-50 \mathrm{~cm}$ y $50-100 \mathrm{~cm})$, siendo significativas en el horizonte de $20-50 \mathrm{~cm}$.

- Los valores de respiración edáfica basal aumentan significativamente en todos los horizontes muestreados.

- Las actividades enzimáticas $\beta$-glucosidasa, fosfatasa y arilsulfatasa disminuyen significativamente en todos los horizontes muestreados (excepto para $\beta$-glucosidasa en el horizonte $20-50 \mathrm{~cm}$ que no es significativa la disminución). Con respecto a la actividad enzimática ureasa se observa un aumento significativo en los valores de la actividad en todos los horizontes muestreados. 


\subsection{CONCLUSIONES}

Tras los resultados obtenidos se ha llegado a las siguientes conclusiones sobre el grado de eliminación de metales en suelo:

- El grado de eliminación de metales Cu, Zn y Cr total en suelo entre los años 2013 y 2017 es favorable y evidente para Zn y Cr total y menos evidente para Cu total. Las variaciones observadas en las concentraciones son notables aunque no son estadísticamente significativas. La vegetación implantada se ha visto influenciada por los periodos de escasez hídrica y por las condiciones meteorológicas, ambos hechos podrían haber condicionado la fitoextracción de metales por parte de la vegetación presente en el cauce y por tanto las concentraciones de metales totales registradas en las muestras de los sedimentos del suelo, especialmente en los horizontes de 0$20 \mathrm{~cm}$ y de $20-50 \mathrm{~cm}$.

- El aumento observado en las fracciones intercambiables de $\mathrm{Cu}, \mathrm{Zn}$ y $\mathrm{Cr}$ podría haberse visto influenciado por la presencia de la vegetación fitoextractora y sus exudados radiculares. El aumento de estas fracciones favorece la acumulación de $\mathrm{Cu}, \mathrm{Zn}$ y $\mathrm{Cr}$ por parte de las plantas.

- La disminución observada en las fracciones solubles de Cu, Zn y Cr podría deberse directamente a la acumulación de los mismos por parte de la vegetación fitoextractora. Dadas las propiedades de los sedimentos del suelo (elevado $\mathrm{pH}$, calcáreos) no existen evidencias notables de efectos de lixiviación de metales.

- Finalmente, la aplicación de la técnica de fitoextracción en condiciones de clima mediterráneo semiárido tras el periodo de fitoextracción 2013-2017 es adecuada pero teniendo en cuenta algunas recomendaciones como la realización de riegos de emergencia, selección de las vegetación autóctona mejor adaptada a las condiciones de clima y la realización de prácticas agronómicas que mejoren el desarrollo de la vegetación implantada como la aplicación aportes nutricionales que favorezcan el desarrollo de la vegetación así como una siega anual de biomasa aérea. 
Capítulo 6

MONITORIZACIÓN AMBIENTAL DE LAS PROPIEDADES FÍSICO-QUÍMICAS Y BIOQUÍMICAS DE LOS SEDIMENTOS DEL SUELO EN PARCELAS EXPERIMENTALES TRATADAS CON AGENTES QUELANTES NATURALES Y MICROORGANISMOS 



\subsection{OBJETIVOS}

Evaluar el efecto de agentes quelantes naturales ácido oxálico, ácido cítrico y el compuesto pro-enzime 108 (solución compuesta principalmente por aminoácidos y en menor proporción por ácidos lácticos, obtenido a partir de proteínas vegetales por un proceso original de fermentación controlada con purificación final por intercambio iónico) y bacterias Pseudomonas fluorescens en la descontaminación de un suelo contaminado por $\mathrm{Cu}, \mathrm{Zn}$ y $\mathrm{Cr}$ a través de la técnica de fitoextracción mediante el uso de diferentes especies vegetales autóctonas:

1. Atriplex halimus

2. Salsola oppositifolia

3. Suaeda vera

4. Vegetación espontánea. Las especies vegetales muestreadas en las subparcelas de vegetación espontánea fueron las siguientes:

Tramo 1: Atriplex semibaccata, Suaeda vera y Zygophyllum fabago.

Tramo 2: Suaeda vera y Atriplex halimus.

Tramo 3: Suaeda vera.

\subsection{DISEÑO EXPERIMENTAL}

En octubre 2015, antes de la plantación de especies vegetales fitoextractoras en el tramo 1 (área general) del proyecto Life Riverphy, se establecieron 5 parcelas de $8 \times 8 \mathrm{~m}^{2}$ para cada tratamiento a testar (ácido oxálico, ácido cítrico, aminoácidos, bacterias Pseudomonas fluorescens y control) $=5$ tratamientos por triplicado (15 parcelas). Las parcelas se separaron mínimo $1 \mathrm{~m}$ entre ellas. Cada parcela se dividió en 4 subparcelas de $4 \times 4 \mathrm{~m}^{2}$, introduciendo en cada una de ellas las especies vegetales a testar (excepto en la subparcela de vegetación espontánea). Se seleccionó una subparcela para Atriplex halimus, otra subparcela para Salsola oppositifolia y otra subparcela para Suaeda vera y se dejó libre una subparcela donde también se adicionaron los agentes quelantes y microorganismos para estudiar el comportamiento de la vegetación espontánea. En total se establecieron 60 subparcelas entre los tramos 1, 2 y 3 (20 subparcelas por tramo). El marco de implantación en las subparcelas con Atriplex halimus, Salsola oppositifolia y Suaeda vera fue de 1 planta/m².

En junio 2016 se adicionaron por primera vez los agentes quelantes naturales y los microorganismos en cada parcela. La dosis de aplicación fue de $5 \mathrm{mmol} / \mathrm{kg}=3,25 \mathrm{~mol} / \mathrm{m}^{2}$. Esto supuso la adición de: 
- Ácido oxálico (AO): 0,29 kg/m² (densidad aparente $1300 \mathrm{~kg} / \mathrm{m}^{3}$ a 0,5 m de profundidad y peso molecular de $393,35 \mathrm{~g} / \mathrm{mol})$. En las tres subparcelas plantadas, se adicionó alrededor de la planta, y la superficie se redujo al 25\% de cada subparcela. En la subparcela de vegetación espontánea se aplicó en toda la superficie. Para cada parcela, tenemos 3 subparcelas de $4 \times 4 \mathrm{~m}^{2} \times 0,25=12 \mathrm{~m}^{2}$, más una subparcela $4 \times 4 \mathrm{~m}^{2}=16 \mathrm{~m}^{2}$. En total tenemos por parcela con un área de aplicación de $12+16 \mathrm{~m}^{2}=28 \mathrm{~m}^{2}$. Se necesitaron 8,12 $\mathrm{kg}$ por parcela. En total son 8,12 × 3 tramos $=24,4 \mathrm{~kg}$ por aplicación.

- Ácido cítrico (AC): 0,62 kg/m² (densidad aparente $1300 \mathrm{~kg} / \mathrm{m}^{3}$ a 0,5 m de profundidad y peso molecular de 192,12 $\mathrm{g} / \mathrm{mol})$. En las tres subparcelas plantadas, se adicionó alrededor de la planta, y la superficie se redujo al $25 \%$ de cada subparcela. En la subparcela de vegetación espontánea se aplicó en toda la superficie. Para cada parcela tenemos 3 subparcelas de $4 \times 4 \mathrm{~m}^{2} \times 0,25=12 \mathrm{~m}^{2}$, más una subparcela $4 \times 4 \mathrm{~m}^{2}=16 \mathrm{~m}^{2}$ (subparcela espontánea). En total tenemos por parcela un área de aplicación de $12+16 \mathrm{~m}^{2}=28 \mathrm{~m}^{2}$. Se necesitaron $17,4 \mathrm{~kg}$ de ácido cítrico por parcela. En total son $17,4 \times 3$ tramos $=52,1 \mathrm{~kg}$ de ácido cítrico por aplicación.

- Aminoácidos Pro-enzime 108 (AA): $25 \mathrm{~mL} / \mathrm{m}^{2}$. En las tres subparcelas plantadas, se adicionaron alrededor de la planta, y la superficie se redujo al $25 \%$ de cada parcela. En la subparcela de vegetación espontánea se aplicó en toda la superficie. Para cada parcela, tenemos 3 subparcelas de $4 \times 4 \mathrm{~m}^{2} \times 0,25=12 \mathrm{~m}^{2}$, más una subparcela $4 \times 4 \mathrm{~m}^{2}=16 \mathrm{~m}^{2}$ ). En total tenemos por parcela un área de aplicación de $12+16 \mathrm{~m}^{2}=28 \mathrm{~m}^{2}$. Se necesitaron $700 \mathrm{~mL}$ por parcela. En total son $700 \mathrm{~mL} \times 3$ tramos $=2100 \mathrm{~mL}$ por aplicacióm.

- Bacterias Pseudomonas fluorescens (BPF): 0,1 kg/m² (1 kg por hectárea). En las tres subparcelas plantadas, se adicionaron alrededor de la planta, y la superficie se redujo al $25 \%$ de cada subparcela. En la subparcela de vegetación espontánea se aplicó en toda la superficie. Para cada parcela tenemos 3 subparcelas de $4 \times 4 \mathrm{~m}^{2} \times 0,25=12 \mathrm{~m}^{2}$, más una parcela $4 \times 4 \mathrm{~m}^{2}=16 \mathrm{~m}^{2}$ ). En total tenemos por parcela un área de aplicación de $12+16 \mathrm{~m}^{2}$ $=28 \mathrm{~m}^{2}$. Se necesitaron 2,8 g por parcela. En total son 2,8 $\times 3$ tramos = 8,4 g por aplicación.

Se programaron 5 aplicaciones en total que se realizaron con frecuencia trimestral entre los años 2016 y 2017:

Aplicación $n^{\circ}$ 1: 29 junio de 2016.

Aplicación no 2: 29 septiembre de 2016.

Aplicación no 3: 25 enero de 2017.

Aplicación no 4: 28 abril de 2017.

Aplicación n 5: 28 junio de 2017. 
A partir de dos semanas después de la primera aplicación de agentes quelantes naturales y microorganismos se comenzó a realizar un monitoreo quincenal de las muestras de suelo rizosférico $(0-20 \mathrm{~cm})$ de cada una de las 15 parcelas con el fin de evaluar si la concentración de metales ( $\mathrm{Cu}, \mathrm{Zn}$ y $\mathrm{Cr}$ solubles y biodisponibles) se mantenía a niveles similares a los valores previos a la aplicación o se bien se reducían o aumentaban los niveles con el tiempo y las aplicaciones. Para ello, se tomó una muestra de cada subparcela y se homogeneizó para formar una muestra compuesta por cada parcela (las muestras se compusieron por 4 submuestras procedentes de cada una de las 4 subparcelas). Las submuestras fueron tomadas en el mismo área de suelo donde se realizó la aplicación de los agentes quelantes naturales y microorganismos. Entre junio de 2016 y septiembre de 2017 se han realizado un total de 27 muestreos quincenales de suelo radicular.

A continuación se muestran las fechas de las aplicaciones y muestreos quincenales realizados:

Muestreo quincenal 1: 29/6/2016 (muestreo inicial)

Aplicación no 1: 29/6/2016 (realizada después del muestreo 1)

Muestreo quincenal 2: 12/7/2016

Muestreo quincenal 3: 26/7/2016

Muestreo quincenal 4: 9/8/2016

Muestreo quincenal 5: 23/8/2016

Muestreo quincenal 6: 6/9/2016

Muestreo quincenal 7: 20/9/2016

Muestreo quincenal 8: 29/9/2016

Aplicación n² 2: 29/9/2016 (realizada después del muestreo 8)

Muestreo quincenal 9:18/10/2016

Muestreo quincenal 10: 2/11/2016

Muestreo quincenal 11: 18/11/2016

Muestreo quincenal 12: 29/11/2016

Muestreo quincenal 13: 12/1/2017

Muestreo quincenal 14: 25/1/2017

Aplicación nº 3: 25/1/2017 (realizada después del muestreo 14)

Muestreo quincenal 15: 7/2/2017

Muestreo quincenal 16: 24/2/2017

Muestreo quincenal 17: 20/3/2017

Muestreo quincenal 18: 17/4/2017

Aplicación no 4: 28/4/2017 (realizada después del muestreo 18) 
Muestreo quincenal 19: 11/5/2017

Muestreo quincenal 20: 23/5/2017

Muestreo quincenal 21: 6/6/2017

Muestreo quincenal 22: 20/6/2017

Aplicación no 5: 28/6/2017 (realizada después del muestreo 22)

Muestreo quincenal 23: 6/7/2017

Muestreo quincenal 24: 20/7/2017

Muestreo quincenal 25: 8/8/2017

Muestreo quincenal 26: 29/8/2017

Muestreo quincenal 27: 21/9/2017 (muestreo final)

En octubre 2015, en octubre/noviembre 2016 y en octubre 2017 se realizaron los muestreos anuales de suelo a diferentes profundidades $(0-20 \mathrm{~cm}, 20-50 \mathrm{~cm}$ y $50-100 \mathrm{~cm})$. En octubre/noviembre 2016 y en octubre 2017 se realizaron los muestreos de seguimiento anuales de vegetación paralelamente con los muestreos anuales de suelo (rizosférico y no rizosférico) en las parcelas experimentales. Para los muestreos de suelo se tomaron muestras compuestas de tres submuestras por subparcela. En octubre/noviembre 2017 concluyó el estudio en las parcelas experimentales.

\subsection{MUESTREOS, DETERMINACIONES ANALÍTICAS Y ANÁLISIS ESTADÍSTICO}

- Caracterización inicial de suelo antes de la plantación y después del arado y del establecimiento de las parcelas (octubre 2015): se tomó una muestra de suelo compuesta en cada parcela (15 muestras) a la profundidad de 0-20 cm, 20-50 cm y 50-100 cm. Propiedades físico-químicas a determinar:

o $\mathrm{Cu}, \mathrm{Zn}, \mathrm{Cr}, \mathrm{Cr}$ (III) y $\mathrm{Cr}(\mathrm{VI})$ totales

o $\mathrm{Cu}, \mathrm{Zn}$ y $\mathrm{Cr}$ por extracción secuencial (fracciones: intercambiables, unidos a carbonatos, unidos a óxidos de Fe y Mn, unidos a materia orgánica y sulfuros y residuales)

o $\mathrm{Cu}, \mathrm{Zn}$ y $\mathrm{Cr}$ solubles

$\mathrm{o} \mathrm{pH}$

o CE

o Carbono orgánico total (COT)

- Carbonato cálcico

- Carbono de la biomasa microbiana (CBM)

o Respiración edáfica basal (REB) 
La concentración de metales totales $\mathrm{Cu}, \mathrm{Zn}$ y $\mathrm{Cr}$ total viene dada por la suma de las fracciones de metales intercambiables, unidos a carbonatos, unidos a óxidos de Fe y Mn, unidos a materia orgánica y sulfuros y residual.

- Evolución quincenal de suelo: se llevaron a cabo muestreos de suelo tras la aplicación de los agentes quelantes naturales y microorganismos en cada parcela con una periodicidad de 2 semanas para monitorizar la evolución de las propiedades físico-químicas mencionadas anteriormente (15 muestras/muestreo quincenal). Propiedades físico-químicas a determinar:
o $\mathrm{pH}$
o CE
o $\mathrm{Cu}, \mathrm{Zn}$ y $\mathrm{Cr}$ solubles
o $\mathrm{Cu}, \mathrm{Zn}$ y $\mathrm{Cr}$ biodisponibles

- Muestreos intermedio y final de suelo (rizosférico y no rizosférico) en octubre/noviembre 2016 y en octubre 2017. Se tomó en cada subparcela una muestra compuesta de suelo a la profundidad de $0-20 \mathrm{~cm}, 20-50 \mathrm{~cm}$ y $50-100 \mathrm{~cm}$. Propiedades físico-químicas a determinar:
$0 \mathrm{pH}$
o $\mathrm{CE}$
o Carbonato cálcico
- Carbono orgánico total (COT)
- Carbono de la biomasa microbiana (CBM)
- Respiración edáfica basal (REB)
o $\mathrm{Cu}, \mathrm{Zn}$ y $\mathrm{Cr}$ solubles
- Cu, Zn y Cr por extracción secuencial (fracciones: intercambiables, unidos a carbonatos, unidos a óxidos de Fe y Mn, unidos a materia orgánica y sulfuros y residuales)
o $\mathrm{Cu}, \mathrm{Zn}, \mathrm{Cr}, \mathrm{Cr}(\mathrm{III})$ y $\mathrm{Cr}(\mathrm{VI})$ totales

Todos los resultados fueron sometidos a un tratamiento estadístico. Para ello se usaron los programas estadísticos SPSS versión 24 y Statistix 9. Mediante la prueba de KolmogorovSmirnov se comprobó si la distribución de datos era normal. En función de que la distribución de los datos fuese o no normal se seleccionaron los test paramétricos y no paramétricos para detectar si existen o no diferencias significativas entre muestras y los test para estudiar las correlaciones entre parámetros y demás. Con respecto a las correlaciones, sólo se han mostrado las más relevantes cuyos valores del coeficiente de regresión es próximo o superior a 0,5. 


\subsection{EVOLUCIÓN ANUAL DE LAS CONCENTRACIONES DE METALES Y PROPIEDADES FÍSICO-QUÍMICAS Y BIOQUÍMICAS}

En las Figuras 6.4.1-6.4.58 se muestra la evolución anual 2015-2016-2017 de las siguientes propiedades físico-químicas y bioquímicas medidas en suelo en los horizontes de $0-20 \mathrm{~cm}$, de 20-50 cm y de 50-100 cm: pH, CE, carbonatos, COT, CBM, REB, metales $\mathrm{Cu}, \mathrm{Zn}$ y $\mathrm{Cr}$ solubles, metales $\mathrm{Cu}, \mathrm{Zn}$ y $\mathrm{Cr}$ intercambiables, metales $\mathrm{Cu}, \mathrm{Zn}$ y $\mathrm{Cr}$ ligados a carbonatos, metales $\mathrm{Cu}, \mathrm{Zn}$ y $\mathrm{Cr}$ ligados a óxidos de Fe y $\mathrm{Mn}$, metales $\mathrm{Cu}, \mathrm{Zn}$ y $\mathrm{Cr}$ unidos a materia orgánica y sulfuros, metales $\mathrm{Cu}$, Zn y Cr residuales y metales $\mathrm{Cu}, \mathrm{Zn}$ y $\mathrm{Cr}$ totales. 


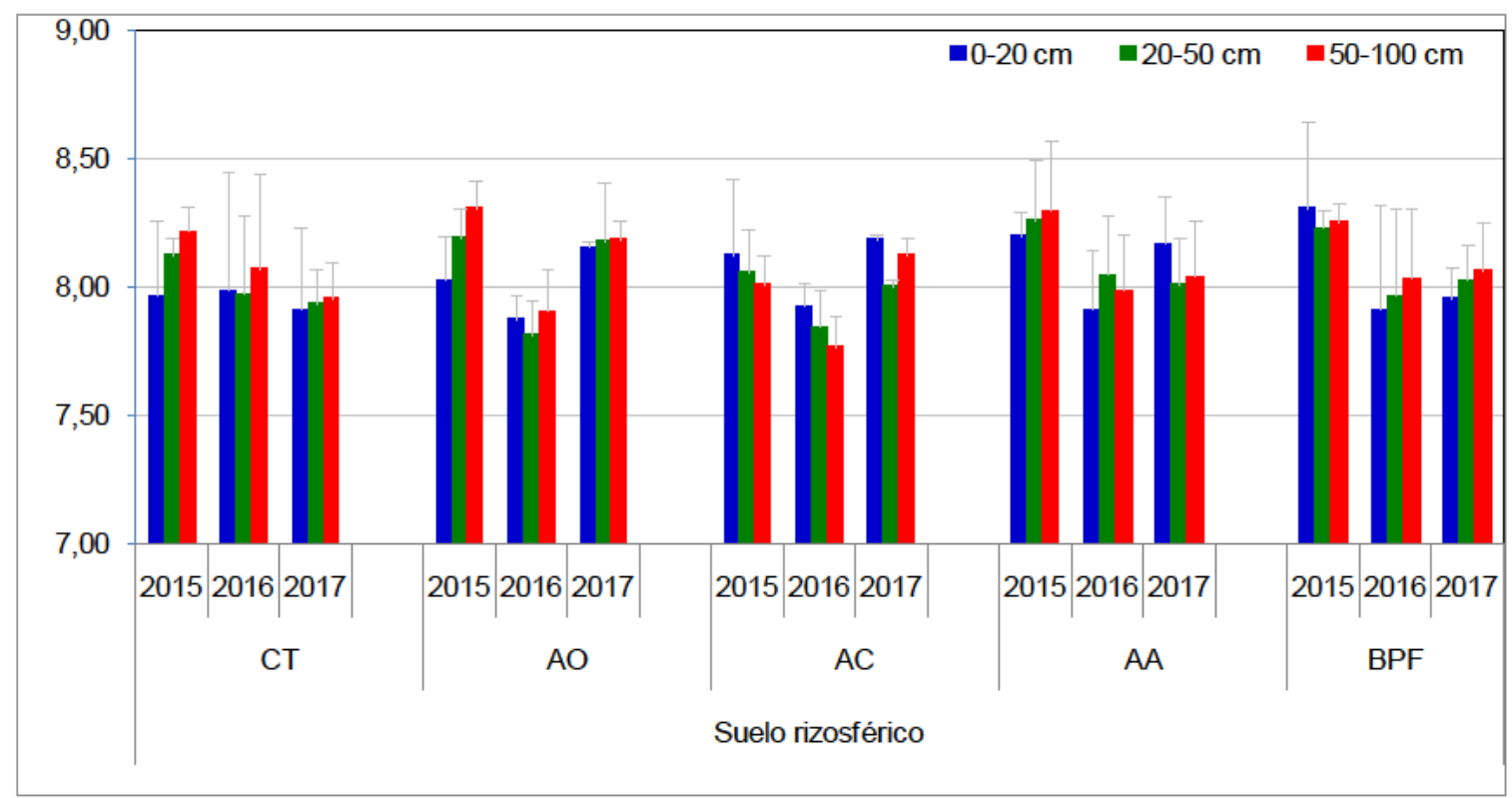

Figura 6.4.1. Evolución temporal de $\mathrm{pH}$ en suelo rizosférico entre 3 muestreos anuales $(2015,2016$ y 2017) en parcelas control (CT) y parcelas tratadas con dosis de $5 \mathrm{mmol} / \mathrm{kg}$ de ácido oxálico $(\mathrm{AO})$, ácido cítrico $(\mathrm{AC})$, aminoácidos $(\mathrm{AA})$ y bacterias Pseudomonas fluorescens (BPF) y 5 aplicaciones (junio 2016, septiembre 2016, enero 2017, abril 2017 y junio 2017), $n=3$.

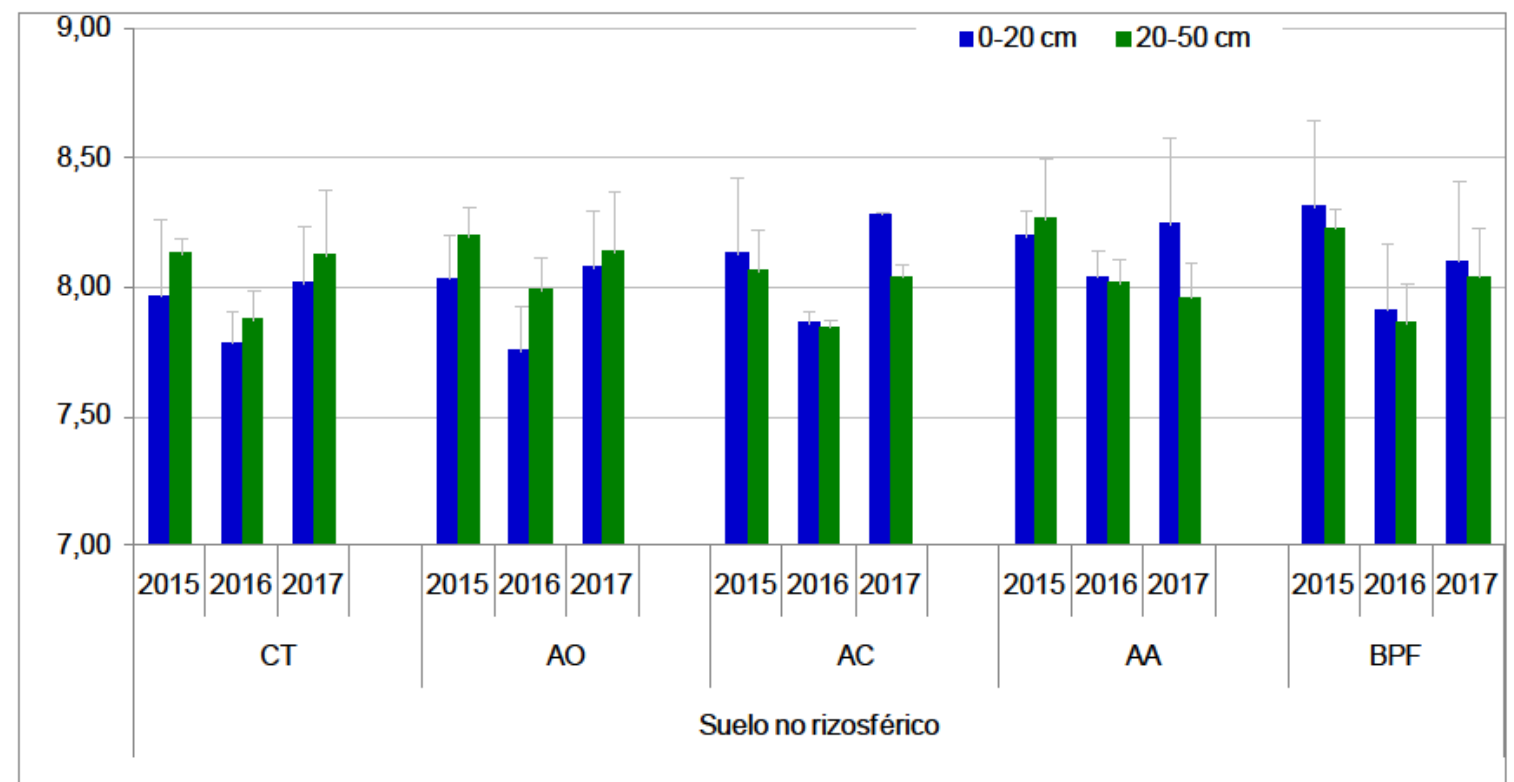

Figura 6.4.2. Evolución temporal de pH en suelo no rizosférico entre 3 muestreos anuales $(2015,2016$ y 2017) en parcelas control (CT) y parcelas tratadas con dosis de $5 \mathrm{mmol} / \mathrm{kg}$ de ácido oxálico $(\mathrm{AO})$, ácido cítrico $(\mathrm{AC})$, aminoácidos $(\mathrm{AA})$ y bacterias Pseudomonas fluorescens (BPF) y 5 aplicaciones (junio 2016, septiembre 2016, enero 2017, abril 2017 y junio 2017), $n=3$. 


\section{Evolución 2015-2016-2017 de pH:}

En las figuras anteriores se puede observar la variación entre los años 2015, 2016 y 2017 de los valores de $\mathrm{pH}$ en los sedimentos del suelo rizosférico y del suelo no rizosférico en las diferentes profundidades muestreadas $(0-20 \mathrm{~cm}, 20-50 \mathrm{~cm}$ y $50-100 \mathrm{~cm})$. En el suelo rizosférico los valores medios de pH fueron 8,04 $(0-20 \mathrm{~cm}), 8,05(20-50 \mathrm{~cm})$ y 8,08 $(50-100$ $\mathrm{cm})$ y oscilaron entre $7,77(\mathrm{AC}, 50-100 \mathrm{~cm}, 2016)$ y $8,31(\mathrm{BPF}, 0-20 \mathrm{~cm}, 2015 ; \mathrm{AO}, 50-100$ $\mathrm{cm}, 2015)$. Para cada uno de los tratamientos no se detectaron diferencias significativas entre las diferentes profundidades muestreadas $(0-20 \mathrm{~cm}, 20-50 \mathrm{~cm}$ y $50-100 \mathrm{~cm})$. Y para cada tratamiento y profundidad tampoco se registraron diferencias significativas entre años, este hecho resalta la gran variabilidad encontrada entre los resultados registrados.

En el suelo no rizosférico los valores medios de pH fueron 8,05 $(0-20 \mathrm{~cm})$ y 8,05 $(20-50 \mathrm{~cm})$ y oscilaron entre 7,76 (AO, 0-20 cm) y 8,31 (BPF, 0-20 cm, 2015). Entre el suelo rizosférico y el suelo no rizosférico (años 2016 y 2017, profundidades de 0-20 cm y 20-50 cm)) solamente se registraron diferencias estadísticamente significativas en las parcelas AC en $2016(20-50 \mathrm{~cm})$. 


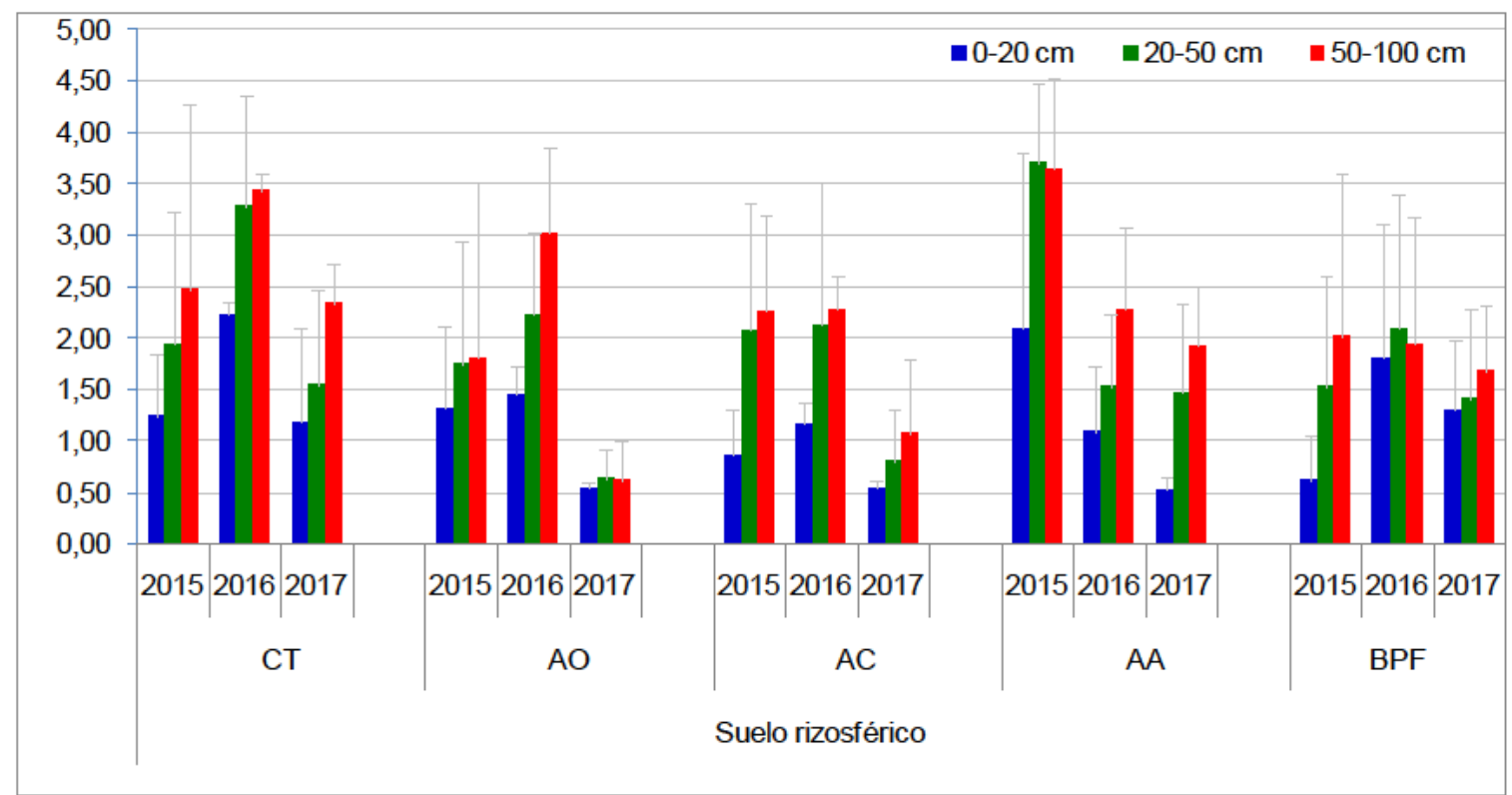

Figura 6.4.3. Evolución temporal de $\mathrm{CE}(\mathrm{dS} / \mathrm{m})$ en suelo rizosférico entre 3 muestreos anuales $(2015,2016$ y 2017) en parcelas control (CT) y parcelas tratadas con dosis de 5 $\mathrm{mmol} / \mathrm{kg}$ de ácido oxálico (AO), ácido cítrico (AC), aminoácidos (AA) y bacterias Pseudomonas fluorescens (BPF) y 5 aplicaciones (junio 2016, septiembre 2016, enero 2017, abril 2017 y junio 2017), $n=3$.

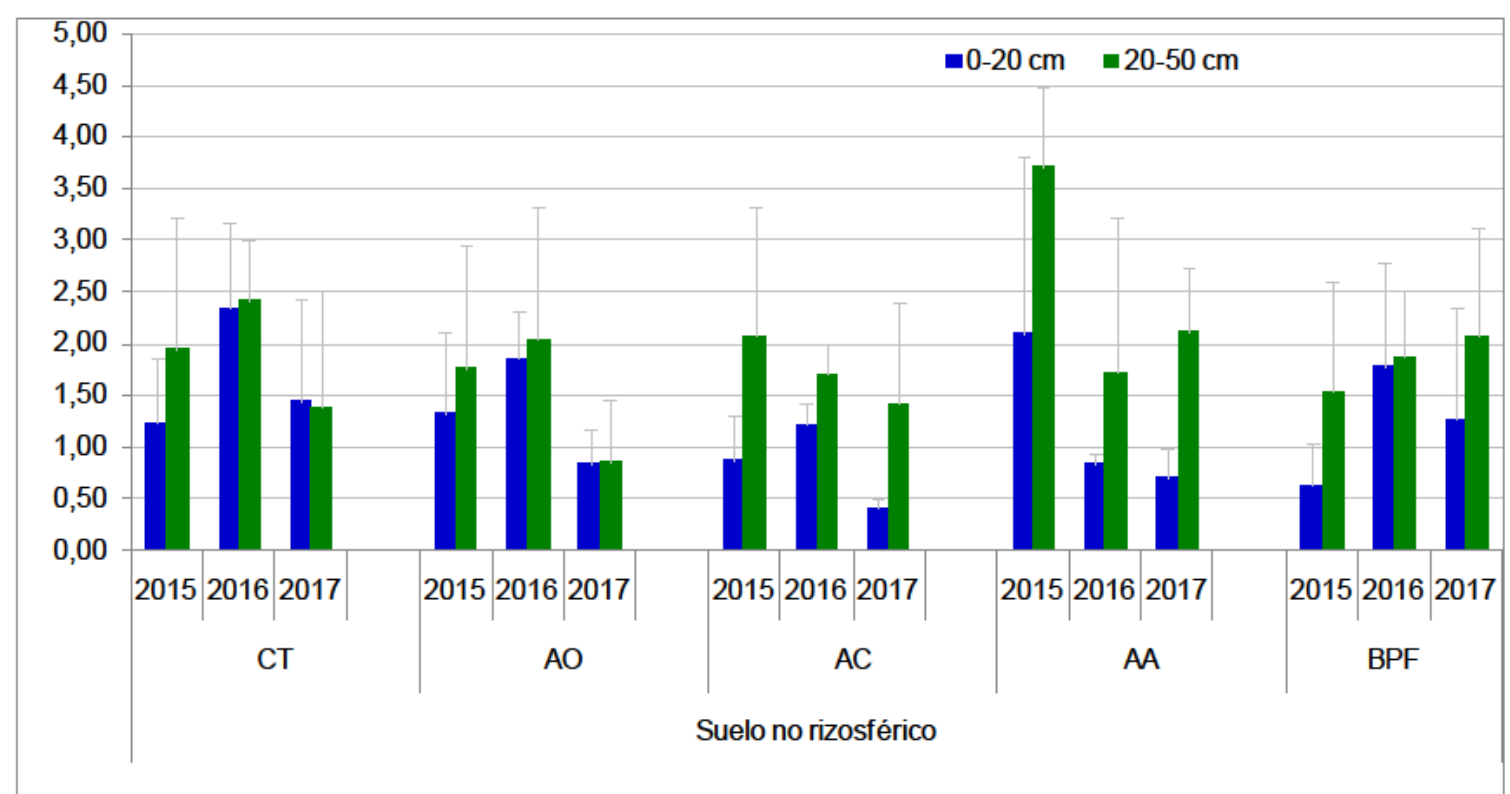

Figura 6.4.4. Evolución temporal de CE (dS/m) en suelo no rizosférico entre 3 muestreos anuales $(2015,2016$ y 2017) en parcelas control (CT) y parcelas tratadas con dosis de 5 $\mathrm{mmol} / \mathrm{kg}$ de ácido oxálico (AO), ácido cítrico (AC), aminoácidos (AA) y bacterias Pseudomonas fluorescens (BPF) y 5 aplicaciones (junio 2016, septiembre 2016, enero 2017, abril 2017 y junio 2017), $n=3$. 


\section{Evolución 2015-2016-2017 de CE:}

En las figuras anteriores se puede observar la variación entre los años 2015, 2016 y 2017 de los valores de CE en los sedimentos del suelo rizosférico y del suelo no rizosférico en las diferentes profundidades muestreadas $(0-20 \mathrm{~cm}, 20-50 \mathrm{~cm}$ y $50-100 \mathrm{~cm})$. En el suelo rizosférico los valores medios de CE fueron 1,20 $(0-20 \mathrm{~cm}), 1,87(20-50 \mathrm{~cm})$ y 2,19 $(50-100$ $\mathrm{cm})$ y oscilaron entre $0,53(\mathrm{AA}, 0-20 \mathrm{~cm}, 2017)$ y $3,64(\mathrm{AA}, 50-100 \mathrm{~cm}, 2015)$ ). Para cada uno de los tratamientos no se detectaron diferencias significativas entre las diferentes profundidades muestreadas $(0-20 \mathrm{~cm}, 20-50 \mathrm{~cm}$ y $50-100 \mathrm{~cm})$. Y para cada tratamiento y profundidad sólo se registraron diferencias significativas entre años en las parcelas AC, exhibiendo valores significativamente superiores a $0-20 \mathrm{~cm}$ y $20-50 \mathrm{~cm}$, lo cual evidencia que no existe lixiviación a horizontes más profundos con la dosis con la que se ha estudiado. En el resto de tratamientos no se han registrado diferencias significativas entre años para cada una de las profundidades, por lo que tampoco se manifiesta riesgo de lixiviación tras la aplicación de los tratamientos en superficie.

En el suelo no rizosférico los valores medios de CE fueron 1,25 $(0-20 \mathrm{~cm})$ y 1,90 $(20-50 \mathrm{~cm})$ y oscilaron entre $0,40(A C, 0-20 \mathrm{~cm}, 2017)$ y 3,71 (AA, 50-100 cm, 2015). Entre el suelo rizosférico y el suelo no rizosférico (años 2016 y 2017, profundidades de 0-20 cm y 20-50 $\mathrm{cm})$ ) solamente se registraron diferencias estadísticamente significativas en las parcelas CT (0-20 cm en 2016 y 20-50 cm en 2017) y en las parcelas AA (0-20 cm en 2016). 


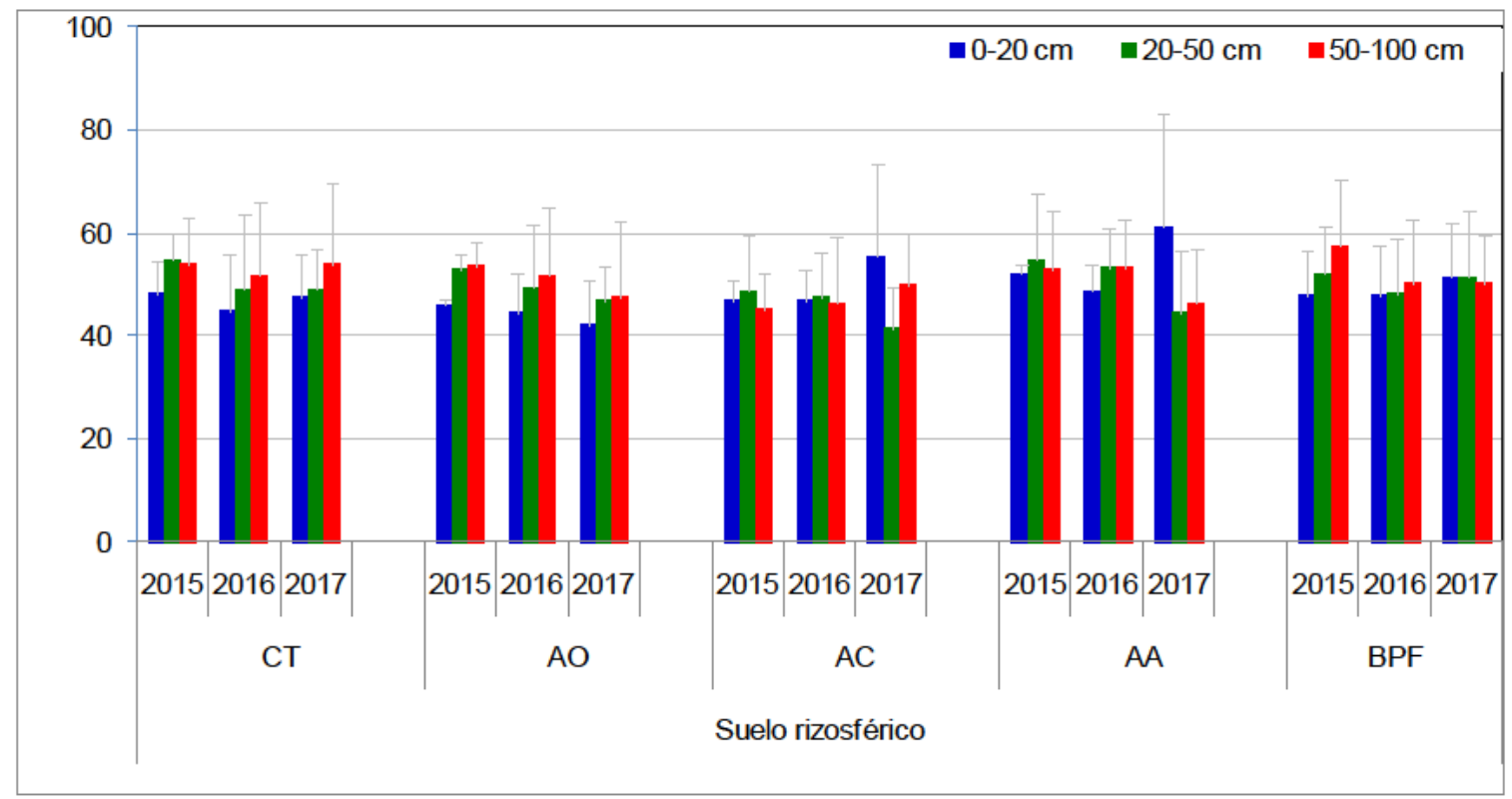

Figura 6.4.5. Evolución temporal de carbonatos (\%) en suelo rizosférico entre 3 muestreos anuales $(2015,2016$ y 2017) en parcelas control (CT) y parcelas tratadas con dosis de 5 $\mathrm{mmol} / \mathrm{kg}$ de ácido oxálico ( $\mathrm{AO})$, ácido cítrico $(\mathrm{AC})$, aminoácidos (AA) y bacterias Pseudomonas fluorescens (BPF) y 5 aplicaciones (junio 2016, septiembre 2016, enero 2017, abril 2017 y junio 2017), $n=3$.

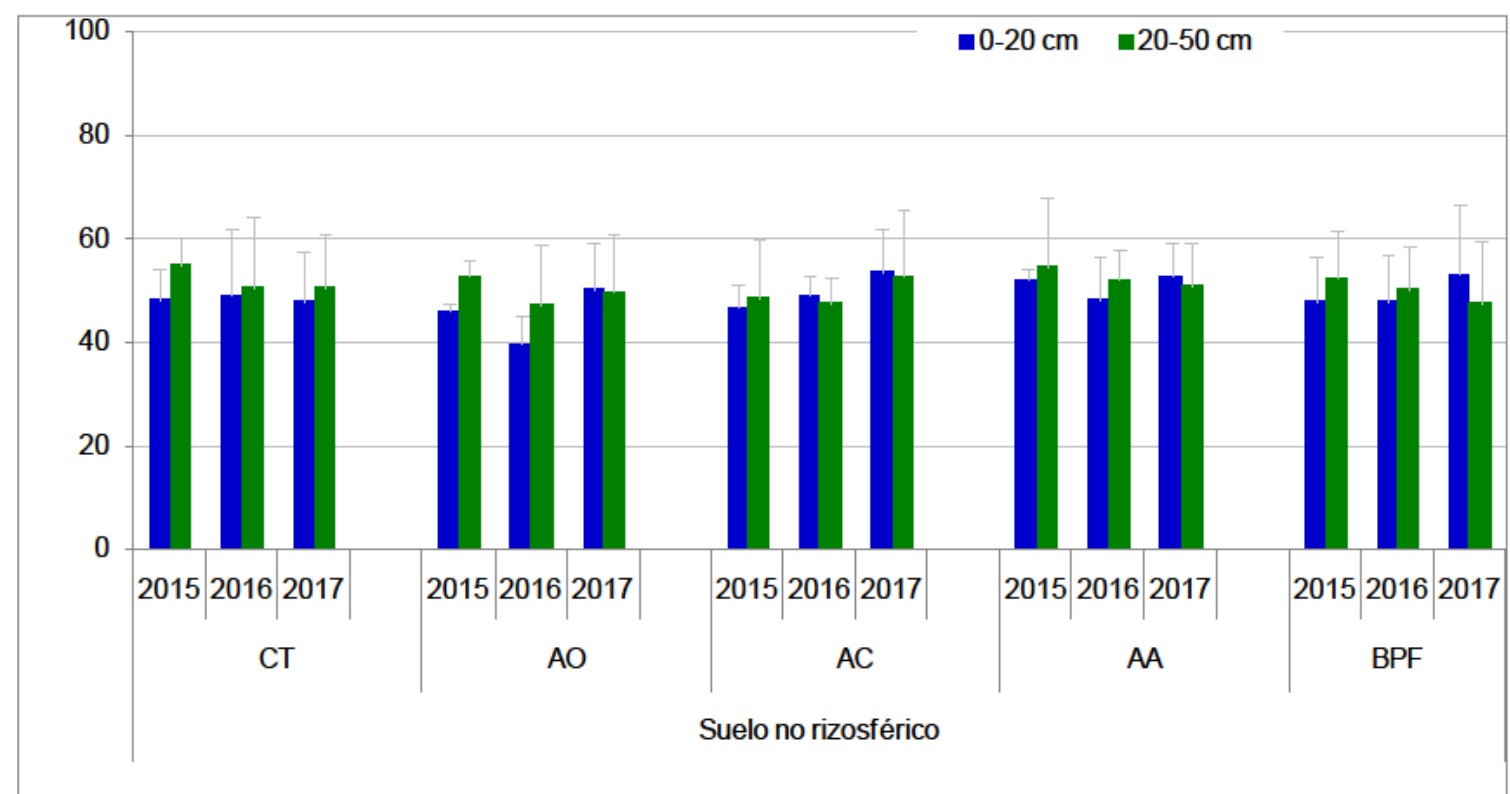

Figura 6.4.6. Evolución temporal de carbonatos (\%) en suelo no rizosférico entre 3 muestreos anuales $(2015,2016$ y 2017$)$ en parcelas control (CT) y parcelas tratadas con dosis de $5 \mathrm{mmol} / \mathrm{kg}$ de ácido oxálico (AO), ácido cítrico ( $\mathrm{AC}$ ), aminoácidos (AA) y bacterias Pseudomonas fluorescens (BPF) y 5 aplicaciones (junio 2016, septiembre 2016, enero 2017, abril 2017 y junio 2017), $\mathrm{n}=3$. 


\section{Evolución 2015-2016-2017 de carbonatos:}

En las figuras anteriores se puede observar la variación entre los años 2015, 2016 y 2017 de los porcentajes de carbonatos en los sedimentos del suelo rizosférico y del suelo no rizosférico en las diferentes profundidades muestreadas $(0-20 \mathrm{~cm}, 20-50 \mathrm{~cm}$ y $50-100 \mathrm{~cm})$. En el suelo rizosférico los porcentajes medios de carbonatos fueron 48,76\% $(0-20 \mathrm{~cm})$, $49,65 \%(20-50 \mathrm{~cm})$ y $51,03 \%(50-100 \mathrm{~cm})$ y oscilaron entre $42,34 \%(\mathrm{AO}, 0-20 \mathrm{~cm}, 2017)$ y 61,31\% (AA, $0-20 \mathrm{~cm}, 2017$ ). Para cada uno de los tratamientos no se detectaron diferencias significativas entre las diferentes profundidades muestreadas $(0-20 \mathrm{~cm}, 20-50 \mathrm{~cm}$ y 50-100 cm). Y para cada tratamiento y profundidad tampoco se registraron diferencias significativas entre años, este hecho resalta la gran variabilidad encontrada entre los resultados registrados.

En el suelo no rizosférico los porcentajes medios de carbonatos fueron $48,80 \%(0-20 \mathrm{~cm})$ y $50,74 \%(20-50 \mathrm{~cm})$ y oscilaron entre $39,73 \%$ (AO, $0-20 \mathrm{~cm}, 2016)$ y $54,93 \%$ (CT, $20-50 \mathrm{~cm}$, 2015). Entre el suelo rizosférico y el suelo no rizosférico (años 2016 y 2017, profundidades de 0-20 cm y $20-50 \mathrm{~cm}$ )) solamente se registraron diferencias estadísticamente significativas en las parcelas AO (0-20 cm en 2017), en las parcelas AA (20-50 cm en 2017) y en las parcelas BPF (0-20 cm en 2017). 


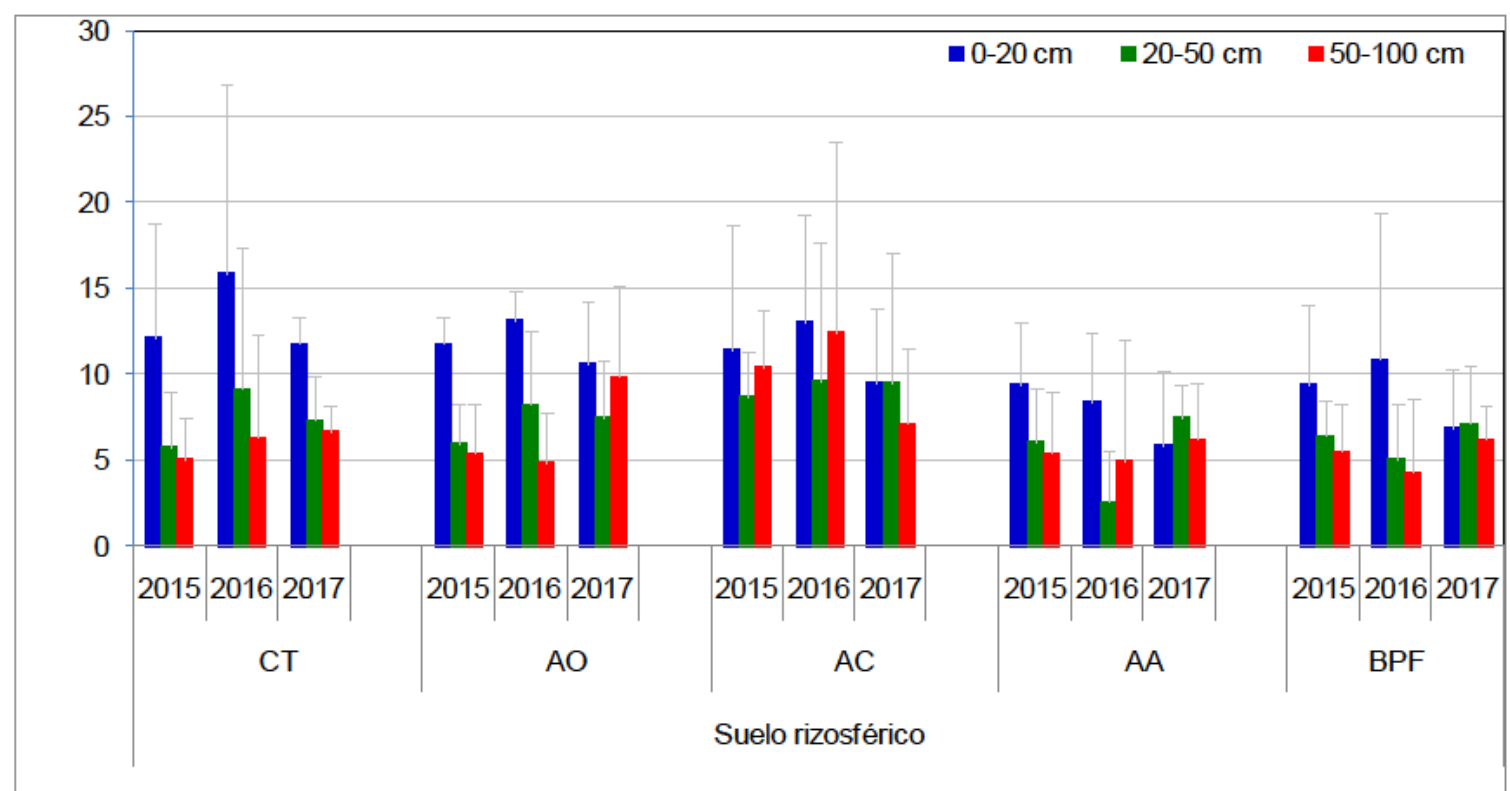

Figura 6.4.7. Evolución temporal de COT $(\mathrm{g} / \mathrm{kg})$ en suelo rizosférico entre 3 muestreos anuales $(2015,2016$ y 2017) en parcelas control (CT) y parcelas tratadas con dosis de 5 $\mathrm{mmol} / \mathrm{kg}$ de ácido oxálico (AO), ácido cítrico ( $\mathrm{AC})$, aminoácidos (AA) y bacterias Pseudomonas fluorescens (BPF) y 5 aplicaciones (junio 2016, septiembre 2016, enero 2017, abril 2017 y junio 2017), $\mathrm{n}=3$.

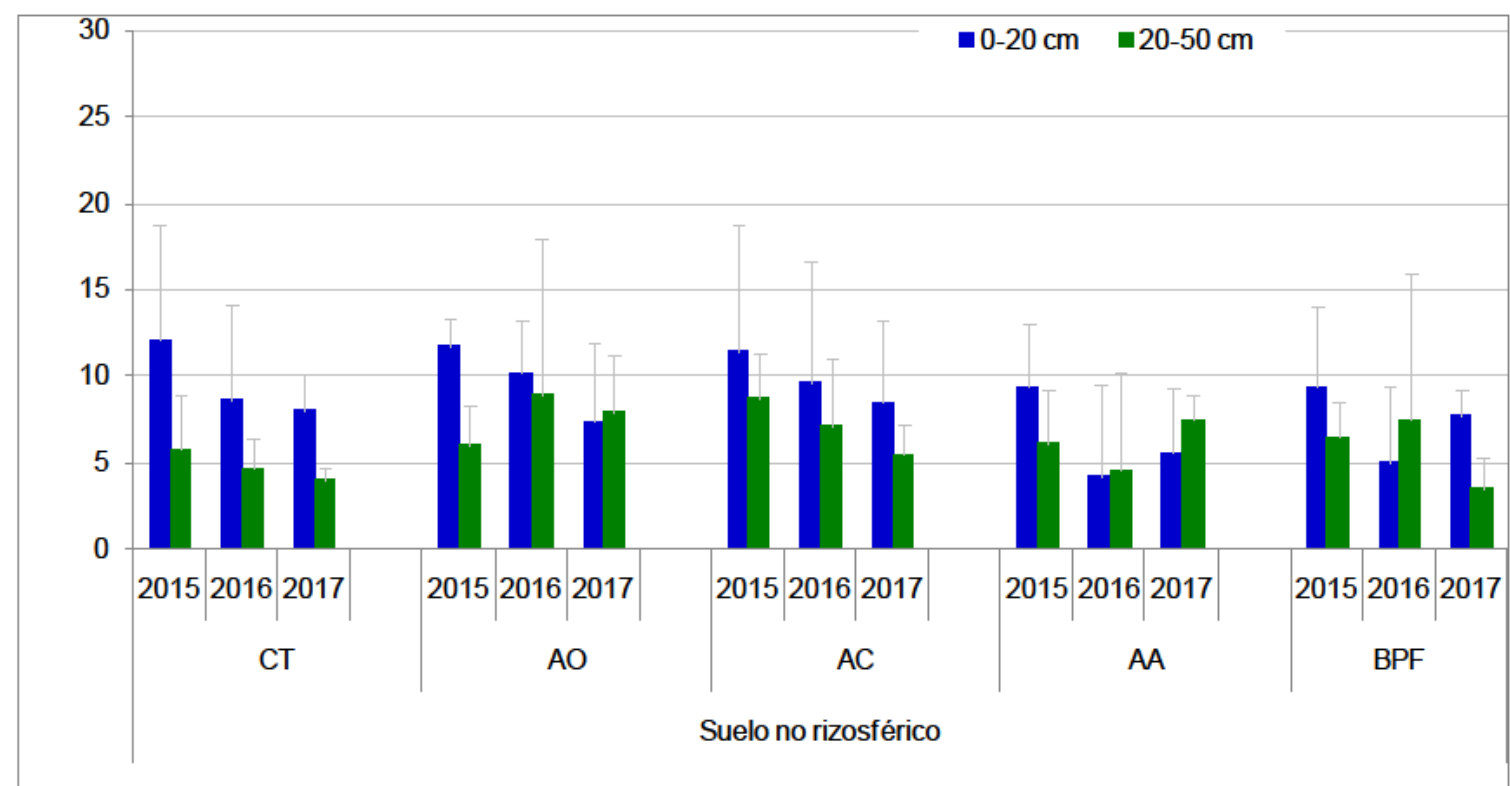

Figura 6.4.8. Evolución temporal de COT $(\mathrm{g} / \mathrm{kg})$ en suelo no rizosférico entre 3 muestreos anuales $(2015,2016$ y 2017) en parcelas control (CT) y parcelas tratadas con dosis de 5 $\mathrm{mmol} / \mathrm{kg}$ de ácido oxálico (AO), ácido cítrico (AC), aminoácidos (AA) y bacterias Pseudomonas fluorescens (BPF) y 5 aplicaciones (junio 2016, septiembre 2016, enero 2017, abril 2017 y junio 2017), $n=3$. 


\section{Evolución 2015-2016-2017 de COT:}

En las figuras anteriores se puede observar la variación entre los años 2015, 2016 y 2017 de las concentraciones de COT en los sedimentos del suelo rizosférico y del suelo no rizosférico en las diferentes profundidades muestreadas $(0-20 \mathrm{~cm}, 20-50 \mathrm{~cm}$ y 50-100 cm). En el suelo rizosférico las concentraciones medias de COT fueron 10,66 g/kg $(0-20 \mathrm{~cm})$, $7,11 \mathrm{~g} / \mathrm{kg}(20-50 \mathrm{~cm})$ y $6,72 \mathrm{~g} / \mathrm{kg}(50-100 \mathrm{~cm})$ y oscilaron entre $2,60 \mathrm{~g} / \mathrm{kg}(\mathrm{AA}, 20-50 \mathrm{~cm}$, 2016) y $15,83 \mathrm{~g} / \mathrm{kg}(\mathrm{CT}, 0-20 \mathrm{~cm}, 2016)$. Para cada uno de los tratamientos no se detectaron diferencias significativas entre las diferentes profundidades muestreadas $(0-20 \mathrm{~cm}, 20-50 \mathrm{~cm}$ y $50-100 \mathrm{~cm}$ ). $Y$ para cada tratamiento y profundidad tampoco se registraron diferencias significativas entre años, este hecho resalta la gran variabilidad encontrada entre los resultados registrados.

En el suelo no rizosférico las concentraciones medias de COT fueron 8,59 g/kg $(0-20 \mathrm{~cm})$ y $6,28 \mathrm{~g} / \mathrm{kg}(20-50 \mathrm{~cm})$ y oscilaron entre $3,56 \mathrm{~g} / \mathrm{kg}(\mathrm{BPF}, 20-50 \mathrm{~cm}, 2017)$ y $13,12 \mathrm{~g} / \mathrm{kg}$ (CT, 0$20 \mathrm{~cm}, 2015$ ). Entre el suelo rizosférico y el suelo no rizosférico (años 2016 y 2017, profundidades de $0-20 \mathrm{~cm}$ y $20-50 \mathrm{~cm}$ )) solamente se registraron diferencias estadísticamente significativas en las parcelas CT (20-50 cm en 2016). 


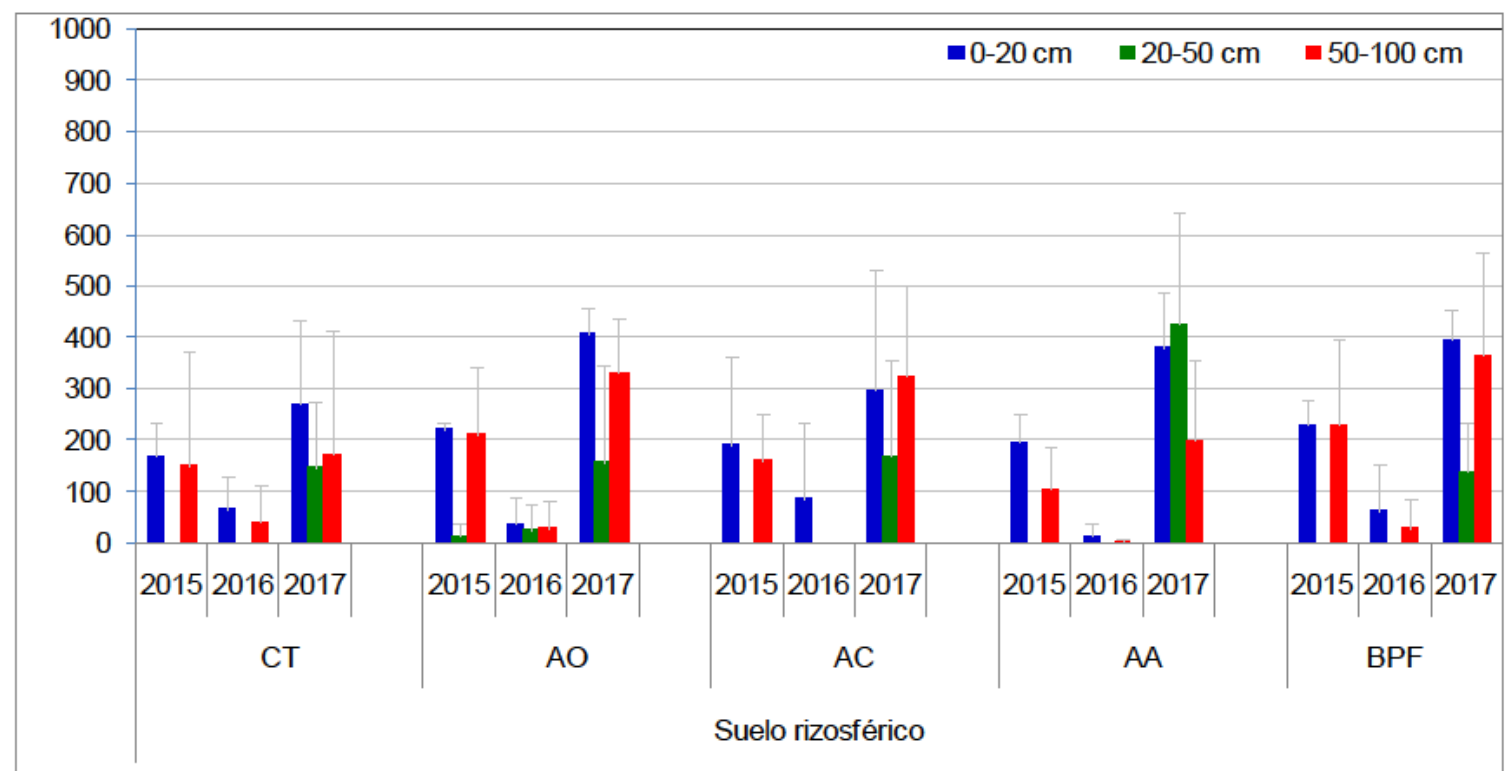

Figura 6.4.9. Evolución temporal del CBM $\left(\mathrm{mg} \mathrm{C} \mathrm{kg}^{-1}\right)$ en suelo rizosférico entre 3 muestreos anuales $(2015,2016$ y 2017) en parcelas control (CT) y parcelas tratadas con dosis de 5 $\mathrm{mmol} / \mathrm{kg}$ de ácido oxálico $(A O)$, ácido cítrico $(A C)$, aminoácidos (AA) y bacterias Pseudomonas fluorescens (BPF) y 5 aplicaciones (junio 2016, septiembre 2016, enero 2017, abril 2017 y junio 2017), $n=3$.

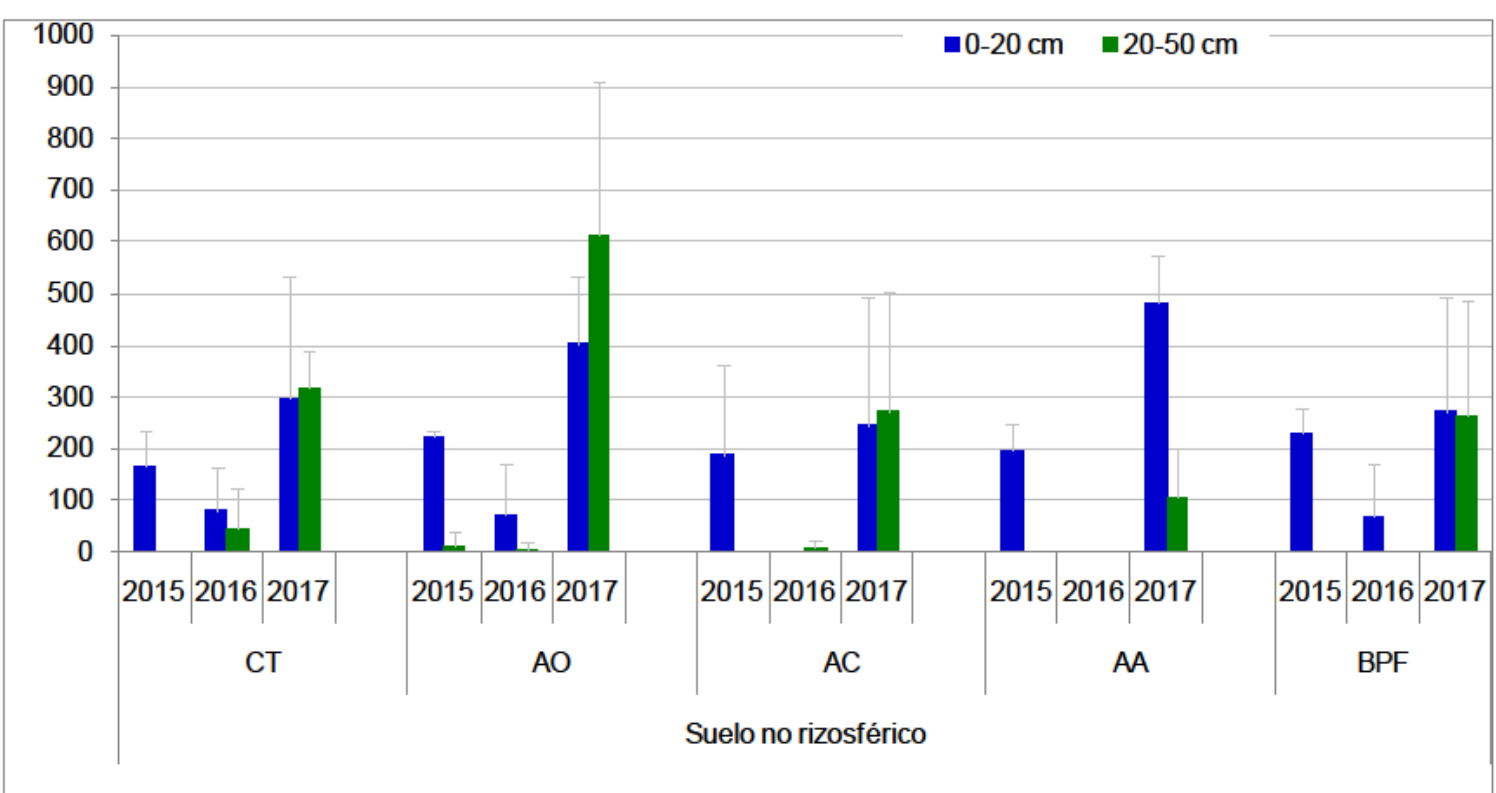

Figura 6.4.10. Evolución temporal del CBM $\left(\mathrm{mg} \mathrm{C} \mathrm{kg}^{-1}\right)$ en suelo no rizosférico entre 3 muestreos anuales $(2015,2016$ y 2017$)$ en parcelas control (CT) y parcelas tratadas con dosis de $5 \mathrm{mmol} / \mathrm{kg}$ de ácido oxálico (AO), ácido cítrico (AC), aminoácidos (AA) y bacterias Pseudomonas fluorescens (BPF) y 5 aplicaciones (junio 2016, septiembre 2016, enero 2017, abril 2017 y junio 2017), $\mathrm{n}=3$. 


\section{Evolución 2015-2016-2017 del CBM:}

En las figuras anteriores se puede observar la variación entre los años 2015, 2016 y 2017 de las concentraciones del CBM en los sedimentos del suelo rizosférico y del suelo no rizosférico en las diferentes profundidades muestreadas $(0-20 \mathrm{~cm}, 20-50 \mathrm{~cm}$ y $50-100 \mathrm{~cm})$. En el suelo rizosférico las concentraciones medias del CBM fueron $201,84 \mathrm{mg} \mathrm{C} \mathrm{kg}^{-1}(0-20$ $\mathrm{cm}), 72,08 \mathrm{mg} \mathrm{C} \mathrm{kg}^{-1}(20-50 \mathrm{~cm})$ y $157,48 \mathrm{mg} \mathrm{C} \mathrm{kg}^{-1}(50-100 \mathrm{~cm})$ y oscilaron entre $0 \mathrm{mg} \mathrm{C}$ $\mathrm{kg}^{-1}$ (CT, 20-50 cm, 2016; AC, 20-50 cm, 2016; AA, 20-50 cm, 2016; BPF, 20-50 cm, 2016) y $427,94 \mathrm{mg} \mathrm{C} \mathrm{kg}^{-1}$ (AA, 20-50 cm, 2017). Para cada uno de los tratamientos no se detectaron diferencias significativas entre las diferentes profundidades muestreadas $(0-20 \mathrm{~cm}, 20-50 \mathrm{~cm}$ y 50-100 cm). Y para cada tratamiento y profundidad, sólo se registraron valores significativamente superiores a $0-20 \mathrm{~cm}$ y $20-50 \mathrm{~cm}$ de profundidad en las parcelas AA y BPF, con valores significativamente superiores en el año 2017 con respecto a los años 2015 y 2016, este hecho evidencia que después de 2 años de experimentación las aplicaciones de aminoácidos y bacterias estimulan el aumento de la carga microbiana presente en el suelo.

En el suelo no rizosférico las concentraciones medias de CBM fueron 195,79 $\mathrm{mg} \mathrm{C} \mathrm{kg}^{-1}$ (0$20 \mathrm{~cm}$ ) y 109,85 mg C kg-1 $(20-50 \mathrm{~cm})$ y oscilaron entre $0 \mathrm{mg} \mathrm{C} \mathrm{kg}^{-1}(\mathrm{AC}, 0-20 \mathrm{~cm}, 2016$; $\mathrm{AA}$, 0-20 cm, 2016) y 612,58 mg C kg $\mathrm{mg}^{-1}$ (A, 20-50 cm, 2016; BPF, 20-50 cm, 2016). Entre el suelo rizosférico y el suelo no rizosférico (años 2016 y 2017, profundidades de 0-20 cm y 20$50 \mathrm{~cm}$ )) solamente se registraron diferencias estadísticamente significativas en las parcelas CT (20-50 cm en 2016 y 0-20 cm en 2017), en las parcelas AA (20-50 cm en 2016), en las parcelas AC (20-50 cm en 2016), en las parcelas AA (0-20 cm en 2016) y en las parcelas BPF (0-20 cm en 2017). Dichas diferencias vuelven a evidenciar la influencia de los tratamientos en el suelo y de la vegetación fitoextractora. 


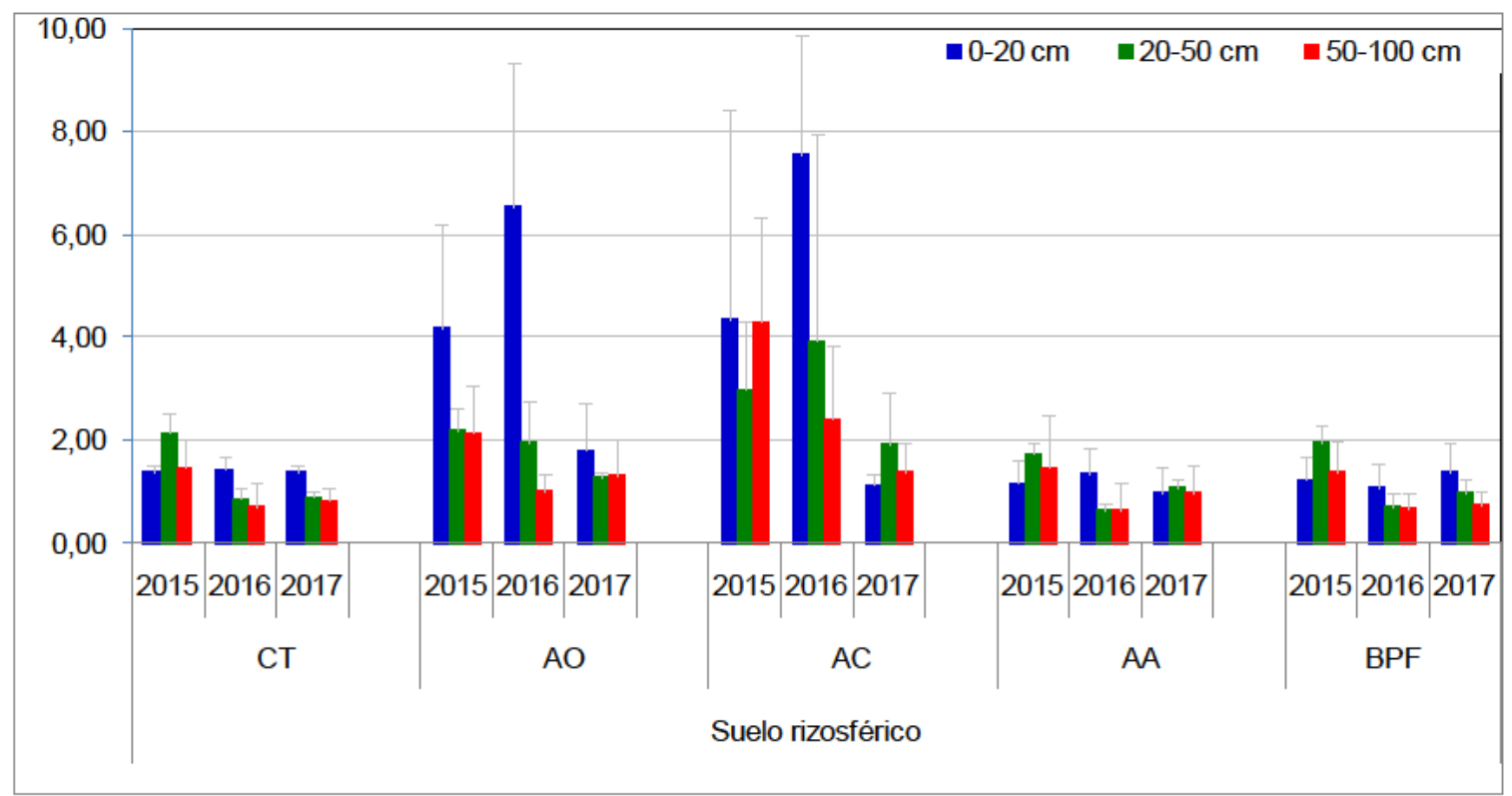

Figura 6.4.11. Evolución temporal de REB $\left(\mathrm{mg} \mathrm{C}-\mathrm{CO}_{2} / \mathrm{kg}\right.$ suelo $\left.\mathrm{h}\right)$ en suelo rizosférico entre 3 muestreos anuales $(2015,2016$ y 2017) en parcelas control (CT) y parcelas tratadas con dosis de $5 \mathrm{mmol} / \mathrm{kg}$ de ácido oxálico (AO), ácido cítrico (AC), aminoácidos (AA) y bacterias Pseudomonas fluorescens (BPF) y 5 aplicaciones (junio 2016, septiembre 2016, enero 2017, abril 2017 y junio 2017), $\mathrm{n}=3$.

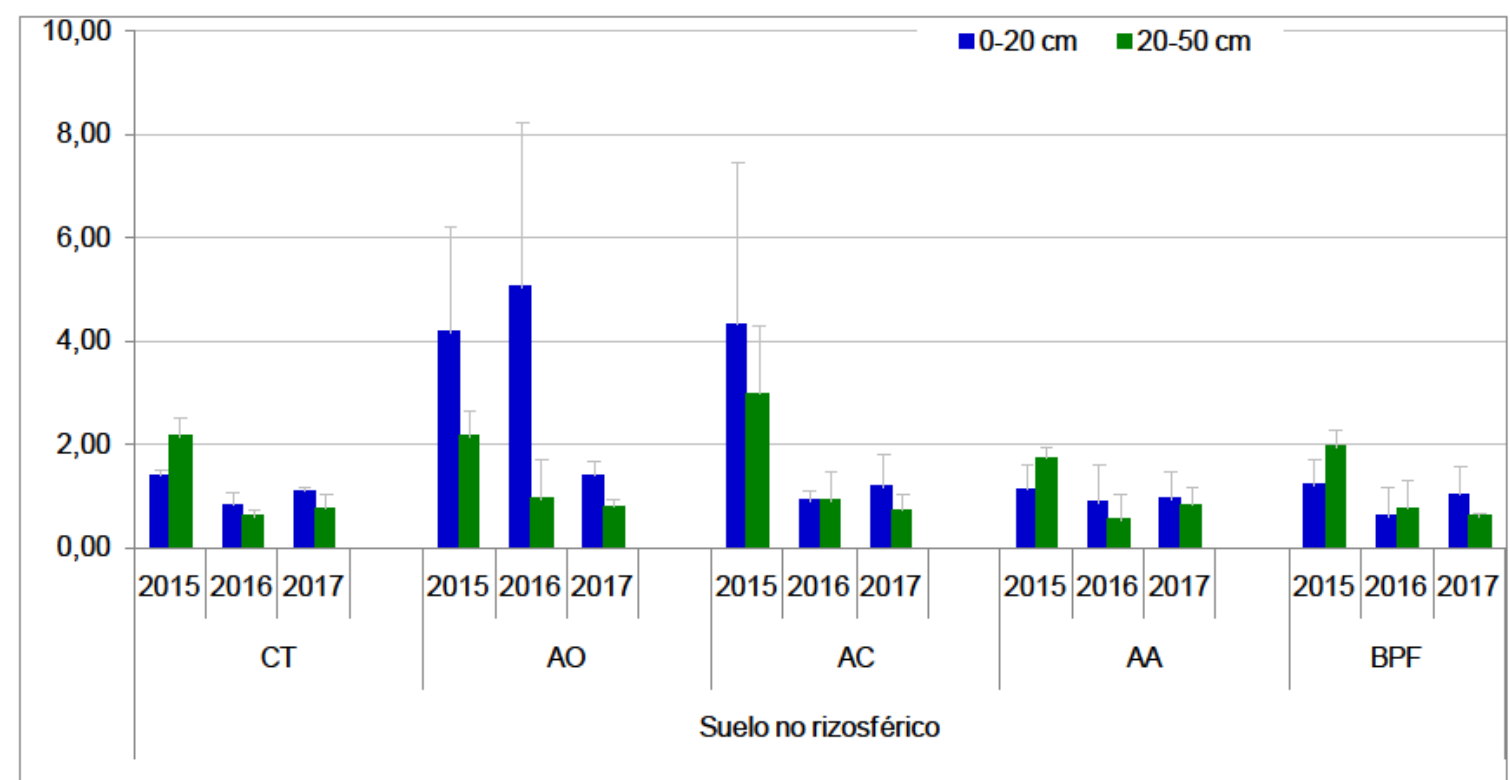

Figura 6.4.12. Evolución temporal de REB $\left(\mathrm{mg} \mathrm{C}-\mathrm{CO}_{2} / \mathrm{kg}\right.$ suelo $\left.\mathrm{h}\right)$ en suelo no rizosférico entre 3 muestreos anuales $(2015,2016$ y 2017) en parcelas control (CT) y parcelas tratadas con dosis de $5 \mathrm{mmol} / \mathrm{kg}$ de ácido oxálico (AO), ácido cítrico ( $A C)$, aminoácidos (AA) y bacterias Pseudomonas fluorescens (BPF) y 5 aplicaciones (junio 2016, septiembre 2016, enero 2017, abril 2017 y junio 2017), n=3. 


\section{Evolución 2015-2016-2017 de la REB:}

En las figuras anteriores se puede observar la variación entre los años 2015, 2016 y 2017 de las concentraciones de la REB en los sedimentos del suelo rizosférico y del suelo no rizosférico en las diferentes profundidades muestreadas $(0-20 \mathrm{~cm}, 20-50 \mathrm{~cm}$ y $50-100 \mathrm{~cm})$. En el suelo rizosférico las concentraciones medias de la REB fueron $2,46 \mathrm{mg} \mathrm{C}-\mathrm{CO}_{2} / \mathrm{kg}$ suelo $\mathrm{h}(0-20 \mathrm{~cm}), 1,68 \mathrm{mg} \mathrm{C}-\mathrm{CO}_{2} / \mathrm{kg}$ suelo $\mathrm{h}(20-50 \mathrm{~cm})$ y $1,43 \mathrm{mg} \mathrm{C}-\mathrm{CO}_{2} / \mathrm{kg}$ suelo $\mathrm{h}(50-$ $100 \mathrm{~cm}$ ) y oscilaron entre $0,64 \mathrm{mg} \mathrm{C}-\mathrm{CO}_{2} / \mathrm{kg}$ suelo $\mathrm{h}(\mathrm{AA}, 20-50 \mathrm{~cm}, 2016)$ y $7,57 \mathrm{mg} \mathrm{C}$ $\mathrm{CO}_{2} / \mathrm{kg}$ suelo $\mathrm{h}$ (AC, 0-20 cm, 2016). Para cada uno de los tratamientos solamente se detectaron diferencias significativas entre las diferentes profundidades muestreadas en las parcelas $A O$, siendo significativamente superiores a la profundidad de $0-20 \mathrm{~cm}$ con respecto al resto de profundidades $(20-50 \mathrm{~cm}$ y $50-100 \mathrm{~cm}$ ) y en las parcelas AA. Para cada tratamiento y profundidad no se registraron diferencias significativas entre años, este hecho podría se debido a la gran variabilidad encontrada entre los resultados registrados.

En el suelo no rizosférico las concentraciones medias de la REB fueron $1,75 \mathrm{mg} \mathrm{C}-\mathrm{CO}_{2} / \mathrm{kg}$ suelo $\mathrm{h}(0-20 \mathrm{~cm})$ y $1,24 \mathrm{mg} \mathrm{C}-\mathrm{CO}_{2} / \mathrm{kg}$ suelo $\mathrm{h}(20-50 \mathrm{~cm})$ y oscilaron entre $0,56 \mathrm{mg} \mathrm{C}$ $\mathrm{CO}_{2} / \mathrm{kg}$ suelo h (AA, 20-50 cm, 2016) y 5,05 mg C-CO $/ \mathrm{kg}$ suelo $\mathrm{h}$ (AO, 0-20 cm, 2016). Entre el suelo rizosférico y el suelo no rizosférico (años 2016 y 2017, profundidades de 0-20 $\mathrm{cm}$ y $20-50 \mathrm{~cm}$ )) solamente se registraron diferencias estadísticamente significativas en las parcelas AC (0-20 cm y $20-50 \mathrm{~cm}$ en 2016). 


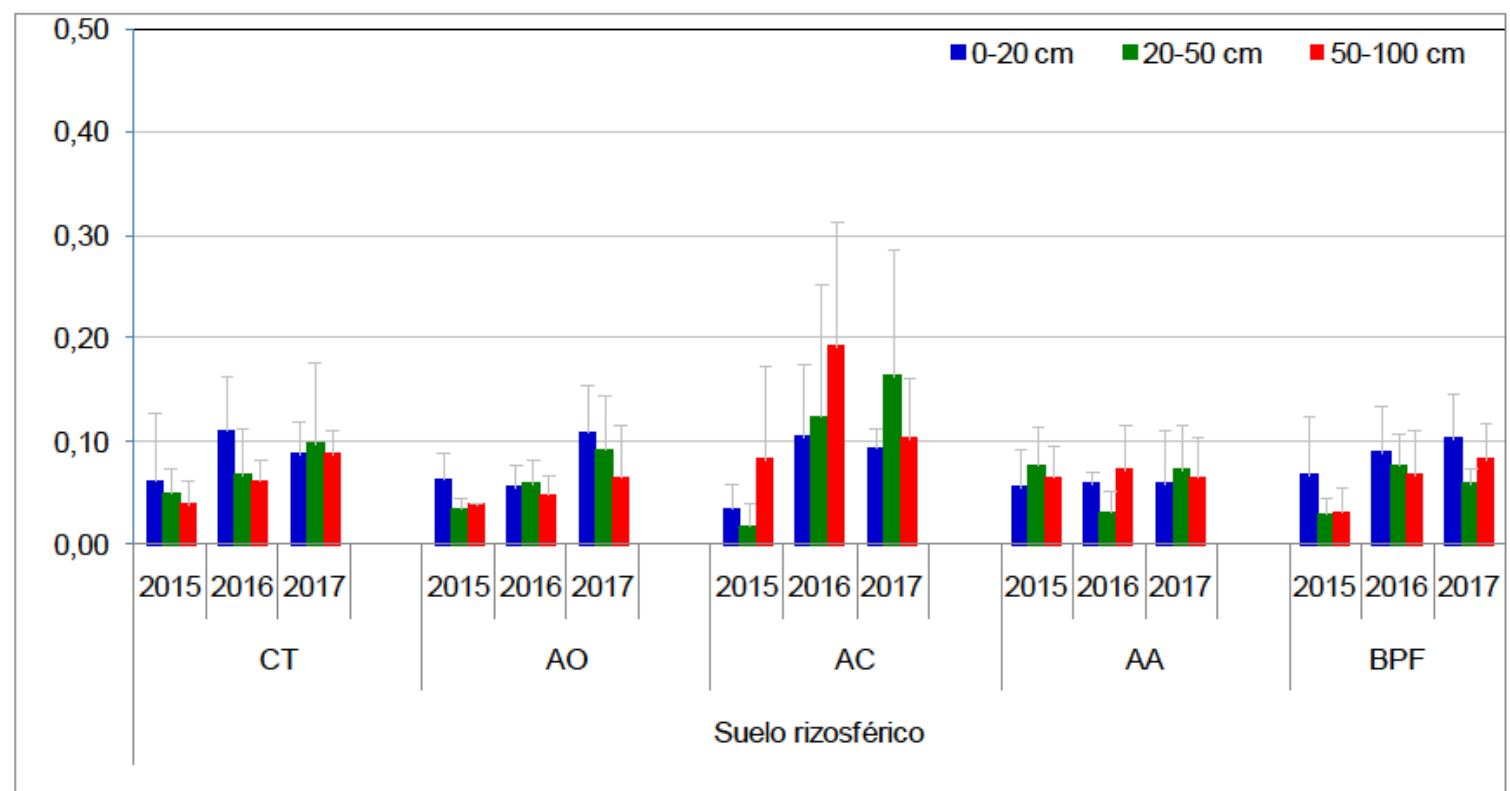

Figura 6.4.13. Evolución temporal de Cu soluble $(\mathrm{mg} / \mathrm{kg})$ en suelo rizosférico entre 3 muestreos anuales $(2015,2016$ y 2017$)$ en parcelas control (CT) y parcelas tratadas con dosis de $5 \mathrm{mmol} / \mathrm{kg}$ de ácido oxálico (AO), ácido cítrico (AC), aminoácidos (AA) y bacterias Pseudomonas fluorescens (BPF) y 5 aplicaciones (junio 2016, septiembre 2016, enero 2017, abril 2017 y junio 2017), $\mathrm{n}=3$.

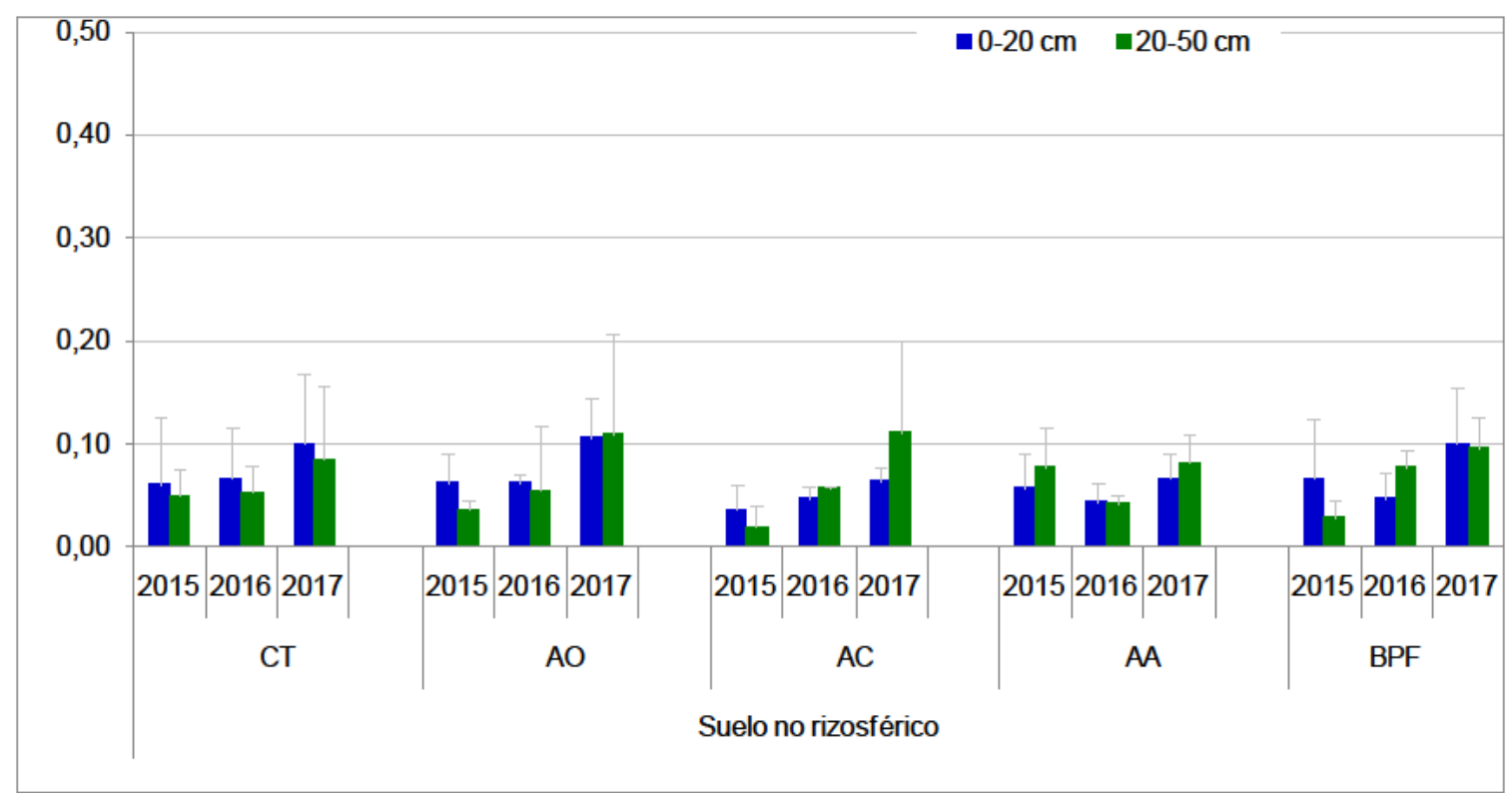

Figura 6.4.14. Evolución temporal de Cu soluble $(\mathrm{mg} / \mathrm{kg})$ en suelo no rizosférico entre 3 muestreos anuales $(2015,2016$ y 2017) en parcelas control (CT) y parcelas tratadas con dosis de $5 \mathrm{mmol} / \mathrm{kg}$ de ácido oxálico (AO), ácido cítrico ( $\mathrm{AC})$, aminoácidos (AA) y bacterias Pseudomonas fluorescens (BPF) y 5 aplicaciones (junio 2016, septiembre 2016, enero 2017, abril 2017 y junio 2017), $n=3$. 


\section{Evolución 2015-2016-2017 de Cu soluble:}

En las figuras anteriores se puede observar la variación entre los años 2015, 2016 y 2017 de las concentraciones de $\mathrm{Cu}$ soluble en los sedimentos del suelo rizosférico y del suelo no rizosférico en las diferentes profundidades muestreadas $(0-20 \mathrm{~cm}, 20-50 \mathrm{~cm}$ y $50-100 \mathrm{~cm})$. En el suelo rizosférico las concentraciones medias de $\mathrm{Cu}$ soluble fueron $0,08 \mathrm{mg} / \mathrm{kg}(0-20$ $\mathrm{cm}), 0,07 \mathrm{mg} / \mathrm{kg}(20-50 \mathrm{~cm})$ y 0,07 mg/kg $(50-100 \mathrm{~cm})$ y oscilaron entre 0,02 mg/kg (AC, 20$50 \mathrm{~cm}, 2015)$ y $0,19 \mathrm{mg} / \mathrm{kg}(\mathrm{AC}, 50-100 \mathrm{~cm}, 2016)$. Para cada uno de los tratamientos no se detectaron diferencias significativas entre las diferentes profundidades muestreadas (0-20 $\mathrm{cm}, 20-50 \mathrm{~cm}$ y $50-100 \mathrm{~cm}$ ). Y para cada tratamiento y profundidad tampoco se registraron diferencias significativas entre años, tampoco para las parcelas AC donde notablemente se observan mayores concentraciones en los años 2016 y 2017 con respecto al año 2015, nuevamente destaca la gran variabilidad encontrada entre los resultados registrados.

En el suelo no rizosférico las concentraciones medias de Cu soluble fueron 0,07 mg/kg (0-20 $\mathrm{cm})$ y $0,07 \mathrm{mg} / \mathrm{kg}(20-50 \mathrm{~cm})$ y oscilaron entre $0,02 \mathrm{mg} / \mathrm{kg}(\mathrm{AC}, 20-50 \mathrm{~cm}, 2016)$ y 0,11 $\mathrm{mg} / \mathrm{kg}$ ( $\mathrm{AO}, 0-20 \mathrm{~cm}, 2017$; AO, 20-50 cm, 2017; AC, 20-50 cm, 2017). Entre el suelo rizosférico y el suelo no rizosférico (años 2016 y 2017, profundidades de 0-20 cm y 20-50 $\mathrm{cm})$ ) solamente se registraron diferencias estadísticamente significativas en las parcelas AC (20-50 cm en 2016). 


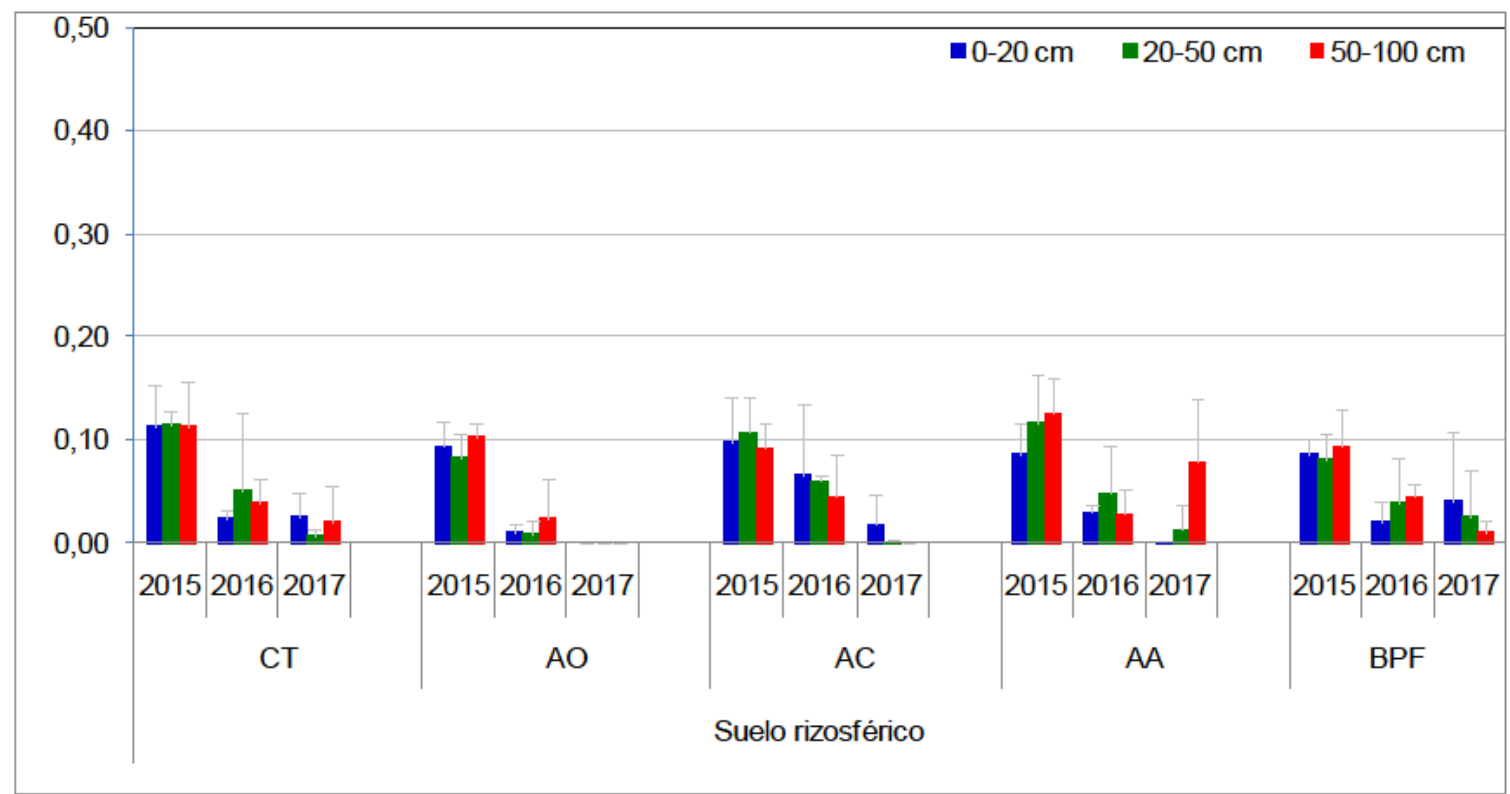

Figura 6.4.15. Evolución temporal de $\mathrm{Zn}$ soluble $(\mathrm{mg} / \mathrm{kg})$ en suelo rizosférico entre 3 muestreos anuales $(2015,2016$ y 2017$)$ en parcelas control (CT) y parcelas tratadas con dosis de $5 \mathrm{mmol} / \mathrm{kg}$ de ácido oxálico (AO), ácido cítrico (AC), aminoácidos (AA) y bacterias Pseudomonas fluorescens (BPF) y 5 aplicaciones (junio 2016, septiembre 2016, enero 2017, abril 2017 y junio 2017), $\mathrm{n}=3$.

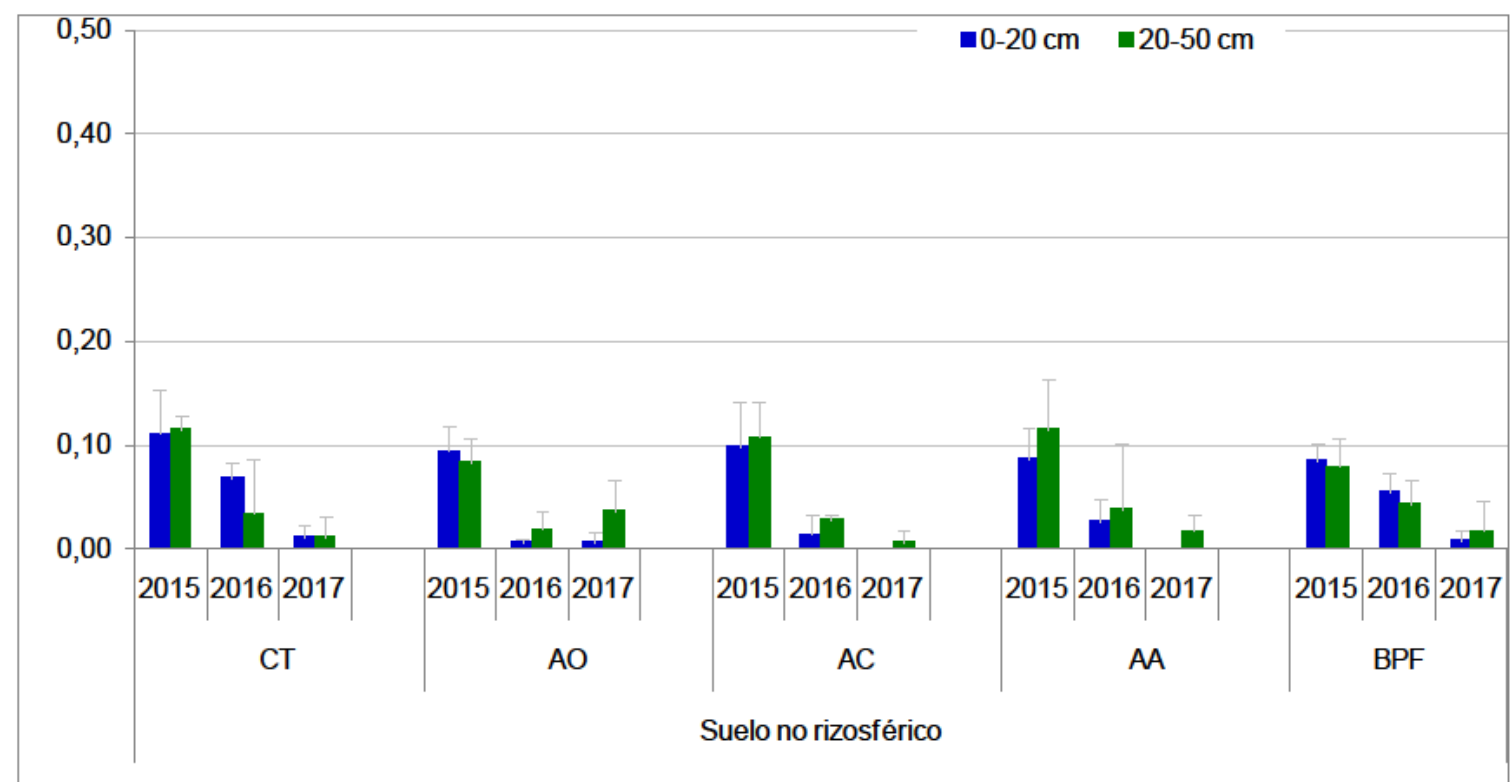

Figura 6.4.16. Evolución temporal de $\mathrm{Zn}$ soluble $(\mathrm{mg} / \mathrm{kg})$ en suelo no rizosférico entre 3 muestreos anuales $(2015,2016$ y 2017$)$ en parcelas control (CT) y parcelas tratadas con dosis de $5 \mathrm{mmol} / \mathrm{kg}$ de ácido oxálico (AO), ácido cítrico ( $\mathrm{AC}$ ), aminoácidos (AA) y bacterias Pseudomonas fluorescens (BPF) y 5 aplicaciones (junio 2016, septiembre 2016, enero 2017, abril 2017 y junio 2017), $n=3$. 


\section{Evolución 2015-2016-2017 de Zn soluble:}

En las figuras anteriores se puede observar la variación entre los años 2015, 2016 y 2017 de las concentraciones de $\mathrm{Zn}$ soluble en los sedimentos del suelo rizosférico y del suelo no rizosférico en las diferentes profundidades muestreadas $(0-20 \mathrm{~cm}, 20-50 \mathrm{~cm}$ y $50-100 \mathrm{~cm})$. En el suelo rizosférico las concentraciones medias de $\mathrm{Zn}$ soluble fueron 0,05 $\mathrm{mg} / \mathrm{kg}(0-20$ $\mathrm{cm}), 0,05 \mathrm{mg} / \mathrm{kg}(20-50 \mathrm{~cm})$ y $0,05 \mathrm{mg} / \mathrm{kg}(50-100 \mathrm{~cm})$ y oscilaron entre $0(A O, 0-20 \mathrm{~cm}$, 2017; AA, 0-20 cm, 2017; AO, 20-50 cm, 2017; AC, 20-50 cm, 2017; AO, 50-100 cm, 2017; $A C, 50-100 \mathrm{~cm}, 2017)$ y $0,13 \mathrm{mg} / \mathrm{kg}(A A, 50-100 \mathrm{~cm}, 2015)$. Para cada uno de los tratamientos no se detectaron diferencias significativas entre las diferentes profundidades muestreadas $(0-20 \mathrm{~cm}, 20-50 \mathrm{~cm}$ y $50-100 \mathrm{~cm})$. Y para cada tratamiento y profundidad se registraron concentraciones de $\mathrm{Cu}$ soluble significativamente superiores para todas las profundidades en el año 2015 con respecto a los años 2016 y 2017. Las variaciones observadas podrían deberse a la absorción de este elemento por parte de las plantas, por otro lado también podrían evidenciar el bajo riesgo de lixiviación de este metal a horizontes más profundos.

En el suelo no rizosférico las concentraciones medias de $\mathrm{Zn}$ soluble fueron $0,05 \mathrm{mg} / \mathrm{kg}(0-20$ $\mathrm{cm}$ ) y $0,05 \mathrm{mg} / \mathrm{kg}(20-50 \mathrm{~cm})$ y oscilaron entre 0 (AC, 0-20 cm, 2017; AA, 0-20 cm, 2017) y 0,12 (CT, 20-50 cm, 2015; AA, 20-50 cm, 2015). Entre el suelo rizosférico y el suelo no rizosférico (años 2016 y 2017, profundidades de 0-20 cm y 20-50 cm)) solamente se registraron diferencias estadísticamente significativas en las parcelas CT $(20-50 \mathrm{~cm}$ en 2017), en las parcelas $A O(0-20 \mathrm{~cm}$ y $20-50 \mathrm{~cm}$ en 2017$)$, en las parcelas $A A(20-50 \mathrm{~cm}$ en 2017) y en las parcelas BPF (0-20 cm en 2017). 


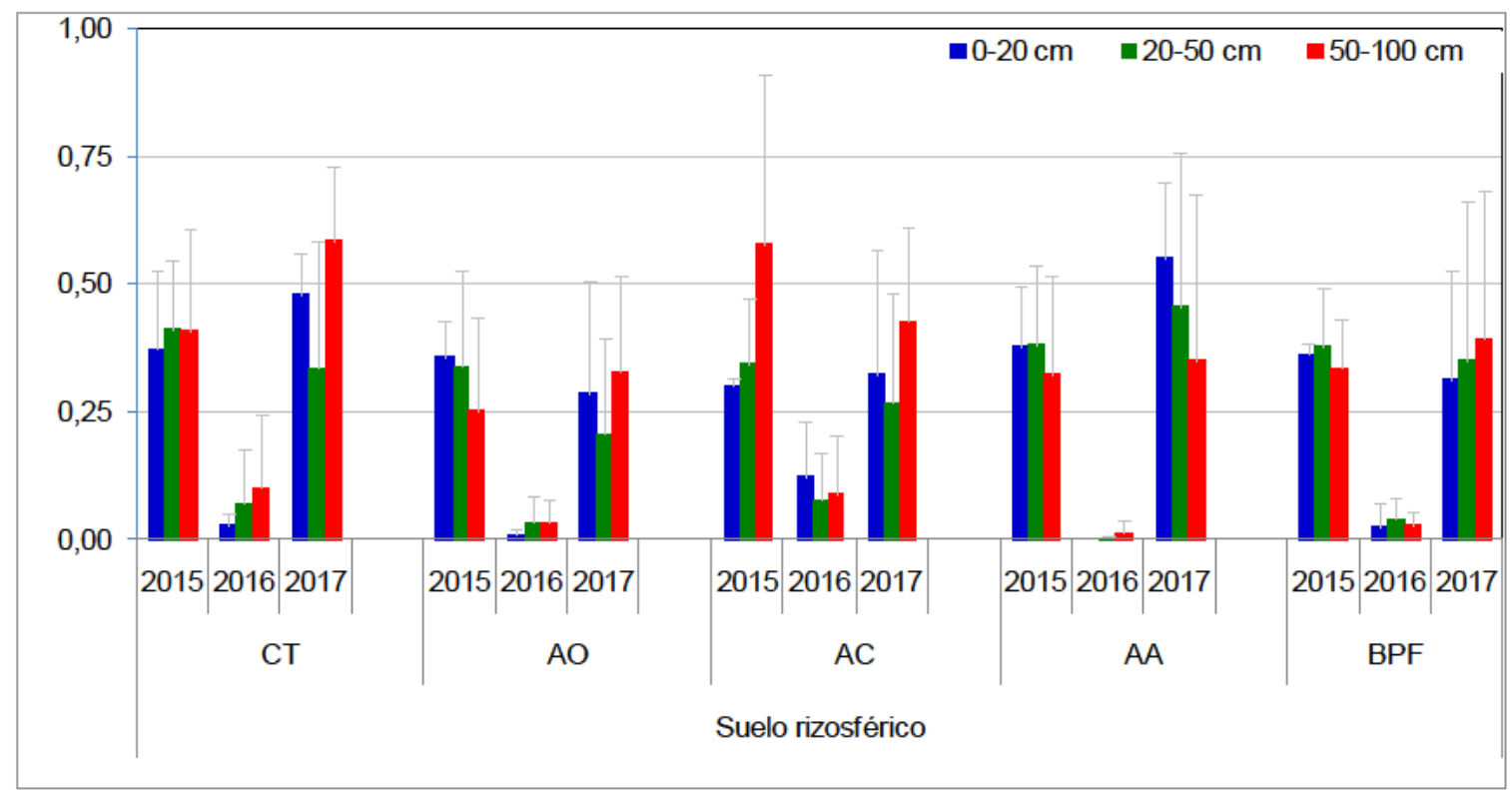

Figura 6.4.17. Evolución temporal de $\mathrm{Cr}$ soluble $(\mathrm{mg} / \mathrm{kg})$ en suelo rizosférico entre 3 muestreos anuales $(2015,2016$ y 2017) en parcelas control (CT) y parcelas tratadas con dosis de $5 \mathrm{mmol} / \mathrm{kg}$ de ácido oxálico (AO), ácido cítrico (AC), aminoácidos (AA) y bacterias Pseudomonas fluorescens (BPF) y 5 aplicaciones (junio 2016, septiembre 2016, enero 2017, abril 2017 y junio 2017), $n=3$.

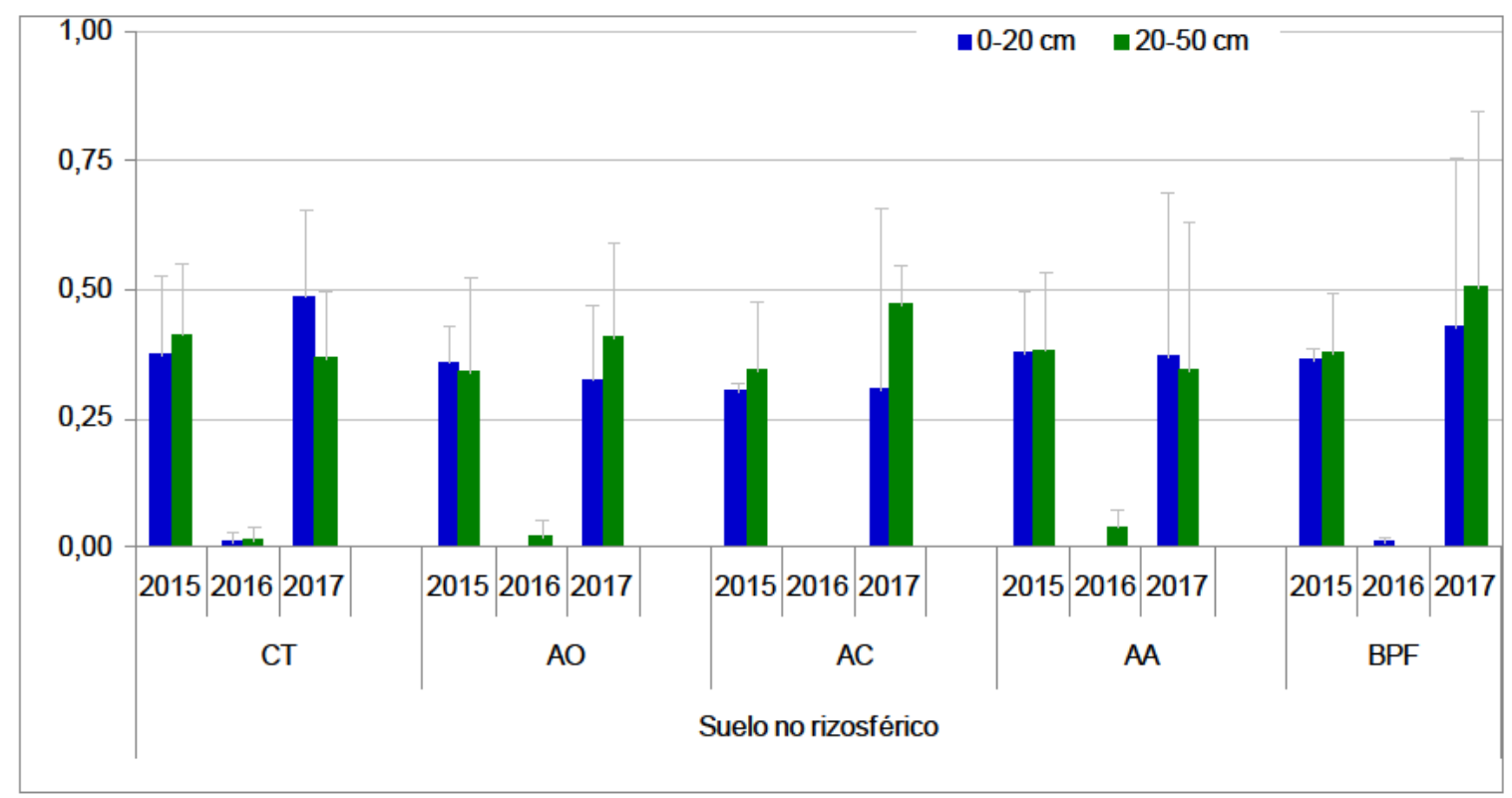

Figura 6.4.18. Evolución temporal de $\mathrm{Cr}$ soluble $(\mathrm{mg} / \mathrm{kg})$ en suelo no rizosférico entre 3 muestreos anuales $(2015,2016$ y 2017) en parcelas control (CT) y parcelas tratadas con dosis de $5 \mathrm{mmol} / \mathrm{kg}$ de ácido oxálico (AO), ácido cítrico ( $A C)$, aminoácidos (AA) y bacterias Pseudomonas fluorescens (BPF) y 5 aplicaciones (junio 2016, septiembre 2016, enero 2017, abril 2017 y junio 2017), $n=3$. 


\section{Evolución 2015-2016-2017 de Cr soluble:}

En las figuras anteriores se puede observar la variación entre los años 2015, 2016 y 2017 de las concentraciones de $\mathrm{Cr}$ soluble en los sedimentos del suelo rizosférico y del suelo no rizosférico en las diferentes profundidades muestreadas $(0-20 \mathrm{~cm}, 20-50 \mathrm{~cm}$ y $50-100 \mathrm{~cm})$. En el suelo rizosférico las concentraciones medias de $\mathrm{Cr}$ soluble fueron $0,26 \mathrm{mg} / \mathrm{kg}(0-20$ $\mathrm{cm}), 0,25 \mathrm{mg} / \mathrm{kg}(20-50 \mathrm{~cm})$ y $0,28 \mathrm{mg} / \mathrm{kg}(50-100 \mathrm{~cm})$ y oscilaron entre 0 (AA, 0-20 cm, 2016; AA, 20-50 cm, 2016) y 0,59 (CT, 50-100 cm, 2017). Para cada uno de los tratamientos no se detectaron diferencias significativas entre las diferentes profundidades muestreadas (0-20 cm, 20-50 cm y 50-100 cm). Para cada tratamiento y profundidad se han registrado concentraciones de $\mathrm{Cr}$ soluble significativamente superiores para todas las profundidades (0-20 cm, 20-50 cm y 50-100 cm) en los años 2015 y 2017 con respecto al año 2016. Este hecho podría evidenciar que la solubilidad del $\mathrm{Cr}$ es temporal y es dinámica ya que las concentraciones varían significativamente con el tiempo, facilitándose así su absorción y acumulación por las plantas y luego vuelven a solubilizarse con el tiempo.

En el suelo no rizosférico las concentraciones medias de $\mathrm{Cr}$ soluble fueron $0,25 \mathrm{mg} / \mathrm{kg}$ (0-20 $\mathrm{cm}$ ) y $0,27 \mathrm{mg} / \mathrm{kg}(20-50 \mathrm{~cm})$ y oscilaron entre 0 (AO, 0-20 cm, 2016; AC, 0-20 cm, 2016; AA, 0-20 cm, 2016; AC, 20-50 cm, 2016; BPF, 20-50 cm, 2016) y 0,51 mg/kg (BPF, 20-50 $\mathrm{cm}, 2017$ ). Entre el suelo rizosférico y el suelo no rizosférico (años 2016 y 2017, profundidades de $0-20 \mathrm{~cm}$ y $20-50 \mathrm{~cm}$ )) solamente se registraron diferencias estadísticamente significativas en las parcelas CT (20-50 cm en 2016), en las parcelas AO (0-20 cm en 2016) y en las parcelas AC (0-20 cm y $20-5 \mathrm{~cm}$ en 2016 y $20-50 \mathrm{~cm}$ en 2017). 


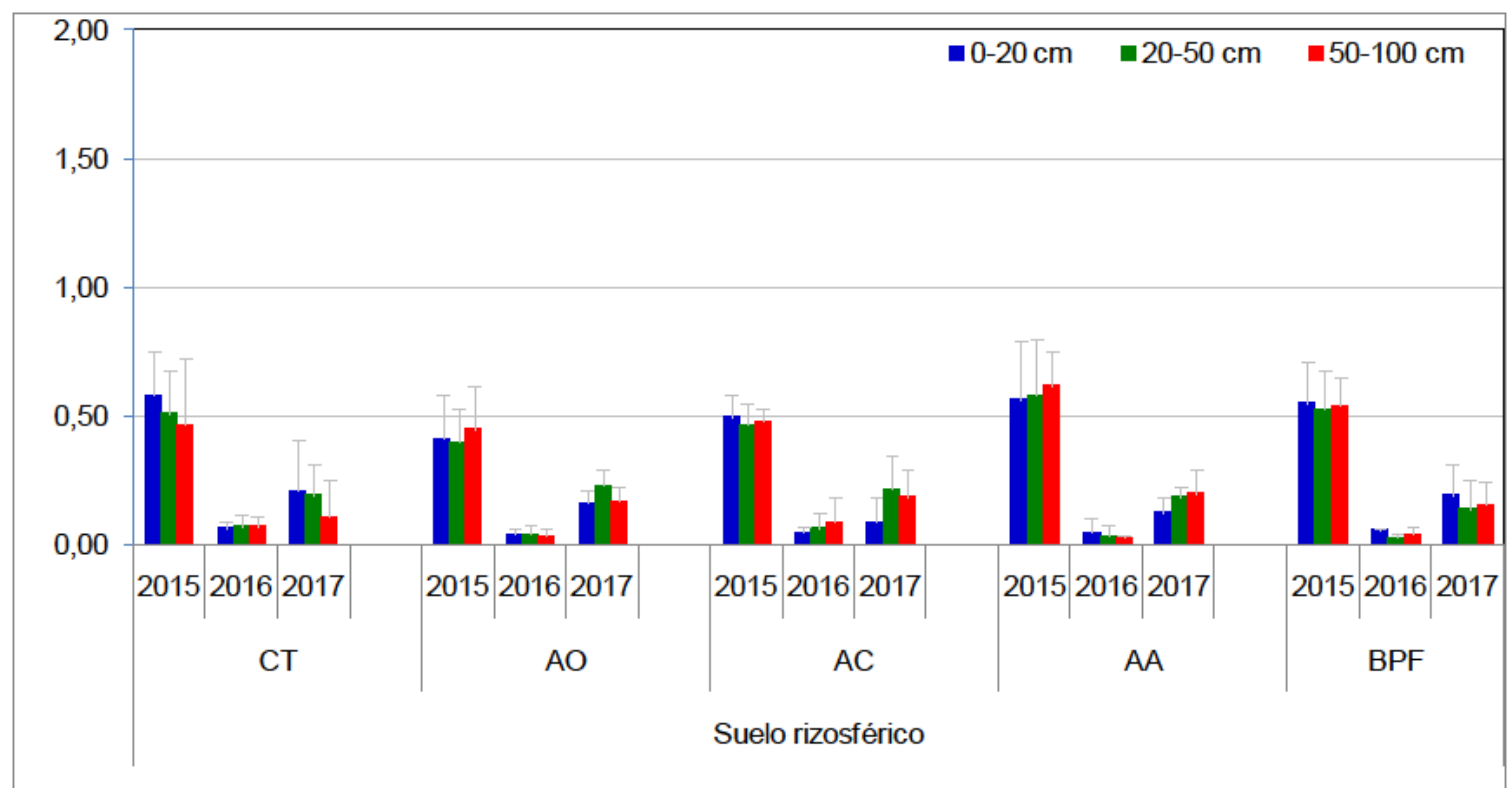

Figura 6.4.19. Evolución temporal de $\mathrm{Cu}$ intercambiable $(\mathrm{mg} / \mathrm{kg})$ en suelo rizosférico entre 3 muestreos anuales $(2015,2016$ y 2017$)$ en parcelas control (CT) y parcelas tratadas con dosis de $5 \mathrm{mmol} / \mathrm{kg}$ de ácido oxálico (AO), ácido cítrico (AC), aminoácidos (AA) y bacterias Pseudomonas fluorescens (BPF) y 5 aplicaciones (junio 2016, septiembre 2016, enero 2017, abril 2017 y junio 2017), $n=3$.

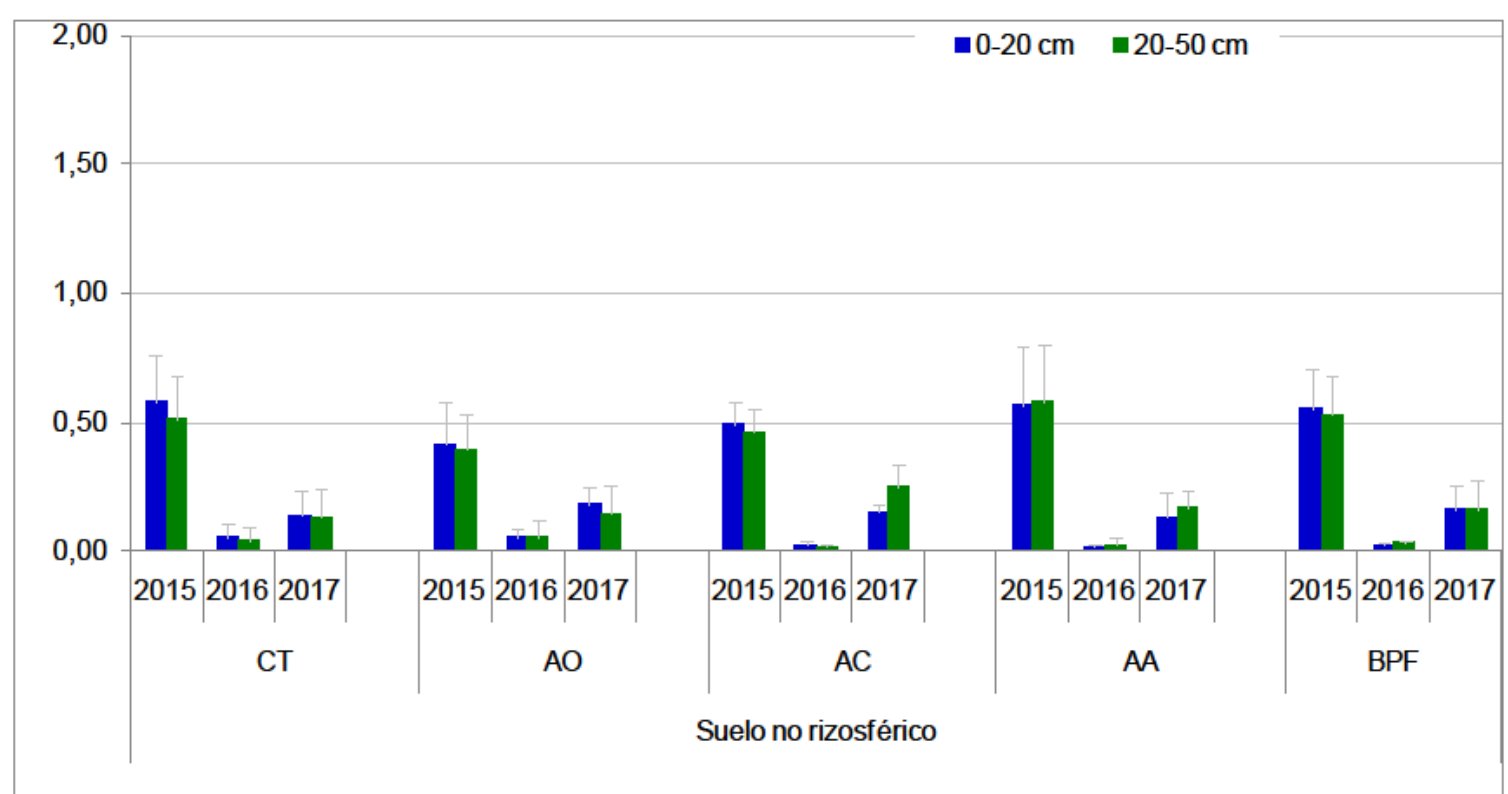

Figura 6.4.20. Evolución temporal de Cu intercambiable $(\mathrm{mg} / \mathrm{kg})$ en suelo no rizosférico entre 3 muestreos anuales $(2015,2016$ y 2017) en parcelas control (CT) y parcelas tratadas con dosis de $5 \mathrm{mmol} / \mathrm{kg}$ de ácido oxálico (AO), ácido cítrico (AC), aminoácidos (AA) y bacterias Pseudomonas fluorescens (BPF) y 5 aplicaciones (junio 2016, septiembre 2016, enero 2017, abril 2017 y junio 2017), $\mathrm{n}=3$. 


\section{Evolución 2015-2016-2017 de Cu intercambiable:}

En las figuras anteriores se puede observar la variación entre los años 2015, 2016 y 2017 de las concentraciones de $\mathrm{Cu}$ intercambiable en los sedimentos del suelo rizosférico y del suelo no rizosférico en las diferentes profundidades muestreadas $(0-20 \mathrm{~cm}, 20-50 \mathrm{~cm}$ y $50-100$ $\mathrm{cm})$. En el suelo rizosférico las concentraciones medias de $\mathrm{Cu}$ intercambiable fueron 0,24 $\mathrm{mg} / \mathrm{kg}(0-20 \mathrm{~cm}), 0,25 \mathrm{mg} / \mathrm{kg}(20-50 \mathrm{~cm})$ y $0,24 \mathrm{mg} / \mathrm{kg}(50-100 \mathrm{~cm})$ y oscilaron entre 0,03 $\mathrm{mg} / \mathrm{kg}$ (BPF, 20-50 cm, 2016; AA, 50-100 cm, 2016) y 0,62 mg/kg (AA, 50-100 cm, 2015). Para cada uno de los tratamientos no se detectaron diferencias significativas entre las diferentes profundidades muestreadas $(0-20 \mathrm{~cm}, 20-50 \mathrm{~cm}$ y $50-100 \mathrm{~cm})$. Al igual que para $\mathrm{Cr}$ soluble, para cada tratamiento y profundidad se han registrado concentraciones de $\mathrm{Cu}$ intercambiable significativamente superiores para todas las profundidades $(0-20 \mathrm{~cm}, 20-50$ cm y 50-100 cm) en los años 2015 y 2017 con respecto al año 2016. Este hecho vuelve a evidenciar que la solubilidad del Cu es temporal y es dinámica ya que las concentraciones varían significativamente con el tiempo, facilitándose así su absorción y acumulación por las plantas y luego vuelven a solubilizarse con el tiempo.

En el suelo no rizosférico las concentraciones medias de $\mathrm{Cu}$ intercambiable fueron 0,24 $\mathrm{mg} / \mathrm{kg}(0-20 \mathrm{~cm})$ y $0,23 \mathrm{mg} / \mathrm{kg}(20-50 \mathrm{~cm})$ y oscilaron entre 0,02 (AA, 0-20 cm, 2016; BPF, 0$20 \mathrm{~cm}, 2016$; AC, 20-50 cm, 2016) y 0,58 mg/kg (AA, 20-50 cm, 2015). Entre el suelo rizosférico y el suelo no rizosférico (años 2016 y 2017, profundidades de 0-20 cm y 20-50 $\mathrm{cm})$ ) solamente se registraron diferencias estadísticamente significativas en las parcelas $A A$ (0-20 cm en 2016 y $20-50 \mathrm{~cm}$ en 2017). 


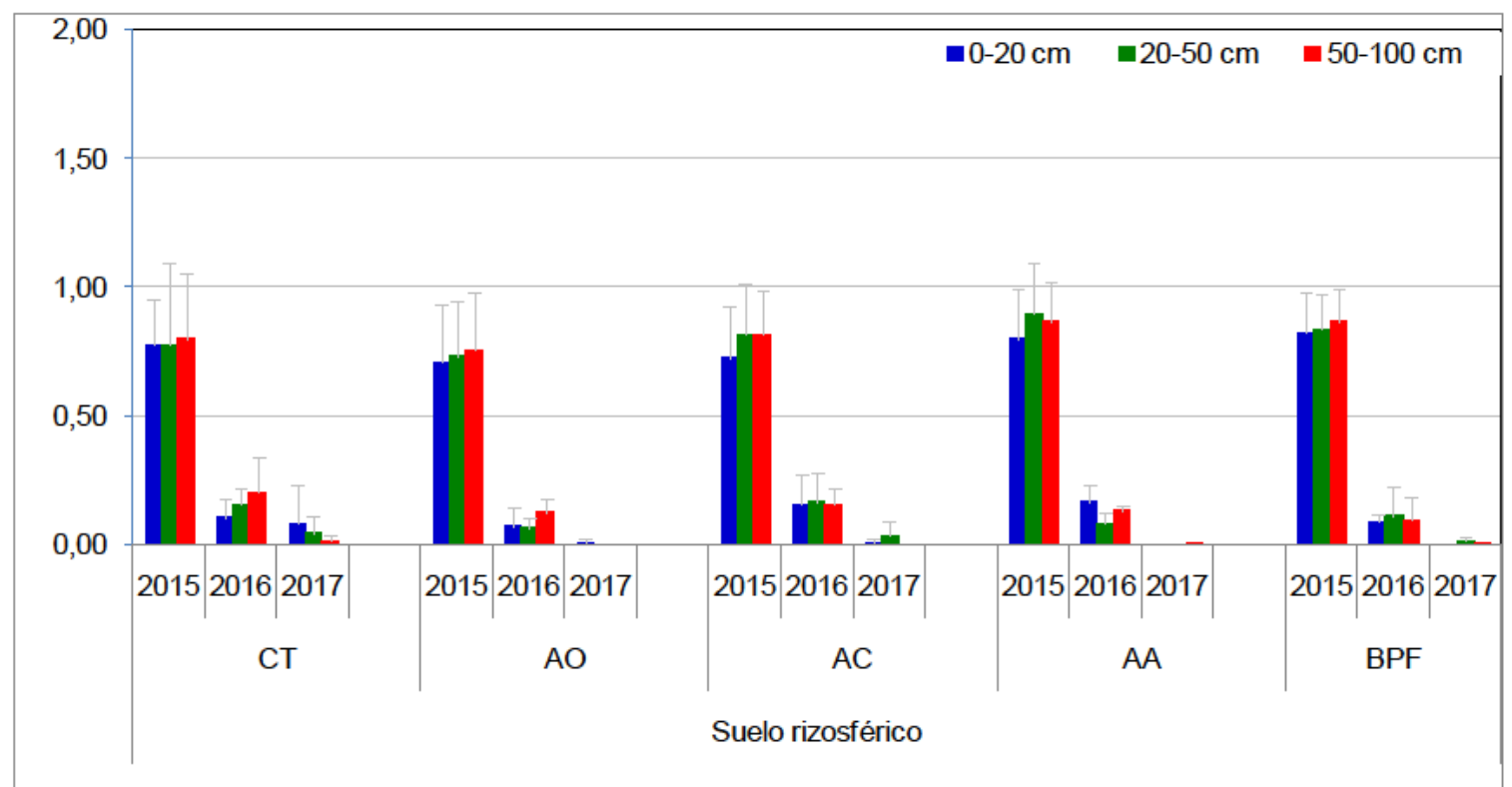

Figura 6.4.21. Evolución temporal de $\mathrm{Zn}$ intercambiable $(\mathrm{mg} / \mathrm{kg})$ en suelo rizosférico entre 3 muestreos anuales $(2015,2016$ y 2017$)$ en parcelas control (CT) y parcelas tratadas con dosis de $5 \mathrm{mmol} / \mathrm{kg}$ de ácido oxálico (AO), ácido cítrico (AC), aminoácidos (AA) y bacterias Pseudomonas fluorescens (BPF) y 5 aplicaciones (junio 2016, septiembre 2016, enero 2017, abril 2017 y junio 2017), $n=3$.

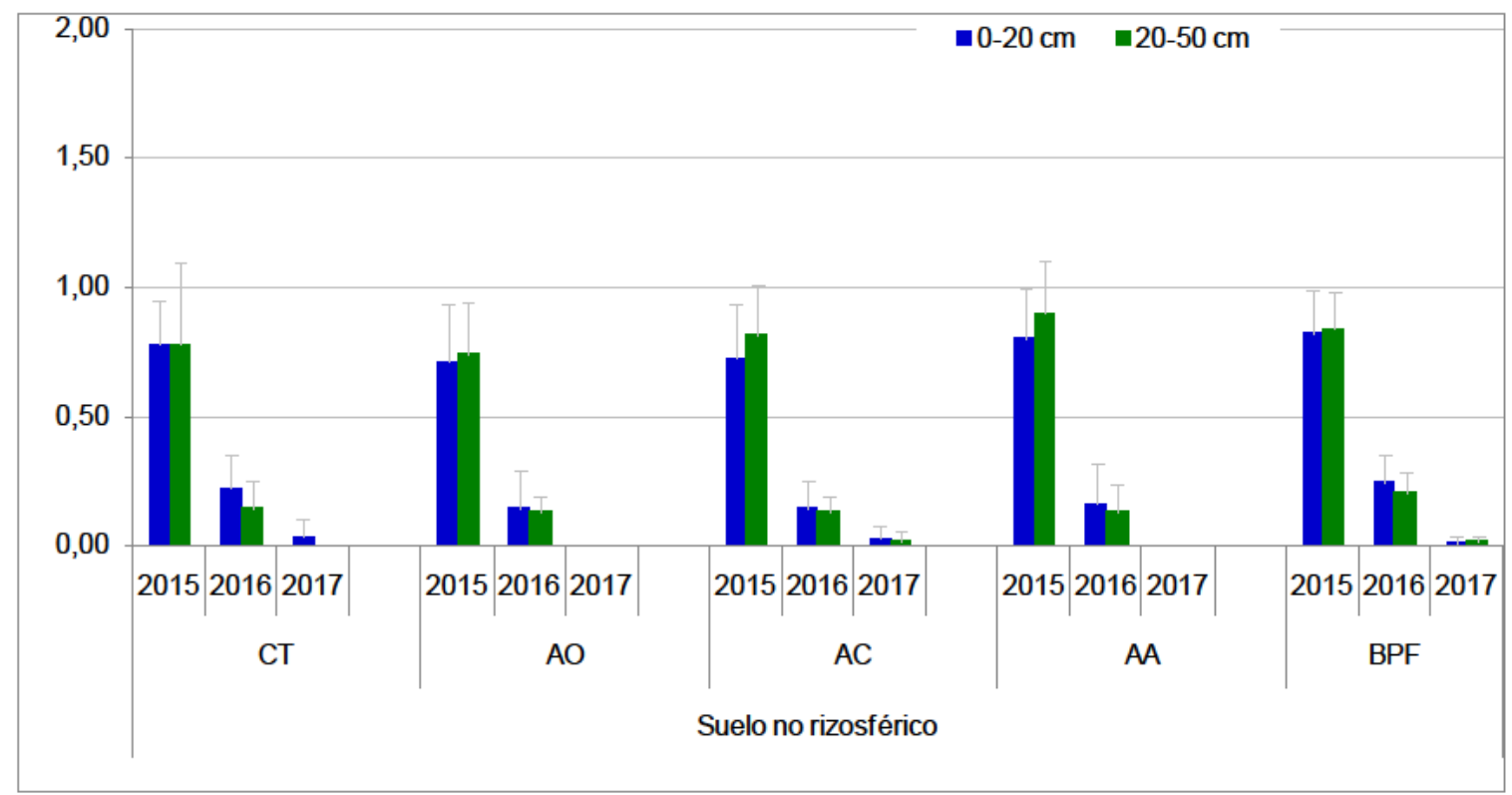

Figura 6.4.22. Evolución temporal de Zn intercambiable $(\mathrm{mg} / \mathrm{kg})$ en suelo no rizosférico entre 3 muestreos anuales $(2015,2016$ y 2017) en parcelas control (CT) y parcelas tratadas con dosis de $5 \mathrm{mmol} / \mathrm{kg}$ de ácido oxálico (AO), ácido cítrico ( $\mathrm{AC}$ ), aminoácidos (AA) y bacterias Pseudomonas fluorescens (BPF) y 5 aplicaciones (junio 2016, septiembre 2016, enero 2017, abril 2017 y junio 2017), $n=3$. 


\section{Evolución 2015-2016-2017 de Zn intercambiable:}

En las figuras anteriores se puede observar la variación entre los años 2015, 2016 y 2017 de las concentraciones de $\mathrm{Zn}$ intercambiable en los sedimentos del suelo rizosférico y del suelo no rizosférico en las diferentes profundidades muestreadas $(0-20 \mathrm{~cm}, 20-50 \mathrm{~cm}$ y $50-100$ $\mathrm{cm})$. En el suelo rizosférico las concentraciones medias de $\mathrm{Zn}$ intercambiable fueron 0,30 $\mathrm{mg} / \mathrm{kg}(0-20 \mathrm{~cm}), 0,32 \mathrm{mg} / \mathrm{kg}(20-50 \mathrm{~cm})$ y $0,32 \mathrm{mg} / \mathrm{kg}(50-100 \mathrm{~cm})$ y oscilaron entre $0 \mathrm{mg} / \mathrm{kg}$ (AA, 0-20 cm, 2017; BPF, 0-20 cm, 2017; AO, 20-50 cm, 2017; AA, 20-50 cm, 2017; AO, 50100 cm, 2017; AC, 50-100 cm, 2017; AA, 50-100 cm, 2017; BPF, 50-100 cm, 2017) y 0,89 $\mathrm{mg} / \mathrm{kg}(\mathrm{AA}, 20-50 \mathrm{~cm}, 2015)$. Para todos los tratamientos no se detectaron diferencias significativas entre las diferentes profundidades muestreadas $(0-20 \mathrm{~cm}, 20-50 \mathrm{~cm}$ y $50-100$ $\mathrm{cm}$ ), evidenciando que no existe riesgo de lixiviación entre los diferentes horizontes. Y para cada tratamiento y profundidad se registraron concentraciones de $\mathrm{Zn}$ soluble significativamente superiores en el año 2015 con respecto a los años 2016 y 2017, esto pone de manifiesto que el Zn intercambiable podría haber sido mayormente acumulado por la vegetación fitoextractora implantada

En el suelo no rizosférico las concentraciones medias de $\mathrm{Zn}$ intercambiable fueron 0,32 $\mathrm{mg} / \mathrm{kg}(0-20 \mathrm{~cm})$ y $0,32 \mathrm{mg} / \mathrm{kg}(20-50 \mathrm{~cm})$ y oscilaron entre $0 \mathrm{mg} / \mathrm{kg}(\mathrm{AO}, 0-20 \mathrm{~cm}, 2017 ; \mathrm{AA}$, 0-20 cm, 2017; CT, 20-50 cm, 2017; AO, 20-50 cm, 2017; AA, 20-50 cm, 2017) y 0,89 mg/kg (AA, 20-50 cm, 2015). Entre el suelo rizosférico y el suelo no rizosférico (años 2016 y 2017, profundidades de $0-20 \mathrm{~cm}$ y $20-50 \mathrm{~cm}$ )) solamente se registraron diferencias estadísticamente significativas en las parcelas CT (20-50 cm en 2016), en las parcelas CT (20-50 cm en 2017), en las parcelas AO (0-20 cm en 2017), en las parcelas AC (20-50 cm en 2017) y en las parcelas BPF (0-20 cm en 2017). 


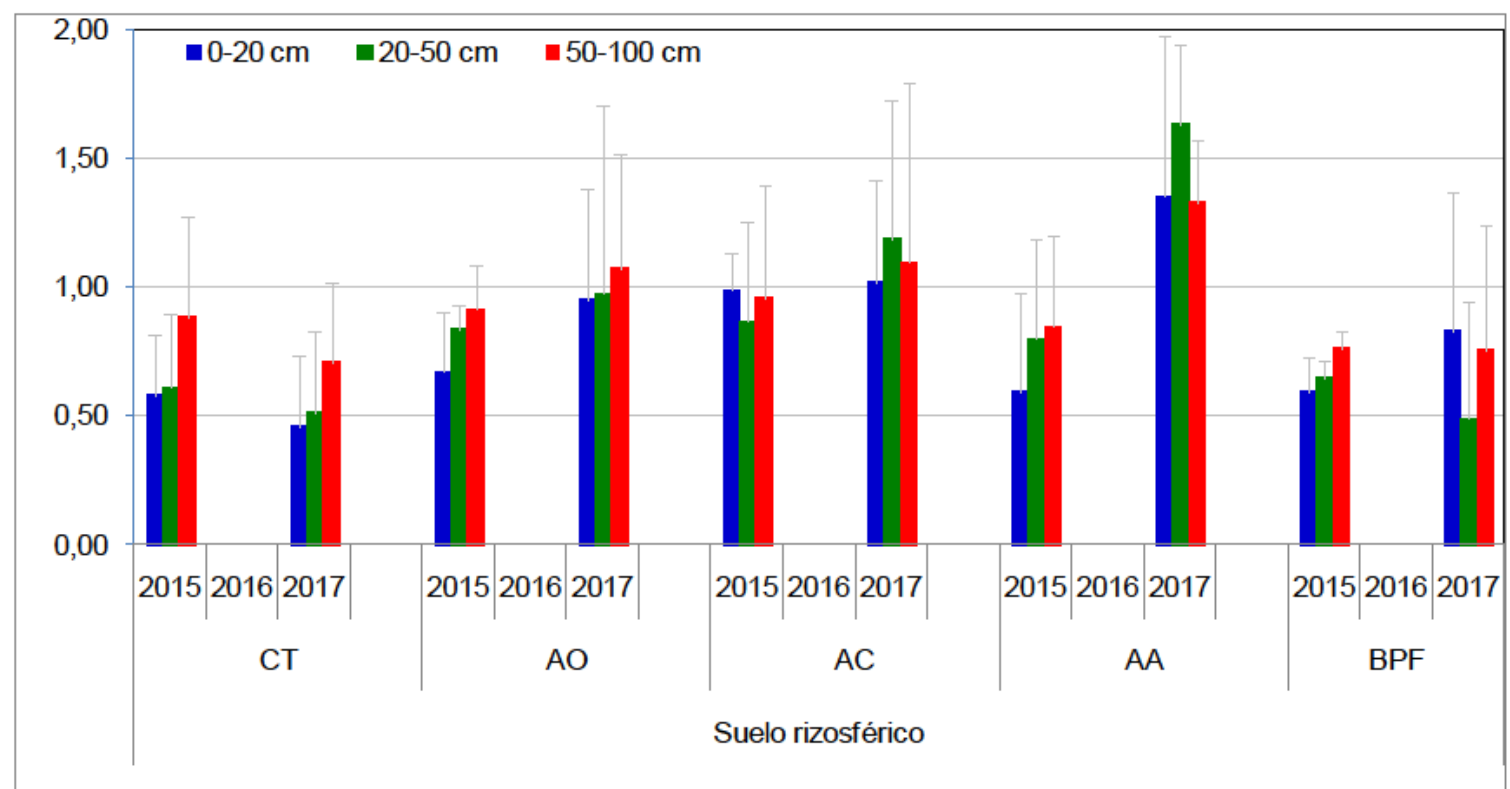

Figura 6.4.23. Evolución temporal de $\mathrm{Cr}$ intercambiable $(\mathrm{mg} / \mathrm{kg})$ en suelo rizosférico entre 3 muestreos anuales $(2015,2016$ y 2017) en parcelas control (CT) y parcelas tratadas con dosis de $5 \mathrm{mmol} / \mathrm{kg}$ de ácido oxálico (AO), ácido cítrico (AC), aminoácidos (AA) y bacterias Pseudomonas fluorescens (BPF) y 5 aplicaciones (junio 2016, septiembre 2016, enero 2017, abril 2017 y junio 2017), $\mathrm{n}=3$.

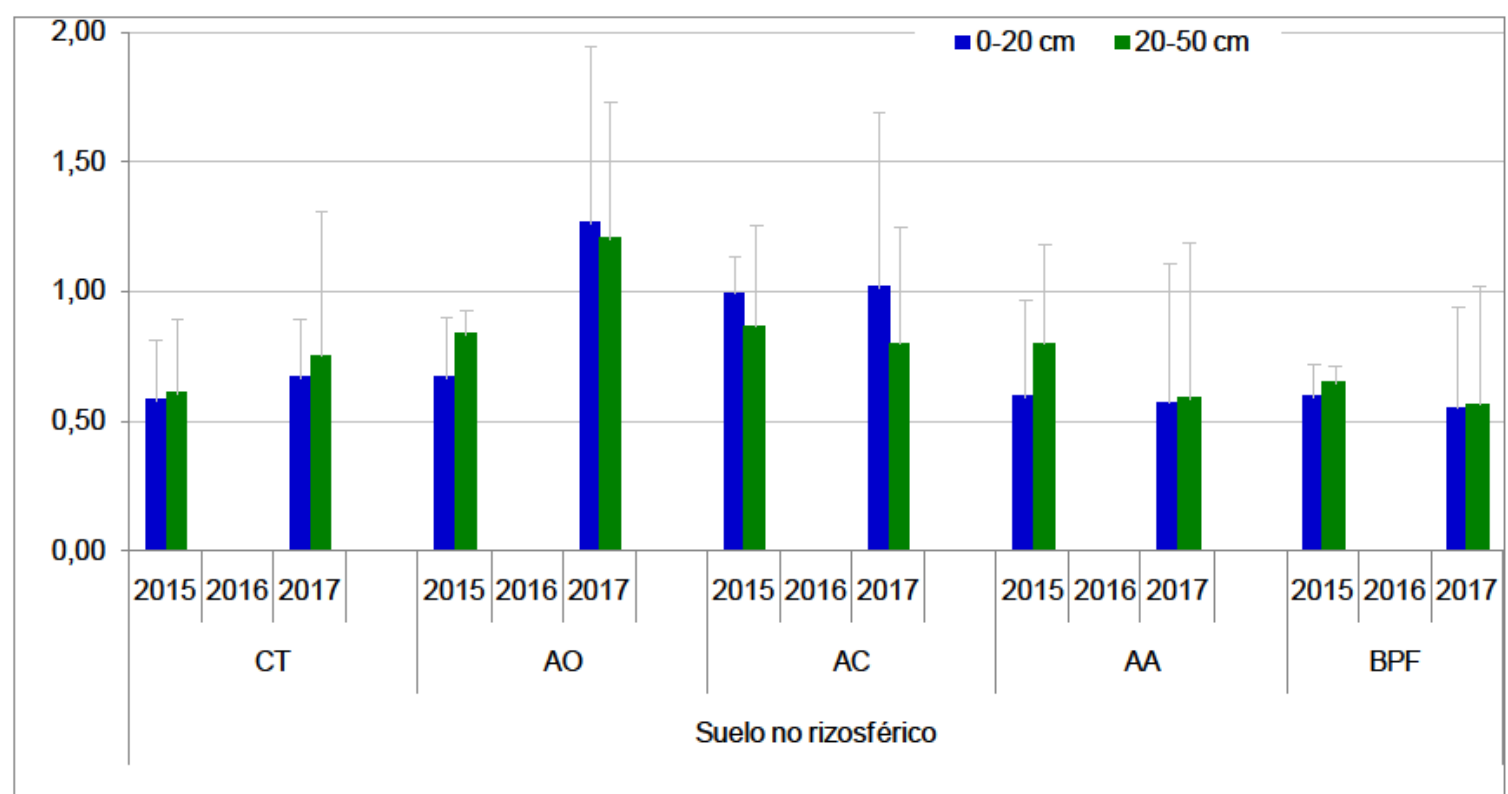

Figura 6.4.24. Evolución temporal de $\mathrm{Cr}$ intercambiable $(\mathrm{mg} / \mathrm{kg})$ en suelo no rizosférico entre 3 muestreos anuales $(2015,2016$ y 2017) en parcelas control (CT) y parcelas tratadas con dosis de $5 \mathrm{mmol} / \mathrm{kg}$ de ácido oxálico (AO), ácido cítrico (AC), aminoácidos (AA) y bacterias Pseudomonas fluorescens (BPF) y 5 aplicaciones (junio 2016, septiembre 2016, enero 2017, abril 2017 y junio 2017), $\mathrm{n}=3$. 


\section{Evolución 2015-2016-2017 de Cr intercambiable:}

En las figuras anteriores se puede observar la variación entre los años 2015, 2016 y 2017 de las concentraciones de $\mathrm{Cr}$ intercambiable en los sedimentos del suelo rizosférico y del suelo no rizosférico en las diferentes profundidades muestreadas $(0-20 \mathrm{~cm}, 20-50 \mathrm{~cm}$ y $50-100$ $\mathrm{cm}$ ). En el suelo rizosférico las concentraciones medias de $\mathrm{Cr}$ intercambiable fueron 0,54 $\mathrm{mg} / \mathrm{kg}(0-20 \mathrm{~cm}), 0,57 \mathrm{mg} / \mathrm{kg}(20-50 \mathrm{~cm})$ y $0,62 \mathrm{mg} / \mathrm{kg}(50-100 \mathrm{~cm})$ y oscilaron entre $0 \mathrm{mg} / \mathrm{kg}$ (todos los tratamientos y profundidades del año 2016) y 1,63 mg/kg (AA, 20-50 cm, 2017). Para cada uno de los tratamientos no se detectaron diferencias significativas entre las diferentes profundidades muestreadas $(0-20 \mathrm{~cm}, 20-50 \mathrm{~cm}$ y $50-100 \mathrm{~cm})$. Y para cada tratamiento y profundidad tampoco se registraron diferencias significativas entre años, este hecho podría se debido a la gran variabilidad encontrada entre los resultados registrados. Para cada tratamiento y profundidad se registraron concentraciones de $\mathrm{Cr}$ intercambiable significativamente superiores en los años 2015 y 2017 con respecto al año 2016, pudiendo deberse a su acumulación principalmente por la vegetación fitoextractora implantada. También se pueden apreciar concentraciones de $\mathrm{Cr}$ intercambiable en suelo rizosférico superiores en las parcelas tratadas con $A O, A C$ y $A A$, aunque no son estadísticamente significativas.

En el suelo no rizosférico las concentraciones medias de $\mathrm{Cr}$ intercambiable fueron 0,50 $\mathrm{mg} / \mathrm{kg}(0-20 \mathrm{~cm})$ y $0,51 \mathrm{mg} / \mathrm{kg}(20-50 \mathrm{~cm})$ y oscilaron entre $0 \mathrm{mg} / \mathrm{kg}$ (todos los tratamientos y profundidades del año 2016) y 1,27 mg/kg (AO, 0-20 cm, 2017). Entre el suelo rizosférico y el suelo no rizosférico (años 2016 y 2017, profundidades de 0-20 cm y 20-50 cm)) solamente se registraron diferencias estadísticamente significativas en las parcelas CT (20-50 cm en 2017) y en las parcelas BPF (20-50 cm en 2017). 


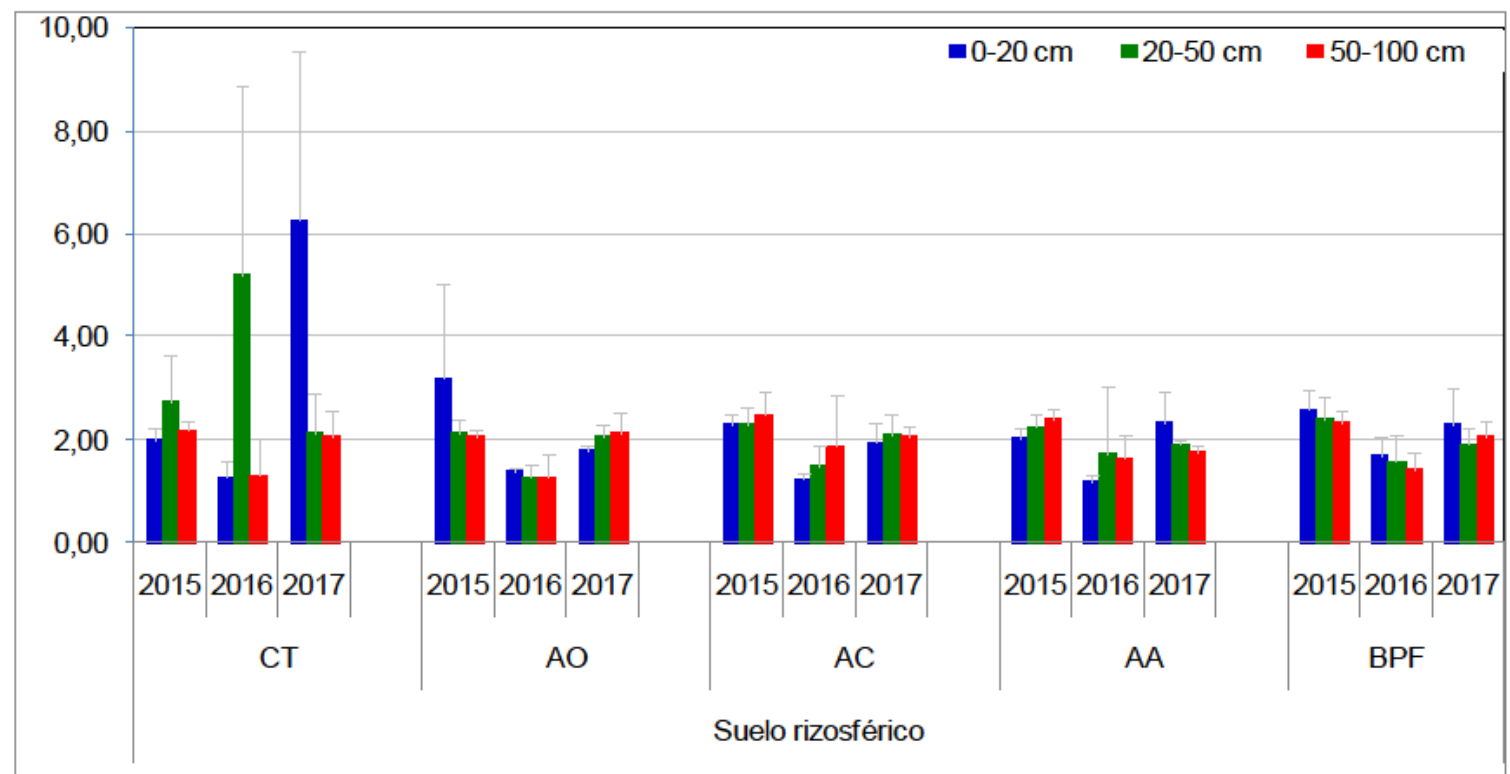

Figura 6.4.25. Evolución temporal de Cu ligado a carbonatos $(\mathrm{mg} / \mathrm{kg})$ en suelo rizosférico entre 3 muestreos anuales $(2015,2016$ y 2017) en parcelas control (CT) y parcelas tratadas con dosis de $5 \mathrm{mmol} / \mathrm{kg}$ de ácido oxálico (AO), ácido cítrico (AC), aminoácidos (AA) y bacterias Pseudomonas fluorescens (BPF) y 5 aplicaciones (junio 2016, septiembre 2016, enero 2017, abril 2017 y junio 2017), $n=3$.

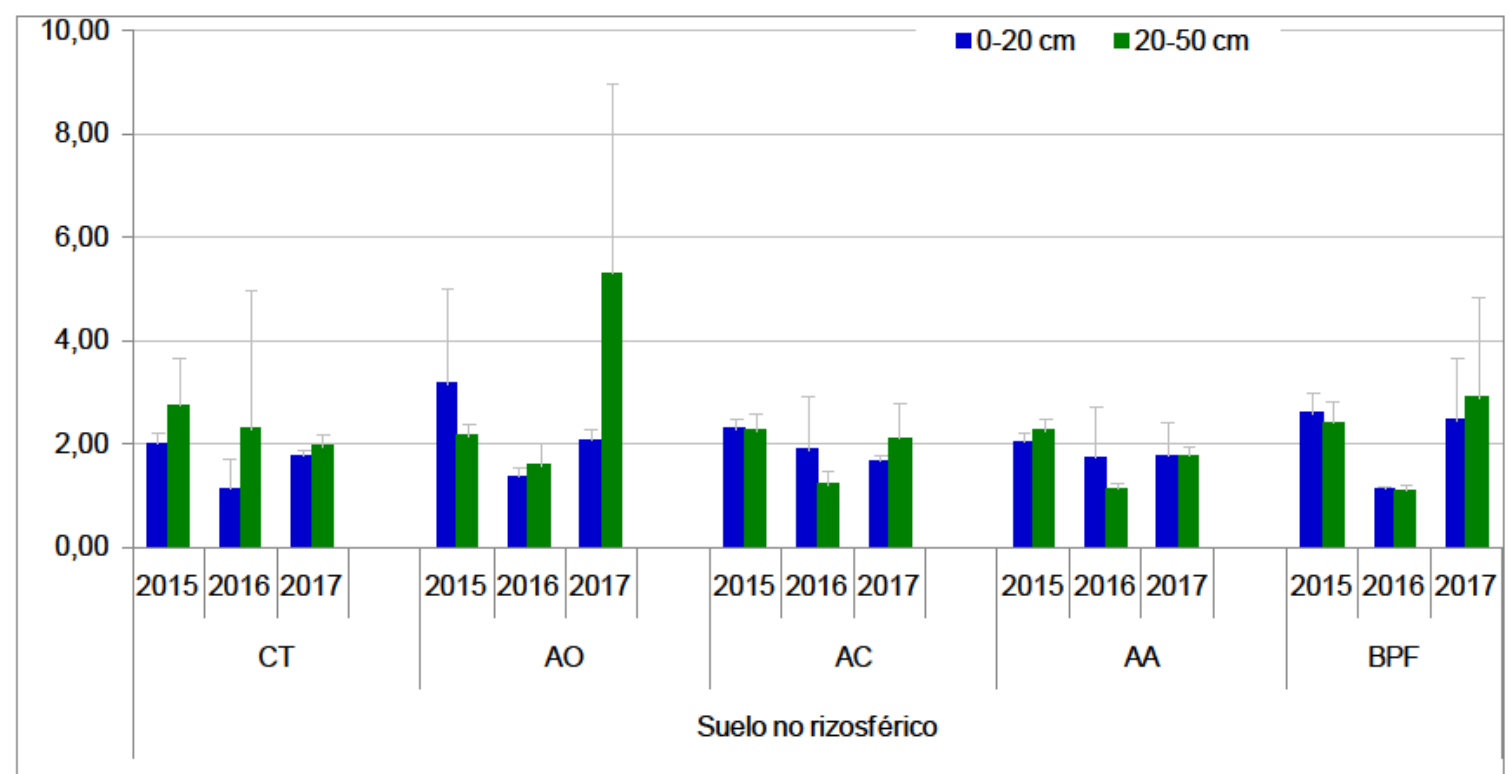

Figura 6.4.26. Evolución temporal de Cu ligado a carbonatos $(\mathrm{mg} / \mathrm{kg})$ en suelo no rizosférico entre 3 muestreos anuales $(2015,2016$ y 2017) en parcelas control (CT) y parcelas tratadas con dosis de $5 \mathrm{mmol} / \mathrm{kg}$ de ácido oxálico (AO), ácido cítrico (AC), aminoácidos (AA) y bacterias Pseudomonas fluorescens (BPF) y 5 aplicaciones (junio 2016, septiembre 2016, enero 2017, abril 2017 y junio 2017), $n=3$. 


\section{Evolución 2015-2016-2017 de Cu ligado a carbonatos:}

En las figuras anteriores se puede observar la variación entre los años 2015, 2016 y 2017 de las concentraciones de $\mathrm{Cu}$ ligado a carbonatos en los sedimentos del suelo rizosférico y del suelo no rizosférico en las diferentes profundidades muestreadas $(0-20 \mathrm{~cm}, 20-50 \mathrm{~cm}$ y $50-$ $100 \mathrm{~cm}$ ). En el suelo rizosférico las concentraciones medias de $\mathrm{Cu}$ ligado a carbonatos fueron $2,24 \mathrm{mg} / \mathrm{kg}(0-20 \mathrm{~cm}), 2,23 \mathrm{mg} / \mathrm{kg}(20-50 \mathrm{~cm})$ y $1,94 \mathrm{mg} / \mathrm{kg}(50-100 \mathrm{~cm})$ y oscilaron entre $1,21 \mathrm{mg} / \mathrm{kg}$ (AA, $0-20 \mathrm{~cm}, 2016)$ y $6,29 \mathrm{mg} / \mathrm{kg}(\mathrm{CT}, 0-20 \mathrm{~cm}, 2017)$. Para cada uno de los tratamientos no se detectaron diferencias significativas entre las diferentes profundidades muestreadas $(0-20 \mathrm{~cm}, 20-50 \mathrm{~cm}$ y $50-100 \mathrm{~cm})$. Y para cada tratamiento $\mathrm{y}$ profundidad no se registraron diferencias significativas entre años, tampoco en las parcelas CT, este hecho resalta la gran variabilidad encontrada entre todos los resultados registrados.

En el suelo no rizosférico las concentraciones medias de Cu ligado a carbonatos fueron 1,95 $\mathrm{mg} / \mathrm{kg}(0-20 \mathrm{~cm})$ y $2,22 \mathrm{mg} / \mathrm{kg}(20-50 \mathrm{~cm})$ y oscilaron entre $1,10 \mathrm{mg} / \mathrm{kg}$ (BPF, 20-50 cm, 2016) y $5,32 \mathrm{mg} / \mathrm{kg}(\mathrm{AO}, 20-50 \mathrm{~cm}, 2017)$. Entre el suelo rizosférico y el suelo no rizosférico (años 2016 y 2017, profundidades de $0-20 \mathrm{~cm}$ y $20-50 \mathrm{~cm}$ )) solamente se registraron diferencias estadísticamente significativas en las parcelas $A O$ (20-50 cm en 2017), en las parcelas AC (0-20 cm en 2016), en las parcelas AA (0-20 cm y 20-50 cm en 2016) y en las parcelas BPF (0-20 cm en 2016 y $20-50 \mathrm{~cm}$ en 2017). 


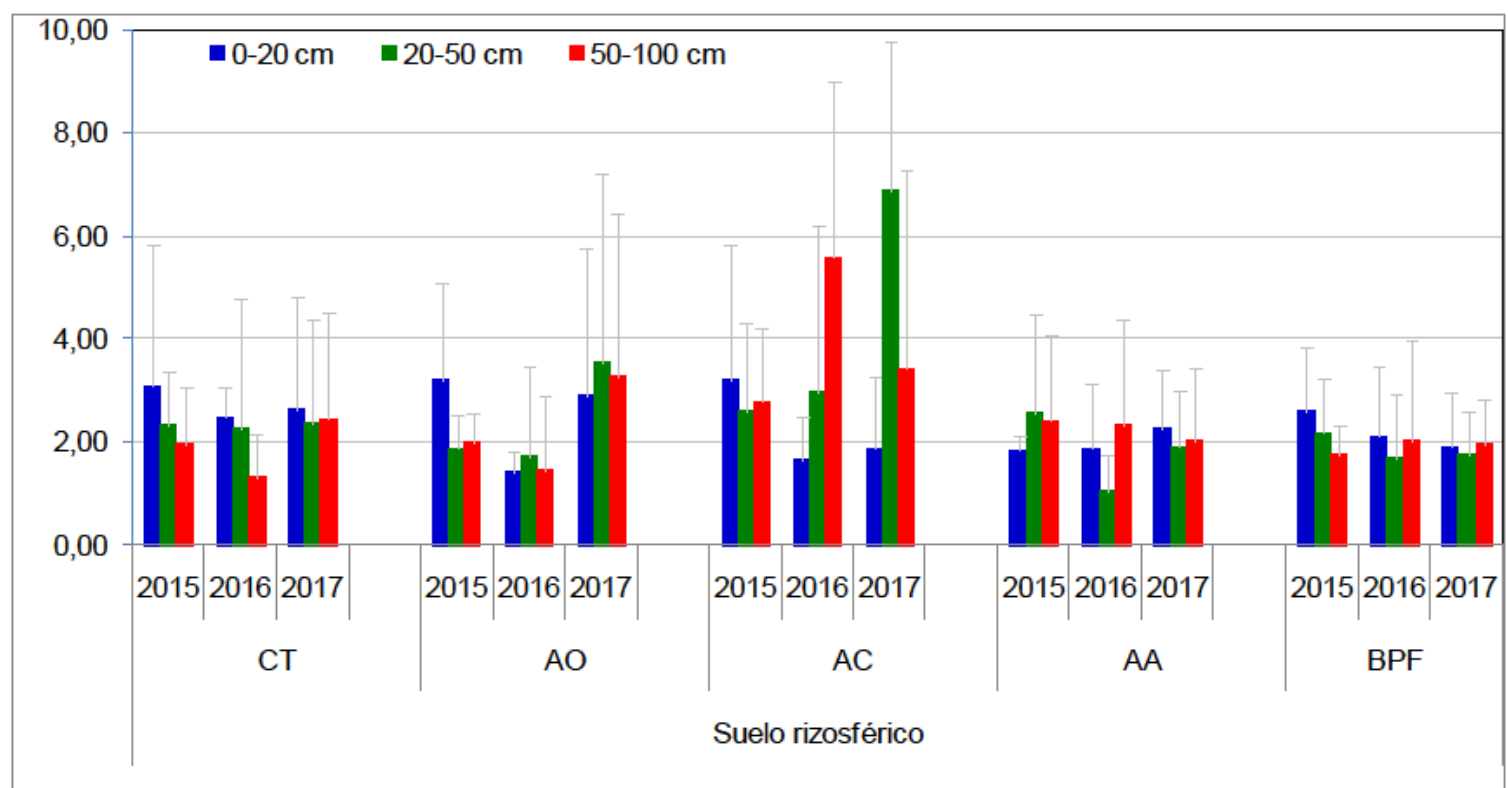

Figura 6.4.27. Evolución temporal de $\mathrm{Zn}$ ligado a carbonatos $(\mathrm{mg} / \mathrm{kg})$ en suelo rizosférico entre 3 muestreos anuales $(2015,2016$ y 2017) en parcelas control (CT) y parcelas tratadas con dosis de $5 \mathrm{mmol} / \mathrm{kg}$ de ácido oxálico (AO), ácido cítrico (AC), aminoácidos (AA) y bacterias Pseudomonas fluorescens (BPF) y 5 aplicaciones (junio 2016, septiembre 2016, enero 2017, abril 2017 y junio 2017), $n=3$.

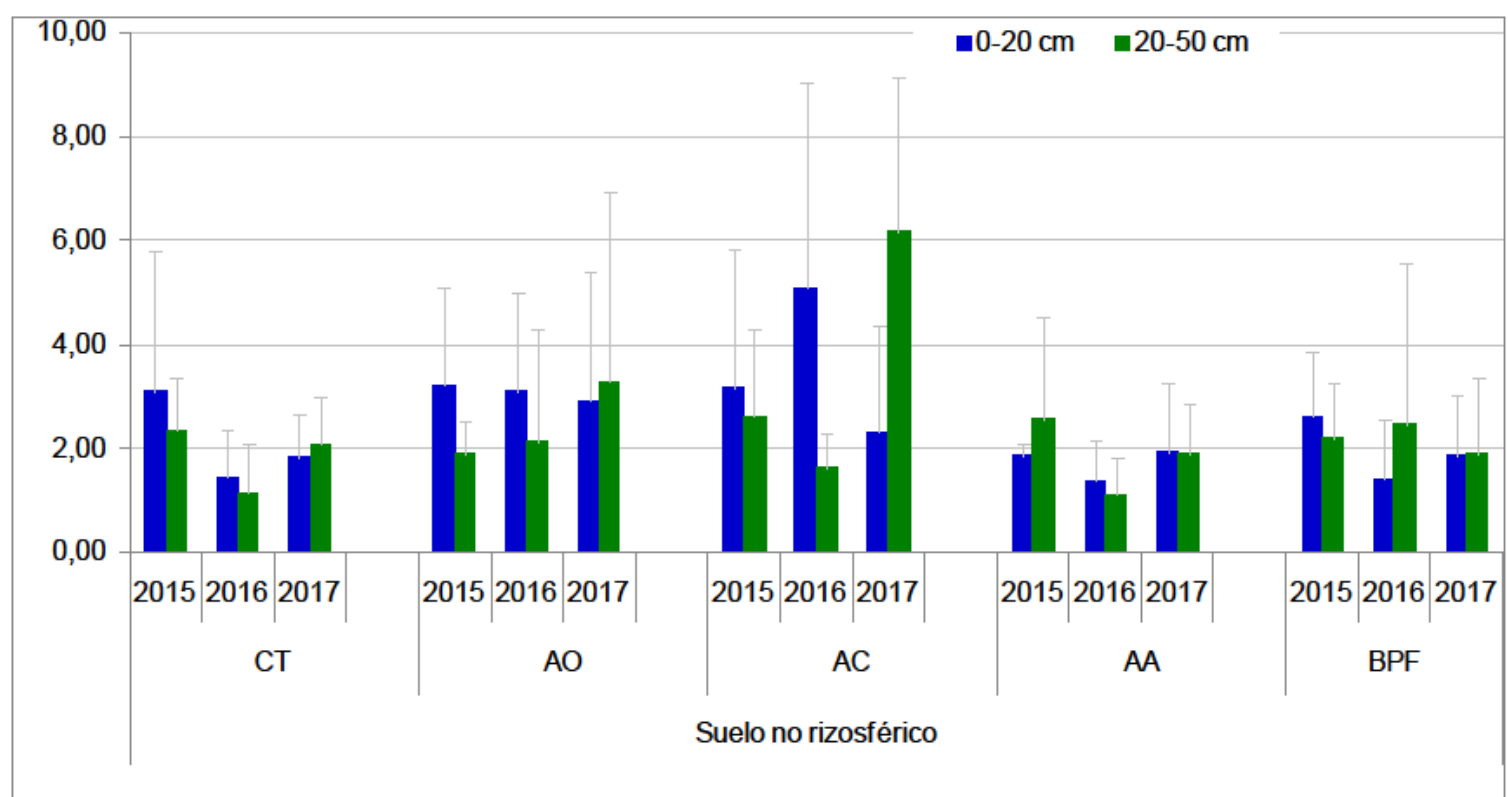

Figura 6.4.28. Evolución temporal de $\mathrm{Zn}$ ligado a carbonatos $(\mathrm{mg} / \mathrm{kg})$ en suelo no rizosférico entre 3 muestreos anuales $(2015,2016$ y 2017) en parcelas control (CT) y parcelas tratadas con dosis de $5 \mathrm{mmol} / \mathrm{kg}$ de ácido oxálico (AO), ácido cítrico (AC), aminoácidos (AA) y bacterias Pseudomonas fluorescens (BPF) y 5 aplicaciones (junio 2016, septiembre 2016, enero 2017, abril 2017 y junio 2017), $n=3$. 


\section{Evolución 2015-2016-2017 de Zn ligado a carbonatos:}

En las figuras anteriores se puede observar la variación entre los años 2015, 2016 y 2017 de las concentraciones de $\mathrm{Zn}$ ligado a carbonatos en los sedimentos del suelo rizosférico y del suelo no rizosférico en las diferentes profundidades muestreadas $(0-20 \mathrm{~cm}, 20-50 \mathrm{~cm}$ y $50-$ $100 \mathrm{~cm}$ ). En el suelo rizosférico las concentraciones medias de $\mathrm{Zn}$ ligado a carbonatos fueron $2,34 \mathrm{mg} / \mathrm{kg}(0-20 \mathrm{~cm}), 2,52 \mathrm{mg} / \mathrm{kg}(20-50 \mathrm{~cm})$ y $2,46 \mathrm{mg} / \mathrm{kg}(50-100 \mathrm{~cm})$ y oscilaron entre $1,04 \mathrm{mg} / \mathrm{kg}$ (AA, 20-50 cm, 2016) y $6,87 \mathrm{mg} / \mathrm{kg}$ (AC, 20-50 cm, 2017). Para cada uno de los tratamientos no se detectaron diferencias significativas entre las diferentes profundidades muestreadas $(0-20 \mathrm{~cm}, 20-50 \mathrm{~cm}$ y $50-100 \mathrm{~cm})$. Y para cada tratamiento $\mathrm{y}$ profundidad tampoco se registraron diferencias significativas entre años, destaca nuevamente la gran variabilidad encontrada entre los resultados registrados.

En el suelo no rizosférico las concentraciones medias de $\mathrm{Zn}$ ligado a carbonatos fueron 2,47 $\mathrm{mg} / \mathrm{kg}(0-20 \mathrm{~cm})$ y $2,36 \mathrm{mg} / \mathrm{kg}(20-50 \mathrm{~cm})$ y oscilaron entre $1,11 \mathrm{mg} / \mathrm{kg}$ (AA, $20-50 \mathrm{~cm}, 2016)$ y $6,19 \mathrm{mg} / \mathrm{kg}(\mathrm{AC}, 20-50 \mathrm{~cm}, 2017)$. Entre el suelo rizosférico y el suelo no rizosférico (años 2016 y 2017 , profundidades de $0-20 \mathrm{~cm}$ y $20-50 \mathrm{~cm}$ )) solamente se registraron diferencias estadísticamente significativas en las parcelas CT (0-20 cm en 2017), en las parcelas AO (0$20 \mathrm{~cm}$ en 2016 y en 2017) y en las parcelas AC (20-50 cm en 2016 y 0-20 cm en 2017). 


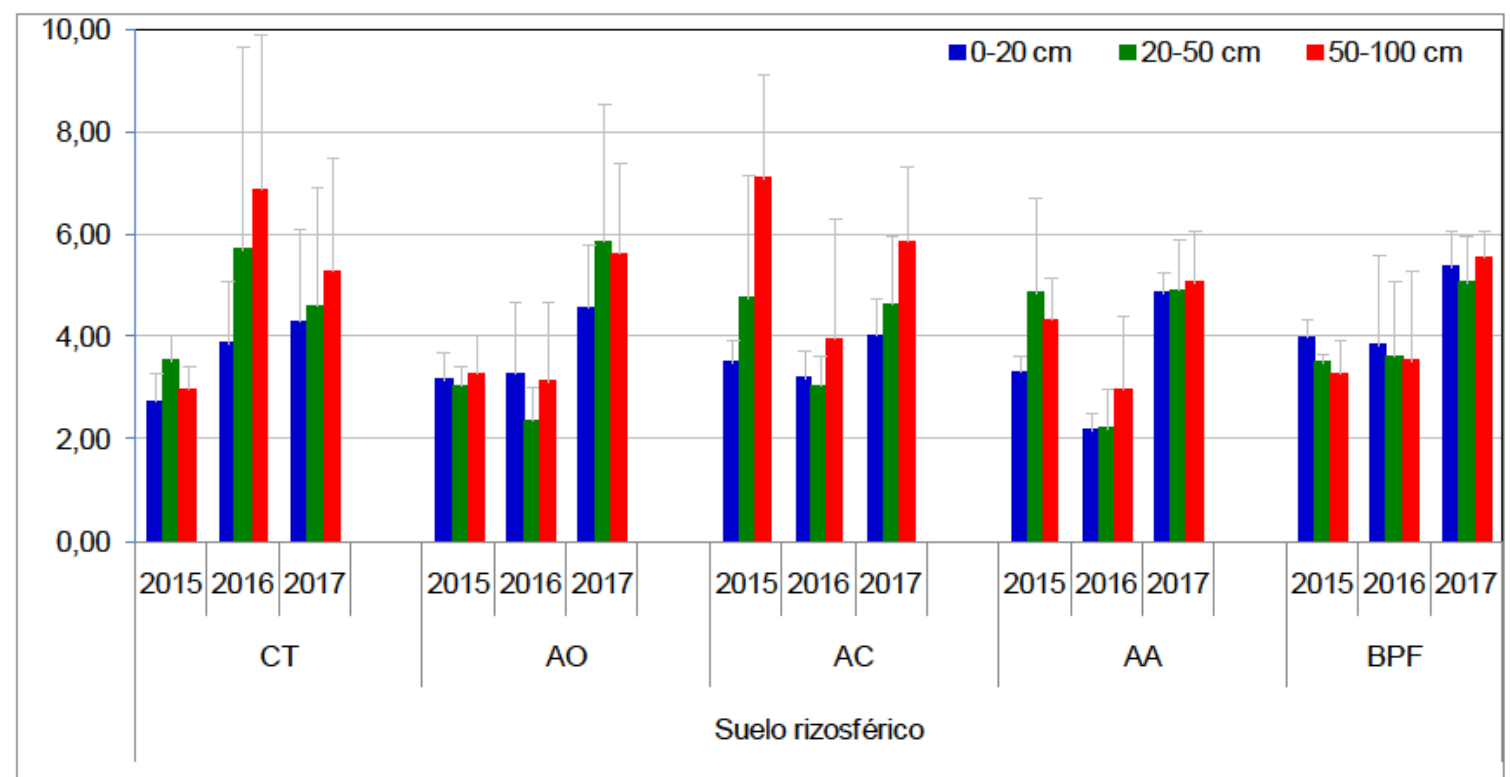

Figura 6.4.29. Evolución temporal de $\mathrm{Cr}$ ligado a carbonatos $(\mathrm{mg} / \mathrm{kg})$ en suelo rizosférico entre 3 muestreos anuales $(2015,2016$ y 2017) en parcelas control (CT) y parcelas tratadas con dosis de $5 \mathrm{mmol} / \mathrm{kg}$ de ácido oxálico $(\mathrm{AO})$, ácido cítrico $(\mathrm{AC})$, aminoácidos $(\mathrm{AA})$ y bacterias Pseudomonas fluorescens (BPF) y 5 aplicaciones (junio 2016, septiembre 2016, enero 2017, abril 2017 y junio 2017), $n=3$.

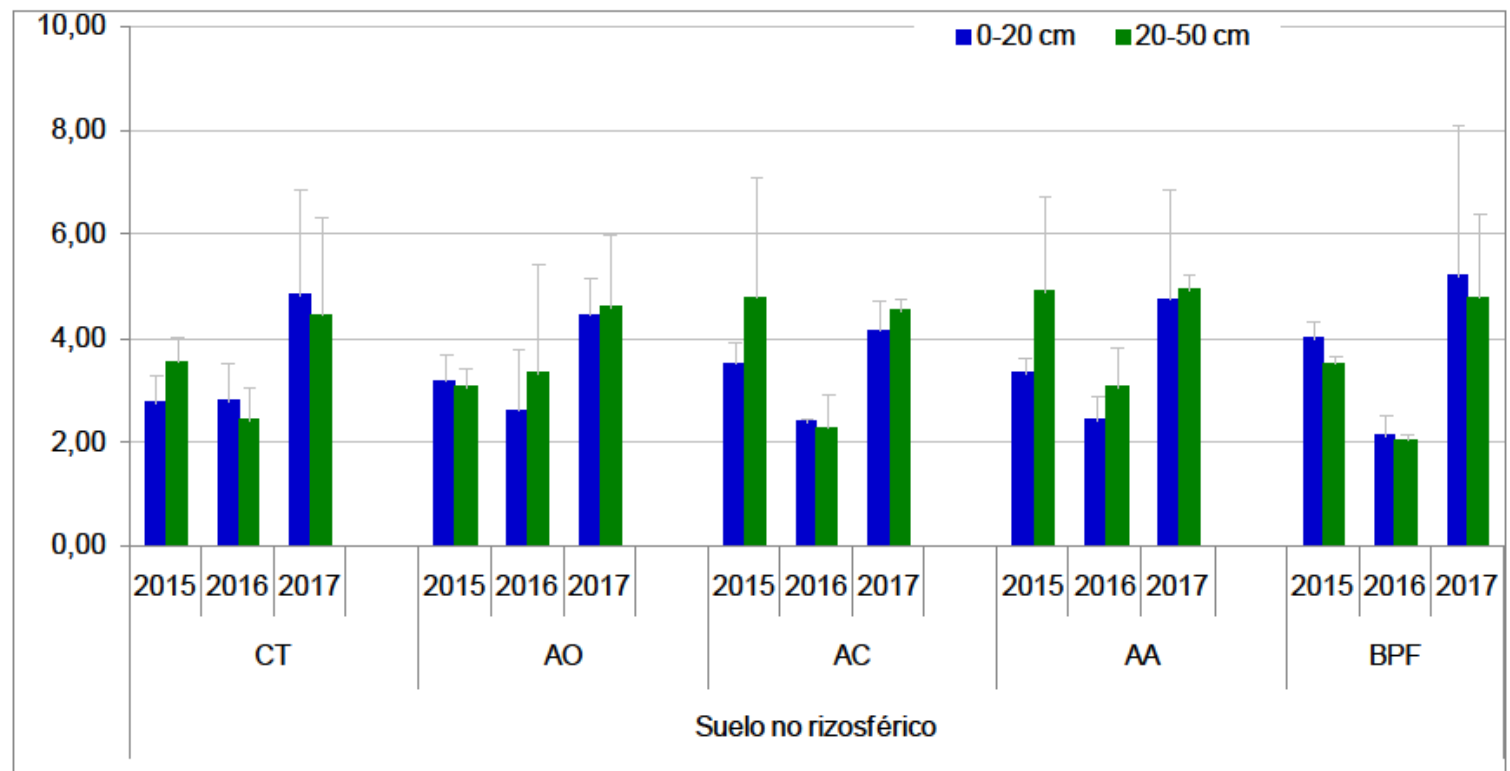

Figura 6.4.30. Evolución temporal de $\mathrm{Cr}$ ligado a carbonatos $(\mathrm{mg} / \mathrm{kg})$ en suelo no rizosférico entre 3 muestreos anuales $(2015,2016$ y 2017) en parcelas control (CT) y parcelas tratadas con dosis de $5 \mathrm{mmol} / \mathrm{kg}$ de ácido oxálico (AO), ácido cítrico (AC), aminoácidos (AA) y bacterias Pseudomonas fluorescens (BPF) y 5 aplicaciones (junio 2016, septiembre 2016, enero 2017, abril 2017 y junio 2017), $n=3$. 


\section{Evolución 2015-2016-2017 de Cr ligado a carbonatos:}

En las figuras anteriores se puede observar la variación entre los años 2015, 2016 y 2017 de las concentraciones de $\mathrm{Cr}$ ligado a carbonatos en los sedimentos del suelo rizosférico y del suelo no rizosférico en las diferentes profundidades muestreadas $(0-20 \mathrm{~cm}, 20-50 \mathrm{~cm}$ y $50-$ $100 \mathrm{~cm}$ ). En el suelo rizosférico las concentraciones medias de $\mathrm{Cr}$ ligado a carbonatos fueron $3,75 \mathrm{mg} / \mathrm{kg}(0-20 \mathrm{~cm}), 4,11 \mathrm{mg} / \mathrm{kg}(20-50 \mathrm{~cm})$ y $4,60 \mathrm{mg} / \mathrm{kg}(50-100 \mathrm{~cm})$ y oscilaron entre $2,18 \mathrm{mg} / \mathrm{kg}$ (AA, $0-20 \mathrm{~cm}, 2016)$ y $7,08 \mathrm{mg} / \mathrm{kg}(\mathrm{AC}, 50-100 \mathrm{~cm}, 2015)$. Para cada uno de los tratamientos no se detectaron diferencias significativas entre las diferentes profundidades muestreadas $(0-20 \mathrm{~cm}, 20-50 \mathrm{~cm}$ y $50-100 \mathrm{~cm})$. Para cada tratamiento y profundidad sólo se registraron concentraciones significativamente superiores en las parcelas AO en el año 2017 con respecto a los años 2015 y 2016, posiblemente debido a la aplicación del tratamiento o a los exudados radiculares generados en estas parcelas.

En el suelo no rizosférico las concentraciones medias de $\mathrm{Cr}$ ligado a carbonatos fueron 3,50 $\mathrm{mg} / \mathrm{kg}(0-20 \mathrm{~cm})$ y $3,74 \mathrm{mg} / \mathrm{kg}(20-50 \mathrm{~cm})$ y oscilaron entre $2,04 \mathrm{mg} / \mathrm{kg}$ (BPF, 20-50 cm, 2016) y $5,20 \mathrm{mg} / \mathrm{kg}$ (BPF, 0-20 cm, 2017). Entre el suelo rizosférico y el suelo no rizosférico (años 2016 y 2017, profundidades de $0-20 \mathrm{~cm}$ y $20-50 \mathrm{~cm}$ )) solamente se registraron diferencias estadísticamente significativas en las parcelas CT (20-50 cm en 2016), en las parcelas AA (20-50 cm en 2017) y en las parcelas BPF $(20-50 \mathrm{~cm}$ en 2016 y 0-20 cm en 2017). 


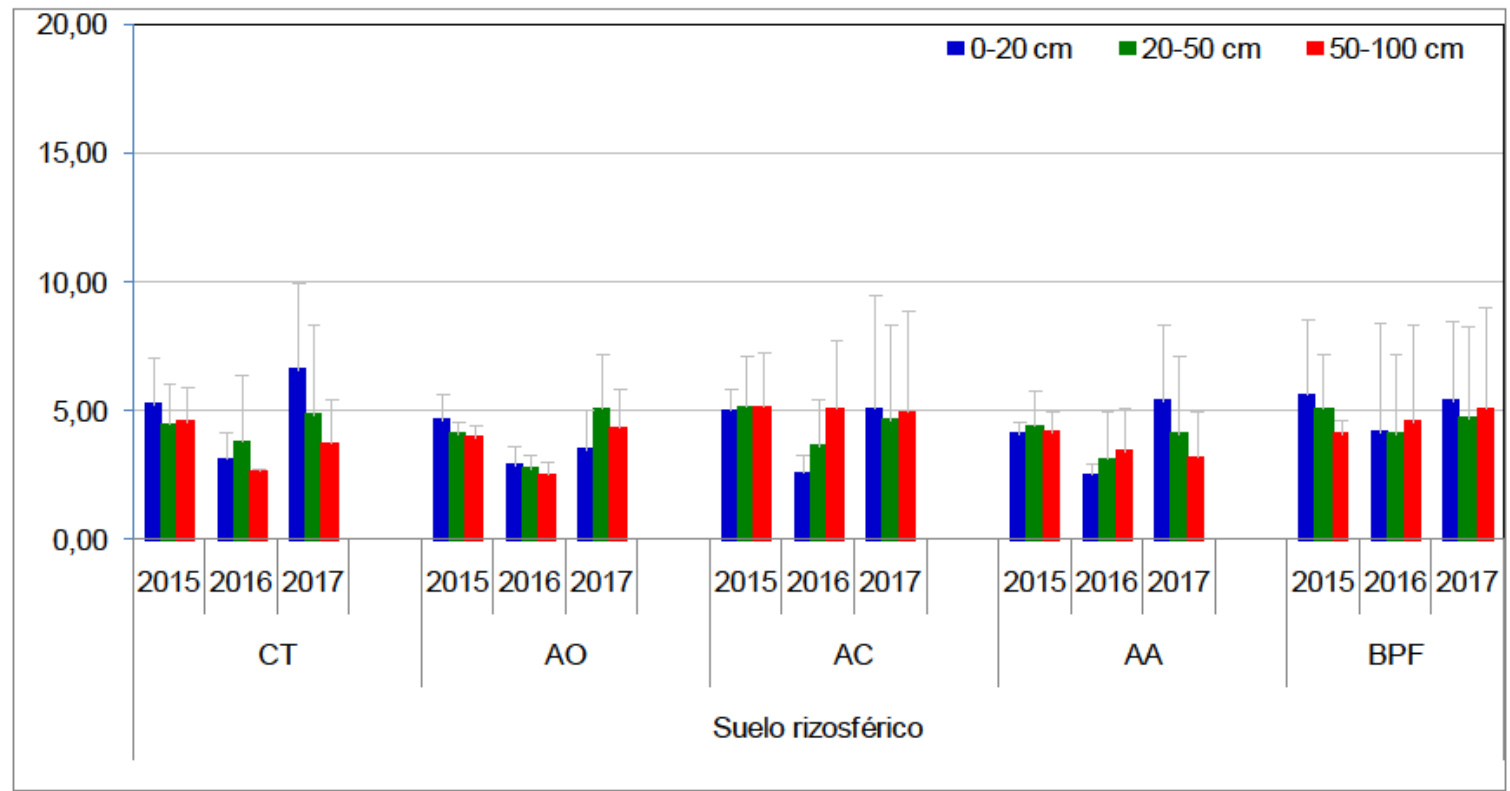

Figura 6.4.31. Evolución temporal de Cu ligado a óxidos de $\mathrm{Fe}$ y $\mathrm{Mn}(\mathrm{mg} / \mathrm{kg})$ suelo rizosférico entre 3 muestreos anuales $(2015,2016$ y 2017) en parcelas control (CT) y parcelas tratadas con dosis de $5 \mathrm{mmol} / \mathrm{kg}$ de ácido oxálico (AO), ácido cítrico (AC), aminoácidos (AA) y bacterias Pseudomonas fluorescens (BPF) y 5 aplicaciones (junio 2016, septiembre 2016, enero 2017, abril 2017 y junio 2017), $n=3$.

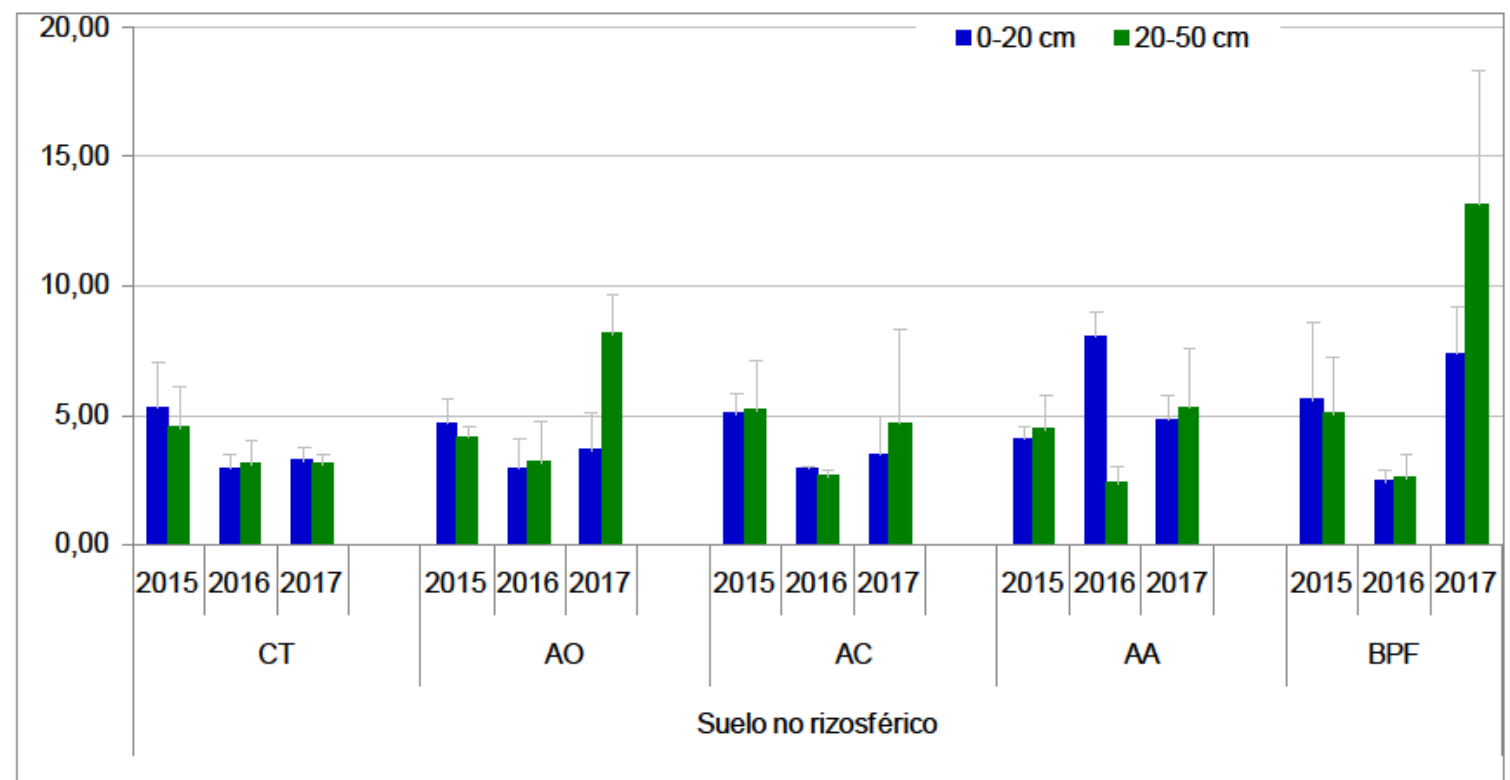

Figura 6.4.32. Evolución temporal de Cu ligado óxidos de $\mathrm{Fe}$ y $\mathrm{Mn}(\mathrm{mg} / \mathrm{kg})$ en suelo no rizosférico entre 3 muestreos anuales $(2015,2016$ y 2017) en parcelas control (CT) y parcelas tratadas con dosis de $5 \mathrm{mmol} / \mathrm{kg}$ de ácido oxálico (AO), ácido cítrico (AC), aminoácidos (AA) y bacterias Pseudomonas fluorescens (BPF) y 5 aplicaciones (junio 2016, septiembre 2016, enero 2017, abril 2017 y junio 2017), n=3. 


\section{Evolución 2015-2016-2017 de Cu ligado a óxidos de Fe y Mn:}

En las figuras anteriores se puede observar la variación entre los años 2015, 2016 y 2017 de las concentraciones de $\mathrm{Cu}$ ligado a óxidos de $\mathrm{Fe}$ y $\mathrm{Mn}$ en los sedimentos del suelo rizosférico y del suelo no rizosférico en las diferentes profundidades muestreadas $(0-20 \mathrm{~cm}$, 20-50 cm y 50-100 cm). En el suelo rizosférico las concentraciones medias de Cu ligado a óxidos de Fe y Mn fueron 4,43 mg/kg $(0-20 \mathrm{~cm}), 4,31 \mathrm{mg} / \mathrm{kg}(20-50 \mathrm{~cm})$ y 4,13 mg/kg (50$100 \mathrm{~cm}$ ) y oscilaron entre $2,56 \mathrm{mg} / \mathrm{kg}(\mathrm{AA}, 0-20 \mathrm{~cm}, 2016)$ y $6,67 \mathrm{mg} / \mathrm{kg}(\mathrm{CT}, 0-20 \mathrm{~cm}, 2017)$. Para cada uno de los tratamientos no se detectaron diferencias significativas entre las diferentes profundidades muestreadas $(0-20 \mathrm{~cm}, 20-50 \mathrm{~cm}$ y $50-100 \mathrm{~cm})$. Y para cada tratamiento y profundidad tampoco se registraron diferencias significativas entre años, este hecho resalta la gran variabilidad encontrada entre los resultados registrados.

En el suelo no rizosférico las concentraciones medias de $\mathrm{Cu}$ ligado a óxidos de $\mathrm{Fe}$ y $\mathrm{Mn}$ fueron $4,46 \mathrm{mg} / \mathrm{kg}(0-20 \mathrm{~cm})$ y $4,79 \mathrm{mg} / \mathrm{kg}(20-50 \mathrm{~cm})$ y oscilaron entre $2,39 \mathrm{mg} / \mathrm{kg}$ (AA, 20$50 \mathrm{~cm}, 2016)$ y $13,17 \mathrm{mg} / \mathrm{kg}$ (BPF, 20-50 cm, 2017). Entre el suelo rizosférico y el suelo no rizosférico (años 2016 y 2017, profundidades de $0-20 \mathrm{~cm}$ y $20-50 \mathrm{~cm}$ )) solamente se registraron diferencias estadísticamente significativas en las parcelas CT $(20-50 \mathrm{~cm}$ en 2017), en las parcelas AO (20-50 cm en 2017), en las parcelas AC (20-50 cm en 2016), en las parcelas AA (0-20 cm en 2016 y en 2017) y en las parcelas BPF (0-20 cm en 2016 y 20$50 \mathrm{~cm}$ en 2017). 


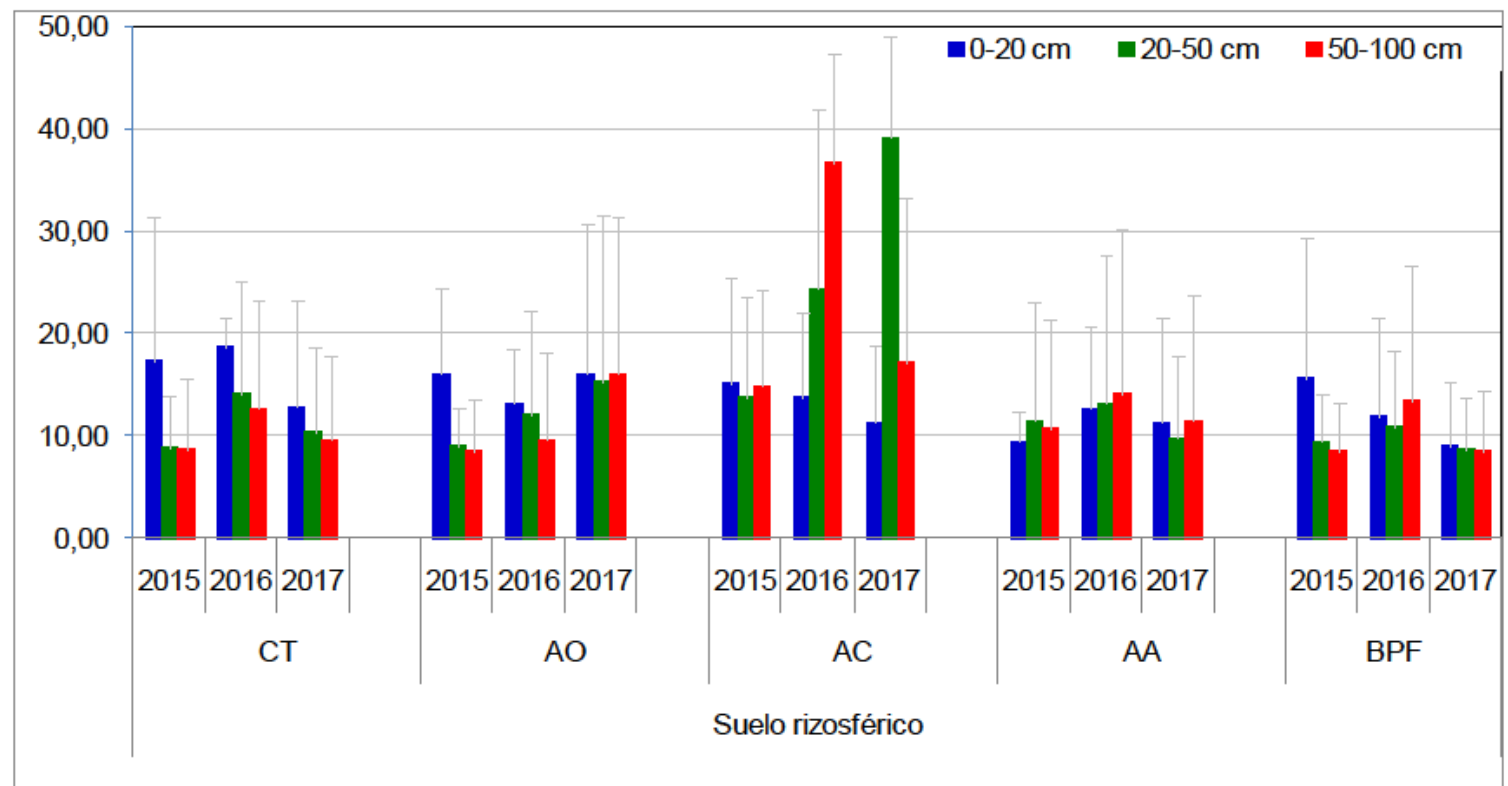

Figura 6.4.33. Evolución temporal de Zn ligado a óxidos de Fe y $\mathrm{Mn}(\mathrm{mg} / \mathrm{kg})$ en suelo rizosférico entre 3 muestreos anuales $(2015,2016$ y 2017) en parcelas control (CT) y parcelas tratadas con dosis de $5 \mathrm{mmol} / \mathrm{kg}$ de ácido oxálico $(A O)$, ácido cítrico $(A C)$, aminoácidos (AA) y bacterias Pseudomonas fluorescens (BPF) y 5 aplicaciones (junio 2016, septiembre 2016, enero 2017, abril 2017 y junio 2017), $\mathrm{n}=3$.

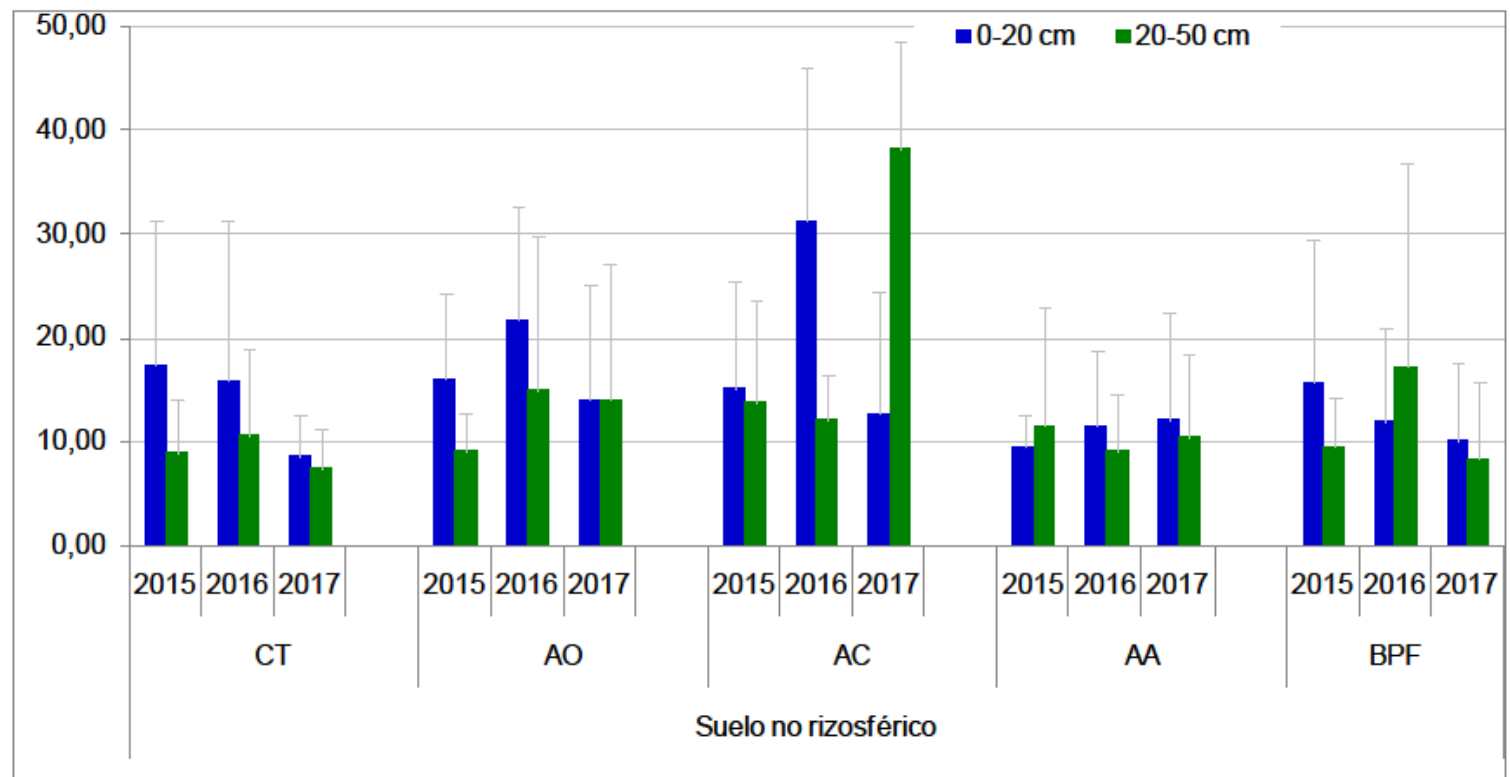

Figura 6.4.34. Evolución temporal de Zn ligado a óxidos de Fe y $\mathrm{Mn}(\mathrm{mg} / \mathrm{kg})$ en suelo no rizosférico entre 3 muestreos anuales $(2015,2016$ y 2017) en parcelas control (CT) y parcelas tratadas con dosis de $5 \mathrm{mmol} / \mathrm{kg}$ de ácido oxálico $(A O)$, ácido cítrico (AC), aminoácidos (AA) y bacterias Pseudomonas fluorescens (BPF) y 5 aplicaciones (junio 2016, septiembre 2016, enero 2017, abril 2017 y junio 2017), n=3. 


\section{Evolución 2015-2016-2017 de Zn ligado a óxidos de Fe y Mn:}

En las figuras anteriores se puede observar la variación entre los años 2015, 2016 y 2017 de las concentraciones de $\mathrm{Zn}$ ligado a óxidos de $\mathrm{Fe}$ y $\mathrm{Mn}$ en los sedimentos del suelo rizosférico y del suelo no rizosférico en las diferentes profundidades muestreadas $(0-20 \mathrm{~cm}$, 20-50 cm y 50-100 cm). En el suelo rizosférico las concentraciones medias de $\mathrm{Zn}$ ligado a óxidos de Fe y Mn fueron 13,61 mg/kg (0-20 cm), 14,03 mg/kg $(20-50 \mathrm{~cm})$ y $13,37 \mathrm{mg} / \mathrm{kg}$ $(50-100 \mathrm{~cm})$ y oscilaron entre $8,38 \mathrm{mg} / \mathrm{kg}$ (BPF, 50-100 cm, 2017) y $39,10 \mathrm{mg} / \mathrm{kg}$ (AC, 20-50 $\mathrm{cm}, 2017$ ). Para cada uno de los tratamientos no se detectaron diferencias significativas entre las diferentes profundidades muestreadas $(0-20 \mathrm{~cm}, 20-50 \mathrm{~cm}$ y $50-100 \mathrm{~cm})$. Y para cada tratamiento y profundidad tampoco se registraron diferencias significativas entre años, este hecho resalta la gran variabilidad encontrada entre los resultados registrados.

En el suelo no rizosférico las concentraciones medias de $\mathrm{Zn}$ ligado a óxidos de $\mathrm{Fe}$ y $\mathrm{Mn}$ fueron $14,88 \mathrm{mg} / \mathrm{kg}(0-20 \mathrm{~cm})$ y $12,96 \mathrm{mg} / \mathrm{kg}(20-50 \mathrm{~cm})$ y oscilaron entre $7,32 \mathrm{mg} / \mathrm{kg}$ (CT, $20-50 \mathrm{~cm}, 2017)$ y $38,13 \mathrm{mg} / \mathrm{kg}$ (AC, $20-50 \mathrm{~cm}, 2017)$. Entre el suelo rizosférico y el suelo no rizosférico (años 2016 y 2017, profundidades de $0-20 \mathrm{~cm}$ y $20-50 \mathrm{~cm}$ )) solamente se registraron diferencias estadísticamente significativas en las parcelas CT (0-20 cm en 2016 y en 2017), en las parcelas AC (20-50 cm en 2016) y en las parcelas AC (20-50 cm en 2016). 


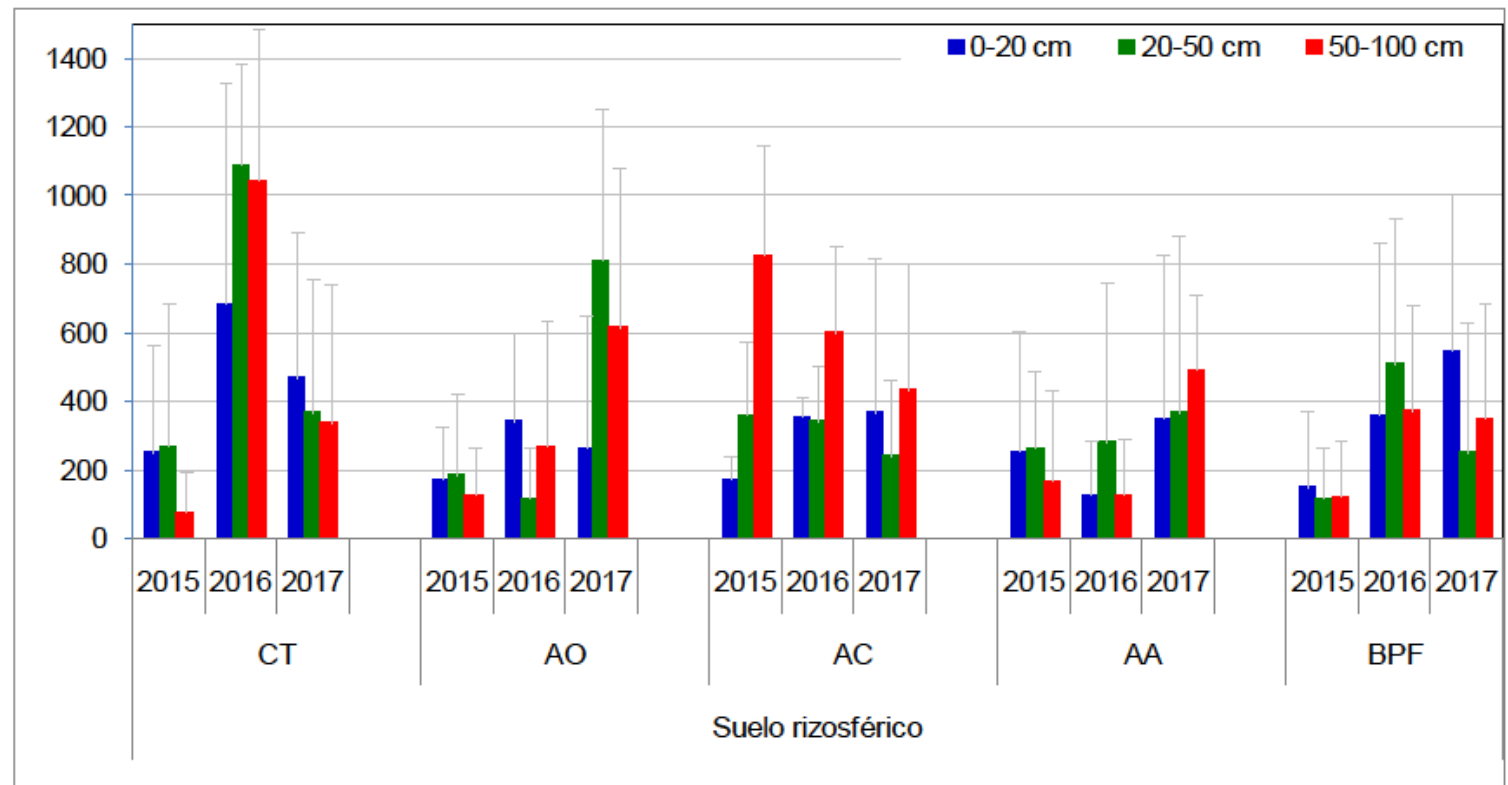

Figura 6.4.35. Evolución temporal de Cr ligado a óxidos de Fe y $\mathrm{Mn}(\mathrm{mg} / \mathrm{kg})$ en suelo rizosférico entre 3 muestreos anuales $(2015,2016$ y 2017) en parcelas control (CT) y parcelas tratadas con dosis de $5 \mathrm{mmol} / \mathrm{kg}$ de ácido oxálico (AO), ácido cítrico (AC), aminoácidos (AA) y bacterias Pseudomonas fluorescens (BPF) y 5 aplicaciones (junio 2016, septiembre 2016, enero 2017, abril 2017 y junio 2017), $\mathrm{n}=3$.

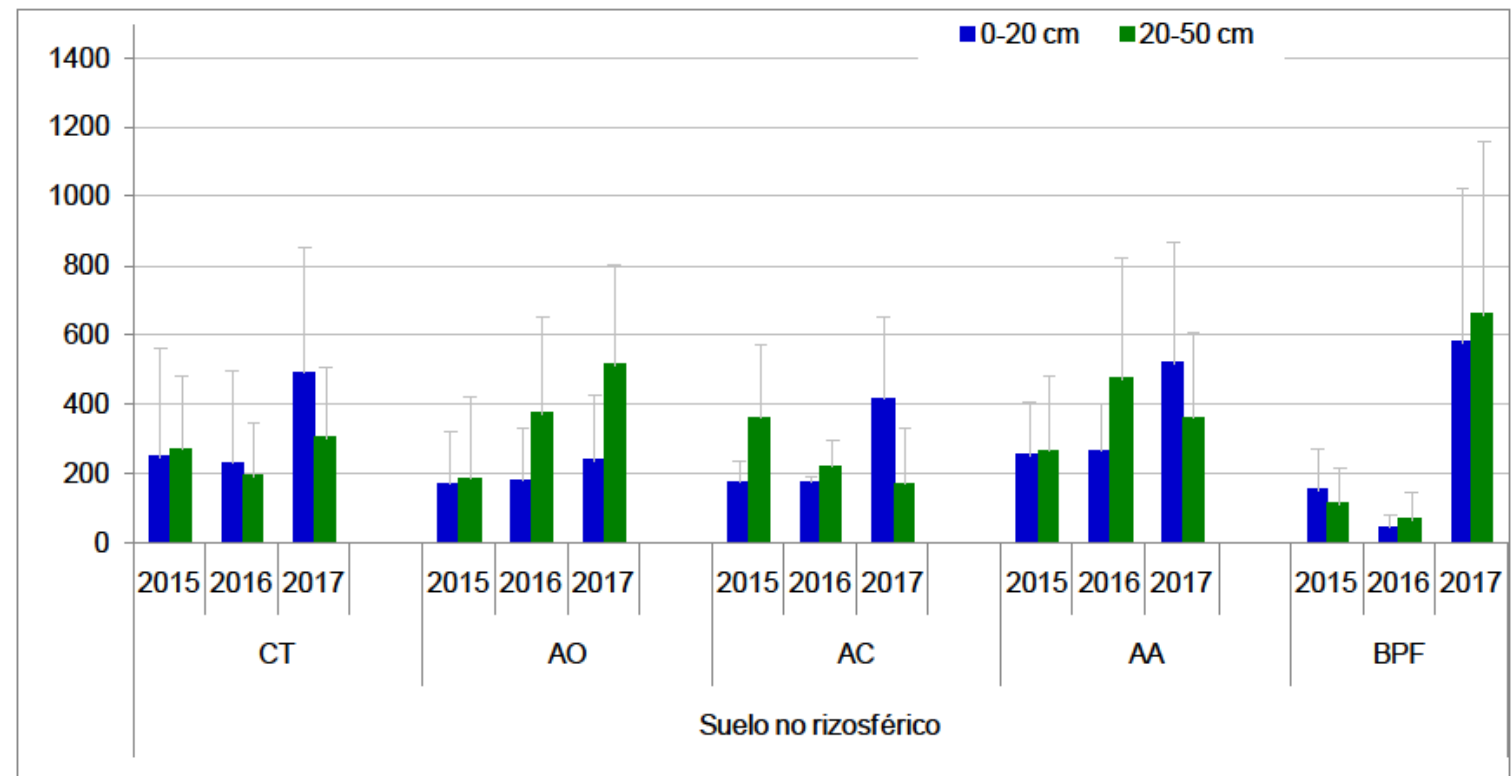

Figura 6.4.36. Evolución temporal de $\mathrm{Cr}$ ligado a óxidos de $\mathrm{Fe}$ y $\mathrm{Mn}(\mathrm{mg} / \mathrm{kg})$ en suelo no rizosférico entre 3 muestreos anuales $(2015,2016$ y 2017) en parcelas control (CT) y parcelas tratadas con dosis de $5 \mathrm{mmol} / \mathrm{kg}$ de ácido oxálico (AO), ácido cítrico (AC), aminoácidos (AA) y bacterias Pseudomonas fluorescens (BPF) y 5 aplicaciones (junio 2016, septiembre 2016, enero 2017, abril 2017 y junio 2017), n=3. 


\section{Evolución 2015-2016-2017 de Cr ligado a óxidos de Fe y Mn:}

En las figuras anteriores se puede observar la variación entre los años 2015, 2016 y 2017 de las concentraciones de $\mathrm{Cr}$ ligado a óxidos de $\mathrm{Fe}$ y $\mathrm{Mn}$ en los sedimentos del suelo rizosférico y del suelo no rizosférico en las diferentes profundidades muestreadas $(0-20 \mathrm{~cm}$, 20-50 cm y 50-100 cm). En el suelo rizosférico las concentraciones medias de $\mathrm{Cr}$ ligado a óxidos de Fe y Mn fueron 326,13 mg/kg (0-20 cm), 372,27 mg/kg (20-50 cm) y 398,32 mg/kg $(50-100 \mathrm{~cm})$ y oscilaron entre $79,17 \mathrm{mg} / \mathrm{kg}(\mathrm{CT}, 50-100 \mathrm{~cm}, 2015)$ y $1087,06 \mathrm{mg} / \mathrm{kg}$ (CT, 20$50 \mathrm{~cm}, 2016)$. Para cada uno de los tratamientos no se detectaron diferencias significativas entre las diferentes profundidades muestreadas $(0-20 \mathrm{~cm}, 20-50 \mathrm{~cm}$ y $50-100 \mathrm{~cm})$. Y para cada tratamiento y profundidad tampoco se registraron diferencias significativas entre años, este hecho resalta la gran variabilidad encontrada entre los resultados registrados.

En el suelo no rizosférico las concentraciones medias de $\mathrm{Cr}$ ligado a óxidos de $\mathrm{Fe}$ y $\mathrm{Mn}$ fueron $277,89 \mathrm{mg} / \mathrm{kg}(0-20 \mathrm{~cm})$ y $303,42 \mathrm{mg} / \mathrm{kg}(20-50 \mathrm{~cm})$ y oscilaron entre $45,45 \mathrm{mg} / \mathrm{kg}$ (BPF, 0-20 cm, 2016) y 662,68 mg/kg (BPF, 20-50 cm, 2017). Entre el suelo rizosférico y el suelo no rizosférico (años 2016 y 2017, profundidades de $0-20 \mathrm{~cm}$ y $20-50 \mathrm{~cm}$ )) solamente se registraron diferencias estadísticamente significativas en las parcelas $A O(20-50 \mathrm{~cm}$ en 2016 y en 2017), en las parcelas AA (20-50 cm en 2017) y en las parcelas BPF (0-20 cm en 2016 y $20-50 \mathrm{~cm}$ en 2016). 


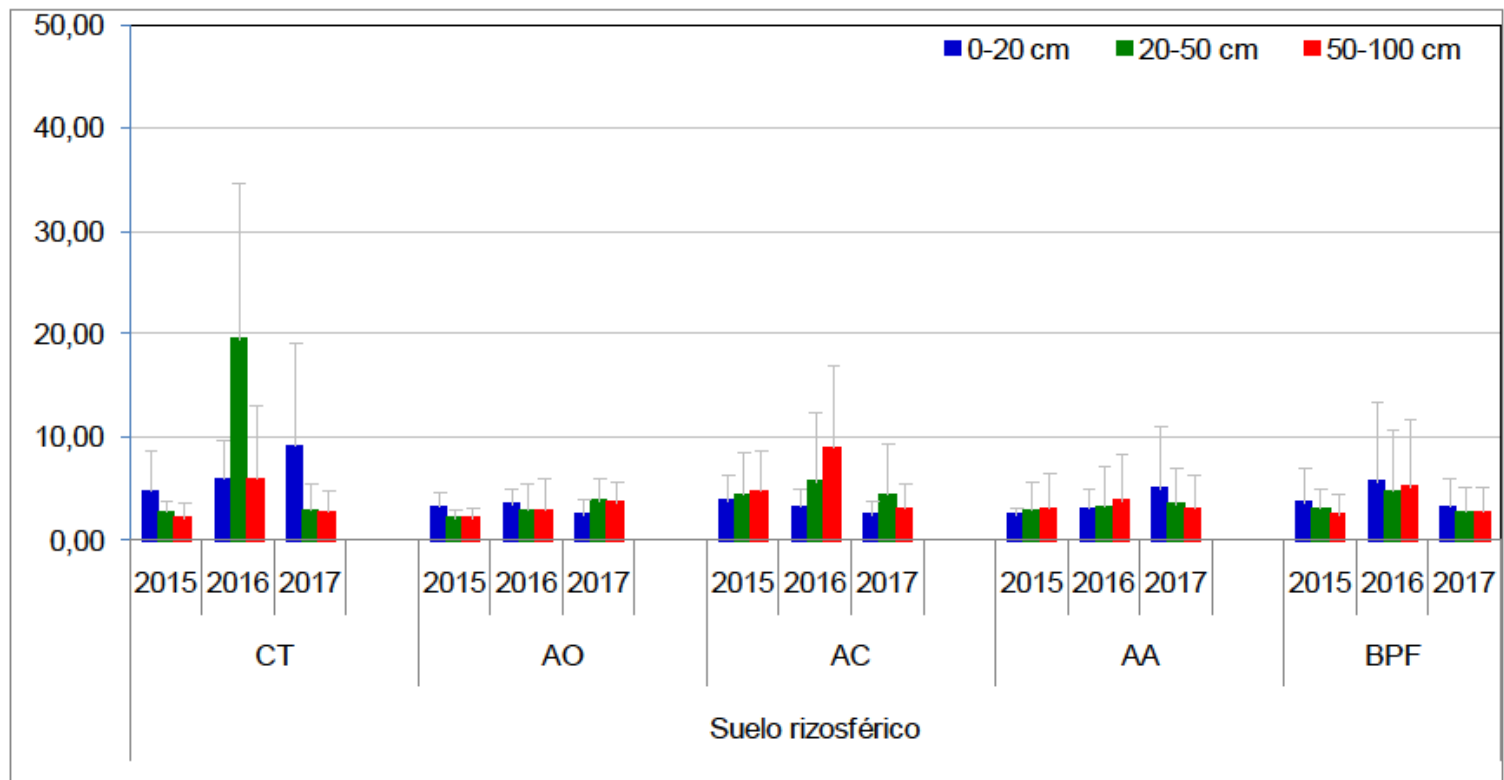

Figura 6.4.37. Evolución temporal de Cu ligado a la materia orgánica $(\mathrm{mg} / \mathrm{kg})$ en suelo rizosférico entre 3 muestreos anuales $(2015,2016$ y 2017) en parcelas control (CT) y parcelas tratadas con dosis de $5 \mathrm{mmol} / \mathrm{kg}$ de ácido oxálico (AO), ácido cítrico (AC), aminoácidos (AA) y bacterias Pseudomonas fluorescens (BPF) y 5 aplicaciones (junio 2016, septiembre 2016, enero 2017, abril 2017 y junio 2017), n=3.

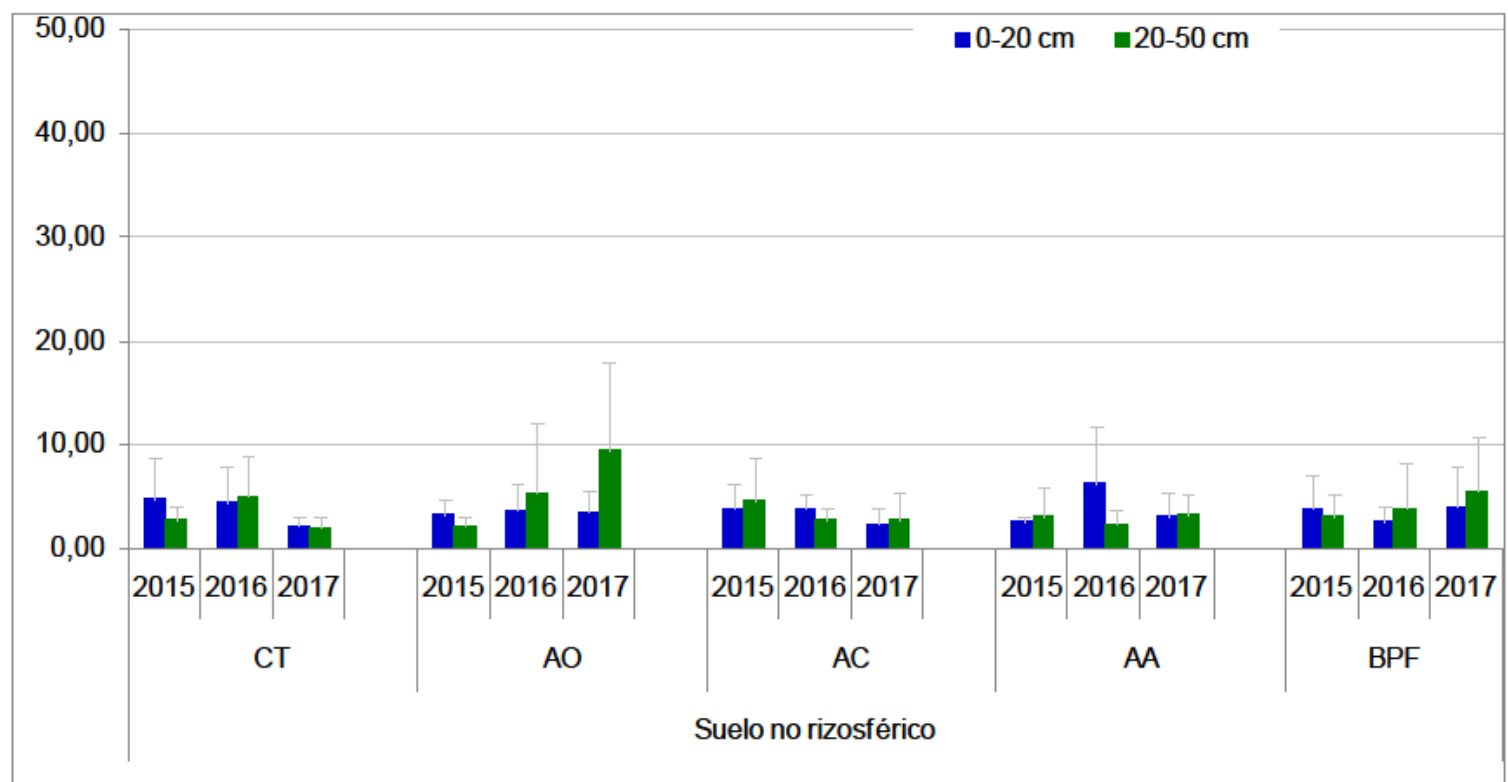

Figura 6.4.38. Evolución temporal de Cu ligado a la materia orgánica $(\mathrm{mg} / \mathrm{kg})$ en suelo no rizosférico entre 3 muestreos anuales $(2015,2016$ y 2017) en parcelas control (CT) y parcelas tratadas con dosis de $5 \mathrm{mmol} / \mathrm{kg}$ de ácido oxálico (AO), ácido cítrico (AC), aminoácidos (AA) y bacterias Pseudomonas fluorescens (BPF) y 5 aplicaciones (junio 2016, septiembre 2016, enero 2017, abril 2017 y junio 2017), n=3. 


\section{Evolución 2015-2016-2017 de Cu ligado a la materia orgánica:}

En las figuras anteriores se puede observar la variación entre los años 2015, 2016 y 2017 de las concentraciones de $\mathrm{Cu}$ ligado a la materia orgánica en los sedimentos del suelo rizosférico y del suelo no rizosférico en las diferentes profundidades muestreadas $(0-20 \mathrm{~cm}$, 20-50 cm y 50-100 cm). En el suelo rizosférico las concentraciones medias de Cu ligado a la materia orgánica fueron 4,20 mg/kg $(0-20 \mathrm{~cm}), 4,66 \mathrm{mg} / \mathrm{kg}(20-50 \mathrm{~cm})$ y 3,86 mg/kg (50-100 $\mathrm{cm}$ ) y oscilaron entre $2,22 \mathrm{mg} / \mathrm{kg}$ (AO, 20-50 cm, 2015) y 19,54 mg/kg (CT, 20-50 cm, 2016). Para cada uno de los tratamientos no se detectaron diferencias significativas entre las diferentes profundidades muestreadas $(0-20 \mathrm{~cm}, 20-50 \mathrm{~cm}$ y $50-100 \mathrm{~cm})$. $Y$ para cada tratamiento y profundidad destaca la concentración registrada en las parcelas CT $(20-50 \mathrm{~cm})$ aunque no es estadísticamente significativa, tampoco se registraron diferencias significativas entre años en el resto de parcelas, destaca nuevamente la gran variabilidad encontrada entre los resultados registrados.

En el suelo no rizosférico las concentraciones medias de Cu ligado a la materia orgánica fueron $3,60 \mathrm{mg} / \mathrm{kg}(0-20 \mathrm{~cm})$ y $3,86 \mathrm{mg} / \mathrm{kg}(20-50 \mathrm{~cm})$ y oscilaron entre $2,00 \mathrm{mg} / \mathrm{kg}$ (CT, 20$50 \mathrm{~cm}, 2017)$ y $9,39 \mathrm{mg} / \mathrm{kg}(\mathrm{AO}, 20-50 \mathrm{~cm}, 2017)$. Entre el suelo rizosférico y el suelo no rizosférico (años 2016 y 2017, profundidades de 0-20 cm y 20-50 cm)) solamente se registraron diferencias estadísticamente significativas en las parcelas CT $(20-50 \mathrm{~cm}$ en 2016), en las parcelas AC (20-50 cm en 2016), en las parcelas AA (0-20 cm en 2017) y en las parcelas BPF (0-20 cm en 2016 y 20-50 cm en 2017). 


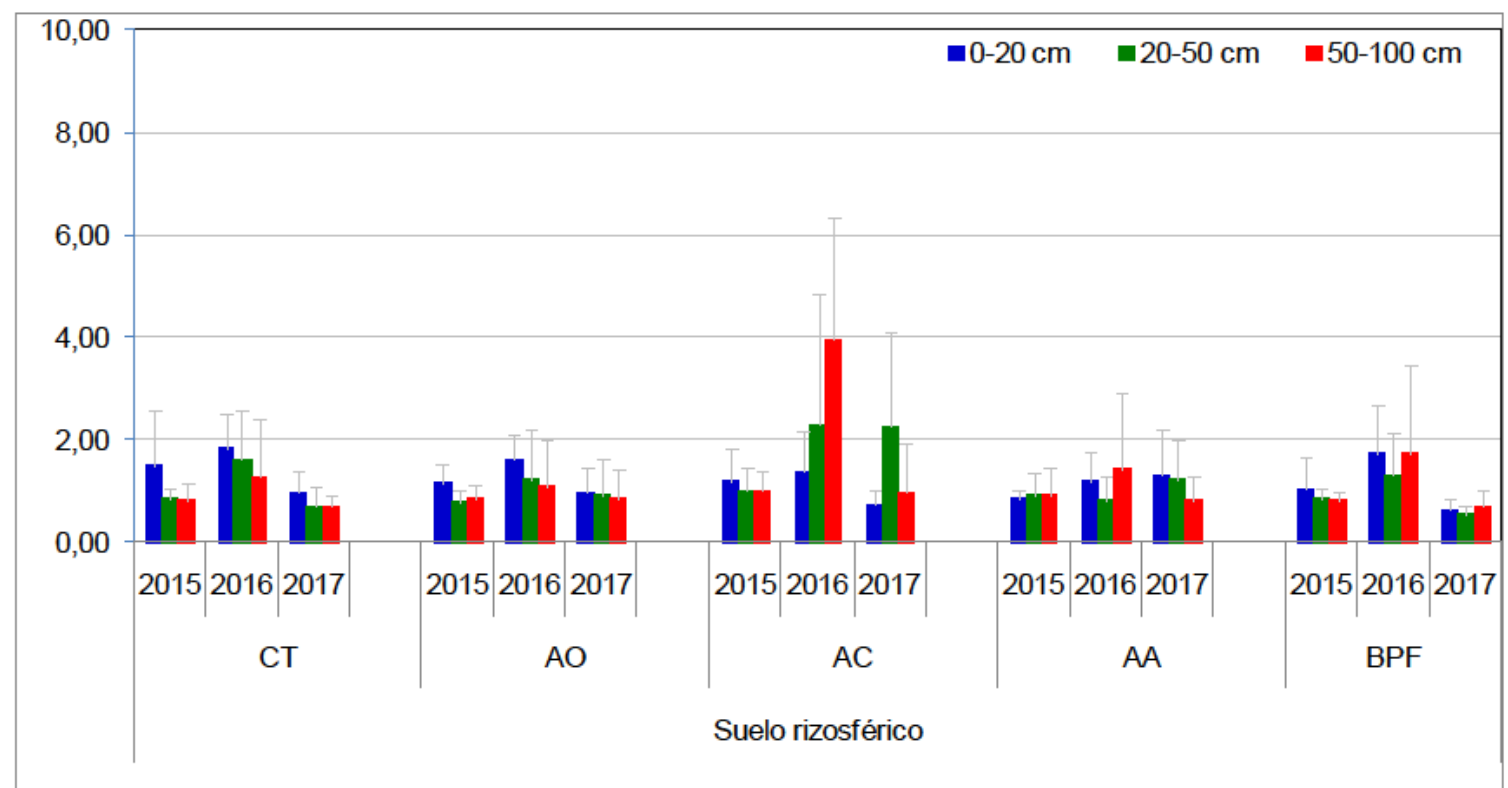

Figura 6.4.39. Evolución temporal de $\mathrm{Zn}$ ligado a la materia orgánica $(\mathrm{mg} / \mathrm{kg})$ en suelo rizosférico entre 3 muestreos anuales $(2015,2016$ y 2017) en parcelas control (CT) y parcelas tratadas con dosis de $5 \mathrm{mmol} / \mathrm{kg}$ de ácido oxálico $(A O)$, ácido cítrico $(A C)$, aminoácidos (AA) y bacterias Pseudomonas fluorescens (BPF) y 5 aplicaciones (junio 2016, septiembre 2016, enero 2017, abril 2017 y junio 2017), $\mathrm{n}=3$.

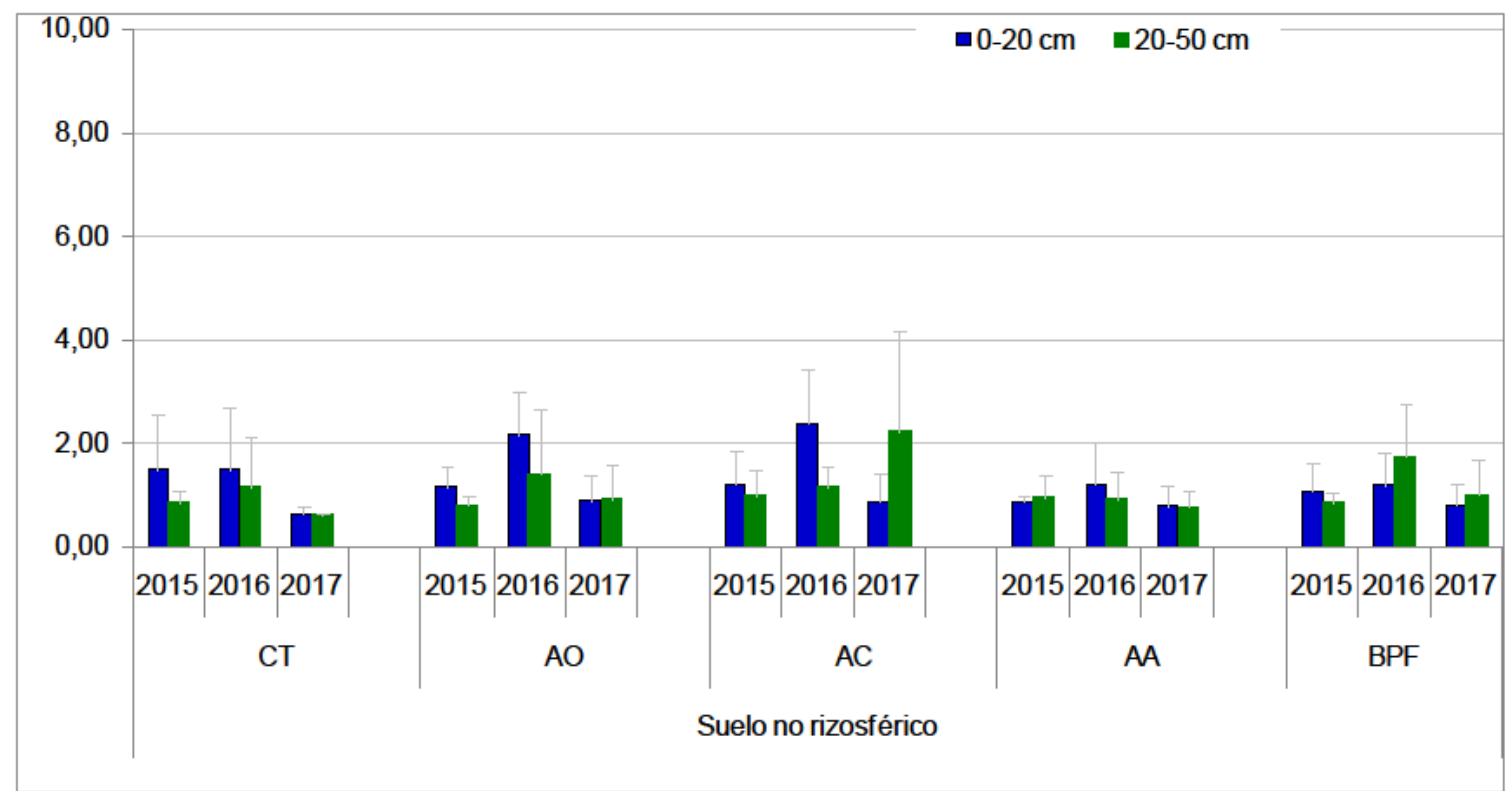

Figura 6.4.40. Evolución temporal de $\mathrm{Zn}$ ligado a la materia orgánica $(\mathrm{mg} / \mathrm{kg})$ en suelo no rizosférico entre 3 muestreos anuales $(2015,2016$ y 2017) en parcelas control (CT) y parcelas tratadas con dosis de $5 \mathrm{mmol} / \mathrm{kg}$ de ácido oxálico (AO), ácido cítrico (AC), aminoácidos (AA) y bacterias Pseudomonas fluorescens (BPF) y 5 aplicaciones (junio 2016, septiembre 2016, enero 2017, abril 2017 y junio 2017), $\mathrm{n}=3$. 


\section{Evolución 2015-2016-2017 de Zn ligado a la materia orgánica:}

En las figuras anteriores se puede observar la variación entre los años 2015, 2016 y 2017 de las concentraciones de $\mathrm{Zn}$ ligado a la materia orgánica en los sedimentos del suelo rizosférico y del suelo no rizosférico en las diferentes profundidades muestreadas $(0-20 \mathrm{~cm}$, 20-50 cm y 50-100 cm). En el suelo rizosférico las concentraciones medias de $\mathrm{Zn}$ ligado a la materia orgánica fueron $1,22 \mathrm{mg} / \mathrm{kg}(0-20 \mathrm{~cm}), 1,17 \mathrm{mg} / \mathrm{kg}(20-50 \mathrm{~cm})$ y $1,20 \mathrm{mg} / \mathrm{kg}(50-100$ $\mathrm{cm}$ ) y oscilaron entre $0,57 \mathrm{mg} / \mathrm{kg}(B P F, 20-50 \mathrm{~cm}, 2017)$ y $3,97 \mathrm{mg} / \mathrm{kg}(\mathrm{AC}, 50-100 \mathrm{~cm}$, 2016). Para cada uno de los tratamientos no se detectaron diferencias significativas entre las diferentes profundidades muestreadas $(0-20 \mathrm{~cm}, 20-50 \mathrm{~cm}$ y $50-100 \mathrm{~cm})$. Y para cada tratamiento y profundidad tampoco se registraron diferencias significativas entre años.

En el suelo no rizosférico las concentraciones medias de $\mathrm{Zn}$ ligado a la materia orgánica fueron $1,21 \mathrm{mg} / \mathrm{kg}(0-20 \mathrm{~cm})$ y $1,09 \mathrm{mg} / \mathrm{kg}(20-50 \mathrm{~cm})$ y oscilaron entre $0,62 \mathrm{mg} / \mathrm{kg}$ (CT, 20$50 \mathrm{~cm}, 2017)$ y $2,37 \mathrm{mg} / \mathrm{kg}(\mathrm{AC}, 0-20 \mathrm{~cm}, 2016)$. Entre el suelo rizosférico y el suelo no rizosférico (años 2016 y 2017, profundidades de 0-20 cm y 20-50 cm)) solamente se registraron diferencias estadísticamente significativas en las parcelas CT (0-20 cm y 20-50 cm en 2017) y en las parcelas AC (20-50 cm en 2016). 


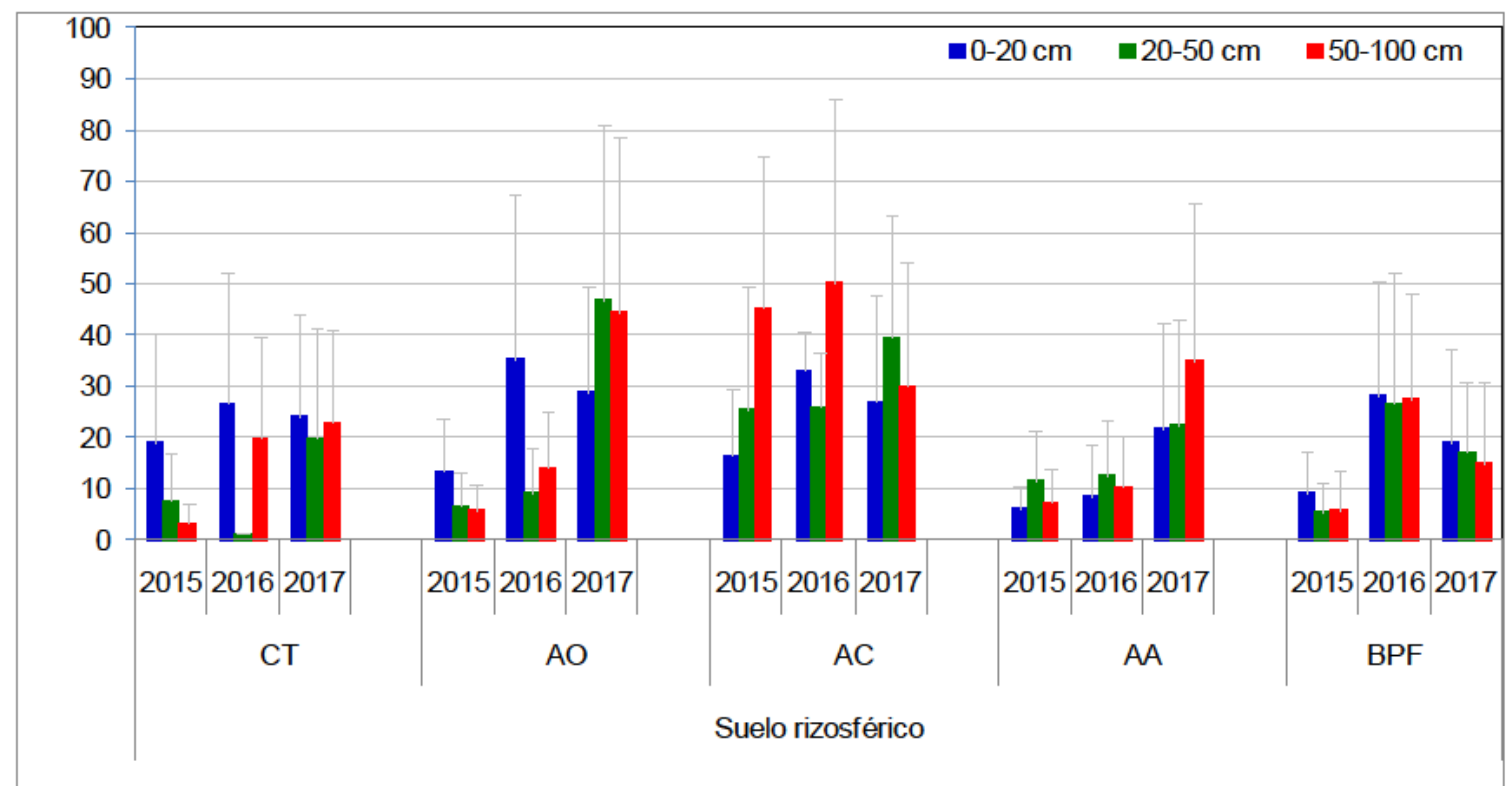

Figura 6.4.41. Evolución temporal de $\mathrm{Cr}$ ligado a la materia orgánica $(\mathrm{mg} / \mathrm{kg})$ en suelo rizosférico entre 3 muestreos anuales $(2015,2016$ y 2017) en parcelas control (CT) y parcelas tratadas con dosis de $5 \mathrm{mmol} / \mathrm{kg}$ de ácido oxálico (AO), ácido cítrico (AC), aminoácidos (AA) y bacterias Pseudomonas fluorescens (BPF) y 5 aplicaciones (junio 2016, septiembre 2016, enero 2017, abril 2017 y junio 2017), $n=3$.

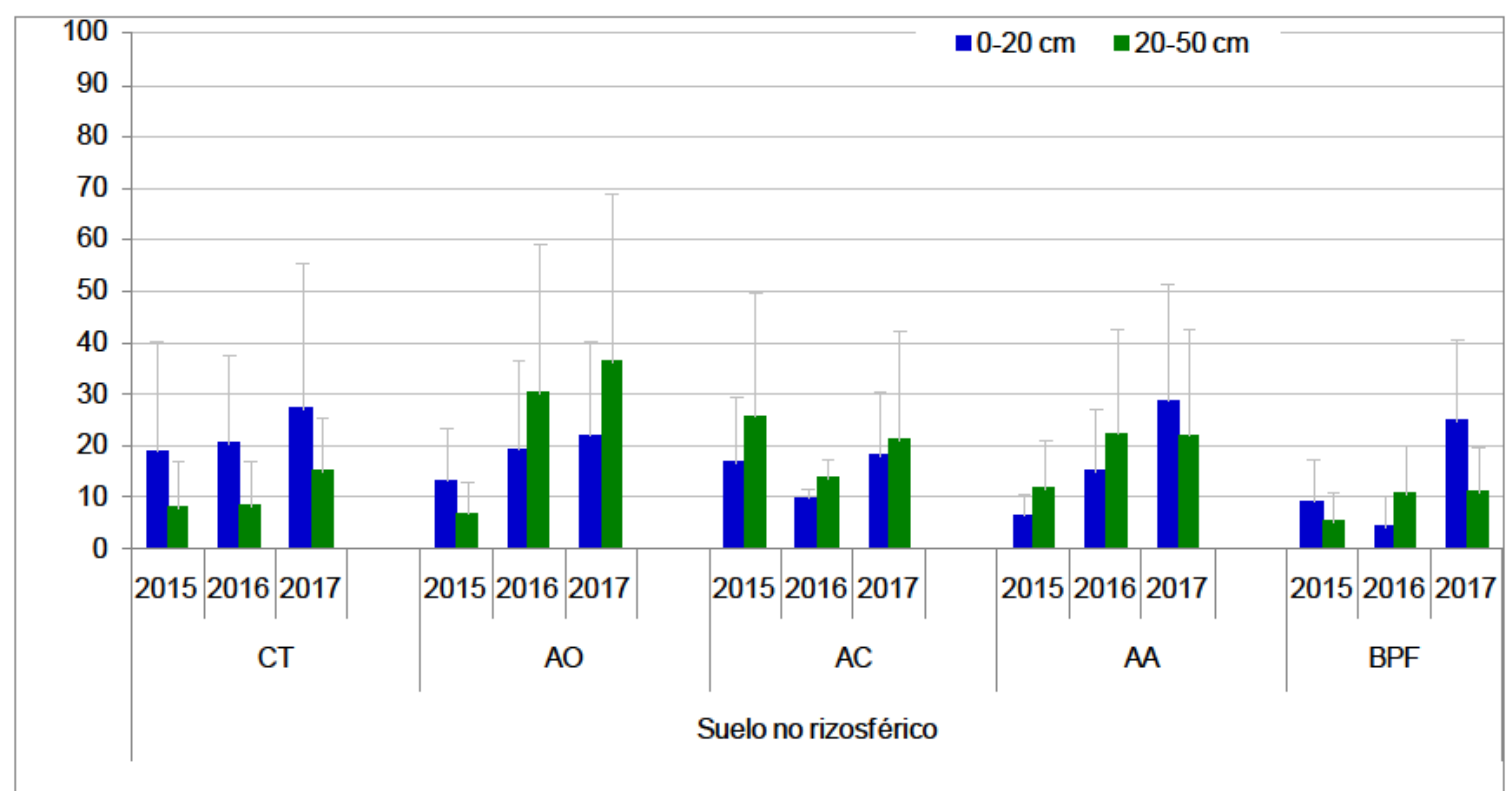

Figura 6.4.42. Evolución temporal de $\mathrm{Cr}$ ligado a la materia orgánica $(\mathrm{mg} / \mathrm{kg})$ en suelo no rizosférico entre 3 muestreos anuales (2015, 2016 y 2017) en parcelas control (CT) y parcelas tratadas con dosis de $5 \mathrm{mmol} / \mathrm{kg}$ de ácido oxálico $(A O)$, ácido cítrico $(A C)$, aminoácidos (AA) y bacterias Pseudomonas fluorescens (BPF) y 5 aplicaciones (junio 2016, septiembre 2016, enero 2017, abril 2017 y junio 2017), $\mathrm{n}=3$. 


\section{Evolución 2015-2016-2017 de Cr ligado a la materia orgánica:}

En las figuras anteriores se puede observar la variación entre los años 2015, 2016 y 2017 de las concentraciones de $\mathrm{Cr}$ ligado a la materia orgánica en los sedimentos del suelo rizosférico y del suelo no rizosférico en las diferentes profundidades muestreadas $(0-20 \mathrm{~cm}$, 20-50 cm y 50-100 cm). En el suelo rizosférico las concentraciones medias de $\mathrm{Cr}$ ligado a la materia orgánica fueron $21,21 \mathrm{mg} / \mathrm{kg}(0-20 \mathrm{~cm}), 18,71 \mathrm{mg} / \mathrm{kg}(20-50 \mathrm{~cm})$ y $22,55 \mathrm{mg} / \mathrm{kg}(50-$ $100 \mathrm{~cm}$ ) y oscilaron entre $1,48 \mathrm{mg} / \mathrm{kg}(\mathrm{CT}, 20-50 \mathrm{~cm}, 2016)$ y $50,23 \mathrm{mg} / \mathrm{kg}$ (AC, 50-100 cm, 2016). Para cada uno de los tratamientos no se detectaron diferencias significativas entre las diferentes profundidades muestreadas $(0-20 \mathrm{~cm}, 20-50 \mathrm{~cm}$ y $50-100 \mathrm{~cm})$. Y para cada tratamiento y profundidad sólo se registraron diferencias significativas entre años en las parcelas $A O(20-50 \mathrm{~cm})$ y en las parcelas $A C(0-20 \mathrm{~cm})$, resultando significativamente superiores en los años 2016 y 2017 con respecto al año 2015 en ambos casos.

En el suelo no rizosférico las concentraciones medias de $\mathrm{Cr}$ ligado a la materia orgánica fueron $17,00 \mathrm{mg} / \mathrm{kg}(0-20 \mathrm{~cm})$ y $16,55 \mathrm{mg} / \mathrm{kg}(20-50 \mathrm{~cm})$ y oscilaron entre $4,35 \mathrm{mg} / \mathrm{kg}$ (BPF, $0-20 \mathrm{~cm}, 2016)$ y $36,13 \mathrm{mg} / \mathrm{kg}(\mathrm{AO}, 20-50 \mathrm{~cm}, 2017)$. Entre el suelo rizosférico y el suelo no rizosférico (años 2016 y 2017, profundidades de 0-20 cm y 20-50 cm)) solamente se registraron diferencias estadísticamente significativas en las parcelas CT (0-20 cm en 2016 y en 2017 y 20-50 cm en 2017), en las parcelas AO (20-50 cm en 2017), en las parcelas AA (0-20 cm en 2017) y en las parcelas BPF (0-20 cm en 2016 y 20-50 cm en 2017). 


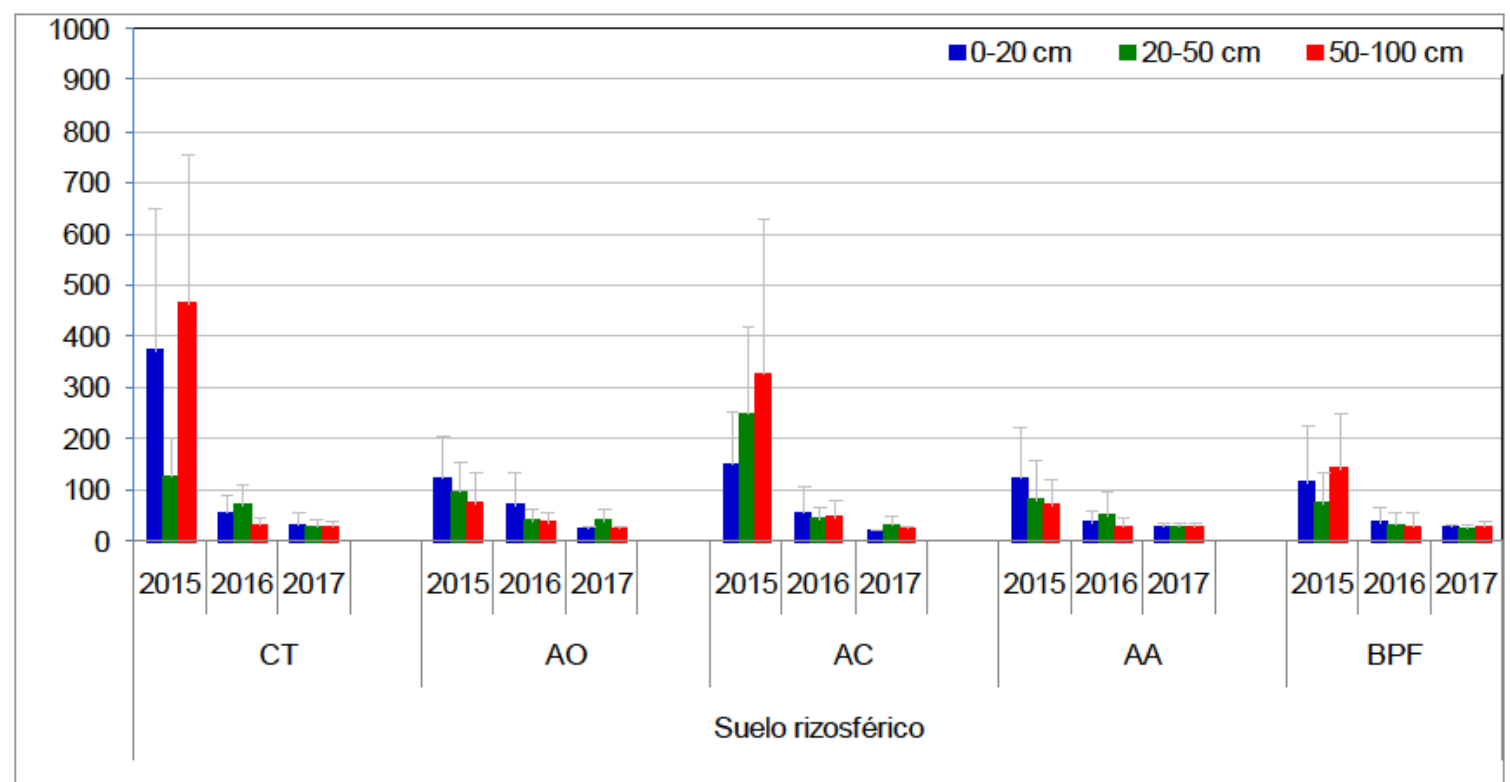

Figura 6.4.43. Evolución temporal de $\mathrm{Cu}$ residual $(\mathrm{mg} / \mathrm{kg})$ en suelo rizosférico entre 3 muestreos anuales $(2015,2016$ y 2017) en parcelas control (CT) y parcelas tratadas con dosis de $5 \mathrm{mmol} / \mathrm{kg}$ de ácido oxálico (AO), ácido cítrico (AC), aminoácidos (AA) y bacterias Pseudomonas fluorescens (BPF) y 5 aplicaciones (junio 2016, septiembre 2016, enero 2017, abril 2017 y junio 2017), $n=3$.

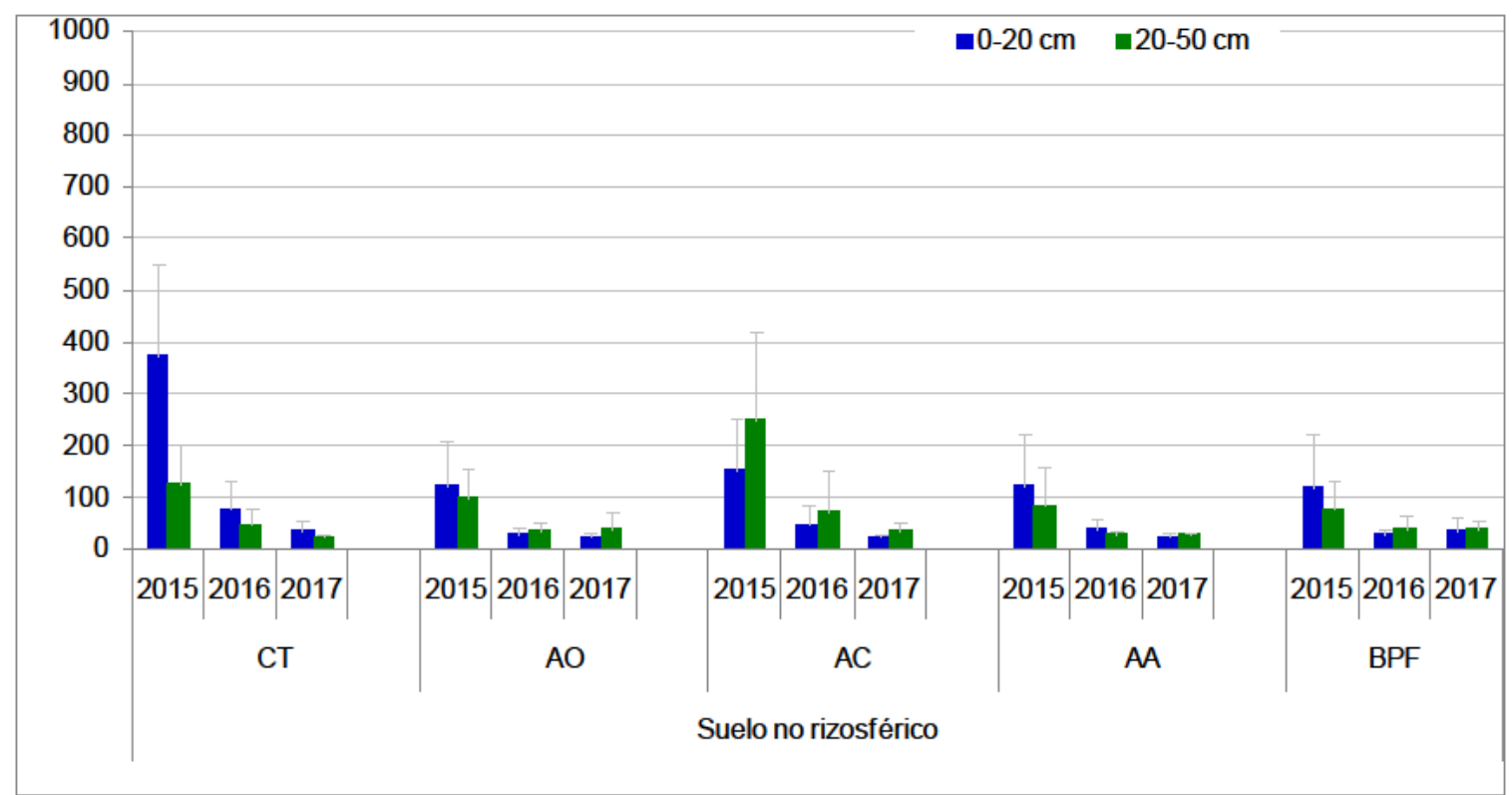

Figura 6.4.44. Evolución temporal de Cu residual $(\mathrm{mg} / \mathrm{kg})$ en suelo no rizosférico entre 3 muestreos anuales $(2015,2016$ y 2017$)$ en parcelas control (CT) y parcelas tratadas con dosis de $5 \mathrm{mmol} / \mathrm{kg}$ de ácido oxálico (AO), ácido cítrico ( $\mathrm{AC}$ ), aminoácidos (AA) y bacterias Pseudomonas fluorescens (BPF) y 5 aplicaciones (junio 2016, septiembre 2016, enero 2017, abril 2017 y junio 2017), $n=3$. 


\section{Evolución 2015-2016-2017 de Cu residual:}

En las figuras anteriores se puede observar la variación entre los años 2015, 2016 y 2017 de las concentraciones de $\mathrm{Cu}$ residual en los sedimentos del suelo rizosférico y del suelo no rizosférico en las diferentes profundidades muestreadas $(0-20 \mathrm{~cm}, 20-50 \mathrm{~cm}$ y 50-100 cm). En el suelo rizosférico las concentraciones medias de Cu residual fueron $85,57 \mathrm{mg} / \mathrm{kg}(0-20$ $\mathrm{cm}), 69,07 \mathrm{mg} / \mathrm{kg}(20-50 \mathrm{~cm})$ y $93,41 \mathrm{mg} / \mathrm{kg}(50-100 \mathrm{~cm})$ y oscilaron entre $21,29 \mathrm{mg} / \mathrm{kg}$ (AC, $0-20 \mathrm{~cm}, 2017)$ y $466,16 \mathrm{mg} / \mathrm{kg}(\mathrm{CT}, 50-100 \mathrm{~cm}, 2015)$. Para cada uno de los tratamientos no se detectaron diferencias significativas entre las diferentes profundidades muestreadas $(0-20 \mathrm{~cm}, 20-50 \mathrm{~cm}$ y $50-100 \mathrm{~cm})$. Y para cada tratamiento y profundidad tampoco se registraron diferencias significativas entre años. $\mathrm{Y}$ para cada tratamiento y profundidad tampoco se registraron diferencias significativas entre años, se pueden observar mayores valores de Cu residual en las parcelas CT y AC (año 2015) aunque dichos valores no son estadísticamente significativos.

En el suelo no rizosférico las concentraciones medias de Cu residual fueron $83,71 \mathrm{mg} / \mathrm{kg}$ (0$20 \mathrm{~cm})$ y $68,31 \mathrm{mg} / \mathrm{kg}(20-50 \mathrm{~cm})$ y oscilaron entre $24,18 \mathrm{mg} / \mathrm{kg}(\mathrm{CT}, 20-50 \mathrm{~cm}, 2017)$ y $374,55 \mathrm{mg} / \mathrm{kg}$ (CT, 0-20 cm, 2015). Entre el suelo rizosférico y el suelo no rizosférico (años 2016 y 2017 , profundidades de $0-20 \mathrm{~cm}$ y $20-50 \mathrm{~cm}$ )) solamente se registraron diferencias estadísticamente significativas en las parcelas AO (0-20 cm en 2017) y en las parcelas BPF (20-50 cm en 2017). 


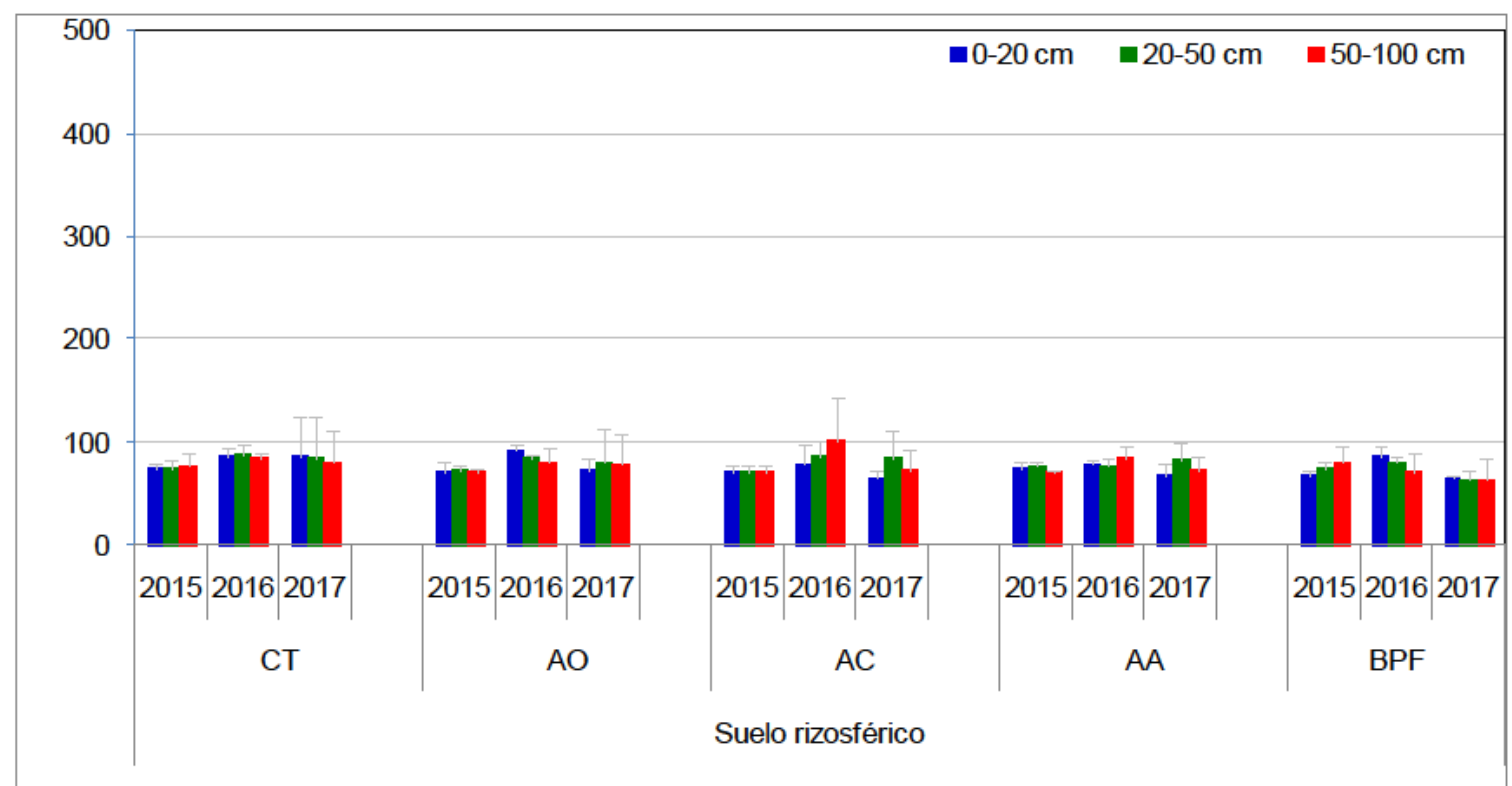

Figura 6.4.45. Evolución temporal de $\mathrm{Zn}$ residual $(\mathrm{mg} / \mathrm{kg})$ en suelo rizosférico entre 3 muestreos anuales $(2015,2016$ y 2017$)$ en parcelas control (CT) y parcelas tratadas con dosis de $5 \mathrm{mmol} / \mathrm{kg}$ de ácido oxálico (AO), ácido cítrico (AC), aminoácidos (AA) y bacterias Pseudomonas fluorescens (BPF) y 5 aplicaciones (junio 2016, septiembre 2016, enero 2017, abril 2017 y junio 2017), $n=3$.

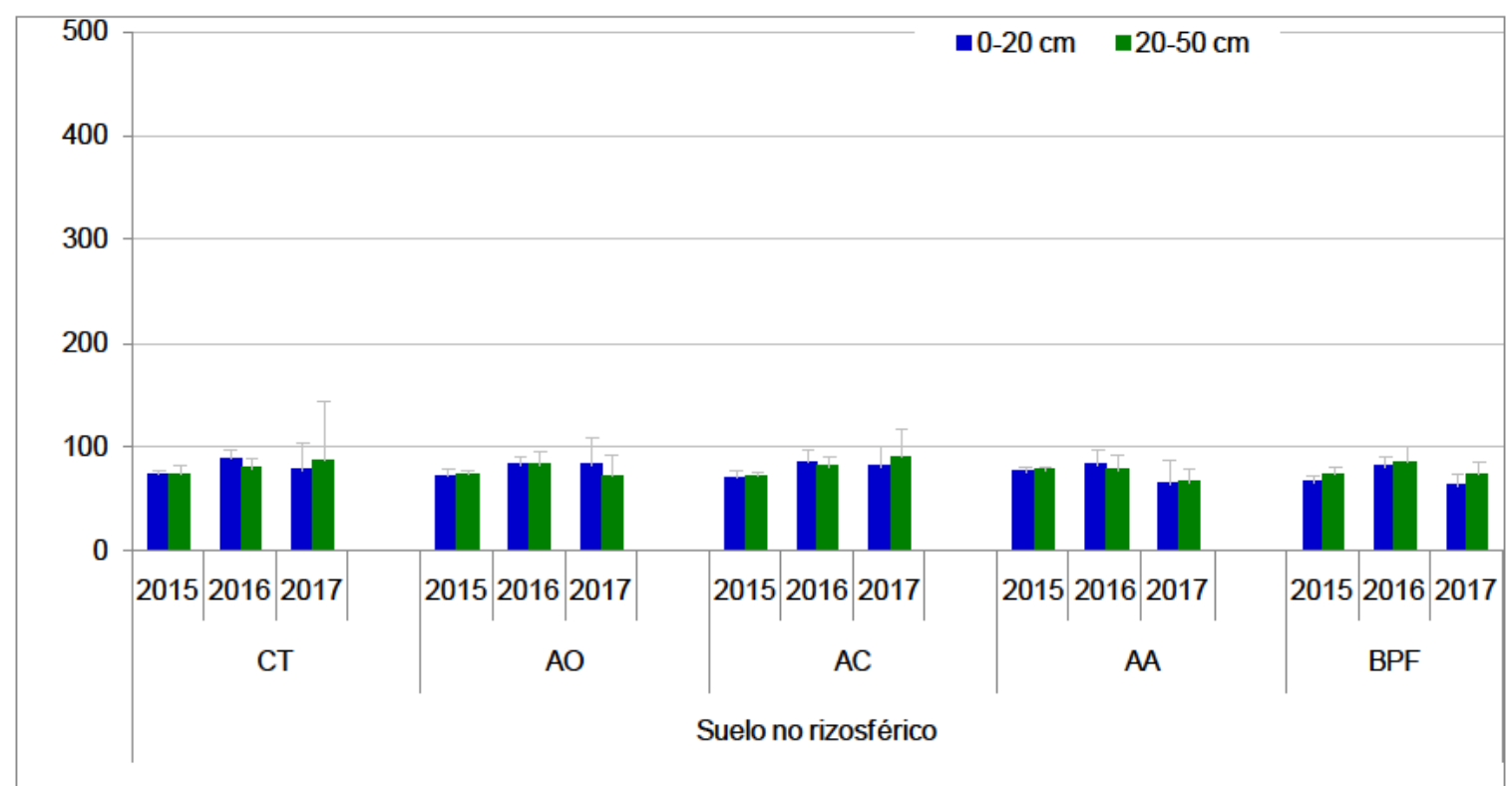

Figura 6.4.46. Evolución temporal de $\mathrm{Zn}$ residual $(\mathrm{mg} / \mathrm{kg})$ en suelo no rizosférico entre 3 muestreos anuales $(2015,2016$ y 2017$)$ en parcelas control (CT) y parcelas tratadas con dosis de $5 \mathrm{mmol} / \mathrm{kg}$ de ácido oxálico (AO), ácido cítrico (AC), aminoácidos (AA) y bacterias Pseudomonas fluorescens (BPF) y 5 aplicaciones (junio 2016, septiembre 2016, enero 2017, abril 2017 y junio 2017), $n=3$. 


\section{Evolución 2015-2016-2017 de Zn residual:}

En las figuras anteriores se puede observar la variación entre los años 2015, 2016 y 2017 de las concentraciones de $\mathrm{Zn}$ residual en los sedimentos del suelo rizosférico y del suelo no rizosférico en las diferentes profundidades muestreadas $(0-20 \mathrm{~cm}, 20-50 \mathrm{~cm}$ y $50-100 \mathrm{~cm})$. En el suelo rizosférico las concentraciones medias de $\mathrm{Zn}$ residual fueron $76,13 \mathrm{mg} / \mathrm{kg}(0-20$ $\mathrm{cm}), 79,02 \mathrm{mg} / \mathrm{kg}(20-50 \mathrm{~cm})$ y $77,83 \mathrm{mg} / \mathrm{kg}(50-100 \mathrm{~cm})$ y oscilaron entre $63,37 \mathrm{mg} / \mathrm{kg}$ (BPF, 20-50 cm, 2017) y $100,88 \mathrm{mg} / \mathrm{kg}$ (AC, $50-100 \mathrm{~cm}, 2016$ ). Para cada uno de los tratamientos no se detectaron diferencias significativas entre las diferentes profundidades muestreadas $(0-20 \mathrm{~cm}, 20-50 \mathrm{~cm}$ y $50-100 \mathrm{~cm})$. Y para cada tratamiento y profundidad tampoco se registraron diferencias significativas entre años, este hecho resalta la gran variabilidad encontrada entre los resultados registrados.

En el suelo no rizosférico las concentraciones medias de $\mathrm{Zn}$ residual fueron $76,62 \mathrm{mg} / \mathrm{kg}$ (0$20 \mathrm{~cm})$ y $78,27 \mathrm{mg} / \mathrm{kg}(20-50 \mathrm{~cm})$ y oscilaron entre $62,92 \mathrm{mg} / \mathrm{kg}(B P F, 0-20 \mathrm{~cm}, 2017)$ y $90,90 \mathrm{mg} / \mathrm{kg}$ (AC, 20-50 cm, 2017). Entre el suelo rizosférico y el suelo no rizosférico (años 2016 y 2017, profundidades de $0-20 \mathrm{~cm}$ y $20-50 \mathrm{~cm}$ )) no se registraron diferencias estadísticamente significativas en ninguna de las parcelas estudiadas. 


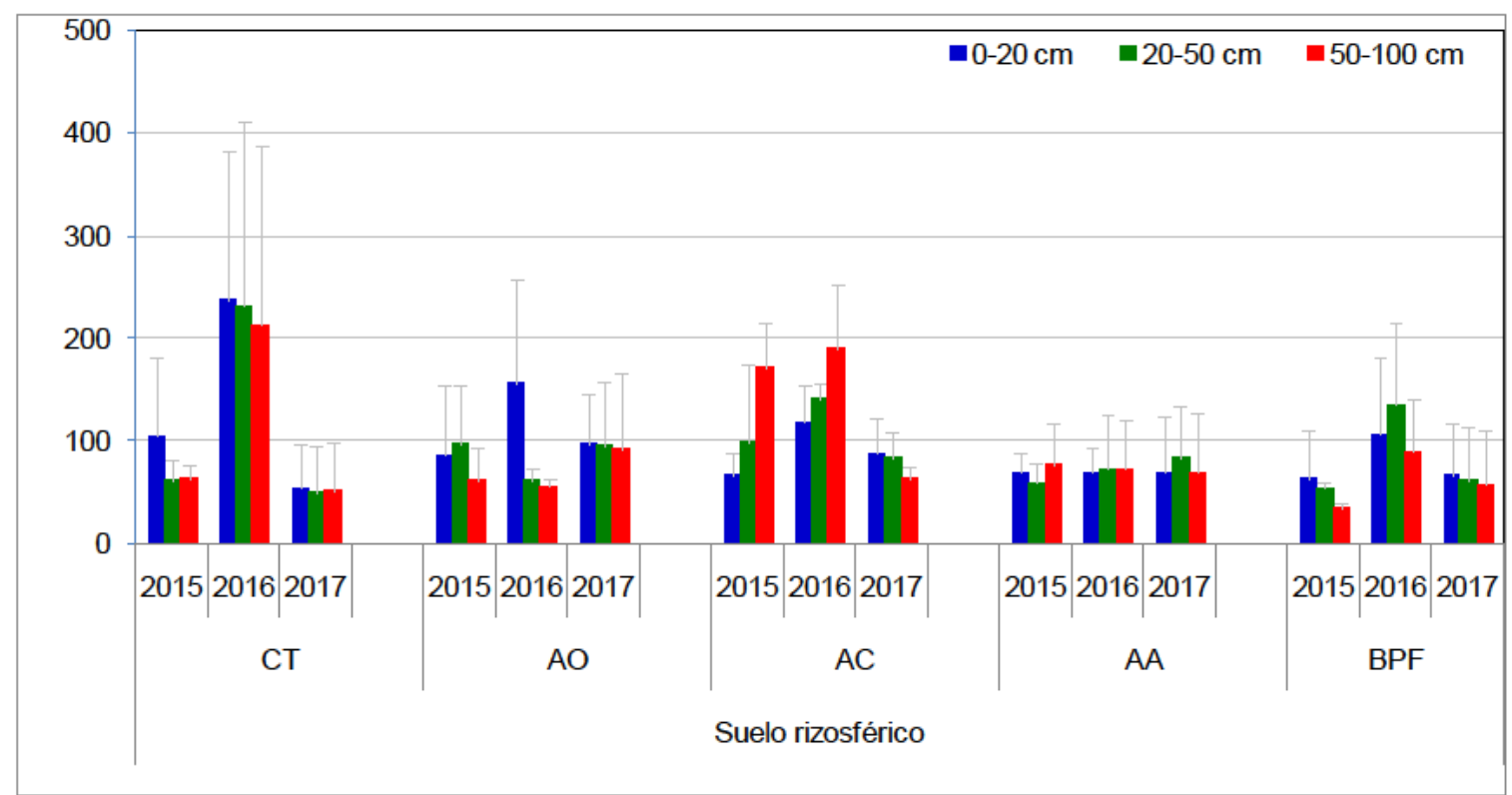

Figura 6.4.47. Evolución temporal de $\mathrm{Cr}$ residual $(\mathrm{mg} / \mathrm{kg})$ en suelo rizosférico entre 3 muestreos anuales $(2015,2016$ y 2017$)$ en parcelas control (CT) y parcelas tratadas con dosis de $5 \mathrm{mmol} / \mathrm{kg}$ de ácido oxálico (AO), ácido cítrico ( $A C)$, aminoácidos (AA) y bacterias Pseudomonas fluorescens (BPF) y 5 aplicaciones (junio 2016, septiembre 2016, enero 2017, abril 2017 y junio 2017), $n=3$.

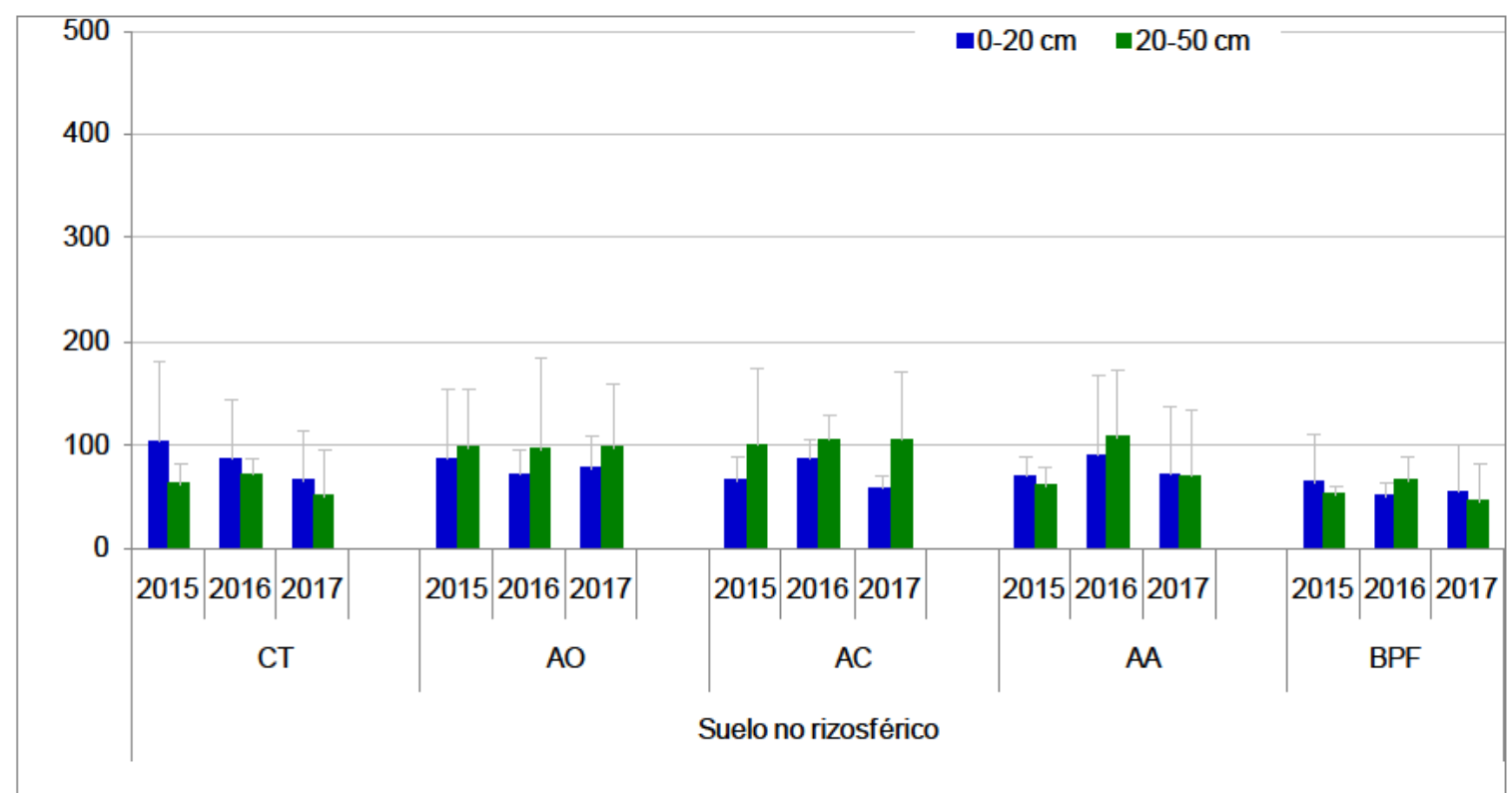

Figura 6.4.48. Evolución temporal de $\mathrm{Cr}$ residual $(\mathrm{mg} / \mathrm{kg})$ en suelo no rizosférico entre 3 muestreos anuales $(2015,2016$ y 2017$)$ en parcelas control (CT) y parcelas tratadas con dosis de $5 \mathrm{mmol} / \mathrm{kg}$ de ácido oxálico (AO), ácido cítrico ( $A C)$, aminoácidos (AA) y bacterias Pseudomonas fluorescens (BPF) y 5 aplicaciones (junio 2016, septiembre 2016, enero 2017, abril 2017 y junio 2017), $\mathrm{n}=3$. 


\section{Evolución 2015-2016-2017 de Cr residual:}

En las figuras anteriores se puede observar la variación entre los años 2015, 2016 y 2017 de las concentraciones de $\mathrm{Cr}$ residual en los sedimentos del suelo rizosférico y del suelo no rizosférico en las diferentes profundidades muestreadas $(0-20 \mathrm{~cm}, 20-50 \mathrm{~cm}$ y $50-100 \mathrm{~cm})$. En el suelo rizosférico las concentraciones medias de $\mathrm{Cr}$ residual fueron 97,44 mg/kg (0-20 $\mathrm{cm}), 93,26 \mathrm{mg} / \mathrm{kg}(20-50 \mathrm{~cm})$ y $91,46 \mathrm{mg} / \mathrm{kg}(50-100 \mathrm{~cm})$ y oscilaron entre $36,12 \mathrm{mg} / \mathrm{kg}$ (BPF. $50-100 \mathrm{~cm}, 2015)$ y $237,39 \mathrm{mg} / \mathrm{kg}$ (CT, 0-20 cm, 2016). Para cada uno de los tratamientos no se detectaron diferencias significativas entre las diferentes profundidades muestreadas $(0-20 \mathrm{~cm}, 20-50 \mathrm{~cm}$ y $50-100 \mathrm{~cm})$. Y para cada tratamiento y profundidad sólo se registraron diferencias significativas entre años en las parcelas $A O(50-100 \mathrm{~cm})$ y en las parcelas AC (50-100 cm), resultando significativamente superiores en los años 2017 y 2015 y 2016 respectivamente.

En el suelo no rizosférico las concentraciones medias de $\mathrm{Cr}$ residual fueron $74,30 \mathrm{mg} / \mathrm{kg}(0-$ $20 \mathrm{~cm})$ y $79,75 \mathrm{mg} / \mathrm{kg}(20-50 \mathrm{~cm})$ y oscilaron entre $45,81 \mathrm{mg} / \mathrm{kg}(B P F, 20-50 \mathrm{~cm}, 2017)$ y $107,66 \mathrm{mg} / \mathrm{kg}$ (AA, 20-50 cm, 2016). Entre el suelo rizosférico y el suelo no rizosférico (años 2016 y 2017, profundidades de 0-20 cm y 20-50 cm)) solamente se registraron diferencias estadísticamente significativas en las parcelas $A O(20-50 \mathrm{~cm}$ en 2016) y en las parcelas AA (20-50 cm en 2017). 


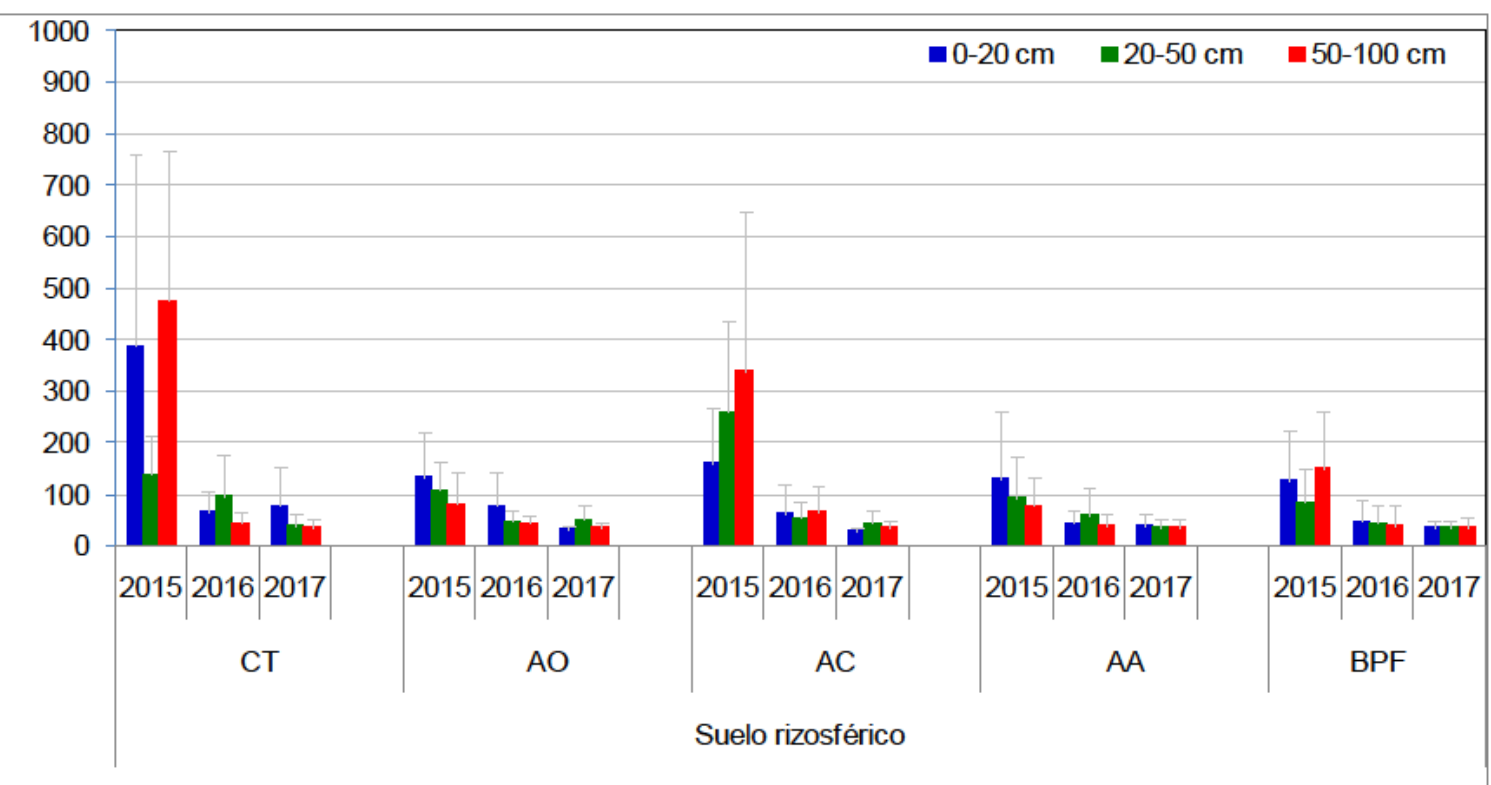

Figura 6.4.49. Evolución temporal de Cu total $(\mathrm{mg} / \mathrm{kg})$ en suelo rizosférico entre 3 muestreos anuales $(2015,2016$ y 2017) en parcelas control (CT) y parcelas tratadas con dosis de 5 $\mathrm{mmol} / \mathrm{kg}$ de ácido oxálico (AO), ácido cítrico (AC), aminoácidos (AA) y bacterias Pseudomonas fluorescens (BPF) y 5 aplicaciones (junio 2016, septiembre 2016, enero 2017, abril 2017 y junio 2017), $n=3$.

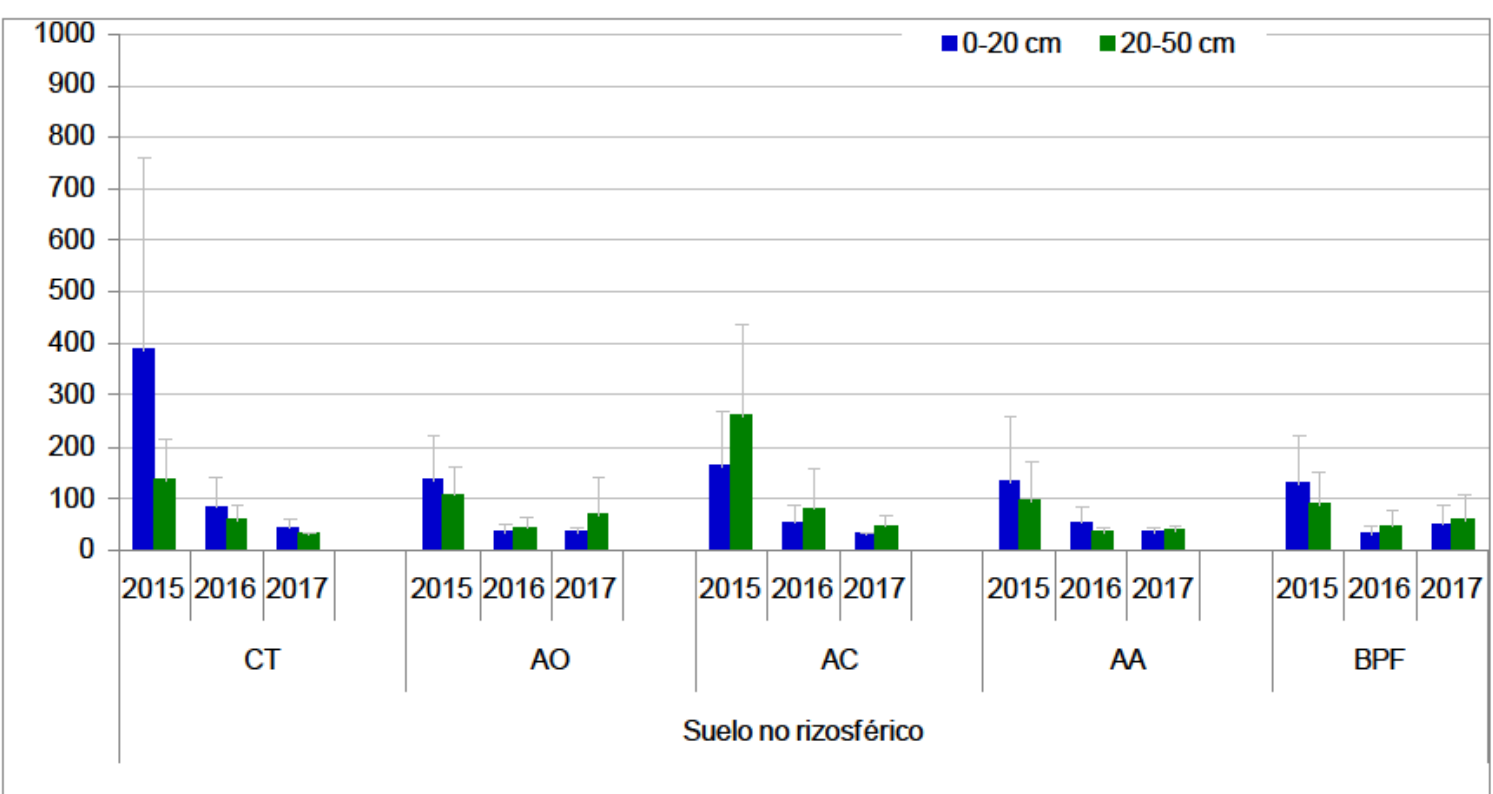

Figura 6.4.50. Evolución temporal de Cu total $(\mathrm{mg} / \mathrm{kg})$ en suelo no rizosférico entre 3 muestreos anuales $(2015,2016$ y 2017$)$ en parcelas control (CT) y parcelas tratadas con dosis de $5 \mathrm{mmol} / \mathrm{kg}$ de ácido oxálico (AO), ácido cítrico (AC), aminoácidos (AA) y bacterias Pseudomonas fluorescens (BPF) y 5 aplicaciones (junio 2016, septiembre 2016, enero 2017, abril 2017 y junio 2017), $n=3$. 


\section{Evolución 2015-2016-2017 de Cu total:}

En las figuras anteriores se puede observar la variación entre los años 2015, 2016 y 2017 de las concentraciones de $\mathrm{Cu}$ total en los sedimentos del suelo rizosférico y del suelo no rizosférico en las diferentes profundidades muestreadas $(0-20 \mathrm{~cm}, 20-50 \mathrm{~cm}$ y 50-100 cm). En el suelo rizosférico las concentraciones medias de Cu total fueron 98,09 $\mathrm{mg} / \mathrm{kg}(0-20$ $\mathrm{cm}), 80,52 \mathrm{mg} / \mathrm{kg}(20-50 \mathrm{~cm})$ y $103,59 \mathrm{mg} / \mathrm{kg}(50-100 \mathrm{~cm})$ y oscilaron entre $30,97 \mathrm{mg} / \mathrm{kg}$ (AC, 0-20 cm, 2017) y 475,68 mg/kg (CT, 50-100 cm, 2015). Para cada uno de los tratamientos no se detectaron diferencias significativas entre las diferentes profundidades muestreadas $(0-20 \mathrm{~cm}, 20-50 \mathrm{~cm}$ y $50-100 \mathrm{~cm})$. Y para cada tratamiento y profundidad tampoco se registraron diferencias significativas entre años, este hecho resalta la gran variabilidad encontrada entre los resultados registrados.

En el suelo no rizosférico las concentraciones medias de Cu total fueron 93,96 mg/kg (0-20 $\mathrm{cm})$ y $79,75 \mathrm{mg} / \mathrm{kg}(20-50 \mathrm{~cm})$ y oscilaron entre $31,38 \mathrm{mg} / \mathrm{kg}(\mathrm{CT}, 20-50 \mathrm{~cm}, 2017)$ y 387,22 $\mathrm{mg} / \mathrm{kg}(\mathrm{CT}, 20-50 \mathrm{~cm}, 2015)$. Entre el suelo rizosférico y el suelo no rizosférico (años 2016 y 2017, profundidades de $0-20 \mathrm{~cm}$ y $20-50 \mathrm{~cm}$ )) solamente se registraron diferencias estadísticamente significativas en las parcelas $A O(0-20 \mathrm{~cm}$ y $20-50 \mathrm{~cm}$ en 2017$)$ y en las parcelas AA (20-50 cm en 2016). 


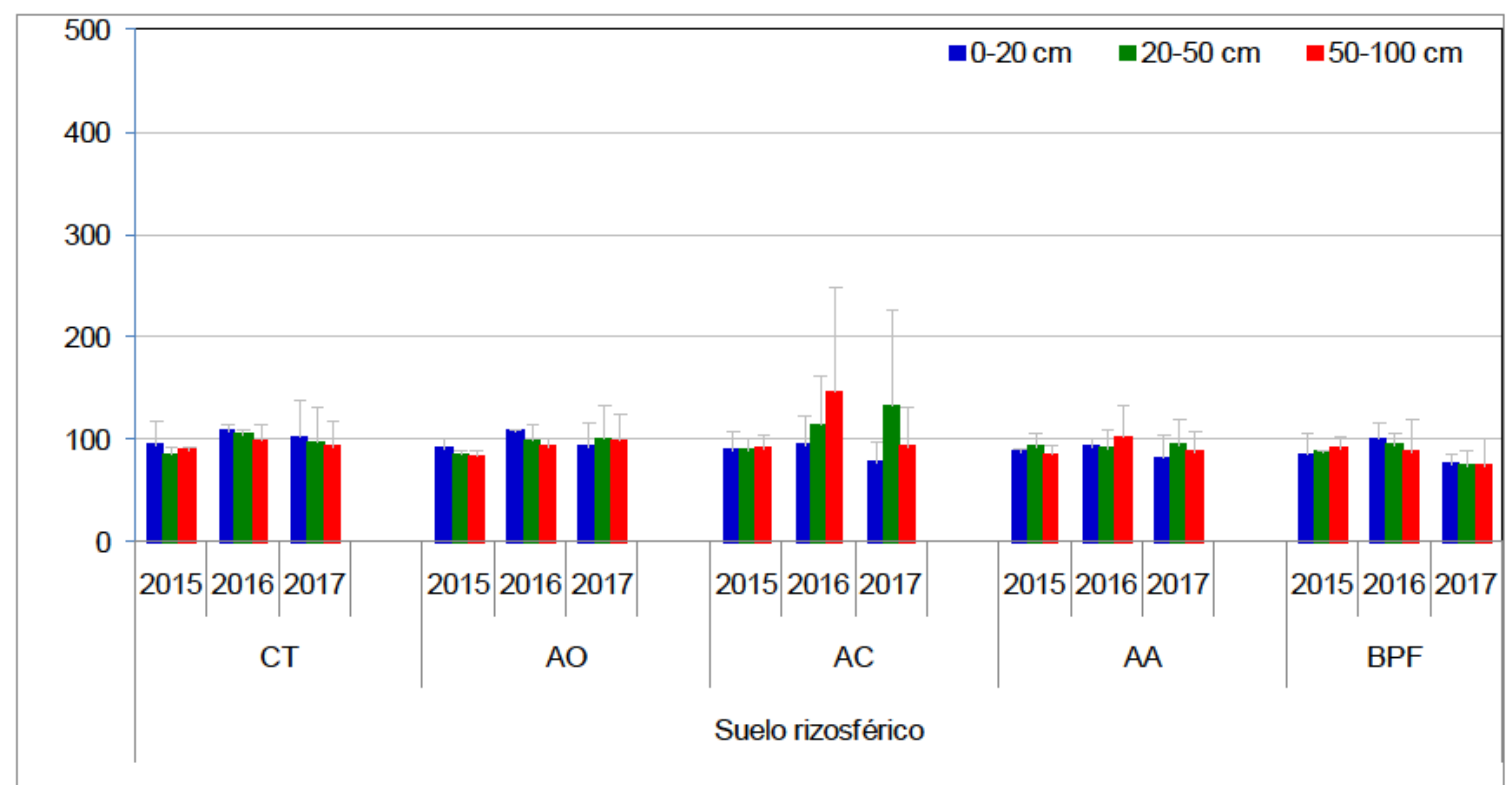

Figura 6.4.51. Evolución temporal de $\mathrm{Zn}$ total $(\mathrm{mg} / \mathrm{kg})$ en suelo rizosférico entre 3 muestreos anuales $(2015,2016$ y 2017) en parcelas control (CT) y parcelas tratadas con dosis de 5 $\mathrm{mmol} / \mathrm{kg}$ de ácido oxálico (AO), ácido cítrico (AC), aminoácidos (AA) y bacterias Pseudomonas fluorescens (BPF) y 5 aplicaciones (junio 2016, septiembre 2016, enero 2017, abril 2017 y junio 2017), $\mathrm{n}=3$.

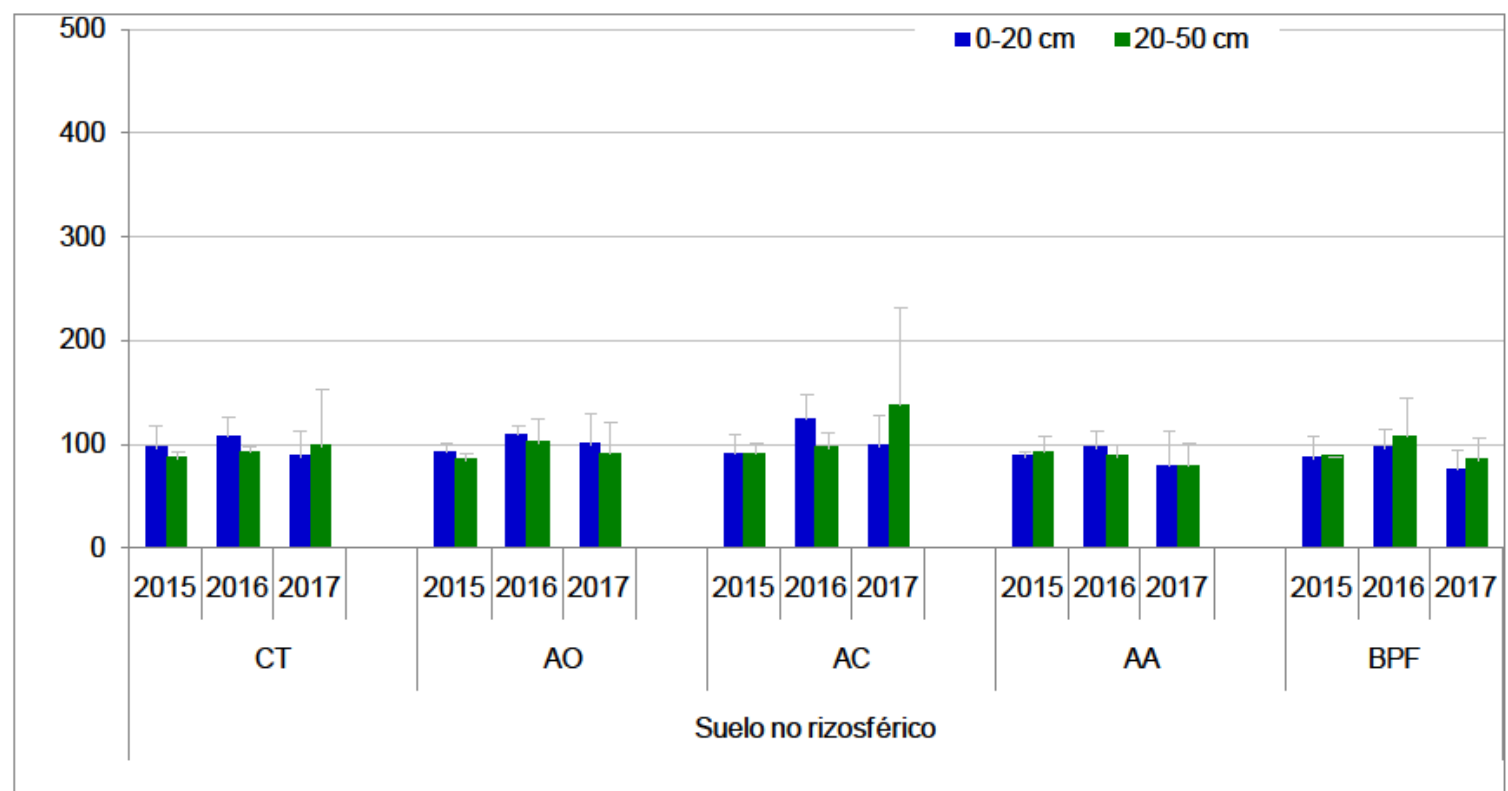

Figura 6.4.52. Evolución temporal de $\mathrm{Zn}$ total $(\mathrm{mg} / \mathrm{kg})$ suelo no rizosférico entre 3 muestreos anuales $(2015,2016$ y 2017) en parcelas control (CT) y parcelas tratadas con dosis de 5 $\mathrm{mmol} / \mathrm{kg}$ de ácido oxálico (AO), ácido cítrico $(\mathrm{AC})$, aminoácidos $(A A)$ y bacterias

Pseudomonas fluorescens (BPF) y 5 aplicaciones (junio 2016, septiembre 2016, enero 2017, abril 2017 y junio 2017), $\mathrm{n}=3$. 


\section{Evolución 2015-2016-2017 de Zn total:}

En las figuras anteriores se puede observar la variación entre los años 2015, 2016 y 2017 de las concentraciones de $\mathrm{Zn}$ total en los sedimentos del suelo rizosférico y del suelo no rizosférico en las diferentes profundidades muestreadas $(0-20 \mathrm{~cm}, 20-50 \mathrm{~cm}$ y 50-100 cm). En el suelo rizosférico las concentraciones medias de $\mathrm{Zn}$ total fueron 93,59 mg/kg $(0-20 \mathrm{~cm})$, $97,05 \mathrm{mg} / \mathrm{kg}(20-50 \mathrm{~cm})$ y $95,18 \mathrm{mg} / \mathrm{kg}(50-100 \mathrm{~cm})$ y oscilaron entre $74,34 \mathrm{mg} / \mathrm{kg}$ (BPF, $20-$ $50 \mathrm{~cm}, 2017)$ y $147,29 \mathrm{mg} / \mathrm{kg}$ (AC, 50-100 cm, 2016). Para cada uno de los tratamientos no se detectaron diferencias significativas entre las diferentes profundidades muestreadas (0-20 $\mathrm{cm}, 20-50 \mathrm{~cm}$ y $50-100 \mathrm{~cm}$ ). Y para cada tratamiento y profundidad tampoco se registraron diferencias significativas entre años, este hecho resalta la gran variabilidad encontrada entre los resultados registrados.

En el suelo no rizosférico las concentraciones medias de $\mathrm{Zn}$ total fueron 95,50 mg/kg (0-20 cm) y $95,00 \mathrm{mg} / \mathrm{kg}(20-50 \mathrm{~cm})$ y oscilaron entre $75,54 \mathrm{mg} / \mathrm{kg}(B P F, 0-20 \mathrm{~cm}, 2017)$ y 137,48 $\mathrm{mg} / \mathrm{kg}(\mathrm{AC}, 20-50 \mathrm{~cm}, 2017)$. Entre el suelo rizosférico y el suelo no rizosférico (años 2016 y 2017, profundidades de $0-20 \mathrm{~cm}$ y $20-50 \mathrm{~cm}$ )) solamente se registraron diferencias estadísticamente significativas en las parcelas CT (20-50 cm en 2017). 


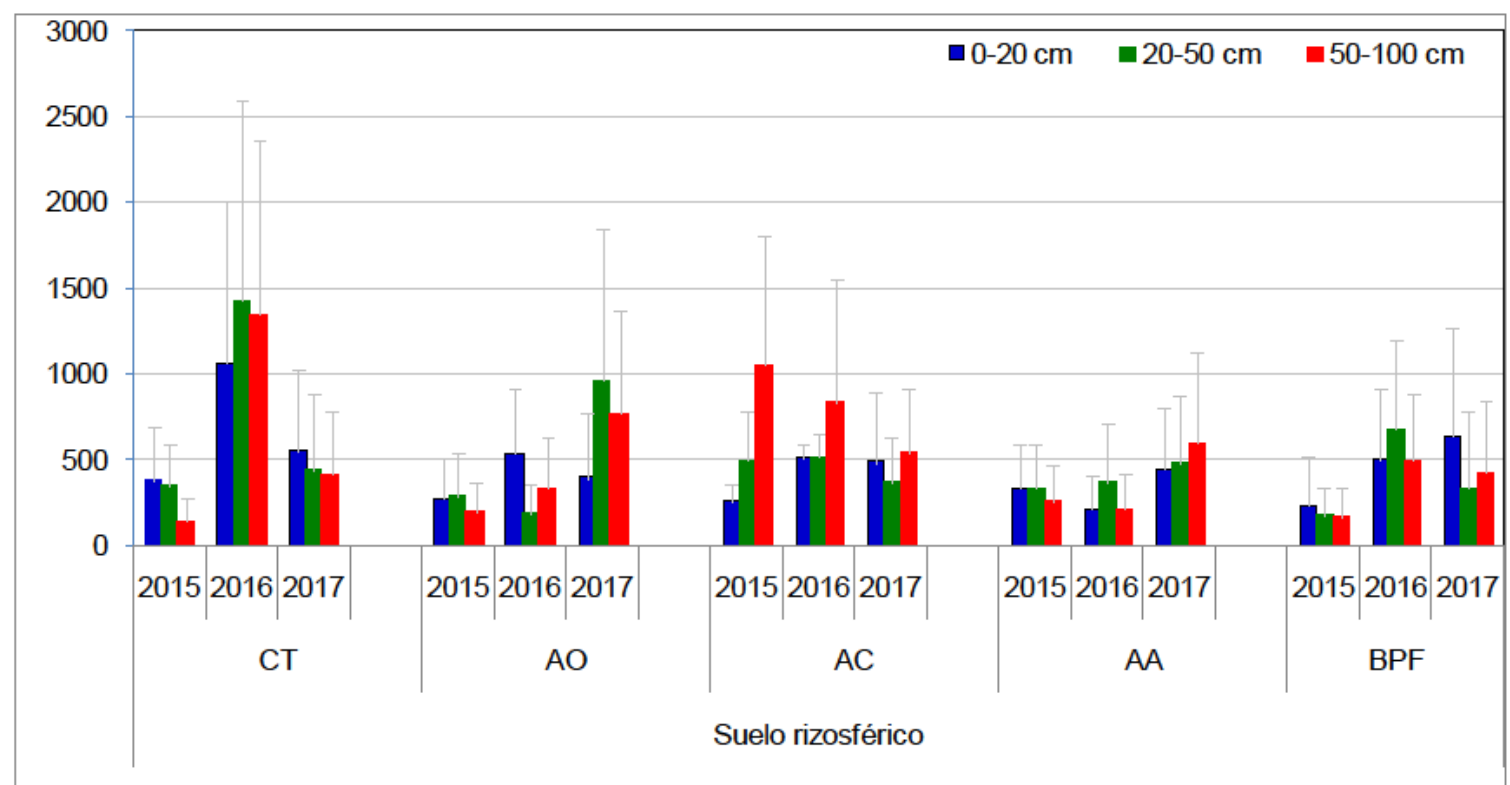

Figura 6.4.53. Evolución temporal de $\mathrm{Cr}$ total $(\mathrm{mg} / \mathrm{kg})$ en suelo rizosférico entre 3 muestreos anuales $(2015,2016$ y 2017) en parcelas control (CT) y parcelas tratadas con dosis de 5 $\mathrm{mmol} / \mathrm{kg}$ de ácido oxálico (AO), ácido cítrico (AC), aminoácidos (AA) y bacterias Pseudomonas fluorescens (BPF) y 5 aplicaciones (junio 2016, septiembre 2016, enero 2017, abril 2017 y junio 2017), $n=3$.

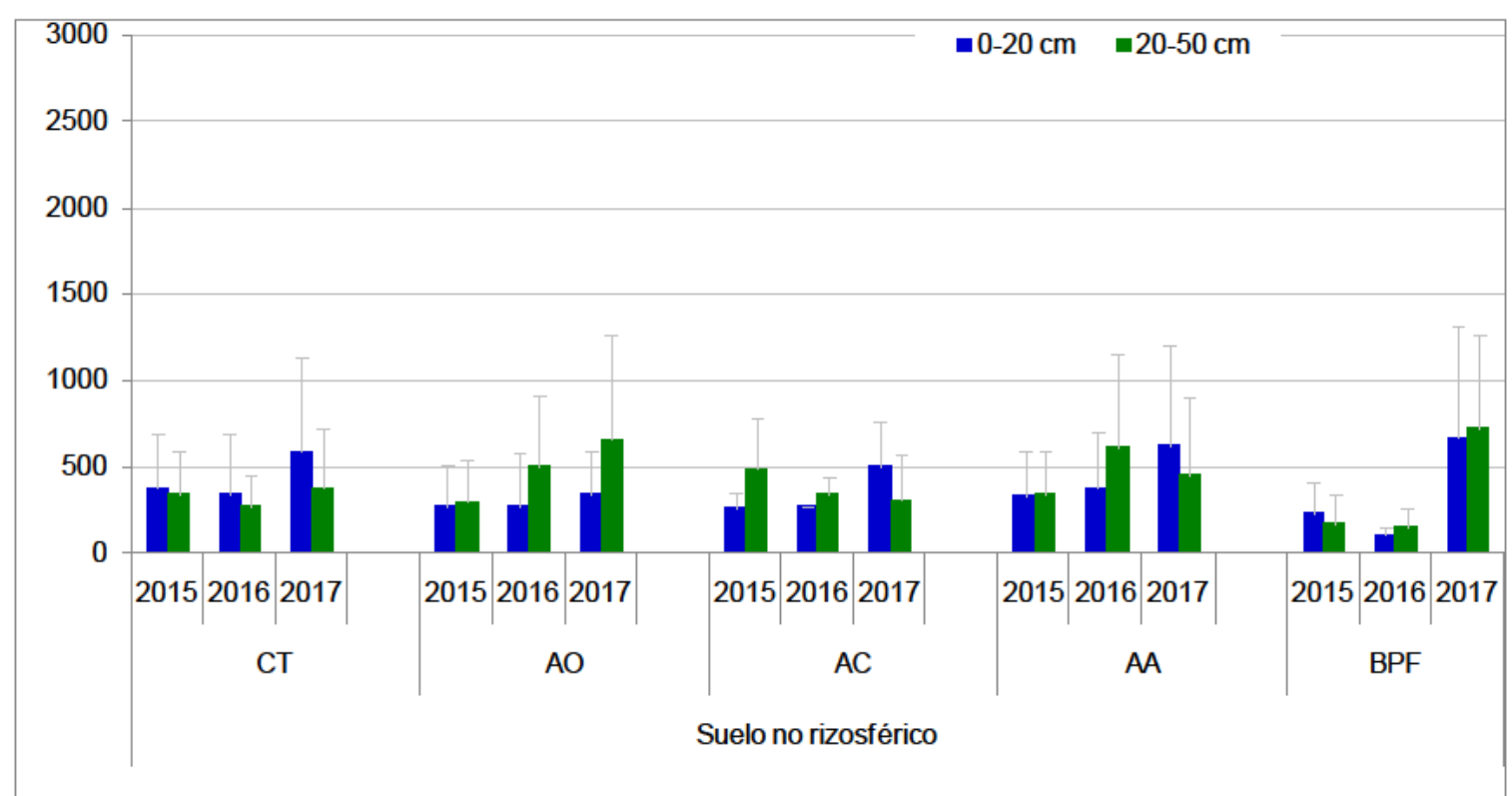

Figura 6.4.54. Evolución temporal de $\mathrm{Cr}$ total $(\mathrm{mg} / \mathrm{kg})$ en suelo no rizosférico entre 3 muestreos anuales $(2015,2016$ y 2017$)$ en parcelas control (CT) y parcelas tratadas con dosis de $5 \mathrm{mmol} / \mathrm{kg}$ de ácido oxálico (AO), ácido cítrico (AC), aminoácidos (AA) y bacterias Pseudomonas fluorescens (BPF) y 5 aplicaciones (junio 2016, septiembre 2016, enero 2017, abril 2017 y junio 2017), $\mathrm{n}=3$. 


\section{Evolución 2015-2016-2017 de Cr total:}

En las figuras anteriores se puede observar la variación entre los años 2015, 2016 y 2017 de las concentraciones de $\mathrm{Cr}$ total en los sedimentos del suelo rizosférico y del suelo no rizosférico en las diferentes profundidades muestreadas $(0-20 \mathrm{~cm}, 20-50 \mathrm{~cm}$ y $50-100 \mathrm{~cm})$. En el suelo rizosférico las concentraciones medias de $\mathrm{Cr}$ total fueron $456.18 \mathrm{mg} / \mathrm{kg}(0-20$ $\mathrm{cm}), 495,36 \mathrm{mg} / \mathrm{kg}(20-50 \mathrm{~cm})$ y $521,72 \mathrm{mg} / \mathrm{kg}(50-100 \mathrm{~cm})$ y oscilaron entre $150,08 \mathrm{mg} / \mathrm{kg}$ (CT, 50-100 cm, 2015) y $1423,64 \mathrm{mg} / \mathrm{kg}(\mathrm{CT}, 20-50 \mathrm{~cm}, 2016)$. Para cada uno de los tratamientos no se detectaron diferencias significativas entre las diferentes profundidades muestreadas $(0-20 \mathrm{~cm}, 20-50 \mathrm{~cm}$ y $50-100 \mathrm{~cm})$. Y para cada tratamiento y profundidad, sólo se detectaron concentraciones significativamente superiores en las parcelas $A O(0-20 \mathrm{~cm}$ en 2016 y en 2017; 20-50 cm en 2017).

En el suelo no rizosférico las concentraciones medias de $\mathrm{Cr}$ total fueron $373,19 \mathrm{mg} / \mathrm{kg}(0-20$ cm) y $403,97 \mathrm{mg} / \mathrm{kg}(20-50 \mathrm{~cm})$ y oscilaron entre $104,24 \mathrm{mg} / \mathrm{kg}(B P F, 0-20 \mathrm{~cm}, 2016)$ y $724,75 \mathrm{mg} / \mathrm{kg}$ (BPF, 20-50 cm, 2017). Entre el suelo rizosférico y el suelo no rizosférico (años 2016 y 2017, profundidades de $0-20 \mathrm{~cm}$ y $20-50 \mathrm{~cm}$ )) solamente se registraron diferencias estadísticamente significativas en las parcelas AO (20-50 cm en 2016 y en 2017), en las parcelas AC (0-20 cm en 2016), en las parcelas AA (0-20 cm y $20-50 \mathrm{~cm}$ en 2017) y en las parcelas BPF (0-20 cm y $20-50 \mathrm{~cm}$ en 2016). 


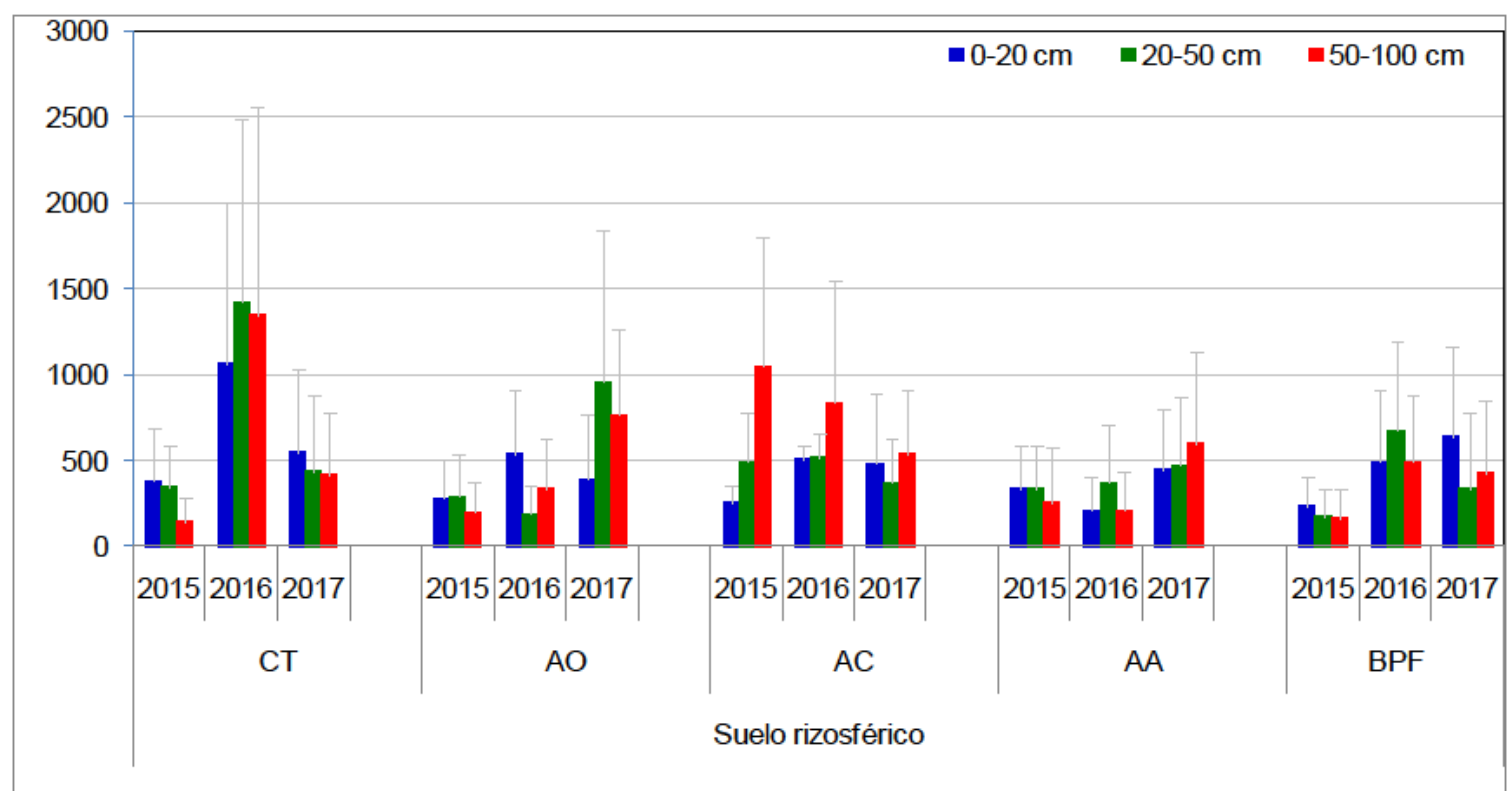

Figura 6.4.55. Evolución temporal de $\mathrm{Cr}$ (III) total $(\mathrm{mg} / \mathrm{kg})$ en suelo rizosférico entre 3 muestreos anuales $(2015,2016$ y 2017$)$ en parcelas control (CT) y parcelas tratadas con dosis de $5 \mathrm{mmol} / \mathrm{kg}$ de ácido oxálico (AO), ácido cítrico ( $\mathrm{AC}$ ), aminoácidos (AA) y bacterias Pseudomonas fluorescens (BPF) y 5 aplicaciones (junio 2016, septiembre 2016, enero 2017, abril 2017 y junio 2017), $n=3$.

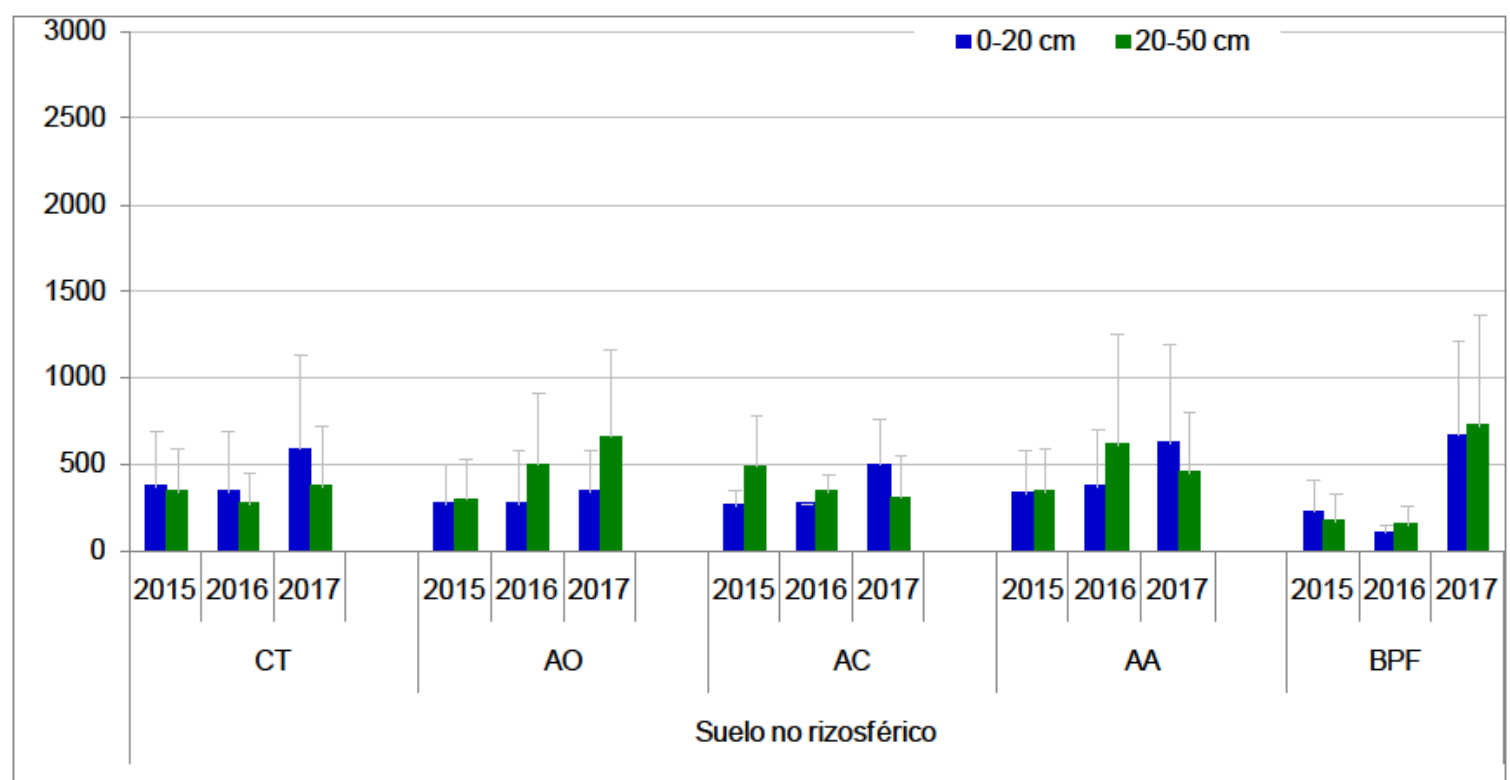

Figura 6.4.56. Evolución temporal de $\mathrm{Cr}$ (III) total $(\mathrm{mg} / \mathrm{kg})$ en suelo no rizosférico entre 3 muestreos anuales $(2015,2016$ y 2017$)$ en parcelas control (CT) y parcelas tratadas con dosis de $5 \mathrm{mmol} / \mathrm{kg}$ de ácido oxálico (AO), ácido cítrico (AC), aminoácidos (AA) y bacterias Pseudomonas fluorescens (BPF) y 5 aplicaciones (junio 2016, septiembre 2016, enero 2017, abril 2017 y junio 2017), $n=3$. 


\section{Evolución 2015-2016-2017 de Cr (III) total:}

En las figuras anteriores se puede observar la variación entre los años 2015, 2016 y 2017 de las concentraciones de $\mathrm{Cr}$ (III) total en los sedimentos del suelo rizosférico y del suelo no rizosférico en las diferentes profundidades muestreadas $(0-20 \mathrm{~cm}, 20-50 \mathrm{~cm}$ y $50-100 \mathrm{~cm})$. En el suelo rizosférico las concentraciones medias de $\mathrm{Cr}$ (III) total fueron 455,68 mg/kg (0-20 $\mathrm{cm}), 494,92 \mathrm{mg} / \mathrm{kg}(20-50 \mathrm{~cm})$ y $521,28 \mathrm{mg} / \mathrm{kg}(50-100 \mathrm{~cm})$ y oscilaron entre $149,63 \mathrm{mg} / \mathrm{kg}$ (CT, 50-100 cm, 2015) y $1422,18 \mathrm{mg} / \mathrm{kg}$ (CT, $20-50 \mathrm{~cm}, 2016)$. Para cada uno de los tratamientos no se detectaron diferencias significativas entre las diferentes profundidades muestreadas $(0-20 \mathrm{~cm}, 20-50 \mathrm{~cm}$ y $50-100 \mathrm{~cm})$. Y para cada tratamiento y profundidad, al igual que con $\mathrm{Cr}$ total, sólo se detectaron concentraciones significativamente superiores en las parcelas AO (0-20 cm en 2016 y 2017; 20-50 cm en 2017).

En el suelo no rizosférico las concentraciones medias de $\mathrm{Cr}$ (III) total fueron $372,69 \mathrm{mg} / \mathrm{kg}$ $(0-20 \mathrm{~cm})$ y 403,65 mg/kg $(20-50 \mathrm{~cm})$ y oscilaron entre $104,24 \mathrm{mg} / \mathrm{kg}(B P F, 0-20 \mathrm{~cm}, 2016)$ y $724,30 \mathrm{mg} / \mathrm{kg}$ (BPF, 20-50 cm, 2017). Entre el suelo rizosférico y el suelo no rizosférico (años 2016 y 2017, profundidades de $0-20 \mathrm{~cm}$ y $20-50 \mathrm{~cm}$ )) solamente se registraron diferencias estadísticamente significativas en las parcelas $A O$ (20-50 cm en 2017), en las parcelas AA (0-20 cm y 20-50 cm en 2017) y en las parcelas BPF (20-50 cm en 2016). 


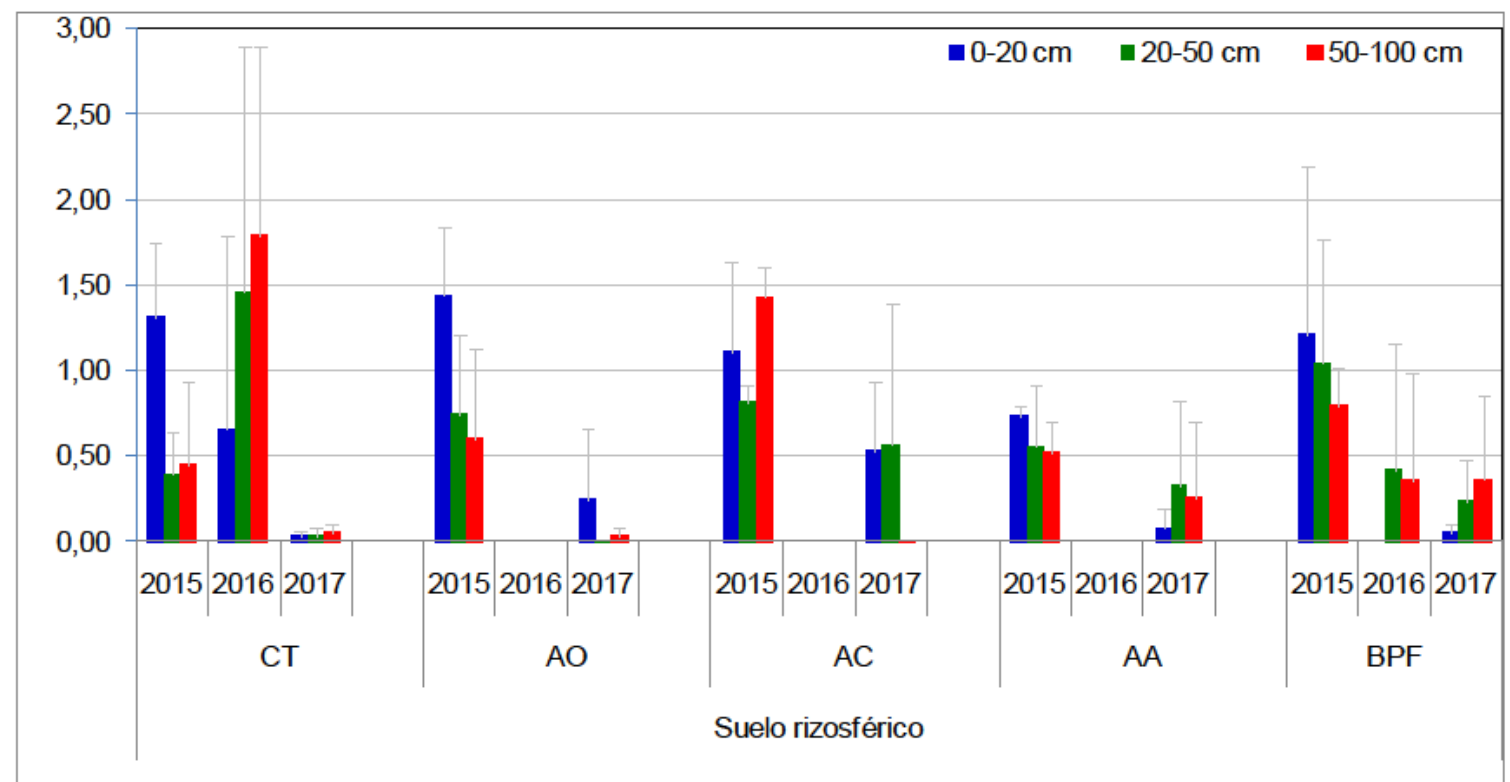

Figura 6.4.57. Evolución temporal de $\mathrm{Cr}(\mathrm{Vl})$ total $(\mathrm{mg} / \mathrm{kg})$ en suelo rizosférico entre 3 muestreos anuales $(2015,2016$ y 2017$)$ en parcelas control (CT) y parcelas tratadas con dosis de $5 \mathrm{mmol} / \mathrm{kg}$ de ácido oxálico (AO), ácido cítrico ( $A C)$, aminoácidos (AA) y bacterias Pseudomonas fluorescens (BPF) y 5 aplicaciones (junio 2016, septiembre 2016, enero 2017, abril 2017 y junio 2017), $n=3$.

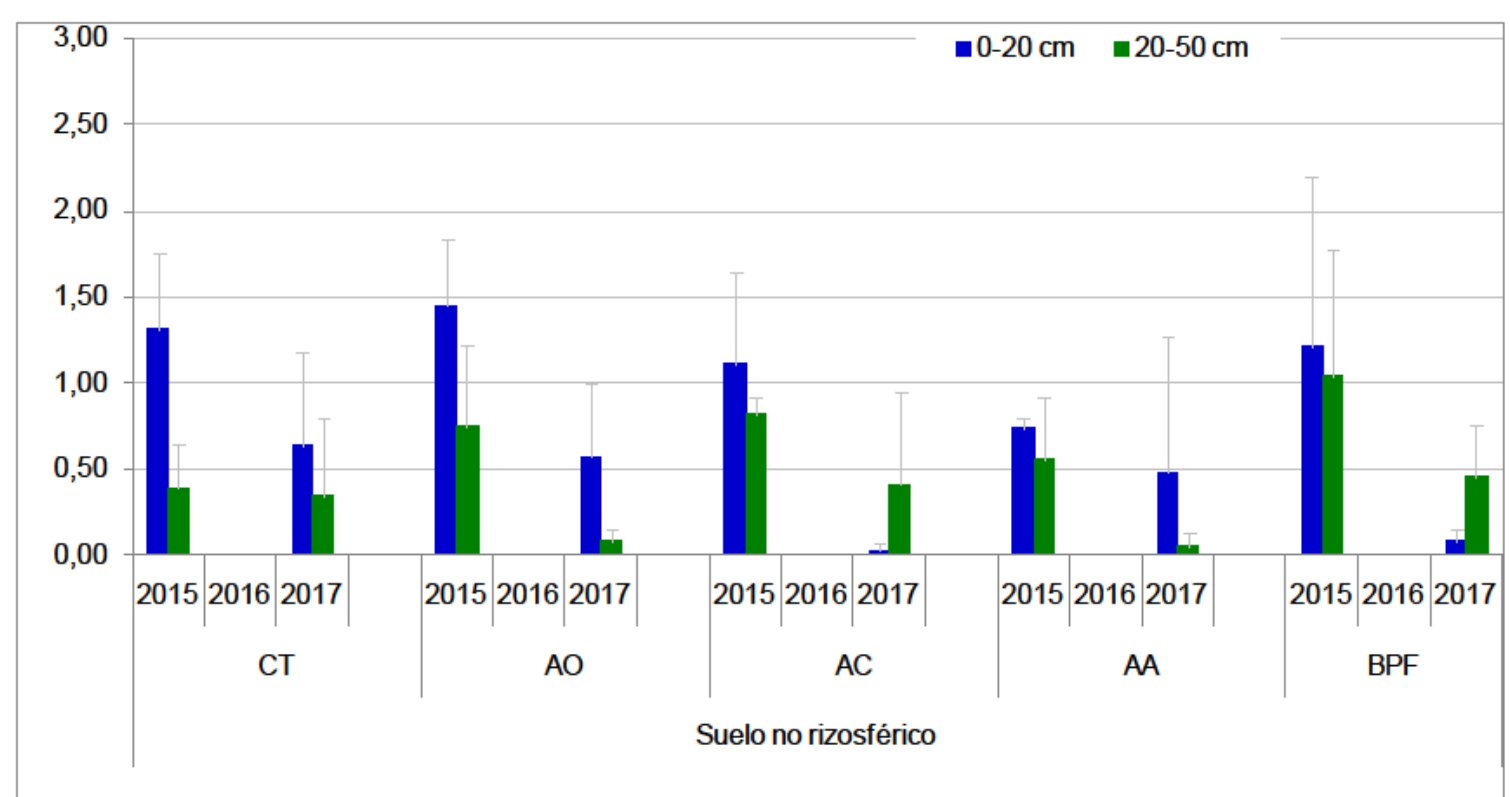

Figura 6.4.58. Evolución temporal de $\mathrm{Cr}(\mathrm{VI})$ total $(\mathrm{mg} / \mathrm{kg})$ en suelo no rizosférico entre 3 muestreos anuales $(2015,2016$ y 2017$)$ en parcelas control (CT) y parcelas tratadas con dosis de $5 \mathrm{mmol} / \mathrm{kg}$ de ácido oxálico (AO), ácido cítrico (AC), aminoácidos (AA) y bacterias Pseudomonas fluorescens (BPF) y 5 aplicaciones (junio 2016, septiembre 2016, enero 2017, abril 2017 y junio 2017), $\mathrm{n}=3$. 


\section{Evolución 2015-2016-2017 de Cr (VI) total:}

En las figuras anteriores se puede observar la variación entre los años 2015, 2016 y 2017 de las concentraciones de $\mathrm{Cr}(\mathrm{VI})$ total en los sedimentos del suelo rizosférico y del suelo no rizosférico en las diferentes profundidades muestreadas $(0-20 \mathrm{~cm}, 20-50 \mathrm{~cm}$ y 50-100 cm). En el suelo rizosférico las concentraciones medias de $\mathrm{Cr}(\mathrm{VI})$ total fueron $0,49 \mathrm{mg} / \mathrm{kg}(0-20$ $\mathrm{cm}), 0,44 \mathrm{mg} / \mathrm{kg}(20-50 \mathrm{~cm})$ y $0,44 \mathrm{mg} / \mathrm{kg}(50-100 \mathrm{~cm})$ y oscilaron entre $0 \mathrm{mg} / \mathrm{kg}$ (AC, todas las profundidades, 2016; AC, todas las profundidades, 2016; AA, todas las profundidades, 2016; BPF, 0-20 cm, 2016) y 1,79 mg/kg (CT, 50-100 cm, 2016). Para cada uno de los tratamientos no se detectaron diferencias significativas entre las diferentes profundidades muestreadas $(0-20 \mathrm{~cm}, 20-50 \mathrm{~cm}$ y $50-100 \mathrm{~cm})$. Y para cada tratamiento y profundidad, sólo se detectaron concentraciones significativamente superiores en el año 2015 con respecto a los años 2016 y 2017 en las parcelas CT (0-20 cm y 20-0 cm), AO (0-20 cm y 20-5 cm), AC $(0-20 \mathrm{~cm}, 20-50 \mathrm{~cm}$ y $50-100 \mathrm{~cm})$ y AA $(0-20 \mathrm{~cm})$, posiblemente debido a su absorción por la vegetación fitoextractora.

En el suelo no rizosférico las concentraciones medias de $\mathrm{Cr}(\mathrm{VI})$ total fueron $0,51 \mathrm{mg} / \mathrm{kg}(0-$ $20 \mathrm{~cm})$ y $0,33 \mathrm{mg} / \mathrm{kg}(20-50 \mathrm{~cm})$ y oscilaron entre $0 \mathrm{mg} / \mathrm{kg}(\mathrm{CT}$, todas las profundidades, 2016, AO, todas las profundidades, 2016; AC, todas las profundidades, 2016; AA, todas las profundidades, 2016, BPF, todas las profundidades, 2016)) y $1,44 \mathrm{mg} / \mathrm{kg}(\mathrm{AO}, 0-20 \mathrm{~cm}$, 2015). Entre el suelo rizosférico y el suelo no rizosférico (años 2016 y 2017, profundidades de 0-20 cm y 20-50 cm)) solamente se registraron diferencias estadísticamente significativas en las parcelas CT (0-20 cm en 2016), en las parcelas AO (20-50 cm en 2016 y en 2017 y 0$20 \mathrm{~cm}$ en 2017), en las parcelas AC (0-20 cm en 2016 y en 2017) y en las parcelas BPF (0$20 \mathrm{~cm}$ y $20-50 \mathrm{~cm}$ en 2016). 
Entre las concentraciones de metales y las propiedades físico-químicas y bioquímicas se han encontrado correlaciones muy interesantes. En algunos casos las correlaciones encontradas muestran una relación directa que las explica totalmente y nos pueden ayudar con la investigación e incluso a mejorar la técnica de fitoextracción, especialmente en el caso de $\mathrm{Cr}$, dada la gran superficie contaminada. A continuación se resumen para cada elemento metálico:

Cobre: la concentración de Cu total viene dada principalmente por la fracción de Cu residual $\left(\mathrm{r}=+0,984^{\star \star}\right)$, seguida por las fracciones Cu ligado a óxidos de Fe y $\mathrm{Mn}\left(\mathrm{r}=+0,673^{\star \star}\right)$ y $\mathrm{Cu}$ ligado a la materia orgánica y sulfuros $\left(r=+0,662^{\star *}\right)$. Por otro lado, también se encuentran correlaciones destacables entre el $\mathrm{Cu}$ total y las siguientes fracciones de $\mathrm{Zn}$ : Zn ligado a carbonatos $\left(r=+0,577^{\star \star}\right)$, Zn ligado a óxidos de Fe y $\mathrm{Mn}\left(\left(\mathrm{r}=+0,540^{\star \star}\right)\right.$ y $\mathrm{Zn}$ ligado a la materia orgánica y sulfuros $\left(r=+0,557^{\star \star}\right)$. Con respecto al $\mathrm{Cr}$ total y sus fracciones no se encuentran correlaciones destacables con el $\mathrm{Cu}$ total. Tampoco se registran correlaciones destacables entre el $\mathrm{Cu}$ total y el resto de propiedades físico-químicas y bioquímicas de los sedimentos del suelo.

Zinc: la concentración de Zn total viene dada principalmente por la fracción de Zn residual $\left(r=+0,846^{\star *}\right)$, seguida por las fracciones $\mathrm{Cu}$ ligado a óxidos de $\mathrm{Fe}$ y $\mathrm{Mn}(\mathrm{r}=+0,597)$ y $\mathrm{Cu}$ ligado a la materia orgánica y sulfuros $\left(r=+0,602^{\star \star}\right)$, estas fracciones a su vez muestran buenas correlaciones con el COT $\left(r=+0,752^{\star \star}\right.$ y $r=+0,659^{\star *}$ respectivamente) y con los carbonatos ( $r=-0,845^{\star \star}$ y $r=-0,719^{\star \star}$ respectivamente). Por otro lado, también se encuentran correlaciones destacables entre el $\mathrm{Cu}$ total y las siguientes fracciones de $\mathrm{Cu}$ y de $\mathrm{Cr}$ : $\mathrm{Cu}$ ligado a la materia orgánica y sulfuros $\left(r=+0,543^{* \star}\right)$ y $\mathrm{Cr}$ residual $\left(+0,510^{\star \star}\right)$. También se registra una correlación moderada entre el $Z n$ total y el COT $\left(r=+0,508^{\star \star}\right)$. Con respecto al Zn soluble destaca la correlación encontrada con el $Z n$ intercambiable $\left(r=+0,742^{\star \star}\right)$ y también entre el Zn intercambiable y el CBM $\left(r=-0,675^{\star *}\right)$.

Cromo: la concentración de $\mathrm{Cr}$ total viene dada principalmente por la fracción de Cr ligado a los óxidos de Fe y $\mathrm{Mn}\left(\mathrm{r}=+0,985^{\star \star}\right)$, seguida de las fracciones de $\mathrm{Cr}$ ligado a la materia orgánica y sulfuros $\left(r=+0,881^{\star \star}\right)$ y de $\mathrm{Cr}$ residual $\left(r=+0,815^{\star \star}\right)$ y en menos medida por la fracción de $\mathrm{Cr}$ ligado a los carbonatos $\left(r=+0,507^{\star *}\right)$, la cual justifica la correlación encontrada entre el $\mathrm{Cr}$ total y los carbonatos $\left(r=-0,662^{\star \star}\right)$. Además, la concentración de $\mathrm{Cr}$ (III) total viene dada directamente por la fracción de $\mathrm{Cr}$ total $(r=+1,000)$. Por otro lado, también se registran correlaciones interesantes entre el $\mathrm{Cr}$ total y las siguientes fracciones de metales: Zn ligado a los carbonatos ( $\left.r=+0,600^{\star \star}\right)$, Cu y Zn ligados a los óxidos de Fe y Mn $\left(r=+0,504^{\star *}\right.$ 
Capítulo 6. MONITORIZACIÓN AMBIENTAL DE LAS PROPIEDADES FÍSICO-QUÍMICAS Y BIOQUÍMICAS DE LOS SEDIMENTOS DEL SUELO EN PARCELAS EXPERIMENTALES TRATADAS

y $r=+0,706^{\star *}$ respectivamente) y $\mathrm{Cu}$ y $\mathrm{Zn}$ ligados a la materia orgánica $\left(r=+0,725^{\star \star}\right.$ y $r=+0,582^{\star \star}$ respectivamente).

Con el resto de propiedades físico-químicas y bioquímicas también se han encontrado correlaciones destacables: carbonatos y COT $(r=-0,687)$ y REB y COT $\left(r=+0,750^{\star \star}\right)$.

\subsection{EVOLUCIÓN QUINCENAL DE LAS CONCENTRACIONES DE METALES Y PROPIEDADES FÍSICO-QUÍMICAS}

En las Figuras 6.5.1-6.5.40 se muestra la evolución quincenal en suelo rizosférico (junio 2016 - septiembre 2017, 27 muestreos) de los resultados de pH, CE, metales Cu, Zn y Cr solubles y metales $\mathrm{Cu}, \mathrm{Zn}$ y $\mathrm{Cr}$ biodisponibles. 


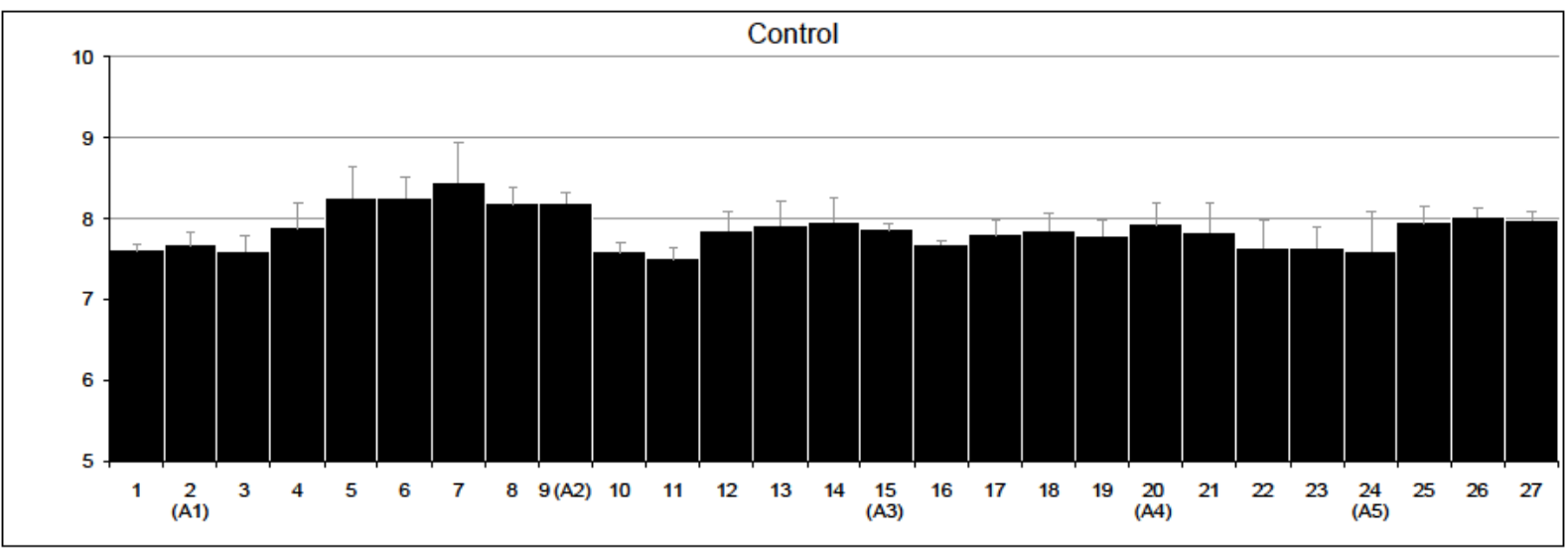

Figura 6.5.1. Evolución temporal de los valores de $\mathrm{pH}$ en suelo rizosférico $(0-20 \mathrm{~cm})$ durante 27 muestreos realizados con periodicidad quincenal entre junio 2016 y septiembre 2017 en parcelas control (CT) y 5 aplicaciones (junio 2016, septiembre 2016, enero 2017, abril 2017 y junio 2017), $n=3$.

En las parcelas control los valores de $\mathrm{pH}$ oscilaron entre 7,50 (valor mínimo) y 8,45 (valor máximo), siendo el valor promedio de $7,87 \pm 0,24$.

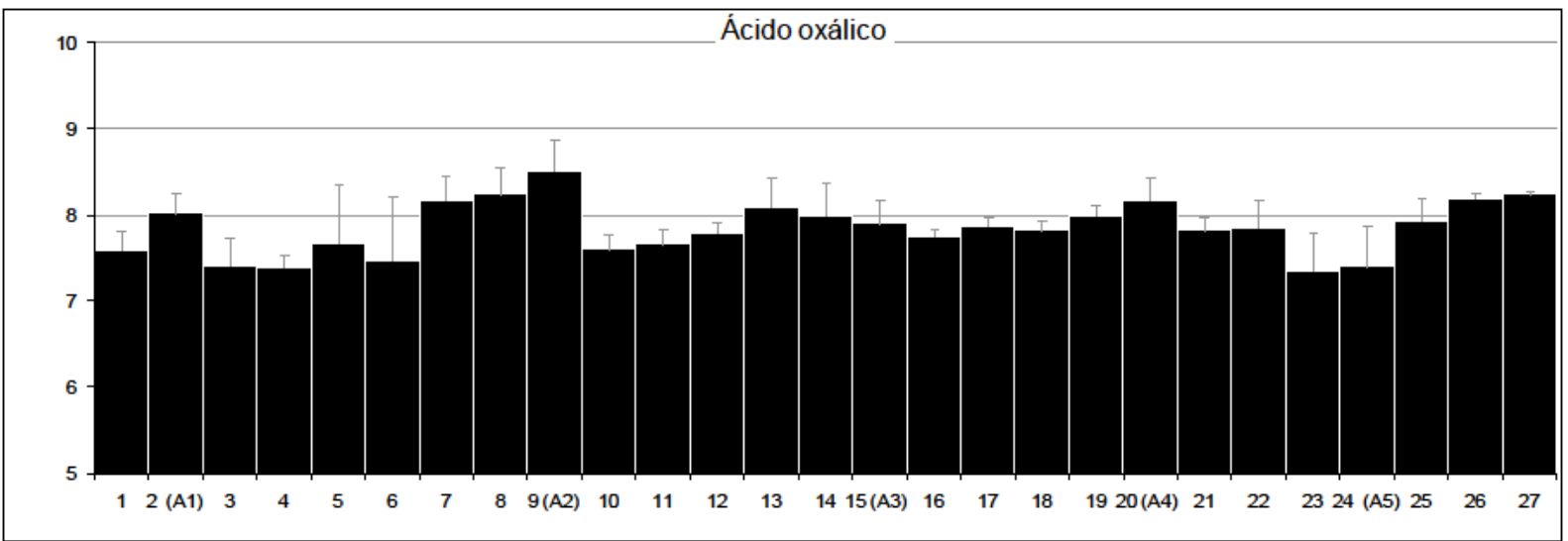

Figura 6.5.2. Evolución temporal de los valores de $\mathrm{pH}$ en suelo rizosférico $(0-20 \mathrm{~cm})$ durante 27 muestreos realizados con periodicidad quincenal entre junio 2016 y septiembre 2017 en parcelas tratadas con dosis de $5 \mathrm{mmol} / \mathrm{kg}$ de ácido oxálico (AO) y 5 aplicaciones (junio 2016, septiembre 2016, enero 2017, abril 2017 y junio 2017), n=3.

En las parcelas tratados con ácido oxálico los valores de $\mathrm{pH}$ oscilaron entre 7,36 (valor

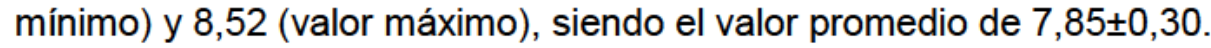




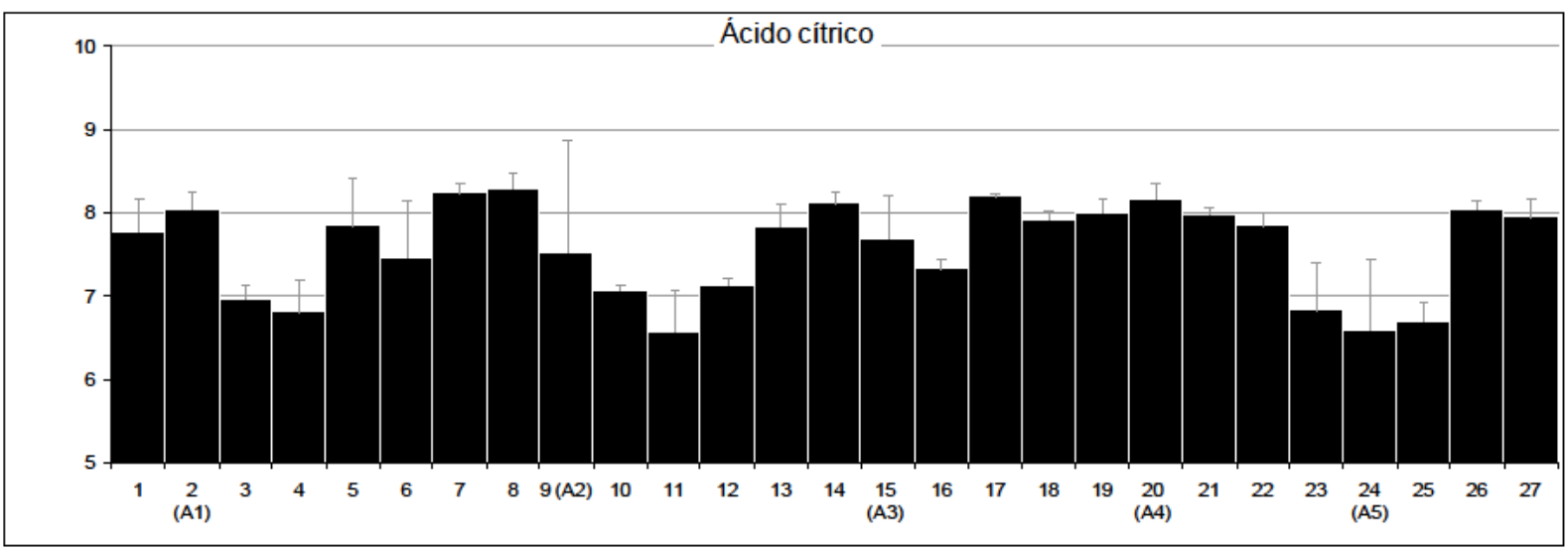

Figura 6.5.3. Evolución temporal de los valores de $\mathrm{pH}$ en suelo rizosférico $(0-20 \mathrm{~cm})$ durante 27 muestreos realizados con periodicidad quincenal entre junio 2016 y septiembre 2017 en parcelas tratadas con dosis de $5 \mathrm{mmol} / \mathrm{kg}$ de ácido cítrico (AC) y 5 aplicaciones (junio 2016, septiembre 2016, enero 2017, abril 2017 y junio 2017), n=3.

En las parcelas tratados con ácido cítrico los valores de $\mathrm{pH}$ oscilaron entre 6,57 (valor mínimo) y 8,30 (valor máximo), siendo el valor promedio de 7,59 $\pm 0,56$.

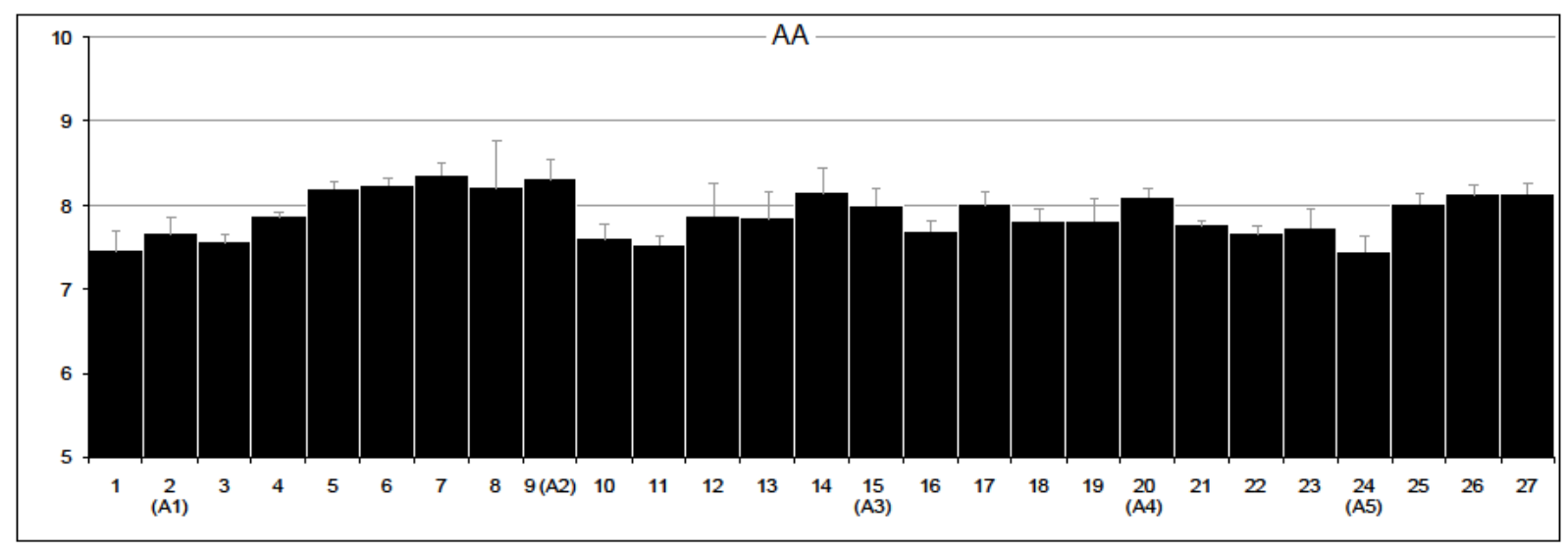

Figura 6.5.4. Evolución temporal de los valores de $\mathrm{pH}$ en suelo rizosférico $(0-20 \mathrm{~cm})$ durante 27 muestreos realizados con periodicidad quincenal entre junio 2016 y septiembre 2017 en parcelas tratadas con aminoácidos (AA) y 5 aplicaciones (junio 2016, septiembre 2016, enero 2017, abril 2017 y junio 2017), n=3.

En las parcelas tratados con aminoácidos los valores de $\mathrm{pH}$ oscilaron entre 7,45 (valor

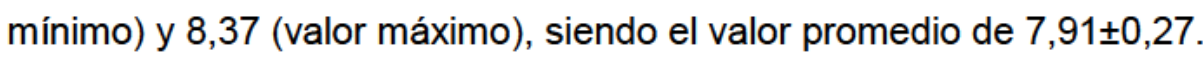




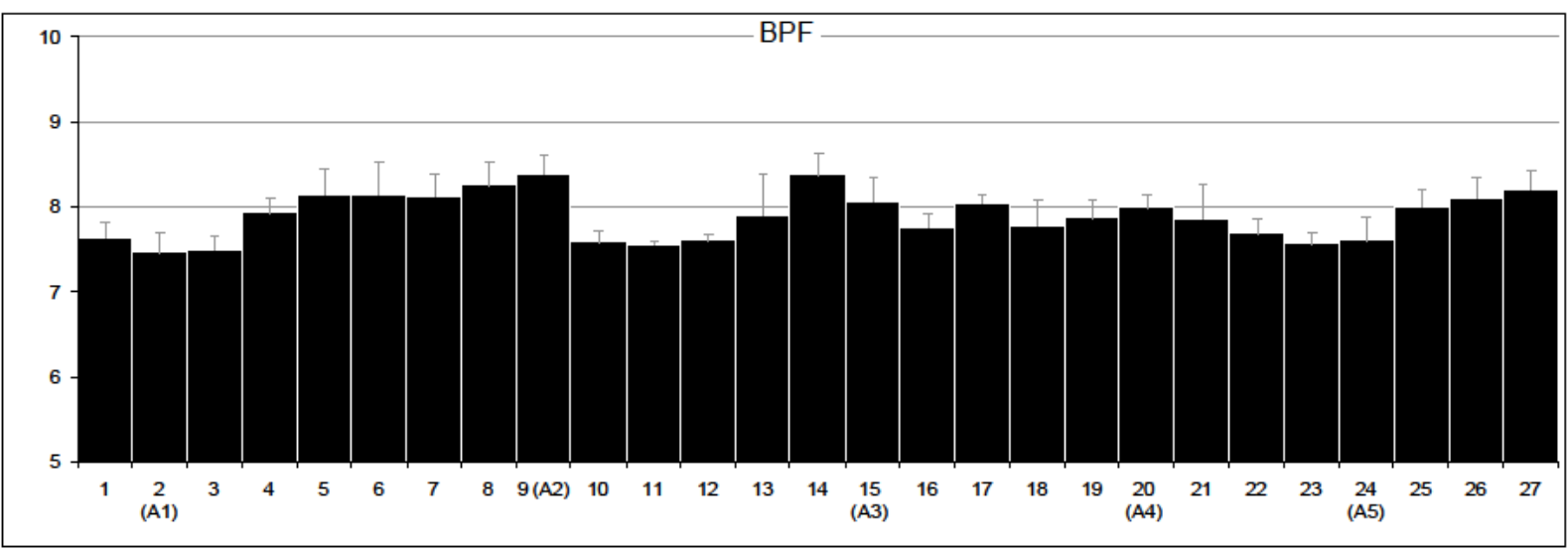

Figura 6.5.5. Evolución temporal de los valores de $\mathrm{pH}$ en suelo rizosférico $(0-20 \mathrm{~cm})$ durante 27 muestreos realizados con periodicidad quincenal entre junio 2016 y septiembre 2017 en parcelas tratadas con bacterias Pseudomonas fluorescens (BPF) y 5 aplicaciones (junio 2016, septiembre 2016, enero 2017, abril 2017 y junio 2017), $n=3$.

En las parcelas tratados con bacterias Pseudomonas fluorescens los valores de $\mathrm{pH}$ oscilaron entre 7,46 (valor mínimo) y 8,39 (valor máximo), siendo el valor promedio de $7,90 \pm 0,27$.

Estadísticamente se observaron valores de $\mathrm{pH}$ significativamente inferiores en las parcelas tratadas con $\mathrm{AC}$ con respecto al resto de tratamientos ( $\mathrm{CT}, \mathrm{AO}, \mathrm{AA}$ y $\mathrm{BPF}$ ). Concretamente se encontró la siguiente tendencia: $A C>C T \sim A O \sim A A \sim B P F$. Los valores estadísticamente más bajos de $\mathrm{pH}$ se registraron en los muestreos 1, 3, 10, 11 y 24 (parcelas $\mathrm{CT}$ ), 3, 4, 23 (justo después de la $A 5$ ) y 24 (parcelas $A O$ ), 11 (parcelas $A C$ ), 24 (parcelas $A A$ ) y muestreos 4,5 , $6,7,8,9$ (justo después de la A2), 10,11,12, 14, 15 (justo después de la A3) y 16 (parcelas $\mathrm{BPF})$. Y los valores estadísticamente más elevados se encontraron en los muestreos 2 (justo después de la $A 1$ ) (parcelas $C T$ ), muestreo 9 (justo después de la $A 2$ ) (parcelas $A O$ ), muestreos 7,8 y 17 (parcelas AC), muestreo 7 (parcelas AA) y muestreo 9 (justo después de la A2) (parcelas BPF), habiéndose realizado las aplicaciones tras los muestreos 1, 8, 14, 18 y 22. Presentando el resto de muestreos un comportamiento intermedio similar. Las aplicaciones se realizaron después de los muestreos 1, 8, 14, 18, 22. 


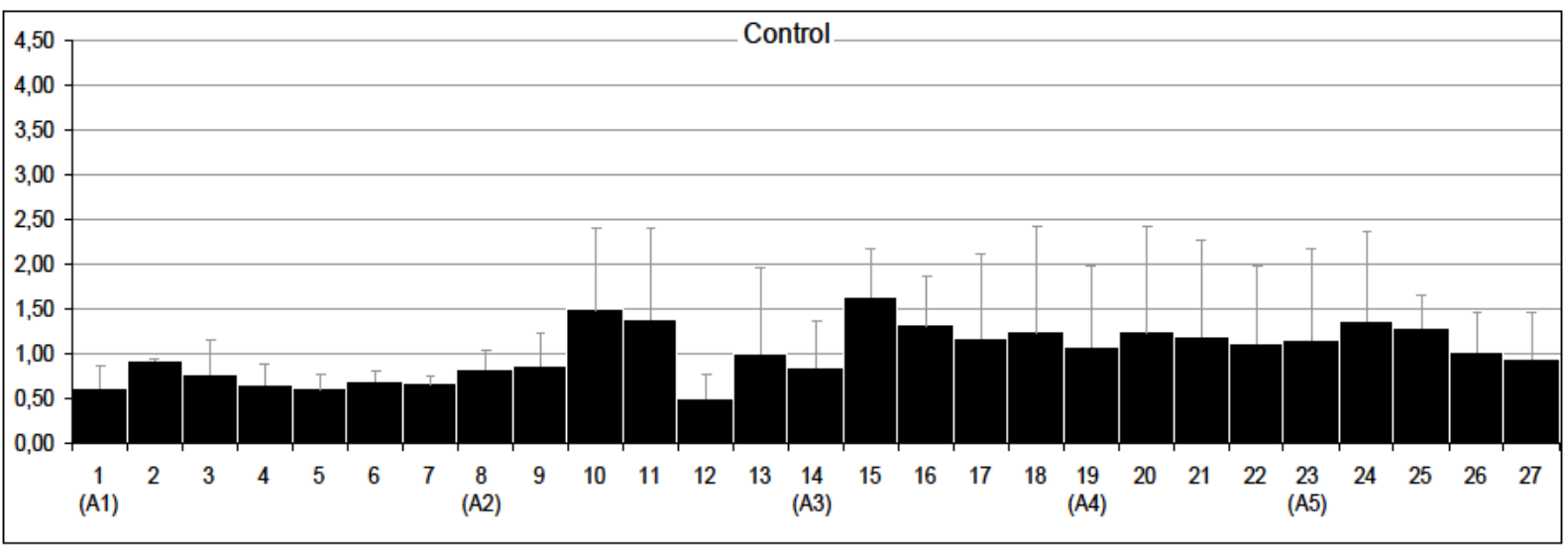

Figura 6.5.6. Evolución temporal de los valores de CE en suelo rizosférico $(0-20 \mathrm{~cm})$ durante 27 muestreos realizados con periodicidad quincenal entre junio 2016 y septiembre 2017 en parcelas control (CT) y 5 aplicaciones (junio 2016, septiembre 2016, enero 2017, abril 2017 $y$ junio 2017), $n=3$.

En las parcelas control los valores de CE oscilaron entre 0,50 (valor mínimo) y 1,63 (valor máximo), siendo el valor promedio de $1,03 \pm 0,30$.

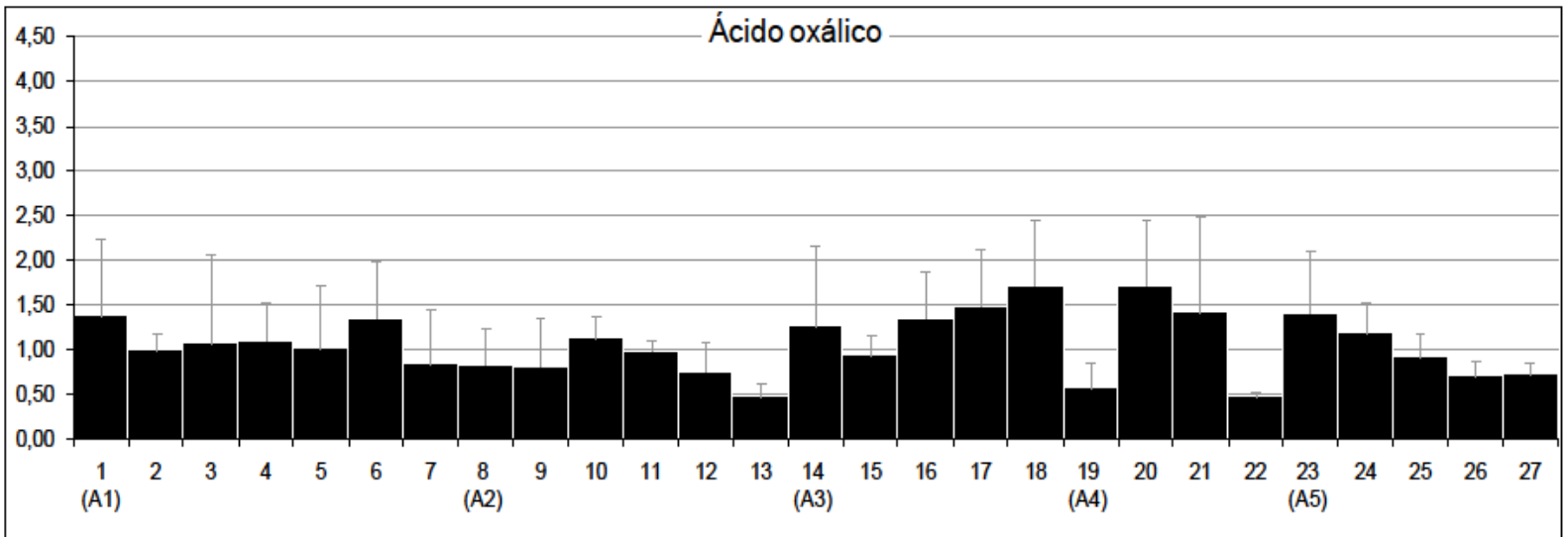

Figura 6.5.7. Evolución temporal de los valores de CE en suelo rizosférico $(0-20 \mathrm{~cm})$ durante 27 muestreos realizados con periodicidad quincenal entre junio 2016 y septiembre 2017 en parcelas tratadas con dosis de $5 \mathrm{mmol} / \mathrm{kg}$ de ácido oxálico (AO) y 5 aplicaciones (junio 2016, septiembre 2016, enero 2017, abril 2017 y junio 2017), n=3.

En las parcelas tratados con ácido oxálico los valores de CE oscilaron entre 0,48 (valor

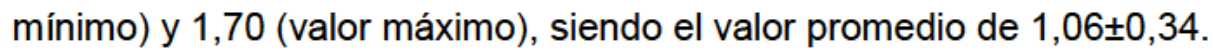




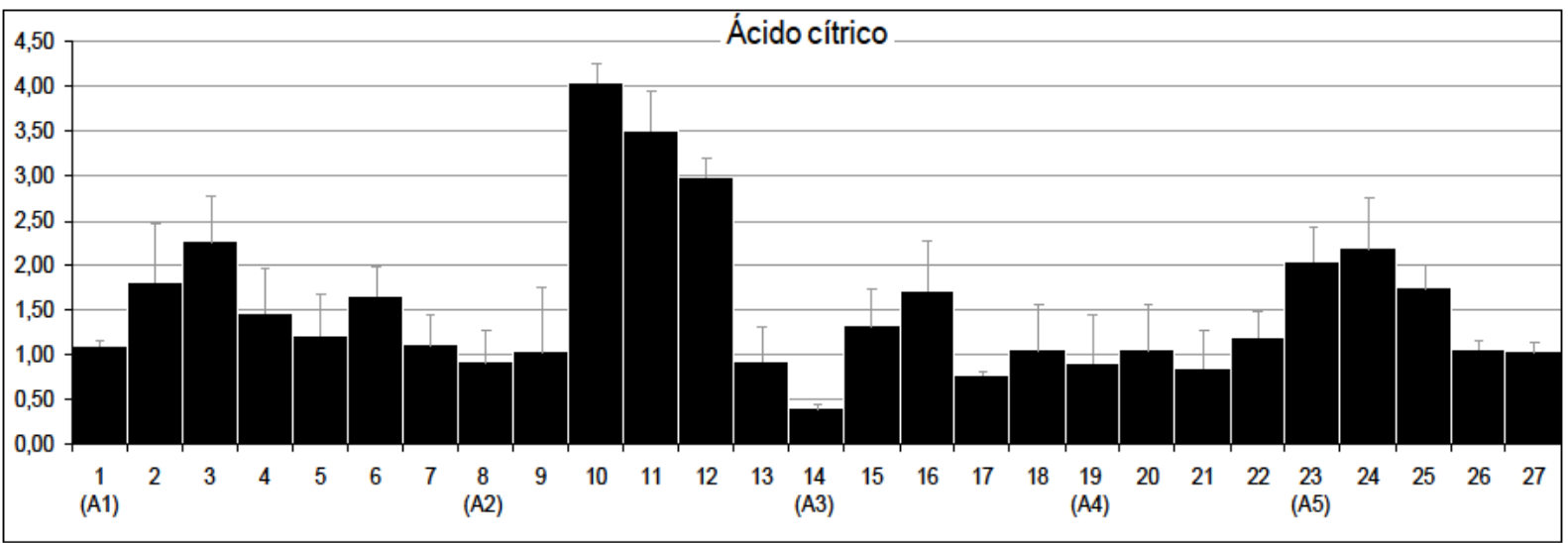

Figura 6.5.8. Evolución temporal de los valores de CE en suelo rizosférico $(0-20 \mathrm{~cm})$ durante 27 muestreos realizados con periodicidad quincenal entre junio 2016 y septiembre 2017 en parcelas tratadas con dosis de $5 \mathrm{mmol} / \mathrm{kg}$ de ácido cítrico (AC) y 5 aplicaciones (junio 2016, septiembre 2016, enero 2017, abril 2017 y junio 2017), $n=3$.

En las parcelas tratados con ácido cítrico los valores de CE oscilaron entre 0,39 (valor

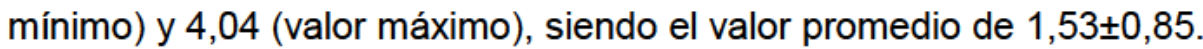

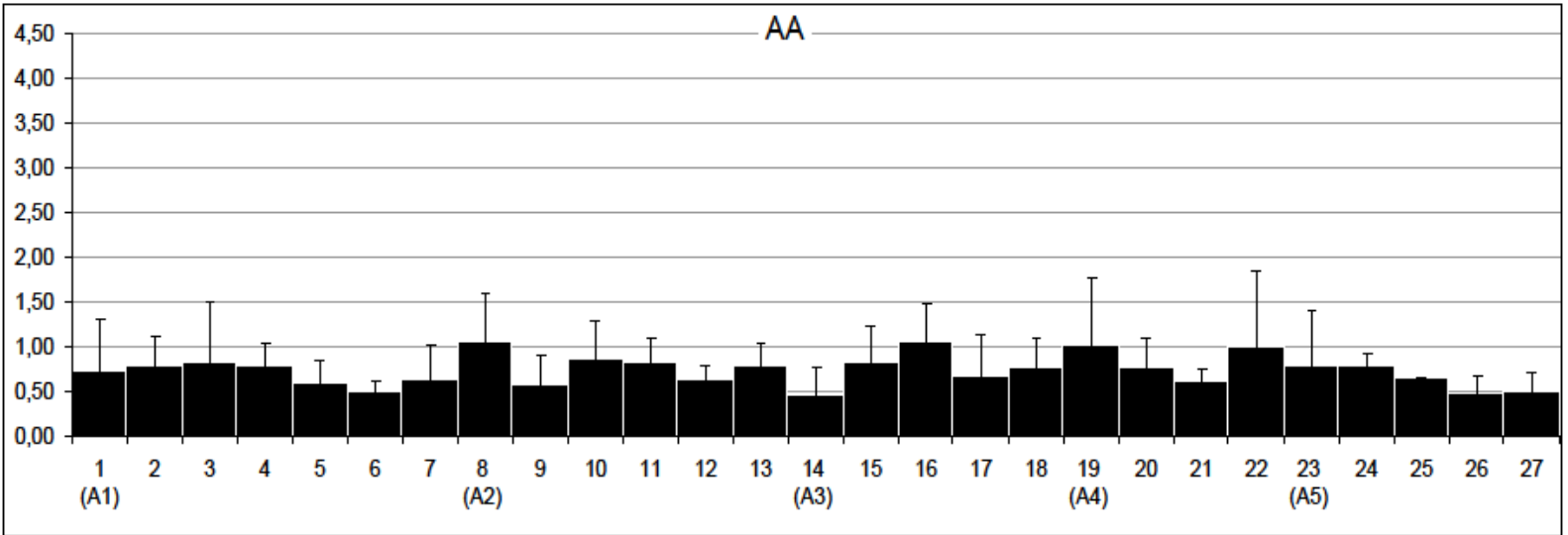

Figura 6.5.9. Evolución temporal de los valores de $C E$ en suelo rizosférico $(0-20 \mathrm{~cm})$ durante 27 muestreos realizados con periodicidad quincenal entre junio 2016 y septiembre 2017 en parcelas tratadas con aminoácidos (AA) y 5 aplicaciones (junio 2016, septiembre 2016, enero 2017, abril 2017 y junio 2017), $\mathrm{n}=3$.

En las parcelas tratados con aminoácidos los valores de CE oscilaron entre 0,47 (valor mínimo) y 1,06 (valor máximo), siendo el valor promedio de $0,74 \pm 0,17$. 


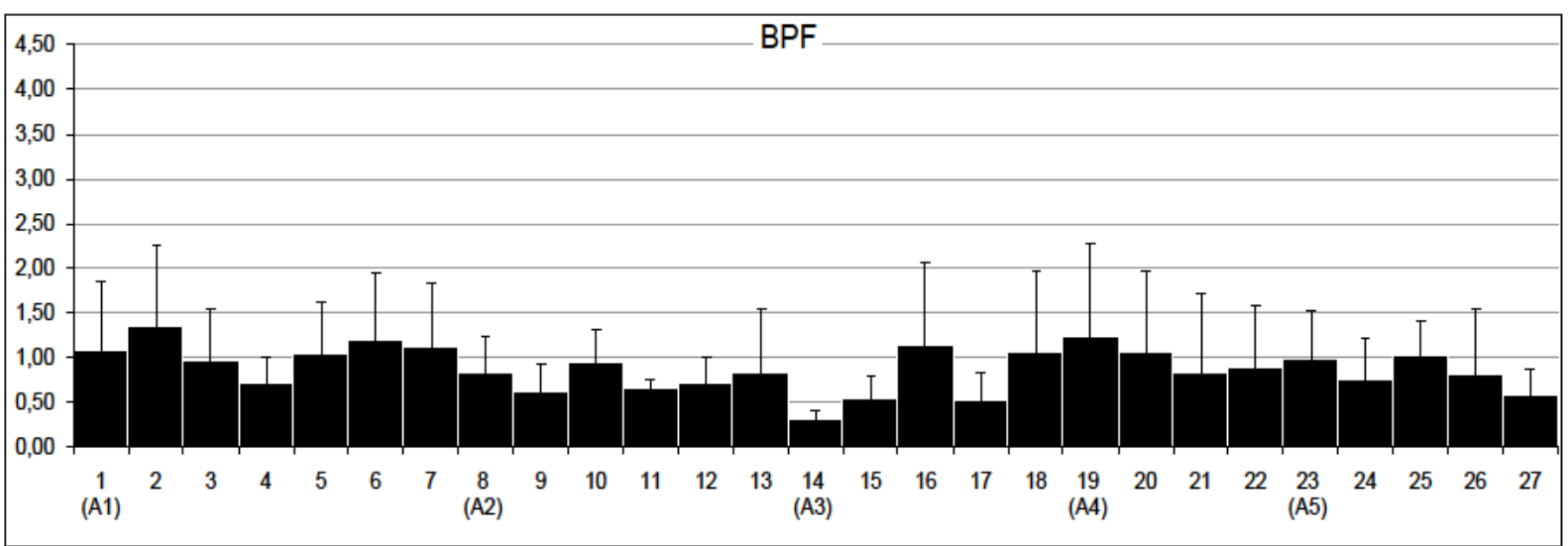

Figura 6.5.10. Evolución temporal de los valores de CE en suelo rizosférico $(0-20 \mathrm{~cm})$ durante 27 muestreos realizados con periodicidad quincenal entre junio 2016 y septiembre 2017 en parcelas tratadas con bacterias Pseudomonas fluorescens (BPF) y 5 aplicaciones (junio 2016, septiembre 2016, enero 2017, abril 2017 y junio 2017), $n=3$.

En las parcelas tratados con bacterias Pseudomonas fluorescens los valores de CE oscilaron entre 0,30 (valor mínimo) y 1,34 (valor máximo), siendo el valor promedio de $0,88 \pm 0,25$.

Estadísticamente se observaron valores de CE significativamente superiores en las parcelas tratadas con $\mathrm{AC}$ con respecto al resto de tratamientos ( $C T, A O, A A$ y BPF). Concretamente se encontró la siguiente tendencia: $A C>C T \sim A O \geq B P F \geq A A$. Puede apreciarse que las parcelas tratadas con $\mathrm{AC}$ además de presentar valores de $\mathrm{pH}$ inferiores también presentan un aumento en los valores de su CE y por tanto una mayor liberación de sales a los sedimentos del suelo. Con respecto a los muestreos y a los valores de la CE, no se registraron diferencias significativas entre muestreos para los tratamientos $C T, A O, A A$ y BPF. Sólo se registraron diferencias estadísticamente significativas entre tratamiento en las parcelas $A C$, el valor estadísticamente más bajo se encontró en el muestreo 14 (justo antes de A3) y el valor estadísticamente más elevado se encontró en el muestreo 10 (poco después de A2). Presentando el resto de muestreos un comportamiento intermedio similar. 


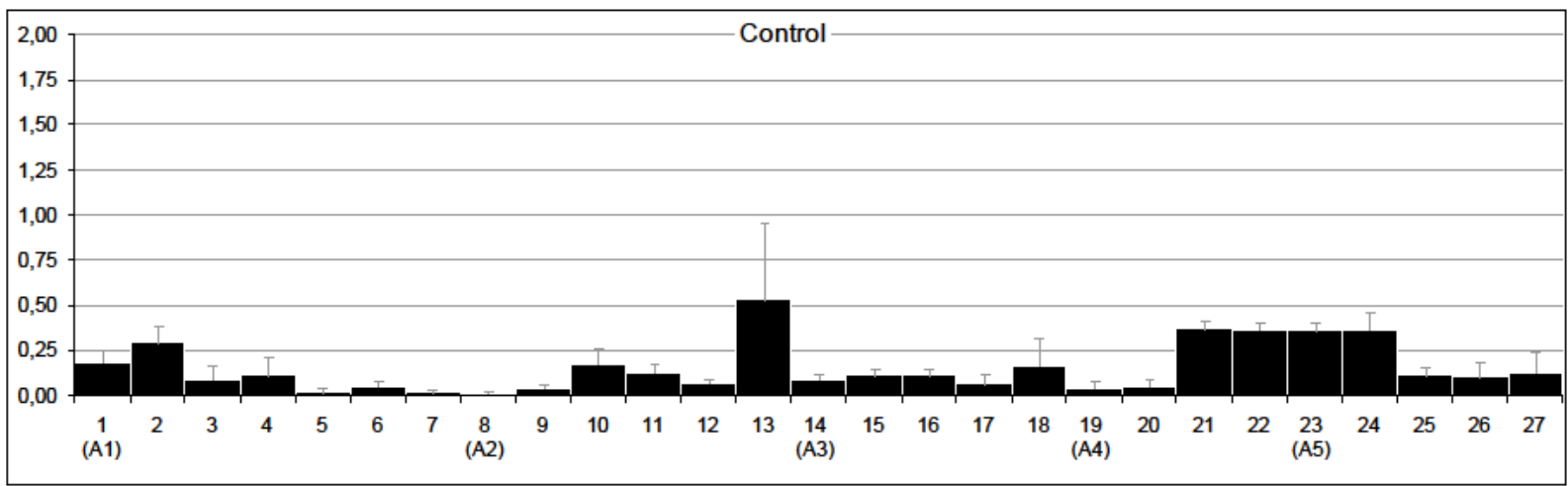

Figura 6.5.11. Evolución temporal de los valores de Cu soluble en suelo rizosférico (0-20

$\mathrm{cm}$ ) durante 27 muestreos realizados con periodicidad quincenal entre junio $2016 \mathrm{y}$ septiembre 2017 en parcelas control (CT) y 5 aplicaciones (junio 2016, septiembre 2016, enero 2017, abril 2017 y junio 2017), $n=3$.

En las parcelas control los valores de Cu soluble oscilaron entre 0,01 (valor mínimo) y 0,53 (valor máximo), siendo el valor promedio de 0,15 $\pm 0,14$.

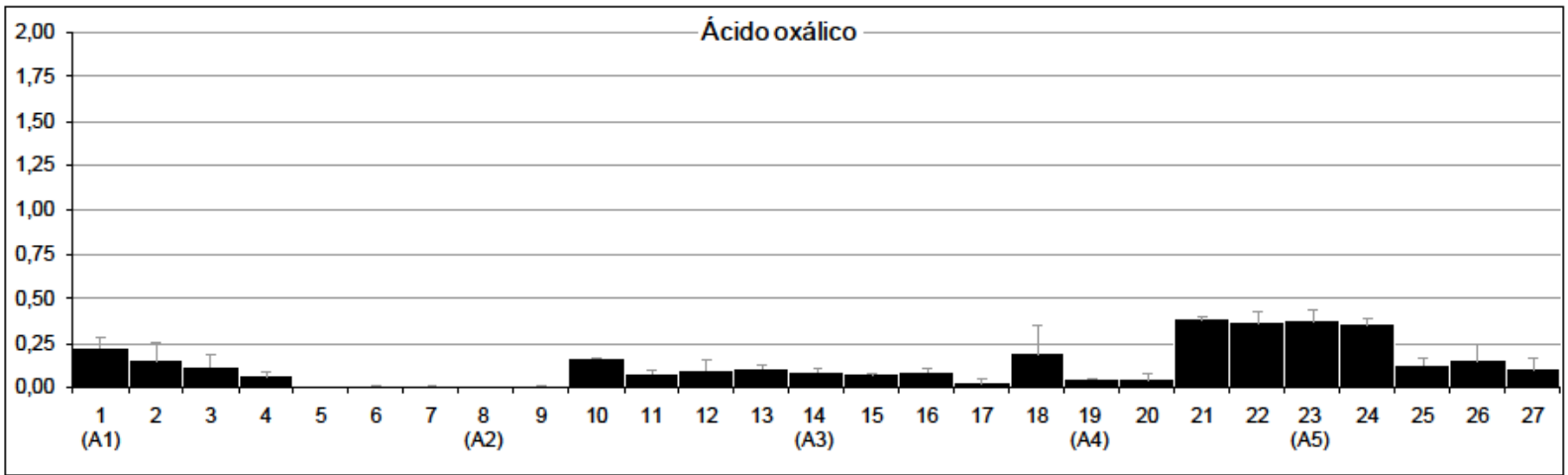

Figura 6.5.12. Evolución temporal de los valores de Cu soluble en suelo rizosférico $(0-20$

$\mathrm{cm}$ ) durante 27 muestreos realizados con periodicidad quincenal entre junio 2016 y septiembre 2017 en parcelas tratadas con dosis de $5 \mathrm{mmol} / \mathrm{kg}$ de ácido oxálico (AO) y 5 aplicaciones (junio 2016, septiembre 2016, enero 2017, abril 2017 y junio 2017), n=3.

En las parcelas tratados con ácido oxálico los valores de Cu soluble oscilaron entre 0 (valor mínimo) y 0,38 (valor máximo), siendo el valor promedio de $0,13 \pm 0,12$. 


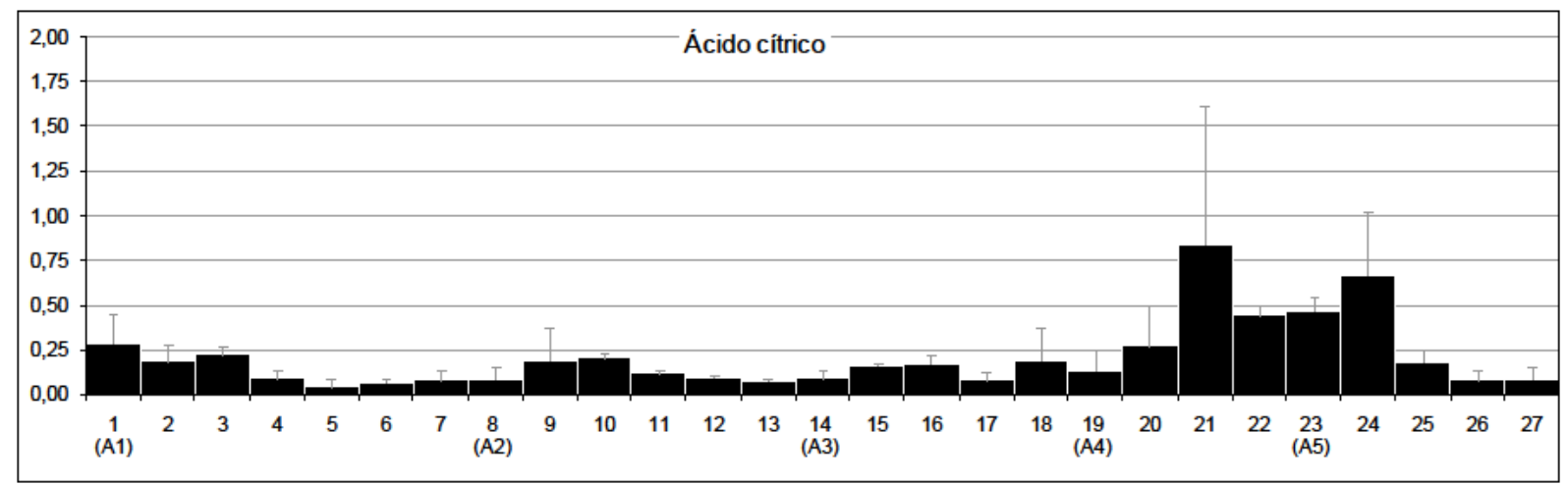

Figura 6.5.13. Evolución temporal de los valores de Cu soluble en suelo rizosférico $(0-20$ $\mathrm{cm}$ ) durante 27 muestreos realizados con periodicidad quincenal entre junio 2016 y septiembre 2017 en parcelas tratadas con dosis de $5 \mathrm{mmol} / \mathrm{kg}$ de ácido cítrico (AC) y 5 aplicaciones (junio 2016, septiembre 2016, enero 2017, abril 2017 y junio 2017), n=3.

En las parcelas tratados con ácido cítrico los valores de $\mathrm{Cu}$ soluble oscilaron entre 0,04

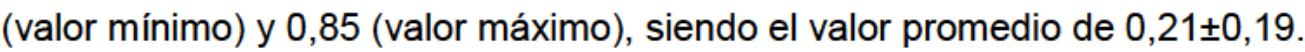

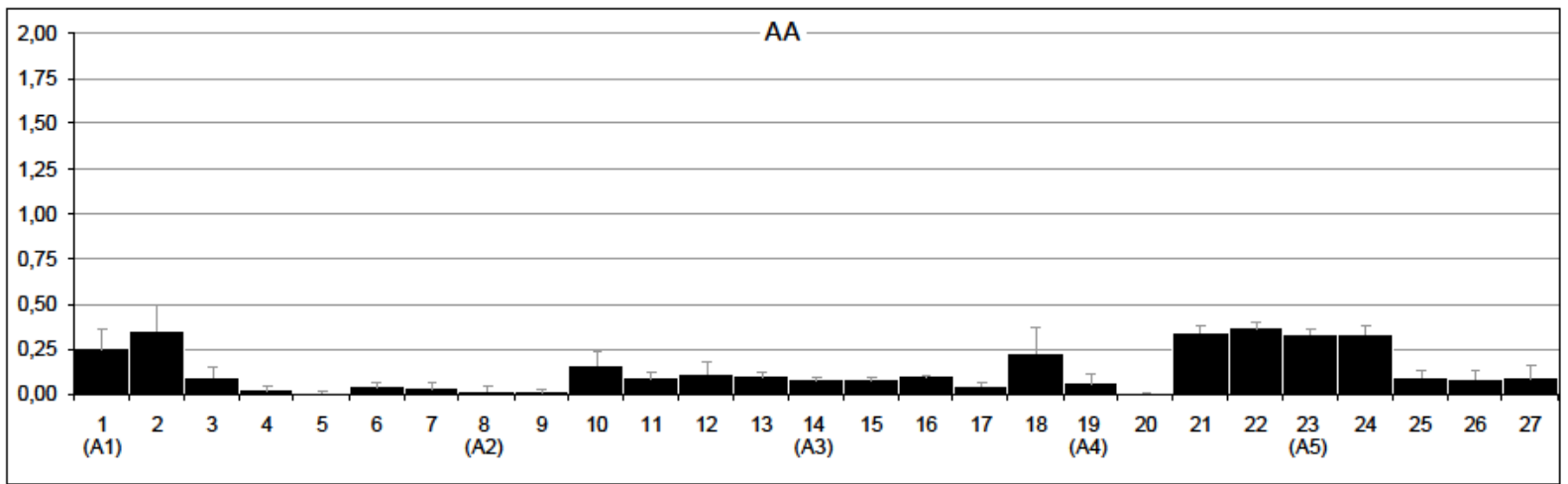

Figura 6.5.14. Evolución temporal de los valores de Cu soluble en suelo rizosférico $(0-20$ $\mathrm{cm}$ ) durante 27 muestreos realizados con periodicidad quincenal entre junio 2016 y septiembre 2017 en parcelas tratadas con aminoácidos (AA) y 5 aplicaciones (junio 2016, septiembre 2016, enero 2017, abril 2017 y junio 2017), $n=3$.

En las parcelas tratados con aminoácidos los valores de $\mathrm{Cu}$ soluble oscilaron entre 0,01

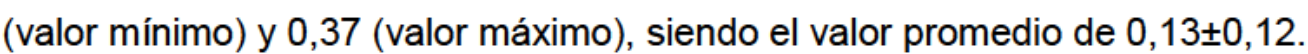




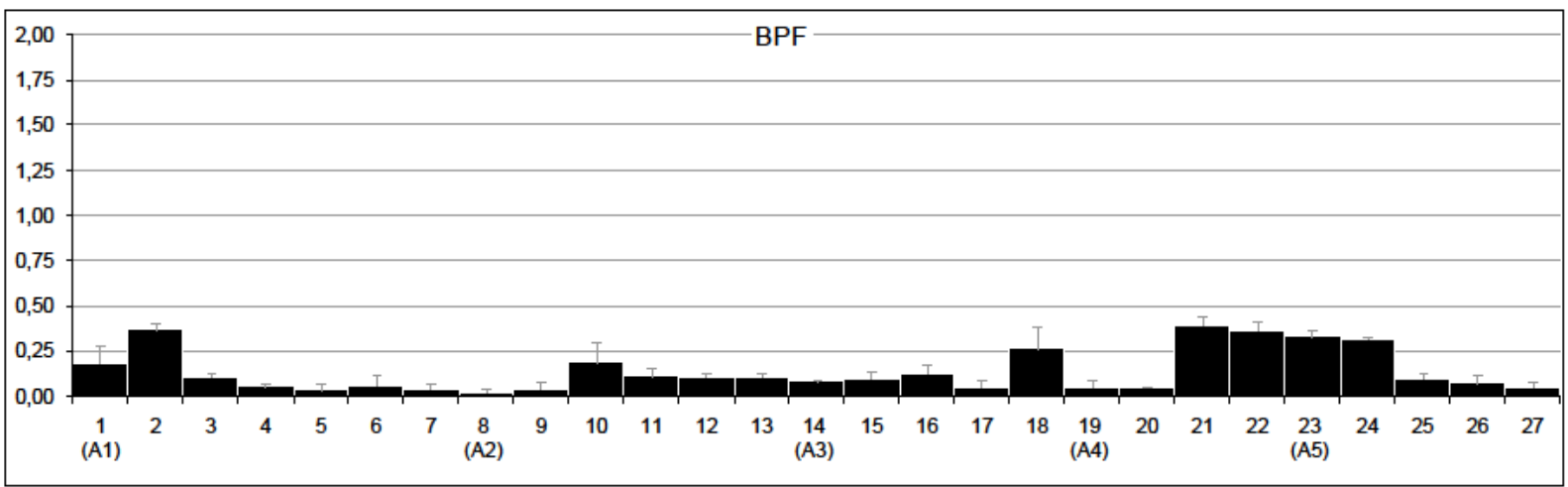

Figura 6.5.15. Evolución temporal de los valores de Cu soluble en suelo rizosférico (0-20

$\mathrm{cm}$ ) durante 27 muestreos realizados con periodicidad quincenal entre junio $2016 \mathrm{y}$ septiembre 2017 en parcelas tratadas con bacterias Pseudomonas fluorescens (BPF) y 5 aplicaciones (junio 2016, septiembre 2016, enero 2017, abril 2017 y junio 2017), n=3.

En las parcelas tratados con bacterias Pseudomonas fluorescens los valores de $\mathrm{Cu}$ soluble oscilaron entre 0,02 (valor mínimo) y 0,39 (valor máximo), siendo el valor promedio de $0,14 \pm 0,12$.

Estadísticamente se observaron valores de $\mathrm{Cu}$ soluble significativamente superiores en las parcelas tratadas con $A C$ con respecto al resto de tratamientos ( $C T, A O, A A$ y $B P F)$. Concretamente se encontró la siguiente tendencia: $A C>C T \sim A A \sim B P F \geq A O$. Los valores estadísticamente más bajos de Cu soluble se registraron en los muestreos 5, 6, 7, 8, 9 (tras A2), 17, 19 (tras A4) y 20 (parcelas CT), muestreos 4, 5, 6, 7, 8, 9 (tras A2), 17, 19 (tras A4) y 20 (parcelas $A O$ ), muestreos 5 y 8 (parcelas $A C$ ), muestreos $4,5,6,7,8,9$ (tras $A 2$ ) y 20 (parcelas AA) y muestreos 8 y 20 (parcelas BPF). Y los valores estadísticamente más elevados se encontraron en el muestreo 13 (parcelas CT), muestreos 21, 22, 23 (tras A5) y 24 (parcelas $A O$ ), muestreo 21 (parcelas $A C$ ), muestreos 2 (tras A1) y 22 (tras A5) (parcelas $A A)$ y muestreos 2 (tras $A 1$ ), 21 y 22 (parcelas BPF), habiéndose realizado las aplicaciones tras los muestreos $1,8,14,18$ y 22 . Presentando el resto de muestreos un comportamiento intermedio similar. 


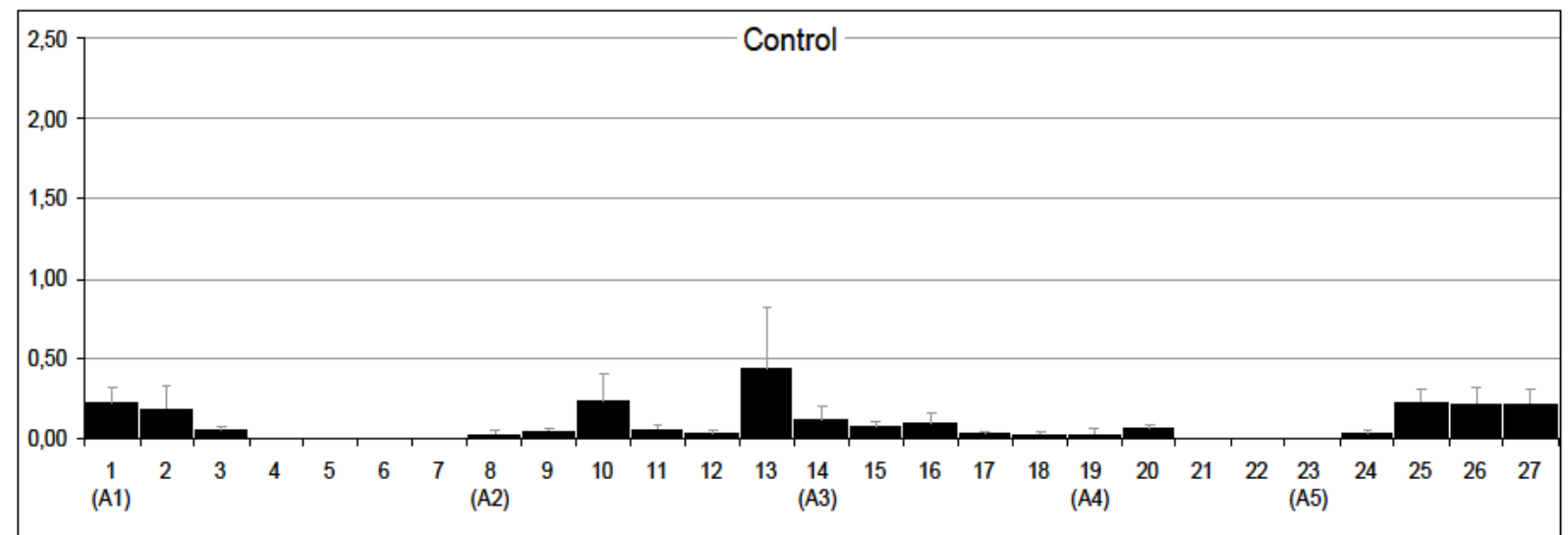

Figura 6.5.16. Evolución temporal de los valores de Zn soluble en suelo rizosférico $(0-20 \mathrm{~cm})$ durante 27 muestreos realizados con periodicidad quincenal entre junio 2016 y septiembre 2017 en parcelas control (CT) y 5 aplicaciones (junio 2016, septiembre 2016, enero 2017 , abril 2017 y junio 2017), $n=3$.

En las parcelas control los valores de Zn soluble oscilaron entre 0 (valor mínimo) y 0,44

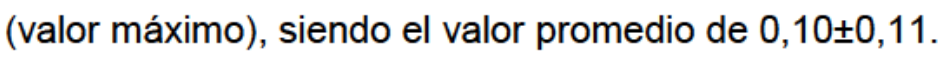

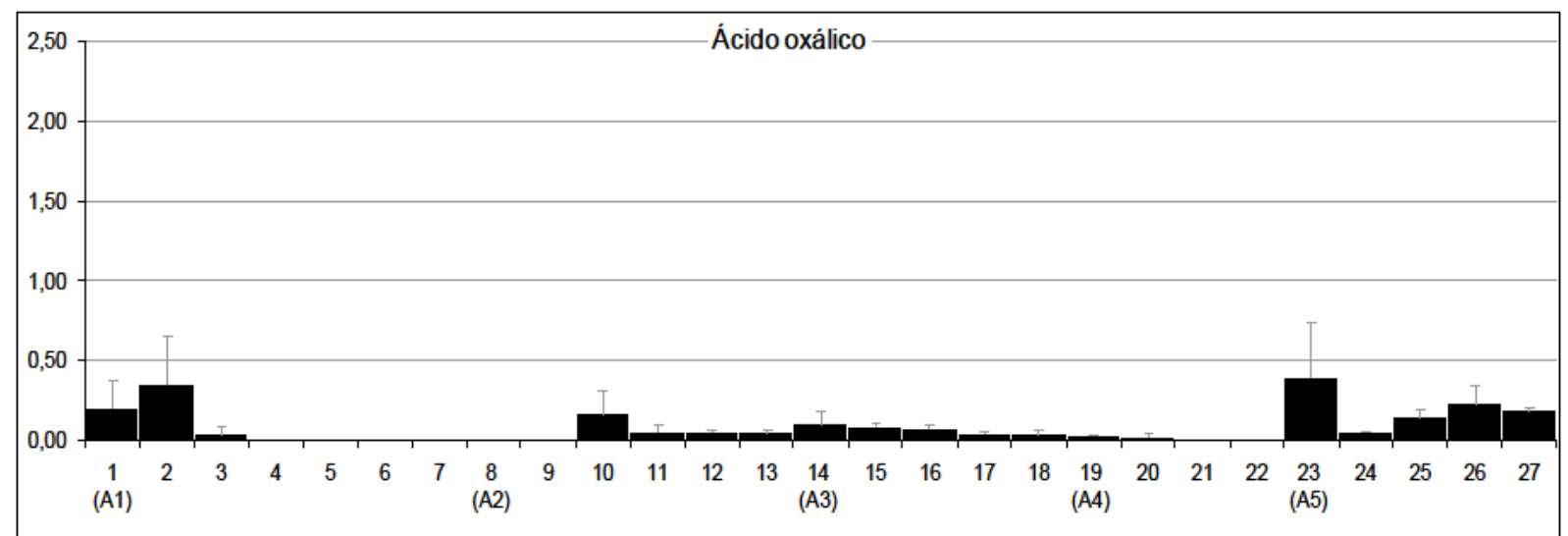

Figura 6.5.17. Evolución temporal de los valores de Zn soluble en suelo rizosférico $(0-20 \mathrm{~cm})$ durante 27 muestreos realizados con periodicidad quincenal entre junio 2016 y septiembre 2017 en parcelas tratadas con dosis de $5 \mathrm{mmol} / \mathrm{kg}$ de ácido oxálico (AO) y 5 aplicaciones (junio 2016, septiembre 2016, enero 2017, abril 2017 y junio 2017), $n=3$.

En las parcelas tratados con ácido oxálico los valores de $Z n$ soluble oscilaron entre 0 (valor

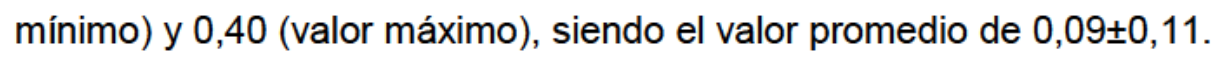




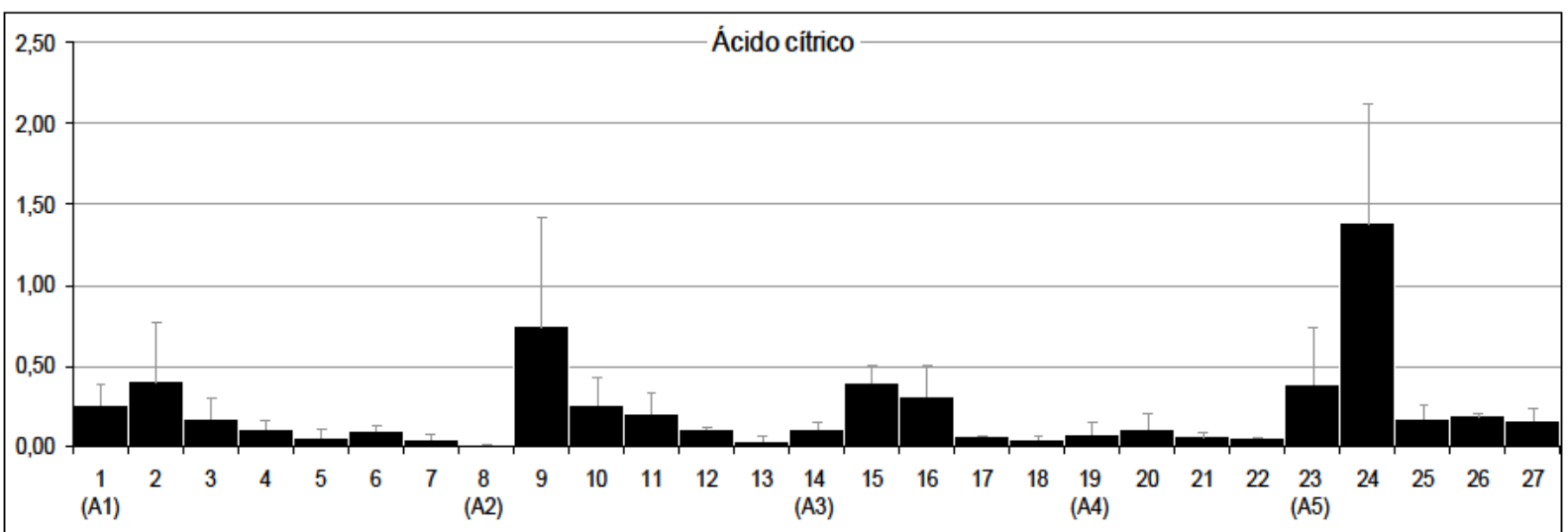

Figura 6.5.18. Evolución temporal de los valores de $\mathrm{Zn}$ soluble en suelo rizosférico $(0-20 \mathrm{~cm})$ durante 27 muestreos realizados con periodicidad quincenal entre junio 2016 y septiembre 2017 en parcelas tratadas con dosis de $5 \mathrm{mmol} / \mathrm{kg}$ de ácido cítrico (AC) y 5 aplicaciones (junio 2016, septiembre 2016, enero 2017, abril 2017 y junio 2017), $n=3$.

En las parcelas tratados con ácido cítrico los valores de $\mathrm{Zn}$ soluble oscilaron entre 0,02 (valor mínimo) y 1,38 (valor máximo), siendo el valor promedio de 0,22 $\pm 0,28$.

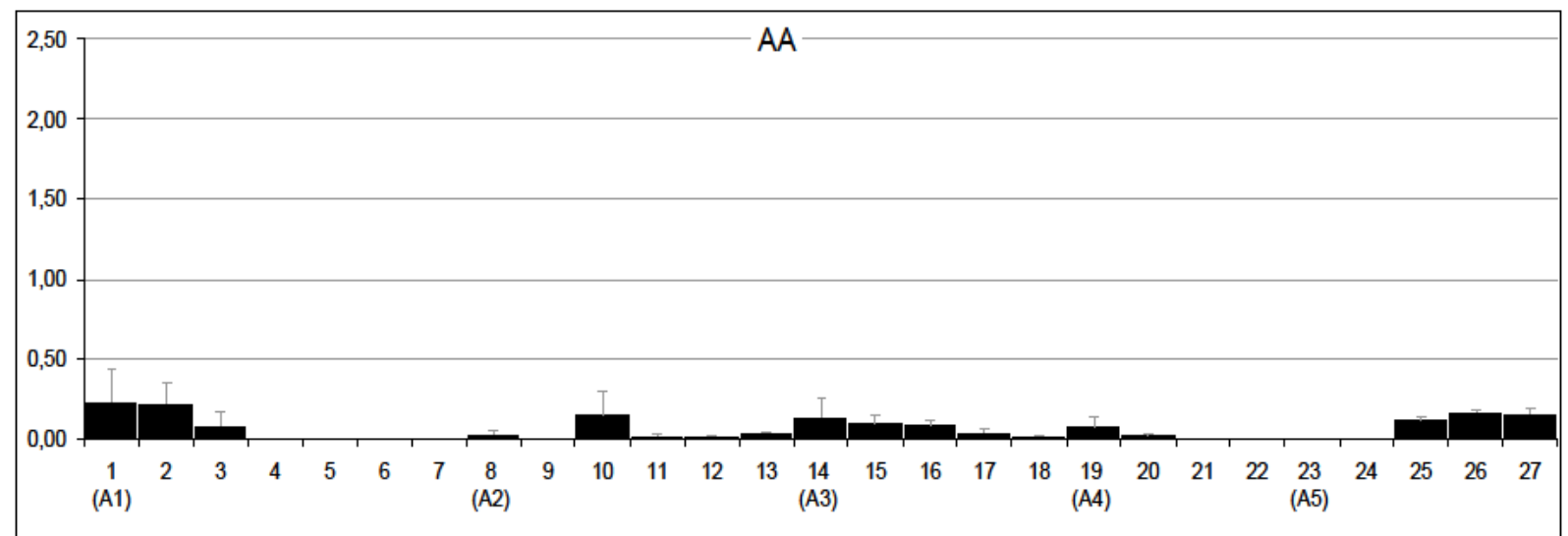

Figura 6.5.19. Evolución temporal de los valores de $Z n$ soluble en suelo rizosférico $(0-20 \mathrm{~cm})$ durante 27 muestreos realizados con periodicidad quincenal entre junio 2016 y septiembre 2017 en parcelas tratadas con aminoácidos (AA) y 5 aplicaciones (junio 2016, septiembre 2016, enero 2017, abril 2017 y junio 2017), $n=3$.

En las parcelas tratados con aminoácidos los valores de $\mathrm{Zn}$ soluble oscilaron entre 0 (valor mínimo) y 0,24 (valor máximo), siendo el valor promedio de $0,07 \pm 0,07$. 


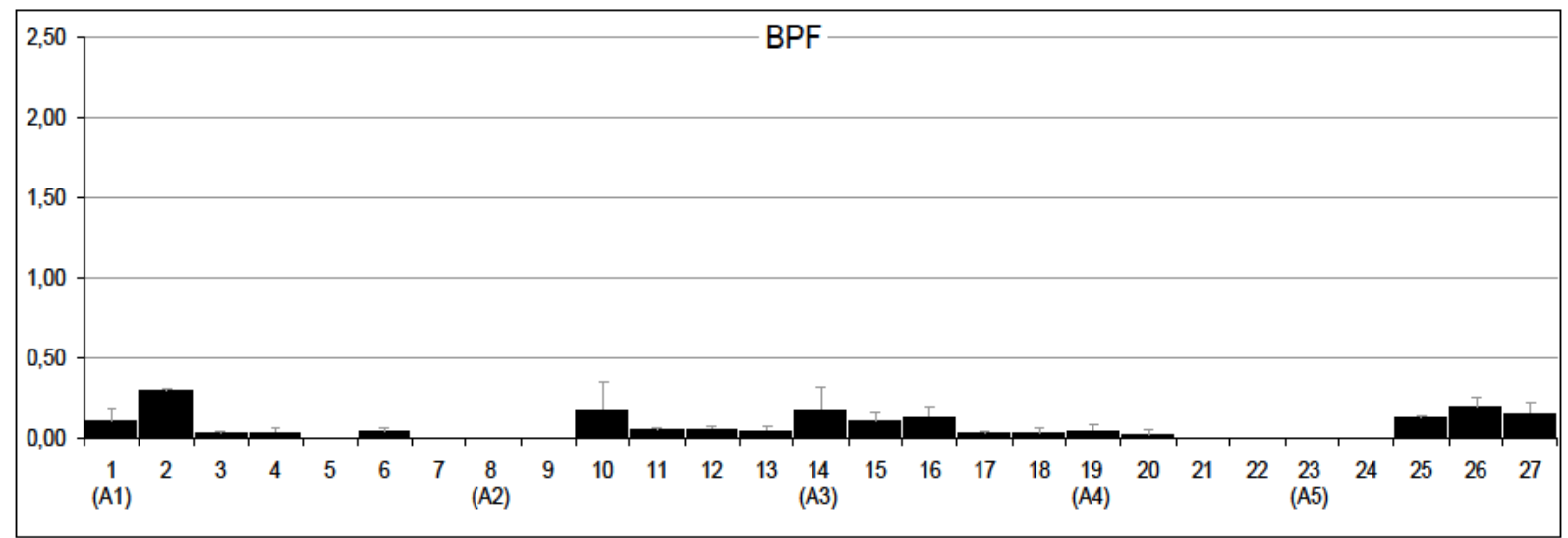

Figura 6.5.20. Evolución temporal de los valores de $Z n$ soluble en suelo rizosférico $(0-20 \mathrm{~cm})$ durante 27 muestreos realizados con periodicidad quincenal entre junio 2016 y septiembre 2017 en parcelas tratadas con bacterias Pseudomonas fluorescens (BPF) y 5 aplicaciones (junio 2016, septiembre 2016, enero 2017, abril 2017 y junio 2017), $n=3$.

En las parcelas tratados con bacterias Pseudomonas fluorescens los valores de Zn soluble oscilaron entre 0 (valor mínimo) y 0,30 (valor máximo), siendo el valor promedio de $0,07 \pm 0,08$.

Estadísticamente se observaron valores de $\mathrm{Zn}$ soluble significativamente superiores en las parcelas tratadas con $A C$ con respecto al resto de tratamientos ( $C T, A O, A A$ y $B P F)$. Concretamente se encontró la siguiente tendencia: $A C>C T \sim A O \sim A A \sim B P F$.

Entre los diferentes muestreos, no se registraron diferencias estadísticamente significativas entre muestreos de suelo en las parcelas $A O, A C$ y $A A$. Solamente se registraron diferencias estadísticamente significativas entre los diferentes muestreos en la parcelas CT y BPF. Los valores estadísticamente más bajos de $Z n$ soluble se registraron en los muestreos 4, 5, 6, 7, 8, 21, 22, 23 y 24 (parcelas CT), muestreos 4, 5, 6, 7, 89 (tras A2), 21, 22, 23 (tras A5) y 24 (parcelas BPF). Y los valores estadísticamente más elevados se encontraron en el muestreo 13 (parcelas CT) y el muestreo 2 (tras A1) (parcelas BPF), habiéndose realizado las aplicaciones tras los muestreos 1, 8, 14, 18 y 22. Presentando el resto de muestreos un comportamiento intermedio similar. 


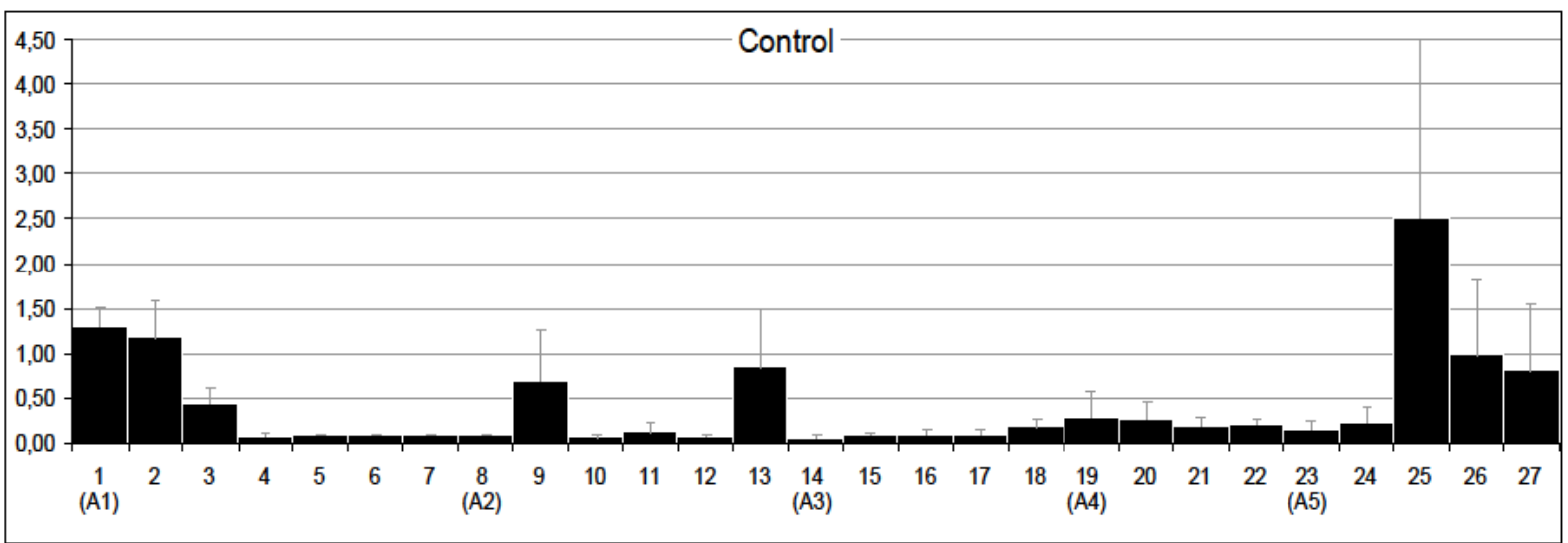

Figura 6.5.21. Evolución temporal de los valores de $\mathrm{Cr}$ soluble en suelo rizosférico $(0-20 \mathrm{~cm})$ durante 27 muestreos realizados con periodicidad quincenal entre junio 2016 y septiembre 2017 en parcelas control (CT) y 5 aplicaciones (junio 2016, septiembre 2016, enero 2017 , abril 2017 y junio 2017), $n=3$.

En las parcelas control los valores de Cr soluble oscilaron entre 0,05 (valor mínimo) y 2,52 (valor máximo), siendo el valor promedio de 0,42 $\pm 0,56$.

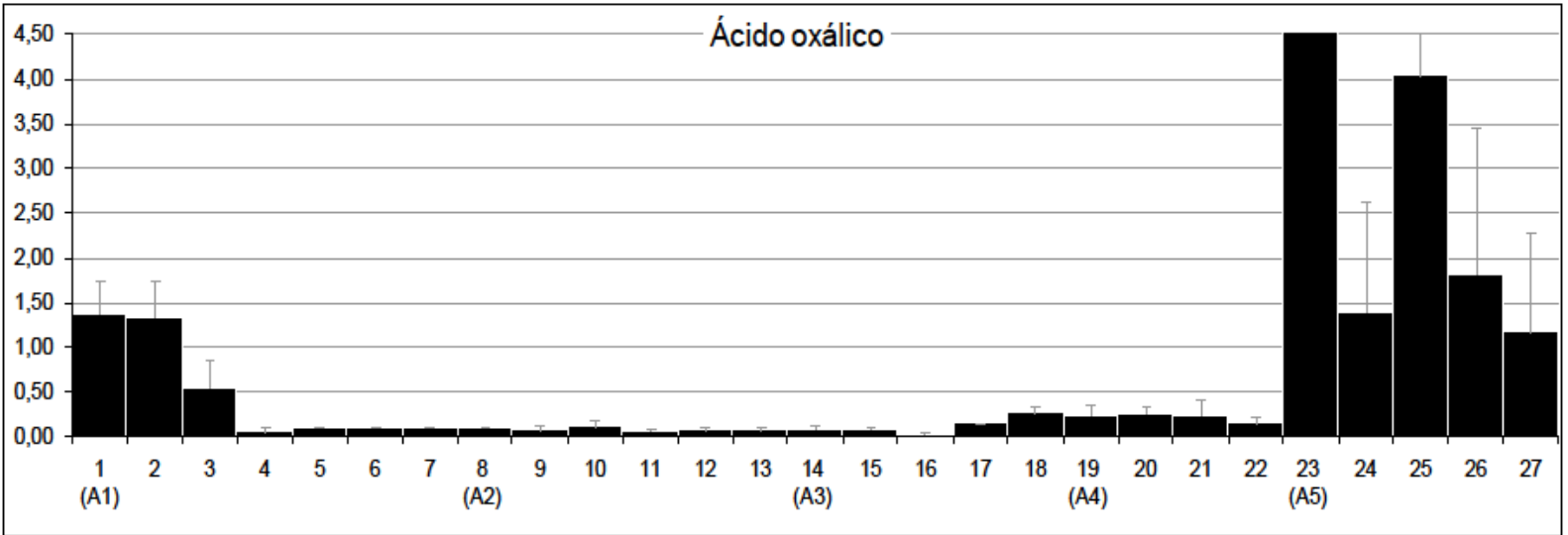

Figura 6.5.22. Evolución temporal de los valores de $\mathrm{Cr}$ soluble en suelo rizosférico $(0-20 \mathrm{~cm})$ durante 27 muestreos realizados con periodicidad quincenal entre junio 2016 y septiembre 2017 en parcelas tratadas con dosis de $5 \mathrm{mmol} / \mathrm{kg}$ de ácido oxálico (AO) y 5 aplicaciones (junio 2016, septiembre 2016, enero 2017, abril 2017 y junio 2017), $n=3$.

En las parcelas tratados con ácido oxálico los valores de $\mathrm{Cr}$ soluble oscilaron entre 0,03

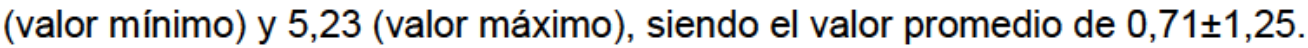




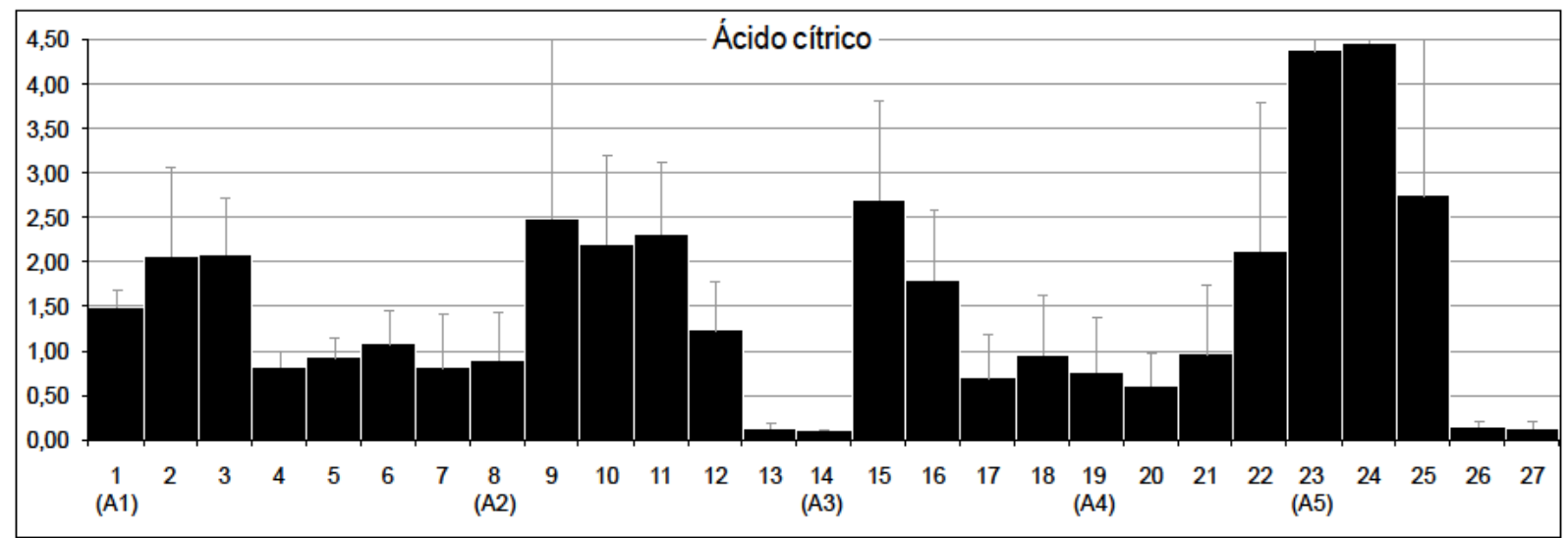

Figura 6.5.23. Evolución temporal de los valores de Cr soluble en suelo rizosférico $(0-20 \mathrm{~cm})$ durante 27 muestreos realizados con periodicidad quincenal entre junio 2016 y septiembre 2017 en parcelas tratadas con dosis de $5 \mathrm{mmol} / \mathrm{kg}$ de ácido cítrico (AC) y 5 aplicaciones (junio 2016, septiembre 2016, enero 2017, abril 2017 y junio 2017), $n=3$.

En las parcelas tratados con ácido cítrico los valores de $\mathrm{Cr}$ soluble oscilaron entre 0,10 (valor mínimo) y 4,47 (valor máximo), siendo el valor promedio de $1,52 \pm 1,17$.

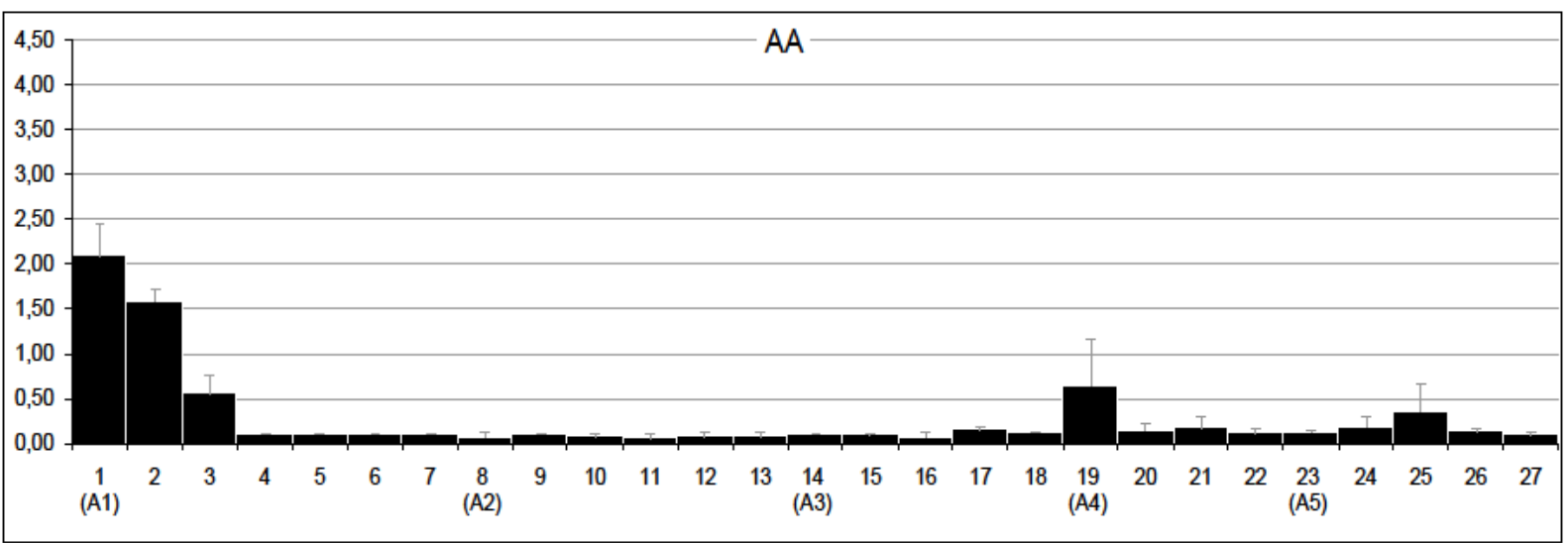

Figura 6.5.24. Evolución temporal de los valores de $\mathrm{Cr}$ soluble en suelo rizosférico $(0-20 \mathrm{~cm})$ durante 27 muestreos realizados con periodicidad quincenal entre junio 2016 y septiembre 2017 en parcelas tratadas con aminoácidos (AA) y 5 aplicaciones (junio 2016, septiembre 2016, enero 2017, abril 2017 y junio 2017), n=3.

En las parcelas tratados con aminoácidos los valores de $\mathrm{Cr}$ soluble oscilaron entre 0,06 (valor mínimo) y 2,10 (valor máximo), siendo el valor promedio de 0,28 $\pm 0,48$. 


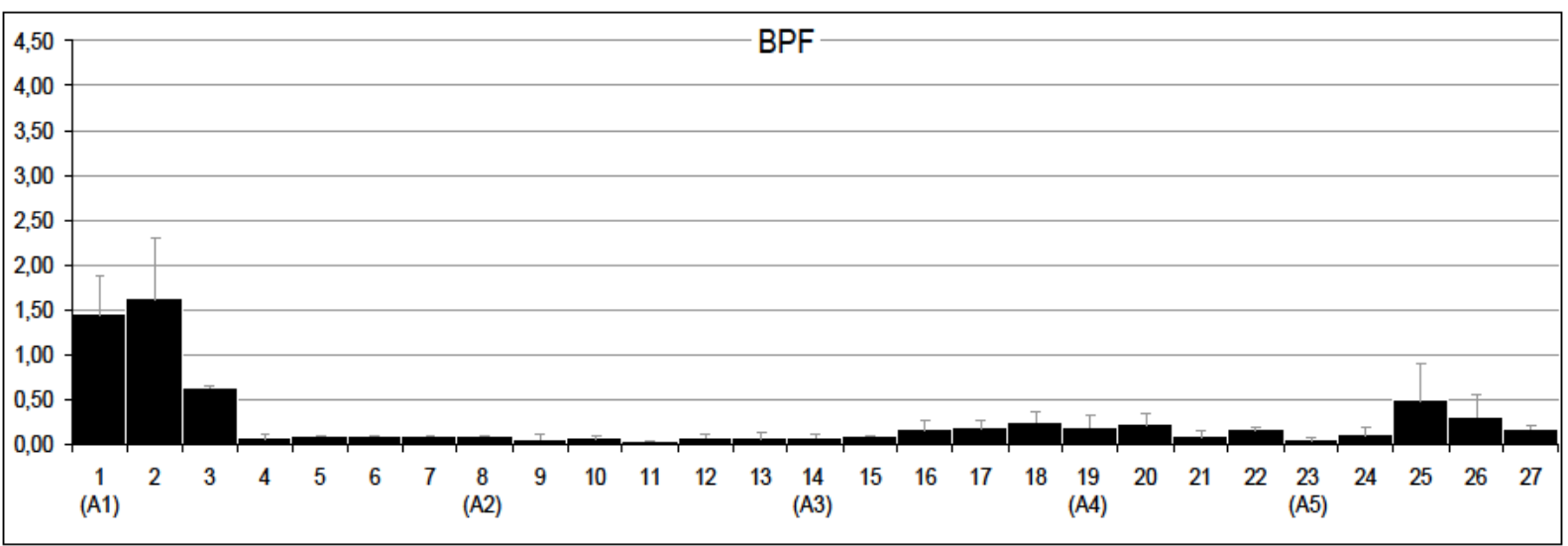

Figura 6.5.25. Evolución temporal de los valores de $\mathrm{Cr}$ soluble en suelo rizosférico $(0-20 \mathrm{~cm})$ durante 27 muestreos realizados con periodicidad quincenal entre junio 2016 y septiembre 2017 en parcelas tratadas con bacterias Pseudomonas fluorescens (BPF) y 5 aplicaciones (junio 2016, septiembre 2016, enero 2017, abril 2017 y junio 2017), $n=3$.

En las parcelas tratados con bacterias Pseudomonas fluorescens los valores de $\mathrm{Cr}$ soluble oscilaron entre 0,05 (valor mínimo) y 1,63 (valor máximo), siendo el valor promedio de $0,26 \pm 0,39$.

Estadísticamente se observaron valores de $\mathrm{Cr}$ soluble significativamente superiores en las parcelas tratadas con $A C$ con respecto al resto de tratamientos ( $C T, A O, A A$ y $B P F)$. Concretamente se encontró la siguiente tendencia: $A C>C T \sim A O \sim A A \sim B P F$. Entre los diferentes muestreos, no se registraron diferencias estadísticamente significativas en las parcelas $A O$. Para el resto de parcelas (CT, AC, AA y BPF) si se registraron diferencias estadísticamente significativas entre los diferentes muestreos. Los valores estadísticamente más bajos de $\mathrm{Cr}$ soluble se registraron en los muestreos 3 , 4, 5, 6, 7, 8, 9 (justo después de la $\mathrm{A} 2$ ), $10,11,12,13,14,15$ (justo después de la $A 3$ ), 16, 17, 18, 19 (justo después de la A4), 20, 21, 22, 23 (justo después de la A5) y 24 (parcelas CT), muestreos 13 y 14 (parcelas $A C$ ), muestreos $4,5,6,7,8,9$ (justo después de la $A 2$ ), 10, 11 y 12, 14, 15 (justo después de la A3) y 16 (parcelas AA) y muestreos 1,2 (justo después de la A1), 4, 5, 6, 7, 8, 9 (justo después de la A2), 15 (justo después de la A3) (parcelas BPF). Y los valores estadísticamente más elevados se encontraron en el muestreo 25 (parcelas CT), muestreo 24 (parcelas $A C$ ), muestreo 1 (parcelas $A A$ ) y muestreos 1 y 2 (justo después de la $A 1$ ) (parcelas BPF), habiéndose realizado las aplicaciones después de los muestreos $1,8,14$, 18 y 22. Presentando el resto de muestreos un comportamiento intermedio similar. 


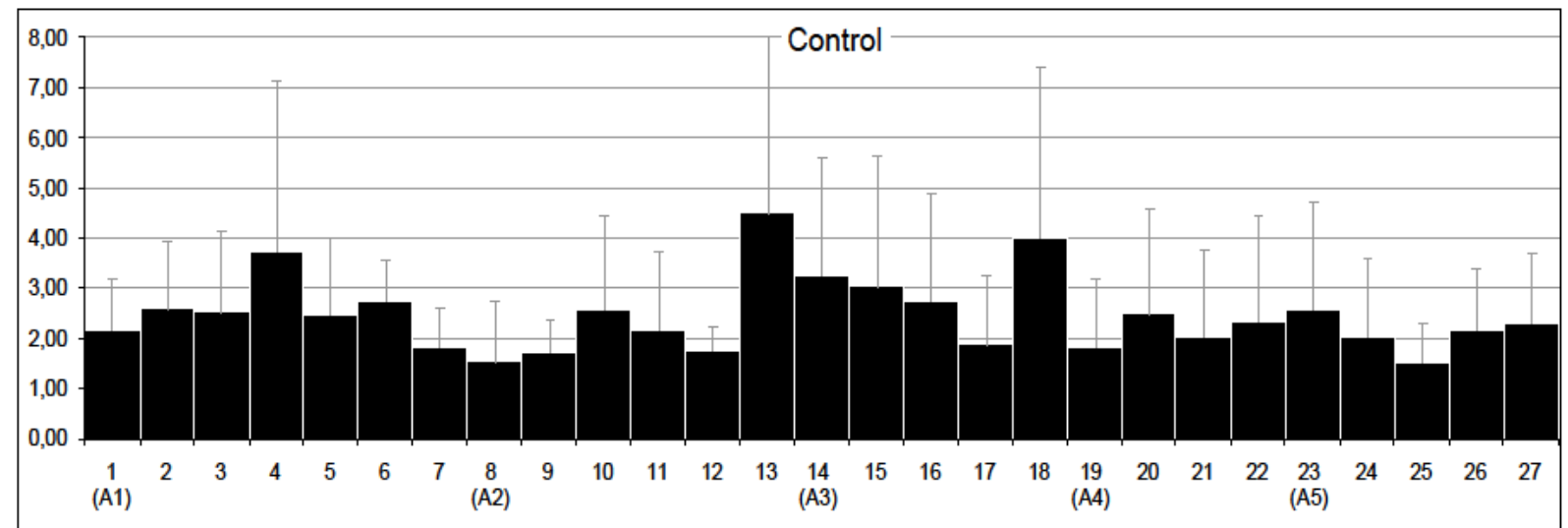

Figura 6.5.26. Evolución temporal de los valores de Cu biodisponible en suelo rizosférico (0$20 \mathrm{~cm}$ ) durante 27 muestreos realizados con periodicidad quincenal entre junio 2016 y septiembre 2017 en parcelas control (CT) y 5 aplicaciones (junio 2016, septiembre 2016, enero 2017, abril 2017 y junio 2017), $n=3$.

En las parcelas control los valores de Cu biodisponible oscilaron entre 1,49 (valor mínimo) y

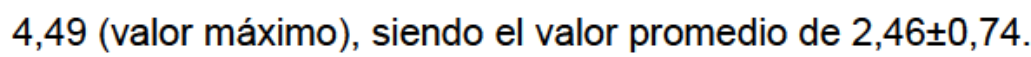

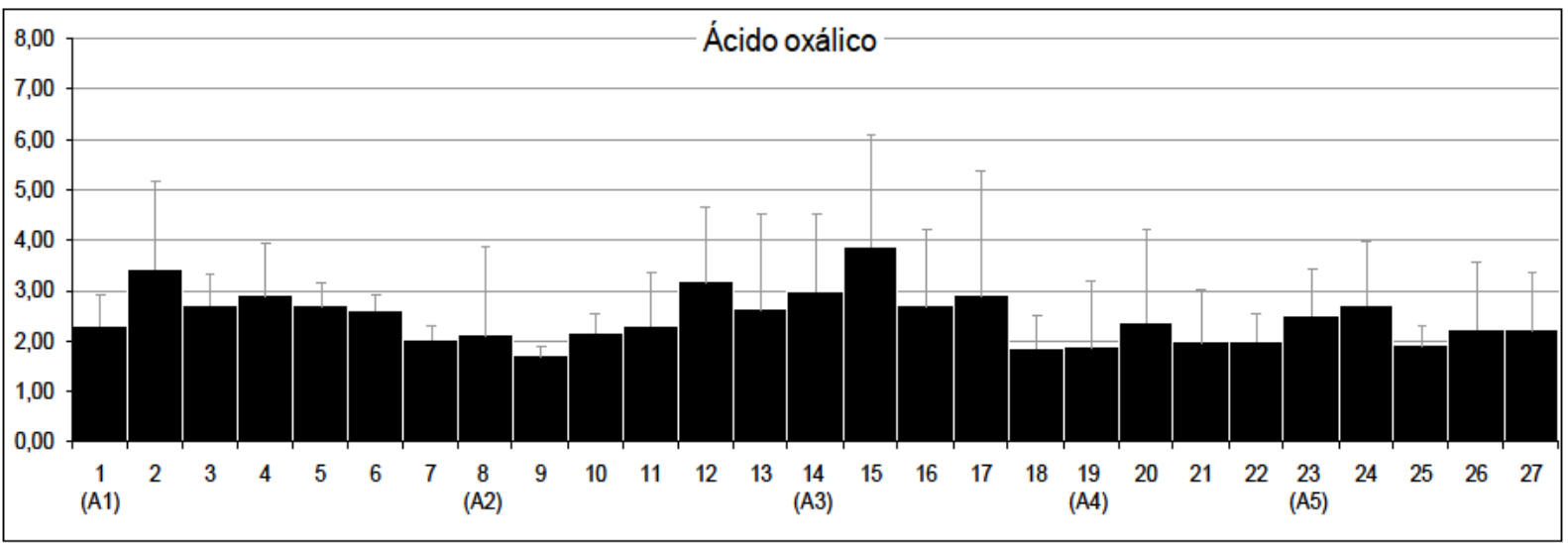

Figura 6.5.27. Evolución temporal de los valores de Cu biodisponible en suelo rizosférico (0$20 \mathrm{~cm}$ ) durante 27 muestreos realizados con periodicidad quincenal entre junio 2016 y septiembre 2017 en parcelas tratadas con dosis de $5 \mathrm{mmol} / \mathrm{kg}$ de ácido oxálico (AO) y 5 aplicaciones (junio 2016, septiembre 2016, enero 2017, abril 2017 y junio 2017), n=3.

En las parcelas tratados con ácido oxálico los valores de Cu biodisponible oscilaron entre 1,71 (valor mínimo) y 3,88 (valor máximo), siendo el valor promedio de $2,47 \pm 0,52$. 


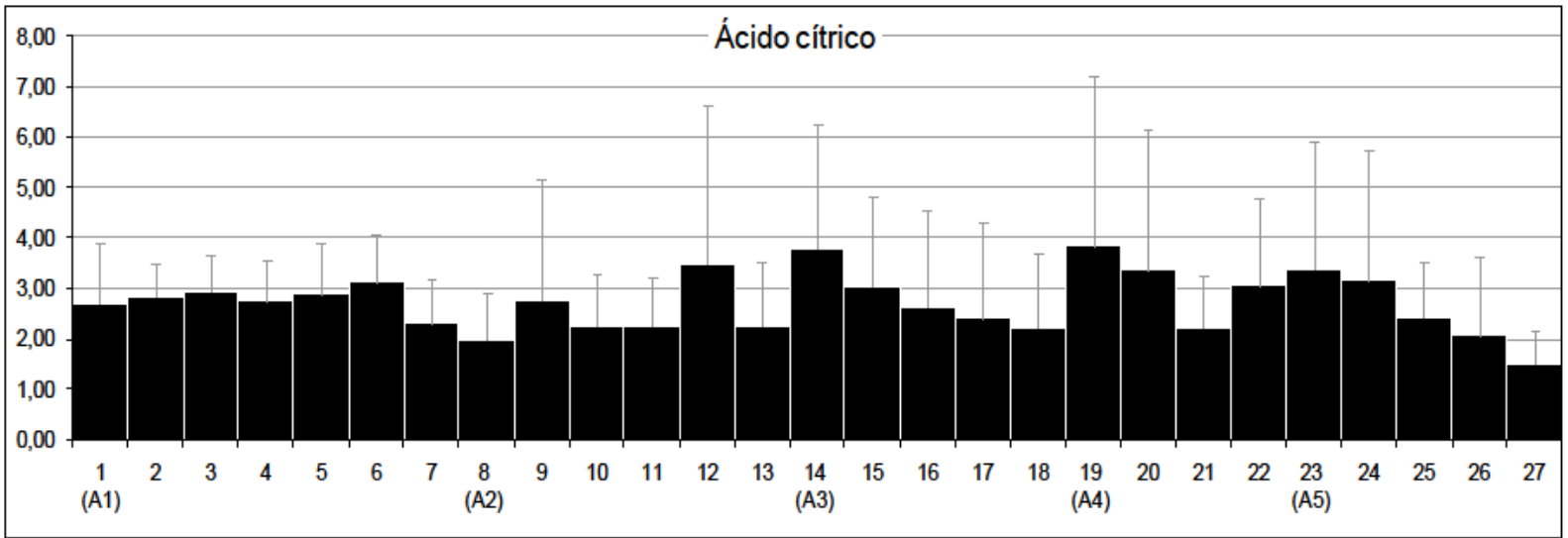

Figura 6.5.28. Evolución temporal de los valores de Cu biodisponible en suelo rizosférico (0-

$20 \mathrm{~cm}$ ) durante 27 muestreos realizados con periodicidad quincenal entre junio $2016 \mathrm{y}$ septiembre 2017 en parcelas tratadas con dosis de $5 \mathrm{mmol} / \mathrm{kg}$ de ácido cítrico (AC) y 5 aplicaciones (junio 2016, septiembre 2016, enero 2017, abril 2017 y junio 2017), n=3.

En las parcelas tratados con ácido cítrico los valores de $\mathrm{Cu}$ biodisponible oscilaron entre 1,49 (valor mínimo) y 3,86 (valor máximo), siendo el valor promedio de $2,73 \pm 0,57$.

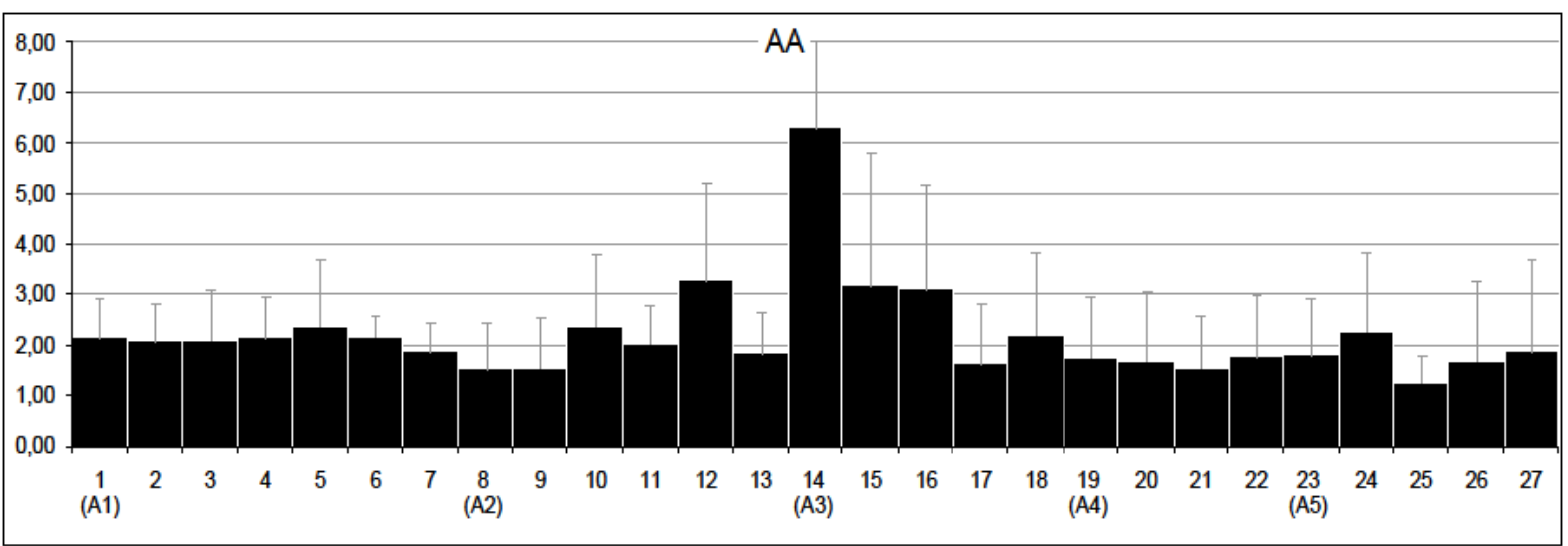

Figura 6.5.29. Evolución temporal de los valores de Cu biodisponible en suelo rizosférico (0$20 \mathrm{~cm}$ ) durante 27 muestreos realizados con periodicidad quincenal entre junio $2016 \mathrm{y}$ septiembre 2017 en parcelas tratadas con aminoácidos (AA) y 5 aplicaciones (junio 2016, septiembre 2016, enero 2017, abril 2017 y junio 2017), $n=3$.

En las parcelas tratados aminoácidos los valores de $\mathrm{Cu}$ biodisponible oscilaron entre 1,22

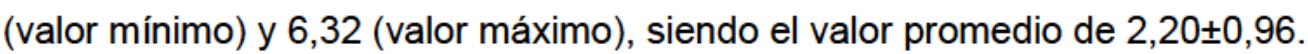




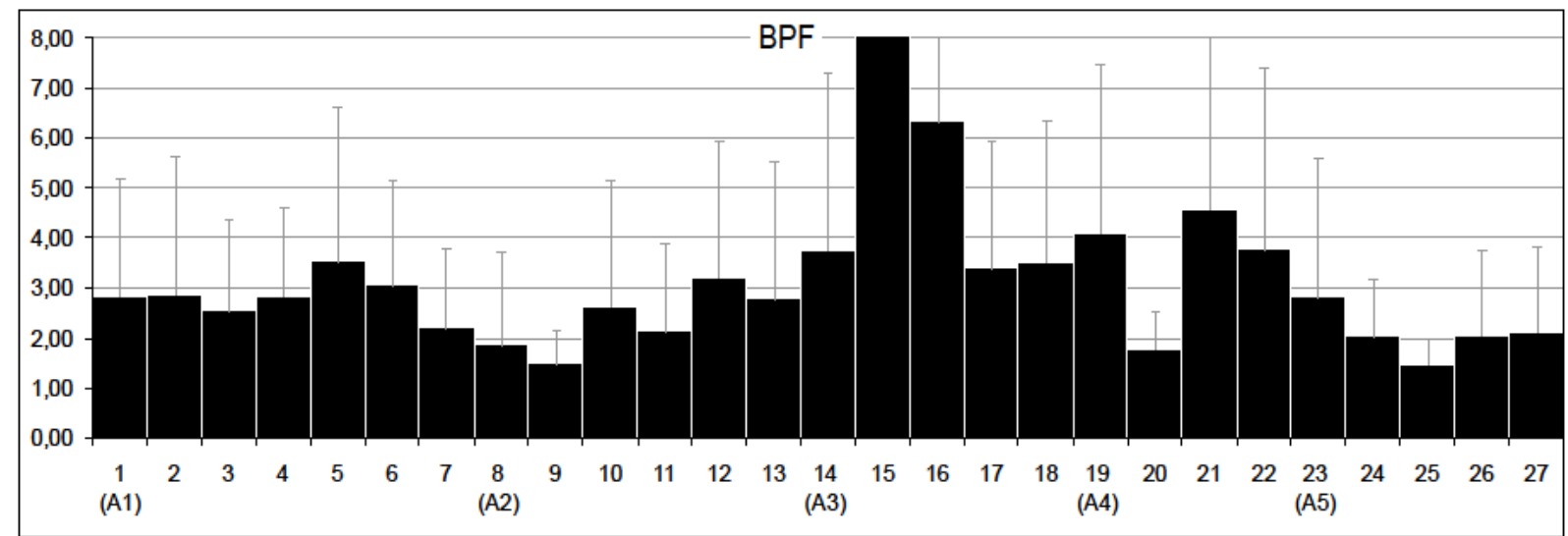

Figura 6.5.30. Evolución temporal de los valores de Cu biodisponible en suelo rizosférico (0-

$20 \mathrm{~cm}$ ) durante 27 muestreos realizados con periodicidad quincenal entre junio $2016 \mathrm{y}$ septiembre 2017 en parcelas tratadas con bacterias Pseudomonas fluorescens (BPF) y 5

aplicaciones (junio 2016, septiembre 2016, enero 2017, abril 2017 y junio 2017), n=3.

En las parcelas tratados con bacterias Pseudomonas fluorescens los valores de $\mathrm{Cu}$ biodisponible oscilaron entre 1,47 (valor mínimo) y 15,15 (valor máximo), siendo el valor promedio de $3,37 \pm 2,58$.

Estadísticamente no se observaron diferencias significativas entre los valores de $\mathrm{Cu}$ biodisponible registrados en las parcelas estudiadas, comportándose por tanto todos los tratamientos por igual. Concretamente se encontró la siguiente tendencia: $C T \sim A O \sim A C \sim A A \sim B P F$. Entre los diferentes muestreos, no se registraron diferencias estadísticamente significativas en las parcelas $A O$. Para el resto de parcelas (CT, AC, AA y BPF) si se registraron diferencias estadísticamente significativas entre los diferentes muestreos. Los valores estadísticamente más bajos de $\mathrm{Cr}$ soluble se registraron en los muestreos $3,4,5,6,7,8,9$ (justo después de la A2), 10,11, 12, 13, 14, 15 (justo después de la A3), 16, 17, 18, 19 (justo después de la A4), 20, 21, 22, 23 (justo después de la A5) y 24 (parcelas CT), muestreos 13 y 14 (parcelas $A C$ ), muestreos $4,5,6,7,8,9$ (justo después de la $A 2$ ), 10, 11 y 12, 14, 15 (justo después de la A3) y 16 (parcelas AA) y muestreos 1,2 (justo después de la A1), 4, 5, 6, 7, 8, 9 (justo después de la A2), 15 (justo después de la A3) (parcelas BPF). Y los valores estadísticamente más elevados se encontraron en el muestreo 25 (parcelas CT), muestreo 24 (parcelas AC), muestreo 1 (parcelas AA) y muestreos 1 y 2 (justo después de la A1) (parcelas BPF), habiéndose realizado las aplicaciones después de los muestreos 1, 8, 14, 18 y 22. Presentando el resto de muestreos un comportamiento intermedio similar. 


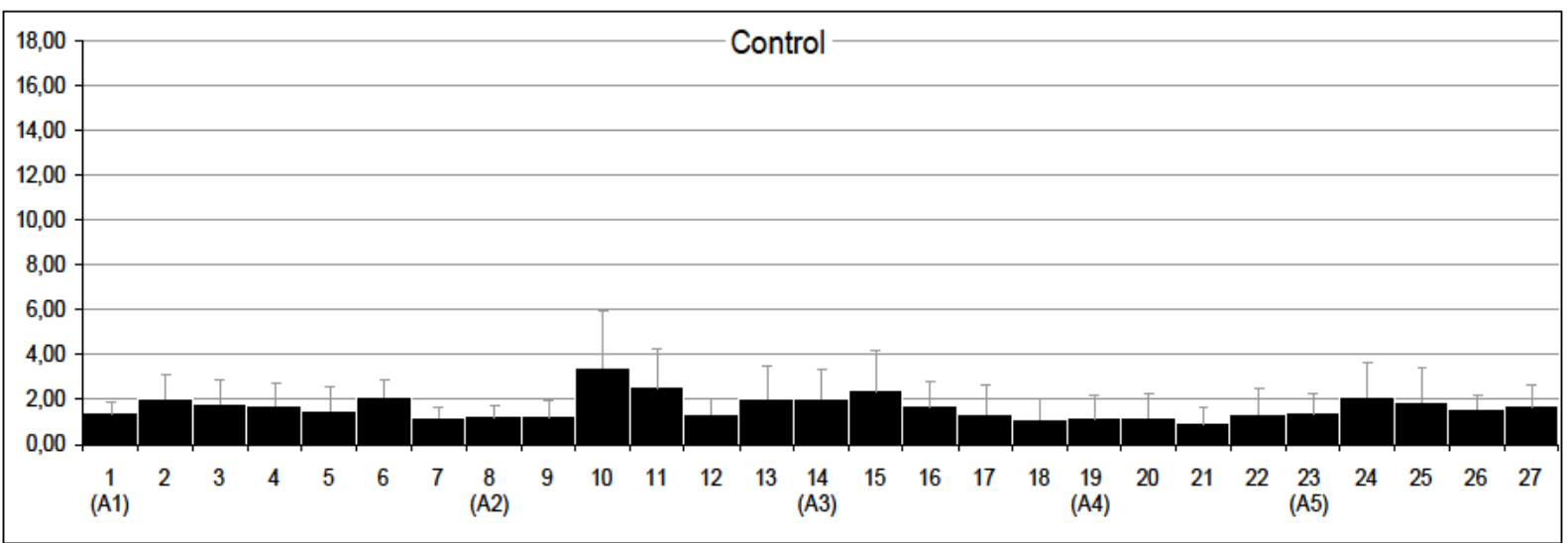

Figura 6.5.31. Evolución temporal de los valores de Zn biodisponible en suelo rizosférico (0$20 \mathrm{~cm}$ ) durante 27 muestreos realizados con periodicidad quincenal entre junio 2016 y septiembre 2017 en parcelas control (CT) y 5 aplicaciones (junio 2016, septiembre 2016, enero 2017, abril 2017 y junio 2017), $n=3$.

En las parcelas control los valores de Zn biodisponible oscilaron entre 0,92 (valor mínimo) y

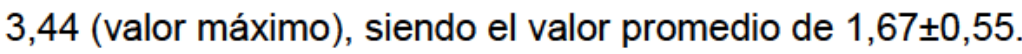

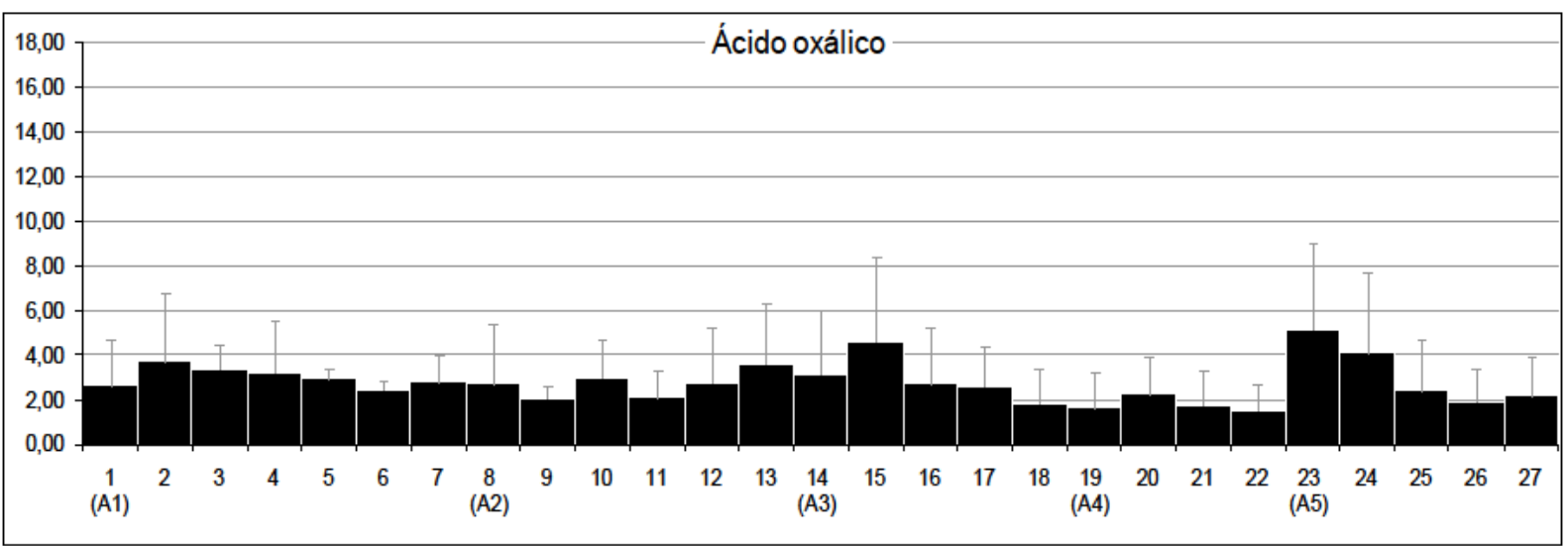

Figura 6.5.32. Evolución temporal de los valores de Zn biodisponible en suelo rizosférico (0$20 \mathrm{~cm}$ ) durante 27 muestreos realizados con periodicidad quincenal entre junio 2016 y septiembre 2017 en parcelas tratadas con dosis de $5 \mathrm{mmol} / \mathrm{kg}$ de ácido oxálico (AO) y 5 aplicaciones (junio 2016, septiembre 2016, enero 2017, abril 2017 y junio 2017), n=3.

En las parcelas tratados con ácido oxálico los valores de $\mathrm{Zn}$ biodisponible oscilaron entre 1,51 (valor mínimo) y 5,11 (valor máximo), siendo el valor promedio de $2,77 \pm 0,89$. 


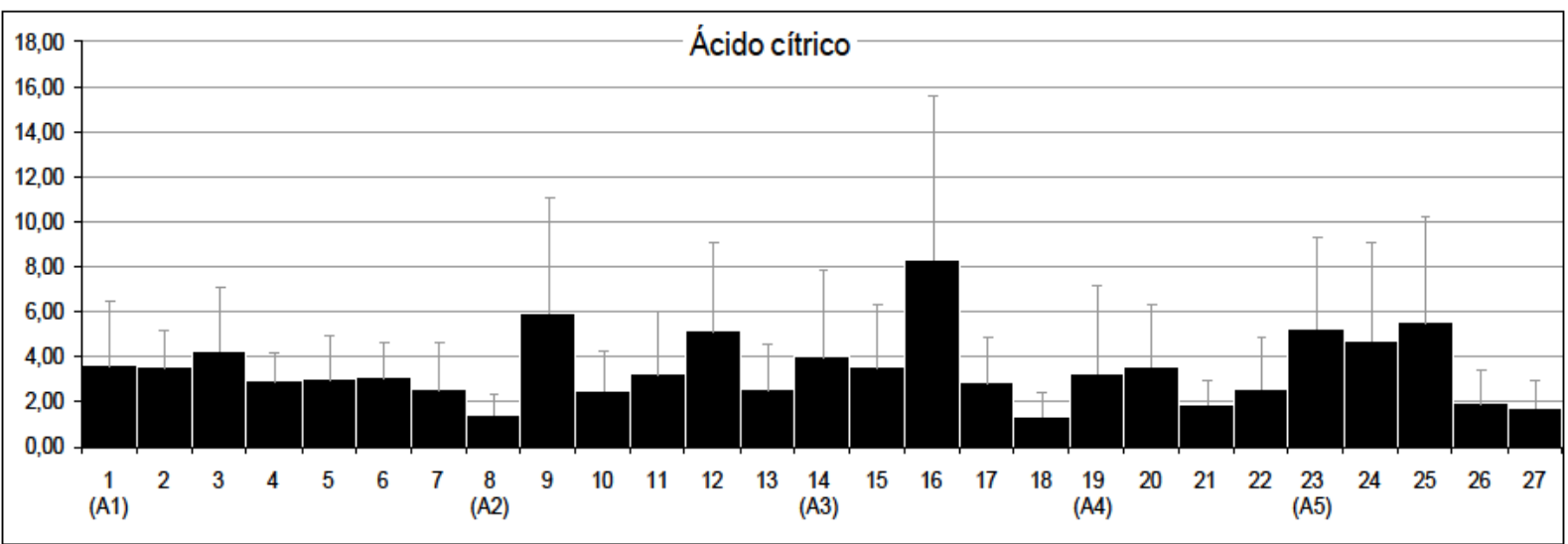

Figura 6.5.33. Evolución temporal de los valores de Zn biodisponible en suelo rizosférico (0-

$20 \mathrm{~cm}$ ) durante 27 muestreos realizados con periodicidad quincenal entre junio 2016 y septiembre 2017 en parcelas tratadas con dosis de $5 \mathrm{mmol} / \mathrm{kg}$ de ácido cítrico (AC) y 5 aplicaciones (junio 2016, septiembre 2016, enero 2017, abril 2017 y junio 2017), n=3.

En las parcelas tratados con ácido cítrico los valores de $\mathrm{Zn}$ biodisponible oscilaron entre 1,31 (valor mínimo) y 8,32 (valor máximo), siendo el valor promedio de $3,47 \pm 1,57$.

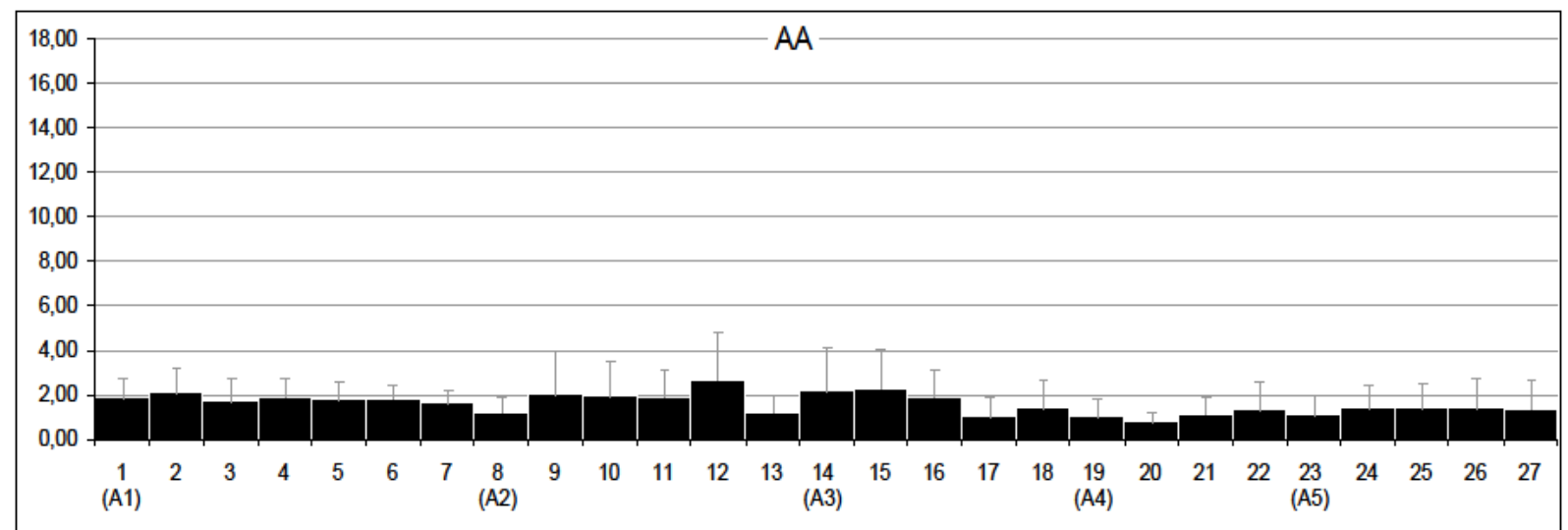

Figura 6.5.34. Evolución temporal de los valores de $\mathrm{Zn}$ biodisponible en suelo rizosférico (0$20 \mathrm{~cm}$ ) durante 27 muestreos realizados con periodicidad quincenal entre junio $2016 \mathrm{y}$ septiembre 2017 en parcelas tratadas con aminoácidos (AA) y 5 aplicaciones (junio 2016, septiembre 2016, enero 2017, abril 2017 y junio 2017), $n=3$.

En las parcelas tratados con aminoácidos los valores de $\mathrm{Zn}$ biodisponible oscilaron entre

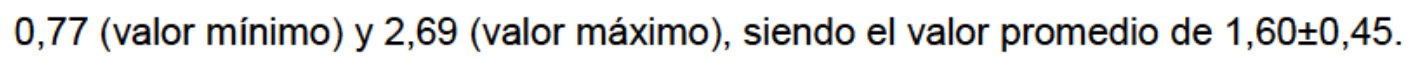




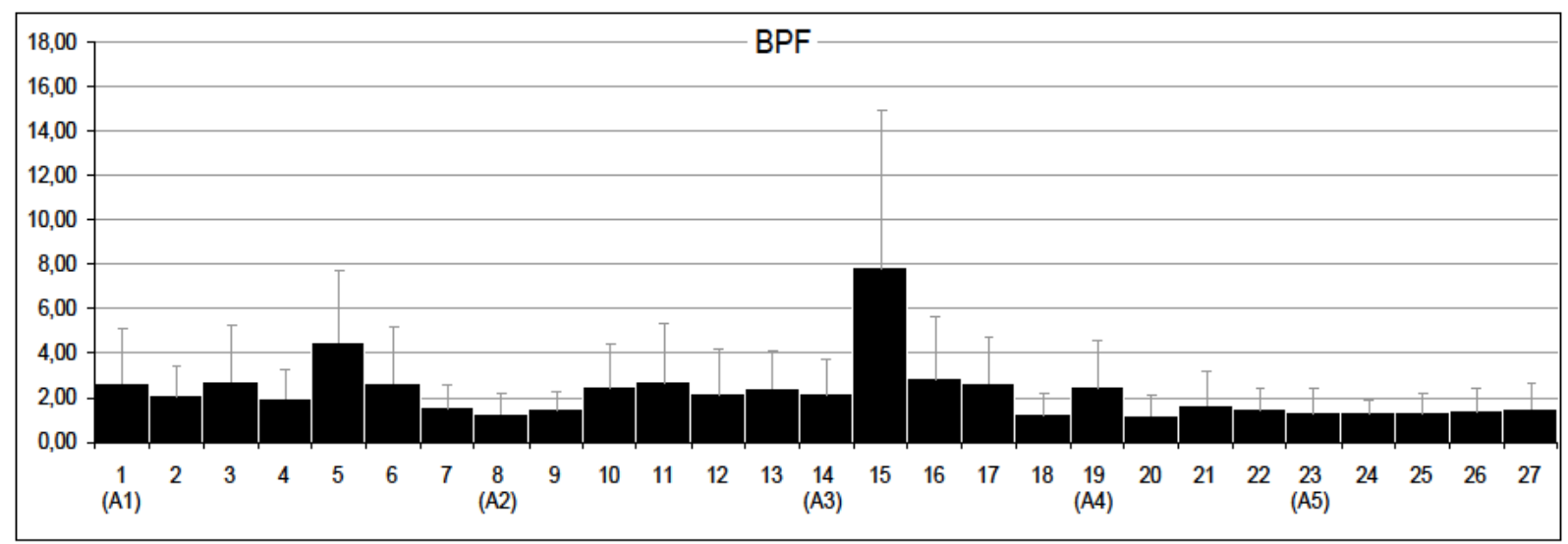

Figura 6.5.35. Evolución temporal de los valores de Zn biodisponible en suelo rizosférico (0$20 \mathrm{~cm}$ ) durante 27 muestreos realizados con periodicidad quincenal entre junio 2016 y septiembre 2017 en parcelas tratadas con bacterias Pseudomonas fluorescens (BPF) y 5 aplicaciones (junio 2016, septiembre 2016, enero 2017, abril 2017 y junio 2017), n=3.

En las parcelas tratados con bacterias Pseudomonas fluorescens los valores de $\mathrm{Zn}$ biodisponible oscilaron entre 1,15 (valor mínimo) y 7,84 (valor máximo), siendo el valor promedio de $2,25 \pm 1,34$.

Estadísticamente se observaron diferencias significativas entre los valores de $\mathrm{Zn}$ biodisponible registrados en las parcelas estudiadas, destacando los valores registrados en las parcelas $A C$ con respecto al resto de parcelas (CT, AO, AA y BPF). Concretamente se encontró la siguiente tendencia: $A C \geq A O \geq C T \sim B P F \geq A A$. Entre los diferentes muestreos, no se registraron diferencias estadísticamente significativas en ninguna de las parcelas estudiadas (CT, AO, AC, AA y BPF). 


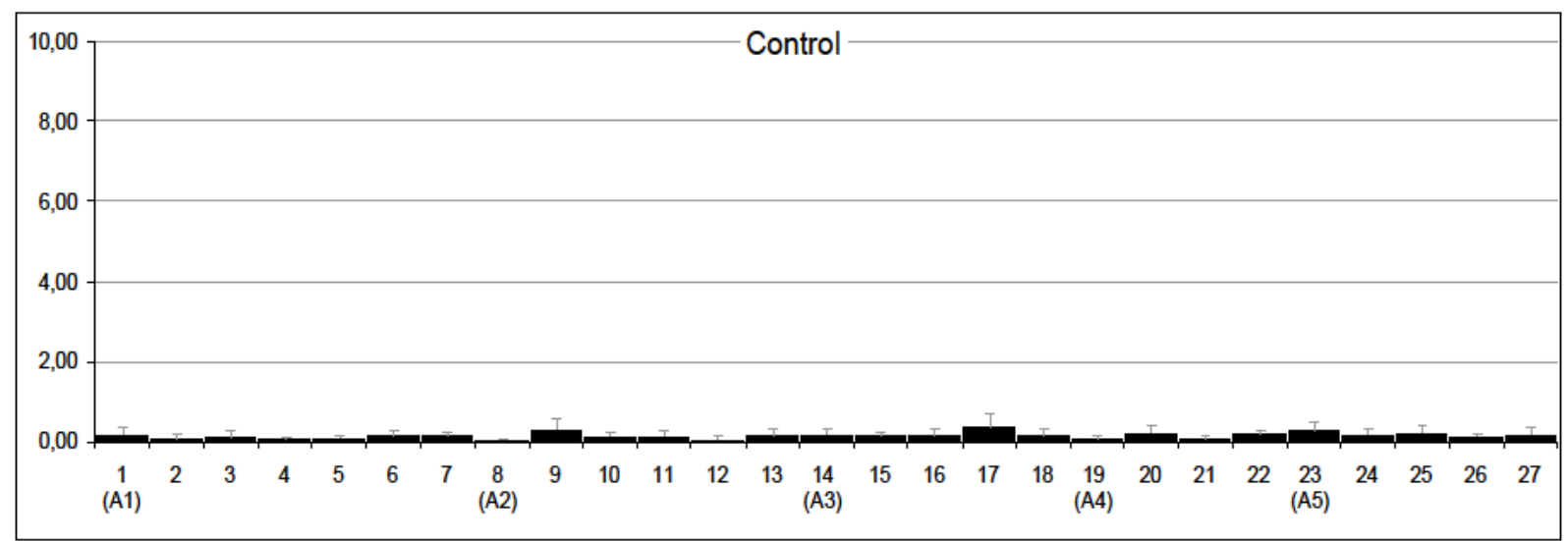

Figura 6.5.36. Evolución temporal de los valores de $\mathrm{Cr}$ biodisponible en suelo rizosférico (0$20 \mathrm{~cm}$ ) durante 27 muestreos realizados con periodicidad quincenal entre junio $2016 \mathrm{y}$ septiembre 2017 en parcelas control (CT) y 5 aplicaciones (junio 2016, septiembre 2016, enero 2017, abril 2017 y junio 2017), n=3.

En las parcelas control los valores de $\mathrm{Cr}$ biodisponible oscilaron entre 0,06 (valor mínimo) y 0,40 (valor máximo), siendo el valor promedio de $0,17 \pm 0,07$.

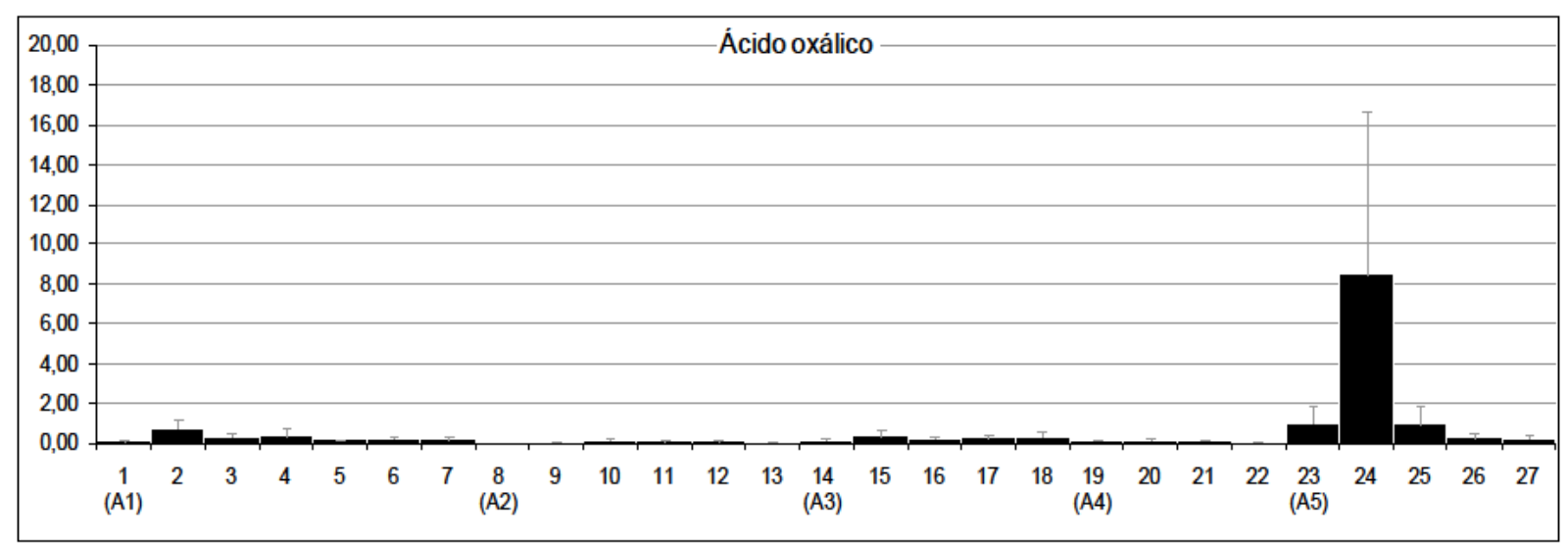

Figura 6.5.37. Evolución temporal de los valores de $\mathrm{Cr}$ biodisponible en suelo rizosférico (0$20 \mathrm{~cm}$ ) durante 27 muestreos realizados con periodicidad quincenal entre junio $2016 \mathrm{y}$ septiembre 2017 en parcelas tratadas con dosis de $5 \mathrm{mmol} / \mathrm{kg}$ de ácido oxálico (AO) y 5 aplicaciones (junio 2016, septiembre 2016, enero 2017, abril 2017 y junio 2017), n=3.

En las parcelas tratados con ácido oxálico los valores de $\mathrm{Cr}$ biodisponible oscilaron entre 0,02 (valor mínimo) y 8,43 (valor máximo), siendo el valor promedio de $0,55 \pm 1,59$. 


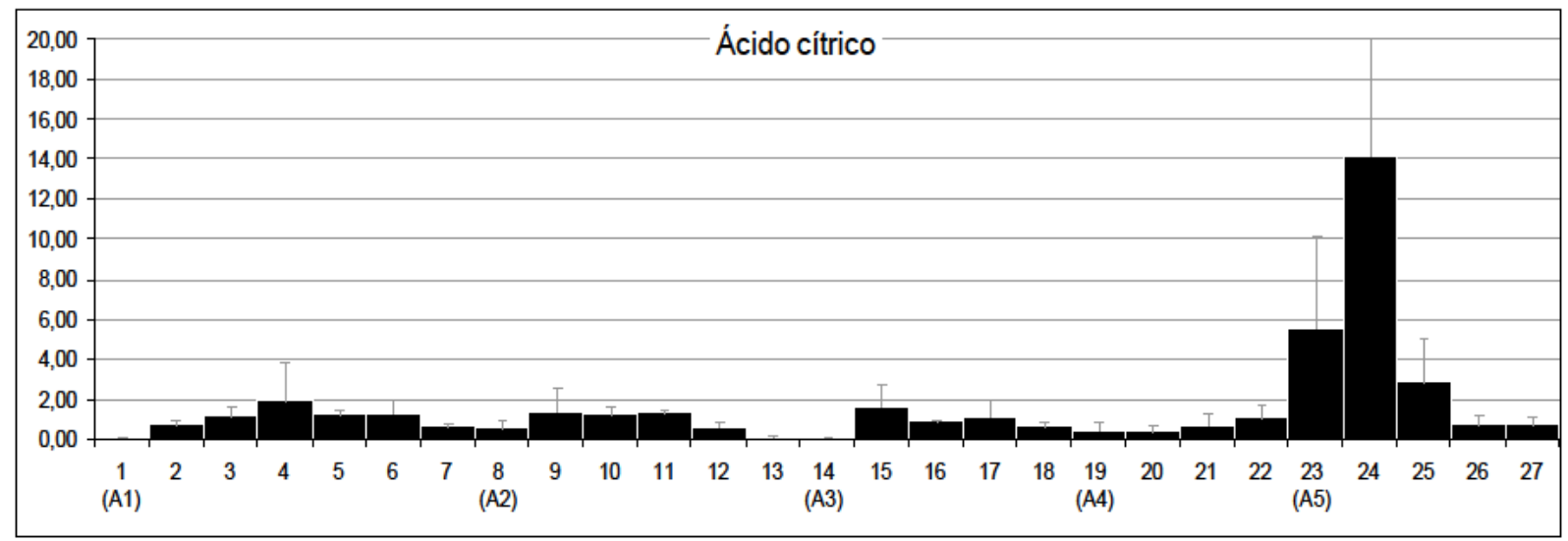

Figura 6.5.38. Evolución temporal de los valores de Cr biodisponible en suelo rizosférico (0$20 \mathrm{~cm}$ ) durante 27 muestreos realizados con periodicidad quincenal entre junio $2016 \mathrm{y}$ septiembre 2017 en parcelas tratadas con dosis de $5 \mathrm{mmol} / \mathrm{kg}$ de ácido cítrico (AC) y 5 aplicaciones (junio 2016, septiembre 2016, enero 2017, abril 2017 y junio 2017), n=3.

En las parcelas tratados con ácido cítrico los valores de $\mathrm{Cr}$ biodisponible oscilaron entre 0,09 (valor mínimo) y 14,21 (valor máximo), siendo el valor promedio de 1,60 22,74.

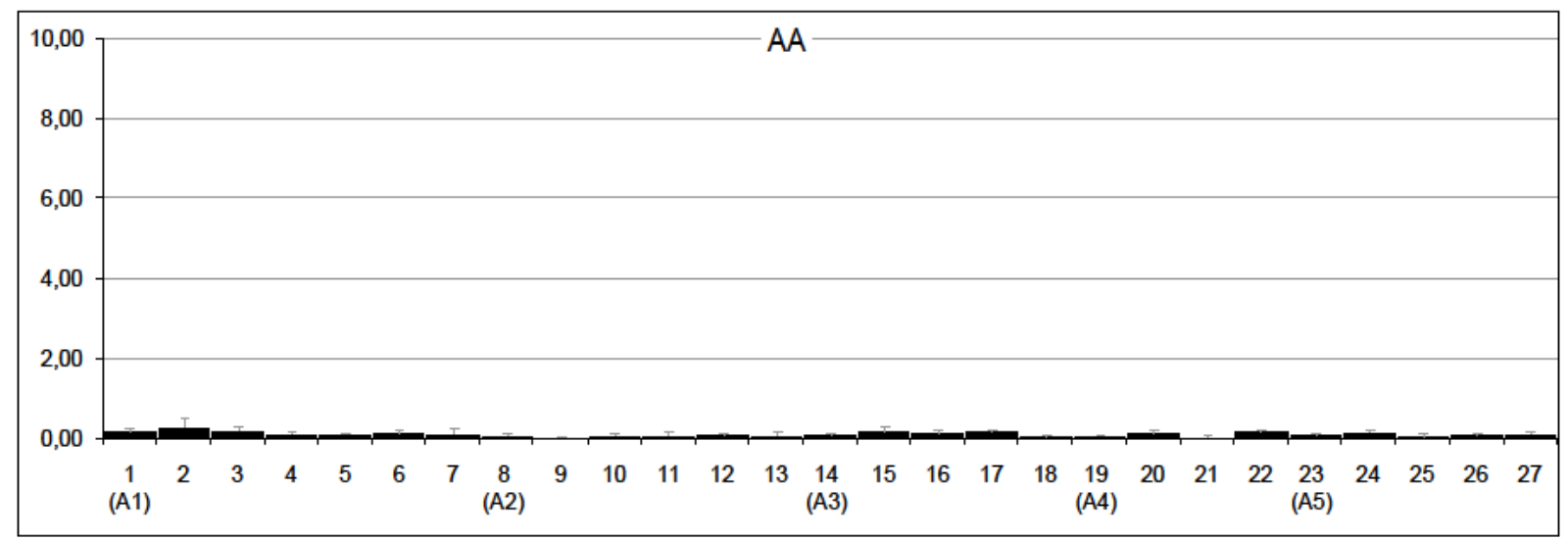

Figura 6.5.39. Evolución temporal de los valores de $\mathrm{Cr}$ biodisponible en suelo rizosférico (0$20 \mathrm{~cm}$ ) durante 27 muestreos realizados con periodicidad quincenal entre junio $2016 \mathrm{y}$ septiembre 2017 en parcelas tratadas con aminoácidos (AA) y 5 aplicaciones (junio 2016, septiembre 2016, enero 2017, abril 2017 y junio 2017), $n=3$.

En las parcelas tratados con aminoácidos los valores de $\mathrm{Cr}$ biodisponible oscilaron entre

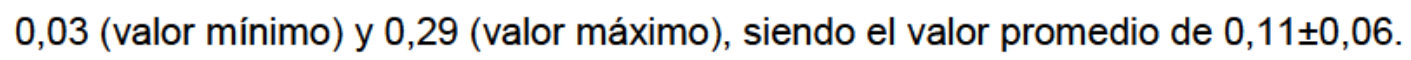




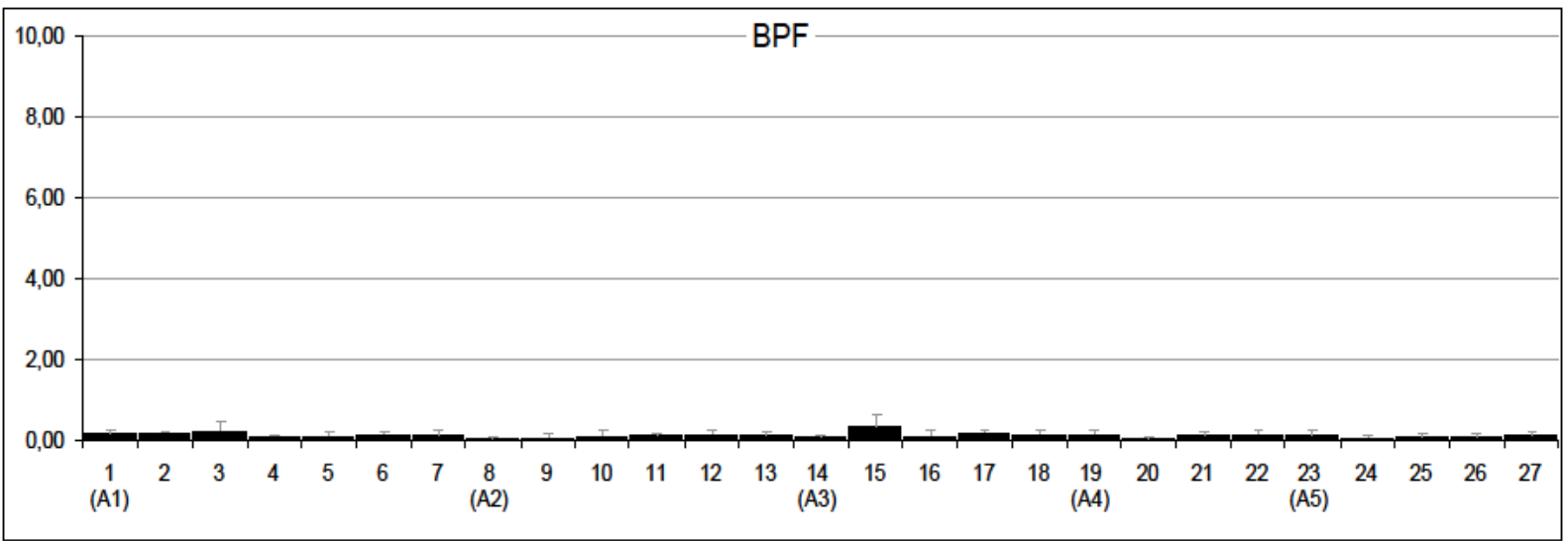

Figura 6.5.40. Evolución temporal de los valores de $\mathrm{Cr}$ biodisponible en suelo rizosférico (0$20 \mathrm{~cm}$ ) durante 27 muestreos realizados con periodicidad quincenal entre junio $2016 \mathrm{y}$ septiembre 2017 en parcelas tratadas con bacterias Pseudomonas fluorescens (BPF) y 5 aplicaciones (junio 2016, septiembre 2016, enero 2017, abril 2017 y junio 2017), n=3.

En las parcelas tratados con bacterias Pseudomonas fluorescens los valores de $\mathrm{Cr}$ biodisponible oscilaron entre 0,04 (valor mínimo) y 0,35 (valor máximo), siendo el valor promedio de $0,13 \pm 0,06$.

Estadísticamente no se observaron diferencias significativas entre los valores de $\mathrm{Cr}$ biodisponible registrados en las parcelas estudiadas, comportándose por tanto todos los

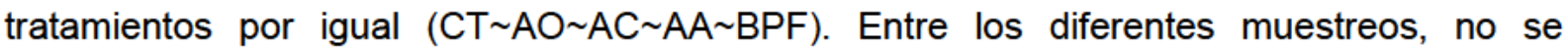
registraron diferencias estadísticamente significativas en las parcelas $C T, A O, A A$ y BPF. Solamente se registraron diferencias estadísticamente significativas entre los diferentes muestreos en las parcelas $\mathrm{AC}$. Los valores estadísticamente más bajos de $\mathrm{Cr}$ soluble se registraron en los muestreos 13 y 14, y los valores estadísticamente más elevados se encontraron en los muestreos 3 (justo después de la A5) y 24., habiéndose realizado las aplicaciones después de los muestreos 1, 8, 14, 18 y 22. Presentando el resto de muestreos un comportamiento intermedio similar.

Con respecto a las concentraciones de metales solubles $(\mathrm{Cu}, \mathrm{Zn}$ y $\mathrm{Cr}$ ) que mostraron los sedimentos del suelo se registraron las siguientes tendencias (siendo estadísticamente significativas):

Parcelas CT: $\mathrm{Cr}>\mathrm{Cu} \sim \mathrm{Zn}$

Parcelas $\mathrm{AO}: \mathrm{Cr}>\mathrm{Cu} \sim \mathrm{Zn}$

Parcelas AC: $\mathrm{Cr}>\mathrm{Cu} \sim \mathrm{Zn}$

Parcelas $A A: C r \geq C u \geq Z n$

Parcelas BPF: $\mathrm{Cr}>\mathrm{Cu} \geq \mathrm{Zn}$ 
En forma soluble, Cr es el metal mayormente presente en los sedimentos del suelo, seguido de Cu y por último de $\mathrm{Zn}$, que en algunas parcelas presenta concentraciones similares a las de Cu.

Similarmente, con respecto a las concentraciones de metales biodisponibles $(\mathrm{Cu}, \mathrm{Zn}$ y $\mathrm{Cr}$ ) que mostraron los sedimentos del suelo se registraron las siguientes tendencias (siendo estadísticamente significativas):

Parcelas CT: Cu Zn>Cr

Parcelas AO: $\mathrm{Cr} \sim \mathrm{Cu} \sim \mathrm{Zn}$

Parcelas AC: $\mathrm{Cu} \sim \mathrm{Zn}>\mathrm{Cr}$

Parcelas AA: $\mathrm{Cu}>\mathrm{Zn}>\mathrm{Cr}$

Parcelas BPF: $\mathrm{Cu}>\mathrm{Zn}>\mathrm{Cr}$

En forma biodisponible, no se observa una clara tendencia de disponibilidad de metales en los sedimentos del suelo. Para cada tratamiento se aprecia una tendencia diferente. El metal menos biodisponible es el $\mathrm{Cr}$, excepto en las parcelas $\mathrm{AO}$ en las que los 3 metales presentan concentraciones similares. Los metales más biodisponibles son $\mathrm{Cu}$ y Zn (parcelas $C T, A C, A A$ y BPF).

En la siguiente tabla se pueden observar las correlaciones registradas. Para el pH destaca la correlación registrada con la $\mathrm{CE}\left(\mathrm{r}=-0,566^{\star \star}\right)$, conforme disminuyen los valores de $\mathrm{pH}$ con las aplicaciones se observa un aumento de los valores de la CE. Este hecho se ha observado claramente en los resultados de $\mathrm{pH}$ y de $\mathrm{CE}$ registrados en las parcelas $\mathrm{AC}$. Además, la CE también presenta una correlación notable con las concentraciones de $\mathrm{Cr}$ biodisponible $\left(r=+0,499^{* *}\right)$, ambas son directamente proporcionales. Entre los metales solubles y los metales biodisponibles se observan correlaciones moderadas y directamente proporcionales, $\mathrm{Cr}$ soluble se correlaciona con $\mathrm{Cu}$ soluble $\left(r=+0,486^{\star \star}\right)$ y $\mathrm{Zn}$ soluble $\left(+0,491^{\star \star}\right)$. Similarmente, el $\mathrm{Zn}$ biodisponible se correlaciona fuertemente con $\mathrm{Cu}$ biodisponible $\left(r=+0,887^{\star \star}\right)$ y con $\mathrm{Cr}$ biodisponible $\left(0,466^{\star \star}\right)$.

Tabla 6.5.1. Resultados del test de correlaciones no paramétricas de Spearman durante 27 muestreos realizados con periodicidad quincenal entre junio 2016 y septiembre 2017 en parcelas tratadas (control, ácido oxálico, ácido cítrico, aminoácidos y bacterias 
Pseudomonas fluorescens) y 5 aplicaciones (junio 2016, septiembre 2016, enero 2017, abril 2017 y junio 2017), $n=405$.

\begin{tabular}{|c|c|c|c|c|c|c|c|c|c|}
\hline $\begin{array}{c}\text { Rho de } \\
\text { Spearman }\end{array}$ & Muestreo & $\mathrm{pH}$ & CE & $\begin{array}{c}\mathrm{Cu} \\
\text { soluble }\end{array}$ & $\begin{array}{c}\text { Zn } \\
\text { soluble }\end{array}$ & $\begin{array}{c}\mathrm{Cr} \\
\text { soluble }\end{array}$ & $\begin{array}{c}\mathrm{Cu} \\
\text { biodisp. }\end{array}$ & $\begin{array}{c}\text { Zn } \\
\text { biodisp. }\end{array}$ & $\begin{array}{c}\mathrm{Cr} \\
\text { biodisp. }\end{array}$ \\
\hline Muestreo & 1,000 & ,065 &,- 013 &, $261^{\star \star}$ &, $106^{*}$ & $116^{\star}$ &,$- 156^{\star \star}$ &,$- 208^{* \star}$ & ,030 \\
\hline $\mathrm{pH}$ & ,065 & 1,000 &,$- 566^{* *}$ &,$- 464^{\star *}$ &,$- 185^{\star *}$ &,$- 383^{* *}$ &,$- 271^{\star \star}$ &,$- 302^{* \star}$ &,$- 346^{* *}$ \\
\hline CE &,- 013 &,$- 566^{\star *}$ & 1,000 &, $186^{* *}$ &, $214^{* *}$ &, $384^{* \star}$ & $296^{* *}$ &, $315^{\star *}$ &, $499^{* \star}$ \\
\hline Cu soluble &, $261^{\star \star}$ &,$- 464^{* \star}$ &, $186^{\star \star}$ & 1,000 &, $232^{\star \star}$ &, $486^{\star \star}$ &, $192^{\star \star}$ &, $199^{\star \star}$ &, $244^{\star \star}$ \\
\hline Zn soluble &, $106^{*}$ &,$- 185^{\star *}$ &, $214^{* *}$ &, $232^{* *}$ & 1,000 & $491^{\star *}$ &, $196^{* *}$ &, $260^{* \star}$ &, $311^{\star *}$ \\
\hline Cr soluble &, $116^{*}$ &,$- 383^{* *}$ &, $384^{\star \star}$ &, $486^{\star \star}$ &, $491^{\star \star}$ & 1,000 & ,088 &, $130^{* *}$ &, $483^{* \star}$ \\
\hline Cu biodisp. &,$- 156^{* *}$ &,$- 271^{* *}$ &, $296^{* *}$ &, $192^{\star \star}$ &, $196^{\star *}$ & ,088 & 1,000 &, $887^{\star \star}$ &, $445^{\star \star}$ \\
\hline Zn biodisp. &,$- 208^{* k}$ &,$- 302^{* *}$ &, $315^{* *}$ & $199^{\star \star}$ &, $260^{\star *}$ &, $130^{* *}$ &, $887^{\star *}$ & 1,000 & $466^{\star *}$ \\
\hline Cr biodisp. & ,030 &,$- 346^{* *}$ &, $499^{\star *}$ &, $244^{\star *}$ &, $311^{\star *}$ & $.483^{* \star}$ &, $445^{* *}$ &, $466^{\star *}$ & 1,000 \\
\hline
\end{tabular}

**. La correlación es significativa en el nivel 0,01 (bilateral). *. La correlación es significativa en el nivel 0,05 (bilateral). 


\subsection{CONCLUSIONES}

Sobre los resultados de la evolución anual 2015-2016-2017 en los sedimentos del suelo de las parcelas control y las parcelas tratadas con agentes quelantes naturales y microorganismos (ácido oxálico, ácido cítrico, aminoácidos y bacterias Pseudomonas fluorescens) se han alcanzado las siguientes conclusiones:

- Los resultados obtenidos en los sedimentos del suelo presentan una gran variabilidad y no nos han permitido apreciar completamente la influencia de los tratamientos en las muestras de los sedimentos del suelo.

- La ausencia de variaciones significativas entre las diferentes profundidades muestreadas de las muestras de suelo rizosférico $(0-20 \mathrm{~cm}, 20-50 \mathrm{~cm}$ y $50-100 \mathrm{~cm})$ indica que el riesgo de lixiviación de sales y de metales es bajo.

- Las variaciones registradas entre el suelo rizosférico y el suelo no rizosférico ponen de manifiesto que existen variaciones en las concentraciones de metales $(\mathrm{Cu}, \mathrm{Zn}$ y $\mathrm{Cr}$ ) en todas las parcelas (incluida la parcela CT) como consecuencia de las aplicaciones y de la presencia de la vegetación fitoextractora.

- Las concentraciones de Cu intercambiable y de $\mathrm{Cr}$ soluble disminuyen notablemente durante el tiempo de experimentación y luego vuelven a aumentar, este hecho pone de manifiesto el carácter dinámico y fluctuante de las mismas debido a que se van liberando desde otras fracciones de estos metales presentes en el suelo.

- La solubilidad de Zn soluble disminuye significativamente en presencia de la vegetación fitoextractora, siendo este metal el que primeramente se acumulada por la vegetación.

Sobre los resultados de la evolución quincenal 2016-2017 en los sedimentos del suelo de las parcelas control y las parcelas tratadas con agentes quelantes naturales y microorganismos (ácido oxálico, ácido cítrico, aminoácidos y bacterias Pseudomonas fluorescens) se han alcanzado las siguientes conclusiones:

- Los valores de pH, CE, metales solubles ( $\mathrm{Cu}, \mathrm{Zn}$ y $\mathrm{Cr}$ ) y $\mathrm{Zn}$ biodisponible son significativamente superiores en las parcelas tratadas con ácido cítrico con respecto al resto de tratamientos (ácido oxálico, aminoácidos y bacterias Pseudomonas fluorescens y control), esto nos indica que tras 5 aplicaciones el tratamiento de las parcelas con ácido cítrico es el más efectivo y notable entre junio 2016 y septiembre 2017. Los resultados registrados en la evolución anual 2015-2016-2017 en las parcelas tratadas con ácido cítrico manifiestan que no existe riesgo de lixiviación, 
siendo este tratamiento el más sobresaliente para favorecer la solubilidad y fitoextracción de metales solubles ( $\mathrm{Cu}, \mathrm{Zn}$ y $\mathrm{Cr}$ ) en los sedimentos del suelo.

- La presencia de metales ( $\mathrm{Cu}, \mathrm{Zn}$ y $\mathrm{Cr}$ ) solubles y biodisponibles en los sedimentos del suelo presenta una tendencia clara y definida independiente de los tratamientos aplicados, por lo que el efecto de los tratamientos tras 5 aplicaciones y 27 muestreos no discrimina entre dichos metales.

- Entre junio 2016 y septiembre 2017 la aplicación de los tratamientos en las dosis estudiadas es recomendable dados los resultados obtenidos, aunque también sería conveniente realizar más aplicaciones para conocer el efecto más a largo plazo e investigar dosis superiores, especialmente de los tratamientos de ácido oxálico, aminoácidos y bacterias Pseudomonas fluorescens.

Como conclusión general sobre el estudio de los sedimentos de suelo afectado por Cu, Zn y $\mathrm{Cr}$ en parcelas tratadas con 5 tratamientos (control, ácido oxálico, aminoácidos y bacterias Pseudomonas fluorescens) con muestreos anuales y muestreos quincenales entre junio 2016 y septiembre 2017 se deduce que en condiciones de clima mediterráneo semiárido el riesgo de lixiviación (hasta $100 \mathrm{~cm}$ de profundidad) de metales solubles y metales biodisponibles ( $\mathrm{Cu}, \mathrm{Zn}$ y $\mathrm{Cr}$ ) es bajo. A largo plazo el tratamiento más notable para aumentar la solubilidad y biodisponibilidad de metales en suelo es el tratamiento con ácido cítrico, realizando siempre y cuando un seguimiento quincenal del suelo rizosférico $(0-20 \mathrm{~cm})$ y un seguimiento anual del suelo rizosférico y del suelo no rizosférico $(0-100 \mathrm{~cm})$. 
Capítulo 7

REFERENCIAS 

Adler P., Rajeev A., El Ghaouth D., Glenn M., Solar J. 1994. Bioremediation of phenolic compounds from water with plant root surface peroxidases. Journal of Environmental Quality 23, 11131117.

Adriano D.C., Wenzel W.W., Vangronsveld J., Bolán N. S. 2004. Role of assisted natural remediation in environmental cleanup. Geoderma 122, 121-142.

Agostini E., Coniglio M.S., Milrad S.R., Tigier H.A., Giulietti A.M. 2003. Phytoremediation of 2, 4dichlorophenol by Brassica napus hairy root cultures. Biotechnology and Applied Biochemistry $37,139-44$

Alexander M. 1999. Biodegradation and Bioremediation $2^{\text {nd }}$ edition Academic Press, London.

Alford E.R., Pilon-Smits E.A.H., Paschke M.W. 2010. Metallophytes - a view from the rhizosphere. Plant Soil 337, 33-50.

Ali H., Khan E., Sajad M.A. 2013. Phytoremediation of heavy metals - Concepts and applications. Chemosphere 91(2), 869-881.

Alloway B.J. 2012. Sources of Heavy Metals and Metalloids in Soils. En: Heavy Metals in Soils. Trace Metals and Metalloids in Soil and Their Bioavailability. Capítulo 2, $3^{\text {rd }}$ edition. University of Reading, UK. p. 11-50.

Anderson J.P.E. 1982. Soil respiration. En: Page, A.L., Miller, R.H. and Keeney DR (Eds.), Methods of soil analysis, Part 2 ( ${ }^{\text {nd }}$ edition). American Society of Agronomy and Soil Science Society of America, Madison, Wisconsin, USA. p. 837-871.

Anderson T., Coats J. 1994. Bioremediation through rhizosphere technology. En: ACS Symposium Series. Am. Chem. Soc. Washington D.C. Vol. 563, p. 204-215.

Anderson T., Coats J. 1995. Screening rhizosphere soil samples for the ability to mineralize elevated concentrations of atrazine and metolachlor. Journal of Environmental Science and Health 30 , 473-484.

Anderson T., Guthrie E., Walton B. 1993. Bioremediation in the rhizosphere. Environmental Science \& Technology 27, 2630-2636.

Antunes, A.P.M, Watkins G.M., Duncan J.R. 2001. Batch studies on the removal of gold (III) from aqueous solution by Azolla filiculoides. Biotechnoly Letters 23, 249-251.

April W., Sims R. 1990. Evaluation of the use of prairie grasses for stimulating polycyclic aromatic hydrocarbon treatment in soil. Chemosphere 20, 253-265.

Atlas R.M., Bartha, R. 2001. Ecología Microbiana \& Microbiología Ambiental. Pearson Educación, Madrid.

Atlas R.M., Unterman R. 1999. Bioremediation. En: Demain AL \& Davies JE (Eds) Manual of Industrial Microbiology and Biotechnology $2^{\text {nd }}$ ed (pp 666-681), ASM Press, Washington D.C.

Bani A., Echevarría G., Sulçe S., Morel J.L., Mullai A. 2007. In-situ phytoextraction of Ni by a native population of Alyssum múrale on an ultramaWc site (Albania). Plant and Soil 293, 79-89.

Barton C., Marx D., Adriano D., Jun-Koo B., Newman L., Czapka S., Blake J. 2005. Phytostabilization of a landfill containing coal combustion waste. Environmental Geosciences. 12, 251-265. 
Becerril Soto J.M., Barrutia Sarasua O., García Plazaola J.I., Hernández A., Olano Mendoza J.M., Garbisu Crespo C. 2007. Especies nativas de suelos contaminados por metales: aspectos ecofisiológicos y su uso en fitorremediación. Ecosistemas 16 (2), 50-55.

Begonia G.B., Davis C.D., Begonia M.F.T., Gray C.N. 1998. Growth Responses of Indian Mustard [Brassica júncea (L.) Czern.] and Its Phytoextraction of Lead from a Contaminated Soil Bull. Environmental Contamanation and Toxicology 61, 38-43.

Beltrá Castillo, JC. 2017. Estudio de la eliminación de metales pesado en un cauce fluvial mediante la técnica de fitoextracción. Proyecto fin de master. Universidad Miguel Hernández.

Bennett L.S., Burkhead J.L., Hale K.L., Terry N., Pilon M., Pilon-Smits E.A.H. 2003. Analysis of transgenic indian mustard plants for phytoremediation of metal-contaminated mine tailings. Journal of Environmental Quality 32, 432-440.

Bennicelli R., Stepniewska Z., Banach A., Szajnocha K., Ostrowski J. 2004. The ability of Azolla caroliniana to remove heavy metals $(\mathrm{Hg}(\mathrm{II}), \mathrm{Cr}(\mathrm{III}), \mathrm{Cr}(\mathrm{VI}))$ from municipal waste water. Chemosphere 55,141-146.

Beynon E.R., Symons Z.C, Jackson R.G., Lorenz A., Rylott E.L., Bruce N.C. 2009. The Rolo of Oxophytodienoate Reductases in the Detoxification of the Explosive 2,4,6-Trinitrotoluene by Arabidopsis. Plant Physiology 151, 253-261.

Bolán N.S., Adriano D.C, Naidu R. 2003. Role of phosphorus in inmobilization and bioavailability of heavy metals in the soil-plant system. Reviews of Environmental Contamination and Toxicology 177, 1-44.

Boniardi N., Rota R., Nano G. 1999. Effect of dissolved metals on the organic load removal efficiency of Lemna gibba. Water Research 33, 530-538.

Boonyapookana B., Parkplan P., Techapinyawat S., DeLaune R.D., Jugsujinda A. 2005. Phytoaccumulation of lead by sunflower (Helianthus annuus), tobacco (Nicotiana tabacum), and vetiver (Vetiveria zizanioides). Journal of Environmental Science and Health 40, 117-137.

Brandt R., Merkl N., Schultze-Kraft R., Infante C. 2006. Potential of vetiver (Vetiveria zizanoides L. Nash) for phytoremediation of hydrocarbon contaminated soils in Venezuela. International Journal of Phytoremediation 8, 273-284.

Breckle S., 1991. Growth under stress: heavy metals. En: Waisel, Y., Eshel, A., Kafkaffi, V., (eds.), "Plant roots: the hidden half". Marcel Dekker, Inc., New York. p. 351-373

Brooks R.R. 1998. Plants that Hyperaccumulate Heavy Metals: Their Role in Phytoremediation, Microbiology, Archaeology, Mineral Exploration and Phytomining. Wallingford, UK:CABInternational.

Burken J.G., Ma X. 2006. Phytoremediation of volatile organic compounds. En: Phytoremediation Rhizoremediation. Springer Netherlands (ed), p. 199-216.

Burrough P.A., McDonnell R.A. 1998. Creating continuous surfaces from point data. En: Burrough, P.A., Goodchild, M.F., McDonnell, R.A., Switzer, P., Worboys, M. (Eds.), Principles of Geographic Information Systems. Oxford University Press, Oxford, UK. 
Buurman P., van Lagen B., Veltorst E.J. 1996. Manual for Soil and Water Analysis. Backhuys publishers, Technical report, Leiden, Netherlands.

Carpena R.O., Bernal M.P. 2007. Claves de la fitorremediación: fitotecnologías para la recuperación de suelos. Ecosistemas 16, 1-3.

Castro S., Davis L.C, Erickson L.E. 2003. Phytotransformation of benzotriazoles. International Journal of Phytoremediation 5, 245-265.

Chandra P., Kulshreshtha K. 2004. Chromium accumulation and toxicity in aquatic vascular plants. The Botanical Review 70, 313-327.

Chandra S.K., Kamala C.T., Chary N.S., Balaram V., Garcia G. 2005. Potential of Hemidesmus indicus for phytoextraction of lead from industrially contaminated soils. Chemosphere 58, 507514.

Chaney R.L., Angle J.S., McIntosh M.S., Reeves R.D., Lid Y.M., Brewer E.P., Chen K.Y., Roseberg R.J., Perner H., Synkowski E.C., Broadhurst C.L., Wang S., Baker A.J.M. 2005. "Using Hyperaccumulator Plants to Phytoextract Soil Ni and Cd". Zeitschrift für Naturforschung C. 60, 190-198.

Chaudhry Q., Schröder P., Werck-Reichhart D., Grajek W., Marecik R. 2002. Prospects and limitations of phytoremediation for the removal of persistent pesticides in the environment. Environmental Science and Pollution Research 9, 4-17.

Cherian S., Oliveira M. 2005. Transgenic plants in phytoremediation: recent advances and new possibilities. Environmental Science \& Technology 39, 9377-9390.

Christofi N., Ivshina I.B. 2002. Microbial surfactants and their use in field studies of soil remediation, Journal of Applied Microbiology 93, 915-929.

Cohen-Shoel Z., Barkay N., Ilzycer D., Gilath L., Tel-Or, E. 2002. Biofiltration of toxic elements by Azolla biomass. Water, Air, \& Soil Pollution 135, 93-104.

Conesa H.M, Faz A., Arnaldos, R. 2007. Initial studies for the phytostabilization of a mine tailing from the Cartagena-La Union Mining District (SE Spain). Chemosphere 66, 38-44.

Crowley E., Alvey S., Gilbert E. 1997. Rhizosphere ecology of xenobiotic-degrading microorganims. En Phytoremediation of soil and water contamination (capítulo 2), 306 p.

Cunningham S., Shann J., Crowley D., Anderson T. 1997. Phytoremediation of contaminated soil and water. En: Phytoremediation of Soil and Water Contaminants (E. L. Kruger, T. A. Anderson y J. R. Coats, Eds.) American Chemical Society, Washington DC p. 2-17.

Cunningham S.D., Berti W.R., Huang J.W.1995. Phytoremediation of contaminated soils. Trends Biotechnology 13, 393-397.

Das K., Das S., Dhundasi S. 2008. Nickel, its adverse health effects an oxidative stress. Indian Journal of Medical Research 128, 412-425.

De la Fuente J.M., Ramirez-Rodriguez V., Cabrera-Ponce J.L., Herrera-Estrella L. 1997. Aluminium tolerance in transgenic plants by alteration of citrate synthesis. Science 276, 1566-1568. 
Dec J., Bollang J. 1994. Use of plant material for the decontamination of water polluted with phenols. Biotechnology and Bioengineering 44, 1132-1139.

Denys S., Rollin C., Guillot F., Baroudi H. 2006. In-Situ Phytoremediation of Pahs Contaminated Soils Following a Bioremediation Treatment. Water, Air, \& Soil Pollution 6, 299-315.

Didierjean L., Gondet L., Perkins R., Lau S.M., Schaller H. 2002. Engineering herbicide metabolism in tobacco and Arabidopsis with CYP76B1, a cytochrome P450 enzyme from Jerusalem artichoke. Journal of Plant Physiology 130, 179-189.

Dietz, A.C, Schnoor J.L. 2001. Advances in phytoremediation. Environmental Health Perspectives 109, 163-168.

Díez J.A. 1982. Consideraciones sobre la utilización de la técnica extractiva de Burriel-Hernando para la evaluación de fósforo asimilable en suelos. Anales de Edafología y Agrobiología 41, 13451353.

Diez Lázaro F.J. 2008. Fitocorrección de suelos contaminados con metales pesados: evaluación de plantas tolerantes y optimización del proceso mediante prácticas agronómicas. Tesis doctoral. Universidad de Santiago de Compostela, $344 \mathrm{p}$.

Dilek D. 2007. Effects of salinity on growth and nickel accumulation capacity of Lemna gibba (Lemnaceae). Journal of Hazardous Materials 147: 74-77.

Document on the best available techniques for the tanning of hides and skins. Marzo 2001. http://eippcb.jrc.ec.europa.eu/reference/BREF/TAN_Published_def.pdf

Dominguez-Solis J.R., Gutierrez-Alcalá G., Vega J.M., Romero L.C, Gotor C. 2001. The cytosolic Oacetylserine(thiol)lyase gene is regulated by heavy metals and can function in cadmium tolerance. Journal of Biological Chemistry 276, 9297-9302.

Doty S.L., James C.A., Moore A.L., Vajzovic A., Singleton G.L., Ma C., Khan Z., Xin G., Kang J.W., Park J.Y., Mellan R., Strauss S.H., Wilkerson J., Farm F., Strand S.E. 2007. Enhanced Phytoremediation of Volatile Environmental Pollutants with Transgenic Trees. Applied Biological Sciences 104, 16816-16821.

Doty S.L., Shang Q.T., Wilson A.M., Moore A.L., Newman L.A., Strand S.E. 2007. Enhanced metabolism of halogenated hydrocarbons in transgenic plants containing mammalian cytochrome P450 2E1. Proceedings of the National Academy of Sciences USA. Vol. 97, n 12, $6287-6291$.

Dushenkov S. 2003. Trends in phytoremediation ofradionuclides, Plant and Soil 249, 167-175.

Dushenkov V., Kumar P.B., Motto H., Raskin I. 1995. Rhizofiltration: the use of plants to remove heavy metals from aqueous streams. Environmental Science \& Technology 29, 1239-1245.

Eapen S., Singh S., D'Souza S.F. 2007. Advances in development of transgenic plants for remediation of xenobiotic pollutants. Biotechnology Advances 25, 442-451.

Eapen S., Suseelan K., Tivarekar S., Kotwal S., Mitra R. 2003. Potential for rhizofiltration of uranium using hairy root cultures of Brassica júncea and Chenopodium amar anticolor. Environmental Research 91, 127-133. 
Elwes J. (1999). Principios de Biorrecuperación, Mac Graw Hill, México, 275 p.

Ernst W.H.O. 1996. Bioavailability of heavy metals and decontamination of soils by plants. Applied Geochemistry 11, 163-167.

Flocco C.G., Lindblom S.D., Smits E.A.H.P. 2004. Overexpression of enzymes involved in glutathione synthesis enhances tolerance to organic pollutants in Brassica júncea. International Journal of Phytoremediation 6, 289-304.

Fogarty R.V., Dostalek P., Patzak M., Votruba J., Tel-Or E., Tobin J.M. 1999. Metal removal by immobilised and non-immobilised Azolla filiculoides. Biotechnology Technology 13, 530-538.

Freeman J.L., Persans M.W., Nieman K., Albrecht C., Peer W., Pickering I.J, Salt D.E. 2004. Increased glutathione biosynthesis plays a role in nickel tolerance in Thalaspi nickel hyperaccumulators. Plant Cell 16, 2176-2191.

Frérot H., Lefébvre C., Gruber W., Collin C., Dos-Santos A., Escarré J. 2006. Specific interactions between local metallicolous plants improve the phyto stabilization of mine soils. Plant and Soil. $282,53-65$

Garbisu C., Becerril J.M, Epelde L., Alkorta I. 2007. Bioindicadores de la calidad del suelo: herramienta metodológica para la evaluación de la eficacia de un proceso fitorremediador. Ecosistemas $16,44-49$.

Ghosh M., Singh S.P. 2005. A review on phytoremediation of heavy metals and utilization of its byproducts. Applied Ecology and Environmental Research 3: 1-18.

Gisbert C., Ros R., Haro A.D., Walker D.J., Bernal M.P., Serrano R., Avino J.N. 2003. A plant genetically modified that accumulates $\mathrm{Pb}$ is especially promising for phytoremediation. Biochemical and Biophysical Research Communications 303, 440-445.

Glass D.J. 1999. U.S. and international markets for phytoremediation. Needham, MA: D. Glass Associates, $266 \mathrm{p}$.

Glazer A.N., Nikaido H. 1995. Microbial Biotechnology: Fundamentals of Applied Microbiology. W.H. Freeman and Company, New York.

Gomez N.E., Cozatl D.M., Sanchez R.M., Mendoza D.G., Perez O.Z., Hernandez A.M., Santamaria J.M. 2009. The Pb-hyperaccumulator aquatic fern Salvinia minima Baker, responds to $\mathrm{Pb}^{2+}$ by increasing phytochelatins via changes in SmPCS expression and in phytochelatin synthase activity. Aquatic Toxicology 91, 320-328.

Gonzalez R.C., Gonzalez-Chavez M.C.A. 2006. Metal accumulation in wild plants surrounding mining wastes: soil and sediment remediation (SSR). Environmental Pollution 144:84-92.

Greipsson, S., 2011. Phytoremediation. Nature Education Knowledge 2, 7.

Groudeva V.I., Groudev S.N., Doycheva A.S. 2001. Bioremediation of waters contaminated with crude oil and toxic heavy metals. International Journal of Mineral Processing 62, 293-299.

Guía Mejores Técnicas Disponibles en España del sector de curtidos. 2003. Ministerio Medio Ambiente. .

Guía mejores técnicas disponibles en España del sector porcino. 20016. Ministerio Medio Ambiente. 
Günter N. Martinoia E. 2002. Closter roots an underground adaptation for survival in extreme environments. Trends in Plant Science 4, 162-167.

Guo L., Cutright T.J. 2015. Effect of citric acid and bacteria on metal uptake in reeds grown in a synthetic acid mine drainage solution. Journal of Environmental Management, 150, 235-242.

Hannink N., Rosser S.J., French C.E., Basran A., Murray J.A.H., Nicklin S., Bruce N.C. 2001. Phytoremediation of TNT by transgenic plants expressing a bacterial nitroreductase. Nature Biotechnology 19, 1168-1172.

Harvey P., Campanela B., Castro P., Harms H., Lichtfouse E., Schäffner A., Smrcek S., Werck D. 2002. Phytoremediation of polyaromatic hydrocarbons, anilines and phenols. Environmental Science and Pollution Research 9, 29-47.

Hasan Abbasi G. 2014. Citric Acid Improves Lead (pb) Phytoextraction in Brassica Napus L. by Mitigating $\mathrm{Pb}$-Induced Morphological and Biochemical Damages. Ecotoxicology and Environmental Safety 109, 38-47.

Hesegawa I.E., Terada M., Sunairi H., Wakita F., Shinmachi A., Noguchi M., Nakajima J. 1997. Genetic improvement of heavy metal tolerance in plants by transfer of the yeast metallothionein gene (CUP1). Plant Soil 196, 277-281.

Hidalgo López A. 2012. Valorización de residuos de biomasa en la industria de la construcción. http://hdl.handle.net/10261/46860.

Higuchi K. 1999. Cloning of nicotianamine synthase genes, novel genes involved in the synthesis of phytosiderophores. Plant Physiology 119, 471-479.

Hirose S., Kawahigashi H., Inoue T., Inui H., Ohkawa H., Ohkawa Y. 2005. Enhanced expression of CYP2C9 and tolerance to sulfonylurea herbicides in transgenic rice plants. Plant Biotechnology 22, 89-96.

Hong M., Farmayan W., Dortch I., Chiang C. 2001. Phytoremediation of MTBE from a groundwater plume. Environmental Science \& Technology 35, 1231-1239.

Hutchinsona S.L., Schwab A.P., Banks M. K. 2001. Phytoremediation of Aged Petroleum Sludge, Effect of Irrigation Techniques and Scheduling. Journal of Environmental Quality 30, 15161522

INE, 2015. CNAE151 Preparación, curtido y acabado del cuero; fabricación de artículos de marroquinería, viaje y de guarnicionería y talabartería; preparación y teñido de pieles

Jaenecke S., de Lorenzo V., Timmis K.N., Diaz E. 1996. A stringently controlled expression system for analysing lateral gene transfer between bacteria. Molecular Microbiology 21, 293-300.

Jakoby W., Ziegler D. 1990. The enzymes of detoxication. Journal of Biological Chemistry 34, 2071520718.

Jian wei W., Chen J., William R., Cunningham R. 1997. Phytoremediation of lead-contaminated soils: role of synthetic chelates in lead phytoextraction. Environmental Science \& Technology 31, 800-805. 
Joner E., Leyval C. 2003. Rhizosphere gradients of polycyclic aromatic hydrocarbon (PAH) dissipation in two industrial soils and the impact of arbuscular mycorrhiza. Environmental Science \& Technology 37, 2371-2375.

Kabata-Pendias, A. (2000) Trace Elements in Soils and Plants. 3rd Edition, CRC Press, Boca Raton.

Kamal M., Ghaly A.E., Mahmoud N, Cote R. 2004. Phytoaccumulation of heavy metals by aquatic plants. Environment International 29, 1029-1039.

Kassel G., Ghoshal D., Goyal A. 2002. Phytoremediation of trichloroethylene using hybrid poplar. Physiology and Molecular Biology of Plants 8, 3-10.

Kawagashi H., Hirose S., Ohkawa H., Ohkawa Y. 2007. Herbicide resistance of transgenic rice plants expressing human CYP1A1. Biotechnology Advances 25, 75-85.

Kelley C., Gaither K.K., Baca-Spry A., Cruickshank B.J. 2000. Incorporation of phytoremediation strategies into the introductory chemistry laboratory. Chemical Educator 5:140-143.

King R.B., Long G.M., Sheldon J.K. 1997. Practical environmental bioremediation, the field guide. Lewis publishers, NY.

Komives T., Gullner G. 2005. Phase I xenobiotic metabolic systems in plants. Z Naturforsch. 60, 179185.

Kramer U., Chardonnens A. 2001. The use of transgenic plants in the bioremediation of soils contaminated with trace elements. Applied Microbiology and Biotechnology 55, 661-672.

Krystofova O., Shestivska V., Galiova M., Novotny K., Kaiser J., Zehnalek J., Babula P., Opatrilova R., Adam V., Kizek R. 2009. Sunflower plants as bioindicators of environmental pollution with lead (II) ions. Sensors 9, 5040-5058.

Kumar P.B.A.N., Dushenkov V., Motto H., Raskin L. 1995. Phytoextraction: the use of plants to remove heavy metals from soils. Environmental Science \& Technology 29, 1232-1238.

Kuo S., Baker A.S. 1980. Sorption of copper, zinc and cadmium by some acid soils. Soil Science Society of America Journal 44, 969-974.

Kuzovkina Y.A., Knee M., Quigley M.F. 2004. Cadmium and copper uptake and translocation in five willow (Salix L.) species. International Journal of Phytoremediation 6(3): 269-287.

Kvesitadze G., Gordeziani M., Khatisashvili G., Sadunishvili and Ramsden J. 2001. Some aspects of the enzymatic basic of phytoremediation. Journal of Biological Physics and Chemistry 1, 4957.

Ley 29/1985, de 2 de agosto, de Aguas.

Li M.S., Luo Y.P., Su Z.Y. 2007. Heavy metal concentrations in soils and plant accumulation in a restored manganese mineland in Guangxi, South China. Environmental Pollution 147: 168175.

Licht L., Isebrands J., 2005. Linking phytoremediated pollutant removal to biomass economic opportunities. Biomass and Bioenergy 28, 203-218. 
Linsay W.L., Norvell W.A. 1978. Development of a DTPA soil test for zinc, iron, manganese and copper. Soil Science Society of America Journal 42, 421-428.

Lone M.I., He Z., Stoffella P.J., Yang X. 2008. Phytoremediation of heavy metal polluted soils and water: progresses and perspectives. Journal of Zhejiang University Science B 9, 210-220.

López-Martínez S., Gallegos-Martínez M.E., Pérez Flores L.J., Gutiérrez Rojas M. 2005. Revista internacional de contaminación Ambiental 21 (2), 91-100.

Ma X., Burken J.G. 2003. TCE diffusion to the atmosphere in phytoremediation applications. Environmental Science \& Technology 37, 2534-2539.

Ma X., Richter A.R., Albers S., Burken J.G. 2004. Phytoremediation of MTBE with hybrid poplar trees. International Journal of Phytoremediation 6: 157-167.

Macek T., Kotrba P., Svatos A., Novakova M., Demnerova K., Mackova M. 2007. Novel roles for genetically modified plants in environmental protection. Trends in Biotechnology 26, 146-152.

Macnair M.R., Tilstone G.H., Smith S.E. 2000. The genetics of metal tolerance and accumulation in higher plants. En: Terry N. y Banuelos G .Eds. Phytoremediation of Contaminated Soil and Water, pp. 235-250, CRC Press, Boca Raton, Florida.

Magri Aloy Albert. 2006. Tecnologías para el tratamiento de purines porcinos (I): Identificación de las principales alternativas.

Mains D., Craw D., Rufaut C.G., Smith C.M.S. 2006. Phytostabilization of gold mine tailings, New Zealand. Part 1: Plant establishment in alkaline saline substrate. International Journal of Phytoremediation 8, 131-147.

Malayeri B.E., Chehregani A., Yousefi N., Lorestani B. 2008. Identification of the hyper accumulator plants in copper and iron mine in Iran. Pak. International Journal of Biological Sciences 11, 490-492.

Maleva M.G., Nekrasova G.F., Bezel V.S. 2004. The Response of Hydrophytes to Environmental Pollution with Heavy Metals. Russian Journal of Ecology 35, 230-235.

Marjories S., Hong F.W., Farmayan J.I., Chen Y.C. 2001. Phytoremediation of MTBE from a Grounwaterplume. Environmental Science \& Technology 35, 1231-1233.

Marquínez J., Lastra J., Fernández E. 2006. Metodología utilizada para cartografiar la peligrosidad de inundaciones en las cuencas del Norte. En Díez, A., Lain, L. y Llorente, M. (Eds.): Mapas de peligrosidad de avenidas e inundaciones: Métodos, experiencias y aplicación. Publicaciones del IGME. Serie: Medio Ambiente. Riesgos Geológicos Madrid. 7:125-141.

Martínez, Pérez. 2007. Niveles de fondo y niveles genéricos de referencia de metales pesados en suelos de la Región de Murcia. Murcia. 304 p.

Mc Graths S.P., Lombi E., Zhao F.J., Dunham S.J. 2001. Phytoremediationof heavy metals Contaminated Soils: Natura Hyperaccumulation versus Chemical Industry. Elsevier applied Sciencie. London

McBride M.B., Blasiak J.J. 1979. Zinc and copper solubility as a function of $\mathrm{pH}$ in a acid soil. Soil Science Society of America Journal 43, 866-870. 
Mench M., Schwitzguebel J.P., Schroeder P., Bert V., Gawronski S., Gupta, S. 2009. Assessment of successful experiments and limitations of phytotechnologies: contaminant uptake, detoxification and sequestration, and consequences for food safety. Environmental Science and Pollution Research 16, 876-900.

Méndez M.O., Maier R.M. 2008. Phytostabilization of Mine Tailings in Arid and Semiarid Environments-An Emerging Remediation Technology. Environmental Health Perspectives $116,278-283$.

Mishra S., Jyot J., Kuhad R.C., Banwari L. 2001. Evaluation of Inoculum Addition To Stimulate In Situ Bioremediation of Oily-Sludge-Contaminated Soil. Applied Microbiology and Biotechnology 67, 1675-1681.

Misra S., Gedamu L. 1989. Heavy metal tolerant transgenic Brassica napus and Nicotiana tabacum L. plants. Theoretical and Applied Genetics 78, 161-168.

Miya K., Firestone K. 2001. Bioremediation and biodegradation. Journal of Environmental Quality 30, 1911-1918.

Mkandawire M., Taubert B., Dude E.G. 2005. Resource manipulation in uranium and arsenic attenuation by Lemna gibba L. (duckweed) in tailing water of a former uranium mine. Water, Air, \& Soil Pollution 166, 83-101.

Mudipalli, A., 2008. Metals (micro nutrients or toxicants) and global health. Indian Journal of Medical Research128, 331-334.

Nannipieri P., Ceccanti B., Cervelli S., Matarese E. 1980. Extraction of phosphatase, urease, protease, organic carbon and nitrogen from soil. Soil Science Society of America Journal 44, 1011-1016.

Nedelkoska T.V., Doran P.M. 2000. Hyperaccumulation of cadmium by hairy roots of Thlaspi caerulescens. Biotechnology and Bioengineering 67, 607-615.

Nesnerova P. 2004. First semi-synthetic preparation of sex pheromones. Green Chemistry 6, 305-307.

Newman L., Wang X., Muiznieks I., Ekuan G., Ruszaj M., Cortellucci R., Domroes D., Karscig G., Newman T., Crampton R., Hashmonay R., Yost M., Heilman P., Duffy J., Gordon M., Strand S. 1999. Remediation of trichloroethylene in an artificial aquifer with trees: A controlled field study. Environmental Science \& Technology 33, 2257-2265.

Odjegba V.I, Fasidi I.O. 2004. Accumulation of trace elements by Pistia stratiotes: Implications for phytoremediation. Ecotoxicology 13, 637-646.

Oller A.L.W., Agostini E., Talano M.A., Capozucca C., Murad S.R., Tigier A. 2005. Overexpression of a basic peroxidase in transgenic tomato (Lycopersicon esculentum Mill cv Pera) hairy roots increases phytoremediation of phenol. Plant Science 169: 1102-1111.

Padmavathiamma P.K., Li L.Y. 2007. Phytoremediation Technology: Hyperaccumulation Metals in Plants. Water, Air, \& Soil Pollution 184, 105-126. 
Pan A., Yang M., Tie F., Li L., Chen Z., Ru B. 1994. Expression of mouse metallothionein-I gene confers cadmium resistance in transgenic tobacco plants. Plant Molecular Biology 24, 341351.

Paul J.H. 1999. Microbial gene transfer: an ecological perspective. Journal of Molecular Microbiology and Biotechnology 1, 45-50.

Peles J.D., Smith M.H., Brisbin I. 2002. Ecological half-life of 137Cs in plants associated with a contaminated stream. Journal of Environmental Radioactivity 59, 169-178.

Pivetz B., Cochran R., Huling S. 1997. Abstract: Phytoremediation of PCP and PAHcontaminantedsoil. Poster 54. In $12^{\text {th }}$ Annual Conference onHazardous Waste Research Abstracts Book, May19-22, Kansas City, Mo. p. 145

Popa K., Cecal A., Humelnicu D., Caraus L., Draghici C.L. 2004. Removal of $60 \mathrm{Co}^{2+}$ and $137 \mathrm{Cs}^{+}$ions from low radioactive solutions using Azolla caroliniana willd. water fern. Central European Journal of Chemistry 2, 434-445.

Prasad M.N.V. 2004. Phytoremediation of metals in the environment for sustainable development. Proceedings of the Indian National Science Academy Part B 70, 71-98.

Prasad M.N.V., Freitas H.M.O. 2003. Metal hyperaccumulation in plants- biodiversity prospecting for phytoremediation technology. Journal of Molecular Biology \& Genetics 6, 276-312.

Pueyo M., López-Sanchez J.F., Rauret G. 2004. Assessment of $\mathrm{CaCl}_{2}, \mathrm{NaNO}_{3}$ and $\mathrm{NH}_{4} \mathrm{NO}_{3}$ extraction procedures for the study of $\mathrm{Cd}, \mathrm{Cu}, \mathrm{Pb}$ and $\mathrm{Zn}$ extractability in contaminated soils. Analytica Chimica Acta 504, 217-226.

Pulford I.D., Dickinson N.M. 2006. "Phytoremediation Technologies using trees". En: Prasat, M.N.V., Sajwan, K.S., Naidu, R., (eds.) "Trace elements in the environment, Biogeochemistry, Biotechnology and Bioremediation".CRC Press. Taylor \& Francis Group. 6000 Broken Sound Parkway NW, Suite 300. Boca Raton, FL 33487-2742.

Quin G., Terry N. 2003. Selenium Removal by Constructed Wetlands: Quantitative Importance of Biological Volatilization in the Treatment of Selenium-Laden Agricultural Drainage Water. Environmental Science \& Technology 37, 606-615.

Rafati M., Khorasani N., Moattar F., Shirvany A., Moraghebi F., Hosseinzadeh S. 2011. Phytoremediation potential of Populus Alba and Morus Alba for Cadmium, Chromuim and Nickel absorption from polluted soil. International Journal of Environmental Research 5, 961970 .

Raskin, I. 1996. Plant genetic engineering may help with environmental cleanup. Proceedings of the National Academy of Sciences USA. 93, 3164-3166.

Real Decreto 606/2003, de 23 de mayo, por el que se modifica el Real Decreto 849/1986, de 11 de abril, por el que se aprueba el Reglamento del Dominio Público

Real Decreto 849/1986, de 11 de abril, por el que se aprueba el Reglamento del Dominio Público Hidráulico que se desarrolla los títulos preliminar, I, IV, V, VI y VII de la 
Real Decreto 9/2008, de 11 de enero, por el que se modifica el Reglamento del Dominio Público Hidráulico, aprobado por el Real Decreto 849/1986, de 11 abril.

Real Decreto Legislativo 1/2001, de 20 de julio, por el que se aprueba el texto refundido de la Ley de Aguas.

Reeves R.D., Baker A.J.M., Borhidi A., Berazain R. 1999. Nickel hyperaccumulation in the serpentine flora of Cuba. Annals of Botany 83, 29-38.

Rieuwerts J.S., Thonton I., Farago M.E., Ashmore M.R. 1998. Factors influencing metals bioavailability in soils: preliminary investigations for the development of a critical loads approach for metals. Chemical Speciation and Bioavailability 10(2), 61-75.

Risser J.A., Baker D.E. 1990. Testing soils for toxic metals. pp. 275-298. En: R. L. Westerman (ed.). Soil Testing and plant analysis. Soil Science Society of America Special Publication 3. Madison, Wisconsin.

Robinson B., Fernández J.E., Madejón P., Marañón T., Murillo J.M., Green S., 2003. Phytoextraction: an assessment of biogeochemical and economic viability. Plant and Soil 249, 117-25.

Roig A., Romero M., Lax A., Fernández F.G. 1980. Estudio comparativo de métodos de determinación de capacidad de cambio catiónica en suelos calizos. Anales de Edafología y Agrobiología 39, 2021-2032.

Romero C., Pellerano R., Acevedo H., Vázquez F. 2006. Estandarización condiciones preliminares para la determinación de cromo en muestras medioambientales. Comunicaciones científicas y tecnológicas. Resumen E-039. Universidad Nacional el Nordeste (Argentina).

Rosenberg E. Ron E.Z. 1996. Bioremediation of petroleum contamination. In: Crawford RL \& Crawford DL (Eds) Bioremediation. Principles and Applications (p. 100- 124). Biotechnology Research Series 6. University Press, Cambridge.

Rugh C.L., Senecoff J.F., Meagher R.B., Merkle S.A. 1998. Development of transgenic yellow poplar for mercury phytoremediation. Nature Biotechnology 16, 925-928.

Salazar M.J., Pignata M.L. 2014. Lead accumulation in plants grown in polluted soils. Screening of native species for phytorremediation. Journal of Geochemical Exploration 137, 29-36.

Salt D.E., Smith R.D., Raskin I. 1998. Phytoremediation. Annual Review of Plant Physiology 49, 643668.

Sánchez-Chardi A., Ribeiro C.A.O., Nadal J. 2009. Metals in liver and kidneys and the effects of chronic exposure to pyrite mine pollution in the shrew Crocidura russula inhabiting the protected wetland of Doñana. Chemosphere 76, 387-394.

Sanderman H. 1992. Plant metabolism of xenobiotics. Trends in Plant Science 1, 82-84

Sauquillo A., Rigol A., Rauret G. 2003. Overview of the use of Leaching/Extraction Tests for Risk Assessment of Trace Metals in Contaminated Soils and Sediments. Trends in Analytical Chemistry 22, 152-159.

Schäffer A., Messener F., Langebartels C., Sanderman H. 2002. Genes and enzymes for in- plant phytoremediation of air waste and soils. Acta Biotechnologica 22, 141-152. 
Scharf K.D., Siddique M., Vierling E. 2001. The expanding family of Arabidopsis thaliana small heat stress proteins and a new family of proteins containing a-crystallin domains (Acd proteins). Cell Stress and Chaperones 6, 225-237.

Schat H., Llugany M., Bernharcl R. 2000. Metal-specific patterns of tolerance, uptake ancl transport of heavy metals in hyperaccumulating and non hyperaccumulating metallophytes. En: Terry N. y Banuelos G. Ecls. Phytoremediation of Contaminated Soil and Wate1; p. 171-188. CRC Press, Boca Raton, FL.

Schwartz C, Echevarría G., Morel J.L. 2003. Phytoextraction of cadmium with Thlaspi caerulescens. Plant and Soil 249, 27-35.

Sekara A., Poniedzialeek M., Ciura J., Jedrszczyk E. 2005. Cadmium and lead accumulation and distribution in the organs of nine crops: implications for phytoremediation. Polish Journal of Environmental Studies 14 (4), 509-516.

Senan R., Abraham T. 2004. Bioremediation of textile azo dyes by aerobic bacterial consortium. Biodegradation 4, 275-280

Sessitsch A., Kuffner M., Kidd P., Vangronsveld J., Wenzel W.W., Fallmann K., Pushenreiter M. 2013. The role of plant-asociated bacteria in the mobilization and phytoextraction of trace elements in contaminated soils. Soil Biology and Biochemistry 60, 182-194.

Severiche C, Gonzalez H.V. 2013. Assesment of an analytical method for determining hexavalent chromium i n water using spectrophotometry. Revista Facultad de Ingenierías USBMed 4(1): 22-26.

Shakoor B., Shafaqat Ali M., Mujahid Farid A.H., Tahira Yasmeen S.H., Saima Aslam Bharwana U.N.,

Sharma, N.C., Gardea-Torresdey J.L., Parsons J., Sahi S.V. 2004. Chemical speciation and cellular deposition of lead in Sesbania drummondii. Environmental Toxicology and Chemistry 23, 2068-2073.

Sheoran V., Sheoran A., Poonia P. 2011. Role of hyperaccumulators in phytoextraction of metals from contaminated mining sites: a review. Critical Reviews in Environmental Science and Technology 41, 168-214.

Shrestha B., Lipe S., Johnson K.A., Zhan T.Q., Retzlaff W., Lin Q. 2006. Soil hydraulic manipulation and organic amendment for the enhancement of selenium volatilization in a soil-pickleweed system. Plant and Soil 288, 189-196.

Siciliano S., Germida J., Banks K., Creer C. 2003. Changes in microbial community composition and function during a polyaromatic hydrocarbon. Applied and Environmental Microbiology 69, 483489.

Silva P.G., Goy J.L., Zazo C., Bardaji T. 1996. Evolución del drenaje en la Depresión del Guadalentín (Murcia, SE España). Geogaceta 20(5), 1100-1103.

Singh D., Archana T., Richa G. 2012. Phytoremediation of lead from wastewater using aquatic plants. Journal of Agricultural Technology 8(1): 1-11. 
Singh O.V., Jain R.K. 2003. Phytoremediation of toxic aromatic pollutants from soil. Applied and Microbiology Biotechnology 63, 128-135.

Singh S., Melo J.S., Eapen S., D'Souza S.F. 2006. Phenol removal by Brassica júncea hairy roots: role of inherent peroxidase and $\mathrm{H} 2 \mathrm{O} 2$. Journal of Biotechnology 123, 43-49.

Sistema Nacional de Cartografía de Zonas Inundables. http://sig.mapama.es/snczi/visor.html?herramienta=DPHZI

Sonoki T., Kajita S., Ikeda S., Uesugi M., Tatsumi K., Katayama Y. 2005. Transgenic tobacco expressing fungal lacease promotes the detoxification of environmental pollutants. Applied Microbiology and Biotechnology 67, 138-142.

Sundberg S.E., Ellington J.J., Evans J.J., Keys D.A., Fisher J.W. 2003. Accumulation of perchlorate in tobacco plants: development of a plant kinetic model. Journal of Environmental Monitoring 5, 505-512.

Suresh B., Sherkhane P.D., Kale S., Eapen S., Ravishankar G.A. 2005. Uptake and degradation of DDT by hairy root cultures of Cichorium intybus and Brassica júncea. Chemosphere 61, 12881292.

Suseela M.R., Sinha S., Singh S., Saxena R. 2002. Accumulation of chromium and scanning electron microscopic studies in Scirpus lacustris L. Treated with metal and tannery effluent. Bulletin of Environmental Contamination and Toxicology 68, 540-548.

Tabatabai M.A. 1982. Soil enzymes. En: Page, A.L., Miller, R.H. and Keeney, D.R. (Eds.), Methods of soil analysis, part 2 ( $2^{\text {nd }}$ edition). American Society of Agronomy and Soil Science Society of America, Madison, Wisconsin. p. 501-538.

Tabatabai M.A., Bremner J.M. 1969. Use of p-nitrophenyl phosphate in assay of soil phosphatase activity. Soil Biology and Biochemistry 1, 301-307.

Tabatabai M.A., Bremner J.M. 1970. Arylsulphatase activity of soils. Soil Science Society of America Journal 34, 225-229.

Telysheva G., Dizhbite T., Lebedeva G., Rossinskaja G., Jurkjane V., Treikale O., Yiesturs U., Daugavietis M. 2002. Lignin- based products stimulating soil phytoremediation. Acta Biotechnologica 22, 167-173.

Thangavel P., Subbhuraam C. 2004. Phytoextraction: role of hyperaccumulators in metal contaminated soils. Proceedings of the Indian National Science Academy part B 70, 109-130.

Thomas J.C, Davies E.C., Malick F.K., Endresz C., Williams C.R., Abbas M., Petrella S., Swisher K., Perron M., Edwards R., Ostenkowski P., Urbanczyk N., Wiesend W.N., Murray K.S. 2003. Yeast metallothionein in transgenic tobacco promotes copper uptake from contaminated soils. Biotechnology Progress 19, 273-280.

Tiller K.G. 1989. Heavy metals in soils and their environmental significance. Advances in soil Science, 9, 113-141.

Timmis K.N., Pieper D.H. 1999. Bacteria designed for bioremediation. Trends in Biotechnology 17, 201-204. 
US EPA Method 3060A. 1996. Alkaline digestión for hexavalent chromium.

USEPA. 1996. Bioremediation of hazardous waste site: practical approaches to implementation. EPA 625-K96-00.

Vain P. 2006. Global trends in plant transgenic science and technology. Trends in Biotechnology 24, 206-211.

Van A., Yoon B., Schnoor J.M. 2004. Biodegradation of nitro-substituted explosives 2,4,6trinitrotoluene, hexahydro-I,3,5-trinitro-1,3,5-triazine and octahydro-1,3,5,7-tetranitro-I,3,5tetrazocine by photosymbiotic Methylbacterium sp. associated with poplar tissues (Populus deltoids xnigra DN-34). Applied and Environmental Microbiology 70, 508-517.

Vance E.D., Brookes P.C., Jenkinson D.S. 1987. An extraction method for measuring soil microbial biomass C. Soil Biology and Biochemistry 19, 703-707.

Vangronsveld J., Herzig R., Weyens N., Boulet J., Adriaensen K., Ruttens A., Thewys T., Vassilev A., Meers E., Nehnelajova E., van der Lelie D., Mench M. 2009. Phytoremediation of contaminated soils and groundwater: lessons from the field. Environmental Science and Pollution Research 16, 765-794.

Vardanyan L.G., Ingole B.S. 2006. Studies on heavy metal accumulation in aquatic macrophytes from Sevan (Armenia) and Carambolim (India) lake systems. Environment International 32: 208218.

Vasudevan N., Rajaram P. 2001. Bioremediation of oil sludge-contaminated soil. Environment International 26, 409-411.

Vázquez S., Agha R., Granado A., Sarro M.J., Esteban E., Penalosa J.M., Carpena R.O. 2006. Use of White Lupin Plant for Phytostabilization of $\mathrm{Cd}$ and As Polluted Acid Soil. Water, Air, \& Soil Pollution 177, 349-365.

Villacieros M. 2005. PCB rhizoremediation by Pseudomonas fluorescens F113 derivatives using a Sinorhizobium meliloti nod system to drive bph gene expression. Applied and Environmental Microbiology 71, 2687-2694.

Viñas M. 2005. Biorremediación de suelos contaminados con hidrocarburos: caracterización, microbiología, química y ecotoxicológica. Facultad de biología. Universidad de Barcelona.

Vishnoi S.R., Srivastava P.N. 2008. Phytoremediation-green for environmental clean. Proceedings of Taal 2007: The $12^{\text {th }}$ World Lake Conference, 1016-1021.

Wackett L.P., Hershberger C.D. 2001. Biocatalysis and biodegradation: Microbial transformation of organic compounds. ASM Press, Washington, D.C.

Walter M.V. 1997. Bioaugmentation. In: Hurst, CJ (Ed) Manual of Environmental Microbiology (p. 753765). ASM Press, Washington, D.C.

Walton B., Hoylman A., Pérez M., Anderson T. 1994. Rhizosphere microbial communities as a plant defense against toxic substances in soils. ACS Symposium Am. Chem. Soc. Series 563, Washington, DC. 
Wand H., Kuschk P., Soltmann U., Stottmeister U. 2002. Enhanced removal of xenobiotics by helophytes. Acta Biotechnologica 22, 175-181.

Watanabe M.E. 1997. Phytoremediation on the brink of commercialization. Environmental Science \& Technology 31, 182-186.

Watt M., Evans J. 1999. Proteoid roots physiology and development. Plant Physiology 121, 317-323.

Weis J.S., Weis P. 2004. Metal uptake, transport and release by wetland plants: implications for phytoremediation and restoration. Environment International 30, 685-700.

Wenzel W.W., Unterbrunner R., Sommer P., Sacco P. 2003. Chelate-assisted phytoextraction using canola (Brassica napus L.) in outdoors pot and lysimeter experiments. Plant and Soil 249, 8396.

Wetzel S., Banks M., Schwab A. 1997. Rhizosphere effects on the degradation of pyrene and anthracene in soil. En: Phytoremediation of soil and water contaminants. (E.L. Kruger, T.A. Anderson, and J.R. Coats, Eds.), ACS American Chemical Society Symposium Series 664. Washington, DC.

Witters N., Mendelsohn R., Van Passel S., Slycken S., Weyens N., Schreurs E., Meers E., Tack F., Vanheusden B., Vangronsveld J. 2012. Phytoremediation, a sustainable remediation technology? II: Economic assessment of $\mathrm{CO}_{2}$ abatement through the use of phytoremediation crops for renewable energy production. Biomass and Bioenergy 39, 470-477.

World Leather. Noviembre 2006. http://www.leather-spain.com.

Wu L.H., Luo Y.M., Xing X.R., Christie P. 2004. "EDTA-enhanced phytoremediation of heavy metal contaminated soil with Indian mustard and associated potential leaching risk". Agriculture, Ecosystems \& Environment 102, 307-318.

Wu Q.T., Wei Z.B., Ouyang Y. 2007. Phytoextraction of Metal-Contaminated Soil by Sedum alfredii H: Effects of Chelator and Co-planting. Water, Air, \& Soil Pollution 180, 131-139.

Yang X.E., Long X.X, Ye H.B., He Z.L., Calvert D.V., Stoffella P.J. 2004. Cadmium tolerance and hyperaccumulation in a new Zn-hyperaccumulating plant species (Sedum alfredii Hance). Plant and Soil 259, 181-189.

Yoon J.M., Oliver D.J., Shanks J.V. 2006. Phytoremediation of 2,4-dinitrotoluene in Arabidopsis thaliana: toxicity, fate and gene expression studies in vitro. Biotechnology Progress 22, 15241531.

Zang Y., He Y., 2006. Co-composting solid swine manure with pine sawdust as organic substrate. Bioresuorce Technology 97, 2024-2031

Zhang B., Wu Z., Cheng S., He F., Wang Y., Gao Y. 2007. Primary study on phytodegradation of Bisphenol A by Eloclea nuttallii. Wuhan University Journal of Natural Sciences 12, 1118-1124.

Zhao M., Duncan J.R. 1998. Removal and recovery of nickel from aqueous solution and electroplating rinse effluent using Azolla filiculoides. Process Biochemistry 33, 249-255. 
Zheng J., Hintelmann H., Dimock B., Dzurko M.S. 2003. Speciation of arsenic in water, sediment, and plants of the Moira watershed, Canada, using HPLC coupled to high resolution ICP-MS. Analytical and Bioanalytical Chemistry 377, 14-24.

Zhuang P., Yang Q.W., Wang H.B., Shu W.S. 2007. Phytoextraction of Heavy Metals by Eight Plant Species in the Field. Water, Air, \& Soil Pollution 184, 235-242.

Zhuang P., Ye Z.H., Lan C.Y, Xie Z.W., Shu W.S. 2005. Chemically assisted phytoextraction of heavy metal contaminated soils using three plant species. Plant and Soil 276, 153-162. 
ANEXOS 


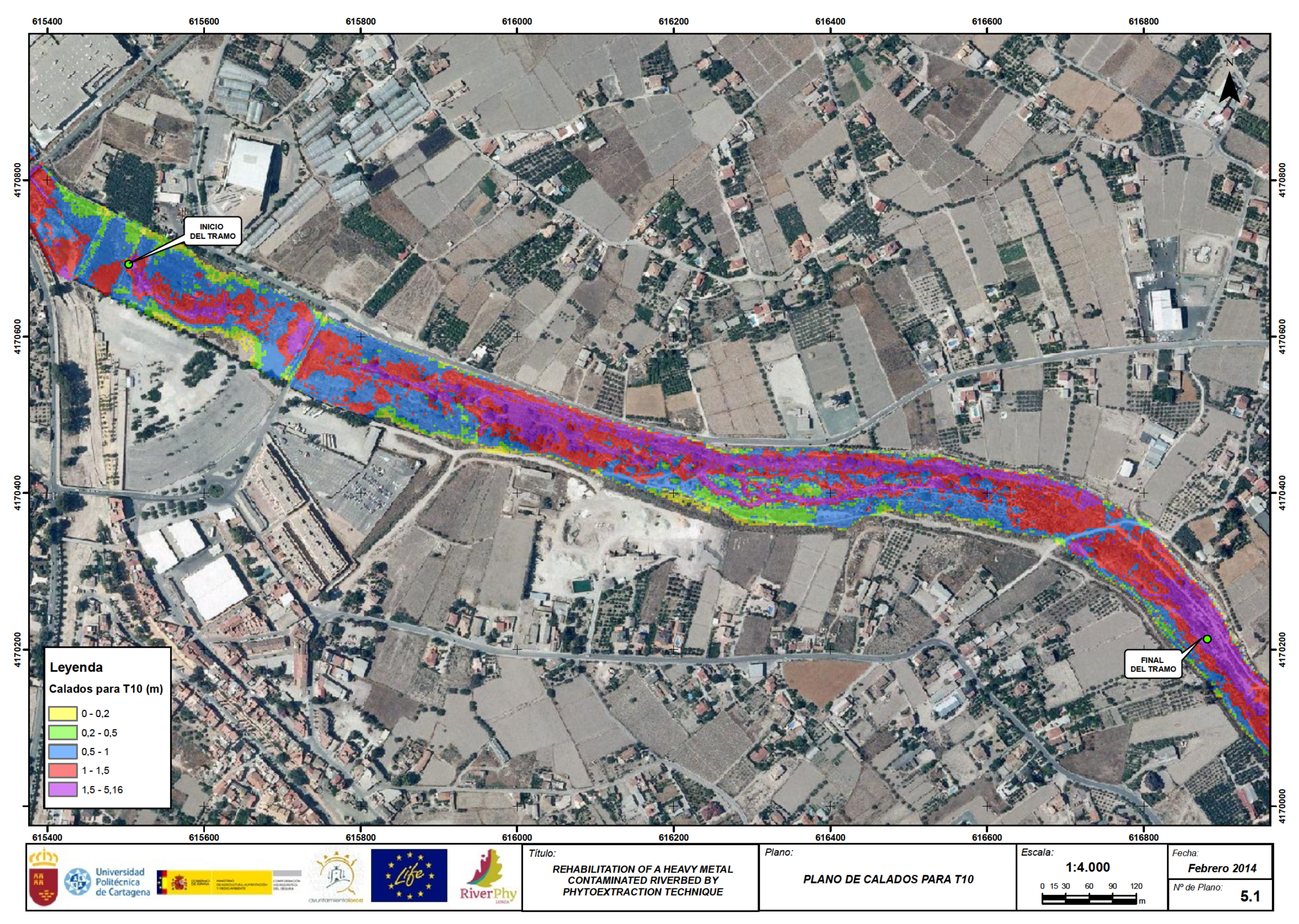




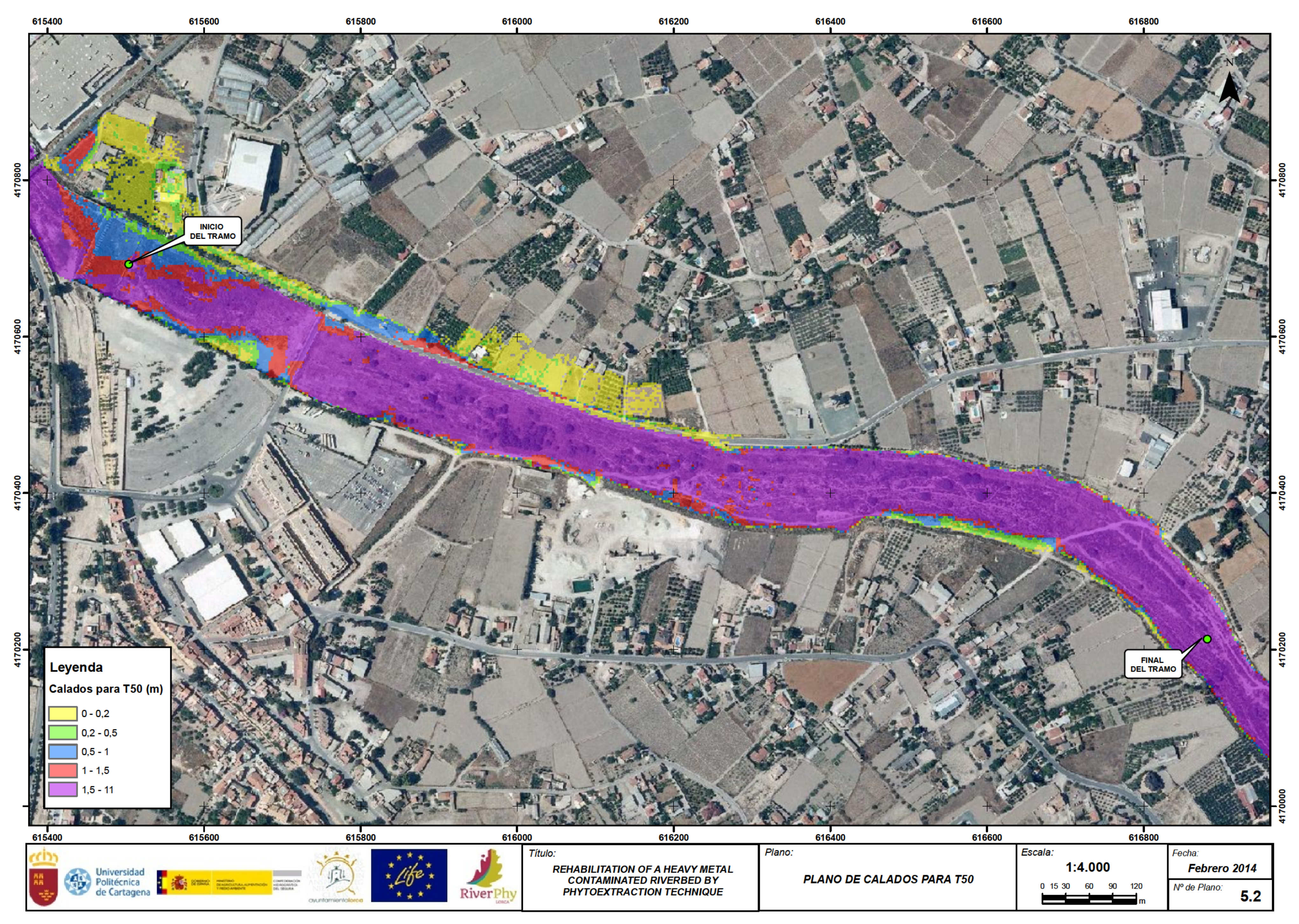




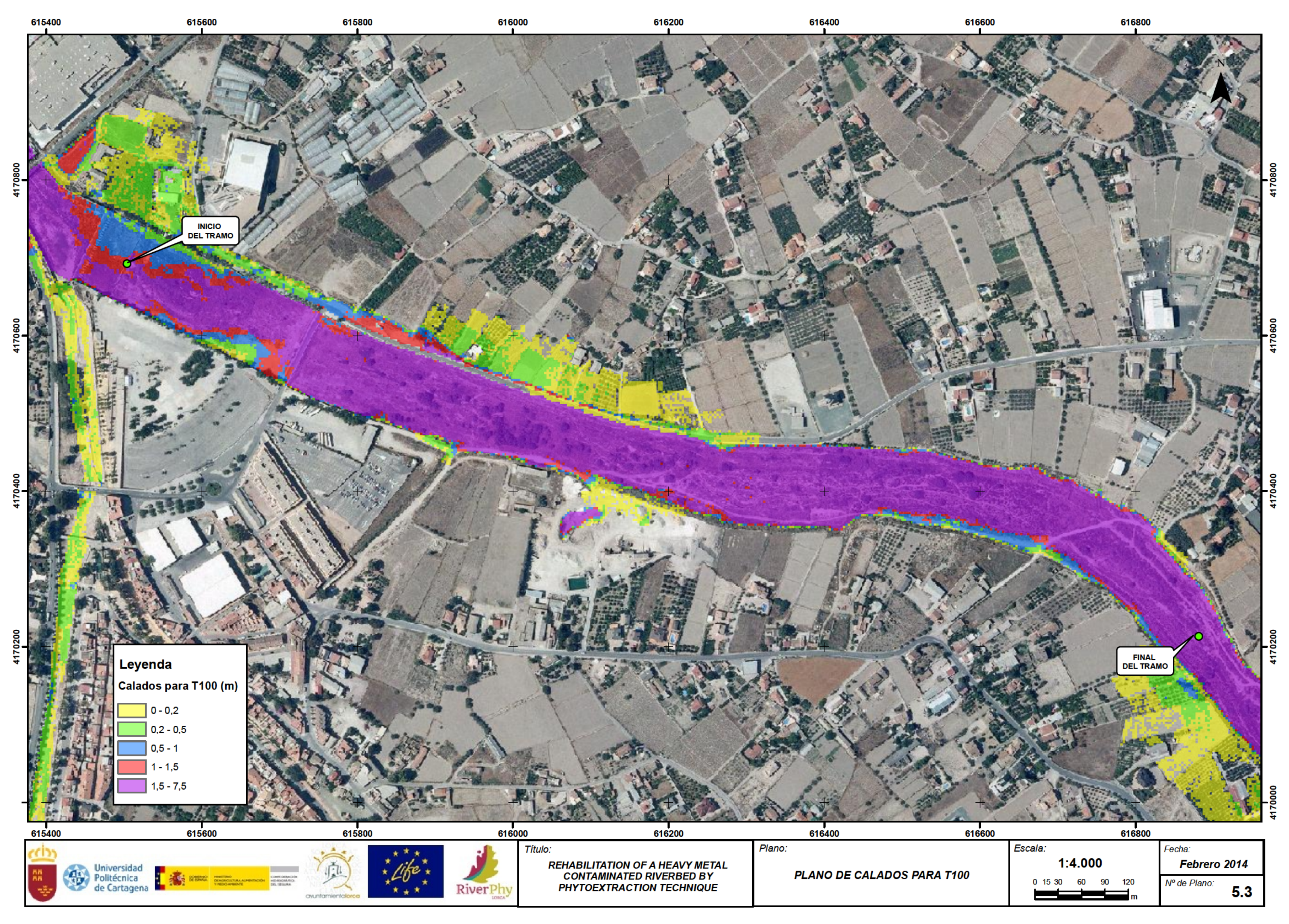




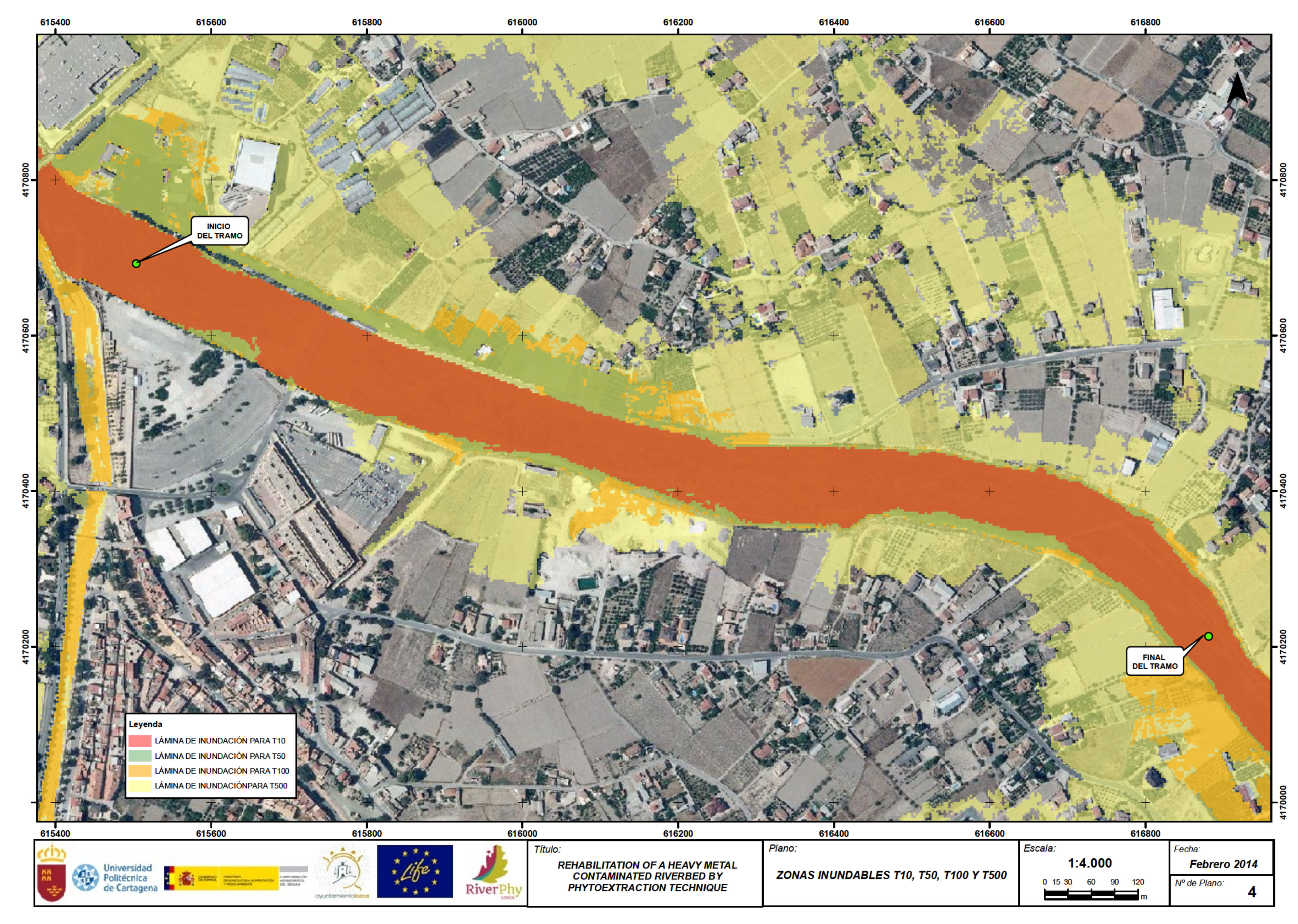




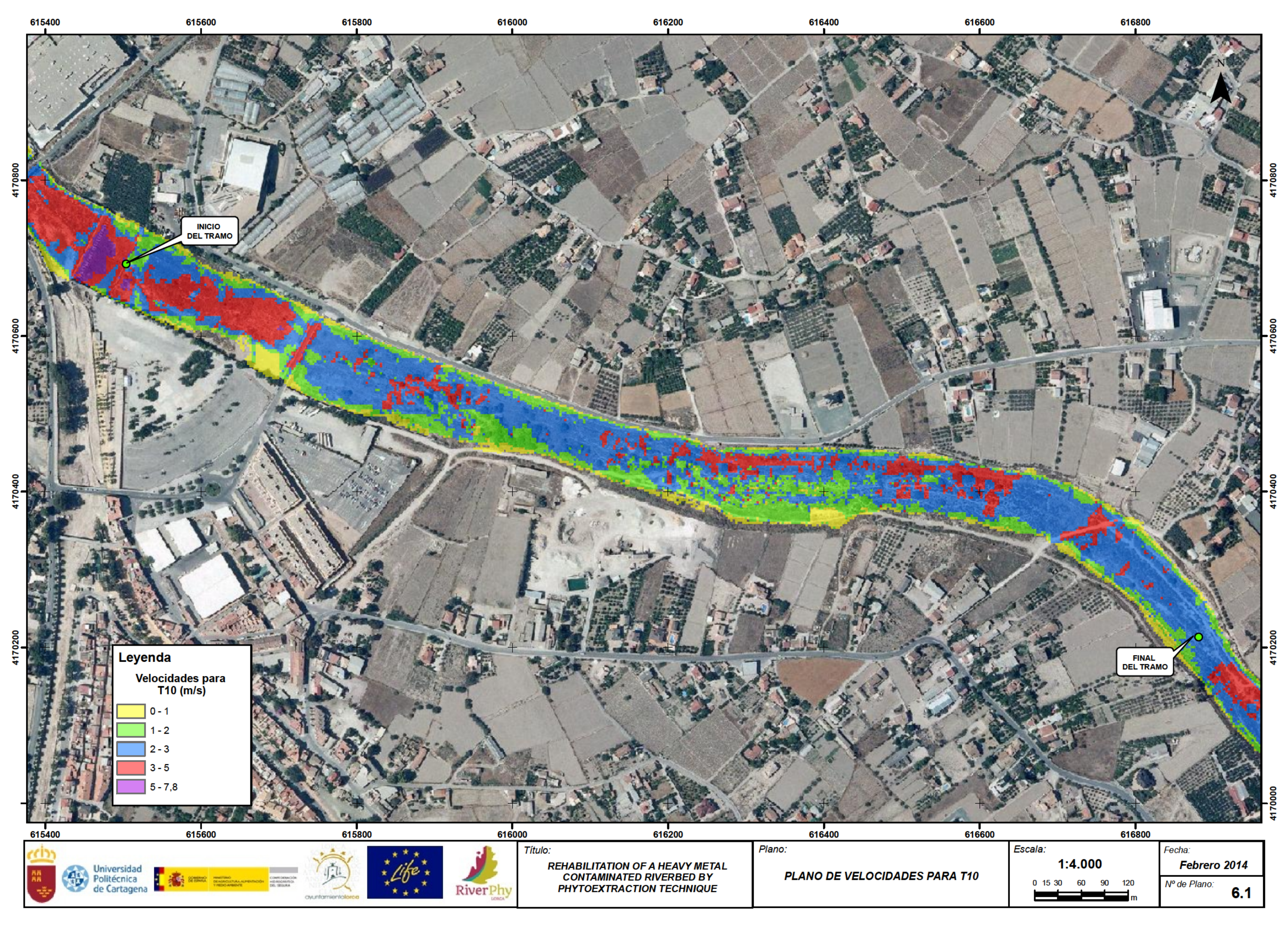




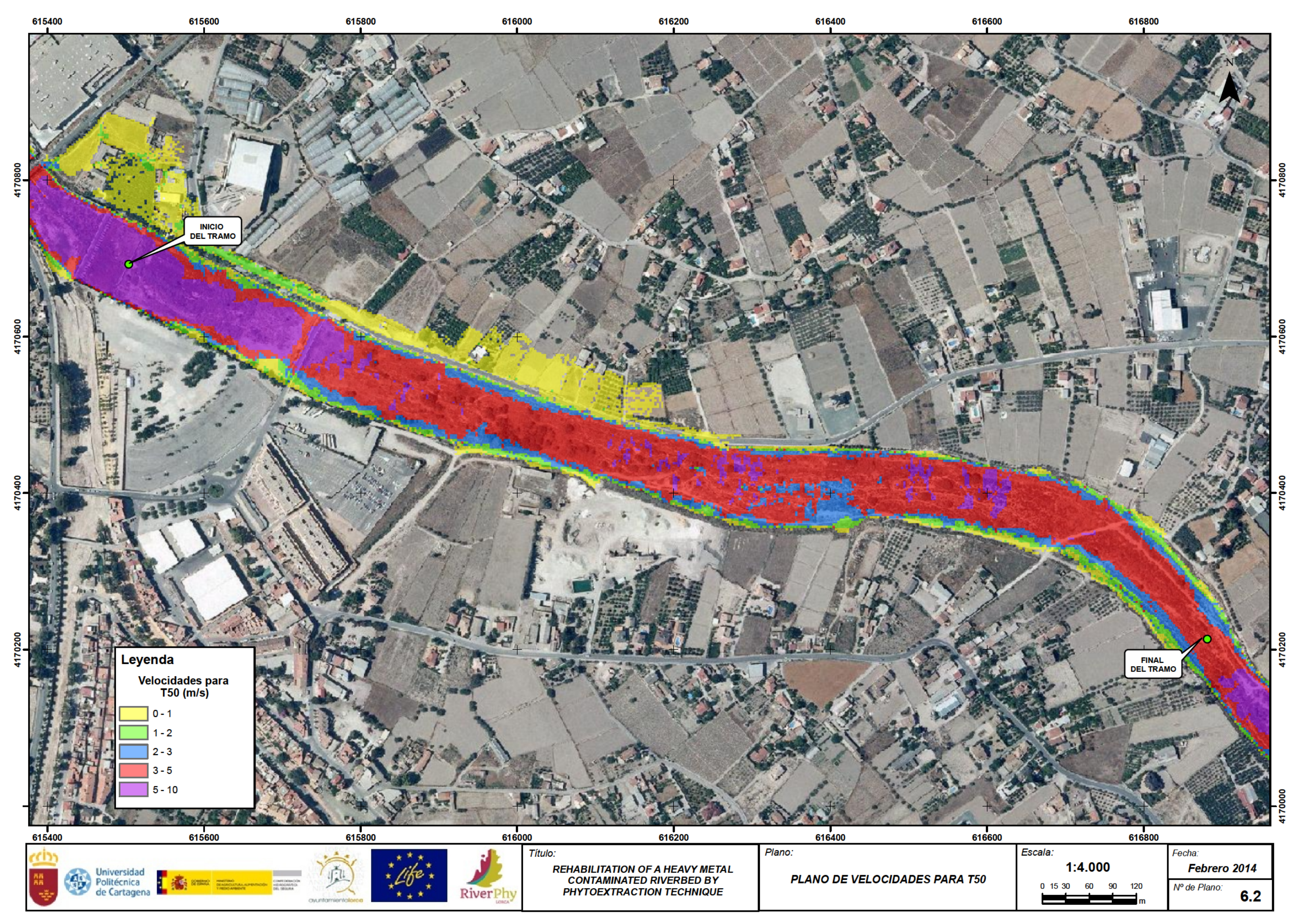




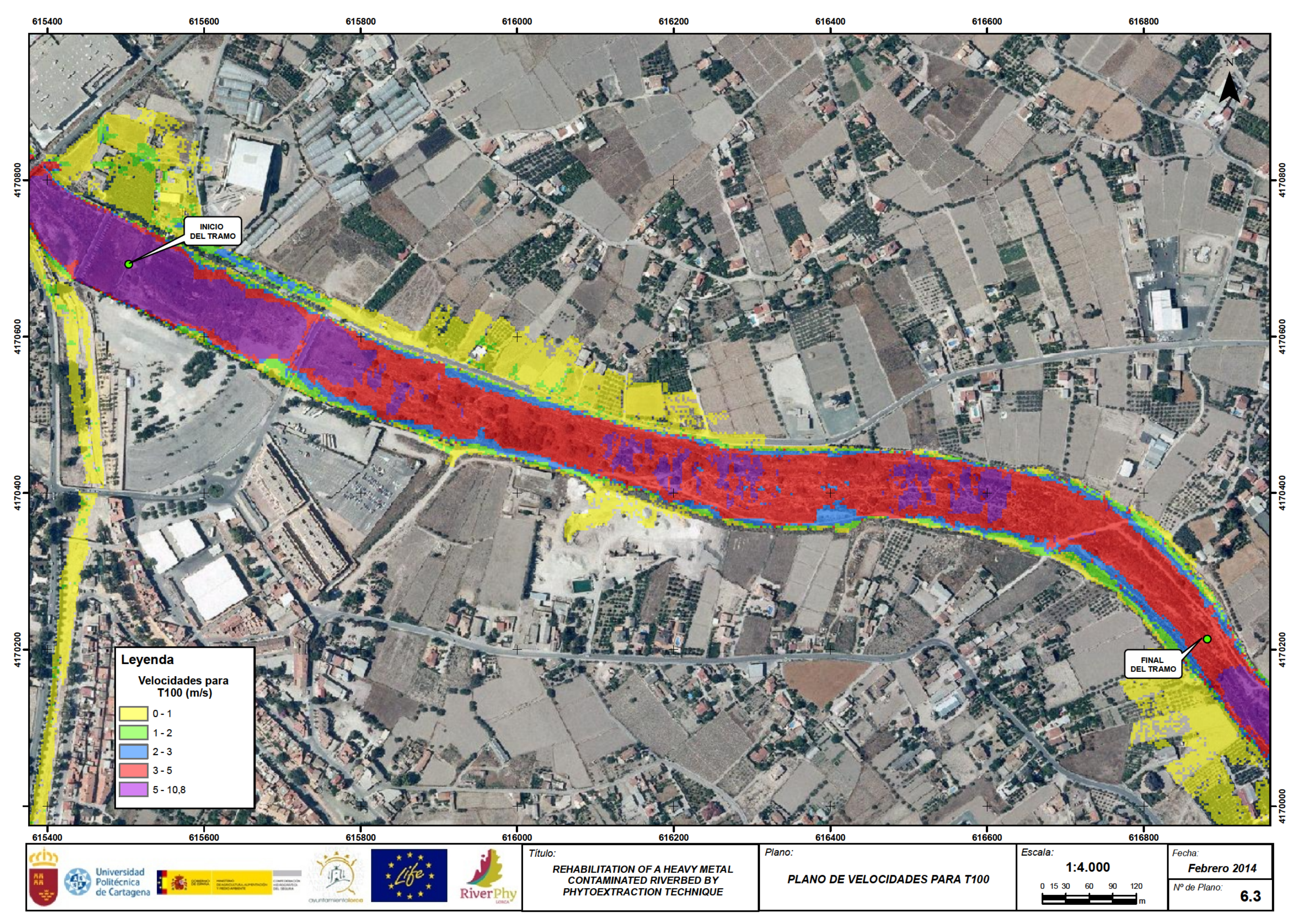




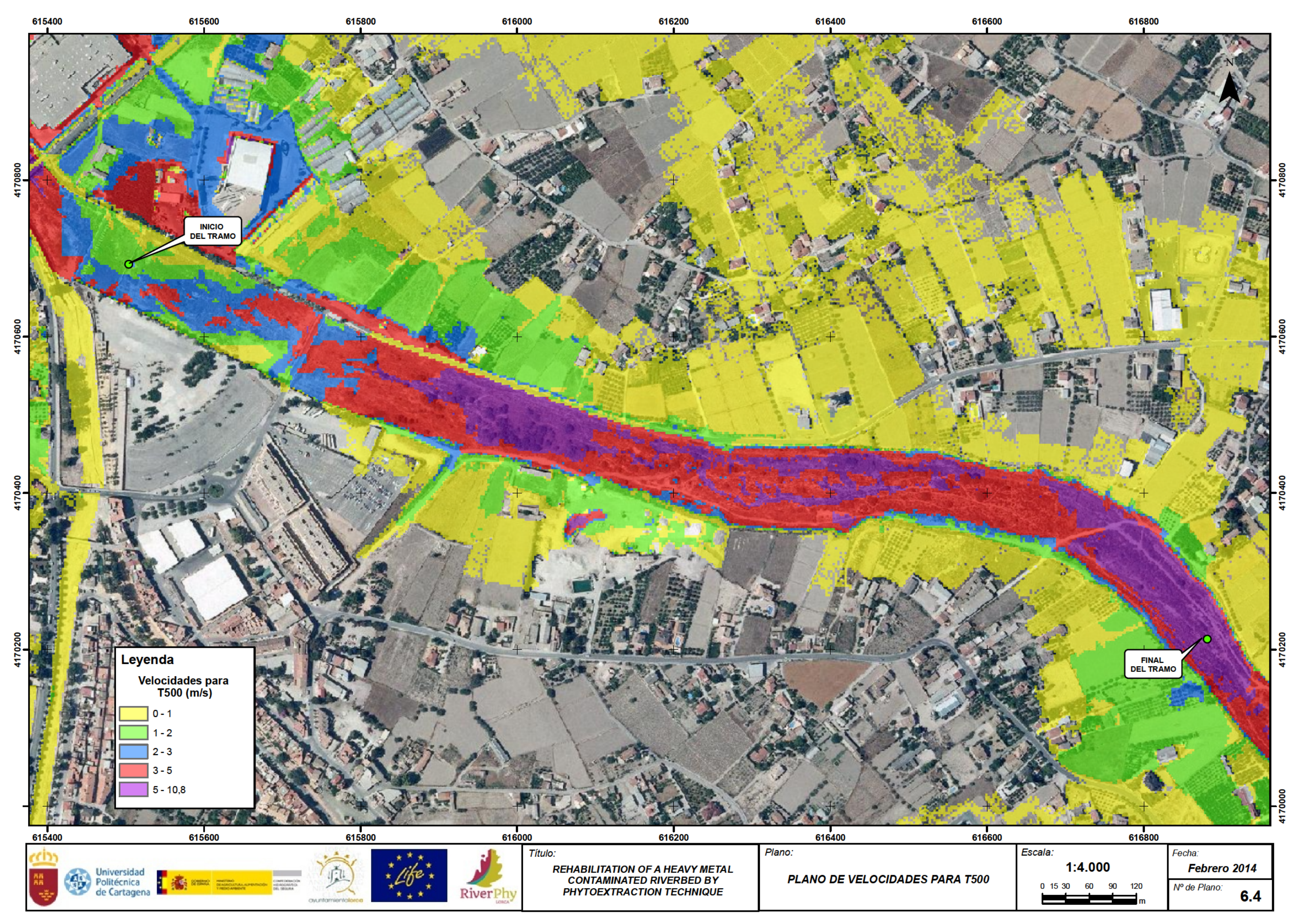




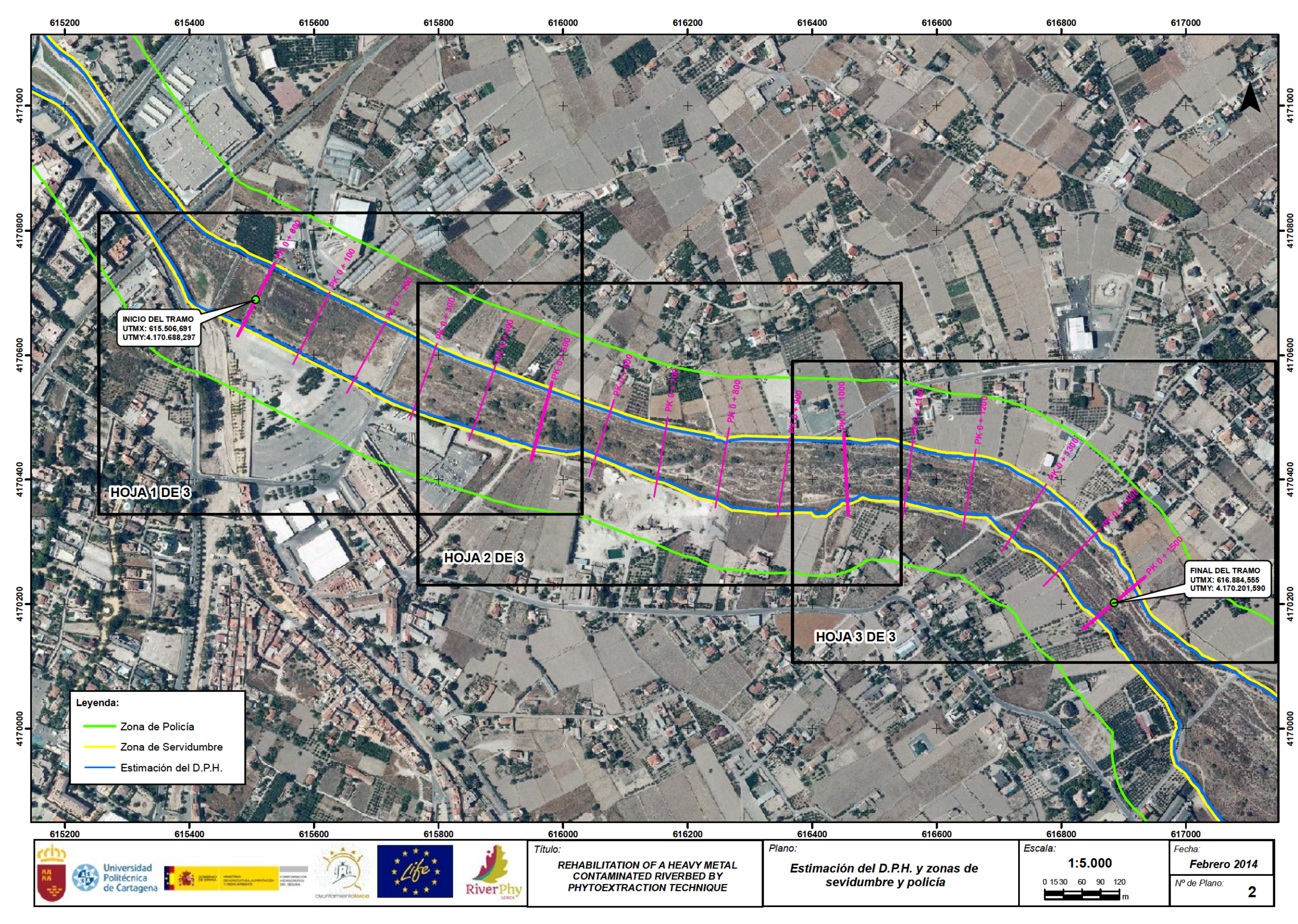




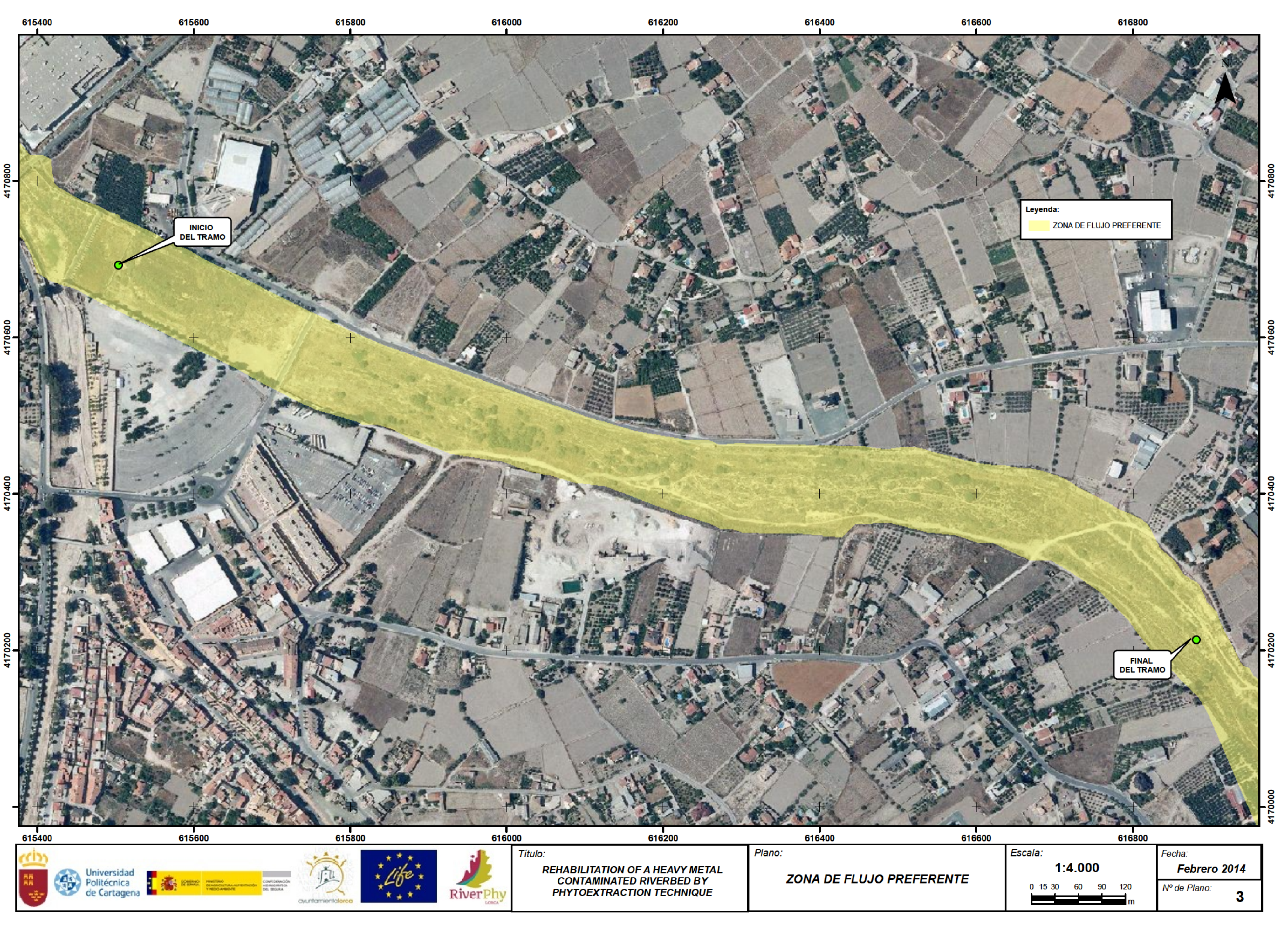




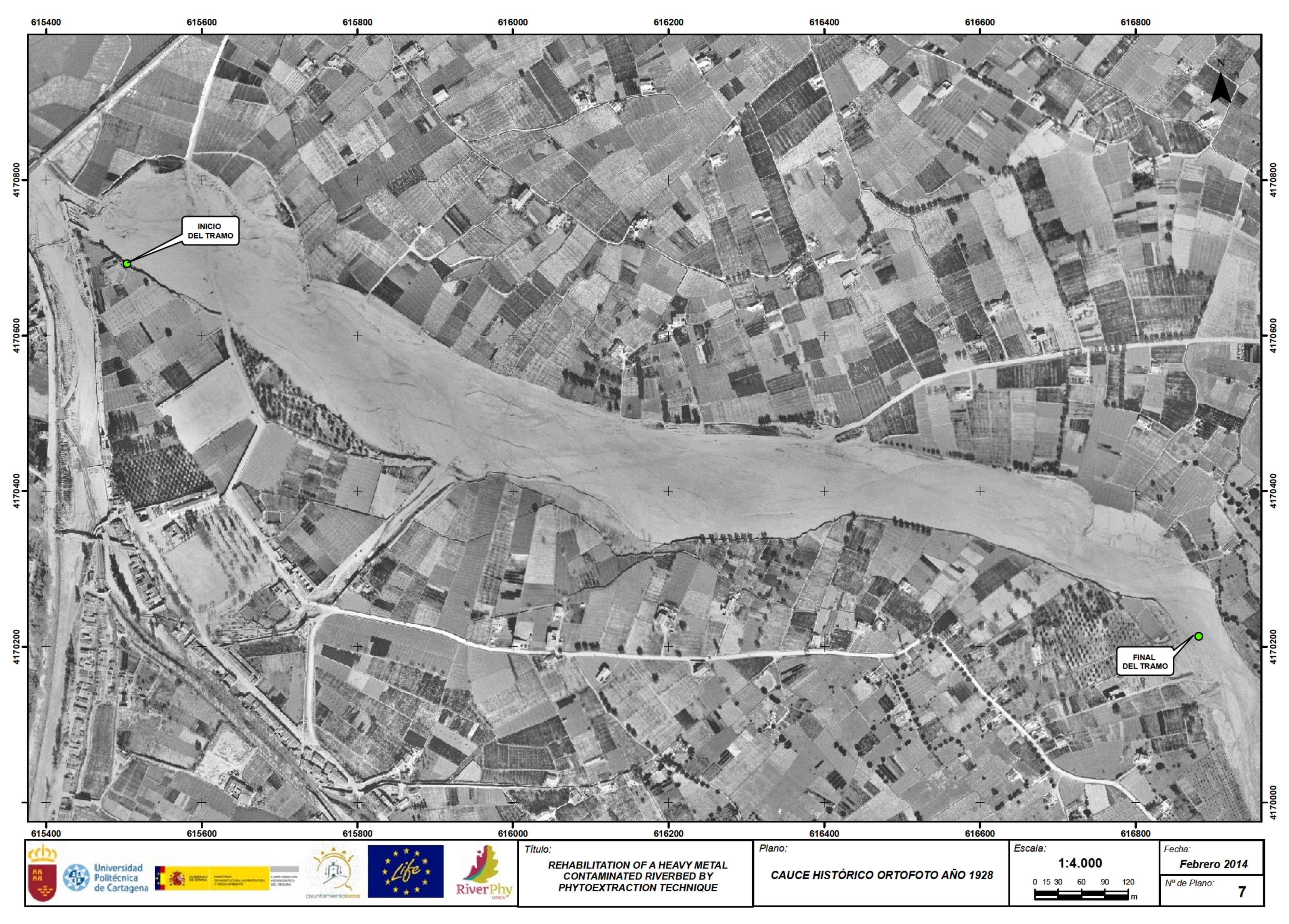




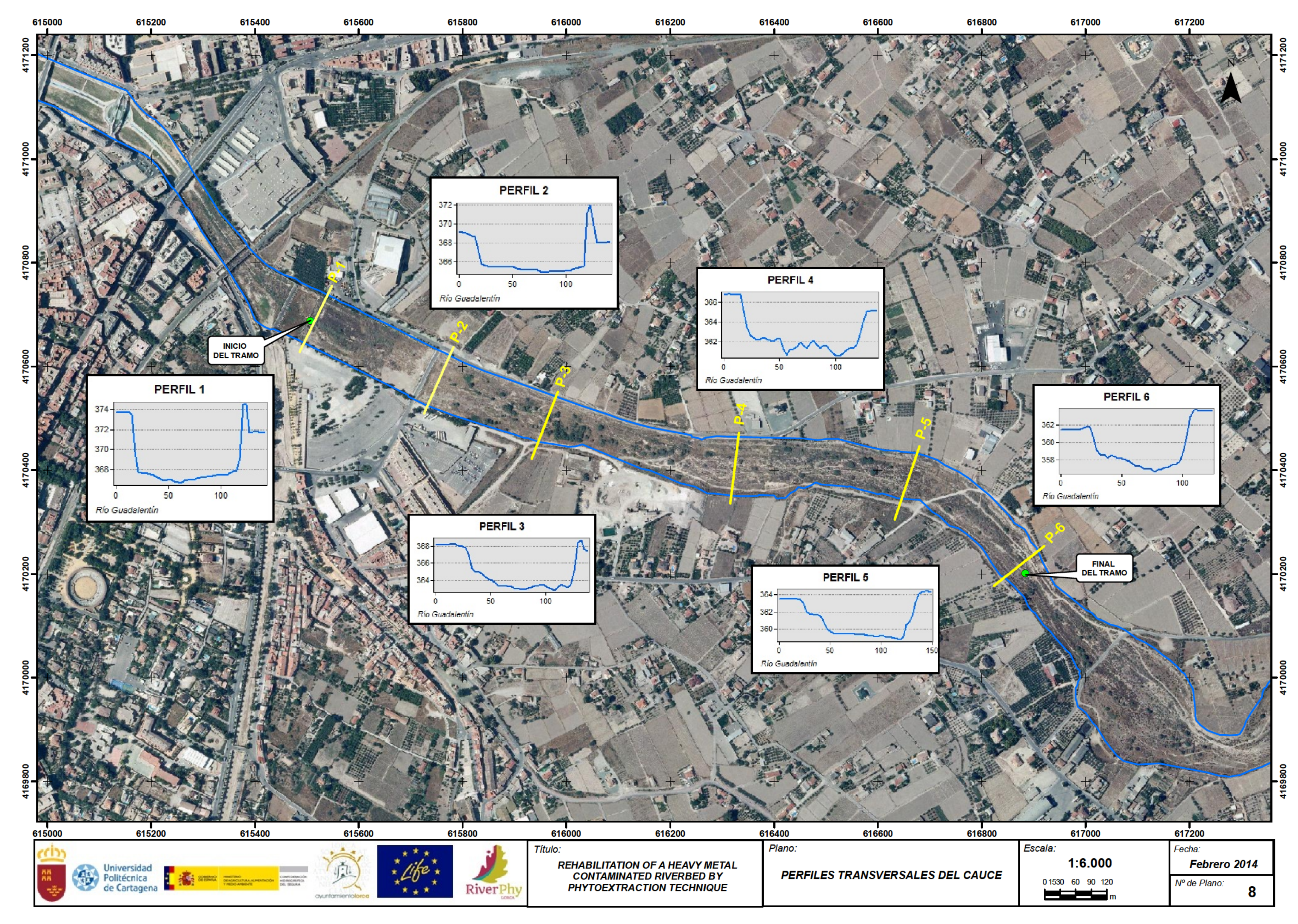




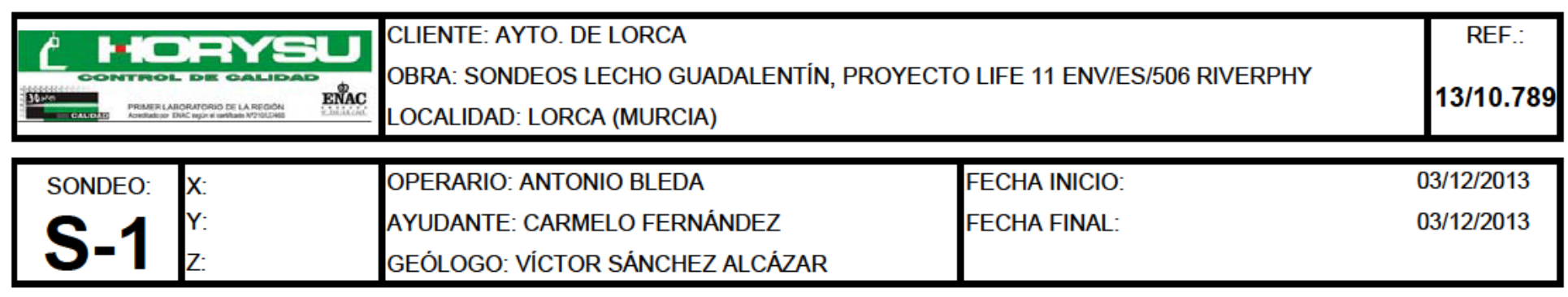

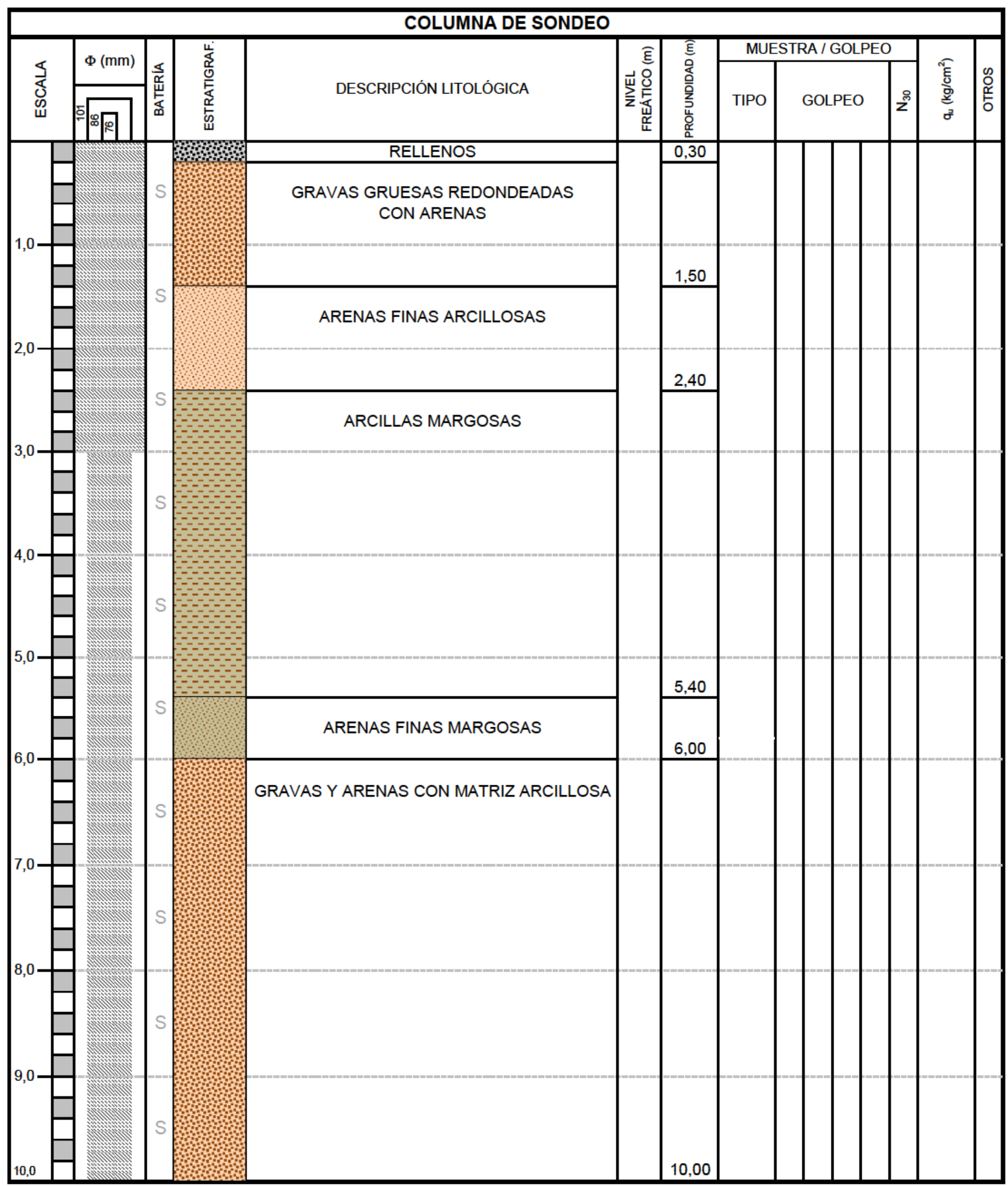

BATERIA:

MUESTRA:
S: SIMPLE D: DOBLE

SPT: ENSAYO DE PENETRACIÓN STÁNDARD MI: MUESTRA INALTERADA MC: MUESTRA DE CAJA

MP: MUESTRA PARAFINADA SPP: ENSAYO SPT CON PUNTAZA CIEGA

$\mathrm{N}_{30}$ : En caso de Muestra Inalterada, el valor de $\mathrm{N}_{30}$ es el obtenido aplicando un factor de correlación con el SPT de 0,6 


\begin{tabular}{|c|l|l|c|}
\hline \hline & $\begin{array}{l}\text { CLIENTE: AYTO. DE LORCA } \\
\text { OBRA: SONDEOS LECHO GUADALENTIN, PROYECTO LIFE 11 ENVIES/506 RIVERPHY } \\
\text { LOCALIDAD: LORCA (MURCIA) }\end{array}$ & REF.: \\
\hline SONDEO: & $\mathrm{X}:$ & OPERARIO: ANTONIO BLEDA & $04 / 12 / 2013$ \\
$\mathbf{S - 2}$ & $\mathrm{Y}:$ & AYUDANTE: CARMELO FERNÁNDEZ & FECHA INICIO: \\
\hline
\end{tabular}

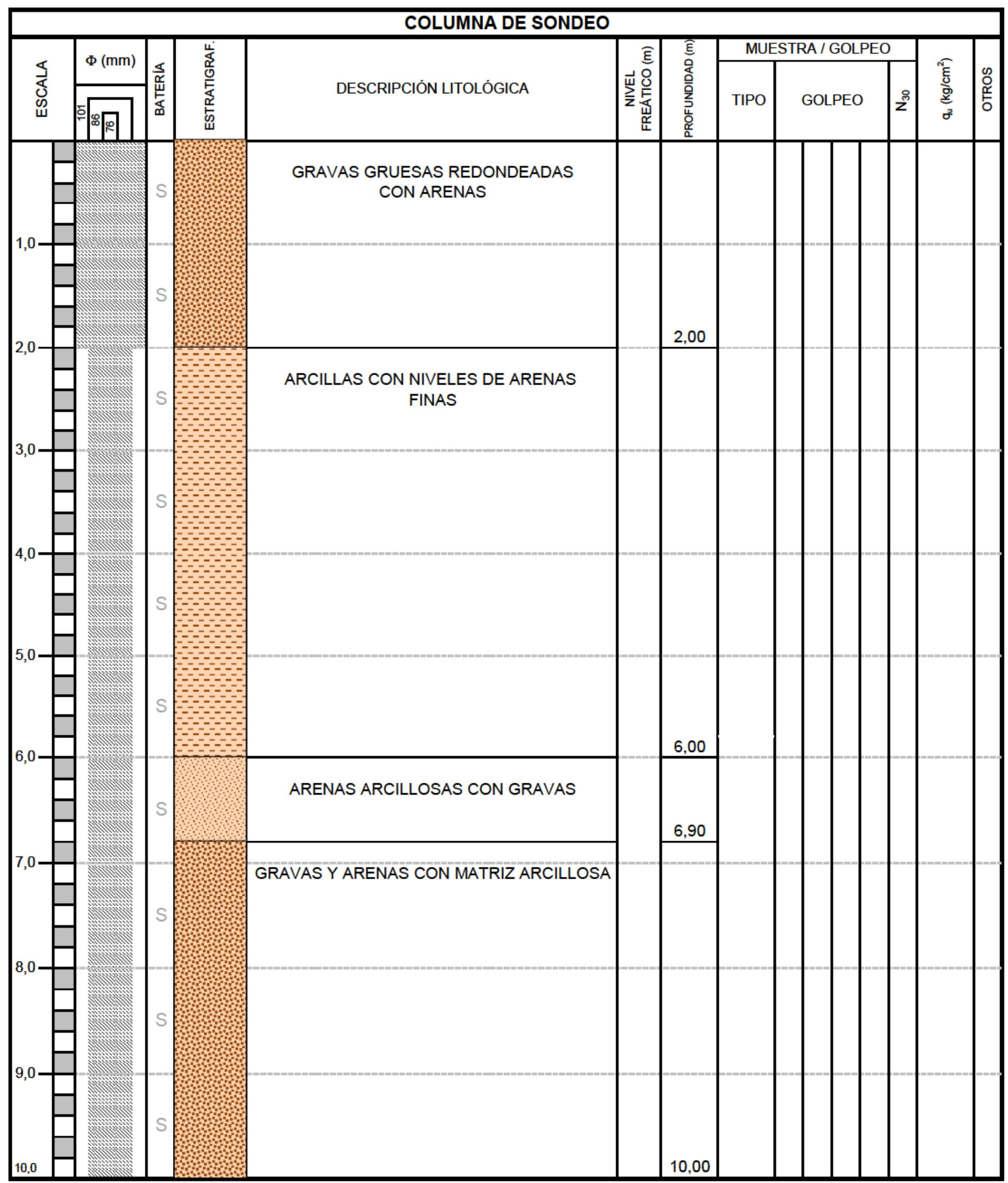

BATERIA:

MUESTRA:
S: SIMPLE D: DOBLE

SPT: ENSAYO DE PENETRACIÓN STÁNDARD MI: MUESTRA INALTERADA MC: MUESTRA DE CAJA

MP: MUESTRA PARAFINADA SPP: ENSAYO SPT CON PUNTAZA CIEGA

$\mathrm{N}_{30}$ : En caso de Muestra Inalterada, el valor de $\mathrm{N}_{30}$ es el obtenido aplicando un factor de correlación con el SPT de 0,6 


\begin{tabular}{|c|l|l|c|}
\hline & CLIENTE: AYTO. DE LORCA & REF.: \\
\hline SONDEO: & $\mathrm{X}:$ & FBRA: SONDEOS LECHO GUADALENTIN, PROYECTO LIFE 11 ENVIES/506 RIVERPHY & $\mathbf{1 3 / 1 0 . 7 8 9}$ \\
\hline $\mathbf{S - 3}$ & $\mathrm{Y}:$ & OPEALIDAD: LORCA (MURCIA) & $03 / 12 / 2013$ \\
\hline & AYUDANTE: CARMELO FERNÁNDEZ & FECHA FINAL: & $04 / 12 / 2013$ \\
\hline
\end{tabular}

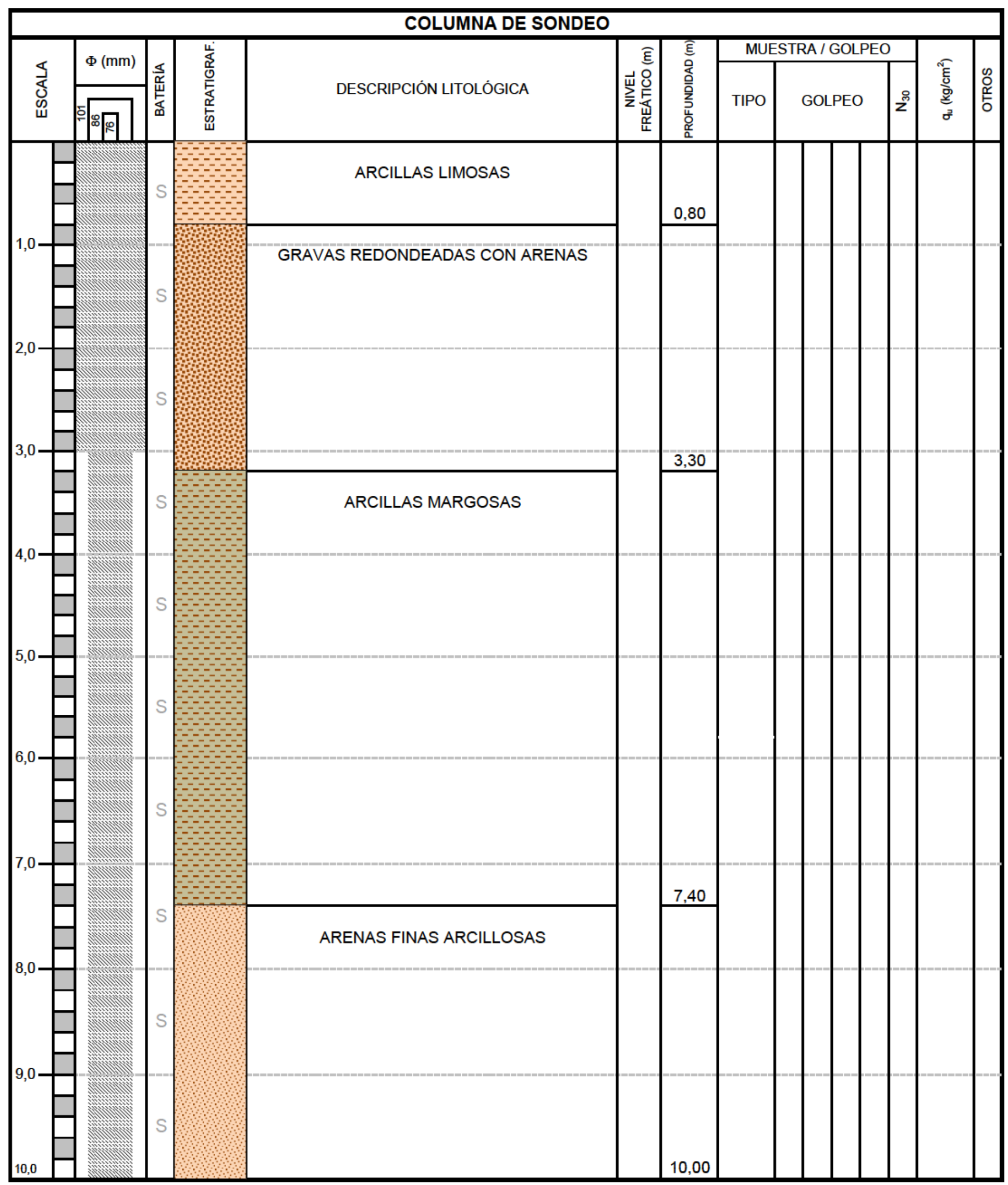

BATERIA:

MUESTRA:
S: SIMPLE D: DOBLE

SPT: ENSAYO DE PENETRACIÓN STÁNDARD MI: MUESTRA INALTERADA MC: MUESTRA DE CAJA

MP: MUESTRA PARAFINADA SPP: ENSAYO SPT CON PUNTAZA CIEGA

$\mathrm{N}_{30}$ : En caso de Muestra Inalterada, el valor de $\mathrm{N}_{30}$ es el obtenido aplicando un factor de correlación con el SPT de 0,6 